\title{
Structural Style And Stratigraphic Architecture Of The Northeastern Brooks Range, Alaska
}

\author{
Benjamin G. Johnson \\ bgjohnson@mix.wvu.edu
}

Follow this and additional works at: https://researchrepository.wvu.edu/etd

Part of the Geology Commons, Paleontology Commons, Stratigraphy Commons, and the Tectonics and Structure Commons

\section{Recommended Citation}

Johnson, Benjamin G., "Structural Style And Stratigraphic Architecture Of The Northeastern Brooks Range, Alaska" (2019). Graduate Theses, Dissertations, and Problem Reports. 3949.

https://researchrepository.wvu.edu/etd/3949

This Dissertation is protected by copyright and/or related rights. It has been brought to you by the The Research Repository @ WVU with permission from the rights-holder(s). You are free to use this Dissertation in any way that is permitted by the copyright and related rights legislation that applies to your use. For other uses you must obtain permission from the rights-holder(s) directly, unless additional rights are indicated by a Creative Commons license in the record and/ or on the work itself. This Dissertation has been accepted for inclusion in WVU Graduate Theses, Dissertations, and Problem Reports collection by an authorized administrator of The Research Repository @ WVU.

For more information, please contact researchrepository@mail.wvu.edu. 


\title{
STRUCTURAL STYLE AND STRATIGRAPHIC ARCHITECTURE OF THE NORTHEASTERN BROOKS RANGE, ALASKA
}

\author{
Benjamin G. Johnson
}

\author{
A dissertation submitted to the \\ Eberly College of Arts and Sciences at \\ West Virginia University \\ in partial fulfillment of requirements for the degree of \\ Doctor of Philosophy in \\ Geology \\ Jaime, Toro, Ph.D., Chair \\ Graham Andrews, Ph.D. \\ Kathleen Benison, Ph.D. \\ Amy Weislogel, Ph.D. \\ Jeffrey Benowitz, Ph. D. \\ Department of Geology and Geography
}

\author{
Morgantown, West Virginia \\ 2019
}

Keywords: Brooks Range, Alaska, Plate tectonics, Structural geology, Sedimentology, Whale Mountain allochthon

Copyright 2018 Benjamin G. Johnson 


\title{
ABSTRACT \\ STRUCTURAL STYLE AND STRATIGRAPHIC ARCHITECTURE OF THE NORTHEASTERN BROOKS RANGE, ALASKA
}

\author{
Benjamin G. Johnson
}

The Arctic Alaska-Chukotka microplate is a large Mesozoic-Cenozoic composite terrane that resides at the northern limit of the North American Cordillera. Although its Mesozoic origins are assuredly linked to the opening of the Amerasian Basin of the Arctic Ocean, its Paleozoic origins can be linked to at least three separate paleocontinents, including northern Laurentia, Baltica, and Siberia. Across the Arctic Alaska portion of the microplate, an internal, mid-Paleozoic suture zone presumably separates rocks of the North Slope subterrane (Laurentian affinity) from a collection of smaller subterranes in the southern Brooks Range and Seward Peninsula (Baltic affinity).

The mountains of the northeastern Brooks Range expose a thick assemblage of Neoproterozoic-Lower Cretaceous rocks that belong to the North Slope subterrane. New data from geological mapping, coupled with zircon $\mathrm{U}-\mathrm{Pb}$ and muscovite ${ }^{40} \mathrm{Ar} /{ }^{39} \mathrm{Ar}$ radiometric ages, reveal that the Neoproterozoic-Ordovician rocks in the NE Brooks Range, assigned to the Firth River Group, Neruokpuk Formation, and the informal Leffingwell formation, record deep-water, slope- to basin-floor sedimentation along the ancient passive margin of northern Laurentia. Stata of the Ordovician-Lower Devonian(?) Clarence River Group (new name) disconformably overlie these passive margin units and record a major shift in the sedimentary source. Detrital zircon U-Pb ages from Clarence River Group strata closely resemble the deep-water, synorogenic strata exposed in the Franklinian Basin of northern Ellesmere Island, and are interpreted to reflect erosion and transport of sediment sourced from the Caledonian orogen.

A rootless thrust sheet places a Cambrian-Middle Ordovician structural complex of basalt, limestone and chert, herein named the Whale Mountain allochthon, above the upper strata of the Clarence River Group. Igneous geochemistry and trilobite paleontology suggest that the Whale Mountain allochthon formed as a series of remote volcanic islands or seamounts that established outboard the Laurentian margin. The emplacement of the allochthon occurred in concert with the locally-defined, Early-Middle Devonian Romanzof orogeny, and it may be linked to the closure of the Iapetus Ocean and the collision between Baltica and Laurentia in the Caledonian orogeny. This major collisional event is responsible for the assembly of the Arctic Alaska-Chukotka microplate, implicating the Whale Mountain allochthon as a potential relic to the suture zone that separates the North Slope subterrane from the rest of Arctic Alaska and Chukotka. 


\section{ACKNOWLEDGEMENTS}

My time in the geology department a WVU is filled with many fond memories. Most notably, the relationship and mentorship I built with my advisor, Jaime Toro. He is a superb field geologist and outdoorsmen, but it is his sense of humor, his positive attitude, and his genuine curiosity that I admire most. At the end of our first field campaign together, after we had floated for $40 \mathrm{~km}$ down the Kongakut River in northern Alaska, I was utterly exhausted. While I was looking for an easy way to cross the river to reach our final take-out point, he told me to never take shortcuts and to embrace the hardships of life. We took the long way home, and this work is a testament to that.

Aside from the influence of Jaime, there are many other people at WVU that I am thankful to have known. My thesis committee members, Graham Andrews, Kathy Benison, and Amy Weislogel, provided a lot of helpful feedback to my research, and I enjoyed learning from them in the classroom. There are several other faculty members within the department that I need to acknowledge: Ryan Shackleton taught me more than I could ever know about structural geology; the late Helen Lang helped me distinguish between clinopyroxene and olivine in thin section; and Joe Donovan introduced me to the wonderful game of squash. I am also grateful to have been a member of a vibrant graduate student body, many of whom I spent countless Friday evenings with at the Brew Pub, resuscitating our soles with cold beer. My officemates, Patrick Frier, Greg Hammond, and Chantelle Parrish were my closest companions, serving as an initial sounding board to my early ideas.

There is an ever-growing list of coauthors, collaborators, and funding sources that I owe many thanks to. Sadly, I do not have the space to acknowledge them all here (see the acknowledgment sections at the end of Chapters 2, 3, and 4). There are a few, however, whose contributions are too great to go unmentioned. Jeff Benowitz, from the University of Alaska Fairbanks, served as an external member of my thesis committee. Not only did he let me borrow his truck in Fairbanks to help prepare for field work, but he provided radiometric ages in a timely fashion and helped me with their interpretation. John Taylor, from Indiana University of Pennsylvania, diligently identified and described all the trilobite specimens that field partners and I hauled from the mountains. His emails still make me smile. Tom Moore, from the 
USGS in Menlo Park, California, is probably more critical of my research than anyone else I know. His insistent review of my first published manuscript, however, profoundly impacted my approach to science, and his $>30$ years of research serves as a foundation to my understanding of Brooks Range geology. And then there is my dear friend and closest collaborator Justin Strauss, who is now an assistant professor at Dartmouth College. Together, we waded through frigid rivers, climbed rugged mountains, and embraced the hardships of life in the Brooks Range, all in an effort to reconstruct our former world.

Above all others, I need to thank my wife, Patricia. She has been by my side since I started this journey. Through my greatest achievements and my biggest shortcomings, it was her adventurous spirit, her patience, and her unconditional support that kept me motivated to finish. Without her, none of this was possible. 


\section{TABLE OF CONTENTS}

LIST OF FIGURES.

vi

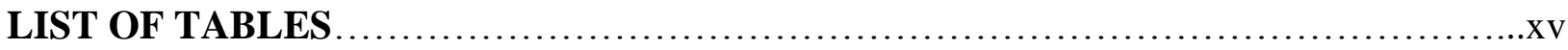

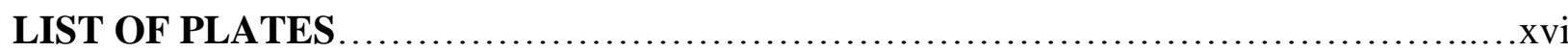

CHAPTER 1: Death of an ocean - birth of an orogen: An introduction to the tectonic history of the North Slope subterrane and its role in the assembly of the Arctic Alaska-Chukotka microplate. .1

CHAPTER 2: Detrital geochronology of pre-Mississippian strata in the northeastern Brooks Range, Alaska: Insights into the tectonic evolution of northern Laurentia.

CHAPTER 3: The Whale Mountain allochthon: A relic of the Iapetus Ocean preserved in the northeastern Brooks Range of Alaska and Yukon

CHAPTER 4: Geological mapping in the Arctic National Wildlife Refuge (ANWR) of the northeastern Brooks Range, Alaska

SUPLEMENTAL MATERIALS. 


\section{LIST OF FIGURES}

\section{CHAPTER 1}

Figure 1.1:

Figure 1.2:

CHAPTER 2

Figure 2.1:

Figure 2.2:

Figure 2.3:

Figure 2.4:
Simplified map of pertinent Proterozoic and Paleozoic orogenic belts, terranes, and cratons mapped onto the modern circum-Arctic continental margins and modified from Colpron and Nelson (2011) and Miller et al. (2011). Star indicates field area of this study..........................2

Simplified tectono-stratigraphic map of the composite Arctic AlaskaChukotka microplate (AACM) after Mull (1982), Miller et al. (2006; 2011), Amato et al. (2009), Moore et al. (1994, 2015), and Strauss et al. (2017, 2018). Prot.-Proterozoic; PSZ-Porcupine Shear Zone; Paleo.Paleozoic; ANWR_Arctic National Wildlife Refuge......................4

Generalized location maps. (A) The distribution of paleo-Arctic terranes in the northern Cordillera (modified from Colpron and Nelson, 2011). (B) Simplified tectonostratigraphic terrane map of northern Alaska (modified from Moore et al., 1994; 2015). Star indicates study area. NEnortheastern; Prot.-Proterozoic; Dev.-Devonian; E. Cret.-Early Cretaceous

Simplified geologic map of the eastern half of the northeastern Brooks Range. Geology compiled after Reiser et al. (1980), Norris (1981a, 1981b), and Lane et al. (1995). Key structures: WMT_-Whale Mountain thrust; RMT - Romanzof Mountain thrust; CDT — Continental Divide thrust (includes the Aichilik Pass thrust of Anderson et al., 1994); FRTFirth River thrust. Solid teeth on thrust faults indicate disruption of stratigraphic section (old on young); open teeth indicate detachment surfaces along which there has been slip but no disruption of the stratigraphic section (young on old). Abbreviations: Mts.-mountains; YT_Yukon; NT_Northwest Territories; BC—British Columbia.......19

Schematic stratigraphic column of pre-Mississippian units in the eastern half of the northeastern (NE) Brooks Range (modified from Kelley et al., 1994). Stratigraphic positions of samples, indicated with sample number and conducted analysis, are approximated, and fossil constraints are from the Yukon side of the NE Brooks Range and may not correlate with sampled units in this study.....................................20

Cross section through the eastern half of the northeastern Brooks Range illustrating the major structural features and deformation trends with no vertical exaggeration (modified from Hanks, 1989; Wallace and Hanks, 1990; Moore, 1999). Approximate location of the section is shown in Figure 2.2. Pre-Mississippian structural features are constrained by field 
data along the Kongakut River, Alaska. Depth of detachment in the preMississippian units is adopted from Hanks (1989) and Peapples et al. (1997). WMT_-Whale Mountain thrust.

Figure 2.5:

Figure 2.6:

Figure 2.7:

Figure 2.8:
Normalized probability density plots of U-Pb detrital zircon ages from the Neruokpuk Formation. Ratio of analyses plotted versus total zircon analyzed is shown in upper right along with the sample number (see Fig. 2.2 for sample location). All analyses were conducted by laser ablationinductively coupled plasma-mass spectrometry at the University of California Santa Cruz. The raw data and filtering methods are reported in Table SM2.3 ...................................................... 31

Normalized probability density plots of $\mathrm{U}-\mathrm{Pb}$ detrital zircon ages from the Clarence River group and one sample (12JT35) from the Ovc map unit of Reiser et al. (1980). Ratio of analyses plotted versus total zircon analyzed is shown in upper right along with the sample number (see Fig. 2.2 for sample location). Samples 12JT22, 12JT23, 12JT24, and 12JT35 were analyzed by laser ablation-inductively coupled plasma-mass spectrometry (LA-ICP-MS) at the University of California Santa Cruz and are reported in Table SM2.3. Sample 40LF13 (bottom) was analyzed by LA-ICP-MS at Stockholm University (grayfilled black line) and by secondary ion mass spectrometry (SIMS) at the NordSIM facility, Swedish Museum of Natural History (dashed black line). These analyses are reported in Tables SM2.4 and SM2.5. Wtd.—weighted; MSWD—mean square of weighted deviates....................................................... 32

Stepwise ${ }^{40} \mathrm{Ar} /{ }^{39} \mathrm{Ar}$ age spectra of muscovite separates from the Neruokpuk Formation. (A) Samples that have retained detrital Ar (37LF13 and J1355-617). (B) Samples that have been partially or completely reset (12JT12 and 12JT13a). Analytical uncertainties are represented by vertical width of bars at the $1 \mathrm{~s}$ level. Steps filled in dark gray were used for plateau age determinations. Weighted mean plateau ages (WMPA) are calculated using at least three contiguous steps that overlap in error at $1 \sigma$, and compose more than $60 \%$ of the ${ }^{39}$ Ar release. Pseudo plateau ages (PPA) are calculated using the weighted mean age of two or more contiguous steps that overlap in error at $1 \sigma$, and compose $50 \%-60 \%$ of the ${ }^{39} \mathrm{Ar}$ released. Analyses are reported in Table

SM2.6. ...

Stepwise ${ }^{40} \mathrm{Ar} /{ }^{39} \mathrm{Ar}$ age spectra on muscovite separates from the Clarence River group. Analytical uncertainties are represented by vertical width of bars at the $1 \mathrm{~s}$ level. Steps filled in dark gray were used for plateau age determinations. Steps filled in dark gray were used for plateau age determinations. Weighted mean plateau ages (WMPA) are calculated using at least three contiguous steps that overlap in error at $1 \sigma$, and compose more than $60 \%$ of the ${ }^{39}$ Ar release. Pseudo plateau ages (PPA) 
are calculated using weighted mean age of two or more contiguous steps that overlap in error at $1 \sigma$, and compose $50 \%-60 \%$ of the ${ }^{39} \mathrm{Ar}$ released.

Analyses are reported in Table SM2.6..............................36

Figure 2.9: Distribution of the single-grain ${ }^{40} \mathrm{Ar} /{ }^{39} \mathrm{Ar}$ total fusion and stepwise integrated ages from sample 14BJ27 (Clarence River group). Analytical uncertainties are represented by the vertical width of bars at the $1 \sigma$ level. The five ages filled in dark gray, composed of four total fusion ages and one stepwise integrated age, were used for weighted (Wtd.) mean age calculation (MSWD - mean square of weighted deviates). Analyses are reported in Table SM2.7 .................................................37

Figure 2.10: $\quad \mathrm{U}-\mathrm{Pb}$ detrital zircon ages from Neoproterozoic-Cambrian units throughout the northeastern Brooks Range. (A) Compared using normalized probability density plots. (B) Compared using cumulative probability plots. Data are from (1) Macdonald et al. (2009); (1, 2, and 4) Strauss et al. (2013); (3) McClelland et al. (2015); (4) Lane et al. (2016); (2, 4, and 5) this study. Fm - formation; gp — group.

Figure 2.11:

$\mathrm{U}-\mathrm{Pb}$ detrital zircon ages from early Paleozoic sedimentary successions of northern Laurentia and associated Caledonian terranes, including: (1) southwestern Svalbard (Gasser and Andresen, 2013); (2) northwestern Svalbard (Pettersson et al., 2010); (3) Pearya terrane (Hadlari et al., 2014); (4) Ellesmere Island (Beranek et al., 2015); (5) northeastern Brooks Range (this study); (6) Ellesmerian clastic wedge in the Canadian Arctic Islands (Anfinson et al., 2012); (7) Ellesmerian clastic wedge in Yukon (Beranek et al., 2010); and (8) Ellesmerian clastic wedge in east-central Alaska (Gehrels and Pecha, 2014). .49

Figure 2.12: $\quad$ Paleogeographic position of terranes and sediment dispersal pathways along northern Laurentia during deposition of the Clarence River group (see text for discussion). Reconstruction is based on Trettin (1987, 1998), Patchett et al. (1999), McClelland et al. (2012), Gasser and Andresen (2013), Pettersson et al. (2010), Colpron and Nelson (2011), Anfinson et al. (2012), and Beranek et al. (2015). NE—-northeastern.................54

\section{CHAPTER 3}

Figure 3.1:

Simplified geologic map of the eastern half of the NE Brooks Range, Alaska, highlighting the distribution of rocks comprising the Whale Mountain allochthon and sample locations. The map is modified from Reiser et al. (1980), Wallace and Hanks, (1990), Mull and Anderson, (1991), Lane et al. (1995), and Johnson et al. (2016). Solid teeth on thrust faults indicate disruption of stratigraphic section (old-on-young); open teeth indicate detachment surfaces along which there has been slip but no disruption of the stratigraphic section (young-on-old). Sample numbers are 
described in the text and outlined in Supplemental Material (Table SM3.1). Sample 12JT35 in the northern belt is from Johnson et al. (2016),

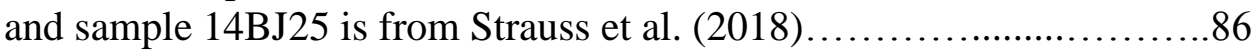

Figure 3.2:

Figure 3.3:

Figure 3.4:

Figure 3.5:
Schematic lithostratigraphy of the southern, central, and northern belts of the Whale Mountain allochthon. Thicknesses are approximated from generalized field observations. U. Ordv. stands for Upper Ordovician .90

Field images and photomicrographs from rocks of the southern belt of the Whale Mountain allochthon in the NE Brooks Range, Alaska. (A) Looking southwest across the Romanzof Mountain Thrust (RMT) at the headwaters of the Aichilik River, showing the J1475 fossil location. (B) Looking east near the fault zone of the RMT at the headwaters of the Jago River, showing the outcrop of zircon U-Pb sample 15BJ06. (C) Looking southwest across intercalated Marsh Fork volcanic rocks and megablocks of the Egaksrak formation in the headwaters of the Jago River. (D) Crosspolarized view of sample 14BJ 22 showing intergranular plagioclase phenocrysts with microcrystalline clinopyroxene. (E) Cross-polarized view of sample 15BJ08 showing aligned actinolite, epidote, plagioclase, and Fe- and Ti-oxide minerals.......................................93

Field images from rocks of the central belt of the Whale Mountain allochthon in the NE Brooks Range, Alaska. (A) Looking east along the southern limb of synclinal ridge, showing interbedded Whale Mountain volcanic rocks and laminated lime mudstone units of the Egaksrak formation (B) Looking northeast at the Leffingwell Fork fossil locality (J1480), which shows the upper Cambrian limestone units above black slate units of the Middle Ordovician-Lower Devonian(?) Clarence River Group including thrust slivers of Egaksrak carbonate units. (C) Close-up of lime mudstone with abundant pebble- and cobble-sized clasts of basalt; penny for scale is $19 \mathrm{~mm}$ across. (D) Looking east at the J1352 fossil location in headwaters of the Malcom River, Yukon; person for scale is circled in yellow and is $\sim 2 \mathrm{~m}$ tall. (E) Close-up of ribbon-bedded lime mudstone at the $\mathrm{J} 1352$ fossil location; hammer for scale is $\sim 32 \mathrm{~cm}$. (F) Pillow textures preserved within folded basalt flows; hammer for scale is $32 \mathrm{~cm}$ long. (G) Close-up of clast-supported conglomerate with wellrounded clast of basalt, diabase, and chert from the Kongakut River, Alaska; pencil for scale is $\sim 15 \mathrm{~cm}$................................................98

Photomicrographs of theWhale Mountain volcanic rocks. (A) Crosspolarized view of sample 12JT13B, showing fractured olivine phenocrysts in a groundmass composed of glass and $\mathrm{Fe}$ - and Ti-oxide minerals. (B) Plane-polarized view of sample 12JT20, showing complete iddingsite alteration of an olivine phenocryst. (C) Cross-polarized view of sample 12JT18 showing glomeroporphyritic olivine and plagioclase, sericitization 
of plagioclase phenocrysts, and chlorite amygdules that have been stretched. (D) Cross-polarized view of sample 20LF13 showing large fractured and altered olivine phenocryst................................99

Figure 3.6

Figure 3.7:

Figure 3.8:

Figure 3.9:
Field images of the Ekaluakat formation from the northern belt of the Whale Mountain allochthon in the NE Brooks Range, Alaska. (A) Closeup taken from volcanic breccia of the Ekaluakat formation exposed in northern Yukon; one-cent piece for scale is $1.9 \mathrm{~cm}$ in diameter. (B) Crosspolarized view of sample 12JT39 showing volcanic clast and clinopyroxene grains in a chert(?) and clay matrix. (C) Close-up of folded and laminated marron argillite, crosscut by steep micro-shear fractures; pencile for scale is $\sim 13 \mathrm{~cm}$. (D) Photo Looking west along the Kongakut River section of the northern belt showing laminated dark-maroon and gray argillite interbed with a faulted, tan-weathering tuff layer; hammer

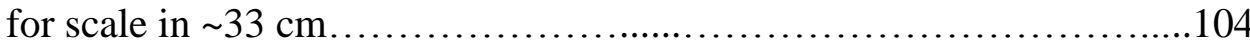

Zircon $\mathrm{U}-\mathrm{Pb}$ ages and $\mathrm{Hf}$ isotopic values from laser ablation-inductively coupled plasma-mass spectrometry (LA-ICP-MS) of volcaniclastic rocks from the central and southern belts of the Whale Mountain allochthon. (B) Concordia plot of 274 grains from sample 15BJ06; gray ellipse represents an excluded measurement because of significant discordance. Inset shows calculated weighted (wtd.) mean age of the six concordant ages. (B) Concordia plot of seven grains from sample 13WW23. Inset shows calculated weighted (wtd.) mean age of the six concordant ages. (C) Hf evolution plot showing $\varepsilon \mathrm{Hf}_{(\mathrm{t})}$ values for each sample (13WW23 and 15BJ06). The average measurement uncertainty for all analyses (upper right) is shown at the $1 \sigma$ level. Reference lines on the Hf plot are as follows: DM-depleted mantle, calculated using ${ }^{176} \mathrm{Hf} /{ }^{177} \mathrm{Hf}_{0}=0.283225$ and ${ }^{176} \mathrm{Lu} /{ }^{177} \mathrm{Hf}_{0}=0.038512$ (Vervoort and Blichert-Toft, 1999); CHURchondritic uniform reservoir, calculated using ${ }^{176} \mathrm{Hf} /{ }^{177} \mathrm{Hf}=0.282785$ and ${ }^{176} \mathrm{Lu} /{ }^{177} \mathrm{Hf}=0.0336$ (Bouvier et al., 2008); gray dashed show interpreted felsic crustal evolution trajectories assuming present-day ${ }^{176} \mathrm{Lu} /{ }^{177} \mathrm{Hf}=$ 0.0115 (Vervoort and Patchett, 1996; Vervoort et al., 1999). Full data tables are provided in the Supplemental Material section at the end of this dissertation.....................................................107

The $\mathrm{Nb} / \mathrm{Y}-\mathrm{Zr} / \mathrm{Ti}$ discrimination plot of Pearce (1996). $\mathrm{Zr} / \mathrm{Ti}$ ratio is used as an index of differentiation, and the $\mathrm{Nb} / \mathrm{Y}$ is used as an alkalinity index ............................................................

(A) Ti-V plot after after Shervais (1982) showing the fields of Low-Ti island arc tholeiite, island arc tholeiite, mid-ocean ridge tholeiite (includes back-arc basin basalt), and alkaline basalt. Solid lines represent constant $\mathrm{Ti} / \mathrm{V}$ ratios of $10,20,50$, and 100 (B) $\mathrm{Zr}-\mathrm{Ti} / \mathrm{V}$ plot showing the changes in the $\mathrm{Ti} / \mathrm{V}$ ratio (controlled by clinopyroxene fractionation) with respect to $\mathrm{Zr}$ (a commonly used differentiation index for altered basalt)............116 
Figure 3.10:

Trace-element variation diagrams. (A) Rare earth elements (REE) normalized to average $\mathrm{C} 1$ chondrite compositions from McDonough and Sun (1995). (B) selected trace element variations that are normalized to average pyrolite mantle compositions of McDonough and Sun (1995)

Figure 3.11:

Trilobites and agnostoid arthropods from the Egaksrak formation at locality J1475. View is dorsal (palpebral for cranidia) unless indicated otherwise. White or black scale bar in each photo is $\sim 1 \mathrm{~mm}$ in length. AM: Aplotaspis new species; (A-C) dorsal stereopair, anterior, and lateral views of large cranidium, CM59287; (D-F) small CM59288, medium CM59289, and very small CM59290 cranidia; (G) large, fragmentary librigena, CM59291; (H-I) stereopair and exterior view of small librigena, CM59292; (J) large, fragmentary pygidium, CM59293; (K) stereopair of large, fragmentary pygidium CM59294; (L) small, fragmentary pygidium CM59295; (M) very small pygidium CM59296. N-P: Stenopilus? sp., dorsal stereopair, anterior oblique, and lateral views of fragmentary small cranidium CM59297. Q-T: Genus species indeterminate 75A, fragmentary large cranidia; (Q-R) dorsal stereopair and anterior oblique views of CM59298; (S-T) dorsal view and anterior-oblique stereopair of CM59299. U-V: Genus species indeterminate 75B; (U) stereopair of large, fragmentary cranidium CM59300; (V) stereopair of large, fragmentary librigena CM59301. W-X: Genus species indeterminate 75C, dorsal and posterior oblique stereopair of fragmentary medium pygidium CM59302. Y-AA: Pseudagnostus cf. P. parvus; (Y-Z) dorsal stereopair and anterior view of fragmentary large cephalon CM59303; (AA) fragmentary large pygidium CM59304. BB-CC: Neoagnostus? sp.; dorsal and posterior views of fragmentary small pygidium CM59305. DD: Pseudagnostus josepha?, fragmentary very small pygidium CM59306.

Figure 3.12:

Trilobites and agnostoid arthropods from the Egaksrak formation at locality J1480. View is dorsal (palpebral for cranidia) unless indicated otherwise. White or black scale bar in each photo is $\sim 1 \mathrm{~mm}$ in length. AD: Idahoiid new genus new species 1; (A-C) dorsal, anterior oblique, and anterior views of cranidium CM59307; (D) large librigena CM59308. E-J: Idahoiid new genus new species 2; (E) stereopair of medium cranidium CM59309; $(\mathrm{F}-\mathrm{G})$ dorsal view and anterior oblique stereopair of medium cranidium CM59310; (H-I) dorsal and anterior oblique views of small cranidium CM59311; (J) large librigena CM59312. K-L: Genus species indeterminate $80 \mathrm{~B}$, dorsal stereopair and anterior oblique view of medium cranidium CM59320. M-Q: idahoiid pygidium 2; (M-N) dorsal stereopair and posterior oblique view of medium pygidium CM59314; (O-Q) dorsal, posterior, and lateral views of small pygidium CM59315. R-S: Idahoiid pygidium 1, stereopair and posterior view of large pygidium CM59313. 
T-W: Plethopeltis? sp.; (T-U) dorsal and anterior oblique views of large cranidium CM59316; (V-W) dorsal and lateral views of medium cranidium CM59317. X-Z: Genus species indeterminate 80A; dorsal, anterior oblique, and anterior views of large cranidium CM59318. AACC: Genus species indeterminate 80C; dorsal, lateral, and posterior views of fragmentary medium pygidium CM59321. DD-GG: Micragnostus sp.; (DD) stereopair of medium cephalon CM59322; (EE) stereopair of medium pygidium CM59323; (FF-GG) dorsal and lateral views of medium pygidium CM59324.

Figure 3.13:

Trilobites from the Egaksrak formation at locality J1352. View is dorsal (palpebral for cranidia) unless indicated otherwise. White or black scale bar in each photo is approximately $1 \mathrm{~mm}$ in length. A-D, Cheilocephalus? sp.; A-C, dorsal and lateral views, and anterior oblique stereopair of medium cranidium CM59325; D, posterior-dorsal view of right posterolateral projection showing "shoulder". E-H, Genus species indeterminate 52A; E-G, dorsal stereopair, lateral, and anterior views of medium cranidium CM59326; $\mathrm{H}$, fragmentary medium librigena CM59327. I-N, Genus species indeterminate 52B; I-K, dorsal, anterior, and lateral views of medium, slightly crushed cranidium CM59328; L, small cranidium CM59329; M-N, dorsal and exterior views of large librigena CM59330. O-V, Genus species indeterminate 52C; O-P, dorsal and anterior-oblique views of medium cranidium CM59331; Q, medium cranidium CM59332; R-S, dorsal and exterior views of large librigena CM59333; T-V, dorsal, posterior, and lateral views of medium pygidium CM59334. W-Y, Genus species indeterminate 52D, dorsal, anterior, and lateral views of medium cranidium CM59335. Z-AA, Genus species indeterminate 52E, dorsal and exterior views of large librigena CM59336. $\mathrm{BB}-\mathrm{CC}$, Genus species indeterminate $52 \mathrm{~F}$, dorsal and exterior views of fragmentary medium librigena CM59337. DD-EE, Agnostoid genus species indeterminate, dorsal and lateral views of small cephalon CM59338

Figure 3.14:
Chronostratigraphic chart showing probable positions of faunal and zircon collections from the Whale Mountain allochthon within the succession of upper Cambrian trilobite-based biochronozones, series, and stages established for Laurentia, and their relationship to global chronostratigraphic units (right-most columns). Chronostratigraphic units after Taylor et al. (2012). Numerical ages for the global stages are from Gradstein et al. (2012). Colors are used to differentiate southern belt collections (blue) from central belt (green) collections. Colored rectangles for fossil collections depict probable ranges; possible ranges shown with colored lines and white dots. Estimated ranges for the zircon $\mathrm{U}-\mathrm{Pb}$ ages are taken from uncertainties depicted in the weight average age from each sample (Fig.

3.7). .129 


\section{CHAPTER 4}

Figure 4.1:

Figure 4.2:

Figure 4.3:

Figure 4.4
(A) Inset map of northern Alaska. (B) Shaded relief map of the northeastern Brooks Range of Alaska and Yukon showing the location of the two 1: 75,000 geological maps from this study (Plates 1 and 2).

Previously published and open file 1: 250,000 geological quadrangles are labeled and outlined in light-red. R.-

River.

Simplified lithostratigraphic architecture of the northeastern Brooks Range, modified from Strauss et al. (2018a). These lithostratigraphic sections are based data published by Dutro et al. (1972), Sable (1977), Ditterman et al. (1975), Mamet and Armstrong (1972), Reiser et al. (1980), Lane (1991), Lane et al. (1995, 2016), Mull and Andersen (1991), Andersen et al. (1994; 1995), Kelley et al. (1994), Strauss et al. (2013; 2018a), and Johnson et al. (2016; 2018). Cry.-Cryogenian; C.-Cambrian; Cam.-Cambrian; Dev.-Devonian; Cr.-Creek; Miss.-Mississippian; Penn.-Pennsylvanian........................................ 186

Selected field images from the northeastern Brooks Range, Alaska. (A) Looking southeast along the northern edge of Bathtub Ridge, showing folds in the Lisburne (PMI) and Sadlarochit ( $\mathrm{RPs}$ ) groups. (B) Looking east across the Kongakut River at parasitic folds in the Lisburne Group (PMI) and Kayak Shale (Mky). (C) Looking north at the top of the Jago Stock, showing the gradational contact between the Devonian granitic rocks (Dgr) and the Kekiktuk Conglomerate (Mkt). (D) Looking northeast in the headwaters of the Kongakut River, showing the erosive contact between the Ulungarat Formation (DMu) and the Kekiktuk Conglomerate. (E) Looking southeast from the eastern wall of the Jago River valley at the Whale Mountain thrust (WMT). Units in the hanging wall are Devonian(?) altered rocks (Dar). (F) Looking southeast at the Romanzof Mountain thrust (RMT), in the headwaters of the Aichilik River, showing the Kekiktuk Conglomerate in foot wall with the Marsh Fork volcanic rocks $(€ m v)$ overlain by Kekiktuk Conglomerate in the hanging wall. 190

Selected field images of sub-Mississippian rocks in the northeastern Brooks Range, Alaska. (A) Looking east along the Kongakut River at subhorizontal, tight to isoclinal, south-verging, class II folds in the Clarence River Group. (B) Looking west along the Kongakut River at sigmoidal veins in the Neruokpuk Formation, showing top-to-the-south shear. (C) Looking west in the upper Jago River, showing tight, north-verging, buckle (class I) folds in the Clarence River Group. (C) Looking northeast along the Kongakut River at sub-horizontal, south-verging, class II folds in Firth River Group strata; Dahl sheep (circled in yellow) are approximately $1.5 \mathrm{~m}$ tall for scale. 202 
Figure 4.5: $\quad$ Lower-hemisphere, equal-area stereographic projections of poles to bedding planes from rocks in the Jago and Kongakut river areas. Filled circles represent poles to bedding planes, great circles represent calculated best-fit great circle to observed data, and open squares represent calculated fold axes of observed

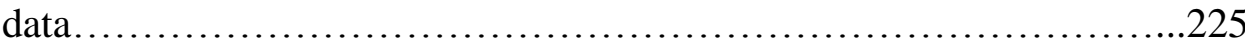

\section{SUPPLEMENTAL MATERIAL}

Figure SM2.1: $\quad$ Photomicrographs from the Neruokpuk Formation and the Clarence River Group. (A) Neruokpuk sample 12JT11 strain shadow around single quartz grain. (B) Neruokpuk sample 12JT12 showing fine-grained authigenic muscovite occupying interstitial spaces between quartz grains. (C) Clarence River Group sample 12JT23 showing various compositions of detrital grains, suggesting an immature composition. (D) Clarence River Group sample 14BJ27 showing coarse=grained detrital muscovite grains aligned within cleavage domains that surround larger quartz grains. Abbreviations: CRF-chert rock fragment; FLD-feldspar grain; QTZquartz grain; VRF-volcanic rock fragments.......................246

Figure SM3.1: $\quad$ Cathodoluminescence images of selected zircon grains from 15BJ06. White dots show the $20 \mu \mathrm{m}$ ablation site of grains in Table SM3.2; Yellow dots show ablation site of potential contaminated grains, also shown in Table SM3.2; Red dots show ablation site of grains with spurious zircon chemistry that are not included in Table SM3.2......................320 


\section{LIST OF TABLES}

\section{CHAPTER 2}

Table 2.1:

Summary of ${ }^{40} \mathrm{Ar} /{ }^{39} \mathrm{Ar}$ Results

\section{CHAPTER 3}

Table 3.1:

Major-element chemistry of the Whale Mountain allochthon ...

Table 3.2:

Trace-element chemistry of the Whale Mountain allochthon

\section{CHAPTER 4}

Table 4.1: $\quad$ Sample catalog from field work in the NE Brooks Range

\section{SUPPLEMENTAL MATERIAL}

Table SM2.1

Sample locations from the NE Brooks Range, AK

Table SM2.2

Geochronology and fossil age constraints

262

Table SM2.3 LA-ICPMS U-Pb isotopic data

(UC Santa Cruz Lab)

Table SM2.4 LA-ICPMS U-Pb isotopic data

(Stockholm University Lab). 304

Table SM2.5 SIMS U-Th-Pb isotopic data

(NordSIMS Lab, Stockholm)

Table SM2.6 Stepwise ${ }^{40} \mathrm{Ar} /{ }^{39} \mathrm{Ar}$ isotope compositions of muscovite (University of Alaska Fairbanks Lab)

Table SM2.7 Single-grain muscovite total fusion ${ }^{40} \mathrm{Ar} /{ }^{39} \mathrm{Ar}$ isotope compositions (University of Alaska Fairbanks Lab)

Table SM3.1

Sample Locations from the Whale Mountain allochthon

Table SM3.2 LA-ICPMS U-Pb isotopic data

(University of Arizona Lab).

Table SM3.3

Hf isotopic data (University of Arizona Lab). 


\section{LIST OF PLATES}

PLATE 1: $\quad$ Preliminary geological map of the Kongakut River, Arctic National wildlife refuge, northeastern Brooks Range, Alaska

PLATE 2: $\quad$ Preliminary geological map of the upper Jago and Aichilik rivers, Arctic National wildlife refuge, northeastern Brooks Range, Alaska 


\section{Chapter 1: Death of an ocean - birth of an orogen: An}

\section{introduction to the tectonic history of the North Slope subterrane}

\section{and its role in the assembly of the Arctic Alaska-Chukotka}

\section{microplate}

Closing an ocean basin requires subduction of dense oceanic lithosphere. The final phase of ocean closure often culminates in the collision between two continental blocks, or terranes, resulting in widespread deformation and metamorphism, uplift of an orogenic belt, and the deposition of a thick wedge of siliciclastic sediment. This is the process of accretionary tectonics. In most cases, the remnants of the subduction zone, and the intervening ocean basin that once separated the two blocks, are almost completely removed from the geological record.

Nevertheless, these features are key to delineating accreted terrane boundaries and understanding the geodynamic and paleogeographic history of assembled orogens.

Preserved in the rock record of North America is a long-lived history of accretionary tectonics. The premier example is the North American Cordillera, a rugged chain of mountains that extend from southern Mexico to Arctic Alaska (Fig. 1.1). Recent tectonic reconstructions have proposed that several Cordilleran terranes have ties to the early Paleozoic Arctic realm, including the paleocontinents of northeastern (NE) Laurentia, northern Baltica, and/or Siberia. (e.g. Colpron and Nelson, 2011; Miller et al. 2011; Cocks and Torsvik, 2011; Metelkin et al., 2014; Strauss et al., 2017). Although no consensus among the models exists regarding the geodynamic pathways of individual terranes, or how these terranes were assembled into the Cordillera, most models call upon translation and/or deformation of terranes along the northern 


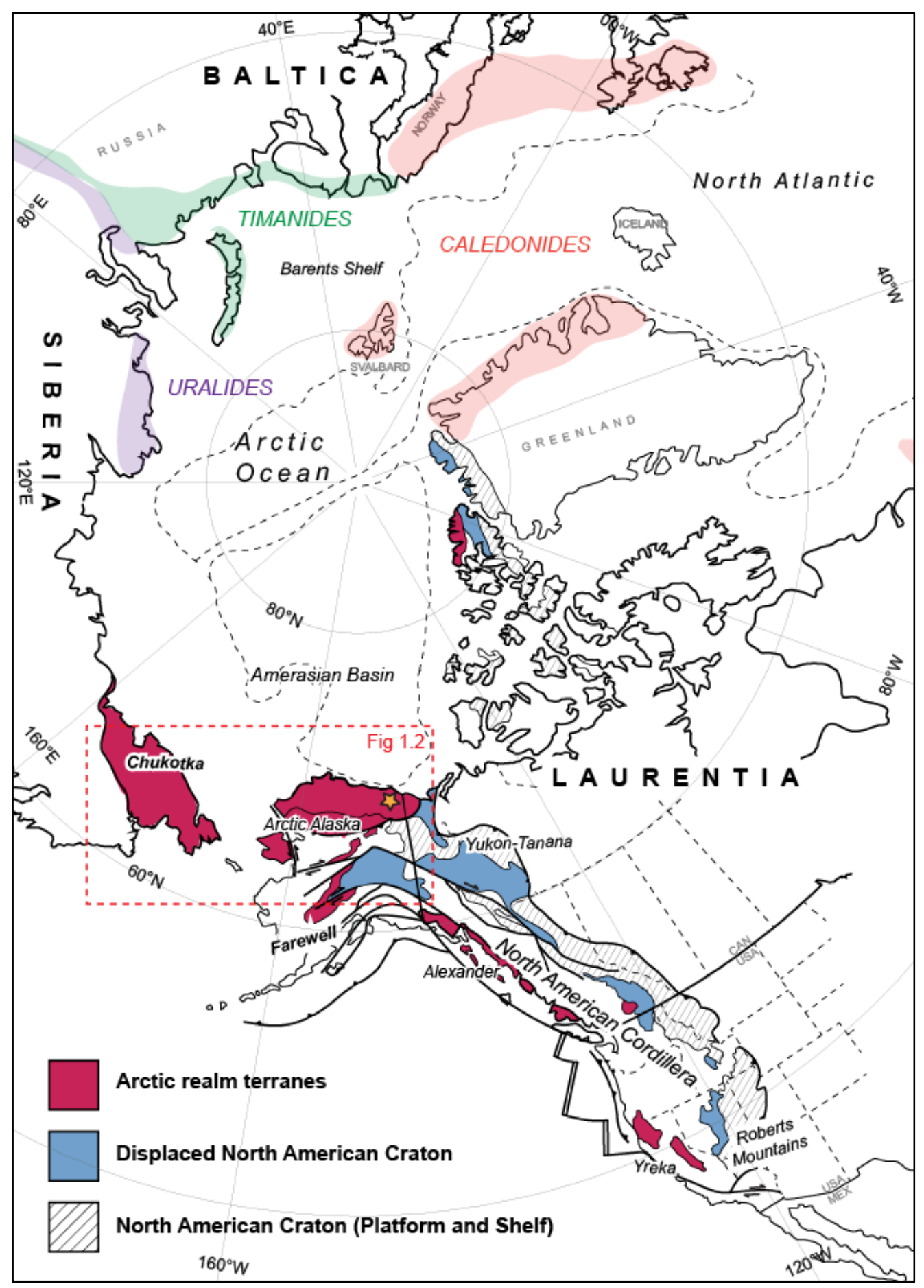

Figure 1.1: Simplified map of pertinent Proterozoic and Paleozoic orogenic belts, terranes, and cratons mapped onto the modern circum-Arctic continental margins and modified from Colpron and Nelson (2011) and Miller et al. (2011). Star indicates field area of this study. 
(present coordinates) margin of Laurentia during the closure of the Iapetus Ocean and the onset of the Caledonian orogeny of East Greenland and Scandinavia (e.g. Colpron and Nelson, 2011).

Lower Paleozoic rocks from the composite Arctic Alaska-Chukotka microplate of northern Yukon, northern Alaska, and NE Russia (Fig. 1.2), preserve the most obvious link between the North American Cordillera and the Arctic realm. Its Mesozoic-Cenozoic configuration and geodynamic history is related to the southward (present coordinates) retreat of the paleo-Pacific margin and the opening of the Amerasian Basin of the Arctic Ocean (e.g., Moore et al., 1994; 2015 Miller et al., 2018), but the early Paleozoic origins of the Arctic Alaska-Chukotka microplate are less certain. A growing body of multidisciplinary evidence suggests that the Arctic Alaska-Chukotka microplate formed by suturing of previously independent terranes in a middle Paleozoic collisional event (e.g., Amato et al., 2009; Miller et al., 2011; 2006; Strauss et al., 2013; 2017). These independent terranes are recognized by their Neoproterozoic and lower Paleozoic affinities to different paleocontinents. Chukotka, the Seward Peninsula, and portions of the southern Brooks Range restore to the Barents Shelf (Fig. 1.1), where sedimentary and igneous rocks formed in response to the Neoproterozoic-Middle Cambrian Timanide orogeny, along the margins of Baltica or as peri-Siberian terranes (e.g. Patrick and McClelland 1995; Blodgett et al., 2002; Dumoulin et al., 2002, 2014; Miller et al., 2011, 2006; Amato et al., 2009, 2014; Till et al., 2014a, 2014b; Gottlieb et al., 2018; Hoiland et al., 2018). Conversely, rocks in the NE Brooks Range, Lisburne Peninsula, and North Slope subsurface (Colville Basin) are unequivocally linked to the northern margin of Laurentia (Dutro et al., 1972; Moore et al., 1994; MacDonald et al., 2009; Strauss et al. 2013; 2018a, 2018b; Cox et al., 2015; McClelland et al., 2015; Lane et al., 2016; Johnson et al., 2016, 2018; Colpron et al. 2018; Nelson et al., 2018). How and when these disparate terranes were assembled to form the 


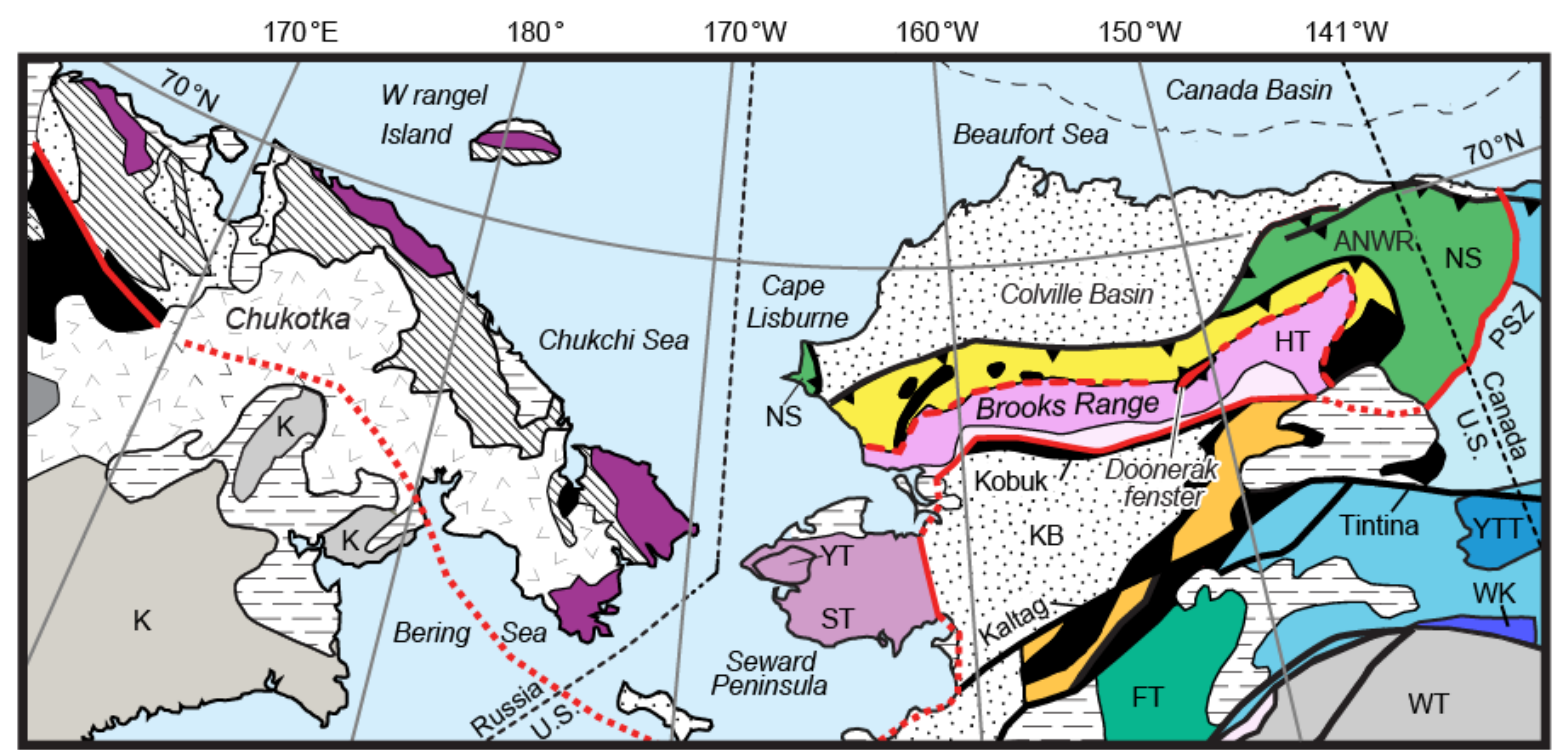

Arctic Alaska-Chukotka Microplate (AACM)

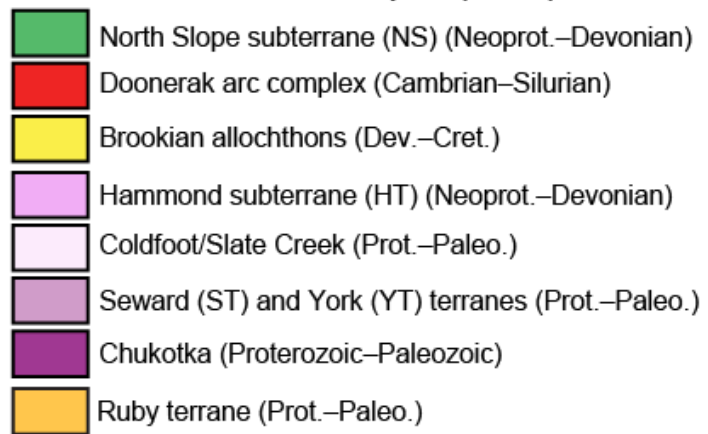

AACM overlap basins and terranes

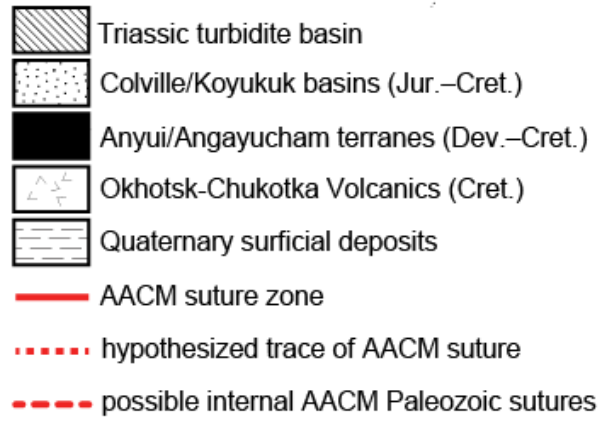

Adjacent Units of Laurentia and Siberia

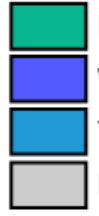

Farewell terrane (FT) (Neoproterozoic-Cretaceous)

Windy-Kluane-Coast terranes (WK) (Mesozoic-Cenozoic)

Yukon-Tanana terrane (YTT) (Devonian-Permian)

Koryak (K) and Wrangellia (WT) terranes (Mesozoic-Cenozoic)

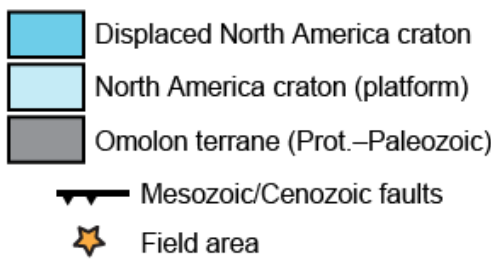

Figure 1.2: Simplified tectono-stratigraphic map of the composite Arctic Alaska-Chukotka microplate (AACM) after Mull (1982), Miller et al. (2006; 2011), Amato et al. (2009), Moore et al. (1994, 2015), and Strauss et al. (2017, 2018). Prot.-Proterozoic; PSZ-Porcupine Shear Zone; Paleo.- Paleozoic; ANWR-Arctic National Wildlife Refuge. 
larger Arctic Alaska-Chukotka microplate remains uncertain because no definitive suture zones have been identified.

Strauss et al. (2013; 2017) and Hoiland et al. (2018) proposed that Neoproterozoic-lower Paleozoic rocks across Arctic Alaska are divided into two groups of crustal fragments, including (1) the North Slope subterrane and (2) the southwestern subterranes, and are separated by an east-west trending suture zone locally marked by the lower Paleozoic Doonerak arc complex in the central Brooks Range (Fig. 1.2). The continuation of this presumed suture zone, however, is unmapped, as it is either buried beneath Devonian-Cretaceous sedimentary rocks of the Brookian allochthons or it resides in the subsurface of the Colville Basin. The central argument of this study is that a relic of this suture zone, herein defined as the Whale Mountain allochthon, was thrusted onto the margin of the parautochthonous North Slope subterrane during the assembly of the Arctic Alaska-Chukotka microplate, perhaps in concert with the final closure of the Iapetus Ocean and the Caledonian orogeny.

What follows is a collection of field observations, radiometric ages, newly identified trilobite faunas, igneous geochemical data, and petrographical descriptions from rocks exposed in the Arctic National Wildlife Refuge of the NE Brooks Range. The data are presented in three standalone chapters, two of which have been published in peer-reviewed journals (Chapters 2 and 3), and the third (Chapter 4) will be submitted for future publication. All three chapters heavily rely on observations gathered over the course of four field campaigns in the NE Brooks Range, spanning from 2012 to 2015.

Chapter 2 (Johnson et al., 2016) presents detrital zircon U-Pb and muscovite 40Ar/39Ar radiometric ages from a Neoproterozoic-Upper Devonian(?), mixed carbonate and siliciclastic, basinal succession. The data support correlations to time-equivalent sedimentary units in the 
Franklinian basin of Arctic Canada and record a pronounced provenance shift linked to the uplift and erosion of the Caledonian orogen of present-day Greenland. This chapter also introduces the Whale Mountain allochthon, a Cambrian-Middle Ordovician structural complex of igneous and marine sedimentary rocks that are in fault contact with the underlying Neoproterozoic-Upper Devonian(?) basinal succession.

Chapter 3 (Johnson et al., 2018) expands on the geological history of the Whale Mountain allochthon by coupling igneous petrology, $\mathrm{U}-\mathrm{Pb}$ geochronology, and trilobite paleontology. It proposes that the allochthon formed as a series of volcanic islands that hosted unique, endemic trilobite faunas, which evolved in isolation, or with limited interchange with, the endemic faunas of the Laurentian platform. The proposed model aligns with the interpretations from Chapter 2, suggesting that the North Slope subterrane restores to the NE margin of Laurentia in the early Paleozoic and that the Whale Mountain allochthon represents an Arctic equivalent of the Iapetus suture observed in eastern North America and western Europe and Scandinavia.

The last chapter, Chapter 4 (unpublished), presents two 1:75,000 geological maps from the NE Brooks Range, which build on the findings from chapters 2 and 3 to elucidate the structural style and the stratigraphic architecture of the region. It also presents a collection of additional field observations and structural data not presented in the other chapters. The maps, cross sections, and structural data show that the Whale Mountain allochthon was emplaced in concert with the locally-defined Romanzof orogeny in the Early-Middle Devonian and was subsequently deformed by Cenozoic phases of the Brookian orogeny. 


\section{REFERENCES}

Amato, J.M., Aleinikoff, J.N., Akinin, V.V., McClelland, W.C., and Toro, J., 2014, Age, chemistry, and correlations of Neoproterozoic -Devonian igneous rocks of the Arctic Alaska-Chukotka terrane: An overview with new U-Pb ages, in Dumoulin, J.A., and Till, A.B., eds., Reconstruction of a Late Proterozoic to Devonian Continental Margin Sequence, Northern Alaska: Its Paleogeographic Significance and Contained Base-Metal Sulfide Deposits: Geological Society of America Special Paper, v. 506, p. 29-57, doi: $10.1130 / 2014.2506(02)$.

Amato, J.M., Toro, J., Miller, E.L., Gehrels, G.E., Farmer, G.L., Gottlieb, E.S., and Till, A.B., 2009, Late Proterzoic-Paleozoic evolution of the Arctic Alaska-Chukotka terrane based on $\mathrm{U}-\mathrm{Pb}$ igneous and detrital zircon ages: Implications for Neoproterozoic paleogeographic reconstructions: Bulletin of the Geological Society of America, v. 121, no. 9, p. 1219-1235, doi: 10.1130/B26510.1.

Blodgett, R.B., Rohr, D.M., and Boucot, A.J., 2002, Paleozoic links among some Alaskan accreted terranes and Siberia based on megafossils, in Miller, E.L., Grantz, A., and Klemperer, S.L. eds., Tectonic Evolution of the Bering Shelf-Chukchi Sea-Arctic Margin and Adjacent Landmasses, Geological Society of America Special Paper 360, p. $272-290$.

Colpron, M., McClelland, W.C., and Strauss, J.V., 2018, Detrital zircon U-Pb geochronological and Hf isotopic constraints on the geological evolution of North Yukon, in Piepjohn, K., Strauss, J.V., Reinhardt, L., and McClelland, W.C., eds., Circum-Arctic Structural Events: Tectonic Evolution of the Arctic Margins and Trans-Arctic Links with Adjacent Orogens: Geological Society of America Special Paper 541, doi: 10.1130/2018.2541(19). 
Colpron, M., and Nelson, J.L., 2011, A Palaeozoic NW Passage and the Timanian, Caledonian and Uralian connections of some exotic terranes in the North American Cordillera, in Spencer, A.M., Embry, A.F., Gautier, D.L., Stoupakova, A. V., and Sørensen, K. eds., Arctic Petroleum Geology, Geological Society of London Memoir 35, p. 463-484.

Cocks, L.R.M., and Torsvik, T.H., 2011, The Palaeozoic geography of Laurentia and western Laurussia: A stable craton with mobile margins: Earth-Science Reviews, v. 106, p. 1-51, doi: 10.1016/j.earscirev.2011.01.007.

Dumoulin, J. A, Harris, A.G., Gagiev, M., Bradley, D.C., Repetski, J.E., and Anonymous, 2002, Lithostratigraphic, conodont, and other faunal links between lower Paleozoic strata in northern and central Alaska and northeastern Russia; Tectonic evolution of the Bering Shelf-Chukchi Sea-Arctic margin and adjacent landmasses, in Miller, E.L., Grantz, A., and Klemperer, S.L. eds., Special Paper - Geological Society of America, Geological Society of America Special Paper 360, Boulder, Colorado, p. 291-312.

Dumoulin, J.A., Harris, A.G., and Repetski, J.E., 2014, Carbonate rocks of the Seward Peninsula, in Dumoulin, J.A., and Till, A.B., eds., Reconstruction of a Late Proterozoic to Devonian Continental Margin Sequence, Northern Alaska: Its Paleogeographic Significance and Contained Base-Metal Sulfide Deposits: Geological Society of America Special Paper 506, p. 59-110.

Cox, G.M., Strauss, J.V., Halverson, G.P., Schmitz, M.A., McClelland, W.C., Stevenson, R.S., and Macdonald, F.A., 2015, Kikiktat volcanics of Arctic Alaska-Melting of harzburgitic mantle associated with the Franklin large igneous province: Lithosphere, v. 7, no. 3, p. $275-295$. 
Dutro Jr., J.T., Brosgé, W.P., and Reiser, H.N., 1972, Significance of recently discovered Cambrian fossils and reinterpretation of Neruokpuk Formation, northeastern Alaska: American Association of Petroleum Geologists Bulletin, v. 56, p. 808-815.

Gottlieb, E. S., Pease, V., Miller, E. L., \& Akinin, V. V., 2018, Neoproterozoic basement history of Wrangel Island and Arctic Chukotka: integrated insights from zircon $\mathrm{U}-\mathrm{Pb}, \mathrm{O}$ and $\mathrm{Hf}$ isotopic studies, in Pease, V.L. and Coakley, B.J. eds., Circum-Arctic Lithosphere Evolution, Geological Society, London, Special Publications, 460, p. 183-206

Hoiland, C.W., Miller, J.J., Pease, V., and Hourigan, J.K., 2018, Detrital zircon U-Pb geochronology and Hf isotope geochemistry of metasedimentary strata in the southern Brooks Range: constraints on Neoproterozoic-Cretaceous evolution of Arctic Alaska, in Pease, V.L. and Coakley, B.J. eds., Circum-Arctic Lithosphere Evolution, Geological Society, London, Special Publications, 460, p. 121-158

Johnson, B.G., Strauss, J.V., Taylor, J.F., Ward, W.P., Colpron, M., McClelland, W.C., and Toro, J., 2018, The Whale Mountain allochthon: A relic of the Iapetus Ocean preserved in the northeastern Brooks Range of Alaska and Yukon, in Piepjohn, K., Strauss, J.V., Reinhardt, L., and McClelland, W.C., eds., Circum-Arctic Structural Events: Tectonic Evolution of the Arctic Margins and Trans-Arctic Links with Adjacent Orogens: Geological Society of America Special Paper 541, https://doi.org/10.1130/2018.2541(20).

Johnson, B.G., Strauss, J. V., Toro, J., Benowitz, J.A., Ward, W.P., and Hourigan, J.K., 2016, Detrital geochronology of pre-Mississippian strata in the northeastern Brooks Range, Alaska: Insights into the tectonic evolution of northern Laurentia: Lithosphere, v. 8, p. 649-667, doi: 10.1130/L533.1. 
Lane, L.S., Gehrels, G.E., and Layer, P.W., 2016, Provenance and paleogeography of the Neruokpuk Formation, northwest Laurentia: An integrated synthesis: Geological Society of America Bulletin, v. 129, p. 239-257, doi: 10.1130/B31234.1.

MacDonald, F. a., McClelland, W.C., Schrag, D.P., and MacDonald, W.P., 2009, Neoproterozoic glaciation on a carbonate platform margin in Arctic Alaska and the origin of the North slope subterrane: Bulletin of the Geological Society of America, v. 121, no. 3, p. 448473, doi: 10.1130/B26401.1.

McClelland, W.C., Colpron, M., Piepjohn, K., von Gosen, W., Ward, W.P., and Strauss, J.V., 2015, Preliminary detrital zircon geochronology of the Neruokpuk Formation in the Barn Mountains, Yukon, in MacFarlane, K.E., Nordling, M.G., and Sack, P.J., eds., Yukon Exploration and Geology 2014: Yukon Geological Survey, p. 123-143.

Metelkin, D.V., Vernikovsky, V. a., and Matushkin, N.Y., 2015, Arctida between Rodinia and Pangea: Precambrian Research, v. 259, p. 114-129, doi:

10.1016/j.precamres.2014.09.013.

Miller, E.L., Kuznetsov, N., Soboleva, a., Udoratina, O., Grove, M.J., and Gehrels, G.E., 2011, Baltica in the Cordillera? Geology, v. 39, no. 8, p. 791-794, doi: 10.1130/G31910.1.

Miller, E.L., Meisling, K.E., Akinin, V.V., Brumley, K., Coakley, B.J., Gottlieb, E.S., Hoiland, C.W., O’Brien, T.M., Soboleva, A., and Toro, J., 2018, Circum-Arctic Lithosphere Evolution (CALE) Transect C: displacement of the Arctic Alaska-Chukotka microplate towards the Pacific during opening of the Amerasia Basin of the Arctic, in Pease, V. and Coakley, B., eds., Circum-Arctic Lithosphere Evolution: Geological Society of London, Special Publications, v. 460, p. 57-120 
Miller, E.L., Toro, J., Gehrels, G.E., Amato, J.M., Prokopiev, A., Tuchkova, M.I., Akinin, V.V., Dumitru, T.A., Moore, T.E., and Cecile, M.P., 2006, New insights into Arctic paleogeography and tectonics from U-Pb detrital zircon geochronology: Tectonics, v. 25, TC3013, doi: 10.1029/2005TC001830.

Moore, T.E., O’Sullivan, P.B., Potter, C.J., and Donelick, R.A., 2015, Provenance and detrital zircon geochronologic evolution of lower Brookian foreland basin deposits of the western Brooks Range, Alaska, and implications for early Brookian tectonism: Geosphere, v. 11, p. 93-122, doi: 10.1130/GES01043.1.

Moore, T.E., Wallace, W.K., Bird, K.J., Karl, S.M., Mull, C.G., and Dillon, J.T., 1994, Geology of northern Alaska, in Plafker, G. and Berg, H.C. eds., The Geology of Alaska, Geological Society of America, The Geology of North America, v. G-1, Boulder, Colorado, p. 49-140.

Mull, C.G., 1982, Tectonic evolution and structural style of the Brooks Range: an illustrated summary, in Powers, R.B. ed., Geological studies of the Cordilleran thrust belt, Rocky Mountain Association of Geologists, Denver, Colo., p. 1-45.

Nelson, L.L., Strauss, J.V., Crockford, P.W., Cox, G.M., Johnson, B.G., Ward, W., Colpron, M., McClelland, W.C., and Macdonald, F.A., 2018, Geochemical constraints on the provenance of pre-Mississippian sedimentary rocks in the North Slope subterrane of Yukon and Alaska, in Piepjohn, K., Strauss, J.V., Reinhart, L., and McClelland, W.C., eds., Circum-Arctic Structural Events: Tectonic Evolution of the Arctic Margins and Trans-Arctic Links with Adjacent Orogens: Geological Society of American Special Paper 541, doi: 10.1130/2018.2541(24). 
Patrick, B.E., and McClelland, W.C., 1995, Late Proterozoic granitic magmatism on Seward Peninsula and a Barentian origin for Arctic Alaska - Chukotka: Geology, v. 23, no. 1, p. $81-84$.

Strauss, J. V., Hoiland, C.W., Ward, W.P., Johnson, B.G., Nelson, L.L., and McClelland, W.C., 2017, Orogen transplant: Taconic-Caledonian arc magmatism in the central Brooks Range of Alaska: Geological Society of America Bulletin, v. 129, no. 5-6, p. 649-676, doi: 10.1130/B31593.1.

Strauss, J.V., Johnson, B.G., Ward, W.P., Nelson L.L., McClelland, W.C., 2018a, PreMississippian stratigraphy and provenance of the North Slope subterrane of Arctic Alaska II: Basinal sediments of the northeastern Brooks Range and their significance in circum-Arctic evolution in in Piepjohn, K., Strauss, J.V., Reinhardt, L., and McClelland, W.C., eds., Circum-Arctic Structural Events: Tectonic Evolution of the Arctic Margins and Trans-Arctic Links with Adjacent Orogens: Geological Society of America Special Paper 541

Strauss, J.V., Macdonald, F.A., and McClelland, W.C., 2018b, Pre-Mississippian stratigraphy and provenance of the North Slope subterrane of Arctic Alaska I: Platformal rocks of the northeastern Brooks Range and their signifi cance in circum-Arctic evolution, in Piepjohn, K., Strauss, J.V., Reinhardt, L., and McClelland, W.C., eds., Circum-Arctic Structural Events: Tectonic Evolution of the Arctic Margins and Trans-Arctic Links with Adjacent Orogens: Geological Society of America Special Paper 541, doi:

$10.1130 / 2018.2541(22)$. 
Strauss, J. V., MacDonald, F.A., Taylor, J.F., Repetski, J.E., and McClelland, W.C., 2013, Laurentian origin for the North Slope of Alaska: Implications for the tectonic evolution of the Arctic: Lithosphere, v. 5, p. 477-482, doi: 10.1130/L284.1.

Till, A.B., Amato, J.M., Aleinikoff, J.N., and Bleick, H.A., 2014a, U-Pb detrital zircon geochronology as evidence for the origin of the Nome Complex, northern Alaska, and implications for regional and trans-Arctic correlations, in Dumoulin, J.A., and Till, A.B., eds., Reconstruction of a Late Proterozoic to Devonian Continental Margin Sequence, Northern Alaska: Its Paleogeographic Significance and Contained Base-Metal Sulfide Deposits: Geological Society of America Special Paper 506, p. 111-131.

Till, A.B., Dumoulin, J.A., Ayuso, R.A., Aleinikoff, J.N., Amato, J.M., Slack, J.F., and Shanks, W.C.P., III, 2014b, Reconstruction of an early Paleozoic continental margin basin on the nature of protoliths in the Nome Complex, Seward Peninsula, Alaska, in Dumoulin, J.A., and Till, A.B., eds., Reconstruction of a Late Proterozoic to Devonian Continental Margin Sequence, Northern Alaska: Its Paleogeographic Significance and Contained Base-Metal Sulfide Deposits: Geological Society of America Special Paper 506. 


\title{
Chapter 2: Detrital geochronology of pre-Mississippian strata in
}

\author{
the northeastern Brooks Range, Alaska: Insights into the
}

\section{tectonic evolution of northern Laurentia}

\author{
Ben G. Johnson'1, Justin V. Strauss², Jaime Toro ${ }^{1}$, Jeff A. Benowitz ${ }^{3}$, William P. Ward ${ }^{4}$, \\ Jeremy K. Hourigan 5 \\ ${ }^{1}$ Department of Geology and Geography, West Virginia University, Morgantown, West Virginia, \\ 26506 USA \\ ${ }^{2}$ Department of Earth Sciences, Dartmouth College, Hanover, New Hampshire 03755, USA \\ ${ }^{3}$ Geophysical Institute, University of Alaska Fairbanks, Fairbanks, Alaska 99775, USA \\ ${ }^{4}$ Department of Earth and Environmental Sciences, University of Iowa, Iowa City, Iowa 52242, \\ USA
}

${ }^{5}$ Department of Earth and Planetary Sciences, University of California-Santa Cruz, Santa Cruz, California 95064, USA

\begin{abstract}
The Arctic Alaska terrane of northern Alaska and Yukon is one of several exotic terranes in the North American Cordillera with putative early Paleozoic connections to the northern Caledonian-Appalachian orogen. The $\mathrm{U}-\mathrm{Pb}$ and ${ }^{40} \mathrm{Ar} /{ }^{39} \mathrm{Ar}$ isotopic data from detrital minerals in pre-Mississippian sedimentary units of the northeastern Brooks Range are presented here to investigate the consequences of Caledonian orogenesis on sediment dispersal trends and the paleogeography of northern Laurentia. Neoproterozoic-Cambrian siliciclastic rocks of the informal Firth River group and the Neruokpuk Formation were most likely deposited along a passive margin that sourced Archean and Paleoproterozoic basement rocks of the Canadian
\end{abstract}


shield and reworked Mesoproterozoic and younger sedimentary units. These strata are overlain by a Lower Ordovician-Lower Devonian succession of fine-grained siliciclastic turbidites, herein referred to as the Clarence River group, which records a prominent shift in provenance most likely associated with the onset of the Caledonian-Appalachian orogeny in northeast Laurentia. U-Pb detrital zircon age populations of ca. 470-420 and 990-820 Ma, along with ${ }^{40} \mathrm{Ar} /{ }^{39} \mathrm{Ar}$ detrital muscovite ages of ca. $470-430 \mathrm{Ma}$, support provenance connections with the East Greenland Caledonides, Pearya, and Svalbard. Partially reset ${ }^{40} \mathrm{Ar} /{ }^{39} \mathrm{Ar}$ ages in these sedimentary successions are linked to low-grade metamorphism associated with the EarlyMiddle Devonian Romanzof orogeny, a poorly understood tectonic event in the Brooks Range that is possibly associated with the emplacement of an allochthonous oceanic assemblage, herein named the Whale Mountain allochthon.

\section{INTRODUCTION}

The expansion of continental margins typically occurs through the process of accretionary tectonics, whereby crustal fragments, or terranes, composed of intraoceanic island arcs, ophiolites, rifted continental fragments, microcontinents, and accretionary complexes are progressively sutured to the edge of a continent (e.g., Dewey and Horsfield, 1970; Coney et al., 1980; Moores, 1982; Saleeby, 1983; Schermer et al., 1984; Şengör et al., 1993). During the Phanerozoic, the Laurentian continent expanded along two major accretionary plate margins: the Caledonian-Appalachian orogen and the North American Cordillera. Numerous plate restorations link these two orogens by proposing that several exotic terranes (e.g., Arctic Alaska, Farewell, Alexander, Klamath-Sierra, and Pearya), now within the North American Cordillera and Canadian Arctic (Fig. 2.1A), were displaced from the northern Caledonian or paleo-Arctic realm 
and translated along the northern margin of Laurentia (e.g., Colpron and Nelson, 2011; Cocks and Torsvik, 2011; Miller et al., 2011).

The Arctic Alaska terrane encompasses the Brooks Range, North Slope, and Seward Peninsula of northern Alaska, all of which contain several independent pre-Mississippian and Mesozoic crustal fragments, or subterranes, that host unique stratigraphic sequences (see review in Moore et al., 1994). During the Jurassic and Early Cretaceous, the south-facing passive margin of the Arctic Alaska terrane collided with the Koyukuk arc; this suture zone is marked by the Angayuchum terrane (Fig. 2.1B), a Devonian-Jurassic assemblage of ophiolitic fragments and pelagic sedimentary deposits (Moore et al., 1994). Some suggest that this suture zone extends westward across the Bering Sea to connect with the South Anyui suture zone of the Chukotka Peninsula, Arctic Russia, forming the composite Arctic Alaska-Chukotka microplate (e.g., Hubbard et al., 1987; Miller et al., 2006; Amato et al., 2009; Moore et al., 2015); however, distinct contrasts in structural styles along both the South Anyui and Angayuchum suture zones may imply different pre-Cretaceous histories for Arctic Alaska and Chukotka (Amato et al., 2015; Till, 2016).

Most Arctic plate models restore the northern edge of Arctic Alaska terrane as the conjugate margin to the Canadian Arctic Islands in Mesozoic time (e.g., Lawver and Scotese, 1990; Grantz et al., 2011). This is achieved by closing the Canada Basin by way of $\sim 60^{\circ}$ rotation of Arctic Alaska about a pole located near the Mackenzie Delta during the Early Cretaceous (Gottlieb et al., 2014, and references therein), but many issues remain unresolved regarding the evolution of the Canada Basin (e.g., Lane, 1997; appendix of Lane et al., 2016). A lasting subject of contention also involves the early Paleozoic position of the North Slope of Arctic Alaska at the time of the Caledonian-Appalachian orogeny (ca. 470-350 Ma). A commonly accepted 


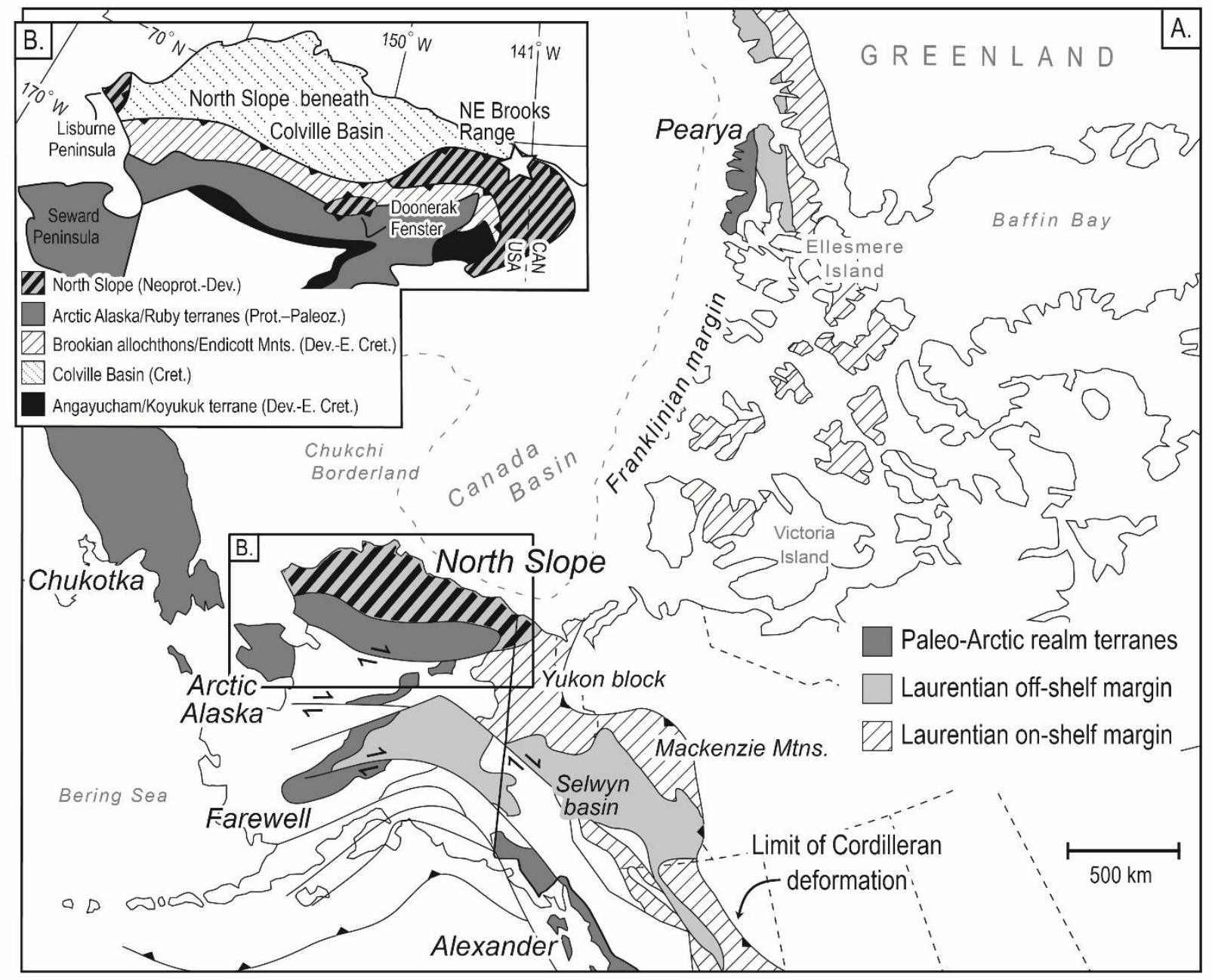

Figure 2.1: Generalized location maps. (A) The distribution of paleo-Arctic terranes in the northern Cordillera (modified from Colpron and Nelson, 2011). (B) Simplified tectonostratigraphic terrane map of northern Alaska (modified from Moore et al., 1994; 2015). Star indicates study area. NE_-northeastern; Prot.-Proterozoic; Dev.-Devonian; E. Cret.Early Cretaceous 
model is that pre-Mississippian strata of the northeastern (NE) Brooks Range were deposited along a Neoproterozoic-Early Devonian passive margin that developed north (in present coordinates) of the Yukon block of northwest Laurentia (Fig. 2.1), before being deformed in the Early-Middle Devonian Romanzof orogeny (e.g., Lane, 1991, 2007; Moore et al., 1994; Cecile et al., 1999; Colpron and Nelson, 2011; Beranek et al., 2010; Lane et al., 2016). In contrast, others have argued that the North Slope has pre-Mississippian origins in northeast Laurentia, and that it did not attain its pre-Canada Basin position until sometime before the Late Devonian or Early Mississippian (Sweeney, 1982; Dumoulin et al., 2000; Macdonald et al., 2009; Strauss et al., 2013; Cox et al., 2015). Resolving these conflicting interpretations has broad implications for Neoproterozoic-Paleozoic plate reconstructions of the circum-Arctic region and CaledonianAppalachian orogeny (Strauss et al., 2013); thus, our objective is to present new data pertaining to the structural and stratigraphic evolution of pre-Mississippian rocks in the NE Brooks Range to directly address these competing models.

\section{GEOLOGICAL FRAMEWORK}

\section{Pre-Mississippian Stratigraphy of the NE Brooks Range}

Pre-Mississippian strata of the North Slope of Arctic Alaska are well exposed in a series of east-west-trending antiforms that compose the NE salient of the Brooks Range (Fig. 2.2). These units are typically referred to as pre-Mississippian because of their regional truncation by a prominent sub-Mississippian unconformity, a characteristic feature of the NE Brooks Range and North Slope subsurface (Moore et al., 1994). A thick (1000-2000 m) succession of moderately to highly deformed quartzite, phyllite, and argillite called the Neruokpuk Formation (Leffingwell, 1919; Reed, 1968; Lane, 1991; Lane et al., 2016) is widely distributed in the Franklin, Romanzof, British, and Barn Mountains (Fig. 2.2). The exact age of the Neruokpuk 


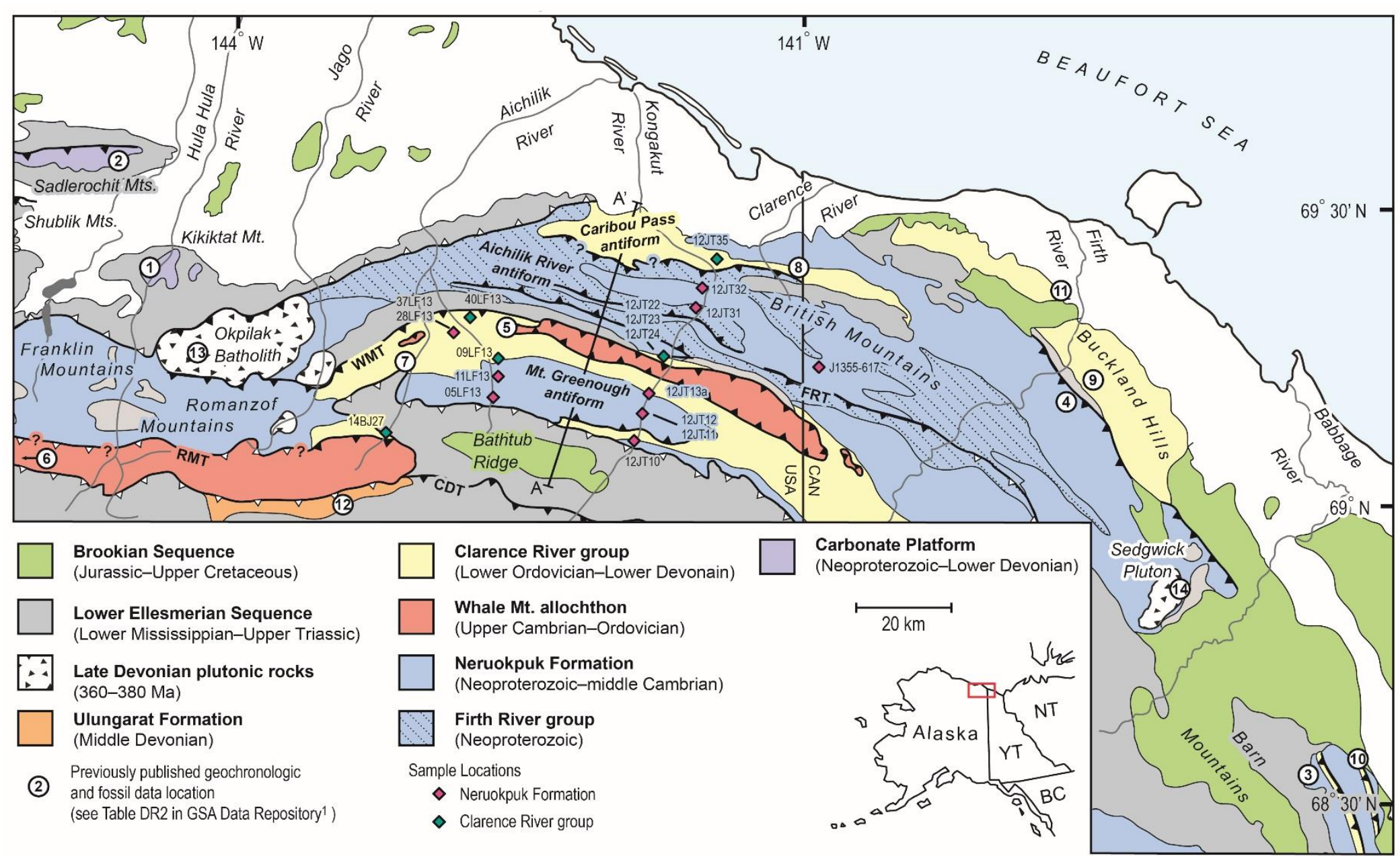

Figure 2.2: Simplified geologic map of the eastern half of the northeastern Brooks Range. Geology compiled after Reiser et al. (1980), Norris (1981a, 1981b), and Lane et al. (1995). Key structures: WMT—Whale Mountain thrust; RMT — Romanzof Mountain thrust; CDT — Continental Divide thrust (includes the Aichilik Pass thrust of Anderson et al., 1994); FRT—Firth River thrust. Solid teeth on thrust faults indicate disruption of stratigraphic section (old on young); open teeth indicate detachment surfaces along which there has been slip but no disruption of the stratigraphic section (young on old). Abbreviations: Mts. — mountains; YT—Yukon; NT— Northwest Territories; BC—British Columbia. 
Formation is not well known, but previously it was suggested that it ranges from Neoproterozoic to middle Cambrian(?) based on the occurrence of Oldhamia ichnofossils in the northern British and Barn Mountains of Yukon (Hofmann and Cecile, 1981; Lane and Cecile, 1989; Lane, 1991; Hofmann et al., 1994; Lane et al., 2016; see Table SM2.1 in the Supplemental Material section for a summary of age constraints on pre-Mississippian units of the NE Brooks Range). The Neruokpuk Formation overlies a highly deformed and poorly studied mixed carbonatesiliciclastic succession (Fig. 2.3), now recognized as the informal Firth River group in the northern British Mountains of Yukon (Lane et al., 2016). In Alaska, the Firth River group includes sequence D and E of Dutro et al. (1972), Domain III of Mull and Anderson (1991), and various carbonate and fine-grained siliciclastic units of Reiser et al. (1980).

In the southern British Mountains of Alaska, a highly deformed and imbricated sequence of predominately fine-grained siliciclastic units, situated below the rocks of the Whale Mountain allochthon, disconformably overlies the Neruokpuk Formation. In the Demarcation Point quadrangle, Reiser et al. (1980) divided these deposits into the following four map units: chert and phyllite (Ccp), calcareous siltstone and sandstone (Css), dark gray to black shale locally metamorphosed to phyllite (map unit $\mathrm{Cp}$ ), and a subordinate lithic sandstone unit (Cs). These map units were all assigned a Cambrian age based on a single locality of poorly preserved echinoderm debris and their assumed stratigraphic position beneath the trilobite-bearing limestone beds of the Whale Mountain volcanic rocks (Fig. 2.3; Reiser et al., 1980). Similar packages of interbedded chert, argillite, and lithic sandstone are broadly distributed throughout northern Yukon, particularly near the Alaska-Yukon border along the Clarence and Malcolm Rivers (Kelley et al., 1994; Lane et al., 1995), in the Buckland Hills region along the Firth River (Lane and Cecile, 1989), and in the Barn Mountains (Cecile, 1988; Cecile and Lane, 1991). Age 
constraints for these strata are provided by a limited number of fossil localities that include Lower Ordovician-upper Silurian (Pridoli) graptolites (Lenz and Perry, 1972; Reiser et al., 1980; Lane and Cecile, 1989; Lane et al., 1995; Norford, 1997). The upper age limit of this sequence is locally constrained by two conodont localities: an upper Silurian (Pridoli)-Lower Devonian (earliest Pragian) fauna collected along the Clarence River in Alaska (Lane et al., 1995) and a Lower Devonian (Emsian?) fauna collected at the very northern limit of the British Mountains (Norris, 1986). Both of these samples were collected from isolated talus slopes, so their stratigraphic positions within the greater pre-Mississippian succession remain somewhat ambiguous.

Lane et al. (2016) split these early Paleozoic units of northern Yukon into two general lithostratigraphic successions: a lower graptolitic-bearing succession of interbedded chert and argillite, and an upper dark gray shale and sandstone turbidite package with subordinate chertpebble conglomerate and limestone. The base of the lower succession is marked by a ridgeforming chert interval that contains Lower Ordovician graptolites (Lane and Cecile, 1989). A similar interval is mapped in the Barn Mountains of Yukon (Cecile, 1988; Cecile and Lane, 1991) and southern British Mountains of Alaska (unit Ccp of Reiser et al., 1980), where it presumably disconformably overlies the Neruokpuk Formation (Dutro et al., 1972). The base of the upper succession is uncertain. Geological mapping in the Buckland Hills region suggests that its contact with the lower succession is discordant (Lane and Cecile, 1989), whereas along the Clarence River and Barn Mountains the boundary between upper and lower succession is gradational (Kelley et al., 1994; Lane et al., 1995) or absent (Cecile, 1988; Cecile and Lane, 1991), respectively. Lane et al. (2016) referred to the lower succession as the Road River Group 
following correlations with equivalent strata in the Yukon block (Gordey and Anderson, 1993) and the upper succession as the informal Buckland Hills succession.

Because we view many of the map relationships as uncertain and the correlations with coeval strata in the Yukon block as suspect, we propose that this entire stratigraphic package should be consolidated into a single lithostratigraphic group, which we informally name the Clarence River group based on a possible type area near the headwaters of Clarence River in the northern British Mountains (Fig. 2.2). The motivation behind this consolidation is because the recognition and documentation of definitive lithostratigraphic boundaries within the different successions have not been established. Moreover, the group designation allows for subsequent separation of distinct formations with type sections when more geological, geochronological, and biostratigraphic data become available. We tentatively propose that the Buckland Hills succession of Lane et al. (2016) constitutes the uppermost formation of the Clarence River group. The base of the Clarence River group is marked by the prominent Ordovician chert interval that is distributed throughout Yukon and Alaska.

In the Romanzof Mountains and along a linear belt in the southern British Mountains, a thick (>700 m) structural complex composed of basalt flows, discontinuous carbonate beds, and an imbricated package of bedded chert, phyllite, and lithic tubidites structurally overlie the preMississippian sedimentary successions. In a broad sense the basalt flows, informally named the Whale Mountain volcanic rocks, geochemically resemble ocean-island basalt, showing enrichment in incompatible, large-ion lithophile, and high-field-strength elements (Moore, 1987; Goodfellow et al., 1995). The age of these volcanic rocks is constrained by upper Cambrian (Furongian) trilobites of Laurentian affinity discovered within the discontinuous carbonate beds that locally interfinger with the basalt flows (Dutro et al., 1972). The imbricated and folded 


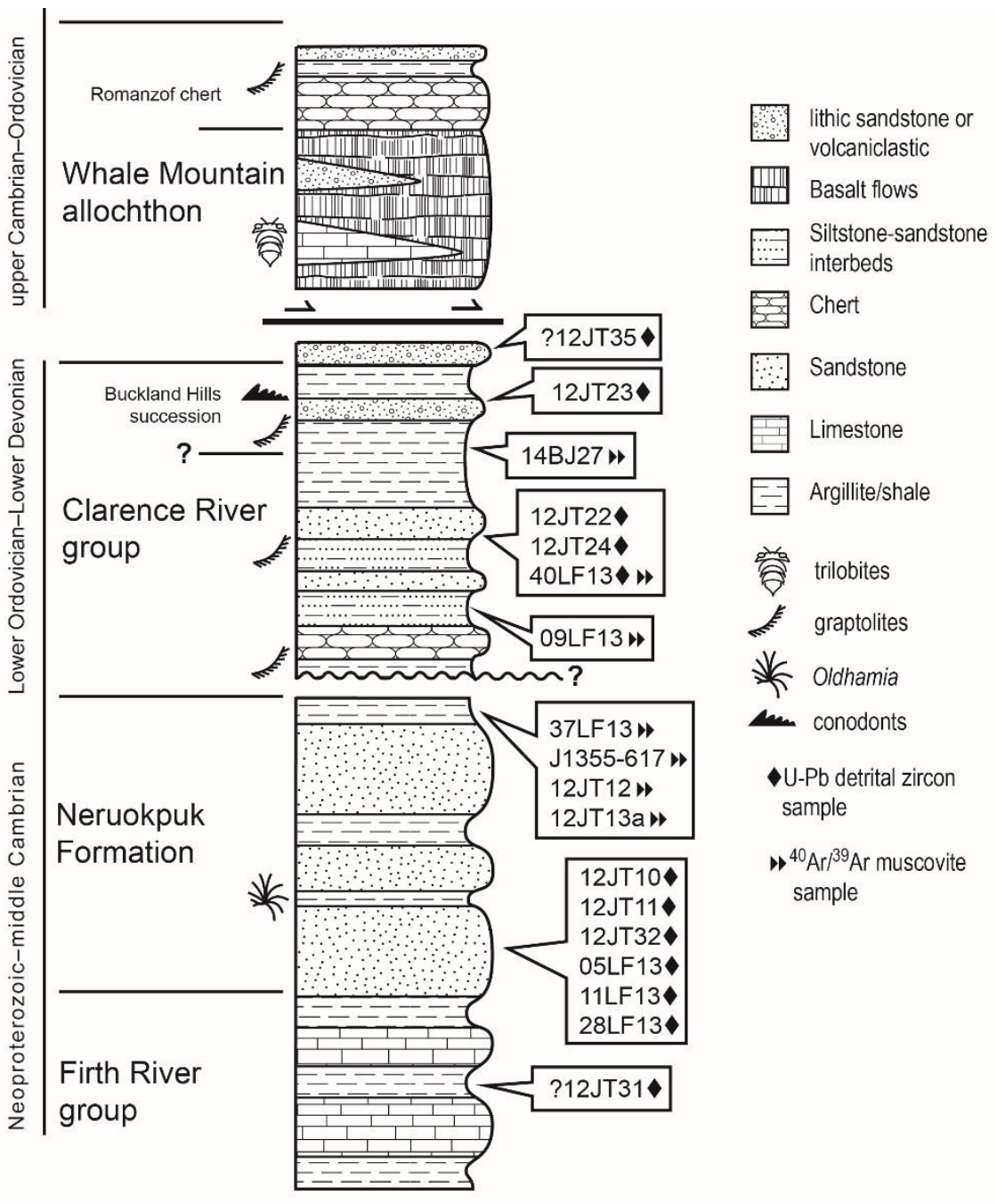

Figure 2.3: Schematic stratigraphic column of pre-Mississippian units in the eastern half of the northeastern (NE) Brooks Range (modified from Kelley et al., 1994). Stratigraphic positions of samples, indicated with sample number and conducted analysis, are approximated, and fossil constraints are from the Yukon side of the NE Brooks Range and may not correlate with sampled units in this study. 
package of bedded chert, phyllite, and lithic turbidite units is widely distributed in the Romanzof Mountains, particularly near the headwaters of the Jago and Aichilik Rivers (Fig. 2.2). Mull and Anderson (1991) informally named these units the Romanzof chert, and along strike in the southern Franklin Mountains, a lithologically similar succession of argillite and radiolarianbearing chert units contains upper Ordovician and possible lower Silurian (Llandovery) graptolite fossils (Moore and Churkin, 1984). The tectonic setting and structural relationships of these rocks are not well understood, and because we have yet to document any depositional and/or conformable relationships, we propose that their incorporation into the pre-Mississippian stratigraphy of the NE Brooks Range be ascribed to the emplacement of a now-dismembered thrust sheet, herein named the Whale Mountain allochthon (Figs. 2.3 and 2.4).

The pre-Mississippian rocks of the NE Brooks Range are crosscut by a suite of Late Devonian intrusive bodies (e.g., Okpilak batholith and Sedgwick pluton; Fig. 2.2), which yield U-Pb zircon ages of ca. 380-360 Ma (Dillon et al., 1987; Mortensen and Bell, 1991; Lane, 2007). These intrusive rocks share mineralogical and compositional similarities to S-type granites, implying that they were derived from the partial melting of lower crustal rocks (Sable, 1977; Newberry et al., 1986). Contact relationships with the older country rock, mainly the Neruokpuk Formation, are abrupt with a limited metamorphic aureole, possibly indicating shallow levels of emplacement and/or a shortage of hydrothermal fluids (Sable, 1977). In many places throughout the field area, the Mississippian Kekiktuk Conglomerate, the basal unit of the lower Ellesmerian sequence (e.g., Moore et al., 1994), overlies with angular unconformity on the pre-Mississippian sedimentary units and Late Devonian intrusive rocks. At the southern edge of the field area, near the headwaters of the Kongakut River (Fig. 2.2), the Kekiktuk Conglomerate also truncates the Middle Devonian Ulungarat Formation of Anderson et al. (1994), formerly 
unit Ds of Reiser et al. (1980). The Ulungarat formation consists of a >300-m-thick, coarseningupward succession of shallow-marine and terrigenous deposits that unconformably overlie the complexly deformed Romanzof chert of the Whale Mountain allochthon; however, this contact relationship is obscured by displacements along a major south-dipping Cenozoic thrust fault (the Aichilik Pass thrust of Anderson et al., 1994).

\section{Deformation in the NE Brooks Range}

The NE Brooks Range was affected by at least two major deformational events. PreMississippian rocks throughout the NE Brooks Range are highly strained into tight, east-trending folds that display a combination of subhorizontal and steeply dipping penetrative fabrics (e.g., Oldow et al., 1987; Lane, 2007). The fabrics are not present in the Middle Devonian Ulungarat formation, implying a regional pre-Middle Devonian phase of deformation (Anderson et al., 1994), now widely known as the Romanzof orogeny (Lane, 2007). The paleogeographic and tectonic setting of this pre-Middle Devonian deformation are not well constrained, although Lane (2007) inferred from field and subsurface data that deformation was localized along the ancestral margin of northwest Laurentia, where a continent-scale terrane encroached from the north (present coordinates) and progressively accreted to the margin in the Early-Middle Devonian. It is critical that this assumes a fixed position of the North Slope with respect to northwest Laurentia throughout the Paleozoic.

The latest phase of deformation in the NE Brooks Range relates to the Late Jurassic(?) to Miocene Brookian orogeny, which is considered to have evolved through two distinct episodes of north-directed contractional deformation (Moore et al., 1994, 2004, 2015). In the NE Brooks Range, Brookian deformation was accommodated by the formation of several regionally spaced antiforms (e.g., Mount Greenough and Aichilik River antiforms; Fig. 2.2). These are typically 
interpreted as a stacked duplex thrust system, with a floor thrust deep within the pre-

Mississippian sequence and a roof thrust in the Kayak Shale of the lower Ellesmerian sequence (e.g., Wallace and Hanks, 1990).

In our cross section through the eastern portion of the NE Brooks Range (Fig. 2.4), we illustrate the Brookian style of deformation as a series of large imbricated fault-bend folds that culminate to a detachment between 8 and $15 \mathrm{~km}$ below the surface, which is derived from previous structural studies in the region (Hanks, 1989; Peapples et al., 1997; Cole et al., 1999; Moore, 1999; O'Sullivan and Wallace, 2002). The ramps of the fault-bend folds are often represented by major thrust faults that are as much as $100 \mathrm{~km}$ in length, including the Whale Mountain and Romanzof Mountain thrusts (WMT and RMT; Fig. 2.2). Apatite fission-track and ${ }^{40} \mathrm{Ar} /{ }^{39} \mathrm{Ar}$ thermochronological data indicate that many of these basement-involved thrusts underwent significant Cenozoic displacement (Hanks, 1993; O’Sullivan, 1994; Peapples et al., 1997; O'Sullivan and Wallace, 2002).

Differentiating between Brookian and Romanzof deformation fabrics in the NE Brooks Range represents a significant challenge to the understanding of the regional structural architecture. Most structural models collectively treat pre-Mississippian units as rigid thrust panels that undergo no internal shortening in response to Brookian contraction (Hanks, 1989; Wallace and Hanks, 1990; Cole et al., 1999; Moore, 1999; O’Sullivan and Wallace, 2002); however, these assumptions are oversimplified and problematic. For example, in the Mount Greenough antiform, the primary study area for this research, the classical north-directed faultbend fold model (e.g., Wallace and Hanks, 1990; Moore, 1999) predicts that most of the structures and bedding planes should dip to the south (Fig. 2.4). In contrast, our field observations show that most of the pre-Mississippian units dip to the north, as illustrated in our 


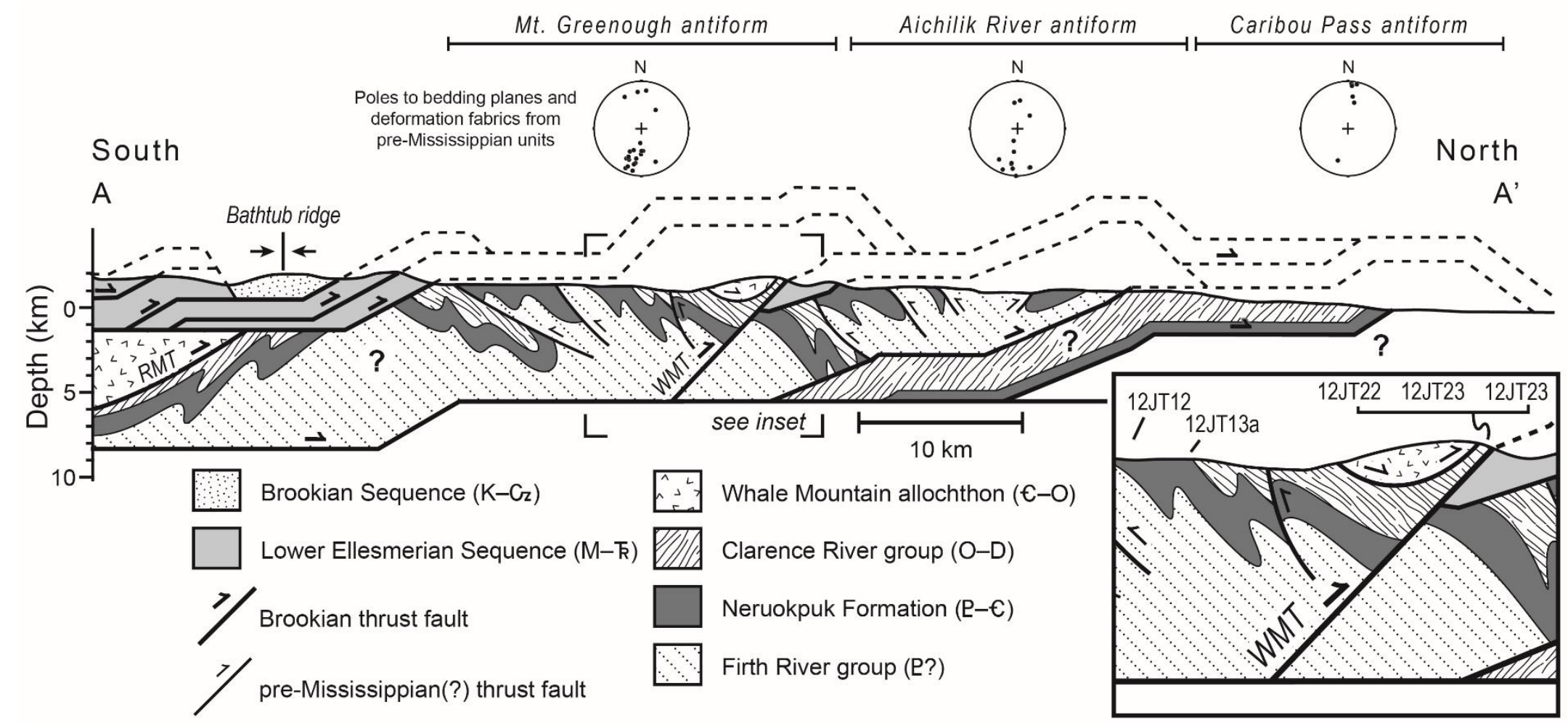

Figure 2.4: Cross section through the eastern half of the northeastern Brooks Range illustrating the major structural features and deformation trends with no vertical exaggeration (modified from Hanks, 1989; Wallace and Hanks, 1990; Moore, 1999). Approximate location of the section is shown in Figure 2.2. Pre-Mississippian structural features are constrained by field data along the Kongakut River, Alaska. Depth of detachment in the pre-Mississippian units is adopted from Hanks (1989) and Peapples et al. (1997). WMTWhale Mountain thrust. 
schematic cross section along the Kongakut River (Fig. 2.4). These structural simplifications also fail to explain the structural relationship between rocks of the Whale Mountain allochthon and Clarence River group, which cannot be restored by simple line-length restorations of a single fault-bend fold as modeled by Moore (1999). Although these issues are largely beyond the scope of this contribution, we highlight important issues brought to light by our new geochronological data that will guide future structural studies in the region.

\section{METHODS AND RESULTS}

\section{U-Pb Detrital Zircon Geochronology}

We analyzed 11 samples of sandstone from the NE Brooks Range for U-Pb detrital zircon geochronology by laser ablation-inductively coupled plasma-mass spectrometry (LA-ICPMS) at the University of California-Santa Cruz following the procedures outlined by Sharman et al. (2013). An additional sample (40LF13) was analyzed by combining LA-ICP-MS at Stockholm University with secondary ion mass spectrometry (SIMS) at the NordSIM facility at the Swedish Museum of Natural History following procedures outlined by Beranek et al. (2013a). The samples are separated into two distinct groups based on their major pre-Mississippian lithostratigraphic associations: (1) the Neoproterozoic-middle Cambrian Neruokpuk Formation (Leffingwell, 1919) and the Firth River group (Lane et al., 2016), and (2) the Lower OrdovicianLower Devonian Clarence River group, including the Buckland Hills succession of Lane et al. (2016). The sample descriptions, raw geochronologic data, and procedures for collecting and interpreting the data are provided in the Supplemental Material section. The individual ages from each sample were filtered on the basis of concordance between $206 \mathrm{~Pb} / 207 \mathrm{~Pb}$ and $206 \mathrm{~Pb} / 238 \mathrm{U}$ ratios, $\mathrm{U}$ and Th concentrations, and degree of uncertainty in the calculated ages (for a detailed 
discussion, see Supplemental Material section). These filtered subsets of the data are presented as stacked normalized age-probability plots (Figs. 2.5 and 2.6).

\section{Neruokpuk Formation and Firth River Group}

The majority of the Neruokpuk Formation samples were collected from a broad belt of predominately north-dipping strata exposed within the core of the Mount Greenough antiform in the southern British Mountains (Fig. 2.2). These samples generally consist of coarse- to finegrained, subrounded, quartz and sublithic arenites, with occasional feldspar, chert fragments, muscovite, and other accessory minerals. Most of these samples contain a complex assemblage of clay minerals that occupy interstitial space or compose the supporting matrix, and some samples have undergone intense deformation resulting in authigenic mica growth and pronounced strain shadows around individual quartz grains (Fig. SM2.1). Beds range between 0.5 and $2 \mathrm{~m}$ thick, are typically interbedded with intensely foliated green-gray argillite, and occasionally show flutes, scours, and Bouma A-D cycles. Two additional samples were collected from within the Aichilik River antiform in the northern British Mountains (Fig. 2.2). One sample (12JT32) was collected from an outcrop of units lithologically similar to the Neruokpuk samples collected in the southern British Mountains and to those described by Lane et al. (2016) in the northern British Mountains of Yukon. Another sample (12JT31) was collected from the phyllite and quartzite of Old Gungy Mountain (map unit pCpq of Reiser et al., 1980), which we assign to the Firth River group because of its inferred lower stratigraphic position with respect to the Neruokpuk Formation (Fig. 2.2). This sample was collected from an outcrop of subvertical, intensely foliated green to gray argillite and interbedded fine-grained quartzite, which is cut by numerous quartz veins that have undergone rotation from left-lateral, east-west shear. 
Samples from the Neruokpuk Formation and Firth River group yield populations of wellrounded to elongate zircon. All seven samples show similar $\mathrm{U}-\mathrm{Pb}$ age distributions with prominent Paleoproterozoic and Neoarchean peaks that are between ca. 2000 and 1700 Ma, 2400 and $2200 \mathrm{Ma}$, and 2600 and $2400 \mathrm{Ma}$ (Fig. 2.5). Mesoproterozoic zircons only constitute subordinate populations in most samples that range between ca. 1500 and 1100 Ma. The Firth River group sample (12JT31) is mostly indistinguishable from the other Neruokpuk samples, with a slightly more prominent population of Mesoproterozoic zircon grains ca. $1300 \mathrm{Ma}$. Sample 12JT10 is the only sample that contains young zircons, represented by two single-grain ages of $632 \pm 29 \mathrm{Ma}$ and $936 \pm 43 \mathrm{Ma}(2 \sigma \sigma)$.

\section{Clarence River Group}

Sandstone samples from the Lower Ordovician-Lower Devonian(?) Clarence River group are texturally and compositionally immature. Individual sample descriptions and photomicrographs are provided in the Supplemental Material section. Four of the samples (12JT22, 12JT23, 12JT24, and 40LF13) were collected from outcrops along the northern edge of the Mount Greenough antiform (Figs. 2.2 and 2.4) in map units Cp and Cs of Reiser et al. (1980). Three of these samples (12JT22, 12JT24, and 40LF13) consist of medium- to fine-grained, angular quartz grains with occasional feldspar and coarse-grained detrital muscovite (Fig. SM2.2). These samples have an abundant (>25\%) clay matrix, dominated by very fine mica, calcite, quartz, chlorite, and other clay minerals. Sample 12JT23 contains a variety of mediumto coarse-grained and angular clasts of monocrystalline and polycrystalline quartz, plagioclase feldspar, and chert, with minor volcanic and sedimentary lithic fragments, devitrified glass, and opaque minerals. The stratigraphic positions of each sample with respect to one another are uncertain, as the outcrops in this region are highly folded and possibly imbricated by minor 


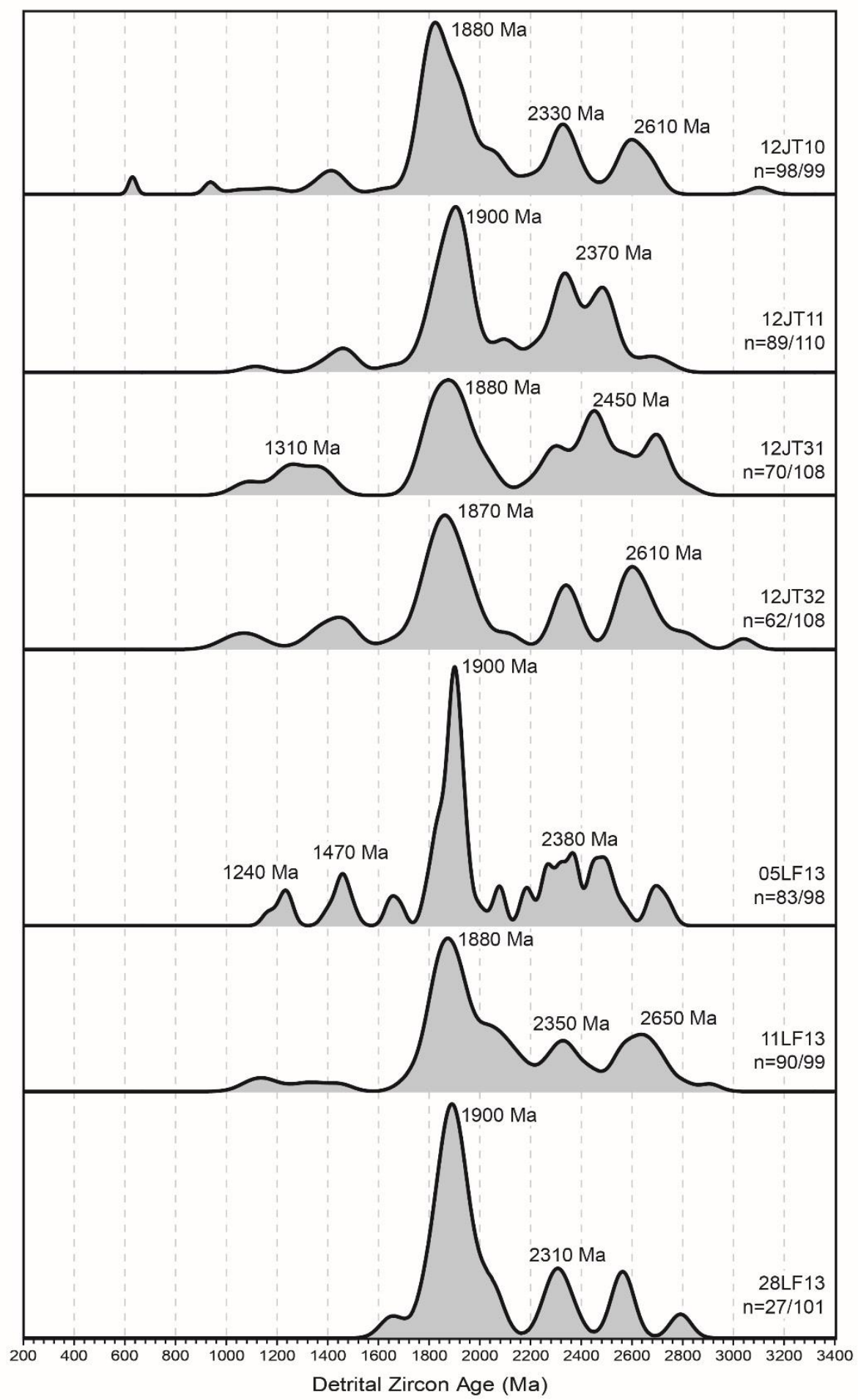

Figure 2.5: Normalized probability density plots of U-Pb detrital zircon ages from the Neruokpuk Formation. Ratio of analyses plotted versus total zircon analyzed is shown in upper right along with the sample number (see Fig. 2.2 for sample location). All analyses were conducted by laser ablation-inductively coupled plasma-mass spectrometry at the University of California Santa Cruz. The raw data and filtering methods are reported in Table SM2.3. 


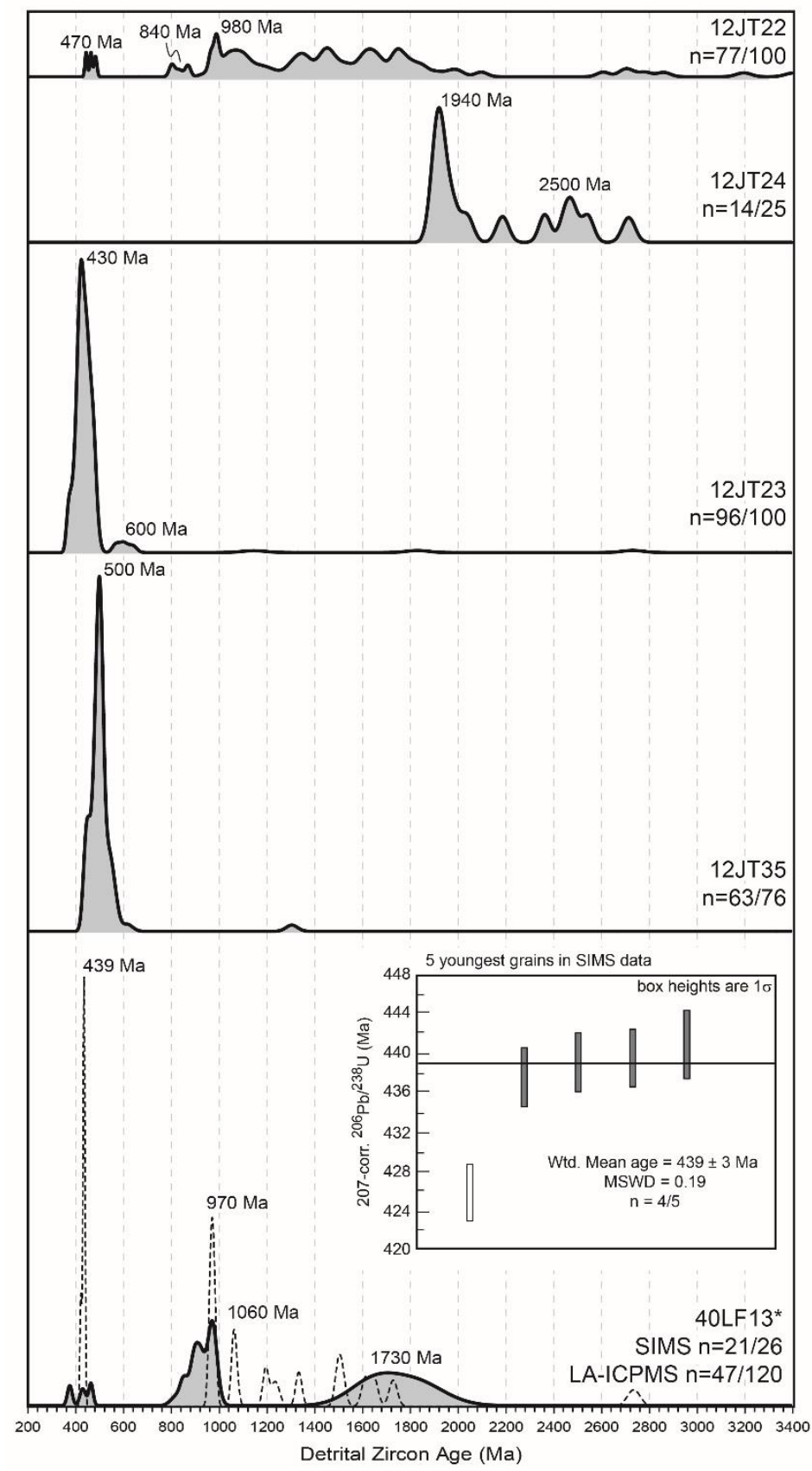

Figure 2.6: Normalized probability density plots of $\mathrm{U}-\mathrm{Pb}$ detrital zircon ages from the Clarence River group and one sample (12JT35) from the Ovc map unit of Reiser et al. (1980). Ratio of analyses plotted versus total zircon analyzed is shown in upper right along with the sample number (see Fig. 2.2 for sample location). Samples 12JT22, 12JT23, 12JT24, and 12JT35 were analyzed by laser ablation-inductively coupled plasma-mass spectrometry (LA-ICP-MS) at the University of California Santa Cruz and are reported in Table SM2.3. Sample 40LF13 (bottom) was analyzed by LA-ICP-MS at Stockholm University (grayfilled black line) and by secondary ion mass spectrometry (SIMS) at the NordSIM facility, Swedish Museum of Natural History (dashed black line). These analyses are reported in Tables SM2.4 and SM2.5. Wtd.-weighted; MSWD — mean square of weighted deviates. 
thrust faults. Beds range between 0.1 and $0.3 \mathrm{~m}$ thick, are typically interbedded with micaceous black siltstone or shale, and characterized by Bouma A-D cycles. A fifth sample (12JT35) was collected from a highly weathered outcrop of volcaniclastic and tuffaceous sandstone units in the northern British Mountains (map unit Ovc of Reiser et al., 1980), an area we refer to informally as the Caribou Pass antiform (Figs. 2.2 and 2.4). The sample contains medium- to fine-grained, subrounded to rounded opaque minerals, sericitized plagioclase, monocrystalline and polycrystalline quartz, volcanic rock fragments, and chert fragments in a clay-carbonate cement.

The distributions of $\mathrm{U}-\mathrm{Pb}$ zircon ages among the Clarence River group samples are variable (Fig. 2.6). Sample 12JT22 is mostly composed of zircon older than $1000 \mathrm{Ma}(\sim 85 \%)$, with a broadly distributed population between ca. 2000 and $1300 \mathrm{Ma}$ and a subordinate population between ca. 1200 and 1000 Ma. The younger population in this sample consists of three grains $(\sim 4 \%)$ that range between ca. 480 and 440 Ma and a second population of grains between ca. 990 and $800 \mathrm{Ma}(\sim 12 \%)$. Sample 12JT24 yields a small fraction of 25 zircon grains with age populations ranging between ca. 2000 and $1900 \mathrm{Ma}(\sim 57 \%)$ and 2700 and $2200 \mathrm{Ma}$ ( 43\%). Zircon U-Pb ages from the lithic sandstone unit, sample 12JT23, comprise a nearly unimodal age population ( 93\%) between ca. 520 and $370 \mathrm{Ma}$ (peak ca. $430 \mathrm{Ma}$; Fig. 2.6). This sample also contains two very small populations of older ages between ca. 650 and $560 \mathrm{Ma}$ ( 4\%) and 2700 and $1150 \mathrm{Ma}(3 \%)$. The volcaniclastic unit, sample 12JT35, also yields a unimodal age population between ca. 570 and $440 \mathrm{Ma}$ (peak ca. $500 \mathrm{Ma}, \sim 97 \%$ of grains; Fig. 2.6). Only two zircon grains yield ages outside of the main population: $620 \pm 40 \mathrm{Ma}$ and $1304 \pm$ $44 \mathrm{Ma}(2 \sigma)$.

Sample 40LF13 was analyzed by LA-ICPMS at the Department of Geological Sciences at Stockholm University. Direct comparison of the zircon ages from this sample with other 
Clarence River group samples should be done with caution because the isotopic measurements were conducted on different instruments with different sets of zircon standards (see Supplemental Material section). This sample yields three broad age populations between ca. 470 and 380 ( 7\%), 990 and $820 \mathrm{Ma}(\sim 40 \%)$, and 2000 and $1530 \mathrm{Ma}$ ( 53\%). In addition to the LAICP-MS ages, 26 euhedral grains were selected and analyzed by SIMS. A filtered subset of $21 \mathrm{U}-$ $\mathrm{Pb}$ ages is plotted along with the LA-ICP-MS data in Figure 2.6. The main age populations are between ca. 440 and $420 \mathrm{Ma}(23 \%), 990$ and 960 (23\%), 1230 and 1000 (19\%), 1510 and 1300 (14\%), and 1726 and $1600 \mathrm{Ma}(14 \%)$, with one Archean grain yielding a single-grain age of $2727 \pm 5 \mathrm{Ma}(1 \sigma)$. The youngest single-grain age is $426 \pm 3 \mathrm{Ma}(1 \sigma)$, and a cluster of four ages, which overlap in age at $1 \sigma$, yield a weighted mean age of $439 \pm 3 \mathrm{Ma}(1 \sigma$; Fig. 2.6). The ca. 1510-1000 Ma zircon ages observed in the SIMS distribution were filtered out from the LA-ICPMS distribution because of substantial uncertainty $(>10 \%)$ in the $206 \mathrm{~Pb} / 207 \mathrm{~Pb}$ age, a typical phenomenon that occurs in LA-ICP-MS data sets at the crossover in precision between $206 \mathrm{~Pb} / 238 \mathrm{U}$ and $206 \mathrm{~Pb} / 207 \mathrm{~Pb}$ ages caused by low intensity of the $207 \mathrm{~Pb}$ signal.

\section{${ }^{40} \mathrm{Ar} /{ }^{39} \mathrm{Ar}$ Muscovite Geochronology}

Stepwise ${ }^{40} \mathrm{Ar} /{ }^{39} \mathrm{Ar}$ dating of single grains of muscovite from four samples from the Neruokpuk Formation and three samples from the Clarence River group was done at the University of Alaska Fairbanks following the procedures outlined by Martin et al. (2015). Stepheating experiments were conducted on one of the samples (12JT24) from an aggregate of very fine-grained muscovite (i.e., whole-rock chip). In another sample (14BJ27), we combined stepwise techniques with single-grain fusion ${ }^{40} \mathrm{Ar} /{ }^{39} \mathrm{Ar}$ geochronology (K-Ar equivalent ages) on 14 individual grains to investigate intrasample age variability. 

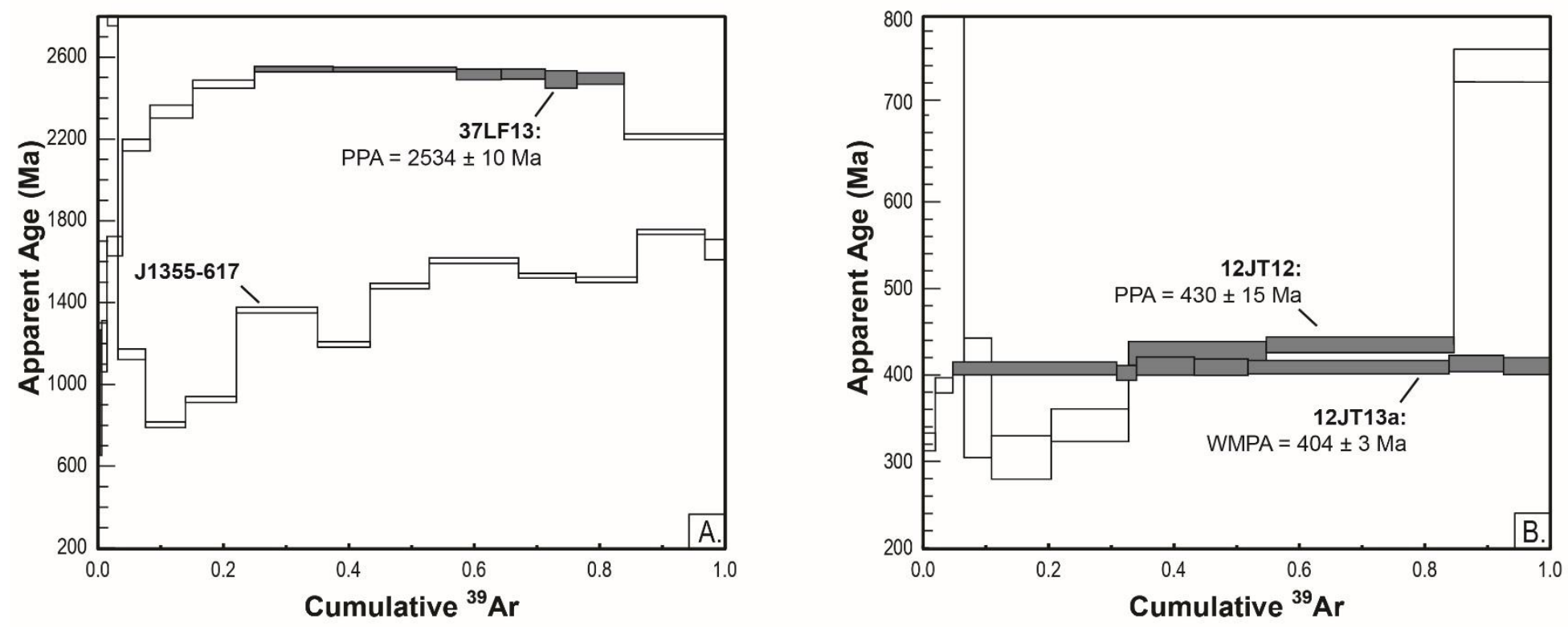

Figure 2.7: Stepwise ${ }^{40} \mathrm{Ar} /{ }^{39} \mathrm{Ar}$ age spectra of muscovite separates from the Neruokpuk Formation. (A) Samples that have retained detrital Ar (37LF13 and J1355-617). (B) Samples that have been partially or completely reset (12JT12 and 12JT13a). Analytical uncertainties are represented by vertical width of bars at the $1 \mathrm{~s}$ level. Steps filled in dark gray were used for plateau age determinations. Weighted mean plateau ages (WMPA) are calculated using at least three contiguous steps that overlap in error at $1 \sigma$, and compose more than $60 \%$ of the ${ }^{39}$ Ar release. Pseudo plateau ages (PPA) are calculated using the weighted mean age of two or more contiguous steps that overlap in error at $1 \sigma$, and compose $50 \%-60 \%$ of the ${ }^{39} \mathrm{Ar}$ released. Analyses are reported in Table SM2.6. 


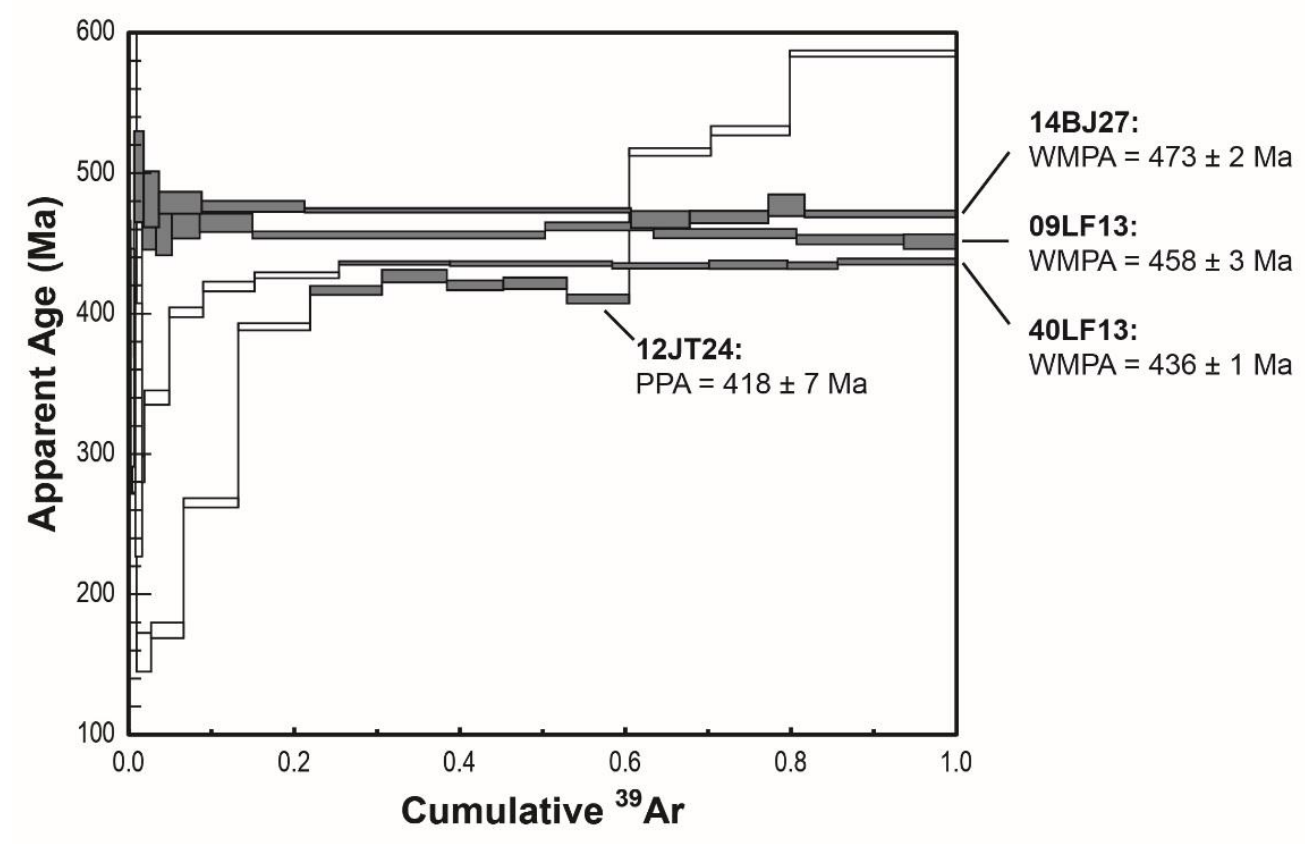

Figure 2.8: Stepwise ${ }^{40} \mathrm{Ar} /{ }^{39} \mathrm{Ar}$ age spectra on muscovite separates from the Clarence River group. Analytical uncertainties are represented by vertical width of bars at the 1s level. Steps filled in dark gray were used for plateau age determinations. Steps filled in dark gray were used for plateau age determinations. Weighted mean plateau ages (WMPA) are calculated using at least three contiguous steps that overlap in error at $1 \sigma$, and compose more than $60 \%$ of the ${ }^{39} \mathrm{Ar}$ release. Pseudo plateau ages (PPA) are calculated using weighted mean age of two or more contiguous steps that overlap in error at $1 \sigma$, and compose $50 \%-60 \%$ of the ${ }^{39} \mathrm{Ar}$ released. Analyses are reported in Table SM2.6. 


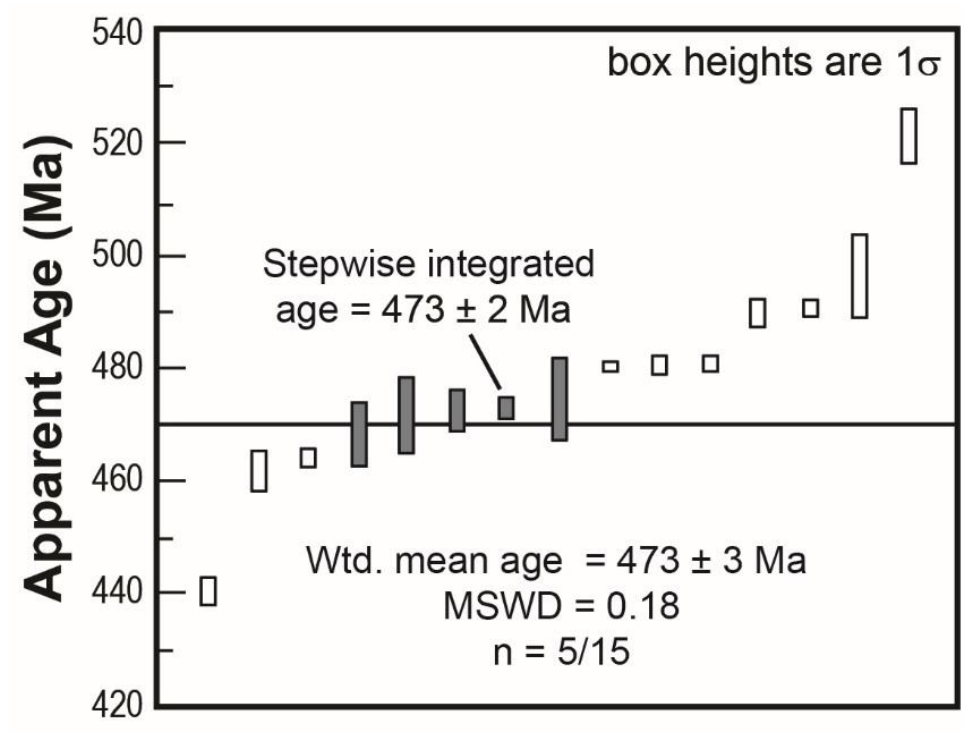

Figure 2.9: Distribution of the single-grain ${ }^{40} \mathrm{Ar} /{ }^{39} \mathrm{Ar}$ total fusion and stepwise integrated ages from sample 14BJ27 (Clarence River group). Analytical uncertainties are represented by the vertical width of bars at the $1 \sigma$ level. The five ages filled in dark gray, composed of four total fusion ages and one stepwise integrated age, were used for weighted (Wtd.) mean age calculation (MSWD_mean square of weighted deviates). Analyses are reported in Table SM2.7. 
The samples collected for the ${ }^{40} \mathrm{Ar} /{ }^{39} \mathrm{Ar}$ analyses have undergone thermal conditions above the diagenetic zone $\left(>200^{\circ} \mathrm{C}\right)$ and are within the range of anchizone to epizone metamorphic grades. All samples contain populations of coarse muscovite grains that are typically $\sim 250-1000 \mu \mathrm{m}$ in length, as well as fine-grained packets of interstitial muscovite that are $\sim 10-100 \square \mathrm{m}$ thick. The sampled muscovite grains are typically situated within thin $(<50$ $\square \mathrm{m}$ ) disjunctive cleavage domains that envelop lens-shaped domains of quartz and other framework minerals. In most cases, we targeted the coarse-grained fraction of muscovite during the separation process. A summary of the ${ }^{40} \mathrm{Ar} /{ }^{39} \mathrm{Ar}$ ages from each sample are presented in Table 2.1 and the step-heating results are illustrated in Figures 2.7 and 2.8. The complete geochronological data, procedural methods, sample preparation techniques, and detailed petrographic descriptions are provided in the Supplemental Material section.

Results from the four Neruokpuk samples show complex and varied age spectra. Two of the samples (37LF13 and J1355-671) show significant scatter between heating steps, but most of the age steps from these samples are older than $800 \mathrm{Ma}$ (Fig. 2.7A), indicating that the analyzed grains are clearly detrital. The other two samples (12JT12 and 12JT13b; Fig. 2.7B) are distinguished by having ${ }^{40} \mathrm{Ar} /{ }^{39} \mathrm{Ar}$ ages that are apparently younger than the depositional age of the Neruokpuk Formation. Sample 12JT13a shows a plateau release at $404 \pm 3 \mathrm{Ma}$ (Fig. 2.5B; $69 \%$ cumulative ${ }^{39}$ Ar release). The stepwise results from sample 12JT12 show an irregularshaped spectrum with 5 of the 12 steps ( $77 \%$ cumulative ${ }^{39}$ Ar release) yielding ages between ca. 430 and $372 \mathrm{Ma}$, where two consecutive steps yield a weighted mean age of $430 \pm 15 \mathrm{Ma}$ (Fig. 2.7B; 51\% cumulative ${ }^{39} \mathrm{Ar}$ release). 
TABLE 2.1: SUMMARY OF ${ }^{40} \mathrm{Ar} /{ }^{39} \mathrm{Ar}$ RESULTS

\begin{tabular}{|c|c|c|c|c|}
\hline Sample & 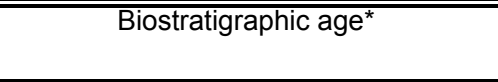 & $\begin{array}{l}\text { Total fusion age } \\
\text { (Ma) } \dagger\end{array}$ & $\begin{array}{l}\text { Plateau age } \\
(\mathrm{Ma}) \S\end{array}$ & Remarks \\
\hline \multicolumn{5}{|c|}{ Neruokpuk Formation } \\
\hline 12JT12 & Neoproterozoic-middle Cambrian & $1086 \pm 11$ & $430 \pm 15$ & $\begin{array}{c}\text { Pseudo plateau age from } 2 \text { of } 12 \text { fractions ( } 52 \% 39 \mathrm{Ar} \text { release), } 77 \% 39 \mathrm{Ar} \text { release is } \\
\text { younger than fossil depositional age. }\end{array}$ \\
\hline 12JT13a & Neoproterozoic-middle Cambrian & $402 \pm 4$ & $404 \pm 3$ & $\begin{array}{l}\text { Weighted mean plateau age from } 7 \text { of } 9 \text { fractions (69\% 39Ar release), steps are younger } \\
\text { than fossil depositional age. }\end{array}$ \\
\hline 37LF13 & Neoproterozoic-middle Cambrian & $2418 \pm 9$ & $2534 \pm 10$ & $\begin{array}{c}\text { Pseudo plateau age from } 6 \text { of } 13 \text { fractions ( } 59 \% \text { 39Ar release), all } 13 \text { fractions are older } \\
\text { than fossil depositional age. }\end{array}$ \\
\hline J1355-617 & Neoproterozoic-middle Cambrian & $1747 \pm 13$ & NA & No plateau age, but all 13 fractions are older than fossil depositional. \\
\hline \multicolumn{5}{|c|}{ Clarence River group } \\
\hline 12JT24 & Lower Ordovician-Lower Devonian(?) & $483 \pm 2$ & $418 \pm 7$ & $\begin{array}{c}\text { Pseudo plateau age from } 5 \text { of } 13 \text { fractions (39\% 39Ar release), } 40 \% 39 \mathrm{Ar} \text {, release is } \\
\text { older than the depositional age. Detrital zircon maximum depositional age comes from } \\
\text { youngest graphical peak in sample } 12 \mathrm{JT} 23 \text { collected nearby. }\end{array}$ \\
\hline 09LF13 & Lower Ordovician-Lower Devonian(?) & $455 \pm 2$ & $458 \pm 3$ & $\begin{array}{c}\text { Weighted mean plateau age from } 9 \text { of } 13 \text { fractions ( } 97 \% 39 \mathrm{Ar} \text { release), remaining } 3 \% \\
\text { 39Ar release is younger than fossil depositional age. }\end{array}$ \\
\hline 40LF13 & Lower Ordovician-Lower Devonian(?) & $427 \pm 2$ & $436 \pm 1$ & $\begin{array}{c}\text { Weighted mean plateau age from } 6 \text { of } 13 \text { fractions ( } 75 \% \text { 39Ar release), remaining } 25 \% \\
\text { 39Ar release is younger than depositional age. Detrital zircon maximum depositional age } \\
\text { comes from the weighted mean age of the youngest } 4 \text { overlapping grains from sample } \\
40 \text { LF13 secondary ion mass spectrometry data (Table SM2.5 in the Supplemental } \\
\text { Material section). }\end{array}$ \\
\hline $\begin{array}{l}\text { 14BJ27 } \\
\text { stepwise }\end{array}$ & Lower Ordovician-Lower Devonian(?) & $473 \pm 2$ & $473 \pm 2$ & $\begin{array}{c}\text { Weighted mean plateau age from } 9 \text { of } 13 \text { fractions (98\% 39Ar release), remaining } 2 \% \\
\text { 39Ar release is variable in age, fractions are both younger and older than fossil } \\
\text { depositional age. }\end{array}$ \\
\hline $\begin{array}{l}14 \mathrm{BJ} 27 \text { single- } \\
\text { grain fusion }(\mathrm{N} \\
=14)\end{array}$ & Lower Ordovician-Lower Devonian(?) & NA & NA & $\begin{array}{l}\text { Total fusion single-grain ages range from } 441 \pm 2 \text { to } 521 \pm 5 \mathrm{Ma} ; 4 \text { ages are within error } \\
\text { of the integrated age from the stepwise experiment, yielding a weighted mean age of } 473 \\
\quad \pm 3 \mathrm{Ma} \text {. All single-grain fusion ages are older than fossil depositional age. }\end{array}$ \\
\hline
\end{tabular}

${ }^{*}$ Biostratigraphic age (fossil age) is constrained by previous studies in Alaska and Yukon (Table SM2.1 in the Supplemental Material section).

†Total fusion age calculated by weighting the individual steps by the fraction of 39Ar released. This is analogous to an integrated age or conventional K-Ar age. NA indicates that integrated age is not applicable.

$\S$ Weighted mean plateau ages are calculated using at least three contiguous steps that overlap in error at $1 \sigma$, and comprise more than $60 \%$ of the ${ }^{39} \mathrm{Ar}$ release. Pseudo plateau ages are calculated using weighted mean age of 2 or more contiguous steps that overlap in error at $1 \sigma$, and comprise $50 \%-60 \%$ of the ${ }^{39} \mathrm{Ar}$ released. NA indicates that a plateau age could not be calculated or that a plateau age is not applicable. 
Three of the four Clarence River group samples (09LF13, 40LF13, and 14BJ27) yield plateau release ages of $458 \pm 3 \mathrm{Ma}\left(97 \%\right.$ of the $\left.{ }^{39} \mathrm{Ar}\right), 436 \pm 1 \mathrm{Ma}\left(\sim 75 \%\right.$ cumulative ${ }^{39} \mathrm{Ar}$ release), and $473 \pm 2$ ( $~ 98 \%$ cumulative ${ }^{39}$ Ar release), respectively (Fig. 2.8$)$. The step-heating results from whole-rock chip sample (12JT24) shows significant scatter between heating steps, with a plateau release age of $418 \pm 7$ Ma constructed from four consecutive steps between ca. 420 and $421 \mathrm{Ma}\left(\sim 40 \%\right.$ cumulative ${ }^{39} \mathrm{Ar}$ release) (Fig. 2.8). The ${ }^{40} \mathrm{Ar} /{ }^{39} \mathrm{Ar}$ single-grain fusion experiments on sample 14BJ27 produced a range of ages from $521 \pm 5$ Ma to $441 \pm 2 \mathrm{Ma}$ (Fig. 2.9). From this sample, we calculated a weighted mean age of $473 \pm 2$ Ma from five overlapping ages generated by four single-grain fusion ages and the integrated age (fusion age equivalent) from the step-heating experiments (Table 2.1).

\section{DISCUSSION}

The presence of Ordovician, Silurian, and Devonian zircon and muscovite from map units that were originally assigned to the Cambrian and Ordovician (e.g., Reiser et al., 1980) requires a reassessment of NE Brooks Range stratigraphy. Challenges associated with stratigraphic correlation across the Alaska-Yukon border in the NE Brooks Range have persisted because fossil localities are sparse and structural complexities disrupt the lateral continuity of major map units (e.g., Lane, 1991). In the following we incorporate our new radiometric ages to make inferences about the structural and stratigraphic architecture of the NE Brooks Range and then place our findings within the context of the early Paleozoic tectonic evolution of northern Laurentia. 


\section{Age and Provenance of the Neruokpuk Formation}

As highlighted herein, the depositional age and depositional environment of the Neruokpuk Formation are still not well understood. At the most fundamental level, the sedimentological, petrological, and provenance characteristics are typical of a passive margin setting (e.g., Leffingwell, 1919; Reed, 1968; Dutro et al., 1972; Lerand, 1973; Lane, 1991; Lane et al., 2016); however, the structural complexity and unfossiliferous nature of these units impedes our current understanding of basin architecture, regional stratigraphic relationships, and correlations with age-equivalent units across the northern margin of Laurentia.

In addition to the new detrital zircon ages presented herein, abundant detrital zircon data are now available from coeval Neoproterozoic-middle Cambrian units in the NE Brooks Range (Fig. 2.10; Macdonald et al., 2009; Strauss et al., 2013; McClelland et al., 2015; Lane et al., 2016). We have compiled these data into five composite detrital zircon suites that represent distinct geographical localities. Suite 1 is compiled from samples dated by Macdonald et al. (2009) and Strauss et al. (2013). These were collected from sedimentary units that are exposed below Neoproterozoic-Ordovician carbonate platform rocks of the northern Sadlerochit Mountains (Fig. 2.2) and are thus older than the Neruokpuk Formation and possibly correlative to the Firth River group on the basis of age. Suite 2 is compiled from samples dated by Strauss et al. (2013) and this study (12JT31), which includes the mixed carbonate and siliciclastic strata of the Firth River group exposed in the northern British Mountains of Alaska (Aichilik River antiform). Suite 3 includes samples from the Neoproterozoic-middle Cambrian strata in the Barn Mountains of Yukon (McClelland et al., 2015), which are typically considered southeastern equivalents of the Neruokpuk Formation (e.g., Lane, 1991). Suite 4 represents the Neruokpuk Formation of the northern British Mountains and is constructed from one sample dated by 
Strauss et al. (2013), three samples dated by Lane et al. (2016), and one sample from this study (12JT32). Suite 5 comprises the five samples dated in this study from the Neruokpuk Formation in the southern British Mountains of Alaska (Mount Greenough antiform).

The Neoproterozoic-middle Cambrian units as a whole contain populations of ca. 12001000, 1500-1300, 2000-1800, and 2800-2600 Ma zircon, but the relative abundances of individual populations, particularly the Mesoproterozoic populations, vary among the composite suites (Fig. 2.10). The zircon signatures from the Sadlerochit Mountains and the Firth River group have similar proportions of each of the major populations, but samples from the Sadlerochit Mountains contain a subpopulation of Neoproterozoic (ca. 980-760 Ma) grains that are not present in any of other composite suites of the NE Brooks Range. The composite Neruokpuk suite from the Barn Mountains also contains Mesoproterozoic populations, but these have slightly smaller proportions (Fig. 2.10B). The Neruokpuk units of the northern and southern British Mountains mostly lack the prominent Mesoproterozoic age populations and have nearly identical cumulative probability trends, indicating that detrital zircons from these two suites were likely shed from the same source region.

The proportional differences among the detrital zircon suites are likely an artifact of stratigraphic age. The samples from the northern Sadlerochit Mountains are stratigraphically below the ca. 720 Ma Kikiktat volcanics (Cox et al., 2015) and contain zircon grains as young as ca. $760 \mathrm{Ma}$, indicating that these units were deposited in the middle Cryogenian (Macdonald et al., 2009; Strauss et al., 2013). The Firth River group samples are typically assumed to be older than the units from the Neruokpuk Formation (e.g., Dutro et al., 1972; Reiser et al., 1980; Lane et al., 2016) and are possibly correlative with the units in the northern Sadlerochit Mountains (Macdonald et al., 2009; Strauss et al., 2013), indicating that they were likely deposited in the 


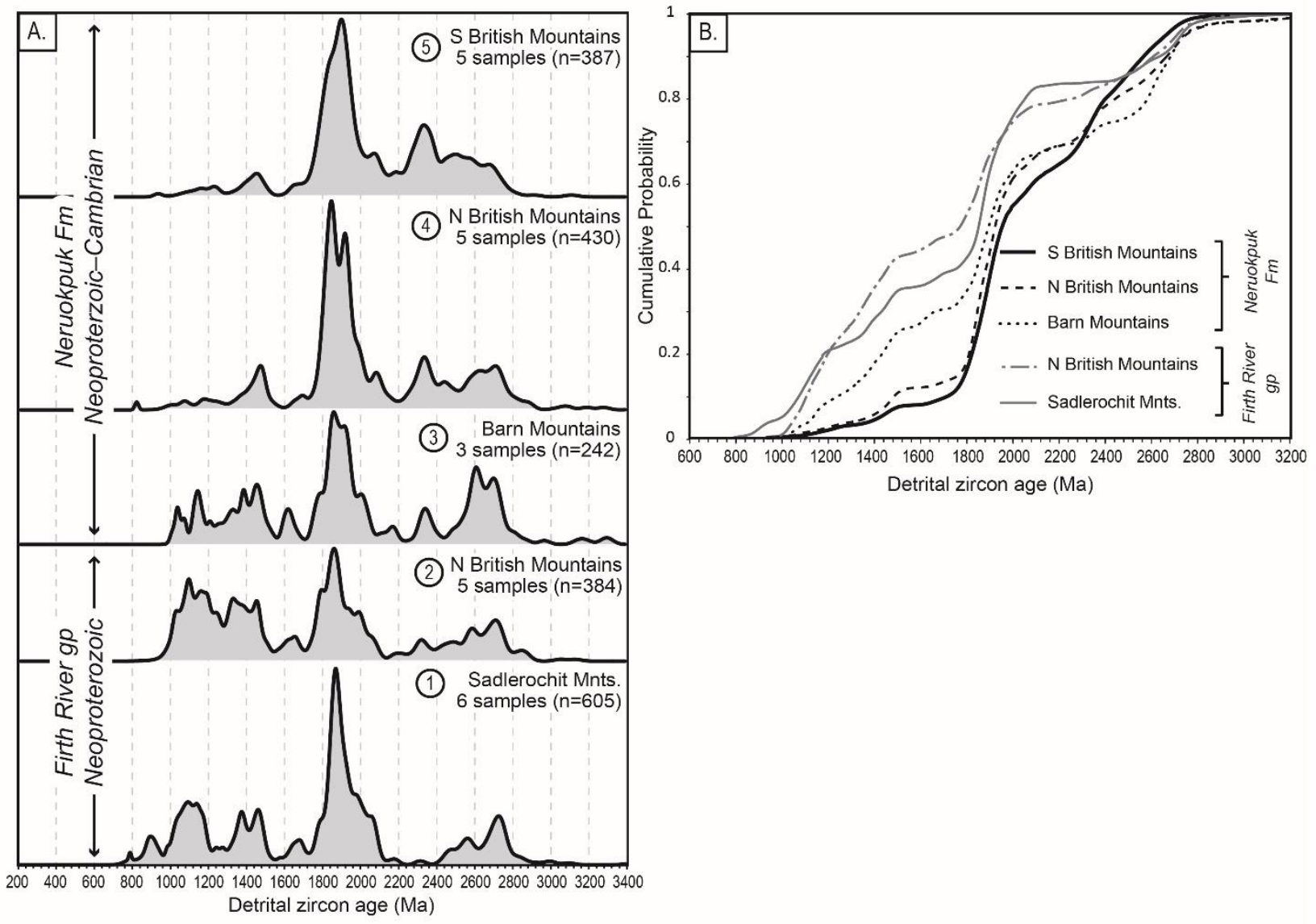

Figure 2.10: $\mathrm{U}-\mathrm{Pb}$ detrital zircon ages from Neoproterozoic-Cambrian units throughout the northeastern Brooks Range. (A) Compared using normalized probability density plots. (B) Compared using cumulative probability plots. Data are from (1) Macdonald et al. (2009); (1, 2, and 4) Strauss et al. (2013); (3) McClelland et al. (2015); (4) Lane et al. (2016); (2, 4, and 5) this study. Fm-formation; gp-group. 
Cryogenian or Ediacaran. The abundant populations of Mesoproterozoic zircon in these composite suites may have been sourced by recycling distal deposits of the Grenville foreland basin that blanketed much of the Laurentian continent in the Neoproterozoic (Rainbird et al., 1992, 1996, 2012). The Neruokpuk units of the northern and southern British Mountains may have been deposited later in the Ediacaran-middle Cambrian(?), by which time the Grenville foreland deposits had been extensively eroded from the source area, leaving mostly Paleoproterozoic and Archean crustal rocks exposed on the craton interior. The zircon signatures from the Barn Mountains could mark a transitional shift in the source region material, a slightly different age population, or a distinct drainage network separated from the one that fed the Neruokpuk units of the British Mountains.

Thick Neoproterozoic-Cambrian siliciclastic successions like the Neruokpuk Formation are widely distributed throughout northern Laurentia and constitute a period of prolific passive margin sedimentation following the breakup of the supercontinent Rodinia (e.g., Stewart, 1976; Bradley, 2008). Abundant detrital zircon studies have been conducted on these units, specifically from sedimentary successions of the surrounding basins of the Yukon block (Leslie, 2009; Hadlari et al., 2012; Lane and Gehrels, 2014; Gehrels and Pecha, 2014), the Canadian Arctic Islands (Anfinson et al., 2012; Hadlari et al., 2012, 2014; Beranek et al., 2013a; Malone et al., 2014), and northern Greenland (Kirkland et al., 2009; Morris et al., 2015). In all cases, like the units in the NE Brooks Range, variable proportions of Mesoproterozoic, Paleoproterozoic, and Archean zircon populations are observed. Nevertheless, recent studies (Lane et al., 2016) argue that zircon signatures from the Neruokpuk units share an affinity with age-equivalent units in northwest Laurentia, specifically the Cambrian strata of nearby Victoria Island (Hadlari et al., 2012). Alternatively, other studies (Strauss et al., 2013; McClelland et al., 2015) have noted that 
the detrital zircon $\mathrm{U}-\mathrm{Pb}$ signatures of the Neruokpuk Formation also closely match those from Ellesmere Island (Anfinson et al., 2012; Beranek et al., 2013a) and northern Greenland (Kirkland et al., 2009), indicating that paleogeographic correlation of the Neruokpuk Formation based solely on detrital zircon signatures is currently ambiguous.

The ${ }^{40} \mathrm{Ar} /{ }^{39} \mathrm{Ar}$ geochronology on muscovite can provide a complementary tool for assessing both the provenance and metamorphic and/or thermal conditions of sedimentary basins. Two of the Neruokpuk samples preserve their detrital Ar (Fig. 2.7). The dominant release from sample 37LF13 is ca. $2500 \mathrm{Ma}$, which overlaps with major thermomagmatic events from the Canadian shield (e.g., Bethune et al., 1999; Ernst and Bleeker, 2010). The complex age spectra in sample J1355-617 precludes any further interpretations, but it likely participated in multiple sedimentary cycles, undergoing various diagenetic and alteration events. Both of these samples were collected at the northern part of the field area, which suggests that sedimentary burial or the degree of pre-Mississippian deformation decreases northward.

The younger fractions released during the step-heating experiments may have also been influenced by partial degassing during Brookian tectonic and/or burial events. This was highlighted in one Neruokpuk sample in the northern British Mountains (Lane et al., 2016), where Ar loss as young as ca. $150 \mathrm{Ma}$ was ascribed to the Jurassic to middle Cretaceous rifting and sedimentation associated with the opening of the Canada Basin. Much of this region is considered to have been unaffected by rifting events (Moore et al., 1994), so an alternative hypothesis is that rocks of the NE Brooks Range were significantly buried by the Late Cretaceous to Cenozoic foredeep deposits of the Brookian orogen. Color alteration of conodonts, vitrinite reflectance, and apatite fission track ages from Bathtub Ridge (Fig. 2.2) predict that the pre-Mississippian strata of the Mount Greenough antiform were buried below $~ 10 \mathrm{~km}$ of 
sediment before being exhumed in the middle Cenozoic (O'Sullivan, 1994; Bird et al., 1999; Moore, 1999); however, an additional $4-7 \mathrm{~km}$ of overburden is needed to reach the $\sim 425-400{ }^{\circ} \mathrm{C}$ muscovite closure temperature (assuming a normal geothermal gradient of $\sim 30^{\circ} \mathrm{C} / \mathrm{km}$ ). Therefore, given the significant releases of ${ }^{39} \mathrm{Ar}$ ca. 430 and $404 \mathrm{Ma}$, we ascribe most of the resetting and/or loss to a major Silurian-Early Devonian lowgrade metamorphic event that occurred during the Romanzof orogeny.

\section{Age and Provenance of the Clarence River Group}

As discussed here, the depositional age and stratigraphic architecture of the newly proposed Clarence River group remain unknown; however, it is clear from the regional stratigraphic architecture and from the U-Pb and ${ }^{40} \mathrm{Ar} /{ }^{39} \mathrm{Ar}$ data that these units not only overlie the older Neruokpuk Formation, but also record a prominent shift in provenance. A useful application of detrital zircon data is the ability to constrain the maximum depositional age of strata (Dickinson and Gehrels, 2009), especially where biostratigraphic constraints are limited (e.g., Kochelek et al., 2011); however, utilizing robust maximum depositional ages from the LAICP-MS data presented herein for the Clarence River group is difficult because of the large uncertainty $(\sim 4.5 \%)$ on many of the individual ages. Furthermore, determining the degree of discordance for grains generally younger than $700 \mathrm{Ma}$ is challenging due to large uncertainties in the $207 \mathrm{~Pb} / 206 \mathrm{~Pb}$ age, a common problem in most detrital zircon data sets (Nemchin and Cawood, 2005), and thus measurements compromised by $\mathrm{Pb}$ loss or inheritance cannot be ruled out. For these reasons, the most conservative estimate for the maximum depositional age from our LA-ICP-MS zircon ages is determined by using the center of the youngest graphical peak from the individual normalized probability distributions (Fig. 2.6). 
Only one sample from the Clarence River group (12JT24) does not contain Paleozoic zircon, whereas the other four samples have maximum depositional peak ages that range between ca. 500 and $430 \mathrm{Ma}$ (Fig. 2.6). Sample 12JT23 has the youngest graphical peak, ca. $430 \mathrm{Ma}$, and although this age is within the middle Wenlock (Gradstein et al., 2012), 19 single-grain ages have normal distributions centered in the Devonian (assuming each zircon age has a normal distribution using the age as the mean and uncertainty as the standard deviation). Despite this, clear clustering of the Devonian grains is not observed in the normalized probability distribution plot and there is no apparent trend in their $\mathrm{U}$ concentrations or $\mathrm{U} / \mathrm{Th}$ ratios, suggesting that they simply represent the youngest ages from a continuous distribution that results from analytical uncertainty or Pb loss. This is also supported in the age distribution of sample 40LF13, where we combined LA-ICP-MS and SIMS techniques. The four overlapping SIMS ages yield a weighted mean age of $439 \pm 3 \mathrm{Ma}$ (Fig. 2.6), which nearly corresponds with the ca. 440 center of the youngest graphical peak in LAICP-MS age distribution, supporting the notion that these peaks conservatively represent maximum depositional ages.

Sample 12JT35 was collected from map unit Ovc of Reiser et al. (1980) in the Caribous Pass antiform (Fig. 2.2) of the northern British Mountains, and has a maximum depositional age of ca. $500 \mathrm{Ma}$ (Furongian). This closely corresponds with the approximate age of the trilobite fossils from the Whale Mountain volcanic rocks and associated limestones in the Mount Greenough antiform (Dutro et al., 1972); this might imply that these volcaniclastic rocks were sourced from Whale Mountain allochthon.

The composite detrital zircon signature of the Clarence River group (Fig. 2.11) implies derivation from several different source areas. The subordinate Archean-Paleoproterozoic populations were likely derived from crystalline basement rocks of Laurentian craton and may 
have been cycled through several sedimentary units prior to deposition. The early

Neoproterozoic (ca. 990-820 Ma) age population of samples 12JT22 and 40LF13 is critical because original source regions within this age range are not widespread throughout Laurentia. Tonian magmatism is typically attributed to postorogenic collapse of the Grenville orogen, as recorded in the Central Gneiss Belt of Ontario, Canada (Ketchum et al., 1998), the East Greenland Caledonides (Kalsbeek et al. 2000; Watt et al., 2000), the Groswater Bay and Pinware terranes of eastern Labrador (Gower, 1996), and the Lewisian uplift in northwestern Scotland (Turnbull et al. 1996). Early Neoproterozoic magmatic rocks are also observed in the periLaurentian terranes of the northern Caledonides, including Pearya (e.g., Trettin, 1998) and the various terranes of Svalbard (e.g., Gee et al., 1995; Ohta et al., 2002; Johansson et al., 2004). These zircon grains may have also been recycled from older sedimentary units that contain prominent early Neoproterozoic populations, such as the late Neoproterozoic Succession II of Pearya (e.g., Malone et al., 2014) and the Eleonore Bay Supergroup of the East Greenland Caledonides (e.g., Watt et al., 2000).

Zircon from the ca. 470-420 Ma age population in the Clarence River group may have been sourced from magmatic rocks emplaced during the Caledonian-Appalachian orogeny, as similar U-Pb zircon ages are reported from magmatic rocks in the East Greenland Caledonides (e.g., Watt et al., 2000; Kalsbeek et al., 2001, 2008; Rehnström, 2010), Pearya (Trettin, 1987; McClelland et al., 2012), Svalbard (e.g., Johansson et al., 2004; Pettersson et al., 2009), New England and western Newfoundland (e.g., van Staal and Barr 2012, and references therein), and the northern British Isles (e.g., Oliver et al., 2008). Caledonian-age magmatism is also observed on various circum-Arctic terranes such as the Alexander terrane (Gehrels and Saleeby, 1987; Beranek et al., 2013b; White et al., 2016) and Klamath and Sierran terranes (Grove et al., 2008). 


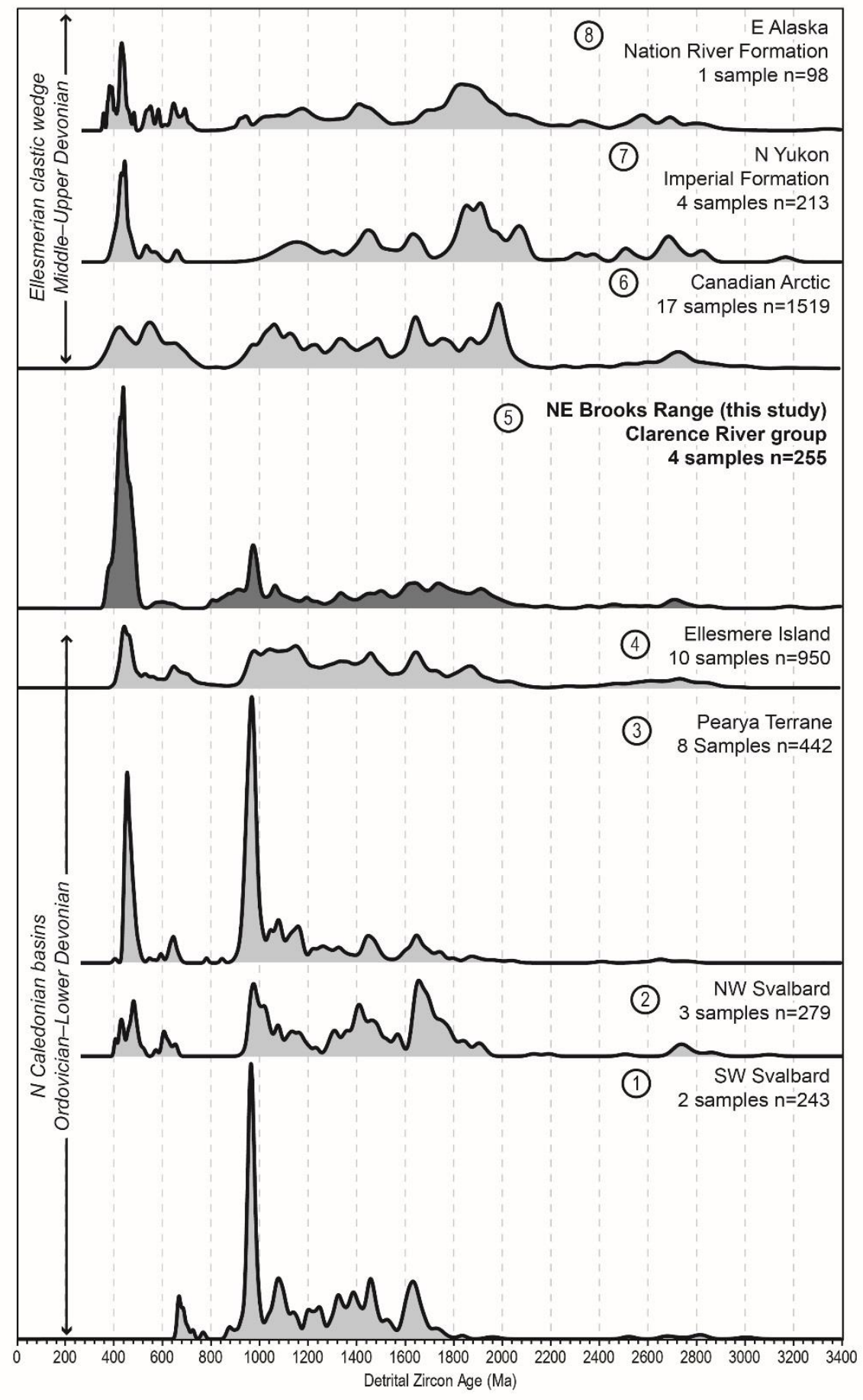

Figure 2.11: U-Pb detrital zircon ages from early Paleozoic sedimentary successions of northern Laurentia and associated Caledonian terranes, including: (1) southwestern Svalbard (Gasser and Andresen, 2013); (2) northwestern Svalbard (Pettersson et al., 2010); (3) Pearya terrane (Hadlari et al., 2014); (4) Ellesmere Island (Beranek et al., 2015); (5) northeastern Brooks Range (this study); (6) Ellesmerian clastic wedge in the Canadian Arctic Islands (Anfinson et al., 2012); (7) Ellesmerian clastic wedge in Yukon (Beranek et al., 2010); and (8) Ellesmerian clastic wedge in east-central Alaska (Gehrels and Pecha, 2014). 
Note that magmatic rocks of this age group are rare in Arctic Alaska, although dredged samples of orthogneiss from the Chukchi Borderland (Fig. 2.1) yield U-Pb ages of ca. $430 \mathrm{Ma}$ (Brumley et al., 2015) and volcanic rocks exposed in the Doonerak fenster of the central Brooks Range (Fig. 2.1B) have ages that range from ca. 470 to $370 \mathrm{Ma}$ (Dutro et al., 1976). Because biostratigraphic constraints are limited for the samples dated in this study, we cannot exclude the possibility that this age population was recycled from an older sedimentary source; however, the compositional and textural immaturities of the Clarence River group samples, especially the presence of volcanic rock fragments and euhedral feldspar grains, imply direct sourcing from primary volcanic material.

The ${ }^{40} \mathrm{Ar} /{ }^{39} \mathrm{Ar}$ muscovite ages from the Clarence River group overlap with the prominent ca. 470-420 Ma detrital zircon population. Like the muscovite extracted from the Neruokpuk samples, we interpret the Clarence River group muscovite as detrital in origin because it is typically coarse grained, has a strong petrologic contrast with the surrounding clay matrix, and is commonly disaggregated into single sheets. Three of four samples analyzed yield robust weighted plateau ages (Fig. 2.8; Table 2.1) that reflect the highly retentive nature of coarse detrital grains. Therefore, we interpret these ${ }^{40} \mathrm{Ar} /{ }^{39} \mathrm{Ar}$ muscovite ages as records of the timing of cooling and/or crystallization of the respective source regions.

The $436 \pm 1 \mathrm{Ma}^{40} \mathrm{Ar} /{ }^{39} \mathrm{Ar}$ muscovite age of sample 40LF13 (Fig. 2.8) is within error of the $439 \pm 3$ Ma weighted-mean age calculated from the cluster of four U-Pb zircon ages (Fig. 2.6). Possible source regions for this detritus are nonexistent along the northwest margin of Laurentia, but are widely exposed in the East Greenland Caledonides, which host ca. 440-430 Ma muscoviterich, postorogenic S-type granites (Kalsbeek et al., 2001). This, along with the textural and compositional immaturities of the samples, implies that the Clarence River group 
was deposited in proximity to the Caledonides during the collision between Baltica and Laurentia. The other plateau ages of ca. 473 and $458 \mathrm{Ma}$ are significantly older than the S-type granites in the East Greenland Caledonides and were likely sourced from magmatic or metamorphic rocks that formed in the early phases of the Caledonian-Appalachian orogeny. A similar age distribution is recorded in southwestern Wales (UK), where detrital muscovite ages from the lower Silurian Old Red Sandstone record exhumation of the Northern and Central Highlands of Scotland during the Early-Middle Ordovician Grampian orogeny (Sherlock et al., 2002).

Unlike the other Clarence River group samples, sample 12JT24 has an irregular, staircaseshaped age spectrum (Fig. 2.8). The complex nature of this spectrum is likely a response to analyzing a fine aggregate of multiple grains in a single step-heating experiment (i.e., wholerock analysis). The sample was most likely perturbed by a low-grade metamorphic event ca. 418 $\mathrm{Ma}$, possibly in relation to the Romanzof orogeny. It is also possible that the sample contains newly formed (authigenic) muscovite that grew via the alteration of other fine-grained clay minerals like illite or kaolinite; this is a common process that occurs in the formation of lowgrade metamorphic rocks (e.g., Hunziker et al., 1986; Verdel et al., 2012).

\section{Paleogeography of the North Slope}

The contact between the Neruokpuk Formation and Clarence River group marks a major shift in the dispersal of sediment in northern Laurentia. We postulate that this fundamental shift in provenance is linked to the closure of the northern tract of the Iapetus Ocean and the onset of the Caledonian orogeny. In this scenario, detritus was funneled from uplifted source regions in the East Greenland Caledonides, Pearya, Svalbard, and other circum-Arctic terranes, and transported axially along the Franklinian margin before filling the pre-Mississippian basin of the 
North Slope (Fig. 2.12). A similar scenario is inferred from age-equivalent strata in the Clements Markham and Hazen fold belts of northern Ellesmere Island, which is supported by paleocurrent trends (Trettin, 1994, 1998), regional shifts in Nd isotopic values (Patchett et al., 1999), and detrital zircon studies (Anfinson et al., 2012; Hadlari et al., 2014; Beranek et al., 2015). Although the exact paleogeographic position of the North Slope with respect to northern Ellesmere Island and the Caledonian orogen is uncertain, the composite detrital zircon signature for the Clarence River group (Fig. 2.11) is remarkably similar to Silurian flysch deposits (e.g., Fire Bay, Lands Lokk, and Danish River formations) of Ellesmere Island (Beranek et al., 2015) and ageequivalent units in Pearya (Hadlari et al., 2014). In addition, the compositional and textural immaturity of the Clarence River group sandstone samples highlights proximity to the source region. These observations provide support for recent paleogeographic interpretations that restore the North Slope to northeast Laurentia in the early Paleozoic (e.g., Strauss et al., 2013; Malone et al., 2014; Cox et al., 2015).

An alternative scenario fixes the North Slope to northwest Laurentia throughout the Paleozoic (e.g., Lerand, 1973; Lane, 1991, 2007; Moore et al., 1994; Rainbird et al., 1996; Cecile et al., 1999; Lane et al., 2016). In this model, synorogenic detritus of the Clarence River group may have arrived by long-distance transport from the Caledonides or from the localized collision of an allochthonous terrane or terranes with the northwest Laurentian margin; the latter is the interpretation of Lane (2007) and Lane et al. (2016), who drew correlations between portions of the Clarence River group (i.e., the Buckland Hills succession) and the upper Devonian Imperial Formation of northern Yukon. The Imperial Formation was deposited in the Ellesmerian clastic wedge (Beranek et al., 2010; Lemieux et al., 2011), which blanketed much of the Canadian Arctic and northwest Laurentian margin during the Late Devonian and Early Mississippian. 
Although the Ellesmerian clastic wedge units are lithologically similar and have comparable detrital zircon (e.g., Beranek et al., 2010; Anfinson et al., 2012; Gehrels and Pecha, 2014) and muscovite ages (Powell and Schneider, 2013), the deposition of the Clarence River group predates Ellesmerian clastic wedge sedimentation, as it was deformed in the Early-Middle Devonian Romanzof event (Anderson et al., 1994; Lane, 2007; Lane et al., 2016). Furthermore, the Clarence River group is crosscut by regional Late Devonian plutonic rocks, which are thought to be a principal source of detritus in Ellesmerian Clastic wedge units (Beranek et al., 2010; Anfinson et al., 2012).

Positioning the North Slope near northeast Laurentia in the Silurian-Early Devonian (Fig. 2.12) requires $>1000 \mathrm{~km}$ of left-lateral displacement along the Franklinian margin of Arctic Canada prior to the Late Devonian-Early Mississippian to achieve a hypothesized pre-Canada Basin paleogeographic configuration (e.g., Gottlieb et al., 2014; Houseknecht and Connors, 2016). In this scenario, the Romanzof orogeny may represent a major transpressional event that occurred along strike with similar deformation associated with the docking of Pearya against the northeast margin of Laurentia (Trettin, 1998, and references therein). A strike-slip orogen along the northern margin of Laurentia in the early Paleozoic is favored by a number of paleogeographic models for the Arctic (e.g., Sweeney, 1982; Oldow et al., 1987; Colpron and Nelson, 2011), and previous studies in the NE Brooks Range have postulated strike-slip displacement along the Kaltag-Porcupine-Rapid fault array in severing stratigraphic ties between the NE Brooks Range and northwest Laurentia (Oldow et al., 1987; Norris, 1997; Strauss et al., 2013; von Gosen et al., 2015). 


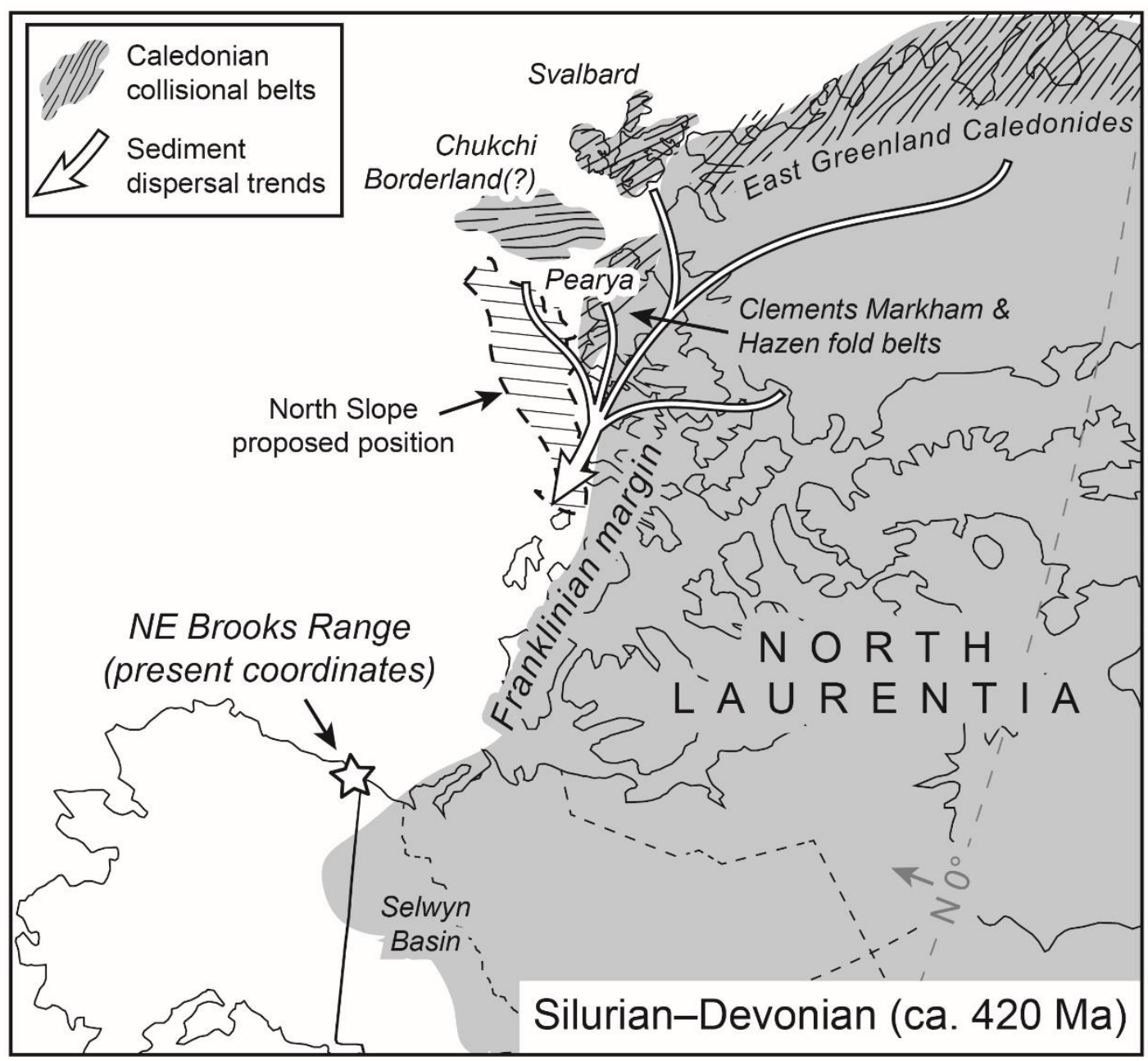

Figure 2.12: Paleogeographic position of terranes and sediment dispersal pathways along northern Laurentia during deposition of the Clarence River group (see text for discussion). Reconstruction is based on Trettin (1987, 1998), Patchett et al. (1999), McClelland et al. (2012), Gasser and Andresen (2013), Pettersson et al. (2010), Colpron and Nelson (2011), Anfinson et al. (2012), and Beranek et al. (2015). NE—northeastern. 


\section{Origin and Emplacement of the Whale Mountain Allochthon}

The basic premise of the Whale Mountain allochthon model is that a structural complex composed of massive basalt flows, radiolarian chert, and limestone was emplaced onto the preMississippian sedimentary units of the North Slope in the form of a single thrust sheet. Although previously researchers have interpreted the volcanic rocks as being in stratigraphic continuity with the other pre-Mississippian units (e.g., Dutro et al., 1972; Reiser et al., 1980; Lane, 1991; Lane et al., 2016), we observed the Clarence River group positioned below the volcanic rocks in almost all cases throughout the NE Brooks Range, indicating a major disruption in the stratigraphic sequence.

In the Mount Greenough antiform (Fig. 2.2), the volcanic rocks are juxtaposed above Clarence River group units by a low-angle thrust fault that was folded into a synform (Fig. 2.4). The age of this structure is unknown; however, along strike the thrust appears to juxtapose the volcanic rocks with the Lisburne Group of the Ellesmerian sequence (Reiser et al., 1980), indicating that some amount of Brookian displacement has occurred along the fault. If all of the displacement was a result of Brookian contraction, then shortening estimates across the NE Brooks Range are significantly underestimated. For example, an additional duplex or thrust panel would be required to retrodeform the Mount Greenough fault-bend fold in the model of Moore (1999) because it does not address the stratigraphic disruption observed between the Clarence River group and the overlying Whale Mountain volcanic rocks.

Alternatively, the emplacement of the Whale Mountain allochthon could have occurred in the Early-Middle Devonian Romanzof orogeny with subsequent reactivation during Brookian shortening. Lane (2007) interpreted the Romanzof orogen as a southward-verging (present coordinates) fold-thrust belt based largely on the lack of deformation in the Yukon block further 
to the south. The northward dips of the structural fabrics and apparent south-directed imbrications of the stratigraphy across the Mount Greenough antiform (Fig. 2.4) both favor a south-vergent model. Conversely, the metamorphic gradient and the intensity of deformation appear to decrease in the northern British Mountains (Sable, 1977), and the pre-Mississippian deformation in the Aichilik River antiform appears to be north vergent along the Aichilik River (Hanks, 1989). These north to south discrepancies in structural style could be the result of the juxtaposition of different pre-Mississippian structural domains along east-west-trending strikeslip faults, supporting the notion that the Romanzof orogeny had a significant transpressional component. However, the relationships between the structural styles of the sedimentary units with those of the Whale Mountain allochthon are obscured by the strong contrast in mechanical competence of the rocks.

A multitude of paleogeographic scenarios are possible for emplacement of the Whale Mountain allochthon and the associated the Romanzof orogeny. We postulate that it occurred (1) from the accretion of an outboard terrane, possibly the southern subterranes of Arctic Alaska, (2) as the North Slope translated along the northern margin of Laurentia, or (3) some combination of both. Nevertheless, several outstanding challenges to the allochthon model remain. First, the source of the thrust sheet is unknown, largely because the fault that separates Whale Mountain allochthon from the Clarence River group is kinematically unconstrained. We prefer a northdirected sense of emplacement that restores the allochthon along a south-dipping thrust sheet to the Romanzof Mountain thrust exposed at the headwaters of the Jago River (RMT; Fig. 2.2). A second challenge is that the tectonic and/or depositional setting of the Whale Mountain allochthon can be interpreted in several ways from the available data. The geochemical signatures of the volcanic rocks are indicative of derivation from sublithospheric mantle (Moore, 
1987; Goodfellow et al., 1995), which is typical for most basalts erupted in oceanic settings (e.g., Pearce, 2008), but continental flood basalts also have similar geochemical signatures (e.g., McKenzie and Bickle, 1988; Gallagher and Hawkesworth, 1992). It is important that these volcanic rocks are intimately associated with thick packages of radiolarian chert, slate and phyllite, and occasional lithic wacke of the Romanzof chert (Moore and Churkin, 1984; Mull and Anderson, 1991); this lends support to a deep marine origin. The structural and stratigraphic relationships of the volcaniclastic rocks exposed in the northern British Mountains, where sample 12JT35 was collected, may contradict the allochthon model. Detailed mapping by Kelley et al. (1994) placed these volcaniclastic rocks in stratigraphic continuity with Clarence River group, and suggested correlation with Whale Mountain volcanic rocks in the Mount Greenough antiform. However, outcrop exposure in northern British Mountains is relatively poor, and a scenario where these volcaniclastic rocks were deposited by reworking the Whale Mountain volcanic rocks and then subsequently imbricated with the Clarence River group units should not be eliminated from possible interpretations.

The Whale Mountain volcanic rocks are comparable to the continental flood basalts of the Selwyn basin on the basis of age (Leslie, 2009; MacNaughton et al., 2016) and geochemistry (Goodfellow et al., 1995), and correlation between the two volcanic suites is a critical component in models that prefer a fixed position of the North Slope with respect to northwest Laurentia (e.g., Lane et al., 2016). An allochthonous relationship between the Whale Mountain volcanic rocks and the pre-Mississippian sedimentary rocks of the North Slope permits the hybridization of the various paleogeographic models. For example, the paleogeographic model favored in this study (Fig. 2.12), with the North Slope originating near northeast Laurentia and translating along the Franklinian margin, could suggest that the Whale Mountain volcanic rocks erupted into an 
oceanward extension of the Selwyn basin and were subsequently assembled with rest of the North Slope by strike-slip juxtapositioning. Alternatively, the rocks of the Whale Mountain allochthon could be correlative to similar-aged volcanic rocks at northern Ellesmere, implying that the emplacement could have happened closer to the main Caledonian collisional belt. Either interpretation is permissible if the allochthon model is considered.

\section{CONCLUSIONS}

The U-Pb and ${ }^{40} \mathrm{Ar} /{ }^{39} \mathrm{Ar}$ isotopic analysis on detrital minerals from 18 samples of preMississippian strata in the NE Brooks Range of Alaska provide new constraints on the structural and stratigraphic architecture of the Arctic Alaska terrane. Two major sedimentary successions are now recognized in the British and Romanzof Mountains of Alaska: a NeoproterozoicCambrian passive margin succession that includes the Firth River group and the Neruokpuk Formation, and the newly identified Lower Ordovician-Lower Devonian Clarence River group. In addition to these sedimentary units, a late Cambrian-Ordovician structural complex composed of massive basalt flows, radiolarian chert, and limestone, herein named the Whale Mountain allochthon, is structurally juxtaposed with the underlying Clarence River group. When compared with the ages of igneous and metamorphic rocks in Laurentia and other circum-Arctic regions, the new detrital geochronological data presented herein shed light on the origin and dispersal of siliciclastic material along the northern margin of Laurentia throughout the Neoproterozoic and early Paleozoic. Specifically, detritus of Firth River group and Neruokpuk Formation was ultimately derived from Archean and Paleoproterozoic basement rocks in Canadian shield and possibly older sedimentary units of the Grenville foreland basin. The Clarence River group was most likely sourced from igneous and metamorphic rocks of Caledonian orogenic belt of northeast Laurentia. 
The pre-Mississippian rocks of the NE Brooks Range were subsequently deformed and underwent low-grade metamorphism during the ill-defined Early-Middle Devonian Romanzof orogeny, which was closely associated with the emplacement of the Whale Mountain allochthon. How this event relates to the greater paleogeography of northern Laurentia and the circum-Arctic is unresolved, but future plate reconstructions should consider the possibility that the North Slope was positioned near northeast Laurentia during the closure of the Iapetus Ocean and Caledonian-Appalachian orogeny.

\section{ACKNOWLEDGMENTS}

Johnson and Toro thank West Virginia University's Faculty Senate Grant and the Circum-Arctic Lithosphere Evolution (CALE) project for providing financial support. Strauss thanks Francis Macdonald and the Department of Earth Sciences at Dartmouth College for support. Geological Society of America graduate student research fellowships also supplied additional funding to Johnson, Strauss, and Ward. We thank Blaze Budd, Patrick Frier, and Lyle Nelson for assistance in the field. Kirk Sweetsir from Yukon Air Service and the staff at Wright Air Service provided critical access to our remote field area. Permission to work in the Arctic National Wildlife Refuge was granted by Alfredo Soto at the United States Fish and Wildlife Service. Many of the ideas presented herein were conceived during discussions with Gil Mull, Bill McClelland, Francis Macdonald, Marwan Wartes, Elizabeth Miller, Victoria Pease, Eric Gottlieb, Carl Hoiland, and Tim O'Brien. The thoughtful and constructive reviews from Maurice Colpron, Tom Moore, and an anonymous reviewer greatly improved this manuscript.

\section{REFERENCES CITED}

Amato, J.M., Toro, J., Miller, E.L., Gehrels, G.E., Farmer, G.L., Gottlieb, E.S., and Till, A.B., 2009, Late Proterozoic-Paleozoic evolution of the Arctic Alaska-Chukotka terrane based 
on U-Pb igneous and detrital zircon ages: Implications for Neoproterozoic paleogeographic reconstructions: Geological Society of America Bulletin, v. 121, p. 1219-1235, doi: 10.1130/B26510.1.

Amato, J.M., Toro, J., Akinin, V.V., Hampton, B.A., Salnikov, A.S., and Tuchkova, M.I., 2015, Tectonic evolution of the Mesozoic South Anyui suture zone, eastern Russia: A critical component of paleogeographic reconstructions of the Arctic region: Geosphere, v. 11, p. 1530-1564, doi: 10.1130/GES01165.1.

Anderson, A.V., Wallace, W.K., and Mull, C.G., 1994, Depositional record of a major tectonic transition in northern Alaska: Middle Devonian to Mississippian rift-basin margin deposits, upper Kongakut River region, eastern Brooks Range, Alaska, in Thurston, D.K., and Fujita, K., eds., 1992 Proceedings, International Conference on Arctic Margins: U.S. Department of the Interior Minerals Management Service, OCS (Outer Continental Shelf) Study MMS 94-0040, p. 71-76.

Anfinson, O.A., Leier, A.L., Embry, A.F., and Dewing, K., 2012, Detrital zircon geochronology and provenance of the Neoproterozoic to Late Devonian Franklinian Basin, Canadian Arctic Islands: Geological Society of America Bulletin, v. 124, p. 415-430, doi: 10.1130/B30503.1.

Beranek, L.P., Mortensen, J.K., Lane, L.S., Allen, T.L., Fraser, T.A., Hadlari, T., and Zantvoort, W.G., 2010, Detrital zircon geochronology of the western Ellesmerian clastic wedge, northwestern Canada: Insights on Arctic tectonics and the evolution of the northern Cordilleran miogeocline: Geological Society of America Bulletin, v. 122, no. 11, p. 1899-1911, doi: 10.1130/B30120.1. 
Beranek, L.P., Pease, V.L., Scott, R.A, and Thomsen, T.B., 2013a, Detrital zircon geochronology of Ediacaran to Cambrian deep-water strata of the Franklinian basin, northern Ellesmere Island, Nunavut: Implications for regional stratigraphic correlations: Canadian Journal of Earth Sciences, v. 50, p. 1007-1018, doi: 10.1139/cjes-2013-0026.

Beranek, L.P., van Staal, C.R., McClelland, W.C., Israel, S., and Mihalynuk, M.G., 2013b, Baltican crustal provenance for Cambrian-Ordovician sandstones of the Alexander terrane, North American Cordillera: Evidence from detrital zircon U-Pb geochronology and Hf isotope geochemistry: Journal of the Geological Society [London], v. 170, p. $7-$ 18, doi: 10.1144/jgs2012-028.

Beranek, L.P., Pease, V.L., Hadlari, T., and Dewing, K., 2015, Silurian flysch successions of Ellesmere Island, Arctic Canada, and their significance to northern Caledonian palaeogeography and tectonics: Journal of the Geological Society [London], v. 172, p. 201-212, doi: 10.1144/jgs2014-027.

Bethune, K.M., Villeneuve, M.E., and Bleeker, W., 1999, Laser ${ }^{40} \mathrm{Ar} /{ }^{39} \mathrm{Ar}$ thermochronology of Archean rocks in Yellowknife Domain, southwestern Slave Province: Insights into the cooling history of an Archean granite-greenstone terrane: Canadian Journal of Earth Sciences, v. 36, p. 1189- 206, doi: 10.1139/e99-006.

Bird, K.J., Burruss, R.C., and Pawlewicz, M.J., 1999, Thermal maturity, in ANWR Assessment Team, The oil and gas resource potential of the 1002 area, Arctic National Wildlife Refuge, Alaska: U.S. Geological Survey Open-File Report 98-34, Chapter VR, http://pubs.usgs.gov/of/1998/ofr-98-0034/VR.pdf64p.

Bradley, D.C., 2008, Passive margins through earth history: Earth-Science Reviews, v. 91, p. 126, doi: $10.1016 /$ j.earscirev.2008.08.001. 
Brumley, K., Miller, E.L., Konstantinou, A., Grove, M., Meisling, K.E., and Mayer, L.A., 2015, First bedrock samples dredged from submarine outcrops in the Chukchi Borderland, Arctic Ocean: Geosphere, v. 11, p. 76-92, doi: 10.1130/GES01044.1.

Cecile, M.P., 1988, Corridor traverse through Barn Mountains, northernmost Yukon, in Current research part D: Interior plains and Arctic Canada: Geological Survey of Canada Paper 88-1D, p. 99-103.

Cecile, M.P. and Lane, L.S., 1991, Geology of the Barn uplift, northern Yukon: Geological Survey of Canada, Open File Map 2342, scale 1:50,000.

Cecile, M.P., Lane, L.S., Khudoley, A.K., and Kos'ko, M.K., 1999, Lower Paleozoic rocks around today's Arctic Ocean: Two ancestral continents and associated plates; Alaskan rotation unnecessary and unlikely: Polarforschung, v. 69, p. 235-241.

Cocks, L.R.M., and Torsvik, T.H., 2011, The Palaeozoic geography of Laurentia and western Laurussia: A stable craton with mobile margins: Earth-Science Reviews, v. 106, p. 1-51, doi:10.1016/j.earscirev.2011.01.007.

Cole, F., Bird, K.J., Mull, C.G., Wallace, W.K., Sassi, W., Murphy, J.M., and Lee, M., 1999, A balanced cross section and kinematic and thermal model across the northeastern Brooks Range mountain front, Arctic National Wildlife Refuge, Alaska, in ANWR Assessment Team, The oil and gas resource potential of the 1002 area, Arctic National Wildlife Refuge, Alaska: U.S. Geological Survey Open-File Report 98-34, p. 60.

Colpron, M., and Nelson, J.L., 2011, A Palaeozoic NW Passage and the Timanian, Caledonian and Uralian connections of some exotic terranes in the North American Cordillera, in Spencer, A.M., et al., eds., Arctic petroleum geology: Geological Society, London, Memoir 35, p. 463-484, doi: 10.1144/M35.31. 
Coney, P.J., Jones, D.L., and Monger, J.W.H., 1980, Cordilleran suspect terranes: Nature, v. 288, p. 329-333, doi: 10.1038/288329a0.

Cox, G.M., Strauss, J.V., Halverson, G.P., Schmitz, M.D., McClelland, W.C., Stevenson, R.S., and Macdonald, F.A., 2015, Kikiktat volcanics of Arctic Alaska-Melting of harzburgitic mantle associated with the Franklin large igneous province: Lithosphere, v. 7, p. 275295, doi: 10 .1130/L435 .1.

Dewey, J.F., and Horsfield, B., 1970, Plate tectonics, orogeny and continental growth: Nature, v. 225, p. 521-525, doi:10 .1038/225521a0.

Dickinson, W.R., and Gehrels, G.E., 2009, Use of U-Pb ages of detrital zircons to infer maximum depositional ages of strata: A test against a Colorado Plateau Mesozoic database: Earth and Planetary Science Letters, v. 288, p. 115-125, doi:10.1016/j.eps1.2009.09.013.

Dillon, J.T., Tilton, G.R., Decker, J., and Kelley, M.J., 1987, Resource implications of magmatic and metamorphic ages for Devonian igneous rocks in the Brooks Range, in Tailleur, I.L., and Weimer, P., eds., Alaskan North Slope geology: Pacific Section, Society of Economic Paleontologists and Mineralogists Book 50, p. 713-723.

Dumoulin, J.A., Harris, A.G., Bradley, D.C., and De Freitas, T.A., 2000, Facies patterns and conodont biogeography in Arctic Alaska and the Canadian Arctic Islands: Evidence against juxtaposition of these areas during early Paleozoic time: Polarforschung, v. 68, p. $257-266$.

Dutro, J.T., Jr., Brosgé, W.P., and Reiser, H.N., 1972, Significance of recently discovered Cambrian fossils and reinterpretation of Neruokpuk Formation, northeastern Alaska: American Association of Petroleum Geologists Bulletin, v. 56, p. 808-815. 
Dutro, J.T., Jr., Brosgé, W.P., Lanphere, M.A., and Reiser, H.N., 1976, Geologic significance of Doonerak structural high, central Brooks Range, Alaska: American Association of Petroleum Geologists Bulletin, v. 60, p. 952-961.

Ernst, R., and Bleeker, W., 2010, Large igneous provinces (LIPs), giant dyke swarms, and mantle plumes: Significance for breakup events within Canada and adjacent regions from 2.5 Ga to the present: Canadian Journal of Earth Sciences, v. 47, p. 695-739, doi: 10.1139/E10-025.

Gallagher, K., and Hawkesworth, C., 1992, Dehydration melting and the generation of continental flood basalts: Nature, v. 358, p. 57-59, doi: 10.1038/358057a0.

Gasser, D., and Anderson, A., 2013, Caledonian terrane amalgamation of Svalbard: Detrital zircon provenance of Mesoproterozoic to Carboniferous strata from Oscar II Land, western Spitsbergen: Geological Magazine, v. 150, p. 1103-1126, doi: 10.1017 /S0016756813000174.

Gee, D.G., Johansson, Å., Ohta, Y., Tebenkov, A.M., Krasil'schikov, A.A., Balashov, Y.A., Larionov, A.N., Gannibal, L.F., and Ryungenen, G.I., 1995, Grenvillian basement and a major unconformity within the Caledonides of Nordaustlandet, Svalbard: Precambrian Research, v. 70, p. 215-234, doi: 10 .1016/0301 -9268 (94)00041 -O.

Krasil'schikov, A.A., Balashov, Y.A., Larionov, A.N., Gannibal, L.F., and Ryungenen, G.I., 1995, Grenvillian basement and a major unconformity within the Caledonides of Nordaustlandet, Svalbard: Precambrian Research, v. 70, p. 215-234, doi: 10.1016/03019268(94)00041-O. 
Gehrels, G.E., and Pecha, M., 2014, Detrital zircon U-Pb geochronology and Hf isotope geochemistry of Paleozoic and Triassic passive margin strata of western North America: Geosphere, v. 10, p. 49-65, doi: 10.1130/GES00889.1.

Gehrels, G.E., and Saleeby, J.B., 1987, Geologic framework, tectonic evolution, and displacement history of the Alexander Terrane: Tectonics, v. 6, no. 2, p. 151, doi: 10.1029/TC006i002p00151.

Goodfellow, W.D., Cecile, M.P., and Leybourne, M.I., 1995, Geochemistry, petrogenesis, and tectonic setting of lower Paleozoic alkalic and potassic volcanic rocks, northern Canadian Cordilleran miogeocline: Canadian Journal of Earth Sciences, v. 32, p. 2167, doi: 10.1139/e95-169.

Gordey, S.P., and Anderson, R.G., 1993, Evolution of the northern Cordilleran miogeocline, Nahanni map area (105-I), Yukon and Northwest Territories: Geological Survey of Canada Memoir 428, $214 \mathrm{p}$.

Gottlieb, E.S., Meisling, K.E., Miller, E.L., and Mull, C.G., 2014, Closing the Canada Basin: Detrital zircon geochronology relationships between the North Slope of Arctic Alaska and the Franklinian mobile belt of Arctic Canada: Geosphere, v. 10, p. 1366-1384, doi: 10.1130/GES01027.1.

Gower, C.F., 1996, The evolution of the Grenville Province in eastern Labrador, Canada, in Brewer, T.S., ed., Precambrian crustal evolution in the North Atlantic region: Geological Society, London, Special Publication 112, p. 197-218, doi:

10.1144/GSL.SP.1996.112.01.11.

Gradstein, F.M., Ogg, J.G., Smith, A.G., and Ogg, G., 2012, The geologic time scale 2012: Boston, Elsevier, 1176 p. 
Grantz, A., Hart, P.E., and Childers, V.A., 2011, Geology and tectonic development of the Amerasia and Canada Basins, Arctic Ocean, in Spencer, A.M., et al., eds., Arctic petroleum geology: Geological Society, London, Memoir 35, p. 771-799, doi: 10.1144/M35.50.

Grove, M.J., Gehrels, G.E., Cotkin, S.J., Wright, J.E., and Zou, H., 2008, Non-Laurentian cratonal provenance of Late Ordovician eastern Klamath blueschists and a link to the Alexander terrane, in Wright, J.E., and Shervais, J.W., eds., Ophiolites, arcs, and batholiths: A tribute to Cliff Hopson: Geological Society of America Special Paper 438, p. 223-250, doi: 10.1130/2008.2438(08).

Hadlari, T., Davis, W.J., Dewing, K., Heaman, L.M., Lemieux, Y., Ootes, L., Pratt, B.R., and Pyle, L.J., 2012, Two detrital zircon signatures for the Cambrian passive margin of northern Laurentia highlighted by new U-Pb results from northern Canada: Geological Society of America Bulletin, v. 124, p. 1155-1168, doi: 10.1130/B30530.1.

Hadlari, T., Davis, W.J., and Dewing, K., 2014, A pericratonic model for the Pearya terrane as an extension of the Franklinian margin of Laurentia, Canadian Arctic: Geological Society of America Bulletin, v. 126, p. 182-200, doi: 10.1130/B30843.1.

Hames, W.E., and Cheney, J.T., 1997, On the loss of ${ }^{40} \mathrm{Ar} *$ from muscovite during polymetamorphism: Geochimica et Cosmochimica Acta, v. 61, p. 3863-3872, doi: 10.1016/S0016-7037(97)00207-X.

Hanks, C.L., 1989, Balanced cross sections of the Aichilik River and Okpilak Batholith regions, northeastern Brooks Range, Alaska: Alaska Division of Geological \& Geophysical Surveys Public Data File 90-2A, 18 p., 2 sheets, scale 1:125,000, doi: 10.14509/1434. 
Hanks, C.L., 1993, The Cenozoic structural evolution of a fold-and-thrust belt, northeastern Brooks Range, Alaska: Geological Society of America Bulletin, v. 105, p. 287-305, doi: 10.1130/0016-7606(1993)105<0287:TCSEOA>2.3.CO;2.

Harrison, T.M., Célérier, J., Aikman, A.B., Hermann, J., and Heizler, M.T., 2009, Diffusion of ${ }^{40} \mathrm{Ar}$ in muscovite: Geochimica et Cosmochimica Acta, v. 73, p. 1039-1051, doi: 10.1016/j.gca.2008.09.038.

Hofmann, H.J., and Cecile, M.P., 1981, Occurrence of Oldhamia and other trace fossils in Lower Cambrian(?) argillites, Niddery Lake map area, Selwyn Mountains, Yukon Territory, in Current research, Part A: Geological Survey of Canada Paper 81-1A, p. 281-289.

Hofmann, H.J., Cecile, M.P., and Lane, L.S., 1994, New occurrences of Oldhamia and other trace fossils in the Cambrian of the Yukon and Ellesmere Island, arctic Canada: Canadian Journal of Earth Sciences, v. 31, p. 767-782, doi: 10.1139/e94-070.

Houseknecht, D.W., and Connors, C.D., 2016, Pre-Mississippian tectonic affinity across the Canada Basin-Arctic margins of Alaska and Canada: Geology, v. 44, p. 507-510, doi: 10.1130/G37862.1.

Hubbard, R.J., Edrich, S.P., and Rattey, R.P., 1987, Geologic evolution and hydrocarbon habitat of the 'Arctic Alaska Microplate': Marine and Petroleum Geology, v. 4, p. 2-34, doi: 10.1016/0264-8172(87)90019-5.

Hunziker, J.C., Frey, M., Clauer, N., Dallmeyer, R.D., Friedrichsen, W., Hochstrasser, K., Roggwiler, P., and Schwander, H., 1986, The evolution of illite to muscovite: Mineralogical and isotopic data from the Glarus Alps, Switzerland: Contributions to Mineralogy and Petrology, v. 92, p. 157-180, doi: 10 .1007/BF00375291. 
Johansson, Å., Larionov, A.N., Gee, D.G., Ohta, Y., Tebenkov, A.M., and Sandelin, S., 2004, Grenvillian and Caledonian tectono-magmatic activity in northeasternmost Svalbard, in Gee, D.G., and Pease, V.L., eds., The Neoproterozoic Timanide orogen of eastern Baltica: Geological Society, London, Memoir 30, p. 207-232, doi: 10.1144/GSL.MEM.2004.030.01.17.

Kalsbeek, F., Higgins, A.K., Jepsen, H.F., Nutman, A.P., Thrane, K., Nutman, A.P., and Jepsen, H.F., 2008, Granites and granites in the East Greenland Caledonides, in Higgins, A.K., et al., eds., The Greenland Caledonides: Evolution of the northeast margin of Laurentia: Geological Society of America Memoir 202, p. 227-249, doi: 10.1130/2008.1202(09).

Kalsbeek, F., Thrane, K., Nutman, A.P., and Jepsen, H.F., 2000, Late Mesoproterozoic to early Neoproterozoic history of the East Greenland Caledonides: Evidence for Grenvillian orogenesis?: Journal of the Geological Society [London], v. 157, p. 1215-1225, doi: 10.1144/jgs.157.6.1215.

Kalsbeek, F., Jepsen, H.F., and Nutman, A.P., 2001, From source migmatites to plutons: Tracking the origin of ca. 435 Ma S-type granites in the East Greenland Caledonian orogen: Lithos, v. 57, p. 1-21, doi: 10.1016/S0024-4937(00)00071-2.

Kelley, J.S., Wrucke, C.T., and Lane, L.S., 1994, Pre-Mississippian rocks in the Clarence and Malcolm rivers area, Alaska and Yukon Territory, in Thurston, D.K., and Fujita, K., eds., 1992 Proceedings, International Conference on Arctic Margins: U.S. Department of the Interior Minerals Management Service, OCS (Outer Continental Shelf) Study MMS 940040, p. 59-64.

Ketchum, J.W.F., Heaman, L.M., Krogh, T.E., Culshaw, N.G., and Jamieson, R.A., 1998, Timing and thermal influence of late orogenic extension in the lower crust: A U-Pb 
geochronological study from the southwest Grenville orogen, Canada: Precambrian Research, v. 89, p. 25-45.

Kirkland, C.L., Pease, V.L., Whitehouse, M.J., and Ineson, J.R., 2009, Provenance record from Mesoproterozoic-Cambrian sediments of Peary Land, North Greenland: Implications for the ice-covered Greenland Shield and Laurentian palaeogeography: Precambrian Research, v. 170, p. 43-60, doi: 10.1016 /j.precamres.2008.11.006.

Kochelek, E.J., Amato, J.M., Pavlis, T.L., and Clift, P.D., 2011, Flysch deposition and preservation of coherent bedding in an accretionary complex: Detrital zircon ages from the upper Cretaceous Valdez Group, Chugach terrane, Alaska: Lithosphere, v. 3, p. 265274, doi: 10.1130/L131.1.

Lane, L.S., 1991, The pre-Mississippian "Neruokpuk Formation,” northeastern Alaska and northwestern Yukon: Review and new regional correlation: Canadian Journal of Earth Sciences, v. 28, p. 1521-1533, doi: 10.1139/e91-136.

Lane, L.S., 1997, Canada Basin, Arctic Ocean: Evidence against a rotational origin: Tectonics, v. 16, p. 363-387, doi: 10.1029/97TC00432.

Lane, L.S., 2007, Devonian-Carboniferous paleogeography and orogenesis, northern Yukon and adjacent Arctic Alaska: Canadian Journal of Earth Sciences, v. 44, p. 679-694, doi: 10.1139/e06-131.

Lane, L.S., and Cecile, M.P., 1989, Stratigraphy and structure of the Neruokpuk Formation, northern Yukon, in Current research, Part G: Frontier Geoscience program, Arctic Canada: Geological Survey of Canada Paper 89-1G, p. 57-62. 
Lane, L.S., and Gehrels, G.E., 2014, Detrital zircon lineages of late Neoproterozoic and Cambrian strata, NW Laurentia: Geological Society of America Bulletin, v. 126, p. 398414, doi: 10.1130/B30848.1.

Lane, L.S., Kelley, J.S., and Wrucke, C.T., 1995, Stratigraphy and structure of the Clarence River area, Yukon-Alaska North Slope: A USGS-GSC co-operative project, in Current research, Part E: Geological Survey of Canada Paper 1995-E, p. 1-9.

Lane, L.S., Gehrels, G.E., and Layer, P.W., 2016, Provenance and paleogeography of the Neruokpuk Formation, northwest Laurentia: An integrated synthesis: Geological Society of America Bulletin, B31234.1, doi: 10.1130/B31234 .1.

Lawver, L.A., and Scotese, C.R., 1990, A review of tectonic models for the evolution of the Canadian Basin, in Grantz, A., et al., eds., The Arctic Ocean region: Boulder, Colorado, Geological Society of America, Geology of North America, v. L, p. 593-618.

Leffingwell, E.K., 1919, The Canning River region, northern Alaska: U.S. Geological Survey Professional Paper 109, 251 p.

Lemieux, Y., Hadlari, T., and Simonetti, A., 2011, Detrital zircon geochronology and provenance of Devono-Mississippian strata in the northern Canadian Cordilleran miogeocline: Canadian Journal of Earth Sciences, v. 48, p. 515-541, doi: 10.1139/E10056.

Lenz, A.C., and Perry, D.G., 1972, The Neruokpuk Formation of the Barn Mountains and Driftwood Hills, northern Yukon: Its age and graptolite fauna: Canadian Journal of Earth Sciences, v. 9, p. 1129-1138, doi: 10.1139/e72-098.

Lerand, M., 1973, Beaufort Sea, in McCrossam, R.G., ed., The future petroleum provinces of Canada—Their geology and potential: Canadian Society of Petroleum Geology Memoir 
1, p. 315-386. Leslie, C.D., 2009, Detrital zircon geochronology and rift-related magmatism: Central Mackenzie Mountains, Northwest Territories [M.S. thesis]: Vancouver, University of British Columbia, 224 p., doi: 10.14288/1.0052744.

Macdonald, F.A., McClelland, W.C., Schrag, D.P., and MacDonald, W.P., 2009, Neoproterozoic glaciation on a carbonate platform margin in Arctic Alaska and the origin of the North Slope subterrane: Geological Society of America Bulletin, v. 121, p. 448-473, doi: 10.1130/B26401.1.

MacNaughton, R.B., Moynihan, D.P., Roots, C.F., and Crowley, J.L., 2016, New occurrences of Oldhamia in eastern Yukon, Canada: Stratigraphic context and implications for Cambrian deep-marine biostratigraphy: Ichnos, v. 23, p. 33-52, doi:

10.1080/10420940.2015.1127232.

Malone, S.J., McClelland, W.C., von Gosen, W., and Piepjohn, K., 2014, Proterozoic evolution of the North Atlantic-Arctic Caledonides: Insights from detrital zircon analysis of metasedimentary rocks from the Pearya terrane, Canadian High Arctic: Journal of Geology, v. 122, p. 623-647, doi: 10.1086/677902.

Martin, A.J., Copeland, P., and Benowitz, J.A., 2015, Muscovite ${ }^{40} \mathrm{Ar} /{ }^{39} \mathrm{Ar}$ ages help reveal the Neogene tectonic evolution of the southern Annapurna Range, central Nepal, in Mukherjee, S., et al., eds., Tectonics of the Himalaya: Geological Society, London, Special Publication 412, p. 199-220, doi: 10.1144/SP412 .5.

McClelland, W.C., Malone, S.J., von Gosen, W., Piepjohn, K., and Läufer, A., 2012, The timing of sinistral displacement of the Pearya terrane along the Canadian Arctic margin: Zeitschrift der Deutschen Gesellschaft für Geowissenschaften, v. 163, p. 251-259, doi: $10.1127 / 1860-1804 / 2012 / 0163-0251$. 
McClelland, W.C., Colpron, M., Piepjohn, K., von Gosen, W., Ward, W.P., and Strauss, J.V., 2015, Preliminary detrital zircon geochronology of the Neruokpuk Formation in the Barn Mountains, Yukon, in MacFarlane, K.E., et al., eds., Yukon exploration and geology 2014: Whitehorse, Yukon Geological Survey, p. 123-143.

McKenzie, D., and Bickle, M.J., 1988, The volume and composition of melt generated by extension of the lithosphere: Journal of Petrology, v. 29, p. 625-679, doi: 10.1093/petrology/29.3.625.

Miller, E.L., Toro, J., Gehrels, G.E., Amato, J.M., Prokopiev, A., Tuchkova, M.I., Akinin, V.V., Dumitru, T.A., Moore, T.E., and Cecile, M.P., 2006, New insights into Arctic paleogeography and tectonics from $\mathrm{U}-\mathrm{Pb}$ detrital zircon geochronology: Tectonics, v. 25, TC3013, doi: 10.1029/2005TC001830.

Miller, E.L., Kuznetsov, N., Soboleva, A., Udoratina, O., Grove, M.J., and Gehrels, G.E., 2011, Baltica in the Cordillera?: Geology, v. 39, p. 791-794, doi: 10.1130 /G31910.1.

Moore, T.E., 1987, Geochemistry and the tectonic setting of volcanic rocks of the Frankinian assemblage, central and eastern Brooks Range, in Tailleur, I., and Weimer, P., eds., Alaskan North Slope geology: Pacific Section, Society of Economic Paleontologists and Mineralogists Publication 50, p. 691-710.

Moore, T.E., 1999, Balanced cross section, Bathtub syncline to Beaufort Sea through Niguanak structural high, Arctic National Wildlife Refuge (ANWR), northeastern Alaska: A balanced cross section and kinematic and thermal model across the northeastern Brooks Range mountain front, Arctic National Wildlife Refuge, Alaska, in ANWR Assessment Team, The oil and gas resource potential of the 1002 area, Arctic National Wildlife Refuge, Alaska: U.S. Geological Survey Open-File Report 98-34, 60 p. 
Moore, T.E., and Churkin, M., Jr., 1984, Ordovician and Silurian graptolite discoveries from the Neruokpuk Formation (sensu lato), northeastern and central Brooks Range, Alaska, in Blodgett, R.B., ed., Paleozoic geology of Alaska and northwestern Canada newsletter: Alaska Geological Society, p. 21-23.

Moore, T.E., Wallace, W.K., Bird, K.J., Karl, S.M., Mull, C.G., and Dillon, J.T., 1994, Geology of northern Alaska, in Plafker, G., and Berg, H.C., eds., The geology of Alaska: Boulder, Colorado, Geological Society of America, Geology of North America, v. G-1, p. 49-140.

Moore, T.E., Potter, C.J., O’Sullivan, P.B., Shelton, K.L., and Underwood, M.B., 2004, Two stages of deformation and fluid migration in the west-central Brooks Range fold and thrust belt, northern Alaska, in Swennen, R., et al., eds., Deformation, fluid flow, and reservoir appraisal in foreland fold and thrust belts: American Association of Petroleum Geologists Hedberg Series no. 1, p. 157-186, doi: 10.1306/1025690H13116.

Moore, T.E., O’Sullivan, P.B., Potter, C.J., and Donelick, R.A., 2015, Provenance and detrital zircon geochronologic evolution of lower Brookian foreland basin deposits of the western Brooks Range, Alaska, and implications for early Brookian tectonism: Geosphere, v. 11, p. 93-122, doi: 10.1130/GES01043.1.

Moores, E.M., 1982, Origin and emplacement of ophiolites: Reviews of Geophysics and Space Physics, v. 20, p. 735-760, doi: 10.1029/RG020i004p00735.

Morris, G.A., Kirkland, C.L., and Pease, V., 2015, Orogenic paleofluid flow recorded by discordant detrital zircons in the Caledonian foreland basin of northern Greenland: Lithosphere, v. 7, p. 138-143, doi: 10.1130/L420.1. 
Mortensen, J.K., and Bell, R.T., 1991, U-Pb zircon and titanite geochronology of the Mount Sedgwick pluton, northern Yukon Territory, in Radiogenic age and isotope studies, Report 4: Geological Survey of Canada Paper 90-2, p. 19-24.

Mull, C.G., and Anderson, A.V., 1991, Franklinian lithotectonic domains, northeastern Brooks Range, Alaska: Alaska Division of Geological \& Geophysical Surveys Public Data File 91-5, 40 p., doi: 10.14509/1472.

Nemchin, A.A., and Cawood, P.A., 2005, Discordance of the U-Pb system in detrital zircons: Implication for provenance studies of sedimentary rocks: Sedimentary Geology, v. 182, p. 143-162, doi: 10.1016/j.sedgeo.2005.07.011.

Newberry, R.J., Dillon, J.T., and Adams, D.D., 1986, Regionally metamorphosed, calc-silicatehosted deposits of the Brooks Range, northern Alaska: Economic Geology and the Bulletin of the Society of Economic Geologists, v. 81, p. 1728-1752, doi: 10.2113/gsecongeo.81.7.1728.

Norford, B.S., 1997, Ordovician and Silurian, in Norris, D.K., ed., Geology and mineral and hydrocarbon potential of northern Yukon Territory and northwestern District of Mackenzie: Geological Survey of Canada Bulletin 422, p. 119-162.

Norris, D.K., 1981a, Geology, Blow River and Davidson Mountains, Yukon Territory-District of Mackenzie: Geological Survey of Canada, "A” Series Map 1516A, scale 1:250,000, 1 sheet, doi: 10.4095/119398.

Norris, D.K., 1981b, Geology, Herschel Island and Demarcation Point, Yukon Territory: Geological Survey of Canada, "A" Series Map 1514A, scale 1:250,000, 1 sheet, doi: 10.4095/109649. 
Norris, D.K., 1986, Lower Devonian Road River Formation on the north flank of Romanzof uplift, northern Yukon Territory, in Current research, Part A: Geological Survey of Canada Paper 86-1A, p. 801-802.

Norris, D.K., 1997, Geological setting, in Norris, D.K., ed., The geology, mineral and hydrocarbon potential of the northern Yukon Territory and northwestern District of Mackenzie: Geological Survey of Canada Bulletin 422, p. 21-64.

Ohta, Y., Larionov, A.N., Tebenkov, A.M., Lepvrier, C., Maluski, H., Lange, M., and Hellebrandt, B., 2002, Single-zircon Pbevaporation and ${ }^{40} \mathrm{Ar} /{ }^{39} \mathrm{Ar}$ dating of the metamorphic and granitic rocks in northwest Spitsbergen: Polar Research, v. 21, p. 7389, doi: 10.1111/j.1751-8369.2002.tb00068.x.

Oldow, J.S., Avé Lallemant, H.G., Julian, F.E., and Seidensticker, C.M., 1987, Ellesmerian(?) and Brookian deformation in the Franklin Mountains, northeastern Brooks Range, Alaska, and its bearing on the origin of the Canada Basin (USA): Geology, v. 15, p. 3741, doi: 10.1130/0091-7613(1987)15<37:EABDIT>2.0.CO;2.

Oliver, G.J.H., Wilde, S.A., and Wan, Y., 2008, Geochronology and geodynamics of Scottish granitoids from the late Neoproterozoic break-up of Rodinia to Palaeozoic collision: Journal of the Geological Society [London], v. 165, p. 661-674, doi: 10.1144/001676492007-105.

O’Sullivan, P.B., 1993, Multiple phases of Tertiary uplift and erosion in the Arctic National Wildlife Refuge, Alaska, revealed by apatite fission track analysis: American Association of Petroleum Geologists Bulletin, v. 77, p. 359-385, doi: 10.1306/BDFF8C0E-171811D7-8645000102C1865D. 
O'Sullivan, P.B., 1994, Timing of Tertiary episodes of cooling in response to uplift and erosion, northeastern Brooks Range, Alaska, in Thurston, D.K., and Fujita, K., eds., 1992 Proceedings, International Conference on Arctic Margins: U.S. Department of the Interior Minerals Management Service, OCS (Outer Continental Shelf) Study MMS 940040, p. 269-274.

O'Sullivan, P.B., and Wallace, W.K., 2002, Out-of-sequence, basement-involved structures in the Sadlerochit Mountains region of the Arctic National Wildlife Refuge, Alaska: Evidence and implications from fission-track thermochronology: Geological Society of America Bulletin, v. 114, p. 1356-1378, doi: 10.1130/0016-7606(2002)114 $<1356$ :OOSBIS >2.0.CO;2.

Patchett, P.J., Roth, M.A., Canale, B.S., De Freitas, T.A., Harrison, J.C., Embry, A.F., and Ross, G.M., 1999, Nd isotopes, geochemistry, and constraints on sources of sediments in the Franklinian mobile belt, Arctic Canada: Geological Society of America Bulletin, v. 111, p. 578-589, doi: 10.1130/0016-7606(1999)111<0578:NIGACO>2.3.CO;2.

Peapples, P.R., Wallace, W.K., Hanks, C.L., Layer, P.W., and O’Sullivan, P.B., 1997, Style, controls, and timing of fold-and-thrust deformation of the Jago stock, northeastern Brooks Range, Alaska: Canadian Journal of Earth Sciences, v. 34, p. 992-1007, doi: 10.1139/e17-082.

Pearce, J.A., 2008, Geochemical fingerprinting of oceanic basalts with applications to ophiolite classification and the search for Archean oceanic crust: Lithos, v. 100, p. 14-48, doi: 10.1016/j.lithos.2007.06.016.

Pettersson, C.H., Tebenkov, A.M., Larionov, A.N., Andresen, A., and Pease, V., 2009, Timing of migmatization and granite genesis in the Northwestern terrane of Svalbard, Norway: 
Implications for regional correlations in the Arctic Caledonides: Journal of the Geological Society [London], v. 166, p. 147-158, doi: 10.1144/0016-76492008-023.

Pettersson, C.H., Pease, V., and Frei, D., 2010, Detrital zircon U-Pb ages of Silurian-Devonian sediments from NW Svalbard: a fragment of Avalonia and Laurentia?: Journal of the Geological Society, v. 167, no. 5, p. 1019-1032, doi: 10.1144/0016-76492010-062.

Powell, J., and Schneider, D.A., 2013, Preliminary results of detrital muscovite ${ }^{40} \mathrm{Ar} /{ }^{39} \mathrm{Ar}$ geochronology from the eastern Mackenzie Mountains and Mackenzie Plain, Northwest Territories: Geological Survey of Canada Current Research 2013-18, 16 p., doi: 10.4095 1292712.

Rainbird, R.H., Heaman, L.M., and Young, G., 1992, Sampling Laurentia: Detrital zircon geochronology offers evidence for an extensive Neoproterozoic river system originating from the Grenville orogen: Geology, v. 20, p. 351-354, doi: 10.1130/00917613(1992)020<0351:SLDZGO>2.3.CO;2

Rainbird, R.H., Jefferson, C.W., and Young, G.M., 1996, The early Neoproterozoic sedimentary Succession B of northwestern Laurentia: Correlations and paleogeographic significance: Geological Society of America Bulletin, v. 108, p. 454-470, doi: 10.1130/0016-7606 (1996) $108<0454:$ TENSSB >2.3.CO;2.

Rainbird, R., Cawood, P., and Gehrels, G., 2012, The Great Grenvillian sedimentation episode: Record of supercontinent Rodinia's assembly, in Busby, C., and Azor, A., eds., Tectonics of sedimentary basins: Recent advances: Chichester, John Wiley \& Sons, Ltd., p. 583601, doi: 10.1002/9781444347166.ch29.

Reed, B.L., 1968, Geology of the Lakes Peters area northeastern Brooks Range, Alaska: U.S. Geological Survey Bulletin 1236, 136 p. 
Rehnström, E.F., 2010, Prolonged Paleozoic magmatism in the East Greenland Caledonides: Some constraints from U-Pb ages and Hf isotopes: Journal of Geology, v. 118, p. 447465, doi: 10.1086/655010.

Reiser, H.N., Brosge, W.P., Dutro, J.T., Jr., and Detterman, R.L., 1980, Geologic map of the Demarcation Point quadrangle, Alaska: U.S. Geological Survey Miscellaneous Investigations Series Map 1133, scale 1:250,000.

Sable, E.G., 1977, Geology of the western Romanzof Mountains, Brooks Range, northeastern Alaska: U.S. Geological Survey Professional Paper 897, 84 p.

Saleeby, J.B., 1983, Accretionary tectonics of the North American Cordillera: Annual Review of Earth and Planetary Sciences, v. 11, p. 45-73, doi: 10.1146 /annurev.ea.11.050183.000401.

Schermer, E.R., Howell, D.G., and Jones, D.L., 1984, The origin of allochthonous terranes: Perspectives on the growth and shaping of continents: Annual Review of Earth and Planetary Sciences, v. 12, p. 107-131, doi: 10.1146/annurev.ea.12.050184.000543.

Şengör, A.M.C., Natal'in, B.A., and Burtman, V.S., 1993, Evolution of the Altaid tectonic collage and Palaeozoic crustal growth in Eurasia: Nature, v. 364, no. 6435, p. 299-307, doi: $10.1038 / 364299 \mathrm{a} 0$.

Sharman, G.R., Graham, S.A., Grove, M., and Hourigan, J.K., 2013, A reappraisal of the early slip history of the San Andreas fault, central California, USA: Geology, v. 41, p. 727730, doi: $10.1130 / \mathrm{G} 34214.1$.

Sherlock, S.C., Jones, K.A., and Kelley, S.P., 2002, Fingerprinting polyorogenic detritus using the laser microprobe ${ }^{40} \mathrm{Ar} /{ }^{39} \mathrm{Ar}$ ultraviolet: Geology, v. 30, p. 515-518, doi: 10.1130/0091-7613(2002)030<0515. 
Stewart, J., 1976, Late Precambrian evolution of North America: Plate tectonics implication: Geology, v. 4, p. 11-15, doi: 10.1130/0091-7613(1976)4<11:LPEONA>2.0.CO;2

Strauss, J.V., MacDonald, F.A., Taylor, J.F., Repetski, J.E., and McClelland, W.C., 2013, Laurentian origin for the North Slope of Alaska: Implications for the tectonic evolution of the Arctic: Lithosphere, v. 5, p. 477-482, doi: 10.1130/L284 .1.

Sweeney, J.F., 1982, Mid-Palaeozoic travels of Arctic Alaska: Nature, v. 298, p. 647-649, doi: $10.1038 / 298647 \mathrm{a} 0$.

Till, A.B., 2016, A synthesis of Jurassic and Early Cretaceous crustal evolution along the southern margin of the Arctic Alaska-Chukotka microplate and implications for defining tectonic boundaries active during opening of Arctic Ocean basins: Lithosphere, v. 8, p. 219-237, doi: 10.1130/L471.1.

Trettin, H.P., 1987, Pearya: A composite terrane with Caledonian affinities in northern Ellesmere Island: Canadian Journal of Earth Sciences, v. 24, p. 224-245, doi: 10.1139/e87 -025.

Trettin, H.P., 1994, Pre-Carboniferous geology of the northern part of the Arctic Islands, Hazen Fold Belt and adjacent parts of central Ellesmere Fold Belt, Ellesmere Island: Geological Survey of Canada Bulletin 430, 260 p., doi: 10.4095/194326.

Trettin, H.P., 1998, Pre-Carboniferous geology of the northern part of the Arctic Islands: Northern Heiberg Fold Belt, Clements Markham Fold Belt, and Pearya; northern Axel Heiberg and Ellesmere islands: Geological Survey of Canada Bulletin 425, 401 p., doi: $10.4095 / 209572$.

Turnbull, M.J.M., Whitehouse, M.J., and Moorbath, S., 1996, New isotopic age determinations for the Torridonian, NW Scotland: Journal of the Geological Society [London], v. 153, p. 955-964, doi: 10.1144/gsjgs.153.6.0955. 
van Staal, C.R., and Barr, S.M., 2012, Lithospheric architecture and tectonic evolution of the Canadian Appalachians and associated Atlantic margin, in Percival, J.A., et al., eds., Tectonic styles in Canada: The LITHOPROBE perspective: Geological Association of Canada Special Paper 49, p. 41-45.

Verdel, C., van der Pluijm, B.A., and Niemi, N., 2012, Variation of illite/muscovite ${ }^{40} \mathrm{Ar} /{ }^{39} \mathrm{Ar}$ age spectra during progressive low-grade metamorphism: An example from the US Cordillera: Contributions to Mineralogy and Petrology, v. 164, p. 521-536, doi: 10.1007 /s00410 -012 -0751-7.

von Gosen, W., Piepjohn, K., Murphy, D.C., Brandes, C., McClelland, W.C., and Colpron, M., 2015, Fault tectonics in the Rapid depression of the Yukon North Slope (Canadian Arctic)-Summary of preliminary results, in MacFarlane, K.E., and Nordling, M.G., eds., Yukon exploration and geology 2014: Whitehorse, Yukon Geological Survey, p. 157165.

Wallace, W.K., and Hanks, C.L., 1990, Structural provinces of the northeastern Brooks Range, Arctic National Wildlife Refuge, Alaska: American Association of Petroleum Geologists Bulletin, v. 74, p. 1100-1118, doi: 10.1306 /0C9B2425-1710-11D7-8645000102C1865D. Watt, G.R., Kinny, P.D., and Friderichsen, J.D., 2000, U-Pb geochronology of Neoproterozoic and Caledonian tectonothermal events in the East Greenland Caledonides: Journal of the Geological Society [London], v. 157, p. 1031-1048, doi: 10.1144 /jgs.157.5.1031.

White, C., Gehrels, G.E., Pecha, M., Giesler, D., Yokelson, I., McClelland, W.C., and Butler, R.F., 2016, U-Pb and $\mathrm{Hf}$ isotope analysis of detrital zircons from Paleozoic strata of the southern Alexander terrane (southeast Alaska): Lithosphere, v. 8, p. 83-96, doi: 10.1130/L475.1. 


\section{Chapter 3: The Whale Mountain allochthon: A relic of the}

\section{Iapetus Ocean preserved in the northeastern Brooks Range of}

\section{Alaska and Yukon}

Benjamin G. Johnson ${ }^{1}$, Justin V. Strauss², John F. Taylor ${ }^{3}$, William P. Ward ${ }^{4}$, Maurice Colpron$^{5}$, William C. McClelland ${ }^{4}$, Jaime Toro ${ }^{1}$

${ }^{1}$ Department of Geology and Geography, West Virginia University, Morgantown, West Virginia, 26506 USA

${ }^{2}$ Department of Earth Sciences, Dartmouth College, Hanover, New Hampshire 03755, USA

${ }^{3}$ Department of Geoscience, Indiana University of Pennsylvania, Indiana, Pennsylvania 15705

USA

${ }^{4}$ Department of Earth and Environmental Sciences, University of Iowa, Iowa City, Iowa 52242, USA

${ }^{5}$ Yukon Geological Survey, Whitehorse, Yukon, Canada YIA 2 C6

\section{ABSTRACT}

The Whale Mountain allochthon is a structural complex composed of lower Paleozoic mafic volcanic and marine sedimentary rocks that are exposed within three fault-bounded, eastwest-trending belts in the northeastern Brooks Range of Alaska and Yukon. Each belt is characterized by a unique structural and stratigraphic architecture. Trace-element systematics from the volcanic rocks define distinctive suites that are geographically restricted to each belt. The volcanic rocks of the southern belt (the Marsh Fork volcanic rocks) have a tholeiitic character and rare earth element trends that resemble modern mid-ocean-ridge basalt. The volcanic rocks of the central belt (the Whale Mountain volcanic rocks) and northern belt 
(Ekaluakat formation; new name) both have an alkaline character, but the northern belt rocks are significantly more enriched in the incompatible trace elements. New zircon U-Pb data from two volcaniclastic rock units, one from the southern belt and another from central belt, yield unimodal age populations that range from ca. 567 to $474 \mathrm{Ma}$, with weighted averages of $504 \pm$ 11 and $512 \pm 1.4$ Ma for each sample. In the central and southern belts of the allochthon, basalt flows are interbedded with discontinuous limestone and dolostone units that contain trilobites and agnostoid arthropods. Three distinct trilobite faunas of late Cambrian (Furongian) age were recovered from widely separated localities. The scarcity of uniquely Laurentian genera, coupled with an abundance of distinctive species that could not be assigned to any established Furongian genus, argues against models that invoke extrusion of these volcanic rocks onto the autochthonous Laurentian shelf or slope. It is thus proposed that the Whale Mountain allochthon formed in a peri-Laurentian setting, possibly as disparate fragments of the northern Iapetus Ocean that were assembled in an ancient accretionary wedge and subsequently accreted to the northern margin of Laurentia during the early Paleozoic.

\section{INTRODUCTION}

Dense oceanic lithosphere is consumed by subduction at convergent margins, erasing most, if not all, evidence of the ancient seafloor from the geologic record. In rare cases, however, relics of ancient ocean basins are preserved within orogenic belts in the form of ophiolites or fragments of oceanic crust, scraped off a subducting plate and entrained into an accretionary wedge. The Iapetus Ocean, the early Paleozoic ancestor to the modern Atlantic Ocean, is a classic example of an ancient ocean basin where the geologic record has largely been destroyed by subduction and the suturing of several large paleocontinents (e.g., van Staal et al., 1998). Disconnected tracts of ophiolites and oceanic fragments scattered along the Northern 
Appalachians (van Staal and Barr, 2012), the British Isles (Chew and Strachan, 2014), and the Scandinavian Caledonides (Corfu et al., 2014) mark the sparse remains of the Iapetus Ocean.

Paleogeographic reconstructions have postulated a continuation of the Iapetus suture into the paleo-Arctic realm (e.g., Lawver, et al., 2002; Colpron and Nelson, 2011; Miller et al., 2011; Pease, 2011; Beranek et al., 2013; Strauss et al., 2017; Hoiland et al., 2017). The composite Arctic Alaska terrane, sometimes grouped within the larger Arctic Alaska-Chukotka microplate (e.g., Miller et al., 2006), is prominently featured in the paleogeographic reconstructions of the Arctic. An abundance of recent geochronological and paleontological evidence suggests that the various subterranes that compose the greater Arctic Alaska terrane can be assigned to at least three separate paleogeographic affinities at the time of Iapetus closure. Southern Arctic Alaska includes the Seward, Hammond, Slate Creek, and Coldfoot subterranes of Moore et al. (1994). Recently, Hoiland et al. (2017) grouped these into a single southern Brooks Range terrane because they share early Paleozoic affinities with northern Baltica (e.g., Patrick and McClelland, 1995; Dumoulin et al., 2002; Amato et al., 2009, 2014; Miller et al., 2011). The northern half of the Arctic Alaska terrane is contained within the North Slope subterrane (herein simplified to the North Slope), which is unequivocally linked to Laurentia (Strauss et al., 2013; McClelland et al., 2015; Lane et al., 2016; Johnson et al., 2016). Residing along the boundary zone between the southern Brooks Range terrane and the North Slope is the Cambrian(?)-Silurian Doonerak arc complex, which was recently inferred by Strauss et al. (2017) to have formed contemporaneously with Taconic-Caledonian arc magmatism along the northeastern edge of Laurentia, thereby preserving a relic of the Iapetus suture within the Arctic Alaska terrane.

An enduring issue involving the paleogeographic restorations of Arctic Alaska relates to the early Paleozoic position of the North Slope along the northern margin of Laurentia. Some 
researchers have argued that the North Slope restores to northeastern (NE) Laurentia, citing similarities between the rocks exposed in the NE Brooks Range (Fig. 3.1), which belongs to the North Slope, and Ellesmere Island in Arctic Canada (Sweeney, 1982; Strauss et al., 2013; Cox et al., 2015; Johnson et al., 2016). Others have argued that the North Slope remained fixed to northwestern $(\mathrm{NW})$ Laurentia, calling for stratigraphic continuity between strata exposed in the NE Brooks Range and the Selwyn Basin of central Yukon and elsewhere in the Canadian Cordillera (Cecile et al., 1999; Lane, 2007; Lane et al., 2016).

A principal component in these debates relates to the tectonic and depositional setting of the upper Cambrian Whale Mountain volcanic rocks, exposed in the NE Brooks Range. Based on the alkaline geochemistry of the volcanic rocks and putative similarities with mafic volcanic rocks in northern Canada, Lane et al. (2016) argued that these volcanic rocks erupted within the continental margin of northwestern (NW) Laurentia. Conversely, Johnson et al. (2016) argued that the volcanic rocks in the NE Brooks Range were fault-bounded and instead belonged to an exotic Cambrian-Ordovician oceanic fragment, which they named the Whale Mountain allochthon. The interpretations of Lane et al. (2016) and Johnson et al. (2016), however, both fundamentally relied on sparse geochemical data from previous reconnaissance studies (Moore, 1987; Goodfellow et al., 1995), and the biostratigraphic data available to constrain the age and paleogeographic affinities of the Whale Mountain allochthon were limited and imprecise. The limited faunal control was particularly problematic, in that the endemic faunas that evolved on the Laurentian platform during the Cambrian provide the most definitive means of discriminating strata that originated on or adjacent to that paleocontinent from exotic packages that arrived subsequently through accretion. Here, we provide new field observations coupled with additional geochronological, geochemical, and paleontological data from the Whale Mountain volcanic 
rocks and other associated units in the NE Brooks Range that support a peri-Laurentian oceanic origin for the Whale Mountain allochthon.

\section{GEOLOGICAL SETTING}

The high topography of the NE Brooks Range forms a structural salient that protrudes more than $100 \mathrm{~km}$ northward from the main front of the Brook Range and stretches from the Canning River in Alaska into northern Yukon (Fig. 3.1). It is a critical region for geological investigation because it exposes a prominent angular unconformity (Figs. 3.1 and 3.2) that separates Lower Mississippian quartz-rich siliciclastic units of the Endicott Group (Brosgéet al., 1962) from a thick (>2000 m) succession of tightly folded and weakly metamorphosed, Neoproterozoic to lower Paleozoic sedimentary and igneous rocks (pre-Mississippian sequence of Moore et al., 1994).

The sub-Mississippian rocks in the NE Brooks Range have been investigated using a variety of different map and stratigraphic schemes (see Strauss et al., this volume, Chapter 23, and references therein for a review). Initially, the Whale Mountain volcanic rocks were assigned to the "volcanic and carbonate member" of the broadly defined Neruokpuk Formation of Dutro et al. (1972). These workers split the Neruokpuk Formation into six regional sequences, lettered A through F, with the "volcanic and carbonate member" concentrated in parts of sequences A and C. Critically, Dutro et al. (1972) also recovered trilobite and brachiopod fossils from the "volcanic and carbonate member" at two localities, one along the Marsh Fork of the Canning River, and another along the Leffingwell Fork of the Aichilik River (Fig. 3.1). The Marsh Fork locality yielded olenellid trilobites of early Cambrian age, whereas the Leffingwell Fork locality yielded trilobites and brachiopods of late Cambrian age (middle Furongian). 


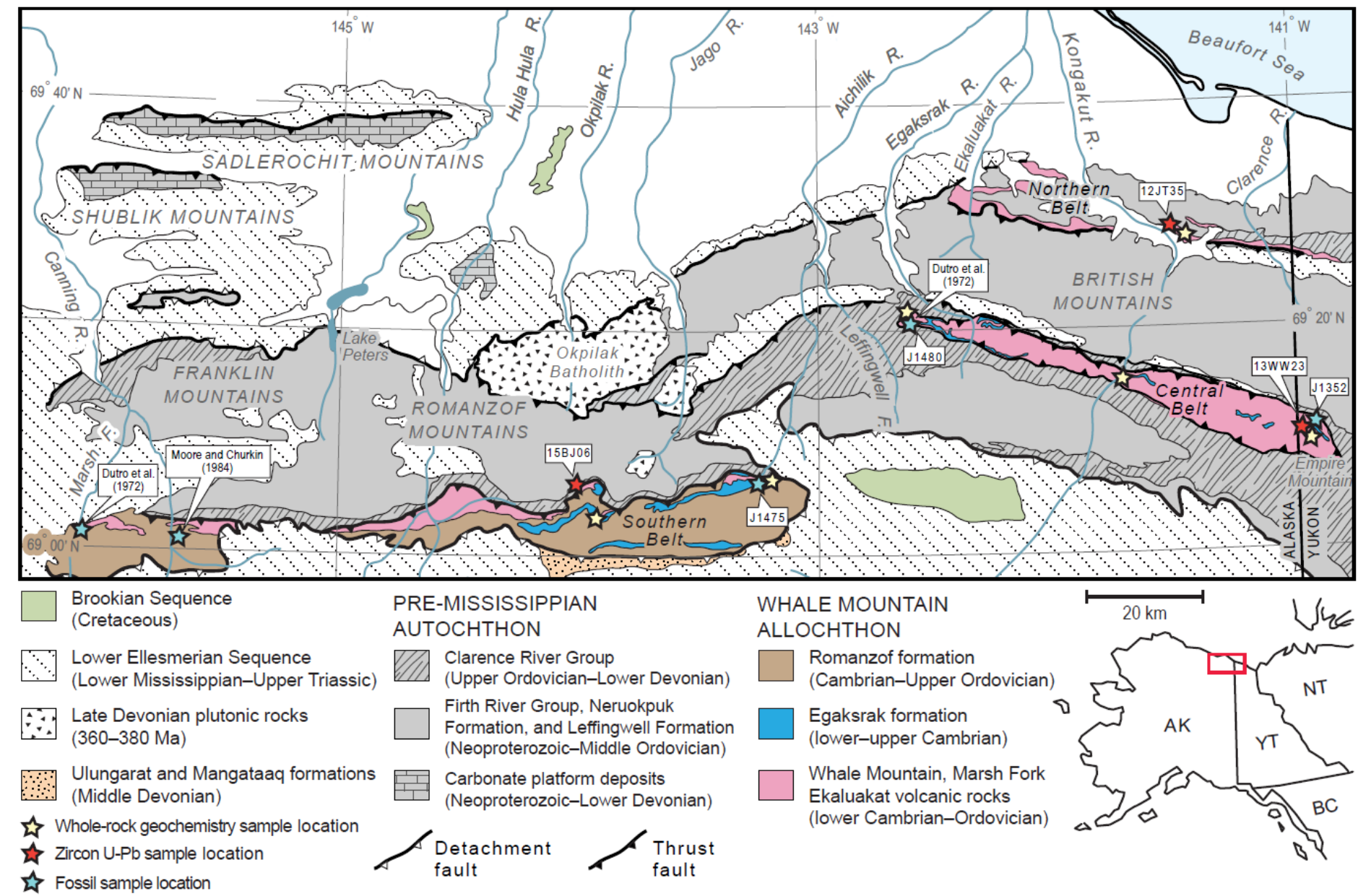

Figure 3.1: Simplified geologic map of the eastern half of the NE Brooks Range, Alaska, highlighting the distribution of rocks comprising the Whale Mountain allochthon and sample locations. The map is modified from Reiser et al. (1980), Wallace and Hanks, (1990), Mull and Anderson, (1991), Lane et al. (1995), and Johnson et al. (2016). Solid teeth on thrust faults indicate disruption of stratigraphic section (old-on-young); open teeth indicate detachment surfaces along which there has been slip but no disruption of the stratigraphic section (young-on-old). Sample numbers are described in the text and outlined in Supplemental Material (Table SM3.1). Sample 12JT35 in the northern belt is from Johnson et al. (2016), and sample 14BJ25 is from Strauss et al. (2018). 
Although Dutro et al. (1972) treated the Neruokpuk Formation as a somewhat coherent stratigraphic package, they, along with an earlier study by Reiser (1970), recognized that a regional thrust fault disrupted parts of the stratigraphic order. The fault was mapped along the base of the volcanic rocks of sequence A in the headwaters of the Aichilik, Jago, Hulahula, and Canning rivers in the Romanzof Mountains, and it was inferred to be concealed by the subMississippian unconformity. Later, during the compilation of the 1: 250,000 scale Demarcation Point geologic quadrangle by Reiser et al. (1980), the sequence nomenclature was abandoned, and the Neruokpuk name was reverted to the original usage of Leffingwell (1919), which restricts the Neruokpuk to the "quartzite and semischist member" of Dutro et al. (1972). The volcanic and carbonate member was also split into two map units: a "Cambrian volcanic and volcaniclastic" unit $(\mathrm{Cv})$ and a "Cambrian limestone" unit $(\mathrm{Cl})$.

Some of the thickest exposures of the volcanic and carbonate rocks occur at Whale Mountain in Alaska, where an 100-km-long, E-W-trending synclinal exposure cuts perpendicularly across the middle reaches of the Kongakut River (Fig. 3.1). Moore (1987) informally named the volcanic rocks exposed along the ridge the "Whale Mountain volcanic rocks," which also included the volcanic rocks exposed at the Leffingwell Fork fossil locality of Dutro et al. (1972), where Moore (1987) analyzed three samples for whole-rock geochemistry. These data, along with a second suite of volcanic samples collected by Goodfellow et al. (1995) from the Yukon segment of the Whale Mountain ridge system, showed that the Whale Mountain volcanic rocks are enriched in incompatible elements (e.g., $\mathrm{Ti}, \mathrm{Zr}, \mathrm{Nb}$ ) and resemble alkaline basalt. Moore (1987) also analyzed eight volcanic samples from exposures along strike at the Marsh Fork locality of Dutro et al. (1972), which were independently assigned to the Marsh Fork volcanic rocks. Moore (1987) showed that the Marsh Fork volcanic rocks had comparable levels 
of incompatible element enrichment as the alkaline Whale Mountain volcanic rocks to the north; however, a few samples had more transitional and tholeiitic compositions.

A separate unit of volcanic rocks was delineated in the northern British Mountains on the map of Reiser et al. (1980). These volcanic rocks extend from the Ekaluakat River in Alaska to the Clarence River at the Alaska-Yukon border (Fig. 3.1). They were originally included in sequence E of Dutro et al. (1972) but were later reassigned to the "Ordovician volcaniclastic and volcanic rocks" (Ovc) map unit by Reiser et al. (1980). The Ordovician age was constrained by a graptolite locality in an adjacent "Ordovician black slate" (Os) map unit, which was tentatively mapped beneath the volcanic rocks. From mapping studies along the Alaska-Yukon border, the volcanic rocks exposed in the Clarence River region were correlated to the thick volcanic flows at Whale Mountain to the south on the basis of lithologic similarity and an apparent gradational contact with Oldhamia-bearing argillite beds (Lane, 1991; Kelley et al., 1994; Lane et al., 1995).

Two recent studies, one by Lane et al. (2016) and another by Johnson et al. (2016), have placed these previously described volcanic rocks of the NE Brooks Range into different stratigraphic positions. In the scheme of Lane et al. (2016), the volcanic rocks, which they named the informal "Whale Mountain formation" reside within a semiconformable succession of Neoproterozoic- Devonian strata. This agrees with previous interpretations from field work conducted in the Clarence River region and along the Alaska-Yukon border (Lane, 1991; Kelley et al., 1994; Lane et al., 1995). Lane et al. (2016) further argued that the volcanic rocks along the Alaska-Yukon border correlate to the Marsh Fork volcanic rocks of Moore (1987), and that these volcanic rocks are all paleogeographic equivalents of volcanic rocks exposed within the Selwyn Basin of central Yukon and elsewhere in the northern Canadian Cordillera (e.g., Goodfellow et al., 1995). Critically, this correlation fixes the North Slope to NW Laurentia in the 
early Paleozoic, suggesting that the Whale Mountain volcanic rocks formed in response to periods of extension along the paleo-Pacific margin.

The scheme of Johnson et al. (2016) is different in that it places the volcanic rocks of the NE Brooks Range within a fault-bounded oceanic assemblage called the Whale Mountain allochthon. Based on mapping along the Kongakut River and Leffingwell Fork in Alaska, coupled with detrital zircon U-Pb and muscovite 40Ar/39Ar geochronology, Johnson et al. (2016) showed that the upper Cambrian Whale Mountain volcanic rocks of Moore (1987) overlie a Upper Ordovician-Lower Devonian(?) succession of interbedded shale, argillite, and lithic-rich sandstone. These sedimentary units were correlated to a similar succession of strata mapped in the Clarence River region along the Alaska-Yukon border (Lane, 1991; Kelley et al., 1994; Lane et al., 1995), which enabled Johnson et al. (2016) to apply the informal Clarence River group name (formalized to the Clarence River Group by Strauss et al., this volume, Chapter 23) to include all similar strata in the NE Brooks Range. This also included the siltstone, shale, sandstone, and lithic-rich pebble conglomerate units exposed in the Buckland Hills of northern Yukon, which Lane et al. (2016) originally assigned to the Lower Devonian "Buckland Hills succession" (updated to the Buckland Hills formation by Strauss et al., this volume, Chapter 23). Johnson et al. (2016) contended that detrital zircon signatures from the Clarence River Group closely resembled those of sedimentary units in the deep-water Franklinian Basin of Ellesmere Island, Arctic Canada (e.g., Beranek et al., 2015). In addition, Johnson et al. (2016) postulated that the emplacement of the Whale Mountain allochthon occurred in concert with protracted terrane accretion in NE Laurentia and the presumed closure of the northern Iapetus Ocean during the Caledonian orogeny. 


\section{SOUTHERN BELT}

Unconformably overlain by middle Devonian Ulungarat and Mangataaq formations
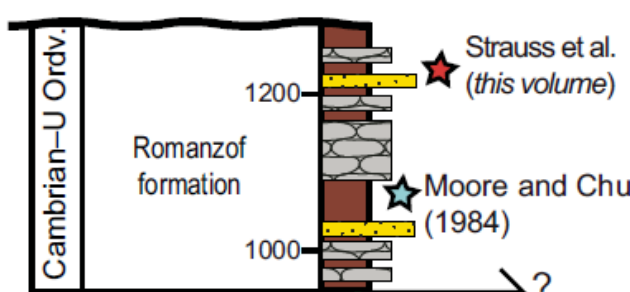

Romanzof

formation$$
\text { (1984) }
$$

$>?$

Marsh Fork

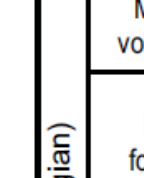

volcanic rocks

Egaksrak formation(?)

800

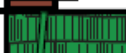

15BJ08

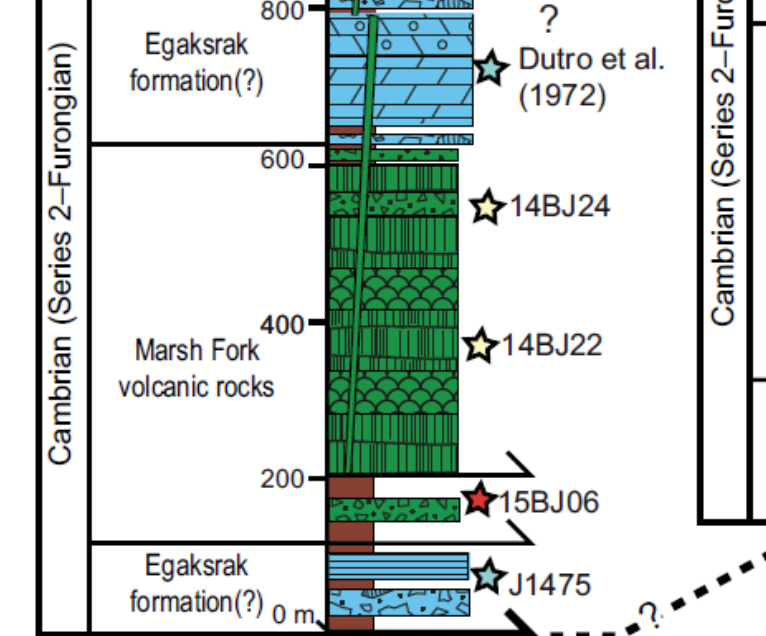

Romanzof Mountain Thrust

\section{CENTRAL BELT}

No units exposed above

No units exposed above 


\section{STRUCTURAL AND STRATIGRAPHIC ARCHITECTURE}

Here, we provide updated lithological descriptions and field observations from the volcanic and sedimentary rocks of the Whale Mountain allochthon in the NE Brooks Range of Alaska and Yukon that were assembled during a series of field campaigns conducted over the course of 5 years (2011-2015). In addition, we put forth new informal terminology for previously unnamed map units (Egaksrak, Romanzof, and Ekaluakat forma $\neg$ tions), which are outlined in Figure 3.2. These rocks are exposed within three E-W-trending thrust sheets or belts, which we refer to as the southern, central, and northern belts (Figs. 3.1 and 3.2). These belts are separated by $\sim 25 \mathrm{~km}$, and each is defined by its own unique structural and stratigraphic architecture.

\section{Southern Belt}

The southern belt of the allochthon stretches across $100 \mathrm{~km}$ of the Romanzof Mountains, from the headwaters of the Aichilik River to the Marsh Fork of the Canning River (Fig. 3.1). Its stratigraphy consists of intensely imbricated assemblages of chert, phyllite, carbonate, and mafic volcanic and volcaniclastic rocks, which were all originally assigned to sequence A of Dutro et al. (1972). In the summer of 2014 and 2015, we conducted several traverses in the headwaters of the Aichilik and Jago Rivers, where we collected several samples for thin-section analysis, three samples for whole-rock igneous geochemical analysis (14BJ24, 14BJ22, and 15BJ08), and one volcaniclastic sample for zircon U-Pb geochronology (15BJ06). We also discovered one new fossil locality (J1475) along the Aichilik River (Figs. 3.1 and 3.3A).

The base of the southern belt section is marked by a south-dipping thrust fault (Fig. 3.3A), the Romanzof Mountain thrust of Johnson et al. (2016), which runs along the entire northern edge of the southern belt (Figs. 3.1 and 3.3A). Early mappers in the region (e.g., Dutro 
et al., 1972; Reiser et al., 1980) recognized that the fault was truncated by the sub-Mississippian unconformity at the headwaters of the Aichilik River. During our traverses of the area in 2014 and 2015, we observed that in discrete locations, the Mississippian Kekiktuk Conglomerate (lower Endicott Group) is exposed in the footwall beneath the fault, indicating that some amount of post-Mississippian displacement has occurred along this structure. In other places, the volcanic and sedimentary rocks of the Whale Mountain allochthon are in direct contact with the Upper Ordovician-Lower Devonian(?) Clarence River Group (Fig. 3.3A).

The fault zone is $>500 \mathrm{~m}$ wide in some places, and it contains a chaotic mix or mélange of different lithostratigraphic units. Along the Aichilik River, the mélange includes dark-maroon, gray, and green volcaniclastic argillite and phyllite that intertongue with discrete blocks of gray to tan-weathering dolostone and limestone. The carbonate blocks are heavily fractured and brecciated and range between $\sim 10$ and $200 \mathrm{~m}$ thick. Our new trilobite locality (J14745) was collected from an 40-m-tall by 100-m-wide block within the fault zone along the western bank of the upper Aichilik River, just south of the Romanzof Mountain thrust (Fig. 3.3A). The rocks at the locality consist predominantly of recrystallized and locally dolomitized lime mudstone and wackestone with a pronounced volcaniclastic matrix. The fossils were recovered from an $\sim 7-\mathrm{cm}-$ thick bed of lime wackestone. Lithologically, these carbonate rocks resemble those from which Olenellus was recovered at the Marsh Fork locality of Dutro et al. (1972), but the fauna confirms a significantly younger age (see Paleontology section below), and the structural complexity of the J1475 locality obscures further stratigraphic comparisons.

Along strike of the Romanzof Mountain thrust, in the headwaters of the Jago River, the fault zone contains a similar succession of dark-maroon, gray, and green volcaniclastic argillite and phyllite, but it is intertongued or imbricated with an $\sim 3$-m-thick massive volcaniclastic 


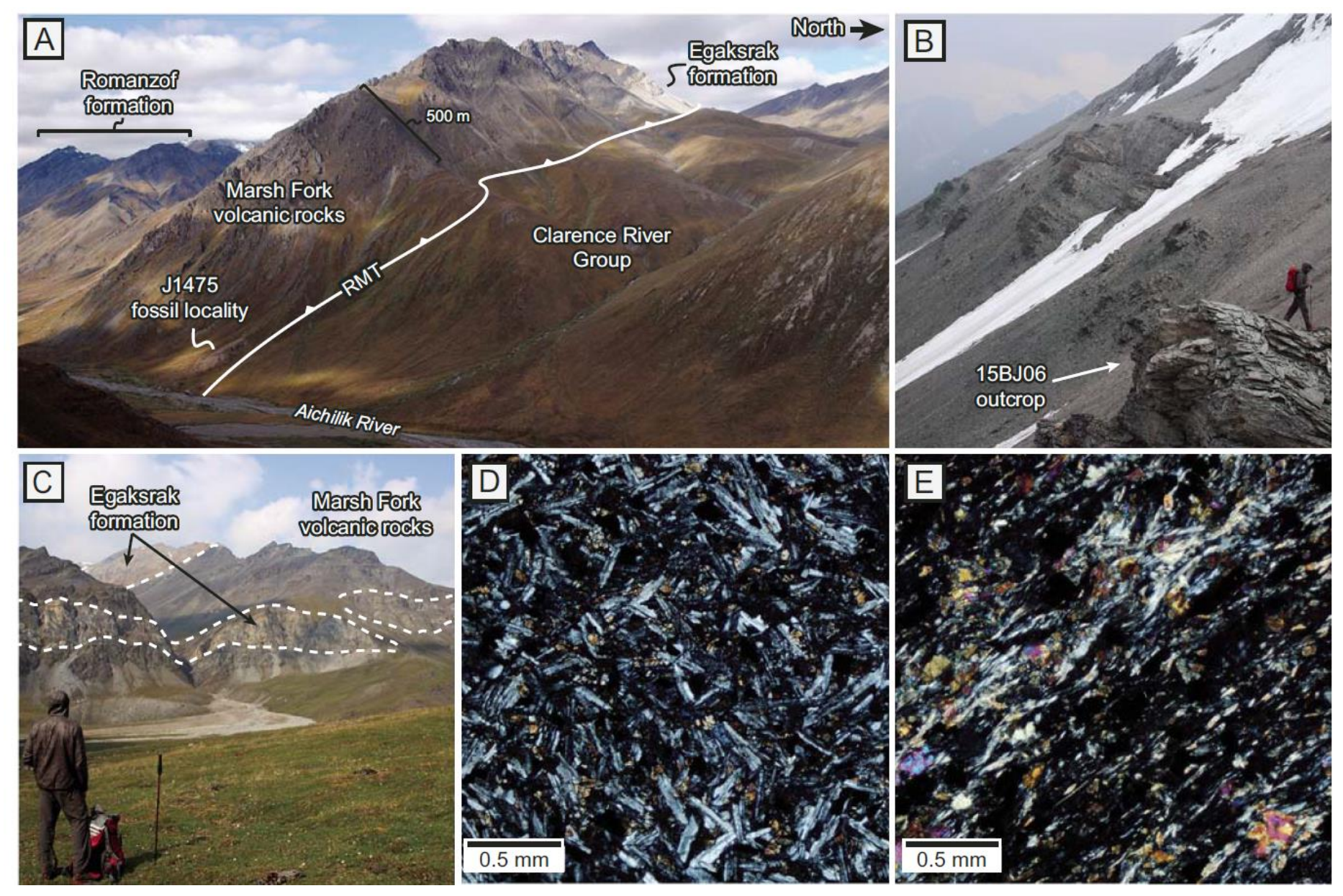

Figure 3.3: Field images and photomicrographs from rocks of the southern belt of the Whale Mountain allochthon in the NE Brooks Range, Alaska. (A) Looking southwest across the Romanzof Mountain Thrust (RMT) at the headwaters of the Aichilik River, showing the J1475 fossil location. (B) Looking east near the fault zone of the RMT at the headwaters of the Jago River, showing the outcrop of zircon U-Pb sample 15BJ06. (C) Looking southwest across intercalated Marsh Fork volcanic rocks and megablocks of the Egaksrak formation in the headwaters of the Jago River. (D) Cross-polarized view of sample 14BJ22 showing intergranular plagioclase phenocrysts with microcrystalline clinopyroxene. (E) Cross-polarized view of sample 15BJ08 showing aligned actinolite, epidote, plagioclase, and Fe- and Ti-oxide minerals. 
sandstone unit (Fig. 3.3B), which we sampled for zircon U-Pb geochronology (15BJ06). The sample consists of sheared and angular volcanic detritus (mostly plagioclase) and volcanic rock fragments. The stratigraphic assignment of this unit is uncertain, but the predominance of angular volcanic material implies a close association to the volcanic flows exposed higher in the southern belt section.

Above the fault zone, the section transitions into an 300-800-m-thick exposure of darkgreenish gray mafic amygdaloidal volcanic flows and subordinate beds of conglomerate, volcaniclastic argillite, and chert. The mafic flows typically show pillow structures or are brecciated, and they resemble the volcanic rocks described by Moore (1987) from the Marsh Fork area at the western limit of the southern belt. We therefore apply the Marsh Fork volcanic rocks name to these exposures. In many places, the volcanic rocks intertongue with large blocks of limestone and dolostone that sometimes exceed $200 \mathrm{~m}$ in thickness and cover areas as wide 10 km in length (Fig. 3.3C). These carbonate blocks consist of gray- and tan-weathering, massive, thickbedded oolitic and peloidal dolostone, as well as calcareous rudstone composed of angular carbonate and volcanic lithoclasts and lime mudstone horizons. Like the carbonate blocks near the fault zone, the megablocks have sharp contacts with the surrounding deformed volcanic units, which may be a product of imbrication by unmapped thrust faults or stratigraphic complexity derived through sediment-gravity flows. We tentatively assign the name Egaksrak formation to all the carbonate units in the southern belt because of lithological similarities to carbonate units in the type area between the Leffingwell Fork and the Egaksrak River (see Central Belt subsection below).

Two volcanic samples (14BJ22 and 14BJ24) were collected from the volcanic and carbonate section exposed along the Aichilik River. The samples are fi ne grained, sparsely 
porphyritic (1\%-5\% phenocrysts) and dominated by plagioclase (>50 vol\%). Plagioclase occurs as euhedral laths, both in the groundmass $(<0.5 \mathrm{~mm}$ in length) and as phenocrysts $(>1 \mathrm{~mm}$ in length). The plagioclase laths in sample 14BJ22 exhibit an intergranular texture with subhedral clinopyroxene and Fe- and Ti-oxide minerals (Fig. 3.3D). The uniform nature of the plagioclase and the intergranular texture in these samples suggest a cumulate origin in a thick lava $\mathrm{fl}$ ow or hypabyssal intrusion. Both samples are sparsely to moderately amygdaloidal (2-10 vol\%). The amygdules typically have an elongate shape, range from 0.25 to $5 \mathrm{~mm}$ in diameter, and are fi lled with chlorite group minerals or calcite. A third volcanic sample (sample 15BJ08) was collected from a 3-m-thick outcrop of greenish-gray metabasalt in the headwaters of the Jago River. These units are heavily sheared and are crosscut by an extensive network of 1-3-cm-thick serpentinite veins. The dominant mineral phases include actinolite, chlorite, epidote, and opaque minerals. Actinolite occurs as elongate subhedral prismatic crystals, up to $1 \mathrm{~mm}$ in length, that define a moderate foliation (Fig. 3.3E). Epidote occurs as rounded, subhedral grains aligned along the actinolite grain boundaries, spatially associated with opaque minerals. The metamorphic mineral assemblage of actinolite, epidote, and chlorite indicates that these rocks were subject to greenschist metamorphic conditions.

Above the volcanic and carbonate units, there is an isoclinally folded package of undetermined thickness containing interbedded radiolarian chert and phyllite with minor beds of volcanic and lithic wacke. These rocks were originally designated as the "chert and phyllite member" by Dutro et al. (1972) and were later split into the "Ordovician-Cabrian chert and phyllite" (OCcp) and the "Ordovician volcanic wacke and tuffaceous sandstone" (OCw) map units of Reiser et al. (1980). Mull and Anderson (1991) referred to this package as the Romanzof chert, but we instead refer to this unit as the Romanzof formation due to its diversity of 
lithofacies. Moore and Churkin (1984) collected Middle Ordovician graptolites from a phyllite and radiolarian chert interval within the Romanzof formation near the Marsh Fork of the Canning River.

The subordinate volcanic and lithic wacke units consist of centimeter- to meter-thick beds that occasionally exhibit erosional bases with channel-fill geometries in the surrounding chert and phyllite. The wacke is generally poorly sorted and composed of fi ne- to medium-grained, angular to subrounded, monocrystalline and polycrystalline quartz, plagioclase, opaque minerals, and chert and basalt lithic fragments. One detrital zircon sample was collected from these units by Strauss et al. (this volume, Chapter 23). The sample yielded 23 concordant U-Pb ages that define a unimodal population from ca. 494 to $436 \mathrm{Ma}$, with a peak at $452 \mathrm{Ma}$, suggesting that parts of the Romanzof formation are as young as Late Ordovician.

The Romanzof formation is overlain by sandstone, shale, and limestone of the Middle Devonian Ulungarat and Mangaqtaaq formations of Anderson et al. (1994). The contact relationships between these two units, however, are not well documented. Anderson et al. (1994) mapped the contact as a faulted unconformity (Aichilik Pass thrust). Because this contact is unconstrained, and because the region is structurally complex, the total estimated thickness of the southern belt section presented in Figure 3.2 should be treated as a structural thickness.

\section{Central Belt}

The central belt of the allochthon stretches from Empire Mountain in northern Yukon to the Leffingwell Fork of the Aichilik River in Alaska (Fig. 3.1). During the summers of 2012, 2013, and 2014, we traversed across three separate locations in the central belt, collecting > 20 volcanic samples for thin section and geochemical analysis and one volcanic wacke sample (13WW23) for zircon U-Pb geochronology. We also discovered one new fossil locality in Yukon 
(J1352) and resampled the fossils from the original locality of Dutro et al. (1972) between the Leffingwell Fork and Egaksrak River (Fig. 3.1).

The stratigraphy of the central belt consists predominantly of intercalated volcanic and carbonate rocks (Fig. 3.2), which were originally assigned to the upper parts the Neruokpuk sequence C of Dutro et al. (1972). The volcanic rocks have since been assigned to the Whale Mountain volcanic rocks by Moore (1987), and we assign the carbonate units to the Egaksrak formation, due to their prominent exposure along the ridge that separates the Leffingwell Fork and the Egaksrak River. The entire central belt appears to be folded into an $~ 10-\mathrm{km}$-wide by $\sim 100$-km-long synclinal ridge that is $>1000 \mathrm{~m}$ thick where it crosses the Kongakut River in Alaska and that thins to $<600 \mathrm{~m}$ thick along the Leffingwell Fork. Like the southern belt section, the base of the central belt section is marked by a complex fault zone mélange of Clarence River Group strata mixed with large slivers of the carbonate units that range from 5 to $200 \mathrm{~m}$ thick. This fault zone also appears to be broadly folded into a syn-form (Fig. 3.4A). The top of the central belt is not covered by any younger lithostratigraphic units, rendering its original stratigraphic thickness indeterminable.

At the western edge of the central belt, near the Leffingwell Fork fossil locality of Dutro et al. (1972), the fault zone becomes subhorizontal and is exposed along a broad saddle in the ridge that divides the Leffingwell Fork and the Egaksrak River (Fig. 3.4B). An 200-m-thick, vertically dipping megablock of intensely sheared limestone is exposed between the black slate of the Clarence River Group and the Whale Mountain volcanic rocks higher in the section (Fig. 3.4B). The block includes contorted beds of discontinuous rudstone that contain angular to wellrounded, pebble- to sand-sized volcanic lithoclasts (Fig. 3.4C). This chaotic interval is bound to the north by a massive gray oolitic and peloidal grainstone unit that is interbedded with finely 

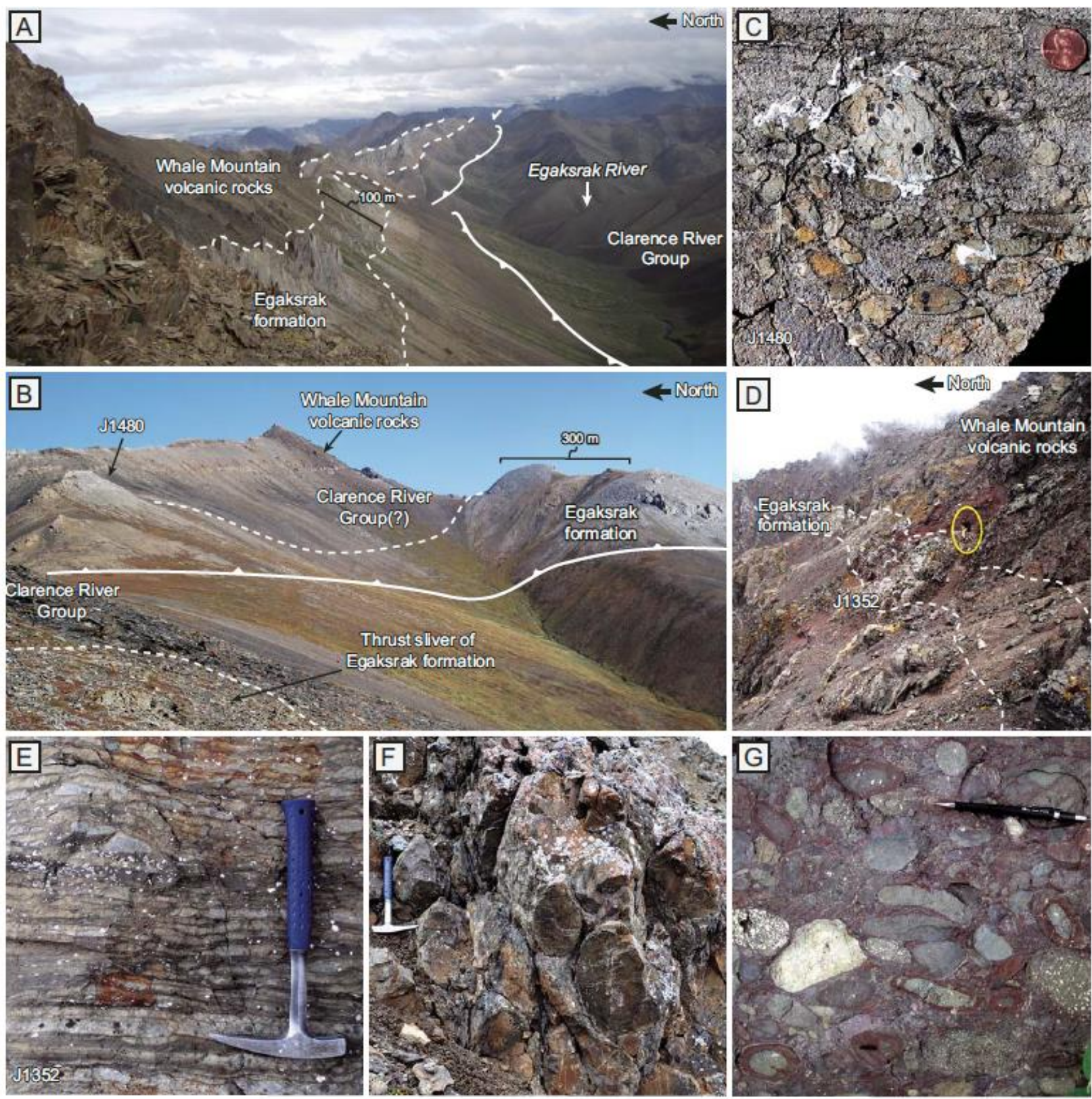

Figure 3.4: Field images from rocks of the central belt of the Whale Mountain allochthon in the NE Brooks Range, Alaska. (A) Looking east along the southern limb of synclinal ridge, showing interbedded Whale Mountain volcanic rocks and laminated lime mudstone units of the Egaksrak formation (B) Looking northeast at the Leffingwell Fork fossil locality (J1480), which shows the upper Cambrian limestone units above black slate units of the Middle Ordovician-Lower Devonian(?) Clarence River Group including thrust slivers of Egaksrak carbonate units. (C) Close-up of lime mudstone with abundant pebble- and cobble-sized clasts of basalt; penny for scale is $19 \mathrm{~mm}$ across. (D) Looking east at the J1352 fossil location in headwaters of the Malcom River, Yukon; person for scale is circled in yellow and is $\sim 2 \mathrm{~m}$ tall. (E) Close-up of ribbonbedded lime mudstone at the J1352 fossil location; hammer for scale is $\sim 32 \mathrm{~cm}$. (F) Pillow textures preserved within folded basalt flows; hammer for scale is $32 \mathrm{~cm}$ long. (G) Close-up of clast-supported conglomerate with well-rounded clast of basalt, diabase, and chert from the Kongakut River, Alaska; pencil for scale is $\sim 15 \mathrm{~cm}$. 


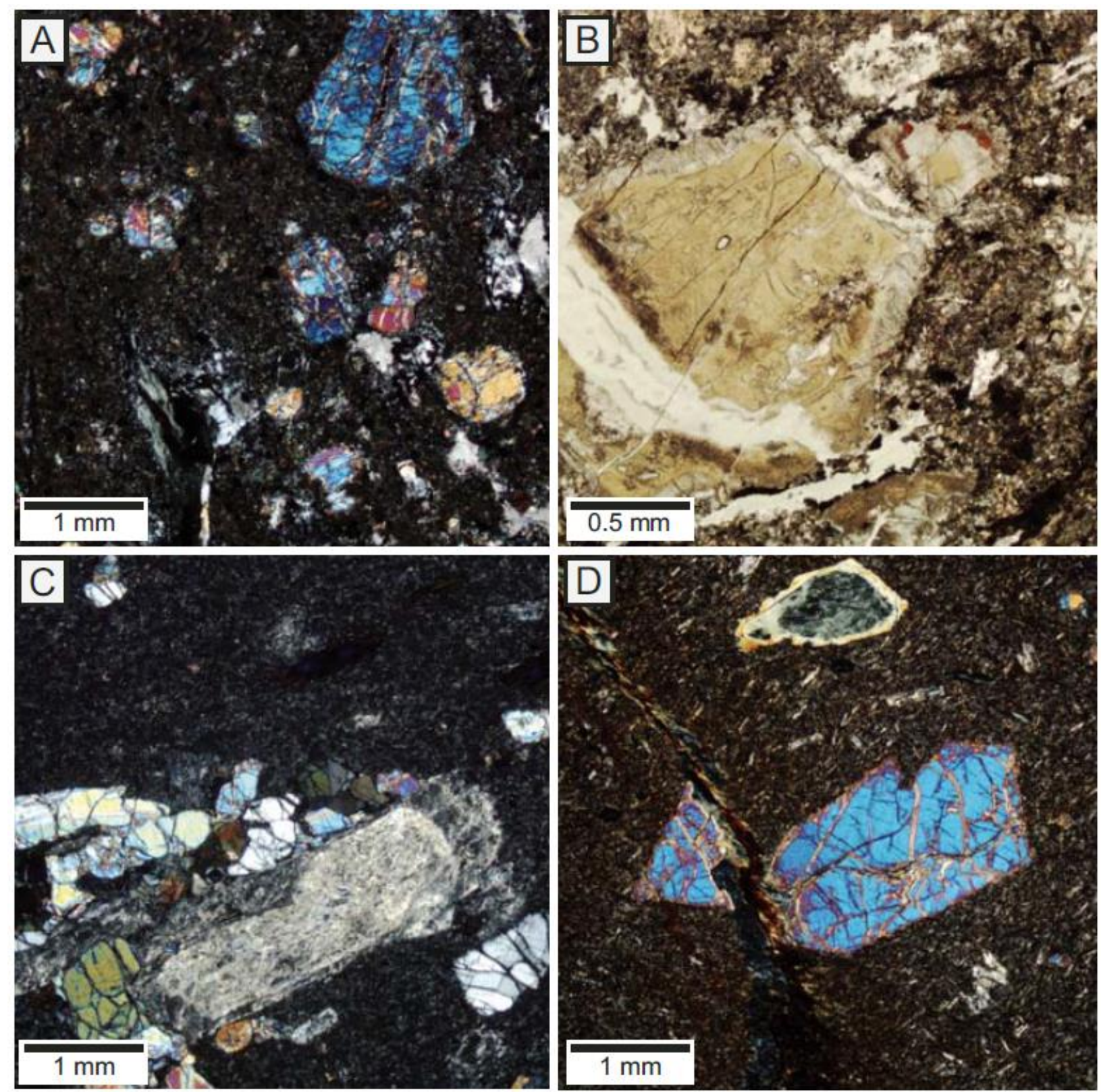

Figure 3.5: Photomicrographs of theWhale Mountain volcanic rocks. (A) Cross-polarized view of sample 12JT13B, showing fractured olivine phenocrysts in a groundmass composed of glass and Fe- and Ti-oxide minerals. (B) Plane-polarized view of sample 12JT20, showing complete iddingsite alteration of an olivine phenocryst. (C) Cross-polarized view of sample 12JT18 showing glomeroporphyritic olivine and plagioclase, sericitization of plagioclase phenocrysts, and chlorite amygdules that have been stretched. (D) Cross-polarized view of sample 20LF13 showing large fractured and altered olivine phenocryst. 
laminated fossiliferous lime mudstone and wackestone. Our fossil locality J1480 was recovered from the laminated mudstone interval, which is likely the same location from which Dutro et al. (1972) collected their sample 6983-CO. Like the carbonate units in the southern belt, the stratigraphic context of these large carbonate blocks is unclear, but the contacts with the surrounding units are typically abrupt or marked by brecciated limestone and volcanic units, suggesting a structural or an olistostromal relationship.

In other locations along the central belt, the lime mudstone units of the Egaksrak formation occur as laterally extensive, $\sim 150$-m-thick beds that crop out for $>10 \mathrm{~km}$ and are interbedded with the volcanic rocks (Fig. 3.4A). Near the headwaters of the Malcolm River in Yukon, the $\mathrm{J} 1352$ fossil locality was discovered in fossiliferous lime and volcaniclastic mudstone, grain-stone, and rudstone interbedded with pillowed Whale Mountain volcanic rocks (Fig. 3.4D). The fossiliferous strata include an $\sim 15$-m-thick lens of ribbon-bedded lime mudstone (Fig. 3.4E), fossiliferous wackestone, reworked meter-scale carbonate olistoliths and rudstone, and volcaniclastic conglomerate and sandstone within a dominantly maroon volcaniclastic mudstone matrix. Thin sections revealed that the carbonate units contain a prominent volcanic matrix composed of disseminated plagioclase laths and abundant chlorite, sericite, and calcite alteration products. Trilobites were recovered from $\sim 2-3-\mathrm{cm}$-thick fossiliferous grainstone or wackestone horizons within the meter-scale carbonate olistoliths, as well as separate beds of fossiliferous grainstone outside the olistoliths.

The Whale Mountain volcanic rocks are prominently exposed where the middle reaches of the Kongakut River cut across the central belt (Fig. 3.1). They include dark-green basalt and diabase that weather dark olive brown and commonly crop out as fractured pillows (Fig. 3.4F), massive flows, or minor hypabyssal intrusions (sills and dikes). The basaltic flows typically 
interfinger with various tuffaceous and volcaniclastic rocks, including lithic and volcanic wacke and conglomerate. The conglomerate is typically clast-supported and contains well-rounded, gravel- to cobble-sized clasts of weathered basalt, diabase, and chert (Fig. 3.4G).

In thin section, the basalt samples from the central belt dis-play a variety of microtextures (Figs. 3.5A-3.5D). Most samples are porphyritic, with textures that range from aphyric $(<1 \%$ phenocrysts) to highly porphyritic (>10\% phenocrysts). Olivine, clinopyroxene, and plagioclase are the dominant phenocrysts, although in some samples, olivine and clinopyroxene are the only phenocrysts present (e.g., 12JT13b; Fig. 3.5A). Many of the large olivine phenocrysts are crosscut by fractures and have undergone extensive serpentinization and iddingsite alteration, in some cases causing complete replacement of olivine by serpentine and other clay minerals (Fig. 3.5B). Plagioclase is commonly present as large $(\sim 1-4 \mathrm{~mm})$ glomerocrysts forming aggregates with olivine (Fig. 3.5C). The plagioclase phenocrysts have undergone saussuritization, replacing the plagioclase with an assemblage of cryptocrystalline $(<0.1 \mathrm{~mm})$ epidote, clinozoisite, zoisite, and sericite. Amygdules are present in almost all samples and typically compose $1 \%-5 \%$ of the rock volume of each sample; they range from 0.25 to $5 \mathrm{~mm}$ in diameter and are semispherical to elongate in shape. The amygdules are typically filled with chlorite group minerals, microcrystalline quartz, calcite, or zeolites (Fig. 3.5C).

The composition and texture of the groundmass also vary from sample to sample. In some samples, the groundmass is composed of microcrystalline to fine-grained $(0.1-1 \mathrm{~mm})$ plagioclase, subhedral Fe- and Ti-oxide minerals, and cryptocrystalline pyroxene or olivine. In other samples, the groundmass is predominantly composed of altered glass and cryptocrystalline to microcrystalline subhedral Fe- and Ti-oxides. When plagioclase microlites are present in the 
groundmass, they are typically aligned in a moderately to weakly developed trachytic texture (Fig. 3.5D).

The basaltic flows and volcaniclastic rocks are locally interbedded with a dark-maroon and gray argillite and phyllite, with minor beds of chert, which could be correlative units of the Romanzof formation in the southern belt. The stratigraphic relationships between the various volcanic and carbonate units throughout the central belt are also somewhat uncertain, but their intercalated nature, and the prevalence of volcanic debris within the carbonate units support a cogenetic relationship.

\section{Northern Belt}

The northern belt of the allochthon extends from the Malcolm River in northern Yukon to the Ekaluakat River in Alaska (Fig. 3.1). The stratigraphy of this belt predominantly consists of volcaniclastic and volcanic-rich sandstone units that interfinger with beds of chert, argillite, and black slate (Fig. 3.2). In Alaska, these units were originally assigned to sequence E of Dutro et al. (1972), and they were subsequently split by Reiser et al. (1980) into three separate Ordovician map units: a "volcaniclastic and volcanic" unit (Ovc), a "black slate" unit (Os), and a "gray phyllite and chert" unit (Opc). On the Yukon side of the international border, these units were mapped as part of a coherent basinal succession of Cambrian-Lower Devonian strata (e.g., Lane,

1991; Lane et al., 1995; Lane et al., 2016); however, we tentatively assign these sedimentary and volcanic rocks to a single informal lithostratigraphic unit, which we name the Ekaluakat formation due to its widespread exposure near the Ekaluakat River in Alaska.

Unlike the southern and central belts of the allochthon, the northern belt has a poorly defined base, where discrimination of the sedimentary rocks of the Ekaluakat formation from those of the Clarence River Group is largely hampered by poor exposure and repeated 
imbrication. However, Reiser et al. (1980) mapped a distinct fault-related breccia unit along the Ekaluakat River that appears to separate volcanic and sedimentary rocks of the Ekaluakat formation from structurally(?) underlying rocks of the Neoproterozoic-Lower Cambrian(?) Firth River Group. Reiser et al. (1980) also reported a ca. 484 Ma K-Ar age on hornblende from a mafic intrusion near the breccia unit. Although we are unsure if the rocks of the Ekaluakat formation are unambiguously correlative with the volcanic and sedimentary rocks of the southern and central belts, this potential tectonic contact is similar to other boundaries with the Whale Mountain allochthon. The top of the Ekaluakat formation is also poorly constrained, because it is either truncated by the unconformity at the base of the overlying Lower Mississippian Endicott Group, or it is in thrust contact with older units (Reiser et al., 1980; Lane et al., 1995).

In the summer of 2012, we traversed along a north- trending ridge on the east bank of the lower Kongakut River, which exposes a steeply southward-dipping $\left(\sim 60^{\circ}-75^{\circ}\right)$ section of Ekaluakat rocks, with the top of the section concealed by the Lower Mississippian Kekiktuk Conglomerate. Below the unconformity and further north along the ridge, the section contains 0.5-1.5-m-thick beds of dark-brown and massive volcanic-rich pebble conglomerate. Similar outcrops were observed during a 2013 expedition on the Yukon side of the border, where clasts from the conglomerate consist of basalt and minor sedimentary lithics that are moderately rounded and range between 2 and $80 \mathrm{~mm}$ in diameter (Fig. 3.6A).

Further north along the Kongakut River section, the volcanic beds become thinner and more fine grained, and we collected two samples (12JT37 and 12JT39) for thin section and geochemical analysis. The two samples resemble tuffaceous breccia, consisting of a fine- to coarse-grained mixture of volcanogenic minerals, including rounded basalt clasts, loose grains of clinopyroxene and plagioclase, and fine-grained chert (Fig. 3.6B). The basalt clasts are 

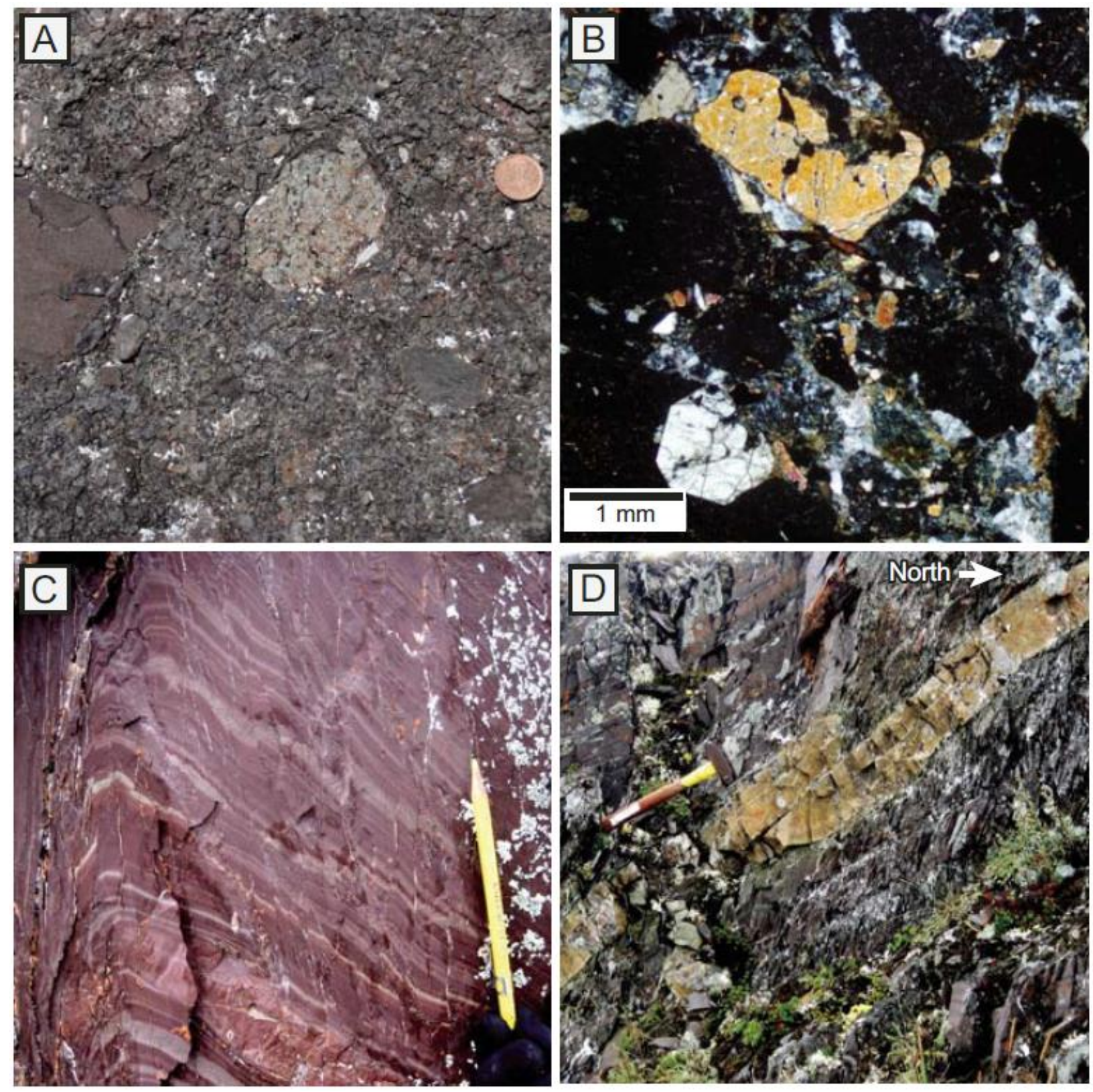

Figure 3.6: Field images of the Ekaluakat formation from the northern belt of the Whale Mountain allochthon in the NE Brooks Range, Alaska. (A) Close-up taken from volcanic breccia of the Ekaluakat formation exposed in northern Yukon; one-cent piece for scale is $1.9 \mathrm{~cm}$ in diameter. (B) Cross-polarized view of sample 12JT39 showing volcanic clast and clinopyroxene grains in a chert(?) and clay matrix. (C) Close-up of folded and laminated marron argillite, crosscut by steep micro-shear fractures; pencile for scale is $\sim 13 \mathrm{~cm}$. (D) Photo Looking west along the Kongakut River section of the northern belt showing laminated dark-maroon and gray argillite interbed with a faulted, tan-weathering tuff layer; hammer for scale in $\sim 33 \mathrm{~cm}$. 
moderately porphyritic, containing 5\%-10\% clinopyroxene (augite) phenocrysts in a glassy to microcrystalline groundmass composed of plagioclase $(<0.2 \mathrm{~mm})$ and $\mathrm{Fe}$ - and Ti-oxide minerals. The clasts are generally fresh, showing little to no alteration from weathering or metamorphism, but in the surrounding groundmass, low-temperature alteration is common. Calcite, microcrystalline quartz, and clay minerals form veinlets in the groundmass and fill amygdules.

The northern parts of the Kongakut River section expose finely laminated, maroon, green, and dark-gray argillite that is crosscut by a steeply dipping network of microshear fractures that occur in the cores of small folds (Fig. 3.6C). The argillite is locally interbedded with a distinctive tan and greenish-gray tuff unit (Fig. 3.6D). A dark-gray, medium- to coarsegrained, volcanic-rich wacke is also occasionally interbedded with the argillite. The wacke consists mostly of reworked volcanic and detrital carbonate grains. Johnson et al. (2016) reported 63 concordant zircon U-Pb ages from this unit (sample 12JT35), 62 of which provided a broad unimodal age population ranging from ca. 602 to $440 \mathrm{Ma}$ and centered at ca. $500 \mathrm{Ma}$.

\section{ZIRCON U-Pb GEOCHRONOLOGY AND Hf ISOTOPE GEOCHEMISTRY}

Zircon U-Pb geochronology and Hf isotope geochemistry from the two volcaniclastic samples (15BJ06 and 13WW23) pro-vide potential constraints on the age and magmatic setting of the volcanic rocks from Whale Mountain allochthon. Standard mineral separation and imaging procedures were followed at the University of Iowa, which included crushing, sieving, water density and magnetic separation, and heavy liquid density separation. The separated zircon grains were mounted in epoxy, ground to expose the grain interiors, and polished prior to cathodoluminescence (CL) and backscattered electron (BSE) imaging using a scanning electron microscope (SEM). 
The mounted zircon grains were taken to the University of Arizona LaserChron Center in Tucson, Arizona, to measure the U-Pb and $\mathrm{Lu}-\mathrm{Hf}$ isotopic ratios by laser ablation-inductively coupled plasma-mass spectrometry (LA-ICP-MS). The CL and BSE images were used to select spot locations for the in-situ measurement from each grain in order to avoid inherited cores, complex zoning, or zones of possible metamictization. The U-Pb isotopes were measured first using a $20-\mu \mathrm{m}$-diameter ablation site to determine the age of each grain following the methods of Gehrels et al. (2008). A subset of the measured grains from the same mounts was analyzed for Hf isotope geochemistry using high-resolution-ICP-MS (HR-ICP-MS) following methods outlined by Gehrels and Pecha (2014). In each Hf isotope analysis, a 40- $\mu$ m-diameter ablation site was centered over the previously excavated $\mathrm{U}-\mathrm{Pb}$ analysis pit to help ensure that the initial $\mathrm{Hf}$ isotopic composition was measured from the same domain as the $\mathrm{U}-\mathrm{Pb}$ age. The detailed analytical procedures and filtering methods, along with tables of the individual measurements, are included in the Supplemental Material section at the end of this dissertation.

$\mathrm{U}-\mathrm{Pb}$ ages from each of the volcaniclastic samples are shown on the two concordia diagrams in Figures 3.7A and 3.7B, which were generated using Isoplot 4.1 software (Ludwig, 2012). Reported uncertainties for each U-Pb age are at the $1 \sigma$ level and include only measurement errors. A "best age” (see Table SM3.2) for each grain was selected using a cutoff of $900 \mathrm{Ma}$ from the calculated ${ }^{206} \mathrm{~Pb} /{ }^{238} \mathrm{U}$ ages. For zircon grains with ${ }^{206} \mathrm{~Pb} /{ }^{238} \mathrm{U}$ ages older than $900 \mathrm{Ma}$, we used the calculated ${ }^{207} \mathrm{~Pb} /{ }^{206} \mathrm{~Pb}$ ages instead. Several ages were excluded/rejected from the data plots or interpretations because of discordance between the ${ }^{206} \mathrm{~Pb} /{ }^{238} \mathrm{U}$ and the ${ }^{206} \mathrm{~Pb} /{ }^{207} \mathrm{~Pb}$ ages calculated for each grain. Grains with $>20 \%$ discordance were rejected, as were grains with $>5 \%$ reverse discordance. 

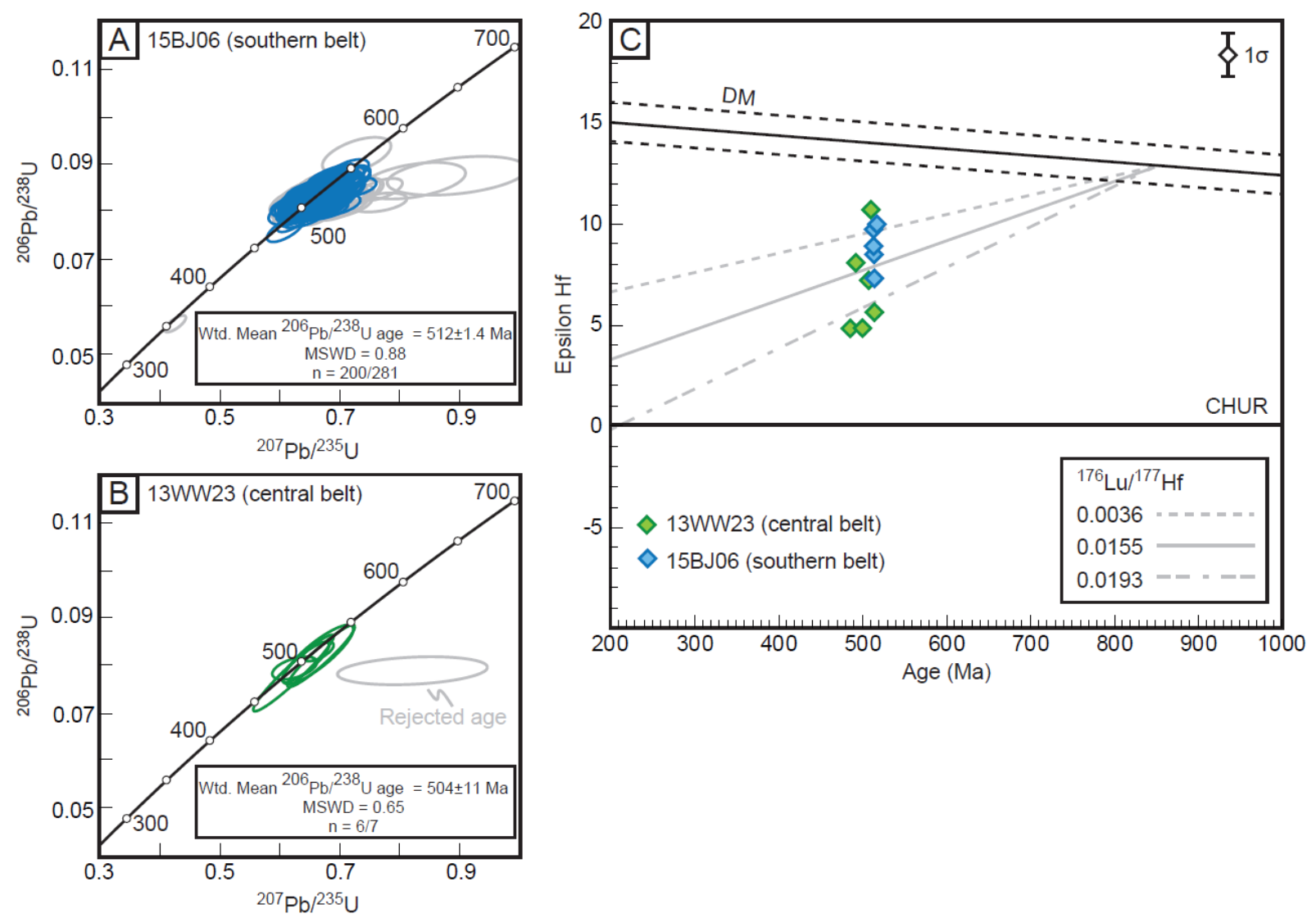

Figure 3.7: Zircon $\mathrm{U}-\mathrm{Pb}$ ages and $\mathrm{Hf}$ isotopic values from laser ablation-inductively coupled plasma-mass spectrometry (LA-ICP-MS) of volcaniclastic rocks from the central and southern belts of the Whale Mountain allochthon. (B) Concordia plot of 274 grains from sample 15BJ06; gray ellipse represents an excluded measurement because of significant discordance. Inset shows calculated weighted (wtd.) mean age of the six concordant ages. (B) Concordia plot of seven grains from sample 13WW23. Inset shows calculated weighted (wtd.) mean age of the six concordant ages. (C) Hf evolution plot showing $\varepsilon \mathrm{Hf}_{(\mathrm{t})}$ values for each sample (13WW23 and 15BJ06). The average measurement uncertainty for all analyses (upper right) is shown at the $1 \sigma$ level. Reference lines on the Hf plot are as follows: DM-depleted mantle, calculated using ${ }^{176} \mathrm{Hf} /{ }^{177} \mathrm{Hf}_{0}=0.283225$ and ${ }^{176} \mathrm{Lu} /{ }^{177} \mathrm{Hf}_{0}=0.038512$ (Vervoort and Blichert-Toft, 1999); CHUR - chondritic uniform reservoir, calculated using ${ }^{176} \mathrm{Hf} /{ }^{177} \mathrm{Hf}=0.282785$ and ${ }^{176} \mathrm{Lu} /{ }^{177} \mathrm{Hf}=$ 0.0336 (Bouvier et al., 2008); gray dashed show interpreted felsic crustal evolution trajectories assuming present-day ${ }^{176} \mathrm{Lu} /{ }^{177} \mathrm{Hf}=0.0115$ (Vervoort and Patchett, 1996; Vervoort et al., 1999). Full data tables are provided in the Supplemental Material section at the end of this dissertation. 


\section{U-Pb Geochronological Results}

The two analyzed samples were composed of highly sheared and angular volcanic detritus (mostly plagioclase) and volcanic rock fragments set within an altered matrix of sericite and calcite. The southern belt sample (15BJ06) yielded more than 300 grains from the heavy mineral separation procedure. Nineteen of these grains analyzed by LA-ICP-MS yielded spurious isotopic ratios and were thus excluded from further data reduction. Using the CL images, we determined that these grains are not zircon because they lacked measurable luminescence (see Supplemental Material section). The remaining 281 grains consisted of light purple to clear angular grains that ranged from $\sim 50$ to $150 \mu \mathrm{m}$ in length. Seventy-three of these grains showed discordance among the $2{ }^{06} \mathrm{~Pb} /{ }^{238} \mathrm{U}$ and ${ }^{206} \mathrm{~Pb} /{ }^{207} \mathrm{~Pb}$ ages and were thus excluded from our "best age" filter. An additional five grains were excluded because they yielded ${ }^{206} \mathrm{~Pb} /{ }^{238} \mathrm{U}$ ages younger than $200 \mathrm{Ma}$. These grains showed strong zonation in the CL images (see Supplemental Material section), and we infer that they were a result of sample contamination. The remaining 203 grains yielded ages from ca. 2578 to $354 \mathrm{Ma}$; however, most of the ages $(\mathrm{n}=200)$ ranged from ca. 544 to $473 \mathrm{Ma}$ and constituted a weighted mean age of $512 \pm 1.4 \mathrm{Ma}(1 \sigma)$ with a mean square weighted deviation (MSWD) of 0.88 (Fig. 3.7A). A MSWD of 0.88 is close to 1.0, which implies that the observed scatter in the ages is consistent with precision, and that the analytical precision of the method employed is unable to resolve differences among the age populations (e.g., Wendt and Carl, 1991).

Sample 13WW23 was collected from the eastern edge of the central belt in Yukon at the same location as fossil locality J1352 (Fig. 3.1). Like sample 15BJ06, 13WW23 is predominately composed of angular volcanic material, and the separated zircon grains are angular and range from $\sim 50$ to $150 \mu \mathrm{m}$ in length. The sample only yielded seven zircon grains, and one of the 
grains was excluded from further discussion because of discordance among the ${ }^{206} \mathrm{~Pb} /{ }^{238} \mathrm{U}$ and

${ }^{206} \mathrm{~Pb} /{ }^{207} \mathrm{~Pb}$ ages. The other six grains had ages ranging from ca. 514 to $485 \mathrm{Ma}$, with a ${ }^{206} \mathrm{~Pb} /{ }^{238} \mathrm{U}$ weighted mean age of $504 \pm 11 \mathrm{Ma}$ (Fig. 3.7B) and MSWD of 0.65 , which could indicate that the observed scatter among the ages is less than that predicted by the analytical uncertainties.

\section{Hf Isotope Geochemistry}

Hafnium isotopic measurements were performed on 11 individual grains: five from sample 15BJ06 and six from sample 13WW23. We specifically targeted grains with ages in the 544-475 Ma range because we inferred that those grains would represent the time at which the volcanic rocks erupted. The data are presented on a Hf-evolution diagram (Figs. 3.7C) that shows $\varepsilon \mathrm{Hf}(\mathrm{t})$ values at the time of crystallization. The $\varepsilon \mathrm{Hf}(\mathrm{t})$ values were determined by comparing the measured Hf isotopic values of an individual grain relative to the known Hf values of a chondritic uniform reservoir (CHUR; Bouvier et al., 2008) at the time of crystallization.

The Hf data from the two samples are similar, with $\varepsilon \mathrm{Hf}(\mathrm{t})$ values that range from 4.8 to 10.7. These values are considered as intermediate and juvenile in composition because they plot just below the depleted mantle trajectory. Several different interpretations can explain these values. One possible explanation is that the extracted melts from which the zircon grains crystallized were produced by melting of Neoproterozoic crust. This is inferred from the Hf evolution trajectories of felsic crust (gray lines in Fig. 3.8C), which are based on the average present-day ${ }^{176} \mathrm{Lu} /{ }^{177} \mathrm{Hf}$ ratio of 0.0115 (Vervoort and Patchett, 1996; Vervoort et al., 1999). A second explanation is that melts were derived from the depleted mantle but experienced contamination from enriched sources, such as old (>1000 Ma) crustal rocks or possibly enriched reservoirs in the mantle. 


\section{IGNEOUS GEOCHEMISTRY}

Twenty-five whole-rock basalt samples were collected from

outcrops in the British and Romanzof Mountains of the NE Brooks Range (Fig. 3.1), including three samples from the southern belt, 20 samples from the central belt, and two samples from the northern belt. The samples were subsequently trimmed to exclude visible alteration and weathering, crushed using a mortar and pestle, and powdered in a SPEX 8515 Shatterbox. The sample powders were shipped to Activation Laboratories LTD (Actlabs) in Ontario, Canada, where they were mixed with a flux of lithium metaborate and lithium tetraborate and fused into glass beads using an induction furnace. The major-element oxides (e.g., SiO2, MgO, etc.) and a subset of trace elements ( $\mathrm{Sr}, \mathrm{Ba}, \mathrm{Sc}, \mathrm{V}, \mathrm{Y}$, and $\mathrm{Zr}$ ) were determined by inductively coupled plasma-optical emission spectrometry (ICP-OES) using a Thermo Jarrell-Ash ENVIRO II ICP or a Varian Vista 735 instrument. The remaining trace elements were determined by ICP-MS using a Perkin Elmer Sciex ELAN 9000 instrument. The calibration of the results was performed using prepared USGS and CANMET certified standard reference materials.

The major- and trace-element compositions of the basalt samples are given in Tables 3.1 and 3.2, with the major-element compositions expressed in weight percent (wt\%), and the trace element compositions described in parts per million ( $\mathrm{ppm})$. The geochemical data were used to distinguish and classify different volcanic suites from each belt. The low to moderate levels of alteration observed in thin section were supported by the moderate (2-7 wt $\%)$ loss on ignition (LOI) values. Alteration likely caused some element mobility, especially for the large ion lithophile elements (LILEs). Several samples had K2O concentrations that were lower than the ICP-OES detection limits $(0.01 \mathrm{wt} \%)$, and many of the samples showed large variations in $\mathrm{Rb}$ and Ce concentrations. Because of this, most of our classifications and interpretations are based 
TABLE 3.1: MAJOR-ELEMENT CHEMISTRY OF THE WHALE MOUNTAIN ALLOCHTHON

\begin{tabular}{|c|c|c|c|c|c|c|c|c|c|c|c|c|}
\hline $\begin{array}{l}\text { Sample } \\
\text { number }\end{array}$ & $\begin{array}{c}\mathrm{SiO}_{2} \\
\text { (wt. \%) } \\
\end{array}$ & $\begin{array}{c}\mathrm{TiO}_{2} \\
\text { (wt. \%) } \\
\end{array}$ & $\begin{array}{c}\mathrm{Al}_{2} \mathrm{O}_{3} \\
\text { (wt. \%) }\end{array}$ & $\begin{array}{c}\mathrm{Fe}_{2} \mathrm{O}_{3}(\mathrm{~T})^{*} \\
\text { (wt. \%) }\end{array}$ & $\begin{array}{c}\mathrm{MnO} \\
\text { (wt. \%) }\end{array}$ & $\begin{array}{c}\mathrm{MgO} \\
\text { (wt. \%) }\end{array}$ & $\begin{array}{c}\mathrm{CaO} \\
\text { (wt. \%) } \\
\end{array}$ & $\begin{array}{l}\mathrm{Na}_{2} \mathrm{O} \\
\text { (wt. \%) }\end{array}$ & $\begin{array}{c}\mathrm{K}_{2} \mathrm{O} \\
\text { (wt. \%) }\end{array}$ & $\begin{array}{l}\mathrm{P}_{2} \mathrm{O}_{5} \\
\text { (wt. \%) } \\
\end{array}$ & $\begin{array}{c}\text { LOI } \\
\text { (wt. \%) }\end{array}$ & Total \\
\hline \multicolumn{13}{|c|}{ Southern Belt } \\
\hline 14BJ22 & 45.02 & 2.865 & 15.11 & 13 & 0.218 & 8.5 & 7.3 & 2.88 & 0.25 & 0.28 & 4.01 & 99.44 \\
\hline 14BJ24 & 54.72 & 1.777 & 12.58 & 13.21 & 0.18 & 4.28 & 4.71 & 3.9 & 0.4 & 0.22 & 4.63 & 100.6 \\
\hline 15BJ08 & 43.64 & 3.055 & 14.25 & 16.11 & 0.229 & 6.57 & 10.63 & 2.58 & 0.13 & 0.32 & 3.25 & 100.8 \\
\hline \multicolumn{13}{|l|}{ Central Belt } \\
\hline 12JT13B & 42.07 & 1.814 & 13.03 & 11.21 & 0.206 & 12.21 & 13.56 & 0.16 & 0.001 & 0.18 & 6.36 & 100.8 \\
\hline 12JT14 & 46.72 & 2.782 & 14.48 & 11.81 & 0.162 & 6.53 & 10.96 & 1.66 & 0.01 & 0.32 & 3.84 & 99.29 \\
\hline 12JT15 & 46.33 & 2.336 & 16.39 & 9.36 & 0.234 & 6.6 & 11.25 & 2.14 & 0.21 & 0.26 & 5.53 & 100.7 \\
\hline 12JT16 & 45.45 & 3.118 & 14.47 & 15.72 & 0.202 & 6.54 & 5.22 & 3.88 & 0.02 & 0.37 & 4.76 & 99.74 \\
\hline 12JT17 & 42.87 & 2.586 & 15.2 & 12 & 0.173 & 7.97 & 12.16 & 1.93 & 0.03 & 0.32 & 4.26 & 99.48 \\
\hline 12JT18 & 48.02 & 2.841 & 16.16 & 10.22 & 0.198 & 8.07 & 6.18 & 4.09 & 0.36 & 0.32 & 4.15 & 100.6 \\
\hline 12JT19 & 49.52 & 2.749 & 13.55 & 11.99 & 0.141 & 6.09 & 10.1 & 0.51 & 0.001 & 0.32 & 5.74 & 100.7 \\
\hline 12JT20 & 41.24 & 1.951 & 14.56 & 11.72 & 0.14 & 9.89 & 13.46 & 0.09 & 0.001 & 0.21 & 5.85 & 99.13 \\
\hline 12JT21 & 49.91 & 3.23 & 13.2 & 14.44 & 0.209 & 5.12 & 7.63 & 3.26 & 0.07 & 0.32 & 3.41 & 100.8 \\
\hline 17LF13 & 48.85 & 2.789 & 16 & 11.33 & 0.14 & 6.38 & 3.31 & 4.08 & 0.95 & 0.31 & 5.15 & 99.29 \\
\hline 18LF13 & 54.97 & 3.373 & 16.27 & 7.63 & 0.064 & 4.24 & 2.69 & 1.87 & 4.3 & 0.41 & 4.14 & 99.96 \\
\hline 19LF13 & 47.4 & 2.938 & 13.88 & 12.03 & 0.199 & 8.2 & 8.44 & 3.59 & 0.46 & 0.34 & 3.15 & 100.6 \\
\hline 20LF13 & 48.78 & 2.443 & 13.67 & 12.53 & 0.17 & 8.19 & 6.85 & 3.96 & 0.41 & 0.27 & 3.56 & 100.8 \\
\hline 21LF13 & 49.07 & 2.721 & 13.8 & 11.45 & 0.158 & 7.13 & 7.88 & 3.98 & 0.66 & 0.32 & 3.74 & 100.9 \\
\hline 22LF13 & 49.26 & 3.045 & 14.59 & 12.55 & 0.181 & 6.45 & 4.01 & 4 & 0.61 & 0.34 & 5.06 & 100.1 \\
\hline 23LF13 & 46.72 & 3.211 & 14.43 & 11.26 & 0.152 & 6.75 & 5.6 & 3.15 & 1.12 & 0.37 & 6.77 & 99.51 \\
\hline 13MC-062 & 47.76 & 2.604 & 13.35 & 12.94 & 0.163 & 8.21 & 7.85 & 4.42 & 0.06 & 0.31 & 3.21 & 100.9 \\
\hline 13MC-063 & 50.33 & 2.317 & 14.98 & 9.19 & 0.219 & 6.51 & 6.3 & 5.21 & 0.06 & 0.28 & 4.15 & 99.56 \\
\hline 13MC-065 & 46.43 & 2.552 & 14.5 & 12.19 & 0.185 & 6.91 & 10.56 & 3.11 & 0.21 & 0.28 & 2.41 & 99.35 \\
\hline 13JVS-362 & 46.82 & 3.066 & 14.91 & 13.34 & 0.181 & 6.15 & 9.11 & 3.69 & 0.41 & 0.38 & 2.11 & 100.2 \\
\hline \multicolumn{13}{|l|}{ Northern Belt } \\
\hline 12JT37 & 39.85 & 5.199 & 9.55 & 15.77 & 0.202 & 9.8 & 10.52 & 2.27 & 1.31 & 0.77 & 4.41 & 99.66 \\
\hline 12JT39 & 45.49 & 4.266 & 12.06 & 12.2 & 0.192 & 5.45 & 11.1 & 4.49 & 0.3 & 0.87 & 4.1 & 100.5 \\
\hline
\end{tabular}

Note: LOI-loss on ignition

${ }^{\star}$ All Fe is converted and reported as ferric because oxidation state was not determined prior to heating during LOI measurements. 
TABLE 3.2: TRACE-ELEMENT CHEMISTRY OF THE WHALE MOUNTAIN ALLOCHTHON

\begin{tabular}{|c|c|c|c|c|c|c|c|c|c|c|c|c|c|c|c|c|c|c|}
\hline $\begin{array}{l}\text { Sample } \\
\text { number }\end{array}$ & $\begin{array}{c}\mathrm{Rb} \\
(\mathrm{ppm}) \\
\end{array}$ & $\begin{array}{c}\mathrm{Sr} \\
(\mathrm{ppm})\end{array}$ & $\begin{array}{c}\mathrm{Cs} \\
(\mathrm{ppm})\end{array}$ & $\begin{array}{c}\mathrm{Ba} \\
(\mathrm{ppm})\end{array}$ & $\begin{array}{c}\mathrm{Cr} \\
(\mathrm{ppm})\end{array}$ & $\begin{array}{c}\text { Co } \\
\text { (ppm) }\end{array}$ & $\begin{array}{c}\mathrm{Ni} \\
(\mathrm{ppm})\end{array}$ & $\begin{array}{c}\mathrm{Cu} \\
(\mathrm{ppm})\end{array}$ & $\begin{array}{c}\mathrm{Zn} \\
(\mathrm{ppm})\end{array}$ & $\begin{array}{c}\text { Sc } \\
(\mathrm{ppm})\end{array}$ & $\begin{array}{c}\mathrm{V} \\
\text { (ppm) }\end{array}$ & $\begin{array}{c}\mathrm{Y} \\
\text { (ppm) }\end{array}$ & $\begin{array}{c}\mathrm{Zr} \\
(\mathrm{ppm}) \\
\end{array}$ & $\begin{array}{c}\mathrm{Nb} \\
(\mathrm{ppm})\end{array}$ & $\begin{array}{c}\mathrm{Hf} \\
\text { (ppm) } \\
\end{array}$ & $\begin{array}{c}\mathrm{Ta} \\
(\mathrm{ppm})\end{array}$ & $\begin{array}{c}\text { Th } \\
\text { (ppm) }\end{array}$ & $\begin{array}{c}\cup \\
(\mathrm{ppm}) \\
\end{array}$ \\
\hline 14BJ22 & 5 & 186 & 2.3 & 92 & 270 & 50 & 130 & 150 & 100 & 50 & 426 & 47 & 204 & 6 & 5.0 & 0.5 & 0.7 & 0.20 \\
\hline 14BJ24 & 6 & 156 & 1.1 & 51 & 210 & 36 & 100 & 30 & 70 & 37 & 268 & 33 & 126 & 4 & 3.1 & 0.3 & 0.4 & $<0.1$ \\
\hline \multicolumn{19}{|l|}{ Central Belt } \\
\hline 12JT13B & $<2$ & 950 & $<0.5$ & 17 & 980 & 62 & 400 & 90 & 80 & 39 & 256 & 14 & 99 & 17 & 2.4 & 1.2 & 1.2 & 0.40 \\
\hline 12JT14 & $<2$ & 1341 & $<0.5$ & 36 & 160 & 40 & 110 & 170 & 100 & 31 & 313 & 22 & 173 & 25 & 4.3 & 1.8 & 2.1 & 0.60 \\
\hline 12JT15 & 4 & 1307 & $<0.5$ & 82 & 190 & 45 & 130 & 180 & 80 & 32 & 291 & 16 & 134 & 19 & 3.4 & 1.4 & 1.6 & 0.40 \\
\hline 12JT19 & $<2$ & 66 & $<0.5$ & 24 & 130 & 39 & 90 & 80 & 90 & 30 & 291 & 23 & 185 & 25 & 4.3 & 1.8 & 2.0 & 0.50 \\
\hline 12JT20 & $<2$ & 944 & $<0.5$ & 34 & 800 & 65 & 400 & 110 & 80 & 37 & 260 & 14 & 105 & 17 & 2.6 & 1.2 & 1.3 & 0.40 \\
\hline 12JT21 & $<2$ & 68 & $<0.5$ & 63 & 30 & 47 & 60 & 60 & 130 & 28 & 417 & 20 & 158 & 28 & 4.0 & 2.0 & 2.2 & 0.70 \\
\hline 17LF13 & 8 & 217 & 1.5 & 1643 & 90 & 42 & 50 & 100 & 110 & 30 & 334 & 21 & 168 & 26 & 4.0 & 1.8 & 2.0 & 0.60 \\
\hline 18LF13 & 53 & 54 & 1.6 & 896 & 150 & 97 & 140 & 110 & 160 & 32 & 329 & 25 & 209 & 30 & 5.2 & 2.2 & 2.5 & 0.60 \\
\hline 19LF13 & 4 & 430 & $<0.5$ & 577 & 190 & 44 & 150 & 40 & 100 & 31 & 322 & 21 & 185 & 32 & 4.3 & 2.2 & 2.4 & 0.80 \\
\hline 20LF13 & 6 & 221 & 3.8 & 391 & 220 & 45 & 150 & 20 & 90 & 29 & 304 & 17 & 132 & 22 & 3.3 & 1.5 & 1.6 & 0.50 \\
\hline 13JVS-362 & 6 & 465 & 0.3 & 169 & 60 & 46 & 60 & 50 & 120 & 34 & 389 & 26 & 184 & 30 & 4.4 & 2.0 & 2.0 & 0.45 \\
\hline \multicolumn{19}{|c|}{ Northern Belt } \\
\hline 12JT37 & 22 & 228 & 2.5 & 521 & 590 & 56 & 260 & 70 & 140 & 29 & 354 & 27 & 401 & 68 & 9.9 & 4.6 & 4.6 & 1.30 \\
\hline 12JT39 & 6 & 659 & 1.0 & 3357 & 30 & 36 & 100 & 90 & 140 & 23 & 366 & 33 & 361 & 59 & 8.4 & 3.9 & 5.0 & 1.60 \\
\hline
\end{tabular}

Note: Measurements with < before the number indicate that the elemental proportions are below the detection limit of the Inductively Coupled Plasma-Mass Spectrometry (ICP-MS). 
TABLE 3.2 CONT'D

\begin{tabular}{|c|c|c|c|c|c|c|c|c|c|c|c|c|c|}
\hline $\begin{array}{l}\text { Sample } \\
\text { number }\end{array}$ & $\begin{array}{c}\text { La } \\
\text { (ppm) }\end{array}$ & $\begin{array}{c}\mathrm{Ce} \\
(\mathrm{ppm})\end{array}$ & $\begin{array}{c}\mathrm{Pr} \\
(\mathrm{ppm})\end{array}$ & $\begin{array}{c}\mathrm{Nd} \\
(\mathrm{ppm})\end{array}$ & $\begin{array}{c}\text { Sm } \\
(\mathrm{ppm})\end{array}$ & $\begin{array}{c}\text { Eu } \\
\text { (ppm) }\end{array}$ & $\begin{array}{c}\mathrm{Gd} \\
(\mathrm{ppm})\end{array}$ & $\begin{array}{c}\mathrm{Tb} \\
(\mathrm{ppm})\end{array}$ & $\begin{array}{c}\text { Dy } \\
\text { (ppm) }\end{array}$ & $\begin{array}{c}\text { Ho } \\
\text { (ppm) }\end{array}$ & $\begin{array}{c}\text { Er } \\
\text { (ppm) }\end{array}$ & $\begin{array}{c}\mathrm{Yb} \\
(\mathrm{ppm})\end{array}$ & $\begin{array}{c}\text { Lu } \\
\text { (ppm) }\end{array}$ \\
\hline \multicolumn{14}{|c|}{ Southern Belt } \\
\hline 14BJ22 & 7.9 & 24.5 & 4.13 & 21.7 & 7.30 & 2.56 & 8.70 & 1.50 & 9.50 & 1.90 & 5.40 & 5.10 & 0.76 \\
\hline 14BJ24 & 4.8 & 15.0 & 2.49 & 13.8 & 4.80 & 1.63 & 5.80 & 1.00 & 6.50 & 1.30 & 3.80 & 3.70 & 0.55 \\
\hline 15BJ08 & 11.0 & 28.2 & 4.16 & 19.5 & 5.90 & 2.31 & 7.00 & 1.30 & 7.70 & 1.50 & 4.30 & 4.00 & 0.59 \\
\hline \multicolumn{14}{|l|}{ Central Belt } \\
\hline 12JT13B & 14.6 & 33.0 & 4.18 & 17.3 & 3.80 & 1.39 & 3.80 & 0.60 & 3.10 & 0.60 & 1.50 & 1.20 & 0.18 \\
\hline 12JT14 & 22.8 & 52.8 & 6.56 & 27.6 & 6.30 & 2.29 & 5.90 & 1.00 & 5.00 & 0.90 & 2.50 & 2.00 & 0.29 \\
\hline 12JT15 & 15.9 & 38.6 & 4.96 & 20.6 & 4.70 & 1.83 & 4.60 & 0.70 & 3.60 & 0.70 & 1.70 & 1.30 & 0.19 \\
\hline 12JT16 & 24.0 & 54.6 & 7.00 & 29.0 & 6.90 & 2.39 & 6.90 & 1.10 & 5.90 & 1.10 & 2.90 & 2.20 & 0.31 \\
\hline 12JT17 & 23.9 & 55.3 & 6.79 & 27.9 & 6.00 & 2.06 & 5.50 & 0.90 & 4.70 & 0.80 & 2.20 & 1.70 & 0.24 \\
\hline 12JT18 & 18.9 & 46.4 & 5.85 & 24.6 & 5.90 & 2.02 & 5.60 & 1.00 & 5.60 & 1.10 & 2.90 & 2.50 & 0.38 \\
\hline 12JT19 & 21.7 & 51.3 & 6.44 & 26.4 & 6.20 & 2.05 & 6.00 & 0.90 & 5.10 & 0.90 & 2.50 & 1.90 & 0.26 \\
\hline 12JT20 & 16.1 & 36.0 & 4.33 & 17.3 & 3.90 & 1.56 & 3.80 & 0.60 & 3.30 & 0.60 & 1.60 & 1.20 & 0.17 \\
\hline 12JT21 & 23.3 & 52.5 & 6.44 & 26.4 & 6.00 & 2.10 & 5.60 & 0.90 & 4.80 & 0.90 & 2.30 & 1.80 & 0.25 \\
\hline \multicolumn{14}{|l|}{ 17LF13 } \\
\hline & 20.8 & 48.7 & 6.11 & 25.2 & 6.00 & 2.34 & 6.00 & 0.90 & 4.80 & 0.90 & 2.30 & 1.70 & 0.24 \\
\hline 18LF13 & 24.5 & 58.7 & 7.08 & 29.3 & 6.50 & 2.02 & 5.70 & 0.90 & 5.00 & 0.90 & 2.50 & 2.00 & 0.30 \\
\hline 19LF13 & 26.6 & 59.5 & 7.14 & 28.7 & 6.40 & 2.10 & 5.90 & 0.90 & 4.80 & 0.90 & 2.30 & 1.70 & 0.24 \\
\hline 20LF13 & 17.5 & 41.6 & 5.27 & 21.9 & 4.80 & 1.81 & 4.70 & 0.70 & 3.80 & 0.70 & 1.80 & 1.40 & 0.21 \\
\hline 21LF13 & 24.5 & 57.3 & 6.98 & 28.5 & 6.10 & 2.16 & 5.80 & 0.90 & 4.60 & 0.80 & 2.20 & 1.80 & 0.26 \\
\hline 22LF13 & 23.2 & 56.2 & 7.13 & 31.0 & 6.90 & 2.48 & 6.40 & 1.00 & 5.00 & 0.90 & 2.30 & 1.70 & 0.23 \\
\hline 23LF13 & 20.9 & 52.0 & 6.72 & 29.1 & 6.50 & 2.30 & 6.00 & 1.00 & 5.00 & 0.90 & 2.40 & 1.80 & 0.24 \\
\hline 13MC-062 & 21.0 & 46.0 & 6.13 & 23.1 & 5.92 & 1.86 & 5.27 & 0.81 & 4.62 & 0.84 & 2.23 & 1.93 & 0.27 \\
\hline 13MC-063 & 16.9 & 41.0 & 5.60 & 24.5 & 5.38 & 1.79 & 5.06 & 0.80 & 4.44 & 0.80 & 2.22 & 1.81 & 0.26 \\
\hline 13MC-065 & 15.7 & 36.9 & 5.02 & 20.6 & 5.41 & 1.84 & 5.14 & 0.81 & 4.27 & 0.77 & 2.08 & 1.81 & 0.25 \\
\hline \multicolumn{14}{|l|}{ 13JVS-362 } \\
\hline & 22.8 & 51.6 & 6.94 & 27.2 & 6.64 & 2.19 & 6.09 & 0.97 & 5.19 & 0.90 & 2.38 & 2.04 & 0.29 \\
\hline \multicolumn{14}{|c|}{ Northern Belt } \\
\hline 12JT37 & 51.5 & 119.0 & 14.70 & 59.6 & 12.60 & 4.07 & 10.70 & 1.50 & 6.90 & 1.10 & 2.70 & 1.80 & 0.26 \\
\hline 12JT39 & 55.4 & 123.0 & 14.80 & 60.5 & 12.40 & 3.86 & 10.90 & 1.50 & 7.50 & 1.30 & 3.20 & 2.30 & 0.31 \\
\hline
\end{tabular}

Note: Measurements with < before the number indicate that the elemental proportions are below the detection limit of the Inductively Coupled Plasma-Mass Spectrometry (ICP-MS). 
on the relative abundances of incompatible and rare earth elements (REEs), which typically remain stable during alteration and metamorphism (e.g., Winchester and Floyd, 1977; Shervais, 1982; Pearce, 1996).

\section{Geochemical Results}

\section{Southern Belt}

The three samples from the Marsh Fork volcanic rocks of the southern belt have majorelement oxide concentrations that resemble average basalt (Table 3.1), although one sample (14BJ24) has elevated $\mathrm{SiO} 2(\sim 55 \mathrm{wt} \%)$ and depleted $\mathrm{MgO}(\sim 4 \mathrm{wt} \%)$ concentrations, resembling andesite rather than basalt. All three samples, however, plot within the tholeiitic basalt field on the $\mathrm{Nb} / \mathrm{Y}-\mathrm{Zr}$ /Ti plot (Fig. 3.8), showing $\mathrm{Nb} / \mathrm{Y}$ ratios $<1$ and $\mathrm{Zr} / \mathrm{Ti}$ ratios $\sim 0.01$. On the Ti-V plot (Fig. 3.9A), the samples fall within the mid-ocean-ridge basalt (MORB) field and have constant $\mathrm{Ti} / \mathrm{V}$ ratios of $\sim 40$. The nearly constant Ti/V ratios among the samples imply that clinopyroxene was not a fractionating melt phase or a refractory mantle phase during the generation of the melt. In support of this assertion, the petrographic work shows that clinopyroxene is only present as an intergranular phase with larger plagioclase (Fig. 3.3B).

The southern belt samples show pronounced depletions of the most incompatible

elements, yielding relatively $\mathrm{fl}$ at to slightly positive slopes on the normalized variation diagrams (Fig. 3.10). The samples also show depletions in the high field strength elements $\mathrm{Th}, \mathrm{U}, \mathrm{Nb}, \mathrm{Ta}$, and $\mathrm{La}$, enrichment in the heavy rare earth elements $\mathrm{Dy}, \mathrm{Yb}, \mathrm{Y}$, and $\mathrm{Lu}$, and relatively flat slopes on the chondrite-normalized REE diagram (Fig. 3.10A). This is supported by the chondritenormalized $\mathrm{LaN} / \mathrm{SmN}$ ratios, which range from 0.6 to 1.2 , representing the lowest ratios among all the samples in the data set. 


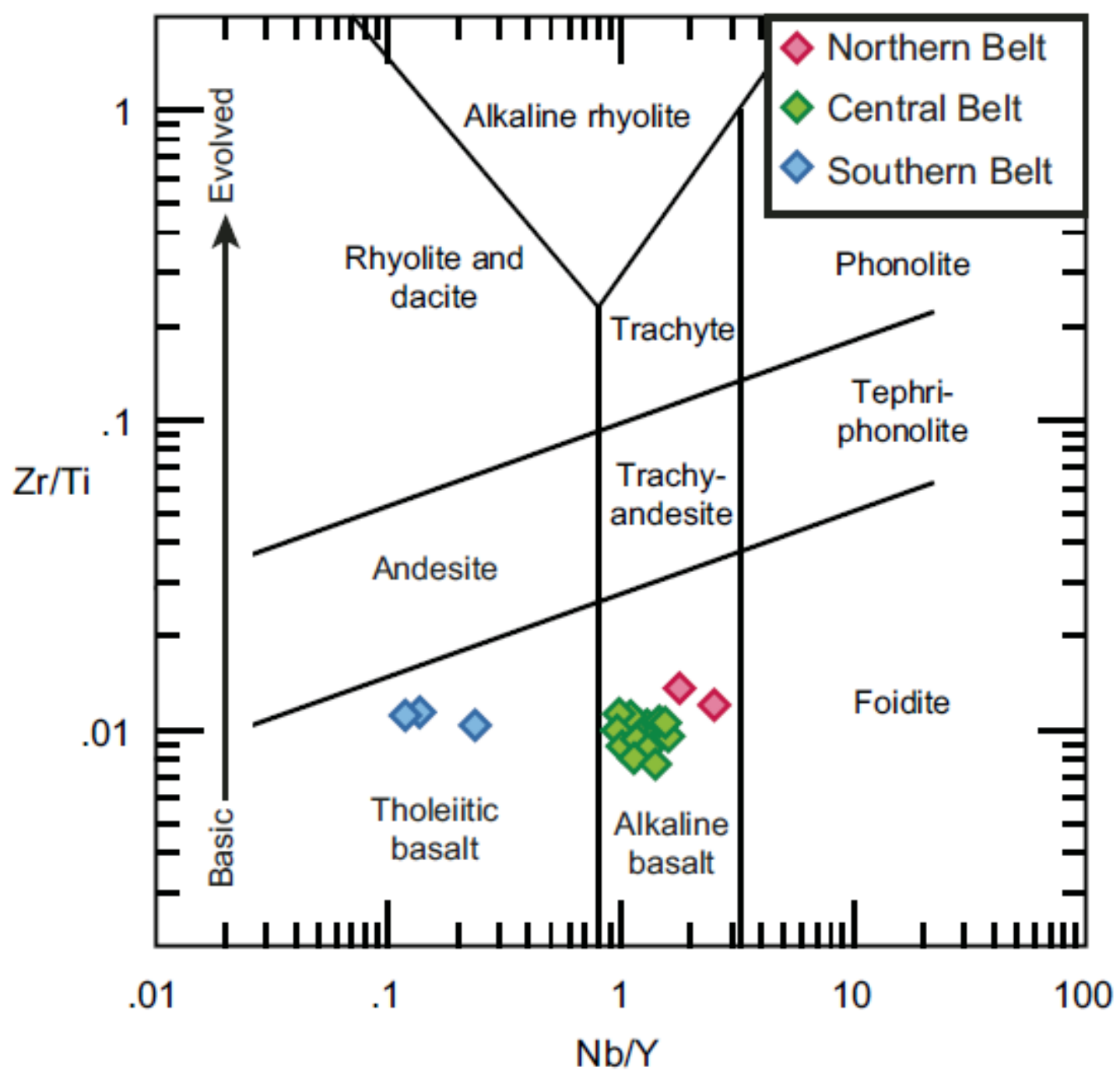

Figure 3.8: The $\mathrm{Nb} / \mathrm{Y}-\mathrm{Zr} / \mathrm{Ti}$ discrimination plot of Pearce (1996). $\mathrm{Zr} / \mathrm{Ti}$ ratio is used as an index of differentiation, and the $\mathrm{Nb} / \mathrm{Y}$ is used as an alkalinity index. 

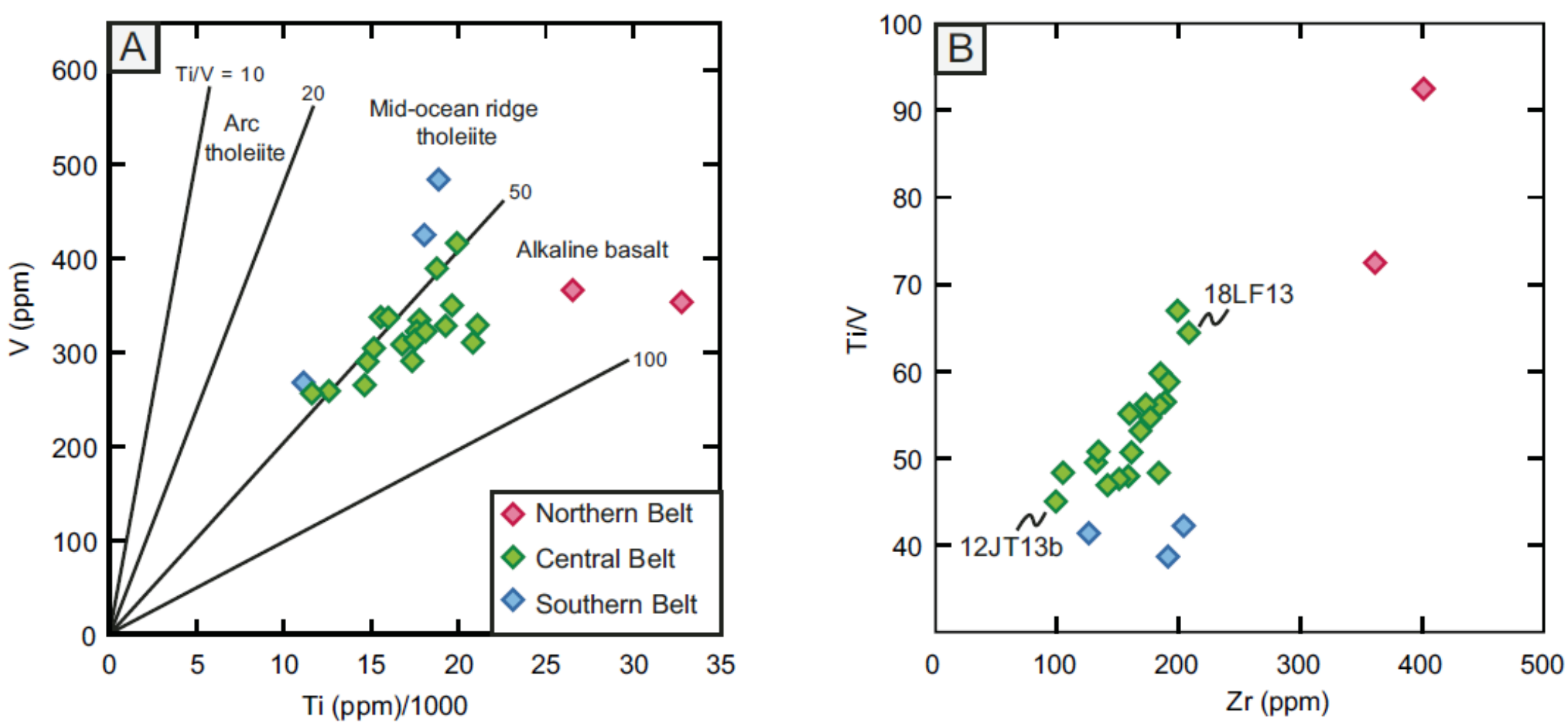

Figure 3.9: (A) Ti-V plot after after Shervais (1982) showing the fields of Low-Ti island arc tholeiite, island arc tholeiite, mid-ocean ridge tholeiite (includes back-arc basin basalt), and alkaline basalt. Solid lines represent constant Ti/V ratios of 10, 20, 50, and 100 (B) $\mathrm{Zr}-\mathrm{Ti} / \mathrm{V}$ plot showing the changes in the $\mathrm{Ti} / \mathrm{V}$ ratio (controlled by clinopyroxene fractionation) with respect to $\mathrm{Zr}$ (a commonly used differentiation index for altered basalt). 

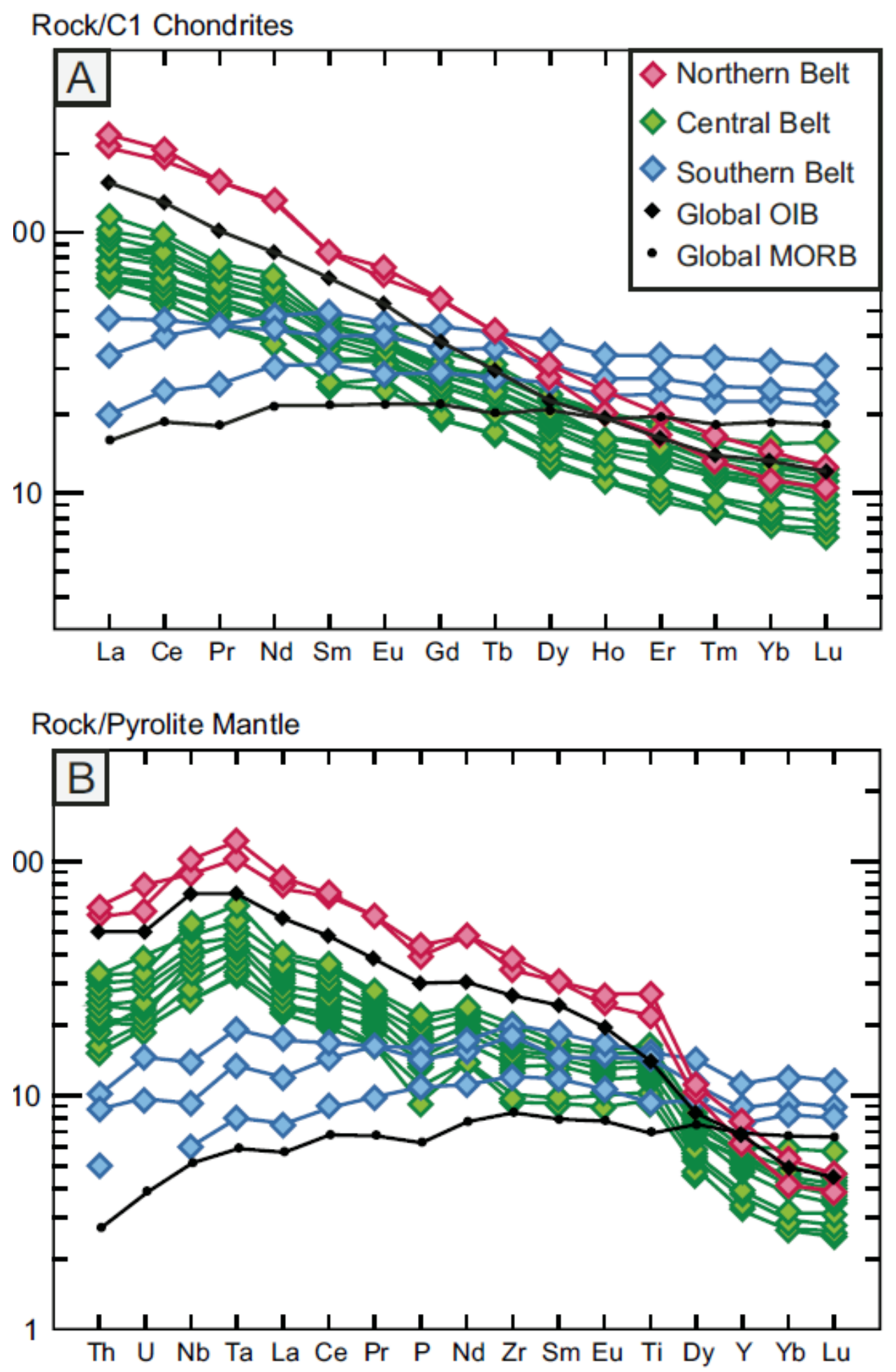

Figure 3.10: Trace-element variation diagrams. (A) Rare earth elements (REE) normalized to average C1 chondrite compositions from McDonough and Sun (1995). (B) selected trace element variations that are normalized to average pyrolite mantle compositions of McDonough and Sun (1995). 


\section{Central Belt}

The 20 Whale Mountain volcanic samples collected from the central belt show significant variation among most major- element compositions (Table 3.1), but they are all within typical compositions of basalt. In general, correlation among element pairs is weak, but $\mathrm{MgO}$, which is a common index of differentiation in basalts, is weakly correlated with $\mathrm{SiO}_{2}, \mathrm{TiO}_{2}, \mathrm{CaO}$, and $\mathrm{P}_{2} \mathrm{O}_{5}$. All the samples from the central belt plot within the alkaline basalt field on the $\mathrm{Nb} / \mathrm{Y}-\mathrm{Zr} / \mathrm{Ti}$ plot (Fig. 3.8) and have $\mathrm{Nb} / \mathrm{Y}$ ratios that are generally $>1$. On the Ti-V discrimination plot (Fig. 3.9A), the samples plot along a linear trend that crosses the $50 \mathrm{Ti} / \mathrm{V}$ ratio line at a low angle. This is likely an effect of clinopyroxene fractionation, which causes an increase in the Ti/V ratio as the melt evolves because clinopyroxene preferentially takes on V3+ over Ti during crystallization. This is supported by an increase in the $\mathrm{Ti} / \mathrm{V}$ ratio with respect to $\mathrm{Zr}$ concentration (Fig. 3.9B).

Much of the intrasample variation for central belt samples can be explained by crystal fractionation. Using $\mathrm{Zr}$, another common fractionation index, sample 18LF13, which has the highest concentration of $\mathrm{Zr}(209 \mathrm{ppm})$ among the suite, plots at the extreme end of the evolution trend line on the $\mathrm{Zr}-\mathrm{Ti} / \mathrm{V}$ plot (Fig. 3.9B). In thin section, sample 18LF13 shows almost no recognizable primary phenocrysts, which is likely due to the extensive sericite alteration of plagioclase. Remnants of olivine or clinopyroxene are also absent. At the other end of the evolution trend line, two samples (12JT13b and 12JT20) have low Zr concentrations (<110 ppm) and low Ti/V ratios, which could be the result of little to no fractionation of clinopyroxene. The two samples are distinguished by high concentrations of $\mathrm{MgO}(>10 \%)$ and high concentrations of the compatible trace elements $\mathrm{Ni}$ (400 ppm each) and $\mathrm{Cr}(>800 \mathrm{ppm})$. This, along with the high abundances of olivine phenocrysts in thin section (Figs. 3.5A and 3.5B), favors 
classification of these two samples as picrites, which could have formed by the accumulation of olivine in a fractionating magma chamber. Samples with more intermediate compositions $(\mathrm{Zr}=$ 140-190 ppm) typically show a greater variety of phenocrysts, including clinopyroxene and plagioclase. In some cases, olivine occurs as inclusions within larger plagioclase phenocrysts (Fig. 3.5C), suggesting that plagioclase crystallized after olivine.

The normalized variation diagrams (Fig. 3.10) support incompatible element enrichment. The steep negative slopes on the REE diagram (Fig. 3.10A), along with the $1.8-2.6 \mathrm{La}_{\mathrm{N}} / \mathrm{Sm}_{\mathrm{N}}$ ratios, indicate that partitioning of the most incompatible REEs into the melt occurred by low degrees of partial melting or by melting of an enriched mantle source. In the pyrolite-normalized diagram (Fig. 3.10B), the slopes drastically drop off after Ti due to the low concentrations of Dy, $\mathrm{Y}, \mathrm{Yb}$, and $\mathrm{Lu}$. This is likely an indication of refractory garnet in the mantle source, because these elements, although highly incompatible with most minerals, are strongly partitioned into garnet and withheld from the melt (see Discussion section).

\section{Northern Belt}

The two volcanic samples from the Ekaluakat formation (12JT37 and 12JT38) collected from the northern belt are characterized by high concentrations of incompatible elements. Both samples show elevated concentrations of $\mathrm{TiO}_{2}(>4 \mathrm{wt} \%), \mathrm{P}_{2} \mathrm{O}_{5}(>0.75 \mathrm{wt} \%)$, and $\mathrm{Zr}(>350 \mathrm{ppm})$. Additionally, the two samples have noticeably lower concentrations of $\mathrm{Al}_{2} \mathrm{O}_{3}(9.55$ and 12.06 wt\%) and $\mathrm{SiO}_{2}$ (39.85 and $45.49 \mathrm{wt} \%$ ) but show a wide range in $\mathrm{MgO}$ concentrations (5.45 and 9.8 wt\%). Both samples plot within the alkaline basalt fields on the $\mathrm{Zr} / \mathrm{Ti}-\mathrm{Nb} / \mathrm{Y}$ plot (Fig. 3.8) of Pearce (1996) and the Ti-V plot (Fig. 3.9) of Shervais (1982). The significant differences between the two Ti/V ratios, 92.5 for $12 \mathrm{JT} 37$ and 72.5 for 12JT39, could be caused by the fractionation of clinopyroxene. Like the central belt samples, the northern belt samples have 
steep negative slopes on the normalized variation diagrams (Fig. 3.10), although the northern belt samples show even greater incompatible element enrichment. They have $\mathrm{La}_{\mathrm{N}} / \mathrm{Sm}_{\mathrm{N}}$ ratios $>2.5$ and low concentrations of $\mathrm{Dy}, \mathrm{Y}, \mathrm{Yb}$, and $\mathrm{Lu}$, reflecting the signature of refractory garnet in the mantle source.

\section{PALEONTOLOGY}

Dutro et al. (1972) were the first to report Cambrian fossils from the rocks here included in the Whale Mountain allochthon. From exposures of their sequence along the Marsh Fork of the Canning River (Fig. 3.1), they recovered a trilobite fauna from their "volcanic and carbonate member," strata assigned here to the Egaksrak formation. The trilobites from the Marsh Fork locality were assigned without reservation to the genus Olenellus, which confirmed an early Cambrian age and "North American affinities" for these rocks of the southern belt. A second collection, recovered from exposures of the same member near the Leffingwell Fork of the Aichilik River in the central belt, contained trilobites, agnostoid arthropods, and calcitic brachiopods. It also was interpreted as a "North American" fauna, but of late Cambrian age. Both the continental affinity and the age were based on identification of one trilobite in the collection as Saratogia. Here, we detail the findings from two new fossil localities and a resampled collection from the Leffingwell Fork locality of Dutro et al. (1972).

\section{Fossil Locality J1475 (Southern Belt)}

The Marsh Fork locality was not resampled in our study, but reconnaissance sampling did yield a new fossil locality near the eastern end of the southern belt in the eastern Romanzof Mountains (Figs. 3.1 and 3.3A). The faunal collection from this locality, designated J1475, includes at least three agnostoid arthropod species, four or five trilobite species, and phosphatic brachiopods. The agnostoids and trilobites, illustrated in Figure 3.11, are identified as: 
(1) Pseudagnostus aff. P. parvus Shergold, 1980;

(2) Pseudagnostus josepha?;

(3) Neoagnostus? sp.;

(4) Aplotaspis new species;

(5) Stenopilus? sp.;

(6) genus species indeterminate $75 \mathrm{~A}$;

(7) genus species indeterminate $75 \mathrm{~B}$; and

(8) genus species indeterminate $75 \mathrm{C}$.

Details on the morphology and taxonomic assignments are provided in Appendix 3.1. It is unknown whether genus species indeterminate (gen. sp. indet.) $75 \mathrm{C}$ is the pygidium of gen. sp. indet. $75 \mathrm{~A}$, gen. sp. indet. 75B, or a fifth trilobite species. The agnostoids and trilobites confirm an age significantly younger than the Marsh Fork fauna and suggests that some of the Egaksrak units in the southern belt are assigned to the upper Cambrian (Furongian Series), although an uppermost middle Cambrian assignment (Guzhangian Stage of the Miaolingian Series) cannot be ruled out entirely. 


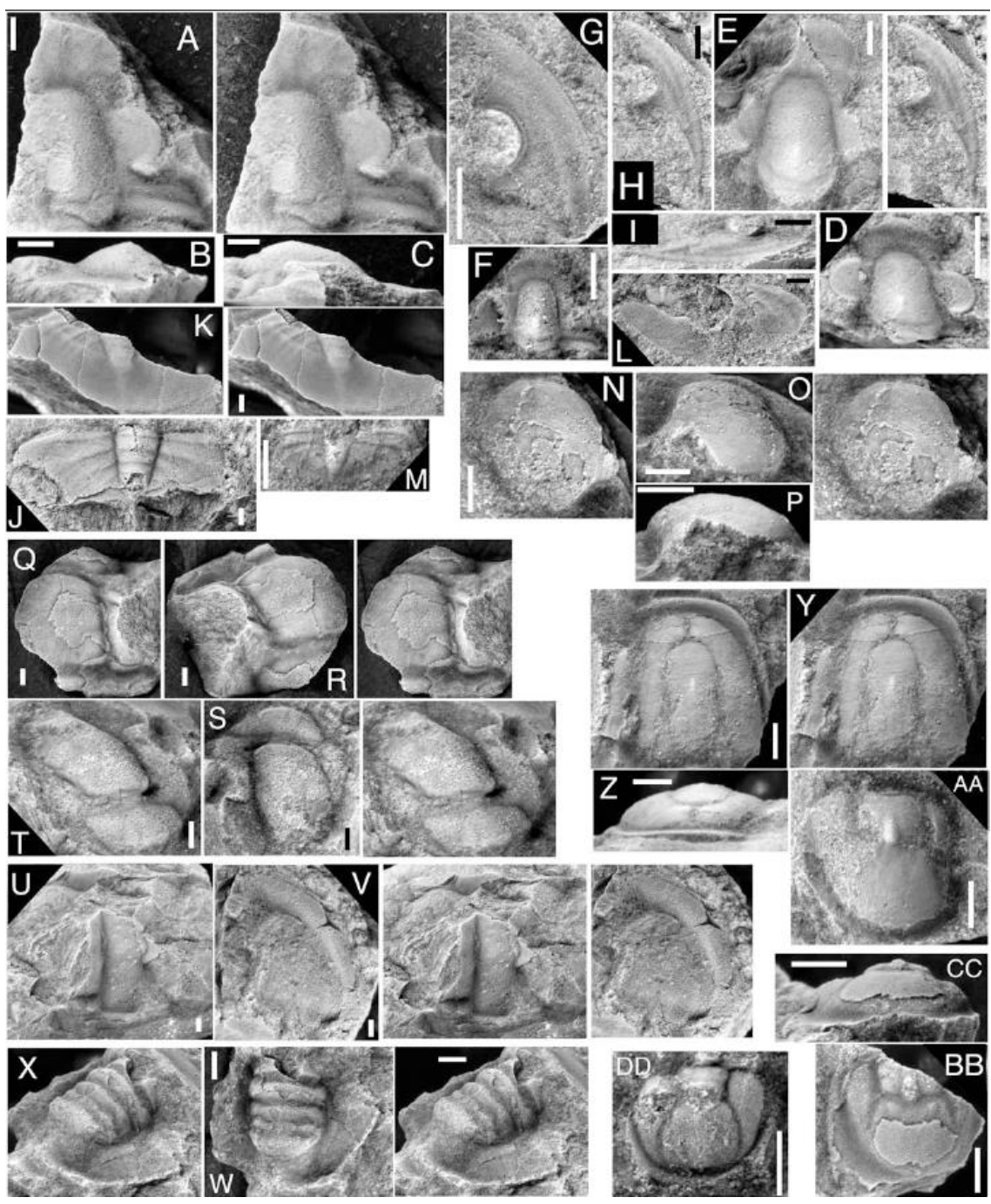

Figure 3.11: Trilobites and agnostoid arthropods from the Egaksrak formation at locality J1475. View is dorsal (palpebral for cranidia) unless indicated otherwise. White or black scale bar in each photo is $\sim 1 \mathrm{~mm}$ in length. A-M: Aplotaspis new species; (A-C) dorsal stereopair, anterior, and lateral views of large cranidium, CM59287; (D-F) small CM59288, medium CM59289, and very small CM59290 cranidia; (G) large, fragmentary librigena, CM59291; (H-I) stereopair and exterior view of small librigena, CM59292; (J) large, fragmentary pygidium, CM59293; (K) stereopair of large, fragmentary pygidium CM59294; (L) small, fragmentary pygidium CM59295; (M) very small pygidium CM59296. N-P: Stenopilus? sp., dorsal stereopair, anterior oblique, and lateral views of fragmentary small cranidium CM59297. Q-T: Genus species indeterminate 75A, fragmentary large cranidia; $(\mathrm{Q}-\mathrm{R})$ dorsal stereopair and anterior oblique views of CM59298; (S-T) dorsal view and anterior-oblique stereopair of CM59299. U-V: Genus species indeterminate 75B; (U) stereopair of large, fragmentary cranidium CM59300; (V) stereopair of large, fragmentary librigena CM59301. W-X: Genus species indeterminate 75C, dorsal and posterior oblique stereopair of fragmentary medium pygidium CM59302. Y-AA: Pseudagnostus cf. P. parvus; (Y-Z) dorsal stereopair and anterior view of fragmentary large cephalon CM59303; (AA) fragmentary large pygidium CM59304. BB-CC: Neoagnostus? sp.; dorsal and posterior views of fragmentary small pygidium CM59305. DD: Pseudagnostus josepha?, fragmentary very small pygidium CM59306 


\section{Fossil Locality J1480 (Central Belt)}

The exposures at the Leffingwell Fork locality were resampled in 2014. The new collection, referred to here as J1480, significantly expanded the number of trilobite and agnostoid specimens available to critically evaluate the taxonomic assignments of Dutro et al. (1972). One agnostoid and six trilobites are represented (Fig. 3.12), including:

(1) Micragnostus sp.;

(2) Plethopeltis? sp.;

(3) idahoiid new genus, new species 1 ;

(4) idahoiid new genus, new species 2;

(5) idahoiid?, genus and species indeterminate;

(6) genus species indeterminate $80 \mathrm{~A}$; and

(7) genus species indeterminate 80B.

The dominance of the fauna by idahoiids, and the similarity of the agnostoid species to specimens of Microagnostus chiushuensis (Kobayashi) illustrated by Westrop (1995) from lower Sunwaptan strata in northwestern Canada support the "mid- Franconian" age assigned to this fauna by Dutro et al. (1972). In modern terms, this equates to the mid-Furongian (Jiangshanian Stage). The idahoiids also link the fauna to Laurentia, but the absence of Saratogia and several other genera that occur in most Saratogia or Idahoia zone faunas across North America (see Discussion) suggests a paleogeographic location somewhat removed from the Laurentian platform itself. 


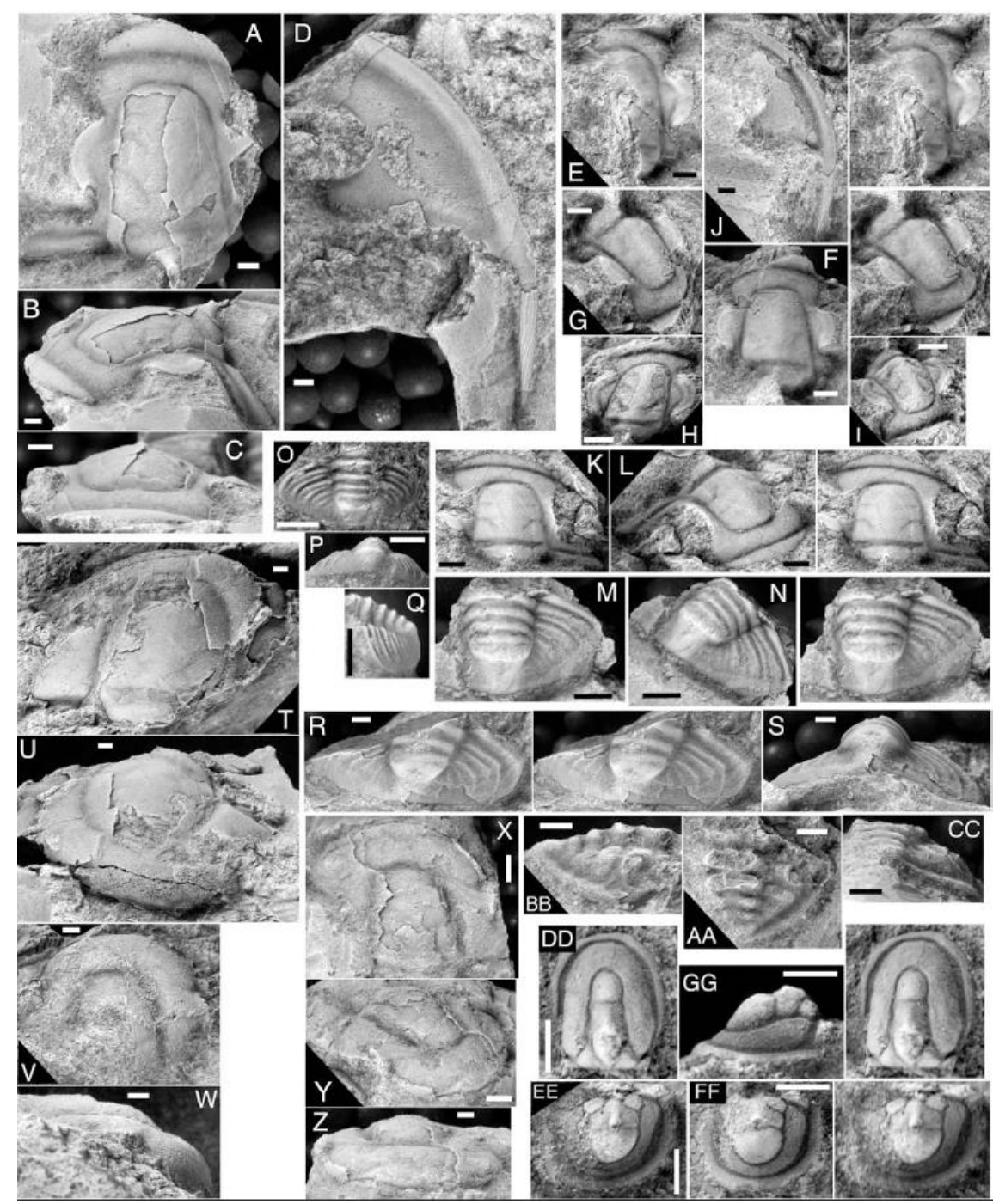

Figure 3.12: Trilobites and agnostoid arthropods from the Egaksrak formation at locality J1480. View is dorsal (palpebral for cranidia) unless indicated otherwise. White or black scale bar in each photo is $\sim 1 \mathrm{~mm}$ in length. A-D: Idahoiid new genus new species 1; (A-C) dorsal, anterior oblique, and anterior views of cranidium CM59307; (D) large librigena CM59308. E-J: Idahoiid new genus new species 2; (E) stereopair of medium cranidium CM59309; (F-G) dorsal view and anterior oblique stereopair of medium cranidium CM59310; $(\mathrm{H}-\mathrm{I})$ dorsal and anterior oblique views of small cranidium CM59311; (J) large librigena CM59312. K-L: Genus species indeterminate 80B, dorsal stereopair and anterior oblique view of medium cranidium CM59320. M-Q: idahoiid pygidium 2; (M-N) dorsal stereopair and posterior oblique view of medium pygidium CM59314; (O-Q) dorsal, posterior, and lateral views of small pygidium CM59315. RS: Idahoiid pygidium 1, stereopair and posterior view of large pygidium CM59313. T-W: Plethopeltis? sp.; (T-U) dorsal and anterior oblique views of large cranidium CM59316; (V-W) dorsal and lateral views of medium cranidium CM59317. X-Z: Genus species indeterminate 80A; dorsal, anterior oblique, and anterior views of large cranidium CM59318. AA-CC: Genus species indeterminate 80C; dorsal, lateral, and posterior views of fragmentary medium pygidium CM59321. DD-GG: Micragnostus sp.; (DD) stereopair of medium cephalon CM59322; (EE) stereopair of medium pygidium CM59323; (FF-GG) dorsal and lateral views of medium pygidium CM59324. 


\section{Fossil Locality J1352 (Central Belt)}

A new fossil locality (J1352) in the central belt, $\sim 70 \mathrm{~km}$ along strike from the Leffingwell Fork locality, yielded a sizable collection (127 specimens) of trilobites and agnostoids. This collection is the most unequivocally synvolcanic sample extracted from the Egaksrak formation. Unlike J1480, which was collected from a carbonate megablock within the mélange at the base of the central belt (Fig. 3.4B), J1352 was recovered from an interval dominated by thinly laminated volcaniclastic wackestone and lime mudstone interstratified with pillow basalt and volcaniclastic strata (Fig. 3.4C). The fossils were recovered from thin lenses and laminae of bioclastic grainstone (Fig. 3.4D), which attest to a shallow environment of deposition, as does the scarcity of agnostoids, which account for only 4 of the 127 specimens. The following taxa are represented and illustrated in Figure 3.13:

(1) agnostoid genus species indeterminate; (6) genus species indeterminate 52D;

(3) genus species indeterminate 52A; (7) genus species indeterminate 52E; and

(4) genus species indeterminate 52B; (8) genus species indeterminate 52F.

(5) genus species indeterminate 52C;

The fauna is assigned an early Furongian age (Paibian Stage) on the presence of a single cranidium with granular texture assigned with slight reservation to Cheilocephalus (see Appendix 3.1). The presence of that genus suggests a linkage to Laurentia, although there have been a few reports of the genus from non-Laurentian successions in Siberia and North China (Westrop et al., 2008). 


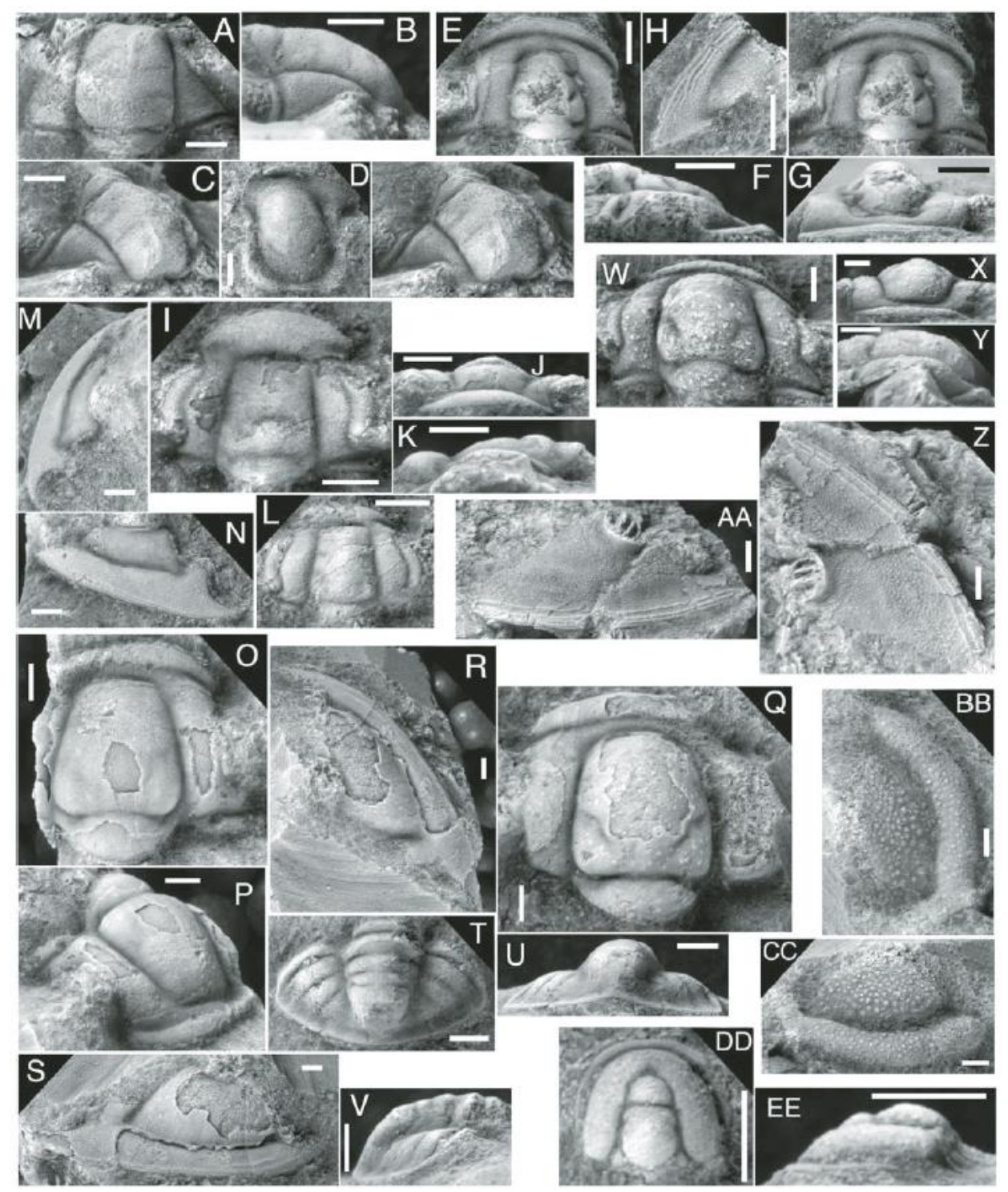

Figure 3.13: Trilobites from the Egaksrak formation at locality J1352. View is dorsal (palpebral for cranidia) unless indicated otherwise. White or black scale bar in each photo is approximately $1 \mathrm{~mm}$ in length. A-D, Cheilocephalus? sp.; A-C, dorsal and lateral views, and anterior oblique stereopair of medium cranidium CM59325; D, posterior-dorsal view of right posterolateral projection showing "shoulder". E-H, Genus species indeterminate 52A; E-G, dorsal stereopair, lateral, and anterior views of medium cranidium CM59326; $\mathrm{H}$, fragmentary medium librigena CM59327. I-N, Genus species indeterminate 52B; I-K, dorsal, anterior, and lateral views of medium, slightly crushed cranidium CM59328; L, small cranidium CM59329; M-N, dorsal and exterior views of large librigena CM59330. O-V, Genus species indeterminate 52C; O-P, dorsal and anterior-oblique views of medium cranidium CM59331; Q, medium cranidium CM59332; $\mathrm{R}-\mathrm{S}$, dorsal and exterior views of large librigena CM59333; T-V, dorsal, posterior, and lateral views of medium pygidium CM59334. W-Y, Genus species indeterminate 52D, dorsal, anterior, and lateral views of medium cranidium CM59335. Z-AA, Genus species indeterminate 52E, dorsal and exterior views of large librigena CM59336. BB-CC, Genus species indeterminate 52F, dorsal and exterior views of fragmentary medium librigena CM59337. DD-EE, Agnostoid genus species indeterminate, dorsal and lateral views of small cephalon CM59338. 


\section{DISCUSSION}

\section{Age of the Whale Mountain Allochthon}

The presence of Olenellus in the Egaksrak formation at the Marsh Fork locality (Dutro et al., 1972) assigns those strata to the Dyeran Stage of Laurentia (global Series 2; Fig. 3.14), confirming that extrusion of lavas in the southern belt had begun prior to the end of the early Cambrian (ca. 509 Ma; Gradstein et al., 2012). This is supported by the ca. 512 Ma weighted average zircon $\mathrm{U}-\mathrm{Pb}$ age from the southern belt volcaniclastic sample 15BJ06 (Fig. 3.7A). The agnostoids and trilobites in collection J1475, however, assign other carbonate rocks of the southern belt to the upper Cambrian (Furongian Series). The presence of Pseudagnostus confirms that the collection is no older than Guzhangian (Miaolingian Series). The lowest occurrences of that genus reported from several continents (Shergold et al., 1990; Peng and Robison, 2000; Varlamov et al., 2006) all lie above the first appearance datum (FAD) of Lejopyge laevigata, the appearance of which marks the base of the Guzhangian Stage (ca. 500 Ma; Gradstein et al., 2012).

At the species level, the trilobites and agnostoids in J1475 more closely resemble younger species from Paibian to lower Jiangshanian strata, suggesting that the fauna is Furongian rather than Guzhangian. As noted in the detailed species comparisons provided in Appendix 3.1, Aplotaspis n. sp. is most similar to Aplotaspis erugata in the Idamean Stage (mid-Paibian) of Australia (Henderson, 1976), and it also resembles Aplotaspis caelata from the Jiangshanian Plicatolina perlata Zone of Siberia (Lazarenko et al., 2006) in pygidial morphology. The only evidence that J1475 could be younger than Jiangshanian, and instead represents Stage 10, is the tentative assignment of a single, poorly preserved cranidium (Figs. 3.11N-3.11P) to the upper Sunwaptan genus Stenopilus. That assignment is far from certain, however, and it would conflict 
with the stratigraphic ranges established for Aplotaspis and the two species of Pseudagnostus that the agnostoids in J1475 most closely resemble (Pseudagnostus josepha and Pseudagnostus parvus), the youngest reported occurrences of which are from uppermost Jiangshanian (lower Sunwaptan Taenicephalus zone or equivalent) strata (Shergold, 1980; Westrop, 1995; Lazarenko et al., 2006; Chatterton and Gibb, 2016). Accordingly, the carbonate rocks containing the J1475 locality are assigned to either the Paibian or Jiangshanian, indicating that the volcanism in the southern belt continued through ca. $497 \mathrm{Ma}$, the approximate age determined for the base of the Paibian Stage (Gradstein et al., 2012).

The age constraints of the Romanzof formation are provided by a collection of biserial graptolites that Moore and Churkin (1984) recovered from a succession of argillite and chert (Romanzof formation) along the Canning River in Alaska. The collection included the genera Climacograptus, Retiograptus, and Didymograptus, which broadly occur in Lower-Middle Ordovician strata throughout parts of North America, Europe, and Asia (e.g., Jackson, 1964). The detrital zircon ages from a lithic- and volcanic-rich sandstone unit of the Romanzof formation suggest a ca. 452 Ma maximum depositional age (Strauss et al., this volume, Chapter 23), expanding the age constraints of the southern belt to potentially record a $60 \mathrm{~m} . \mathrm{y}$. history that ranges from the early Cambrian (ca. $512 \mathrm{Ma}$ ) to the Late Ordovician (ca. $452 \mathrm{Ma}$ ).

The rocks of the central belt span a much narrower range in age than those from the southern belt. The two faunas recovered from the Egaksrak formation are assigned to the Furongian, with the trilobites and agnostoid from the Leffingwell Fork locality (J1480) indicating a Jiangshanian age, and the probable Cheilocephalus in the new collection (J1352) placing it in the Paibian Stage or lowermost Jiangshanian Stage (Fig. 3.14). Despite reassignment of the agnostoid and idahoiid trilobites reported by Dutro et al. (1972) from the Leffingwell Fork 


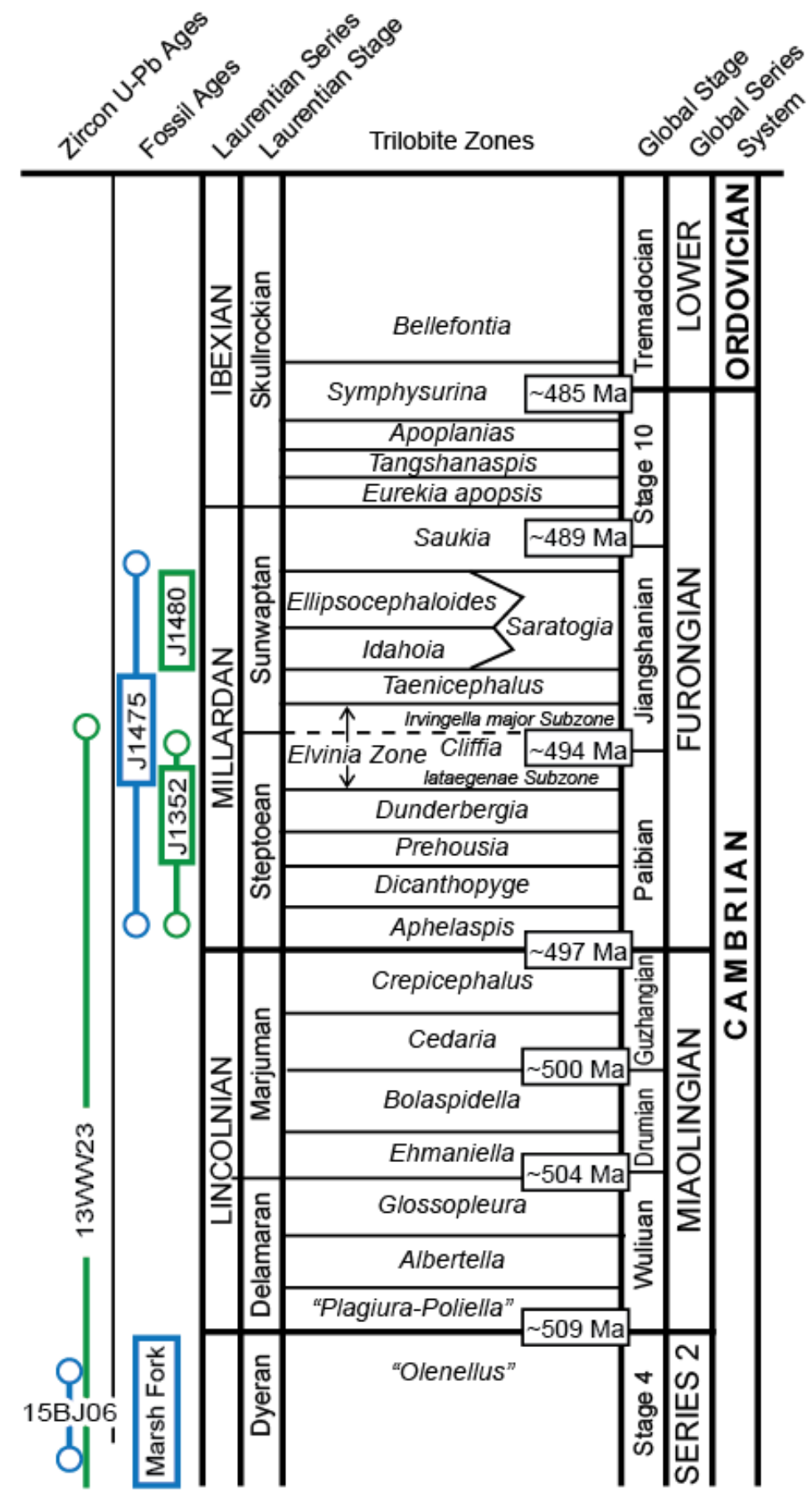

Figure 3.14: Chronostratigraphic chart showing probable positions of faunal and zircon collections from the Whale Mountain allochthon within the succession of upper Cambrian trilobite-based biochronozones, series, and stages established for Laurentia, and their relationship to global chronostratigraphic units (right-most columns). Chronostratigraphic units after Taylor et al. (2012). Numerical ages for the global stages are from Gradstein et al. (2012). Colors are used to differentiate southern belt collections (blue) from central belt (green) collections. Colored rectangles for fossil collections depict probable ranges; possible ranges shown with colored lines and white dots. Estimated ranges for the zircon U-Pb ages are taken from uncertainties depicted in the weight average age from each sample (Fig. 3.7). 
locality to different genera (see Appendix 3.1), the new information provided by collection J1480 confirms their assessment of the fauna as "Franconian" (now lower Sunwaptan) in age. Like coeval faunas assigned to the Saratogia or Idahoia zones in various locations across North America, J1480 is dominated by idahoiid species. The close resemblance of Micragnostus sp. to specimens of M. chiushuensis illustrated by Westrop (1995) from the lower Sunwaptan Noelaspis jeffreyi fauna in the Rabbitkettle Formation of northwestern Canada reinforces this correlation.

The uniqueness of the fauna from locality J1352 makes correlation with previously described faunas difficult; however, the one small cranidium identified as Cheilocephalus? sp. probably does represent that primarily Steptoean genus. The generic assignment is tentative only because no pygidium or librigena is available to fortify it. Cheilocephalus is widely distributed across Laurentia in strata of Steptoean (Paibian) age, with a single occurrence in deep-water deposits of uppermost Marjuman (Guzhangian) age in Newfoundland (Westrop et al., 2008). However, that older species of Cheilocephalus lacks the granular sculpture displayed by the cranidium in $\mathrm{J} 1352$.

The Furongian fossil age of the central belt carbonate rocks is supported by the ca. 504 Ma weighted mean U-Pb age from the 13WW23 sample (Fig. 3.7B), which was taken from the same location as the $\mathrm{J} 1352$ fossil collection. The $~ 7-10$ m.y. gap between the ca. 504 Ma zircon age and the ca. 497 Ma relative fossil age of the carbonate rocks could simply reflect uncertainty between all the ages, including those of the globally calibrated time scale (Fig. 3.14).

Alternatively, the gap in ages could reflect transitions between volcanic eruptions and carbonate deposition, or that the zircon grains recovered from 13WW23 are of detrital origin and only constrain a maximum depositional age on the Egaksrak carbonate strata. In addition, the 
structural complexity, in both the southern and central belts, obscures many of the stratigraphic and relative age relationships between the carbonate and volcanic rocks, however, is supported by the prevalence of volcanic material observed in outcrops and thin sections of the carbonate rocks in the southern and central belts of the allochthon.

The upper age limit of the central belt is constrained only by the Furongian age of the faunas from the Egaksrak formation. Reiser et al. (1980), however, did map equivalents of the Romanzof formation in the interior parts of the central belt. Although we never traversed those locations, we did observe several sequences of volcaniclastic phyllite beds with minor chert, which could correlate to the Romanzof formation in the southern belt. The presence of this formation implies that some of the central belt rocks can be assigned to the Upper Ordovician.

The rocks of the northern belt, assigned in this study to the Ekaluakat formation (Fig. 3.2), are the least constrained in terms of age, and correlation to the other belts of the allochthon is uncertain. The zircon U-Pb ages from a tuffaceous sandstone unit of the Ekaluakat formation, reported from sample 12JT35 of Johnson et al. (2016), have a nearly unimodal age distribution centered at ca. $500 \mathrm{Ma}$. This overlaps with the zircon U-Pb ages reported from the southern and central belts, and it implies that the volcanic and volcaniclastic rocks from all three belts formed at roughly the same time. The ca. $484 \mathrm{Ma}$ K-Ar age reported by Reiser et al. (1980) also falls within the general ca. 512-452 Ma age range of rocks from the southern and central belts; however, the age is characterized by very low precision ( \pm 20 m.y.).

Several fossil localities, most of which include Ordovician and Silurian graptolite genera, have been reported from argillite and slate units in the northern belt (Reiser et al., 1980; Lane et al., 1995); however, most of these rocks are now considered part of the Cambrian-Ordovician Leffingwell formation or the Upper Ordovician-Lower Devonian(?) Clarence River Group 
(Johnson et al., 2016; Nelson et al., this volume; Strauss et al., this volume, Chapter 23). Despite these potential geochronological connections and proposed stratigraphic revisions, it remains possible that rocks of the northern belt do not correlate with the other two belts and therefore are not part of the Whale Mountain allochthon. Johnson et al. (2016) speculated that the ca. $500 \mathrm{Ma}$ volcaniclastic strata had formed by recycling of Whale Mountain allochthon rocks from the southern and/or central belts and that they belonged to the younger Clarence River Group. This may be supported by the fact that the volcanic and volcaniclastic rocks in the northern belt are imbricated with Clarence River Group strata along several small-scale, north-directed thrust faults (Kelley et al., 1994; Lane et al., 1995), whereas the central and southern belts are abruptly separated from the other rocks in the NE Brooks Range by large-scale thrust faults that cross the entire map area.

\section{Paleogeographic Setting of the Whale Mountain Allochthon}

Constraining the paleogeographic setting of the Whale Mountain allochthon is of fi rstorder significance to reconstructing the early Paleozoic history of the circum-Arctic region. Previous investigators (e.g., Lane, 1991; Cecile et al., 1999; Lane et al., 2016) linked the volcanic rocks in the NE Brooks Range, herein treated separately as the Marsh Fork, Whale Mountain, and Ekaluakat units, to lower Cambrian-Upper Ordovician rift-related alkaline basalt and ultrapotassic flows that are exposed within off-shelf areas of the ancestral NW Laurentian margin, including the Selwyn Basin, Kechika trough, and elsewhere in the Canadian Cordillera (Hart, 1986; Goodfellow et al., 1995; Cecile et al., 1997; Pyle and Barnes, 2003). The lithostratigraphic, geochemical, and paleontological evidence presented in this study reveals a more complex story of the Whale Mountain allochthon, making paleogeographic links between the allochthon and the Canadian Cordillera problematic. We argue that the Whale Mountain 
allochthon represents a diverse assortment of oceanic rocks originating outboard of the Laurentian margin that were assembled into an ancient accretionary wedge that formed in front of an Iapetus subduction zone.

\section{Constraints from Lithofacies and Biofacies}

The lithofacies and biofacies of the sedimentary rocks from the allochthon record a variety of depositional settings, and the mixed stratigraphic relationships with the mafic volcanic rocks resemble the chaotic architecture of an accretionary complex. In the southern belt, lithofacies from individual blocks or outcrops of the Egaksrak formation reflect deposition in periplatformal carbonate slope, shallow-marine oolitic shoal, and peritidal shelf environments. In many ways, the Egaksrak blocks resemble the Oman Exotics of the Hawasina Nappes in eastern Oman (Searle and Graham, 1982; Pillevuit et al., 1997), or the Calera Lime-stone units of the Franciscan Complex in northern California (Tarduno et al., 1985). Similar to these analogs, the interlayered architecture of Egaksrak carbonate units and the Marsh Fork volcanic rocks likely resulted from several processes, including fi ne-grained pelagic settling of carbonate sediment on the basin floor, gravity sliding and mass transport of shallow-marine sediment, or repeated structural imbrication.

The faunal collections from the southern belt, including the early Cambrian fauna with Olenellus reported by Dutro et al. (1972) and the new collection from locality J1475, contain taxa that are common in deep-marine facies. Olenellus, while common in deeper-shelf and proximal off-shelf environments, was widely distributed across the facies belts that surrounded Laurentia (e.g., Palmer and Halley, 1979). The collection from locality J1475, however, unequivocally represents a deep-marine, off-platform fauna. Sclerites of the ceratopygid genus Aplotaspis make up more than 55\% (30 of 54 specimens) of collection J1475. Ceratopygid 
trilobites are dominant, or at least major components, of deep-marine faunas in the upper Cambrian sections of several paleocontinents. The lower Furongian Proceratopyge rectispinata fauna described by Pratt (1992) from the Rabbitkettle Formation in northwestern Canada is a good Laurentian example, as is the Franconian 2 fauna in the Hillard Limestone of eastern Alaska from which Palmer (1968) described Yuepingia glabra.

Many other non-Laurentian occurrences of ceratopygidrich, deep-marine biofacies have been reported from the Furongian and uppermost strata of Miaolingian in Asia and Australia. Aplotaspis and Proceratopyge are key elements of lower-slope biofacies described from Siberia (Pegel, 2000). They also abound in deep-marine deposits of the Georgina Basin of northeastern Australia (Henderson, 1976) and played a major role in zonation of the thick, deep-marine succession of the Jiangnan slope belt that bordered the Yangtze Platform in China (Peng, 1992). The high percentage of agnostoid arthropods in J1475, which make up 28\% (12 out of 54) of the specimens recovered, is greater than that typically found in shallow-marine faunas but comparable to relative abundances of agnostoids reported for many collections that represent deeper-shelf to off-platform biofacies (e.g., Pratt, 1992; Westrop, 1995).

The Romanzof formation records hemipelagic sedimentation dominated by suspension rainout of fi ne-grained siliciclastic and biogenic detritus (Reiser et al., 1980; Moore, 1987; Mull and Anderson, 1991; Anderson et al., 1994; Nelson et al., this volume; Strauss et al., this volume, Chapter 23); furthermore, the lack of fi ne-grained pelagic carbonate deposits in the Romanzof formation most likely reflects deposition below the carbonate compensation depth. Fine-grained strata of the Romanzof formation are locally interbedded with lithic arenites and wackes that could represent trench-filling deposits, delivered by turbidity currents and sourced from an active volcanic margin (Strauss et al., this volume, Chapter 23). 
The sedimentary rocks of the central and northern belts, although different in terms of their individual depositional settings, suggest sedimentation on or near a volcanic island. Similar to that described earlier from the southern belt, the Egaksrak formation of the central belt was most likely deposited in a combination of deep- and shallow-marine settings. The presence of interbedded volcanic matrix-supported lime rudstone, mudstone, and bioclastic grainstone at the J1352 locality reflects a combination of deep-marine suspension, sediment gravity, and turbidite sedimentation along a slope or steep-gradient setting. In contrast, the abundance of peloids, ooids, bioclasts, and rounded volcanic clasts (Fig. 3.4C) in some of the packstone and grainstone facies reflects some degree of reworking of shallow-marine carbonate sediment by wave action, as do the rounded clasts that compose the conglomeratic units that are interbedded with the basalt flows (Fig. 3.4G). The relative scarcity of agnostoids in faunal collections from sample localities J1352 and J1480 provides additional support for a shallow-water setting of the carbonate rocks in the central belt. Therefore, based upon the interstratification of shallow-water carbonates and alkaline basalt flows with ocean-island basalt (OIB) character, we interpret this belt to record deposition near an atoll or submerged volcanic island.

The Ekaluakat formation (Fig. 3.2) of the northern belt reflects deposition in a deepmarine basin, where the primary mode of deposition was pelagic and hemipelagic settling mixed with turbidity currents and possibly weak bottom currents. Notably, the sedimentary rocks of the Ekaluakat formation appear to lack abundant continental detritus. This is indicated by the near absence of detrital zircon grains older than $1 \mathrm{Ga}$ from these units (Johnson et al., 2016) and by $\varepsilon \mathrm{Nd}(\mathrm{t})$ values $>+4$ in the fine-grained units (Nelson et al., this volume). Several tuffaceous and volcaniclastic units are also interbedded throughout the sedimentary section (Fig. 3.6D), further supporting deposition along or at the base of a submerged volcanic slope. 


\section{Constraints from Igneous and Zircon Geochemistry}

The geochemical and petrological characteristics of Marsh Fork volcanic rocks in the southern belt closely resemble MORB. Their tholeiitic character (Fig. 3.8), unfractionated concentrations of $\mathrm{Dy}, \mathrm{Y}, \mathrm{Yb}$, and $\mathrm{Lu}$, and the gentle slopes on the normalized variation diagrams (Fig. 3.10) imply that the volcanic rocks were derived from a shallow $(<80 \mathrm{~km})$, garnet-free mantle source that was depleted in incompatible elements (e.g., Salters and Stracke, 2004; Kushiro, 2001). Shallow melting conditions and the eruption of tholeiitic basalt are most commonly found along mid-ocean ridges, where the degree of partial melting is high and the flux of incompatible elements into the melt is diluted.

Although the southern belt samples show overall enrichment of most trace elements compared to the global average of MORB (Arevalo and McDonough, 2010), the trends on normalized variation diagrams are nearly parallel (Fig. 3.10). The enrichment was likely driven by postmelting crystallization of the magma. Some oceanic-island-arc suites have similar traceelement trends, but most of these suites also include negative $\mathrm{Nb}$ and Ta anomalies (e.g., Elliott, 2003). Furthermore, the $>50 \mathrm{Ti} / \mathrm{V}$ ratios (Fig. 3.9A) are significantly higher than most island-arc suites (Shervais, 1982). Tholeiitic basalt is also common in oceanic and continental flood basalt provinces; however, these suites are typically more enriched in the incompatible elements with respect to MORB-type lavas (e.g., Hooper and Hawkesworth, 1993).

The volcanic rocks from the central and northern belts have petrological and geochemical characteristics that resemble alkaline basalt. Alkaline magmas are produced in a variety of tectonic settings, but empirical models show that alkaline magmas are typically generated under deep, high-pressure conditions that suppress the amount of partial melting and concentrate incompatible elements into the melt (e.g., Yoder and Tilley, 1962; Green and Ringwood, 1967; 
Jaques and Green, 1980). A deep melting regime for the central and northern belt suites is supported by the relative depletions of Dy, Y, Yb, and Lu. These elements are typically withheld from the melt if the mantle source includes refractory garnet, which becomes stable at the expense of spinel below $85 \mathrm{~km}$ depth (Robinson and Wood, 1998). Deep melting conditions are further supported by the low oxygen fugacities inferred from the $<50 \mathrm{Ti} / \mathrm{V}$ ratios (Shervais, 1982).

The enrichment of incompatible elements observed in the central and northern belt suites is also linked to melting of an enriched or fertile mantle source. There are several hypothesized types of fertile sources in the mantle (Hofmann, 2003), but melting of such sources typically requires a deep thermal anomaly or hotspot. Hotspot volcanism is commonly observed at intraplate oceanic-island settings or at off-axis seamounts, and the incompatible element trends of the central and northern belt suites follow the global OIB average (Sun and McDonough, 1989); however, similar trends have been observed from continental hotspots, including those found along the Cameroon line of western Africa (Fitton, 1987).

Isotopic compositions are particularly useful for determining mantle source geochemistry, because most isotopes do not fractionate during partial melting or crystallization processes. Although we did not measure any isotopes from our basalt samples, the $\varepsilon \mathrm{Hf}(\mathrm{t})$ zircon values of +4 to +11 from the two samples, 15BJ06 and 13WW23 (Fig. 3.7), present several implications. Notably, the $\varepsilon \mathrm{Hf}(\mathrm{t})$ values are slightly displaced from the depleted mantle trajectory of Vervoort and Blichert-Toft (1999). This could imply that the source material from which the zircon crystallized was derived from (1) isotopically fertile mantle sources, (2) melts of Neoproterozoic crust, or (3) mixed depleted mantle melts and older (Paleoproterozoic?) crustal contaminants. Given the prevalence of mafic melts recorded in our geochemical data set and the 
absence of silicic melts, the volcanic rocks of the allochthon were not likely generated by crustal melting or assimilation. A cogenetic relationship between the melts that produced the volcanic rocks and those from which the zircon crystallized implies that the displaced $\varepsilon \mathrm{Hf}(\mathrm{t})$ values, like the OIB geochemical signatures, reflect derivation from an isotopically fertile mantle source. Future studies that directly measure the isotopic compositions of the volcanic rocks will test this interpretation.

The segregation of MORB-type rocks in the southern belt from OIB-type rocks in the central and northern belts is a perplexing issue. Plausibly, the rocks from all three belts could have formed in different tectonic settings, or each belt could reflect temporal changes in melting conditions. Although OIB- and MORB-type lavas can be found in continental rift settings, MORB-type rocks are typically subordinate, and none of samples analyzed in the study exhibited the ultra-alkaline character observed in many rift provinces (e.g., Kampunzu and Mohr, 1991). The volcanic rocks of the Whale Mountain allochthon thus either formed by conventional oceanic melting mechanisms, mid-ocean-ridge decompression or intraplate hotspots, or they formed by renewed extension along a previously attenuated segment of continental crust, such as the continent-ocean transition at the distal reaches of a passive margin.

Interpretations that link the volcanic rocks in the NE Brooks Range to extensional events along NW Laurentia typically cite similarities with the alkaline volcanic rocks exposed in the Selwyn Basin (e.g., Lane et al., 2016). These include the Old Cabin Formation and Nibbery volcanic rocks, which are characterized by pillowed basalt flows that are interbedded with the off-shelf carbonates of the Rabbitkettle Formation (Hart, 1986; Cecile, 2000; Goodfellow et al., 1995). The base of Old Cabin Formation is constrained by a 499 Ma zircon U-Pb age (MacNaughton et al., 2016), which overlaps with the zircon ages reported in this study. 
Goodfellow et al. (1995), however, showed distinct geochemical differences between the Whale Mountain volcanic rocks and the volcanic rocks of the Selwyn Basin, suggesting that the Selwyn Basin volcanic rocks formed by partial melting of lithospheric mantle, whereas the Whale Mountain volcanic rocks formed by partial melting of enriched portions of the asthenosphere. In addition, the MORB-like basalt flows and imbricated chert units in the southern belt of the allochthon, which were not examined in the Goodfellow et al. (1995) geochemical study, are unlike anything exposed in the Selwyn Basin or the Canadian Cordillera.

In many ways, the Whale Mountains allochthon resembles the Franciscan Complex in northern California, which includes a wide array of both tholeiitic and alkaline volcanic rocks mixed with both deep-marine chert and shallow-marine limestone (e.g., Shervais and Kimbrough, 1987; Tarduno et al., 1985; MacPherson et al., 1990). The Hawasina Nappes in eastern Oman are another good analog, where chaotic mélanges of intercalated alkaline volcanic and shallow-marine carbonate rocks, the Oman Exotics, are imbricated with deep-marine sedimentary and subordinate tholeiitic volcanic rocks, all of which were thrusted onto passivemargin sequences of the Arabian Platform during the closure of the Tethys Ocean (e.g., Béchennec et al., 1990; Pillevuit et al., 1997).

\section{Constraints from Paleobiogeography}

The most unequivocal tie to Laurentia provided by the faunas from the Egaksrak formation is the Olenellus reported by Dutro et al. (1972) from their Marsh Fork locality. This uniquely Laurentian genus was widely distributed across the facies belts that surrounded Laurentia in the early Cambrian (e.g., Palmer and Halley, 1979), but it is particularly common in intermediate-and deep-marine facies that accumulated in open-shelf and off-shelf environments. If the cranidium from locality J1475 identified here as Stenopilus? sp. does represent that genus, 
which is uncertain (see Appendix 3.1), it reinforces the evidence of proximity to Laurentia provided for the southern belt by Olenellus. Stenopilus is one of several plethopeltid genera closely associated with microbial reefs of the Laurentian platform (Ludvigsen and Westrop, 1983; Taylor et al., 2009), but it also occurs in deep-marine, toe-of-slope deposits sourced by downslope transport of sediment from reefs at the platform margin and upper slope (Ludvigsen et al., 1989). Like Olenellus, Stenopilus is uniquely Laurentian, and it requires at least proximity to that paleocontinent. However, having been reported from both platform and off-platform deposits, neither of these genera resolves whether the volcanic rocks of the southern belt were extruded on the Laurentian platform or were part of an oceanic volcanic succession outboard of the Laurentian margin.

Dutro et al. (1972) based their interpretation of the fauna at their Leffingwell Fork locality as one of North American (i.e., Laurentian) aspect on assignment of a single, fragmentary cranidium to the idahoiid genus Saratogia. This was a reasonable conclusion, given the prevalence of Saratogia and other idahoiids in early Sunwaptan faunas described previously from Montana and Wyoming (Grant, 1965), Texas (Longacre, 1970), and Oklahoma (Stitt, 1971). It was also reported in later studies of coeval faunas in Alberta (Westrop, 1986) and the Appalachians (Ludvigsen and Westrop, 1983; Taylor et al., 2009). However, the large collection (J1480) recovered in 2014 from the Leffing well Fork locality reveals that it is not a typical Saratogia/Idahoia zone fauna. As explained in detail in Appendix 3.1, J1480 is dominated by two new idahoiid species that cannot be assigned to any established genus. Saratogia is not represented, nor are other genera that characterize faunas of this age in various facies across Laurentia, such as Drumaspis, Wilbernia, and Ptychaspis. 
Wilbernia is particularly widespread, occurring not only in most idahoiid-rich early Sunwaptan platform faunas, but even in coeval slope deposits in the Rabbitkettle Formation in NW Canada (Westrop, 1995). Drumaspis is similarly widespread in both shallow- and deepmarine faunas, the latter including the "Franconian 2" fauna described by Palmer (1968) from the Hillard Limestone, the off-platform equivalent of the Jones Ridge Formation in east-central Alaska. Although the dominance by idahoiids does suggest proximity to Laurentia, the absence of all characteristic and widespread Saratogia/Idahoia zone genera is difficult to reconcile with origination on or even directly adjacent to the Laurentian platform. The only specimens in J1480 that might represent a Laurentian genus are three cranidia assigned with considerable uncertainty to Plethopeltis (Figs. 3.12T-3.12W). These cranidia to some extent resemble Plethopeltis saratogensis, a species associated with Saratogia in the Appalachians (Ludvigsen and Westrop, 1983; Taylor et al., 2009), but they differ in some critical features (Appendix 3.1). Given these differences, the poor preservation, and lack of an associated pygidium or librigena, the assignment is quite tentative, and the link to Laurentia is equally tenuous.

The strongest evidence that the Egaksrak formation in the central belt did not originate on the Laurentian platform is provided by collection J1352, which consists of 127 specimens recovered from strata interstratified with pillow basalt and volcaniclastic rocks. Except for one cranidium, which probably represents Cheilocephalus, the fauna is remarkably unfamiliar. The species are distinct and specialized individually and collectively display a wide range of morphologies. Such differentiated faunas in the Laurentian platform succession characterize the middle to upper parts of the Cambrian stages, and the constituent genera and species are easily recognized as Laurentian taxa and diagnostic of their respective zones. The diverse faunas of the Crepicephalus, Elvinia, and Saukia zones at the tops of the Marjuman, Steptoean, and 
Sunwaptan Stages, respectively, exemplify this, and at least a few of the endemic genera that characterize those zones are found consistently in coeval deep-marine deposits that accumulated along the Laurentian margin (Raymond, 1924; Rasetti, 1944; Palmer, 1968; Ludvigsen et al., 1989; Pratt, 1992; Westrop, 1995). None of the five to six genera in J1352 could be assigned to any established genus from Laurentia, or any other paleocontinent. For this reason, the paleogeographic model we favor for the rocks of the central belt is extrusion in an oceanic setting close enough to Laurentia for very limited interchange with the shallow-marine faunas of that paleocontinent, and hence the idahoiids and possible Plethopeltis in J1480 and Cheilocephalus in J1352, but sufficiently removed to allow for evolution of unique, endemic trilobite faunas in the shallow environments around the volcanic islands.

The data presented in this study do not directly address whether the Whale Mountain allochthon formed outboard NW or NE Laurentia. A peri-Laurentian origin for the allochthon, as recognized by the faunal collections from the Egaksrak formation, aligns with recent models that restore portions of the Arctic Alaska terrane to NE Laurentia in the early Paleozoic (e.g., Strauss et al., 2013, 2017, this volume, Chapter 23; Johnson et al., 2016). In the context of Mesozoic terrane boundaries, earlier studies grouped the pre-Mississippian rocks exposed in the NE Brooks Range and the Doonerak region of the central Brooks Range into the North Slope subterrane (e.g., Jones et al. 1987; Moore et al., 1994). The recent models of Strauss et al. (2017), however, severed the early Paleozoic ties between the Doonerak region and the North Slope, suggesting that the Ordovician-Silurian volcanic assemblages at Doonerak formed in response to subduction of Iapetus lithosphere outboard NE Laurentia, whereas the rocks of the North Slope had formed as a lateral continuation of the deep-marine, Franklinian Basin at northern Ellesmere Island in Arctic Canada (Johnson et al., 2016; Nelson et al., this volume; 
Strauss et al., this volume, Chapter 23). This restoration calls for an ancient oceanic basin or marginal seaway that separated the North Slope from the Doonerak arc in the early Paleozoic. We contend that Whale Mountain allochthon is a relic of this basin, and it now marks the early Paleozoic suture between the North Slope and the Doonerak region.

The exact paleogeographic configuration of the basin remains unclear, because it is not possible, with the data presented in this study, to determine whether the rocks of the Whale Mountain allochthon formed in a true oceanic basin or in some type of marginal seaway that separated the Laurentian margin from outboard terranes. The faunal collections from the Egaksrak formation, particularly those of J1352, suggests that at least some portion of the allochthon formed in an open-ocean setting, allowing for faunal communities of the Egaksrak formation to evolve in isolation. The assembly and emplacement of the allochthon are also unclear. The allochthon's structural position above Upper Ordovician-Lower Devonian(?) strata of the Clarence River Group suggests that emplacement occurred in post-Early Devonian time (Johnson et al., 2016), but future work is needed to reconstruct the paleogeographic origins of each belt.

\section{CONCLUSIONS}

The general implications of this work reveal that the pre-Mississippian rocks of the NE Brooks Range cannot be assigned to a coherent stratigraphic architecture. The fault-bounded rocks of the Whale Mountain allochthon record a complex geological history, dating from Series 2 of the Cambrian (ca. $512 \mathrm{Ma}$ ) to the Late Ordovician (ca. $452 \mathrm{Ma}$ ). Field observations and igneous geochemistry show that the assorted igneous and sedimentary rocks formed in diverse depositional and tectonic settings, ranging from basin floor settings founded on MORB-type lavas to shallow platform settings that capped isolated volcanic islands. The new trilobite faunal 
collections from the Egaksrak formation greatly expand the biostratigraphic record of the NE Brooks Range, with important implications for reconstructing the paleogeography of northern Laurentia. A few of the identified species have loose affinities to Laurentia, but all three collections are missing many of the diagnostic Laurentian platform species that are found throughout Upper Cambrian carbonate units from western to eastern North America. One of the fossil locations (J1352) yielded a collection of species that do not have a recognized affinity with any of the major late Cambrian paleocontinents.

We conclude that the rocks of the Whale Mountain allochthon did not form on the stable platforms that surrounded Laurentian in the late Cambrian, but instead formed in a periLaurentian setting, perhaps in the open waters of the Iapetus Ocean. The allochthon was later assembled when disparate rock assemblages were episodically scraped from a subducting oceanic plate into an ancient accretionary wedge and collectively emplaced onto the Laurentian margin at the time of basin closure.

\section{APPENDIX 3.1: SYSTEMATIC PALEONTOLOGY}

Illustrated specimens are reposited in the invertebrate paleontology collections at the Carnegie Museum of Natural History (prefix CM) in Pittsburgh, Pennsylvania, USA.

\section{FAMILY AGNOSTIDAE M'COY, 1849}

\section{Genus Micragnostus Howell, 1935}

Opinions vary widely regarding the relationships of several late Cambrian agnostoid genera, among them Homagnostus, Micragnostus, Oncagnostus, and Trilobagnostus. Recent discussions of the problem can be found in Choi et al. (2004) and Westrop and Eoff (2012). The approach taken by Choi et al. (2004) is adopted here, with the assignment of species with 
relatively short and parallel-sided glabellae and pygidial axes, and weakly developed or absent median preglabellar furrows to the genus Micragnostus.

\section{Micragnostus sp.}

\section{Illustrations: Figures 3.12DD-3.12GG.}

Remarks: The agnostoids in collection J1480, originally identified by Dutro et al. (1972) as Geragnostus sp., resemble in all respects the specimens illustrated by Westrop (1995, his plate and figs. 14-16) for Micragnostus chiushuensis (Kobayashi). However, the deformed nature of the specimens from the Egaksrak formation renders detailed comparison difficult and precludes certain assignment to that species. Accordingly, they are left in open nomenclature as Micragnostus sp. The reassignment from Geragnostus does not reflect a disagreement with the initial identification in Dutro et al. (1972); it results from a widely accepted revision of that genus by Fortey (1980), who restricted it to species possessing a complex F3 glabellar furrow divided into three segments, with the glabellar node located barely behind the central segment. Species like the one in J1480, which display an undivided F3 and more posteriorly placed glabellar node, now fall within Micragnostus.

\section{Genus Pseudagnostus Jaekel, 1909}

\section{Pseudagnostus josepha? (Fig. 3.11DD)}

Remarks: The morphology of the one, small pygidium in collection J1475 identified as P. josepha? falls within the broad concept used for P. josepha by Peng and Robison (2000). (See Westrop and Eoff [2012] for an alternate view of the range of variation that should be encompassed by this and other agnostoid species.) The Alaska pygidium is nearly identical to one of the small pygidia illustrated by Peng and Robison (2000, their fig. 10-5), differing only in displaying a slightly narrower border furrow and more firmly impressed axial furrow along the 
posterior half of the posteroaxis. Westrop (1995) and Chatterton and Gibb (2016) reported similar species that they left in open nomenclature as $P$. cf. $P$. josepha from the Rabbitkettle Formation in the Northwest Territories and southeastern British Columbia, respectively.

\section{Pseudagnostus aff. $P$. parvus Shergold, 1980 (Figs. 3.11Y-3.11AA)}

Remarks: This species in collection $\mathrm{J} 1475$ resembles $P$. parvus in its long, parabolic cephalon with a long and relatively narrow glabella, anteriorly placed glabellar node just behind a nearly obsolete F3, fairly narrow borders, and broad, deep border furrows. It differs in displaying a more transverse (less rounded) anterior margin, and a broader and less pointed anterior glabellar lobe.

Genus Neoagnostus Kobayashi, 1955

\section{Neoagnostus? sp. (Figs. 3.11BB-3.11CC)}

Remarks: This single, fragmentary pygidium in collection $\mathrm{J} 1475$ resembles $N$. canadensis (Billings) in possessing well impressed but only weakly divergent axial furrows along the anterior half of the posteroaxis, and an exceptionally broad border furrow that is widest near the posterolateral corners. It resembles pygidia illustrated for this species by Shergold (1977, his plate 16 and fi g. 10) and Ludvigsen et al. (1989, his plate 4 and fig. 7 ) in these respects, but it differs in the shallowing of the axial furrows along the posterior half of the posteroaxis and resultant lack of elevation of the back of the axis above the border furrow.

\section{Agnostoid gen. sp. undetermined (Figs. 3.13DD-3.13EE)}

Remarks: This one cephalon in collection J1352 resembles a number of Furongian species in genera such as Homagnostus, Micragnostus, and Oncagnostus in its forwardly placed glabellar node, short and somewhat inflated posteroglabella, relatively small basal lobes, and partial 
median preglabellar furrow. However, its small size and lack of an associated pygidium preclude certain assignment even to genus.

\section{Class TRILOBITA}

\section{Family IDAHOIIDAE Lochman, 1956}

Remarks: The dominant trilobites in J1480 are confidently assigned to the Idahoiidae based on their anteriorly truncate, subtrapezoidal glabellae, large, band-like palpebral lobes, faintly impressed palpebral furrows, prominent dorsally and ventrally directed occipital spines, and broad preglabellar and librigenal fields traversed by genal cecae. Two distinct idahoiid species are represented in the collection. The cephalon for each species could be reconstructed owing to a contrast in depth of border furrows and slope of genal/preglabellar fields, which allowed recognition of the corresponding librigena for each cranidium. Unfortunately, neither of the two pygidia displays any trait to link it with the appropriate cephalon, and they are treated separately below as Idahoiid pygidium 1 and 2 .

Ludvigsen and Westrop (1983) significantly revised the Idahoiidae in a monograph describing a fauna from New York that included Saratogia calcifera (Walcott), the type species of Saratogia. Among the changes was reduction of Idahoia to a subgenus of Saratogia, with separation of the subgenera based on contrasting pygidial morphologies. A long axis extending to the posterior margin, and a narrow, convex border characterize the pygidium of Saratogia (Saratogia), while species of Saratogia (Idahoia) have pygidial axes that terminate well in front of the margin at the inner edge of a broad, gently concave border. Neither pygidium in collection J1480 displays the requisite features to justify assignment to either of these subgenera, nor to any other idahoiid genus such Minkella, Meeria, and Psalaspis. A single cranidium, here referred to 
as Idahoiid? genus and species indeterminate, displays some of the characteristic features of Minkella, but it differs in too many respects to allow confident assignment to that genus.

Idahoiid new genus, new species 1 (Figs. 3.12A-3.12D)

Remarks: Although the basic form of the cranidium and librigenal of this species is quite similar to that of Saratogia, it is set apart by the weak impression of its axial, border, occipital, and lateral glabellar furrows, even where exfoliated. The gentle and even slope of the preglabellar field and broad, only moderately impressed anterior border furrow are also distinctive.

\section{Idahoiid new genus, new species 2 (Figs. 3.12E-3.12J)}

Remarks: This species differs from the other idahoiid species in J1480 in its more deeply incised furrows, especially the anterior, lateral, and posterior border furrows. Other differences include a steeply downsloping preglabellar field, slightly upturned anterior border, and S1 furrows that bifurcate distally and terminate well short of the axial furrow. The palpebral lobes are also elevated above the level of the narrow interocular fixigenae. It shares many of these features with some species of Saratogia (Idahoia), such as Saratogia (I.) fria Lochman and Hu (1959). However, as noted above, neither of the associated idahoiid pygidia in J1480 is consistent with assignment to that genus.

\section{Idahoiid pygidium 1 (Figs. 3.12R-3.12S)}

Remarks: A strongly convex axis comprising three rings and a terminal piece is elevated well above abaxially downsloping pleural fields marked by three pairs of pleurae. The axis ends well forward of the posterior margin at the inner edge of a fairly wide border, as is typical of Saratogia (Idahoia) pygidia. However, the border is flat to slightly dorsally convex, as opposed to strongly concave in that subgenus, and it makes up significantly less of the sagittal length of 
the pygidium. The border also differs in being interrupted by a postaxial ridge and being traversed by the very narrow (exsagittal) posterior bands of the two anteriormost pleurae, for which intersection with the margin is marked by minute, inconspicuous terminal spines.

\section{Idahoiid pygidium 2 (Figs. 3.12M-3.12Q)}

Remarks: The axis, consisting of four axial rings and a terminal piece, is more parallelsided and broader (transverse) at the posterior end than that of pygidium 1 . The four pairs of pleurae display anterior and posterior bands of equal width (exsagittal) and pleural furrows that are relatively narrow and deeply incised. The pleural bands and furrows terminate at the inner margin of a gently convex border that is narrower (exsagittal) than that of pygidium 1, but much wider and less convex than that of Saratogia (Saratogia). The border ends adaxially at the sides of a broad postaxial ridge.

\section{Idahoiid? genus and species indeterminate (Figs. 3.12K-3.12L)}

Remarks: The small, thorn-like occipital spine and narrow anterior border on this single cranidium in $\mathrm{J} 1480$ resemble those of Minkella, but the palpebral lobes are longer than is characteristic of that genus, and the glabella is shorter relative to its width than that of any idahoiid. However, given the deformed condition of most sclerites in this collection, it is possible that the cranidium has experienced some anterior-posterior compression. Consequently, its assignment to the Idahoiidae is uncertain.

\section{Genus Plethopeltis Ulrich in Bridge, 1931}

Plethopeltis? sp. (Figs. 3.12T-3.12W)

Remarks: The cranidia identified as Plethopeltis? sp. resemble in most respects those of Plethopeltis saratogensis, a species associated with Saratogia in the lower Sunwaptan of New York (Ludvigsen and Westrop, 1983). However, the occipital ring preserved on the most 
complete cranidium (Figs. 3.12T-3.12U) does not expand posteriorly axially to produce a blunt occipital spine, as is characteristic of $P$. saratogensis. Instead, it displays a transverse posterior margin and remains fairly narrow (sagittal) across the axis. No species of Plethopeltis displays such an occipital ring. Given the atypical form of the occipital ring, and the absence of either a librigena or pygidium to reinforce or refute assignment to Plethopeltis, the generic assignment is questionable.

\section{Genus Stenopilus, Clark, 1924}

\section{Stenopilus? sp. (Figs. 3.11N-3.11P)}

Remarks: A single, effaced (smooth) cranidium in collection J1475 is assigned with reservation to the genus Stenopilus, owing to its strong sagittal and transverse convexity, relatively short (exsagittal) posterior areas, and strongly convex, overhung posterior margin. Certain assignment to that genus is not possible, however, because tightly adhering matrix made it impossible to expose the anterior and lateral margins to confirm the presence of a strong anterior arch, and small eyes on the steeply sloping sides of the cranidium. These features set Stenopilus apart from other effaced genera.

\section{Family CERATOPYGIDAE Linnarsson, 1869}

\section{Genus Aplotaspis Henderson, 1976}

An anteriorly tapering glabella, narrow (exsagittal) posterolateral extensions, and a concave pygidial border identify the ceratopygid that dominates collection J1475 as a species of either Aplotaspis Henderson (1976) or Yuepingia Lu (1956). The eyes are larger than is typical of Aplotaspis, more closely resembling those of Yuepingia, but most cephalic and pygidial characteristics are more compatible with assignment to the former genus. Yuepingia niobiformis displays a concave pygidial border, but it is much narrower than the strongly convex pleural 
fields, unlike the very broad border in Aplotaspis, which equals or exceeds the width of more restricted, flatly convex pleural fi elds. All other species of Yuepingia for which pygidia have been described have either a narrow, flat to gently convex border, or no border at all, with pleural furrows and the pygidial axis extending almost to the margin. The pygidial axis of Aplotaspis ends at the inner edge of the wide, concave border, and it is followed posteriorly by a faint, tapering postaxial ridge that extends to the margin. All but the most anterior pair of faintly impressed pleurae also terminate at or just beyond the inner edge of the border. A similarly broad, concave lateral border, equal in width to the genal field on the librigena of Aplotaspis $\mathrm{n}$. sp. (Fig. 3.11G), also supports assignment to that genus, resembling that of the type species, $A$. erugata (Whitehouse), and contrasting with the relatively narrow, flat to convex borders that characterize species of Yuepingia.

A rigorous, parsimony-based reevaluation of these genera, and closely related taxa such as Charchaqia and Pseudoyuepingia, is badly needed but falls beyond the scope of the present study. At present, such an analysis would be severely hampered by the large number of species for which the pygidium and/or librigena remain unknown, and little if any information on ontogenetic variation is available. An example of such limitations can be found in Henderson (1976), wherein much smaller palpebral lobes were included among the primary characteristics that set Aplotaspis apart from Yuepingia. The deficiency in the comparison is that the single cranidium of Yuepingia illustrated (Henderson, 1976, his plate 48 and fig. 12), with palpebral lobes conspicuously larger than those shown for Aplotaspis, is a small sclerite only half the size of the figured Aplotaspis cranidia. As relative size of the palpebral lobes usually decreases through ontogeny (compare Figs. 3.11D and 3.11A herein), the size difference of the illustrated specimens exaggerates the contrast in the size of this feature between the genera. Future work 
may ultimately confi rm that species of Yuepingia consistently display larger eyes than those of Aplotaspis, but that hypothesis is yet to be tested through quantitative comparison of collections large enough to account for ontogenetic variation.

Bao and Jago (2000) placed Aplotaspis in synonymy with Charchaqia, arguing that the width of the pygidial border is too variable within Charchaqia to justify placement of species with a longer border in a separate genus, i.e., Aplotaspis. As evidence, they noted variability in the width of the border on pygidia figured by Henderson (1976) for the type species of Aplotaspis (A. erugata), and on pygidia of Charchaqia halli that they illustrated from Tasmania. Unfortunately, two of the specimens of C. halli (Bao and Jago, 2000, their plate 2 and figs. 1 and 2) are internal molds on which the imprint of the pygidial doublure gives the false impression of a relatively broad, concave border. The two rubber casts made from external molds (Bao and Jago, 2000, their plate 2 and figs. 1 and 2) show that the convex pleural fields actually extend nearly to the margin, terminating at the inner edge of a very narrow, convex border. A quantitative comparison of border length/pygidial length ratios (discussed below) between the two genera, utilizing figured specimens of several species in both, does not support the claim of intergrading variation, and their synonymy is rejected. Aplotaspis is retained as a separate genus, and a broad, dorsally concave border on the librigena and the pygidium remains one of the primary features that distinguish it from Charchaqia, Yuepingia, and Pseudoyeupingia.

The pygidial border length used for comparison of these genera was obtained by measuring the distance along the axis from the posterior margin to the point on the axis in line with the inner edge of the border. That axial border length was divided by the axial length of the pygidium (excluding the articulating half ring) to obtain a border/length ratio that expresses the percentage of the pygidial length constituted by the border. Although border width does vary 
somewhat in Aplotaspis erugata, measurements from the images of four pygidia illustrated by Henderson (1976) reveal that the concave border makes up at least a third of the axial length of the pygidium, and in some specimens accounts for nearly half. The ratios obtained for the four pygidia of Aplotaspis erugata ranged from 0.34 to 0.45 . The border constitutes just over half (border/length ratio $=0.51$ ) of the axial length of the pygidium figured for Aplotaspis mucrora (Henderson, 1976, his plate 48 and fig. 14). In contrast, species of Charchaquia display short (sagittal), flat to upwardly convex borders that constitute no more, and usually considerably less, than one fifth of the axial pygidial length. Pygidia illustrated by Peng (1992) for the type species of Charchaqia, Charchaqia norini (his fig. 53L), and for Charchaqia glabrescens (his fig. 55F) yielded border/length ratios of 0.19 and 0.125 , respectively. The border/length ratio determined for Charchaqia lata Troedsson (Chien, 1961, his plate 5 and fig. 2) is 0.13 . As previously noted, the concavity along the margin of the internal molds of $C$. halli illustrated by Bao and Jago (2000, their plate 2 and figs. 1 and 2) is the imprint of the pygidial doublure. The true border, visible on their figure 3 , is an extremely narrow, convex rim that yields a border/length ratio less than 0.05 .

\section{Aplotaspis new species (Figs. 3.11A-3.11M)}

Aplotaspis n. sp. is most similar to A. erugata in displaying an ellipsoidal pygidium that is much wider (transverse) than long, with a transverse margin behind the axis, as opposed to the subcircular pygidia of A. mucrora and A. caelata, and subtriangular pygidium of $A$. ex. gr. erugata Varlamov et al. (2006). It also resembles the genotype in its very narrow (exsagittal), strap-like posterolateral projections, unequally divided by a well-impressed border furrow into wider posterior borders and exceptionally narrow posterior fixigenae. It differs from A. erugata in having more gently concave cephalic and pygidial borders, the inner boundaries of which are 
marked by faint ridges rather than distinct furrows, and significantly larger palpebral lobes. In both species, the back of the palpebral lobe sits approximately in line with the glabellar node. The palpebral lobes in A. erugata and A. mucrora extend forward only approximately halfway to the front of the glabella from the glabellar node. Those of Aplotaspis n. sp. extend more than two thirds of the way, resembling species of Yuepingia, such as Y. niobiformis Lu and Y. glabra Palmer, in this regard. It is distinguished from those species by the greater length of the frontal area, broad and concave lateral and pygidial borders, and much wider (transverse) and less convex pygidium. The only species of Yuepingia that displays a frontal area as long (sagittal), and librigena as broad (transverse) as Aplotaspis n. sp. is Yuepingia brevica Lu and Zhu (1980), for which only two poorly preserved cranidia and one librigena are illustrated. The cranidia display more parallel-sided glabellae than Aplotaspis n. sp., and the librigena is unequally divided by a shallow border furrow into a broad genal field and much narrower, dorsally convex border. With no associated pygidium to assist in generic assignment, it is uncertain whether $Y$. brevica is properly placed in Yuepingia. Although the material available for Aplotaspis n. sp. is adequate to confirm that it is a new species, the specimens are too few and fragmentary to allow complete description and naming of the new taxon.

FAMILY CHEILOCEPHALIDAE SHAW, 1956

\section{Genus Cheilocephalus Berkey, 1898}

\section{Cheilocephalus? sp. (Figs. 3.13A-3.13D)}

Remarks: A single, small cranidium in collection J1352 displays most of the diagnostic features of this genus. Small, forwardly placed palpebral lobes are centered opposite weakly impressed S2 furrows, creating large triangular posterior areas. Short (exsagittal) and narrow, dorsally concave anterior fixigenae lie between faint eye ridges and a very narrow, convex, 
anterior border. It also displays (Figs. 3.13C-3.13D) the characteristic sharp downward flexure and slight inflation of the posterior border directly behind the palpebral lobe, referred to by Palmer (1965) as a "shoulder" and analyzed in greater detail by Westrop et al. (2008). This species is left in open nomenclature, rather than being assigned to Cheilocephalus without reservation, only because there is no associated pygidium or hypostome to fortify such assignment. Of the Laurentian species that display similar granular sculpture, Cheilocephalus? sp. most closely resembles Cheilocephalus brachyops Palmer (1965), especially the small cranidium (Palmer, 1965, his plate 1 and fig. 14) illustrated from Shingle Pass, Nevada. Like that small (axial length $\sim 2 \mathrm{~mm}$ ) cranidium of $C$. brachyops, the small (3.2-mm-long) cranidium in J1352 displays a short, nearly quadrate glabella and extremely short frontal area. The J1352 cranidium differs in having less strongly divergent posterior branches of the facial suture, narrower (transverse) and more steeply downsloping posterior areas, more distinct and slit-like S2 furrows, and a less transverse anterior margin that is curved backward strongly in front of the eye ridges. The weakly divergent posterior facial sutures set the Alaska species apart from all other species of Cheilocephalus. However, no comparably small cranidia have been illustrated for Cheilocephalus granulosus Palmer, nor for Cheilocephalus buttsi Resser, a species from the Ore Hill limestone in Pennsylvania (Wilson, 1951), in which unusually narrow (transverse) anterior fixigenae resemble those of Cheilocephalus? sp.

\section{Family UNCERTAIN}

The collections from the Egaksrak formation include at least 10 additional species for which no suitable genus could be found. These are left in open nomenclature as genus species indeterminate (gen. sp. indet.) with a number and letter designation, where the number is the last 
two digits of the collection number. Eight of these species are represented by only one or two fragmentary sclerites.

Genus species indeterminate 52A (Figs. 3.13E-3.13H)

Remarks: This species, represented by a single cranidium and fragmentary librigena, resembles some Steptoean (Paibian) genera such as Drabia and Sulcocephalus. It resembles Drabia in the basic form of the cephalon, and Sulcocephalus in its more rounded glabella and deep S1 furrow isolated from the axial furrow. Neither of those genera, however, has the elevated occipital ring (LO), discontinuous occipital furrow (SO), and relatively broad and heavily terraced cephalic border displayed by gen. sp. indet. 52A.

Genus species indeterminate 52B (Figs. 3.13I-3.13N)

Remarks: This species resembles Croixana Nelson, 1951, in its subtrapezoidal, anteriorly truncated glabella and inflated frontal area, with the anterior border furrow expressed only at the anterolateral corners. However, it lacks the characteristic pits created by deepening of the axial furrow at the anterior corners of the glabella. It also differs from all known species of Croixana (see Westrop, 1986) in its exceptionally long palpebral lobes (>2/3 the length of the glabella), centered well behind instead of opposite the $2 \mathrm{~S}$ furrows, and wide interocular fixigenae, which are nearly half the width of the glabella at its midlength. The anterior border furrow also differs in trending laterally and slightly anteriorly inward from margin, rather than being directed posterolaterally toward the anterior corners of the glabella as in Croixana.

\section{Genus species indeterminate 52C (Figs. 3.130-3.13V)}

Remarks: Distinctive features of this common species in J1352 include a gently anteriorly tapering glabella with sigmoid S1 furrows that bifurcate distally without reaching the deep and narrow axial furrows; a moderately convex cephalic border of constant width separated 
from slightly inflated genal fields by a narrow well-impressed furrow, and from the glabella by a narrow, slightly depressed preglabellar field; an inflated occipital ring with an ellipsoidal shape created by strong curvature of its posterior margin; an SO that is shallow and bowed forward over the axis, deepening and broadening behind L1; and widely spaced, coarse granules covering the glabella and genal fields. Fine, closely spaced granules cover the librigenal spine and pleural bands and axial rings of the pygidium. A broad border furrow that narrows behind the axis separates moderately convex pleural fields crossed by narrow, well-impressed pleural furrows from a very narrow convex border. The posterior margin rises adaxially to create a shallow notch behind the axis.

Genus species indeterminate 52D (Figs. 3.13W-3.13Y)

Remarks: The two cranidia in J1352 that represent this species display many of the features that characterize gen. sp. indet. 52C, but they differ in being wider than long and more strongly convex (sagittal and transverse), and having a much narrower anterior border that is more tapered and more strongly directed abaxially.

Genus species indeterminate 52E (Figs. 3.13Z-3.13AA)

Remarks: No associated cranidium, or established Furongian genus, was found to be compatible with the broad, flat to gently concave genal field, dense granular sculpture, long and inwardly curved anterior facial suture, and prominently terraced border of this single librigena in $\mathrm{J} 1352$.

Genus species indeterminate 52F (Figs. 3.13BB-3.13CC)

Remarks: The dense texture of coarse granules and broad, convex border of this single librigena in J1352 confi rm that it has no corresponding cranidium in the collection. No genus 
was found with librigenae displaying those features and a minute, cylindrical, laterally directed librigenal spine.

Genus species indeterminate 75A (Figs. 3.11Q-3.11T)

Remarks: Two fragmentary cranidia in collection J1475 represent this granulose species, which has an inflated anterior border that tapers rapidly abaxially behind a strongly curved anterior margin, and in front of a transverse border furrow that shallows over the axis in front of a narrow, sunken preglabellar field.

\section{Genus species indeterminate 75B (Figs. 3.11U-3.11V)}

Remarks: A single librigena and fragmentary cranidium in collection J1475 represent this species. They are readily matched by a long, strongly divergent anterior branch of the facial suture, a relatively short (exsagittal) and elevated palpebral lobe, and scattered coarse granules on the fixigenae and steeply downsloping genal field, which terminates distally at the inner edge of a broad (transverse) gently convex lateral border.

\section{Genus species indeterminate 75C (Figs. 3.11W-3.11X)}

Remarks: This single, fragmentary pygidium in collection J1475 displays a broad, strongly convex, parallel-sided axis elevated above flat to slightly concave pleural fields with prominent depressed areas near the posterior margin in line with the sides of the axis.

\section{Genus species indeterminate 80A (Figs. 3.12X-3.12Z)}

Remarks: This species is represented by several poorly preserved cranidia in collection J1480 that resemble those of Plethopeltis? sp. In basic form, but they display a narrow (sagittal), laterally tapering anterior border and a prominent eye ridge.

Genus species indeterminate 80B (Figs. 3.12AA-3.12CC) 
Remarks: This single, fragmentary, triangular pygidium in collection J1480 displays a posteriorly tapering, flat-topped axis with narrow (sagittal) axial rings separated by deep ring furrows, narrow and similarly incised pleural fields, and a steeply downsloping, gently convex, and terraced border that narrows adaxially and might disappear entirely at the axis where the deeply notched posterior margin reaches its highest point.

\section{ACKNOWLEDGMENTS}

Johnson and Toro thank West Virginia University's Faculty Senate Grant and the Circum-Arctic Lithosphere Evolution (CALE) project for providing financial support. Strauss was supported by a National Science Foundation (NSF) Graduate Research Fellowship and a grant from the NSF Tectonics Division (EAR-1624131). Financial support for study of the faunas was provided through a NSF Sedimentary Geology and Paleobiology grant (award 1325333) to Taylor, who also acknowledges invaluable assistance from fellow paleontologists

J.R. Laurie and S.R. Westrop in evaluating the taxonomic and paleogeographic affinities of the trilobites and agnostoid arthropods of the Egaksrak formation. Indiana University of

Pennsylvania students W.T. Kamerer and J.D. King assisted in the analysis of the faunas through senior research projects on the agnostoids and trilobites, respectively. The Geological Society of America Graduate Student Research Fellowships also supplied additional funding to Johnson, Strauss, and Ward. Field work in 2013 was conducted through the Circum-Arctic Structural Events (CASE) 13 expedition to northern Yukon, which was graciously supported by the Bundesanstalt für Geowissenschaften und Rohstoffe (BGR) and Yukon Geological Survey. We thank Karsten Piepjohn of BGR for funding the CASE 13 expedition, and Blaze Budd, Patrick Frier, and Lyle Nelson for assistance in the field. Kirk Sweetsir from Yukon Air Service and the staff at Wright Air Service provided critical access to our remote field area. Permission to work 
in the Arctic National Wildlife Refuge was granted by Alfredo Soto at the U.S. Fish and Wildlife Service. Many of the ideas presented herein were conceived during spirited discussions with Tom Moore, Gil Mull, Francis Macdonald, Marwan Wartes, Tyrone Rooney, Elizabeth Miller, Eric Gottlieb, and Tim O'Brien. Finally, we are grateful to Carl Hoiland and Brian Pratt, who provided thoughtful reviews that drastically improved the manuscript, and we appreciate the editorial handling by Christian Koeberl and Karsten Piepjohn.

\section{REFERENCES CITED}

Amato, J.M., Aleinikoff, J.N., Akinin, V.V., McClelland, W.C., and Toro, J., 2014, Age, chemistry, and correlations of Neoproterozoic-Devonian igneous rocks of the Arctic Alaska-Chukotka terrane: An overview with new U-Pb ages, in Dumoulin, J.A., and Till, A.B., eds., Reconstruction of a Late Proterozoic and Early Paleozoic Continental Margin - Seward Peninsula and Correlative Rocks of the Arctic Alaska-Chukotka Terrane: Geological Society of America Special Paper 506, p. 29-57, https://doi.org/10.1130/2014.2506(02).

Amato, J.M., Toro, J., Miller, E.L., Gehrels, G.E., Farmer, G.L., Gottlieb, E.S., and Till, A.B., 2009, Late Proterozoic-Paleozoic evolution of the Arctic Alaska-Chukotka terrane based on U-Pb igneous and detrital zircon ages: Implications for Neoproterozoic paleogeographic reconstructions: Geological Society of America Bulletin, v. 121, p. 1219-1235, https://doi.org/10.1130/B26510.1.

Anderson, A.V., Wallace, W.K., and Mull, C.G., 1994, Depositional record of a major tectonic transition in northern Alaska: Middle Devonian to Mississippian rift-basin margin deposits, upper Kongakut River region, eastern Brooks Range, Alaska, in Thurston, D.K., and Fujita, K., eds., 1992 Proceedings of the International Conference on Arctic Margins: 
Anchorage, Alaska, U.S. Department of the Interior, Minerals Management Service, OCS (Outer Continental Shelf) Study MMS 94-0040, p. 71-76.

Arevalo, R., and McDonough, W.F., 2010, Chemical variations and regional diversity observed in MORB: Chemical Geology, v. 271, p. 70-85, https://doi.org/10.1016/j.chemgeo.2009.12.013.

Bao, J.S., and Jago, J.B., 2000, Late late Cambrian trilobites from near Birch Inlet, south-western Tasmania: Palaeontology, v. 43, p. 881-917, https://doi.org/10.1111/1475-4983.00154.

Béchennec, F., Le Metour, J., Rabu, D., Bourdillon-de-Grissac, C., de Wever, P., Beurrier, M., and Villey, M., 1990, The Hawasina Nappes: Stratigraphy, palaeogeography and structural evolution of a fragment of the south- Tethyan passive continental margin, in Robertson, A.H.F., Searle, M.P., and Ries, A.C., eds., The Geology and Tectonics of the Oman Region: Geological Society, London, Special Publication 49, p. 213-223, https://doi.org/10.1144/GSL.SP.1992.049.01.14.

Beranek, L.P., van Staal, C.R., McClelland, W.C., Israel, S., and Mihalynuk, M.G., 2013, Detrital zircon Hf isotopic compositions indicate a northern Caledonian connection for the Alexander terrane: Lithosphere, v. 5, p. 163-168, https://doi.org/10.1130/L255.1.

Beranek, L.P., Pease, V.L., Hadlari, T., and Dewing, K., 2015, Silurian flysch successions of Ellesmere Island, Arctic Canada, and their significance to northern Caledonian palaeogeography and tectonics: Journal of the Geological Society [London], v. 172, p. 201-212, https://doi.org/10.1144/jgs2014-027.

Bouvier, A., Vervoort, J.D., and Patchett, P.J., 2008, The Lu-Hf and Sm-Nd isotopic composition of CHUR: Constraints from unequilibrated chondrites and implications for 
the bulk composition of terrestrial planets: Earth and Planetary Science Letters, v. 273, p. 48-57, https://doi.org/10.1016/j.eps1.2008.06.010.

Brosgé, W.P., Dutro, J.T., Jr., Mangus, M.D., and Reiser, H.N., 1962, Paleozoic sequences in the eastern Brooks Range, Alaska: American Association of Petroleum Geologists Bulletin, v. 46, p. $2174-2198$.

Cecile, M.P., 2000, Geology of the Northeastern Niddery Lake Map Area, East-Central Yukon and Adjacent Northwest Territories: Geological Survey of Canada Bulletin 553, 120 p., https://doi.org/10.4095/211664.

Cecile, M.P., Morrow, D.W., and Williams, G.K., 1997, Early Paleozoic (Cambrian to Early Devonian) tectonic framework, Canadian Cordillera: Bulletin of Canadian Petroleum Geology, v. 45, p. 54-74.

Cecile, M.P., Lane, L.S., Khudoley, A.K., and Kos'ko, M.K., 1999, Lower Paleozoic rocks around today's Arctic Ocean: Two ancestral continents and associated plates; Alaskan rotation unnecessary and unlikely: Polarforschung, v. 69, p. 235-241.

Chatterton, B.D.E., and Gibb, S., 2016, Furongian (Upper Cambrian) Trilobites from the McKay Group, Bull River Valley, near Cranbrook, Southeastern British Columbia, Canada: Palaeontographica Canadiana 35, 275 p.

Chew, D.M., and Strachan, R.A., 2014, The Laurentian Caledonides of Scotland and Ireland, in Corfu, F., Gasser, D., and Chew, D.M., eds., New Perspectives on the Caledonides of Scandinavia and Related Areas: Geological Society, London, Special Publication 390, p. 45-91, https://doi.org/10.1144/SP390.16.

Chien, Y.Y., 1961, Cambrian trilobites from Sandu and Duyan, southern Kweichow: Acta Palaeontologica Sinica, v. 9, p. 91-139. 
Choi, D.K., Lee, J.G., and Sheen, B.C., 2004, Upper Cambrian agnostoid trilobites from the Machari Formation, Yongwol, Korea: Geobios, v. 37, p. 159-189, https://doi.org/10.1016/j.geobios.2003.02.004.

Colpron, M., and Nelson, J.L., 2011, A Palaeozoic NW Passage and the Timanian, Caledonian and Uralian connections of some exotic terranes in the North American Cordillera, in Spencer, A.M., Embry, A.F., Gautier, D.L., Stoupakova, A.V., and Sørensen, K., eds., Arctic Petroleum Geology: Geological Society, London, Memoir 35, p. 463-484, https://doi.org/10.1144/M35.31.

Corfu, F., Andersen, T.B., and Gasser, D., 2014, The Scandinavian Caledonides: Main features, conceptual advances and critical questions, in Corfu, F., Gasser, D., and Chew, D.M., eds., New Perspectives on the Caledonides of Scandinavia and Related Areas: Geological Society, London, Special Publication 390, p. 9-43, https://doi.org/10.1144/SP390.25.

Cox, G.M., Strauss, J.V., Halverson, G.P., Schmitz, M.D., McClelland, W.C., Stevenson, R.S., and MacDonald, F.A., 2015, Kikiktat volcanics of Arctic Alaska-Melting of harzburgitic mantle associated with the Franklin large igneous province: Lithosphere, v. 7, p. 275-295, https://doi.org/10.1130/L435.1.

Dumoulin, J.A., Harris, A.G., Gagiev, M., Bradley, D.C., and Repetski, J.E., 2002, Lithostratigraphic, conodont, and other faunal links between Lower Paleozoic strata in northern and central Alaska and northeastern Russia, in Miller, E.L., Grantz, A., and Klemperer, S.L., eds., Tectonic Evolution of the Bering Shelf-Chukchi Sea-Arctic Margin and Adjacent Landmasses: Geological Society of America Special Paper 360, p. 291-312, https://doi.org/10.1130/0-8137-2360-4.291. 
Dutro, J.T., Jr., Brosgé, W.P., and Reiser, H.N., 1972, Signifi cance of recently discovered Cambrian fossils and reinterpretation of Neruokpuk Formation, northeastern Alaska: American Association of Petroleum Geologists Bulletin, v. 56, p. 808-815.

Elliott, T., 2003, Tracers of the slab, in Eiler, J., ed., Inside the Subduction Factory: American Geophysical Union Geophysical Monograph 138, p. 23-45, https://doi.org/10.1029/138GM03.

Fitton, J.G., 1987, The Cameroon line, West Africa: A comparison between oceanic and continental alkaline volcanism, in Fitton, J.G., and Upton, B.G.J., eds., Alkaline Igneous Rocks: Geological Society, London, Special Publication 30, p. 273-291, https://doi.org/10.1144/GSL.SP.1987.030.01.13.

Fortey, R.A., 1980, The Ordovician Trilobites of Spitsbergen III, Remaining Trilobites of the Valhallfonna Formation: Norsk Polarinstitutt Skrifter 171, 163 p.

Gehrels, G.E., and Pecha, M., 2014, Detrital zircon U-Pb geochronology and Hf isotope geochemistry of Paleozoic and Triassic passive margin strata of western North America: Geosphere, v. 10, p. 49-65, https://doi.org/10.1130/GES00889.1.

Gehrels, G.E., Valencia, V.A., and Ruiz, J., 2008, Enhanced precision, accuracy, efficiency, and spatial resolution of U-Pb ages by laser ablation-multicollector-inductively coupled plasma-mass spectrometry: Geochemistry Geophysics Geosystems, v. 9, Q03017, https://doi.org/10.1029/2007GC001805.

Goodfellow, W.D., Cecile, M.P., and Leybourne, M.I., 1995, Geochemistry, petrogenesis, and tectonic setting of Lower Paleozoic alkalic and potassic volcanic rocks, northern Canadian Cordilleran miogeocline: Canadian Journal of Earth Sciences, v. 32, no. 8, p. 1236-1254, https://doi.org/10.1139/e95-101. 
Gradstein, F.M., Ogg, J.G., Smith, A.G., and Ogg, G., 2012, The Geologic Time Scale: Cambridge, UK, Cambridge University Press, 1176 p.

Grant, R.E., 1965, Faunas and Stratigraphy of the Snowy Range Formation (Upper Cambrian) in Southwestern Montana and Northwestern Wyoming: Geological Society of America Memoir 96, 171 p., https://doi.org/10.1130/MEM96-p1.

Green, D.H., and Ringwood, A.E., 1967, The genesis of basaltic magmas: Contributions to Mineralogy and Petrology, v. 15, p. 103-190, https://doi.org/10.1007/BF00372052.

Hart, C.J.R., 1986, The Geology of the Old Cabin Creek Massif, Selwyn Basin, Yukon Territory [B.S. thesis]: Hamilton, Ontario, Canada, McMaster University, 111 p.

Henderson, R.A., 1976, Upper Cambrian (Idamean) trilobites from western Queensland, Australia: Palaeontology, v. 19, p. 325-364.

Hofmann, A.W., 2003, Sampling mantle heterogeneity through oceanic basalts: Isotopes and trace elements, in Carlson, R.W., ed., Treatise on Geochemistry, Volume 2: The Mantle and Core: Oxford, Elsevier, p. 61-101.

Hoiland, C.W., Miller, E.L., Pease, V., and Hourigan, J.K., 2017, Detrital zircon U-Pb geochronology and Hf isotope geochemistry of metasedimentary strata in the southern Brooks Range: Constraints on Neoproterozoic-Cretaceous evolution of Arctic Alaska, in Pease, V.L., and Coakley, B.J., eds., Circum-Arctic Lithosphere Evolution: Geological Society, London, Special Publication 460, p. 121-158, https://doi.org/10.1144/SP460.16

Hooper, P.R., and Hawkesworth, C.J., 1993, Isotopic and geochemical constraints on the origin and evolution of the Columbia River Basalt: Journal of Petrology, v. 34, p. 1203-1246, https://doi.org/10.1093/petrology/34.6.1203. 
Jackson, D.E., 1964, Observations on the sequence and correlation of Lower and Middle Ordovician graptolite faunas of North America: Geological Society of America Bulletin, v. 75, p. 523-534, https://doi.org/10.1130/0016-7606(1964)75[523:OOTSAC]2.0.CO;2.

Jaques, A.L., and Green, D.H., 1980, Anhydrous melting of peridotite at $0-15 \mathrm{~Kb}$ pressure and the genesis of tholeiitic basalts: Contributions to Mineralogy and Petrology, v. 73, p. 287-310, https://doi.org/10.1007/BF00381447.

Johnson, B.G., Strauss, J.V., Toro, J., Benowitz, J.A., Ward, W.P., and Hourigan, J.K., 2016, Detrital geochronology of pre-Mississippian strata in the northeastern Brooks Range, Alaska: Insights into the tectonic evolution of northern Laurentia: Lithosphere, v. 8, p. 649-667, https://doi.org/10.1130/L533.1.

Jones, D.L., Silberling, N.J., Coney, P.J., and Plafker, G., 1987, Lithotectonic Terrane Map of Alaska: U.S. Geological Survey Miscellaneous Field Studies Map MF-874, scale $1: 2,500,000$.

Kampunzu, A.B., and Mohr, P., 1991, Magmatic evolution and petrogenesis in the East African Rift System, in Kampunzu, A.B., and Lubala, R.T., eds., Magmatism in Extensional Structural Settings: Berlin, Springer, p. 85-136.

Kelley, J.S., Wrucke, C.T., and Lane, L.S., 1994, Pre-Mississippian rocks in the Clarence and Malcolm Rivers area, Alaska and Yukon Territory, in 1992 Proceedings of the International Conference on Arctic Margins: Anchorage, Alaska, U.S. Department of the Interior, Minerals Management Service, OCS (Outer Continental Shelf) Study MMS 940040, p. 59-64. 
Kushiro, I., 2001, Partial melting experiments on peridotite and origin of midocean ridge basalt: Annual Review of Earth and Planetary Sciences, v. 29, p. 71-107, https://doi.org/10.1146/annurev.earth.29.1.71.

Lane, L.S., 1991, The pre-Mississippian "Neruokpuk Formation,” northeastern Alaska and northwestern Yukon: Review and new regional correlation: Canadian Journal of Earth Sciences, v. 28, p. 1521-1533, https://doi.org/10.1139/e91-136.

Lane, L.S., 2007, Devonian-Carboniferous paleogeography and orogenesis, northern Yukon and adjacent Arctic Alaska: Canadian Journal of Earth Sciences, v. 44, p. 679-694, https://doi.org/10.1139/e06-131.

Lane, L.S., Kelley, J.S., and Wrucke, C.T., 1995, Stratigraphy and Structure of the Clarence River Area, Yukon-Alaska North Slope: A USGS-GSC Co-Operative Project: Current Research Part E: Geological Survey of Canada Paper 1995-E, p. 1-9, https://doi.org/10.4095/205183.

Lane, L.S., Gehrels, G.E., and Layer, P.W., 2016, Provenance and paleogeography of the Neruokpuk Formation, northwest Laurentia: An integrated synthesis: Geological Society of America Bulletin, v. 128, p. 239-257, https://doi.org/10.1130/B31234.1.

Lawver, L.A., Grantz, A., and Gahan, L.M., 2002, Plate kinematic evolution of the present Arctic region since the Ordovician, in Miller, E.L., Grantz, A., and Klemperer, S.L., eds., Tectonic Evolution of the Bering Shelf-Chukchi Sea-Arctic Margin and Adjacent Landmasses: Geological Society of America Special Paper 360, p. 333-358, https://doi.org/10.1130/0-8137-2360-4.333.

Lazarenko, N.P., Gogin, I.Y., Pegel, T.V., Sukhov, S.S., Abaimova, G.P., Egorova, L.I., Federov, A.B., Raevskaya, E.G., and Ushatinskaya, G.T., 2006, Cambrian stratigraphy of 
the northeastern Siberian Platform and potential stratotypes of lower boundaries of the proposed Upper Cambrian Chekurovkian and Nelegerian stages in the Ogon'or Formation section at the Khos-Nelege River, in Rozanov, A.Y., and Varlamov, A.I., eds., The Cambrian System of the Siberian Platform, Part 2: North-east of the Siberian Platform, XIII International Field Conference of the Yakutia, Russia, Cambrian Stage Subdivision Working Group: International Commission on Cambrian Stratigraphy, p. 61139.

Leffingwell, E. de K., 1919, The Canning River Region, Northern Alaska: U.S. Geological Survey Professional Paper 109, 251 p.

Longacre, S.A., 1970, Trilobites of the Upper Cambrian Ptychaspid Biomere, Wilberns Formation, Central Texas: Paleontological Society Memoir 4, 70 p.

Lu, Y.H., 1956, An Upper Cambrian trilobite faunule from eastern Kweichou: Acta Palaeontologica Sinica, v. 4, p. 365-380.

Lu, Y.K., and Zhu, Z.L., 1980, Cambrian trilobites from Chuxian-Quanjiao region, Anhui: Memoirs of the Nanjing Institute of Geology and Palaeontology, v. 16, p. 1-33.

Ludvigsen, R., and Westrop, S.R., 1983, Franconian Trilobites of New York State: New York State Museum Memoir 23, 83 p.

Ludvigsen, R., Westrop, S.R., and Kindle, C., 1989, Sunwaptan (Upper Cambrian) Trilobites of the Cow Head Group, Western Newfoundland, Canada: Palaeontographica Canadiana 6, $175 \mathrm{p}$.

Ludwig, K.R., 2012, User's Manual for Isoplot/Ex, Version 3.75: A Geochronological Toolkit for Microsoft Excel: Berkeley Geochronology Center Special Publication 5, 75 p. 
MacNaughton, R.B., Moynihan, D.P., Roots, C.F., and Crowley, J.L., 2016, New occurrences of Oldhamia in eastern Yukon, Canada: Stratigraphic context and implications for Cambrian deep-marine biostratigraphy: Ichnos, v. 23, p. 33-52, https://doi.org/10.1080/10420940.2015.1127232.

MacPherson, G.J., Phipps, S.P., and Grossman, J.N., 1990, Diverse sources for igneous blocks in Franciscan mélanges, California Coast Ranges: The Journal of Geology, v. 98, p. 845862, https://doi.org/10.1086/629457.

McClelland, W.C., Colpron, M., Piepjohn, K., von Gosen, W., Ward, W.P., and Strauss, J.V., 2015, Preliminary detrital zircon geochronology of the Neruokpuk Formation in the Barn Mountains, Yukon, in MacFarlane, K.E., Nordling, M.G., and Sack, P.J., eds., Yukon Exploration and Geology 2014: Whitehorse, Yukon Geological Survey, p. 123-143.

McDonough, W.F., and Sun, S.-s., 1995, The composition of the Earth: Chemical Geology, v. 120, p. 223-253, https://doi.org/10.1016/0009-2541(94)00140-4.

Miller, E.L., Kuznetsov, N., Soboleva, A., Udoratina, O., Grove, M.J., and Gehrels, G.E., 2011, Baltica in the Cordillera?: Geology, v. 39, p. 791-794, https://doi.org/10.1130/G31910.1.

Miller, E.L., Toro, J., Gehrels, G.E., Amato, J.M., Prokopiev, A., Tuchkova, M.I., Akinin, V.V., Dumitru, T.A., Moore, T.E., and Cecile, M.P., 2006, New insights into Arctic paleogeography and tectonics from U-Pb detrital zircon geochronology: Tectonics, v. 25, TC3013, https://doi.org/10.1029/2005TC001830.

Moore, T.E., 1987, Geochemistry and the tectonic setting of volcanic rocks of the Franklinian assemblage, central and eastern Brooks Range, in Tailleur, I., and Weimer, P., eds., Alaskan North Slope Geology: Pacifi c Section, Society of Economic Paleontologists and Mineralogists (SEPM) Publication 50, p. 691-710. 
Moore, T.E., and Churkin, M., Jr., 1984, Ordovician and Silurian graptolite discoveries from the Neruokpuk Formation (sensu lato), northeastern and central Brooks Range, Alaska, in Blodgett, R.B., ed., Paleozoic Geology of Alaska and Northwestern Canada Newsletter 1: Anchorage, Alaska Geological Society, p. 21-23.

Moore, T.E., Wallace, W.K., Bird, K.J., Karl, S.M., Mull, C.G., and Dillon, J.T., 1994, Geology of northern Alaska, in Plafker, G., and Berg, H.C., eds., The Geology of Alaska: Boulder, Colorado, Geological Society of America, The Geology of North America, v. G-1, p. 49140.

Mull, C.G., and Anderson, A.V., 1991, Franklinian Lithotectonic Domains, Northeastern Brooks Range, Alaska: Alaska Division of Geological \& Geophysical Surveys Public Data File 91-5, 40 p., https://doi.org/10.14509/1472.

Nelson, L.L., Strauss, J.V., Crockford, P.W., Cox, G.M., Johnson, B.G., Ward, W., Colpron, M., McClelland, W.C., and Macdonald, F.A., 2018, this volume, Geochemical constraints on the provenance of pre-Mississippian sedimentary rocks in the North Slope subterrane of Yukon and Alaska, in Piepjohn, K., Strauss, J.V., Reinhart, L., and McClelland, W.C., eds., Circum-Arctic Structural Events: Tectonic Evolution of the Arctic Margins and Trans-Arctic Links with Adjacent Orogens: Geological Society of American Special Paper 541, Chapter 24, https://doi.org/10.1130/2018.2541(24).

Palmer, A.R., 1965, Trilobites of the Cambrian Pterocephaliid Biomere in the Great Basin, United States: U.S. Geological Survey Professional Paper 493, 105 p.

Palmer, A.R., 1968, Cambrian Trilobites of East-Central Alaska, United States: U.S. Geological Survey Professional Paper 559B, 115 p. 
Palmer, A.R., and Halley, R.R., 1979, Physical Stratigraphy and Trilobite Biostratigraphy of the Carrara Formation (Lower and Middle Cambrian) in the Southern Great Basin: U.S. Geological Survey Professional Paper 1047, 131 p.

Patrick, B.E., and McClelland, W.C., 1995, Late Proterozoic granitic magmatism on Seward Peninsula and a Barentian origin for Arctic Alaska-Chukotka: Geology, v. 23, p. 81-84, https://doi.org/10.1130/0091-7613(1995)023<0081:LPGMOS>2.3.CO;2.

Pearce, J.A., 1996, A User's Guide to Basalt Discrimination Diagrams: Geological Association of Canada Short Course Notes 12, p. 79-113.

Pease, V.L., 2011, Eurasian orogens and Arctic tectonics: An overview, in Spencer, A.M., Embry, A.F., Gautier, D.L., Stoupakova, A.V., and Sørensen, K., eds., Arctic Petroleum Geology: Geological Society, London, Memoir 35, p. 311-324.

Pegel, T.V., 2000, Evolution of trilobite biofacies in Cambrian basins of the Siberian Platform: Journal of Paleontology, v. 74, p. 1000-1019, https://doi.org/10.1017/S0022336000017571.

Peng, S., 1992, Upper Cambrian Biostratigraphy and Trilobite Faunas of the Cili-Taoyuan Area, Northwestern Hunan, China: Association of Australasian Palaeontologists Memoir 13, 119 p.

Peng, S., and Robison, R.A., 2000, Agnostid Biostratigraphy across the Middle-Upper Cambrian Boundary in Hunan, China: Paleontological Society Memoir 53, 104 p.

Pillevuit, A., Marcoux, J., Stampfl i, G., and Baud, A., 1997, The Oman Exotics: A key to the understanding of the Neotethyan geodynamic evolution: Geodinamica Acta, v. 10, p. 209-238, https://doi.org/10.1080/09853111.1997.11105303. 
Pratt, B.R., 1992, Trilobites of the Marjuman and Steptoean Stages (Upper Cambrian), Rabbitkettle Formation, Southern Mackenzie Mountains, Northwest Canada: Palaeontographica Canadiana 9, 179 p.

Pyle, L., and Barnes, C., 2003, Lower Paleozoic stratigraphic and biostratigraphic correlations in the Canadian Cordillera: Implications for the tectonic evolution of the Laurentian margin: Canadian Journal of Earth Sciences, v. 40, p. 1739-1753, https://doi.org/10.1139/e03049.

Rasetti, F., 1944, Upper Cambrian trilobites from the Levis Conglomerate: Journal of Paleontology, v. 18, p. 229-258.

Raymond, P.E., 1924, New Upper Cambrian and Lower Ordovician trilobites from Vermont: Proceedings of the Boston Society of Natural History, v. 37, p. 389-446.

Reiser, H.N., 1970, Northeastern Brooks Range—A surface expression of the Prudhoe Bay section, in Adkison, W.L., and Brosgé, W.P., eds., Proceedings of the Geological Seminar on the North Slope of Alaska: Los Angeles, California, Pacifi c Section, American Association of Petroleum Geologists, p. K1-K13.

Reiser, H.N., Brosge, W.P., Dutro, J.T., Jr., and Detterman, R.L., 1980, Geologic Map of the Demarcation Point Quadrangle, Alaska: U.S. Geological Survey Miscellaneous Investigations Series Map 1133, scale 1:250,000.

Robinson, J.A.C., and Wood, B.J., 1998, The depth of the spinel to garnet transition at the peridotite solidus: Earth and Planetary Science Letters, v. 164, p. 277-284, https://doi.org/10.1016/S0012-821X(98)00213-1.

Salters, V.J.M., and Stracke, A., 2004, Composition of the depleted mantle: Geochemistry Geophysics Geosystems, v. 5, Q05B07, https://doi.org/10.1029/2003GC000597. 
Searle, M.P., and Graham, G.M., 1982, “Oman Exotics”-Oceanic carbonate build-ups associated with the early stages of continental rifting: Geology, v. 10, p. 43-49, https://doi.org/10.1130/0091-7613(1982)10<43:OECBAW>2.0.CO;2.

Shergold, J.H., 1977, Classifi cation of the trilobite Pseudagnostus: Palaeontology, v. 20, p. 69100.

Shergold, J.H., 1980, Late Cambrian Trilobites from the Chatsworth Limestone, Western Queensland: Australian Bureau of Mineral Resources, Geology and Geophysics Bulletin 186, $111 \mathrm{p}$.

Shergold, J.H., Laurie, J.R., and Sun, X., 1990, Classifi cation and Review of the Trilobite Order Agnostida Salter, 1864: An Australian Perspective: Australian Bureau of Mineral Resources, Geology and Geophysics Report 296, 93 p.

Shervais, J.W., 1982, Ti-V plots and the petrogenesis of modern and ophiolitic lavas: Earth and Planetary Science Letters, v. 59, p. 101-118, https://doi.org/10.1016/0012$821 X(82) 90120-0$.

Shervais, J.W., and Kimbrough, D.L.K., 1987, Alkaline and transitional subalkaline metabasalts in the Franciscan Complex mélange, California, in Morris, E.M., and Pasteris, J.D., eds., Mantle Metasomatism and Alkaline Magmatism: Geological Society of America Special Paper 215, p. 165-182, https://doi.org/10.1130/SPE215-p165.

Stitt, J.H., 1971, Late Cambrian and Earliest Ordovician Trilobites, Timbered Hills and Lower Arbuckle Groups, Western Arbuckle Mountains, Murray County, Oklahoma: Oklahoma Geological Survey Bulletin 110, 83 p. 
Strauss, J.V., Macdonald, F.A., Taylor, J.F., Repetski, J.E., and McClelland, W.C., 2013, Laurentian origin for the North Slope of Alaska: Implications for the tectonic evolution of the Arctic: Lithosphere, v. 5, p. 477-482, https://doi.org/10.1130/L284.1.

Strauss, J.V., Hoiland, C.W., Ward, W.P., Johnson, B.G., Nelson, L.L., and McClelland, W.C., 2017, Orogen transplant: Taconic-Caledonian arc magmatism in the central Brooks Range of Alaska: Geological Society of America Bulletin, v. 129, p. 649-676, https://doi.org/10.1130/B31593.1.

Strauss, J.V., Johnson, B.G., Colpron, M., Nelson, L.L., Perez, J.L., Benowitz, J.A., Ward, W.P., and McClelland, W.C., 2018, this volume, Pre-Mississippian stratigraphy and provenance of the North Slope subterrane of Arctic Alaska II: Basinal rocks of the northeastern Brooks Range and their significance in circum-Arctic evolution, in Piepjohn, K., Strauss, J.V., Reinhardt, L., and McClelland, W.C., eds., Circum-Arctic Structural Events: Tectonic Evolution of the Arctic Margins and Trans-Arctic Links with Adjacent Orogens: Geological Society of America Special Paper 541, Chapter 23, https://doi.org/10.1130/2018.2541(23).

Sun, S.-s., and McDonough, W.F., 1989, Chemical and isotopic systematics of oceanic basalts: Implications for mantle composition and processes, in Saunders, A.D., and Norry, M.J., eds., Magmatism in the Ocean Basins: Geological Society, London, Special Publication 42, p. 313-345, https://doi.org/10.1144/GSL.SP.1989.042.01.19.

Sweeney, J.F., 1982, Mid-Palaeozoic travels of Arctic-Alaska: Nature, v. 298, p. 647-649, https://doi.org/10.1038/298647a0. 
Tarduno, J.A., McWilliams, M., Debiche, M.G., Sliter, W.V., and Blake, M.C., 1985, Franciscan Complex Calera limestones: Accreted remnants of Farallon plate oceanic plateaus: Nature, v. 317, p. 345-347, https://doi.org/10.1038/317345a0.

Taylor, J.F., Brezinski, D.K., Repetski, J.E., and Welsh, N.M., 2009, The Adamstown submergence event: Faunal and sedimentological record of a late Cambrian (Furongian) transgression in the Appalachian region, in Laurie, J.R., ed., Cambro-Ordovician Studies IV: Association of Australasian Palaeontologists Memoir 37, p. 641-666.

Taylor, J.F., Repetski, J.E., Loch, J.D., and Leslie, S.A., 2012, Biostratigraphy and chronostratigraphy of the Cambrian-Ordovician Great American Carbonate Bank, in Derby, J.R., Fritz, R.D., Longacre, S.A., Morgan, W.A., and Sternbach, C.A., eds., The Great American Carbonate Bank: The Geology and Economic Resources of the Cambrian-Ordovician Sauk Megasequence of Laurentia: American Association of Petroleum Geologists Memoir 98, p. 15-35.

van Staal, C.R., and Barr, S.M., 2012, Lithospheric architecture and tectonic evolution of the Canadian Appalachians and associated Atlantic margin, in Percival, J.A., Cook, F.A., and Clowes, R.M., eds., Tectonic Styles in Canada: The LITHOPROBE Perspective: Geological Association of Canada Special Paper 49, p. 41-45.

van Staal, C.R., Dewey, J.F., Niocaill, C.M., and McKerrow, W.S., 1998, The CambrianSilurian tectonic evolution of the Northern Appalachians and British Caledonides: History of a complex, west and southwest Pacifi ctype segment of Iapetus: Geological Society, London, Special Publication 143, p. 197-242, https://doi.org/10.1144/GSL.SP.1998.143.01.17. 
Varlamov, A.I., Pak, K.L., and Rosova, A.V., 2006, The Upper Cambrian of the Chopko River section, Norilsk region, northwestern Siberian Platform: Stratigraphy and trilobites: Palaeontological Journal, v. 40, Supplement 1, p. S1-S56.

Vervoort, J.D., and Blichert-Toft, J., 1999, Evolution of the depleted mantle: Hf isotope evidence from juvenile rocks through time: Geochimica et Cosmochimica Acta, v. 63, p. 533-556, https://doi.org/10.1016/S0016-7037(98)00274-9.

Vervoort, J.D., and Patchett, P.J., 1996, Behavior of hafnium and neodymium isotopes in the crust: Constraints from Precambrian crustally derived granites: Geochimica et Cosmochimica Acta, v. 60, p. 3717-3733, https://doi.org/10.1016/0016-7037(96)002013.

Vervoort, J.D., Patchett, P.J., Blichert-Toft, J., and Albarède, F., 1999, Relationships between Lu-Hf and Sm-Nd isotopic systems in the global sedimentary system: Earth and Planetary Science Letters, v. 168, p. 79-99, https://doi.org/10.1016/S0012-821X(99)00047-3.

Wallace, W.K., and Hanks, C.L., 1990, Structural provinces of the northeastern Brooks Range, Arctic National Wildlife Refuge, Alaska: American Association of Petroleum Geologists Bulletin, v. 74, p. 1100-1118.

Wendt, I., and Carl, C., 1991, The statistical distribution of the mean squared weighted deviation: Chemical Geology-Isotope Geoscience Section, v. 86, p. 275-285, https://doi.org/10.1016/0168-9622(91)90010-T.

Westrop, S.R., 1986, Trilobites of the Upper Cambrian Sunwaptan Stage, Southern Canadian Rocky Mountains, Alberta: Palaeontographica Canadiana 3, 179 p. 
Westrop, S.R., 1995, Sunwaptan and Ibexian (Upper Cambrian-Lower Ordovician) Trilobites of the Rabbitkettle Formation, Mountain River Region, Northern Mackenzie Mountains, Northwest Canada: Palaeontographica Canadiana 12, 75 p.

Westrop, S.R., and Eoff, J.D., 2012, Late Cambrian (Furongian: Paibian, Steptoean) agnostoid arthropods from the Cow Head Group, western Newfoundland: BioOne, v. 86, p. 201237, https://doi.org/10.1666/11-034.1.

Westrop, S.R., Eoff, J.D., Ng, T.-W., Dengler, A.A., and Adrain, J.M., 2008, Classifi cation of the late Cambrian (Steptoean) trilobite genera Cheilocephalus Berkey, 1898 and Oligometopus Resser, 1936 from Laurentia: Canadian Journal of Earth Sciences, v. 45, p. 725-744, https://doi.org/10.1139/E08-026.

Wilson, J.L., 1951, Franconian trilobites of the central Appalachians: Journal of Paleontology, v. 25, p. 617-654.

Winchester, J.A., and Floyd, P.A., 1977, Geochemical discrimination of different magma series and their differentiation products using immobile elements: Chemical Geology, v. 20, p. 325-343, https://doi.org/10.1016/0009-2541(77)90057-2.

Yoder, H.S., and Tilley, C.E., 1962, Origin of basalt magmas: An experimental study of natural and synthetic rock systems: Journal of Petrology, v. 3, p. 342-532, https://doi.org/10.1093/petrology/3.3.342. 


\title{
Chapter 4: Geological mapping in the Arctic National Wildlife
}

\section{Refuge (ANWR), northeastern Brooks Range, Alaska}

\author{
Benjamin G. Johnson ${ }^{1}$, Justin V. Strauss ${ }^{2}$, William P. Ward ${ }^{3}$, Jaime Toro ${ }^{1}$ \\ ${ }^{1}$ Department of Geology and Geography, West Virginia University, Morgantown, West Virginia,
} 26506 USA

${ }^{2}$ Department of Earth Sciences, Dartmouth College, Hanover, New Hampshire 03755, USA

${ }^{4}$ Department of Earth and Environmental Sciences, University of Iowa, Iowa City, Iowa 52242, USA

\begin{abstract}
Geological maps from the Arctic National Wildlife Refuge (ANWR) in the northeastern (NE) Brooks Range, Alaska, aid in the appraisal of hydrocarbon resources buried beneath the Arctic subsurface, but they also provide critical clues in reconstructing the tectonic history of the circum-Arctic region. Two 1:75,000 scale geological maps from the British and Romanzof mountains in the NE Brooks Range were created by integrating field-based observations with remote sensing data, such as the new 5-m ArcticDEM and satellite imagery from Google Earth. The maps include more than 20 distinct lithostratigraphic and lithodemic units and features a prominent sub-Mississippian unconformity, which truncates some of the thickest deposits of the lower Paleozoic strata in Arctic North America. Imbrication and folding of the unconformity, which is delineated by the Lower Mississippian Kekiktuck Conglomerate, is related to the late phases of Brookian contraction that occurred during the Cenozoic uplift of the NE Brooks Range. Below the unconformity, the rocks are deformed into tight to isoclinal, rotated folds, which are in strong discordance with the upright detachment folds that characterize overlying strata above the Kekiktuck Conglomerate, including the Kayak Shale and Lisburne Group. This earlier phase of deformation, the Romanzof orogeny, is attributed to the emplacement of the
\end{abstract}


Whale Mountain allochthon, an oceanic assemblage of Cambrian-Middle Ordovician volcanic and marine sedimentary rocks, and delineates an internal, middle Paleozoic suture within the greater Arctic Alaska-Chukotka microplate.

\section{INTRODUCTION}

The Brooks Range of Arctic Alaska and Yukon is one of the most sparsely mapped mountain ranges in North America. It is a steep and rugged region that extends more than 1,000 $\mathrm{km}$ in an east-west direction from northern Yukon to the Chukchi Sea (Fig. 4.1), reaching widths of up to $300 \mathrm{~km}$ and covering more than 50 million acres of largely uninhabited wilderness. The eastern portion of the Brooks Range is contained within the Arctic National Wildlife Refuge (ANWR) in Alaska and Ivvavik and Vuntut national parks in Yukon. The ANWR is the largest $\left(>70,000 \mathrm{~km}^{2}\right)$ and wildest, publicly owned land in the United States. It is host to a fragile ecosystem, containing some 200 species of migratory birds, more than 35 different kinds of land mammals, and several species of fish and marine mammals, notably polar bears.

About 60 miles northwest of ANWR, along the northern edge of the North Slope, lies Prudhoe Bay (Fig. 4.1A), the site of North America's single largest oil discovery. In 2001, the United States Geological Survey estimated recoverable resources beneath subsurface of the coastal plain in ANWR (1002 Area; Fig. 4.1B) to contain about 10.4 billion barrels of oil (Bird and Houseknecht, 2001), making it an attractive target for future oil and gas development. This has led to tension between environmentalists and proponents of oil and gas drilling. The rocks in the subsurface of the ANWR coastal plain are exposed in the adjacent northeastern (NE) Brooks Range to the south (Fig. 4.1B). Geological mapping efforts in the Brooks Range portion of the ANWR and in Ivavvik National Park of Yukon have and continue to provide critical information to future assessments of the petroleum resources contained within ANWR (e.g., Reiser, 1970). 


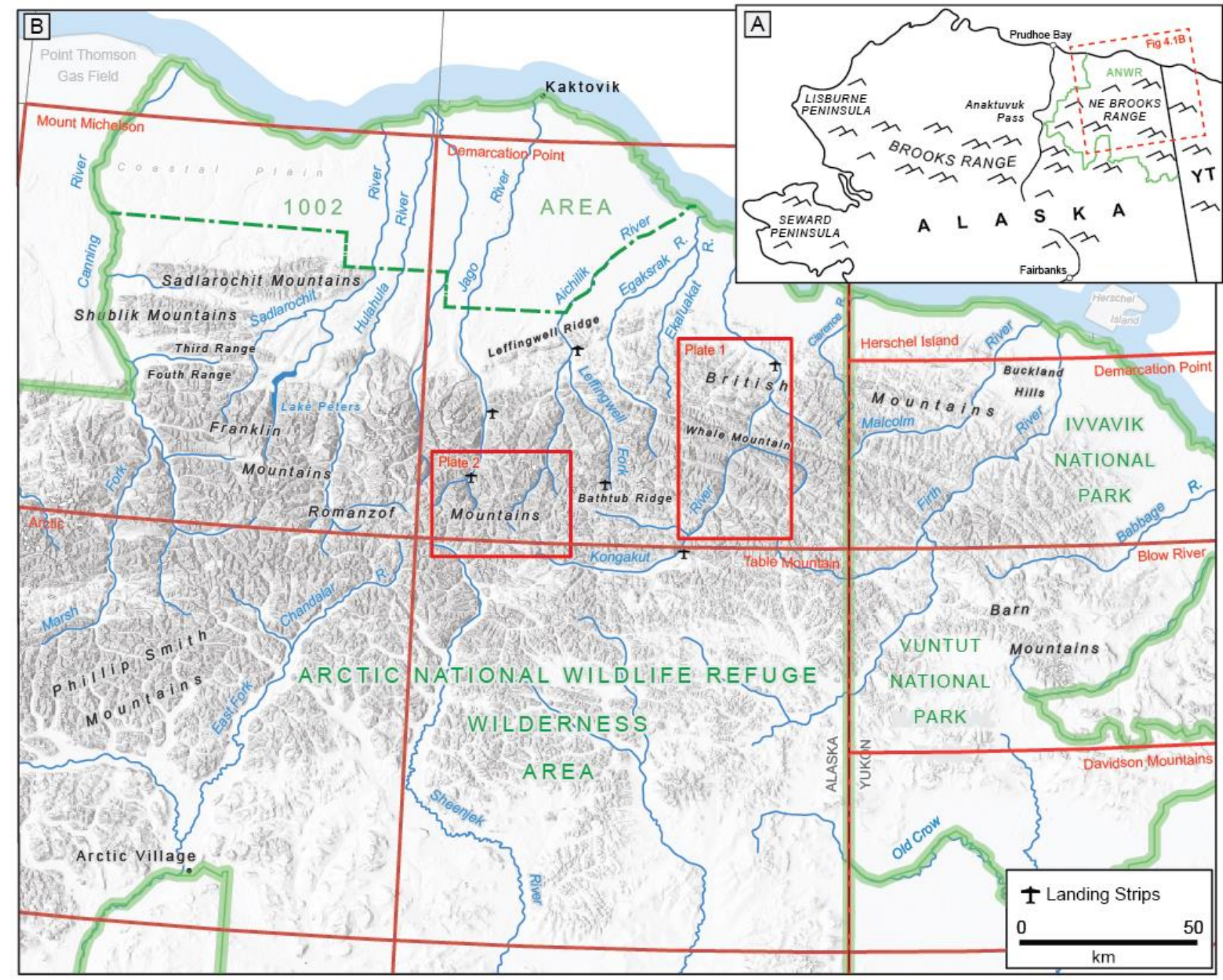

Figure 4.1: (A) Inset map of northern Alaska. (B) Shaded relief map of the northeastern Brooks Range of Alaska and Yukon showing the location of the two 1: 75,000 geological maps from this study (Plates 1 and 2). Previously published and open file 1: 250,000 geological quadrangles are labeled and outlined in light-red. R.-River. 
Aside from their impact on natural resource assessments, geological maps from the NE Brooks Range provide clues to the geological and tectonic history of the circum-Arctic region. Late Mesozoic to Cenozoic deformation produced a broad structural salient that protruded the deformation front to within $35 \mathrm{~km}$ of the Arctic coastline and built the highest topography along the entire Brooks Range trend. The salient exposes a thick susseccsion of sedimentary, igneous, and metamorphic rocks that range in age from late Neoproterozoic to Cretaceous. Thick Pleistocene glacial and fluvial deposits also fill a network of narrow river valleys that run south to north, carrying snowmelt and rainwater from the high mountains of the continental divide to the Arctic coast. In this manuscript, observations made over the course of five field seasons (2011 to 2015) in the NE Brooks Range are assembled into two, 1: 75,000 scale geological maps (Plates 1 and 2), with an emphasis on the sub-Mississippian structural and stratigraphic architecture. We review nearly 100 years of geological investigation and provide some new observations to organize the various lithostratigraphic and lithodemic units in the NE Brooks Range into a coherent scheme that can be applied to future mapping efforts.

\section{APPROACH}

The 1:75,000 scale geological maps generated in this study (Plates 1 and 2) are focused in two key areas of the NE Brooks Range: along the Kongakut River (Plate 1), and in the headwaters of the Jago and Aichilik rivers (Plate 2). Field work was conducted in the summer, with individual campaigns lasting two to five weeks at a time. Access to our remote field area was achieved by bush plane, landing on gravel strips along major rivers (Fig. 4.1). Most of the observations included in this study were gathered during the 2012-2015 field campaigns, although J.V. Strauss and others explored the Elkaluakat River (Fig. 4.1) in the summer of 2011. 
In the late summer of 2012, we traversed down the Kongakut River (Fig. 4.1) using a raft. In the following summer of 2013, we traversed the Leffingwell Fork of the Aichilik River (Fig. 4.1) also using a raft; however, much of the Leffingwell Fork was too shallow for paddling and we were forced to pull the raft with nylon ropes for most of the trip. Concurrently with the Leffingwell Fork expedition, a separate expedition was run in the Malcom and Firth river areas of northern Yukon (Fig. 4.1). This expedition was part of the Circum-Arctic Structural Events (CASE) project and was sponsored by the Federal Institute for Geosciences and Natural Resources in Germany (BGR) and the Yukon Geological Survey (YGS). The upper Jago and Aichilik drainages in Alaska were explored in the summer of 2014 and 2015, but the region was traversed by hiking with heavy ( 100 lbs.) backpacks. Throughout these field seasons we collected >130 rock samples (Table 4.1) and made several hundred structural measurements. Many of the results and observations from this fieldwork were published in Johnson et al. (2016; 2018), Strauss et al., (2018a), and Nelson et al. (2018).

The observations and measurements from the field were assembled into a geographical information system (GIS) using a combination of ESRI ArcMap 10 and Google Earth software. We used previously published and unpublished geological maps of the region, including the maps of Sable (1977), Reiser et al. (1980), Hanks (1989, 1993), Homza (1991), Anderson (1993), Imm et al. (1993), Lane et al. (1995), and Peapples et al. (1997) as a reference for unit contacts. We then applied the stratigraphic nomenclature of Strauss et al. (2018a), specifically to illustrate the distribution and structure of the sub-Mississippian units. In addition, we integrated Landsat and DigitalGlobe ( $)$ (2018) satellite imagery from Google Earth, in conjunction with the $5 \mathrm{~m}$ ArcticDEM created by the Polar Geospatial Center from DigitalGlobe (9 (2018) imagery, to interpolate and draw map lines between waypoints taken from the field. 
TABLE 4.1: SAMPLE LIST FROM THE NE BROOKS RANGE

\begin{tabular}{|c|c|c|c|c|c|c|c|c|c|}
\hline $\begin{array}{l}\text { Sample } \\
\text { Name }\end{array}$ & Latitude & Longitude & Map Unit & Analyses & $\begin{array}{l}\text { Sample } \\
\text { Name }\end{array}$ & Latitude & Longitude & Map Unit & Analyses \\
\hline \multicolumn{5}{|c|}{ Kongkut River, 2012} & \multicolumn{5}{|c|}{ Leffingwell Fork, 2012} \\
\hline 12JT01 & 69.072 & -142.204 & $\mathrm{Kk}$ & TS & 01LF13 & 69.185 & -142.602 & Mky & TS \\
\hline 12JT02 & 69.044 & -142.161 & $\mathrm{~Kb}$ & TS, DZ & 02LF13 & 69.192 & -142.599 & $€ n$ & TS \\
\hline 12JT03 & 69.040 & -142.069 & kPs & TS & 03LF13 & 69.182 & -142.576 & Mky & TS \\
\hline 12JT04 & 69.052 & -142.053 & $\mathrm{kPs}$ & TS & 04LF13 & 69.186 & -142.662 & Mkt & TS \\
\hline 12JT05 & 69.104 & -141.919 & Mky & TS, DZ & 05LF13 & 69.185 & -142.664 & $\epsilon_{n}$ & TS, DZ \\
\hline 12JT06 & 69.107 & -141.908 & Mky & TS & 06LF13 & 69.214 & -142.666 & $€ n$ & TS, DZ \\
\hline 12JT07 & 69.108 & -141.907 & Mky & TS & 07LF13 & 69.214 & -142.666 & $€ n$ & TS \\
\hline 12JT08 & 69.108 & -141.907 & Mkt & TS, DZ & 08LF13 & 69.214 & -142.666 & $€ n$ & TS \\
\hline 12JT09 & 69.108 & -141.907 & Mkt & TS, DZ & 09LF13 & 69.266 & -142.658 & $€ n, O € I$, Soa & TS, AR \\
\hline 12JT10 & 69.110 & -141.908 & $\mathrm{SOa}$ & TS, DZ & 10LF13 & 69.264 & -142.658 & $€ n, O € I$, Soa & TS \\
\hline 12JT11 & 69.158 & -141.865 & $\epsilon_{n}$ & TS, DZ & 11LF13 & 69.263 & -142.658 & $\mathrm{SOa}$ & $\mathrm{TS}, \mathrm{DZ}$ \\
\hline 12JT12 & 69.211 & -141.849 & $€ n$ & $\mathrm{TS}, \mathrm{AR}$ & 12LF13 & 69.271 & -142.684 & $\mathrm{SOa}$ & TS \\
\hline 12JT13a & 69.227 & -141.831 & $€ n, O € I$, Soa & TS,AR & 13LF13 & 69.583 & -142.644 & $€ e$ & TS \\
\hline 12JT13b & 69.251 & -141.729 & $€ w v$ & $\mathrm{TS}, \mathrm{GC}$ & 14LF13 & 69.346 & -142.644 & $€ e$ & TS \\
\hline 12JT14 & 69.251 & -141.729 & €wv & $\mathrm{TS}, \mathrm{GC}$ & 15LF13 & 69.346 & -142.644 & $€ e$ & TS \\
\hline 12JT15 & 69.251 & -141.729 & €wv & $\mathrm{TS}, \mathrm{GC}$ & 16LF13 & 69.347 & -142.653 & $€ e$ & $\mathrm{TS}$ \\
\hline 12JT16 & 69.251 & -141.729 & Ewv & $\mathrm{TS}, \mathrm{GC}$ & 17LF13 & 69.348 & -142.639 & Ewv & $\mathrm{TS}, \mathrm{GC}$ \\
\hline 12JT17 & 69.251 & -141.729 & Ewv & $\mathrm{TS}, \mathrm{GC}$ & 18LF13 & 69.348 & -142.639 & €wv & $\mathrm{TS}, \mathrm{GC}$ \\
\hline 12JT18 & 69.251 & -141.729 & Ewv & $\mathrm{TS}, \mathrm{GC}$ & 19LF13 & 69.348 & -142.639 & Ewv & $\mathrm{TS}, \mathrm{GC}$ \\
\hline 12JT19 & 69.251 & -141.729 & Ewv & $\mathrm{TS}, \mathrm{GC}$ & 20LF13 & 69.348 & -142.639 & $€ w v$ & TS,GC \\
\hline 12JT20 & 69.251 & -141.729 & Ewv & TS,GC & 21LF13 & 69.348 & -142.639 & Ewv & TS,GC \\
\hline 12JT21 & 69.247 & -141.724 & Ewv & $\mathrm{TS}, \mathrm{GC}$ & 22LF13 & 69.348 & -142.639 & Ewv & TS,GC \\
\hline 12JT22 & 69.279 & -141.727 & Dbh & $\mathrm{TS}, \mathrm{DZ}$ & 23LF13 & 69.348 & -142.639 & Ewv & TS,GC \\
\hline 12JT23 & 69.280 & -141.747 & Dbh & TS, DZ & 24LF13 & 69.314 & -142.704 & SOa & TS \\
\hline 12JT24 & 69.280 & -141.747 & Dbh & TS, DZ, AR & 25LF13 & 69.347 & -142.853 & $\mathrm{SOa}$ & TS \\
\hline 12JT25 & 69.276 & -141.754 & Ewv & TS & 26LF13 & 69.352 & -142.855 & $\mathrm{SOa}$ & TS \\
\hline 12JT26 & 69.290 & -141.753 & $\mathrm{OEI}$ & TS & 27LF13 & 69.357 & -142.858 & $€ n$ & TS \\
\hline 12JT29 & 69.328 & -141.694 & Z€fr & TS & 28LF13 & 69.357 & $142.858-$ & $€ n$ & TS, DZ \\
\hline 12JT30 & 69.339 & -141.643 & ZEfr & TS & 29LF13 & 69.358 & -142.858 & €n,O€I, Soa & TS \\
\hline 12JT31 & 69.387 & -141.535 & ZEfr & TS, DZ & 30LF13 & 69.369 & -142.871 & Dbh & TS \\
\hline 12JT32 & 69.425 & -141.508 & $€ n$ & TS, DZ & 31LF13 & 69.372 & -142.875 & Dbh & TS \\
\hline 12JT33 & 69.447 & -141.452 & Mkt & TS, DZ & 32LF13 & 69.363 & -142.919 & Dbh & TS \\
\hline 12JT34 & 69.457 & -141.453 & OCe & TS & 33LF13 & 69.360 & -142.921 & OEI & TS \\
\hline 12JT35 & 69.468 & -141.465 & O€e & TS, DZ & 34LF13 & 69.360 & -142.921 & O€I & TS \\
\hline 12JT36 & 69.468 & -141.465 & O€e & TS & $35 \mathrm{LF} 13$ & 69.358 & -142.922 & OEI & TS \\
\hline 12JT37 & 69.469 & -141.469 & O€e & TS,GC & 36 LF13 & 69.358 & -142.921 & $€ n$ & TS \\
\hline 12JT38 & 69.469 & -141.469 & OCe & TS & 37LF13 & 69.357 & -142.921 & $€ n$ & TS, AR \\
\hline \multirow[t]{8}{*}{ 12JT39 } & 69.457 & -141.451 & O€e & TS,GC & 38LF13 & 69.361 & -142.884 & Dbh & TS \\
\hline & & & & & $39 L F 13$ & 69.359 & -142.884 & Dbh & TS \\
\hline & & & & & 40LF13 & 69.375 & -142.912 & Dbh & TS, DZ, AR \\
\hline & & & & & 41LF13 & 69.388 & -142.950 & kPs & TS \\
\hline & & & & & 42LF13 & 69.451 & -143.009 & ZEfr & TS \\
\hline & & & & & 43LF13 & 69.467 & -142.910 & ZEfr & TS \\
\hline & & & & & 44LF13 & 69.474 & -142.827 & ZEfr & TS, DZ \\
\hline & & & & & 45LF13 & 69.474 & -142.827 & Z€fr & C \\
\hline
\end{tabular}


TABLE 4.1: SAMPLE LIST FROM THE NE BROOKS RANGE CONT'D

\begin{tabular}{|c|c|c|c|c|c|c|c|c|c|}
\hline $\begin{array}{l}\text { Sample } \\
\text { Name }\end{array}$ & Latitude & Longitude & Map Unit & Analyses & $\begin{array}{l}\text { Sample } \\
\text { Name }\end{array}$ & Latitude & Longitude & Map Unit & Analyses \\
\hline \multicolumn{5}{|c|}{ Leffingwell Fork, 2012} & \multicolumn{5}{|c|}{$\underline{\text { Jago and Chandalar rivers, } 2015}$} \\
\hline 46LF13 & 69.474 & -142.827 & Z€fr & TS & 15BJ01 & 69.086 & -143.576 & $€ m v$ & NA \\
\hline 47LF13 & 69.474 & -142.827 & Z€fr & TS & 15BJ02 & 69.135 & -143.782 & Dgr & TS \\
\hline 48LF13 & 69.474 & -142.827 & Z€fr & TS & 15BJ03 & 69.135 & -143.782 & Dgr & TS \\
\hline \multicolumn{5}{|c|}{ Jago and Aichilik rivers, 2014} & 15BJ04 & 69.123 & -143.825 & $€ n$ & NA \\
\hline 14BJ01 & 69.098 & -144.629 & Qa & NA & 15BJ05 & 69.109 & -143.843 & Z€fr & NA \\
\hline 14BJ02 & 69.314 & -143.522 & $€ n$ & TS & 15BJ06 & 69.109 & -143.894 & $€ m v$ & TS,DZ \\
\hline 14BJ03 & 69.303 & -143.456 & Mky & TS & 15BJ07 & 69.086 & -143.905 & $€ n$ & NA \\
\hline 14BJ04 & 69.239 & -143.714 & $\mathrm{Dbh}, \mathrm{SOa}$ & TS & 15BJ08 & 69.069 & -143.908 & $€ m v$ & NA \\
\hline 14BJ05 & 69.239 & -143.714 & $\mathrm{Dbh}, \mathrm{SOa}$ & TS & 15BJ09a & 69.060 & -143.885 & Dgr & TS \\
\hline 14BJ06 & 69.240 & -143.715 & Dbh, SOa & TS & 15BJ09b & 69.060 & -143.885 & Dgr & TS \\
\hline 14BJ05 & 69.241 & -143.717 & Dbh, SOa & TS & 15BJ09c & 69.060 & -143.885 & Dgr & TS \\
\hline 14BJ07 & 69.230 & -143.681 & Dgr & TS & 15BJ09d & 69.060 & -143.885 & Dgr & TS \\
\hline 14BJ08 & 69.272 & -143.528 & Dgr & TS & 15BJ09c & 69.060 & -143.885 & Dgr & TS \\
\hline 14BJ09 & 69.261 & -143.510 & Dgr & TS & 15BJ10 & 69.097 & -143.583 & Soa & TS,DZ,AR \\
\hline 14BJ10 & 69.261 & -143.510 & Mkt & TS & 15BJ11 & 69.097 & -143.572 & Dbh & TS,DZ,AR \\
\hline 14BJ11 & 69.254 & -143.508 & Dgr & TS & 15BJ12 & 68.996 & -144.110 & $\mathrm{Di}$ & NA \\
\hline 14BJ12 & 69.254 & -143.508 & $\epsilon_{n}$ & TS & 15BJ13 & 68.999 & -144.105 & $\mathrm{Di}$ & NA \\
\hline 14BJ13 & 69.356 & -143.539 & PMI & TS & 15BJ14 & 69.106 & -143.899 & Dv & NA \\
\hline 14BJ14 & 69.362 & -143.653 & Dgr & TS & 15BJ15a & 68.970 & -144.369 & Dv & NA \\
\hline 14BJ15 & 69.360 & -143.663 & Dgr & TS & 15BJ15b & 68.970 & -144.369 & Dv & NA \\
\hline 14BJ16 & 69.318 & -143.551 & $\mathrm{Qa}$ & TS & 15BJ15c & 68.970 & -144.369 & Dv & NA \\
\hline 14BJ17 & 69.318 & -143.551 & Dgr & TS & 15BJ15d & 68.970 & -144.369 & Dv & NA \\
\hline 14BJ18 & 69.303 & -143.506 & $\mathrm{Da}$ & TS & 15BJ15e & 68.970 & -144.369 & Dv & NA \\
\hline 14BJ19 & 69.114 & -142.707 & $\mathrm{~Kb}$ & TS & & & & & \\
\hline 14BJ20 & 69.081 & -143.068 & OEr & TS, DZ & & & & & \\
\hline 14BJ21 & 69.041 & -143.132 & Dmu & TS & & & & & \\
\hline 14BJ22 & 69.117 & -143.173 & $\epsilon m v$ & TS,GC & & & & & \\
\hline 14BJ23 & 69.116 & -143.175 & $€ m v$ & TS,GC & & & & & \\
\hline 14BJ24 & 69.117 & -143.179 & $\epsilon m v$ & TS,GC, DZ & & & & & \\
\hline 14BJ25 & 69.100 & -143.112 & $O \in r$ & TS, DZ & & & & & \\
\hline 14BJ26 & 69.124 & -143.218 & Dbh & TS, DZ & & & & & \\
\hline 14BJ27 & 69.125 & -143.226 & Dbh & $\mathrm{TS}, \mathrm{Ar}$ & & & & & \\
\hline 14BJ28 & 69.122 & -143.169 & $€ \mathrm{I}$ & TS & & & & & \\
\hline 14BJ29 & 69.339 & -142.679 & Dbh & TS, DZ & & & & & \\
\hline 14BJ30 & 70.136 & -143.591 & $€ i$ & TS & & & & & \\
\hline
\end{tabular}

TS-Thin Section; DZ-Detrital zircon; $\mathrm{Ar}-{ }^{40} \mathrm{Ar} /{ }^{39} \mathrm{Ar}$; GC-Geochemistry; NA-Not available 


\section{LITHOSTRATIGRAPHIC UNITS}

The entire NE Brooks Range comprises more than 20 individual lithostratigraphic units. Their incorporation into the two 1:75,000 scale geological maps presented on Plates 1 and 2 is dependent a multitude of factors, including the degree of exposure, thickness, and how distinguishable they are in satellite imagery. We have excluded the Neoproterozoic to Devonian carbonate and volcanic units exposed in the Shublik and Sadlerochit mountains (Fig. 4.1) from the descriptions below because they are not included in our maps (Plates 1 and 2), and the reader is referred to Strauss et al. (2018b) and references therein for a more complete review of that region. What follows below is a description all the map units that are exposed in our map areas (Fig. 4.1; Plates 1 and 2). Their relative position and thicknesses are schematically illustrated in Figure 4.2.

\section{Qa - Surface alluvium, undivided (Pleistocene-Holocene)}

The river valleys in the NE Brooks Range are mostly covered by an $\sim 1$ to $>100 \mathrm{~m}$ surface alluvium consisting of unconsolidated silt, sand, gravel, cobbles, and boulders. Much of this sediment is deposited in active channels and floodplains of rivers, streams, alluvial fans, piedmont slopes, and in the moraines of ancient and modern glaciers. The region records several alpine glacial events dating back to the Early Pleistocene (e.g., Detterman et al., 1958, Reed, 1968).

\section{$\mathrm{Kb}$ - Bathtub Graywacke (Lower Cretaceous)}

The type section of the Bathtub Graywacke is exposed on the north flank of Bathtub Ridge (Fig. 4.1), which stretches for $30 \mathrm{~km}$ east-west in the upper reaches of the Kongakut River (Detterman, et al., 1975). A second reference section is exposed along Sabbath Creek, a tributary of the lower Jago River, north of the Brooks Range front. The graywacke forms a resistive cap 


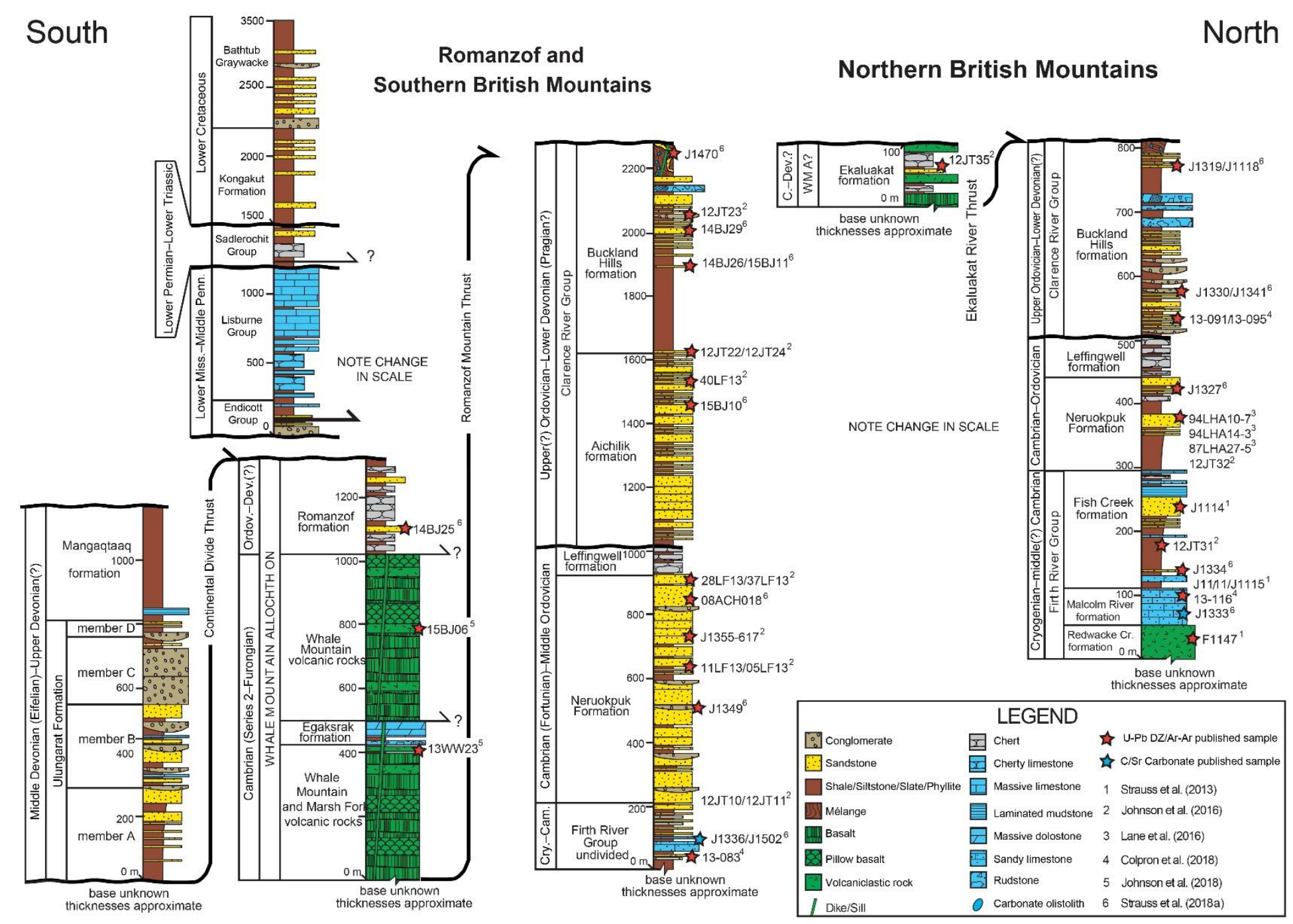

Figure 4.2: Simplified lithostratigraphic architecture of the northeasteastern Brooks Range, modified from Strauss et al. (2018a). These lithostratigraphic sections are based data published by Dutro et al. (1972), Sable (1977), Ditterman et al. (1975), Mamet and Armstrong (1972), Reiser et al. (1980), Lane (1991), Lane et al. (1995, 2016), Mull and Andersen (1991), Andersen et al. (1994; 1995), Kelley et al. (1994), Strauss et al. (2013; 2018a), and Johnson et al. (2016; 2018). Cry.-Cryogenian; C.-Cambrian; Cam.Cambrian; Dev.-Devonian; Cr.-Creek; Miss.-Mississippian; Penn.-Pennsylvanian. 
composed of up to $750 \mathrm{~m}$ of mainly subfeldspathic, lithic-rich, dark-grayish-green graywacke, with interbeds of siltstone, shale, and conglomerate. The contact with the underlying shale units of the Kongakut Formation appears conformable and is marked by the lowest exposure of massive greywacke.

The age of the Bathtub Graywacke is only constrained by the biostratigraphic ages from the units exposed above and below its boundaries (Detterman et al., 1975). The uppermost beds of the underlying Kongakut formation are assigned to the middle part of the Lower Cretaceous (Hauterivian-Berremian), and although no Aptian or Albian units have not been firmly identified in Brooks Range of Alaska, there are units assigned to the Upper Cretaceous (Cenomanianlower Maastrichtian) and the Aptian-Albian stages that are exposed in the Yukon portion of the Brooks Range and in the Richardson Mountains (e.g., Norris, 1981a, 1981b; Dixon, 2004, Colpron et al., 2018). Detterman et al. (1975) therefore assigned the Bathtub Graywacke to the Albian, and suggested that it is equivalent, in part, to the Fortress Mountain Formation exposed in the foothills of the central Brooks Range if Alaska (Patton, 1956).

\section{Kk - Kongakut Formation (Upper Jurassic(?)-Lower Cretaceous)}

The Kongakut Formation includes four members: the informal clay shale, pebble shale, and siltstone members and the formal Kemic Sandstone Member (Dettermen et al., 1975). Other authors, working along the mountain front and costal plain of ANWR, raised the Kemic Sandstone and pebble shale members of the Kongakut Formation to formal formational rank and suggested that the Kongakut Formation name be geographically restricted to the rocks exposed at Bathtub Ridge (Mull, 1987; Molenaar et al., 1987). At its type locality along the flanks of Bathtub Ridge (Fig. 4.1), the Kongakut Formation is $\sim 700 \mathrm{~m}$ thick. Its basal surface marks a unconformity that truncates the underlying Ivishak Formation of the Sadlerochit Group, which 
represents the surface equivalent of the seismically imaged Lower Cretaceous Unconformity (LCU) in the subsurface at Prudhoe Bay and throughout other parts of northern Alaska (e.g., Molenaar et al., 1987). The basal part of the Kongakut section is marked by a nonresistant, saddle-forming, dark-gray fissile shale (clay shale member). The clay shale member grades into the Kemic Sandstone, which is composed of fine grained quartz arenite that forms resistant ledges along the northern part of Bathtub Ridge. Above the Kemic Sandstone, the section grades into the manganiferous pebbly shale and olive-gray siltstone members.

The age of the Kongakut Formation is constrained by a sparse collection of mega and microfauna, which assign most of the sedimentary intervals to the middle part of the Lower Cretaceous (Hauterivian-Berremian), but the lowermost section of the Kongakut Formation (clay shale member) is characterized by a mixed microfauna that suggests a lowermost Cretaceous-uppermost Jurassic assignment (Detterman et al., 1975; Reiser et al., 1980). This implies that the clay shale member at Bathtub Ridge is, in part, time correlative with the Kingak Shale, a Lower-Upper Jurassic sequence of dark, fissile shale exposed at the southeastern end of the Sadlerochit Mountains and in the North Slope subsurface (e.g., Leffingwell, 1919; Hubbard et al., 1987)

\section{RPs - Sadlerochit Group, undivided (Lower Permian-Lower Triassic)}

The Sadlerochit Group includes two formal formations: a lower Echooka Formation and an upper Ivishak Formation, both of which are divided into several formal members (Ditterman et al., 1975). The group is named for its type area along the southern flank of Sadlerochit Mountains in the Mount Michelson 1:250,000 quadrangle, roughly $60 \mathrm{~km}$ to the northeast of our main study area (Fig. 4.1). A nearly complete section of Sadlerochit Group strata, however, is exposed at the base of Bathtub Ridge, which we examined in the field campaigns of 2012 and 
2014. Collectively, the Sadlerochit Group ranges from 200 to $500 \mathrm{~m}$ thick, and appears to be folded in concert with the underlying Lisburne Group (Fig 4.3A). Paleontological evidence indicates that the Sadlerochit Group is marked by unconformities on its upper and lower boundaries, separating it from the overlying Kongakut Formation and underlying Lisburne Group.

The lower half of the Sadlerochit Group, the Echooka Formation, comprises two members. The Joe Creek Member is in the lowest unit and is defined by a succession of duskyyellow, thin to massively bedded dense chert, siliceous siltstone, and carbonate mudstone. The Joe Creek Member grades into the Ikiakpaurak Member, which consists of dark gray sandstone, predominantly composed of fine- to very-fine-grained quartz and chert fragments. The Ikiakpaurak Member grades into a recessive-weathering unit of siltstone and shale, defined by Detterman et al. (1975) as the Kavik Member, which forms the lower third of the Ivishak Formation. Above the Kavic Member lies the $\sim 15$ to $100 \mathrm{~m}$ thick Ledge Sandstone Member. Well known as the main oil-producing reservoir in the subsurface at Prudhoe Bay, the Ledge Sandstone is defined by the massive, resistive, and iron-stained sandstone unit that is locally conglomeratic. It is present in all outcrops of the Sadlerochit Group in the NE Brooks Range, but is thickest in the area near Ledge Creek, a tributary of the Sadlerochit River, where it forms numerous ledges or hogbacks along the east end of the Sadlerochit Mountains. In some parts of the NE Brooks Range, the Ledge Sandstone is conformably overlain by recessive-weathering shale and siltstone beds of the Fire Creek Member, but in other cases the Ledge Sandstone is truncated by the Lower Cretaceous unconformity. 


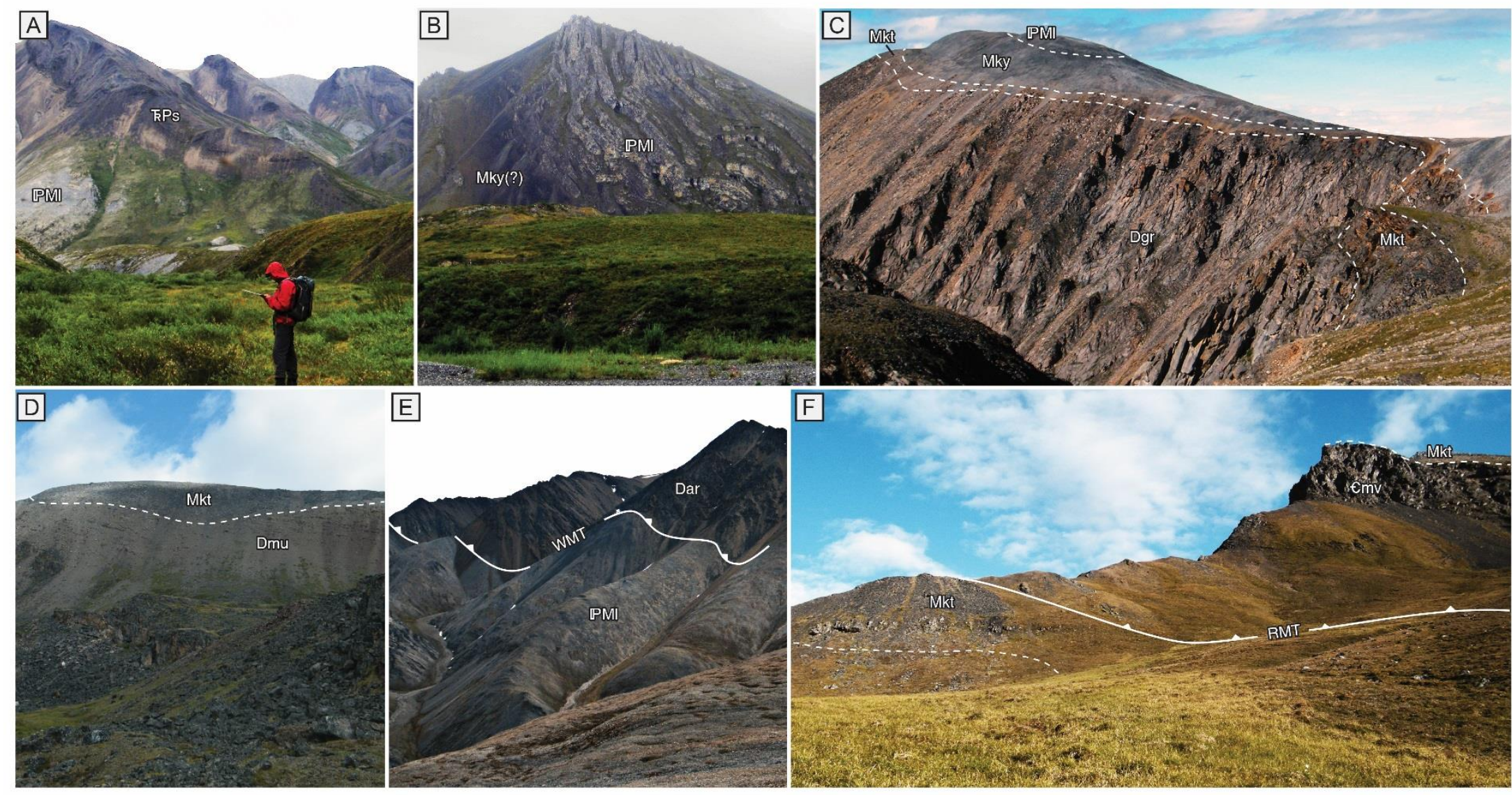

Figure 4.3: Selected field images from the northeastern Brooks Range, Alaska. (A) Looking southeast along the northern edge of Bathtub Ridge, showing folds in the Lisburne (PMI) and Sadlarochit ( $\mathrm{kPs}$ ) groups. (B) Looking east across the Kongakut River at parasitic folds in the Lisburne Group (PMI) and Kayak Shale (Mky). (C) Looking north at the top of the Jago Stock, showing the gradational contact between the Devonian granitic rocks (Dgr) and the Kekiktuk Conglomerate (Mkt). (D) Looking northeast in the headwaters of the Kongakut River, showing the erosive contact between the Ulungarat Formation (DMu) and the Kekiktuk Conglomerate. (E) Looking southeast from the eastern wall of the Jago River valley at the Whale Mountain thrust (WMT). Units in the hanging wall are Devonian(?) altered rocks (Dar). (F) Looking southeast at the Romanzof Mountain thrust (RMT), in the headwaters of the Aichilik River, showing the Kekiktuk Conglomerate in foot wall with the Marsh Fork volcanic rocks (€mv) overlain by Kekiktuk Conglomerate in the hanging wall. 


\section{PMI - Lisburne Group, undivided (Lower Mississippian-Middle Pennsylvanian)}

The Lisburne Group is divided into three formal limestone formations: Wachsmuth Limestone, Alpha Limestone, and Wahoo Limestone. The Lisburne name was originally assigned to limestone units exposed in the upper Anaktuvuk River valley of the central Brooks Range by Schrader (1902), who correlated the central Brooks Range units to a similar limestone and shale section exposed in the area of the Lisburne Peninsula along the NW coast of Alaska (Fig. 4.1B). Leffingwell (1919), who was working in the Canning River area, later applied the Lisburne name to many of the Paleozoic limestone units in the NE Brook Range. Later, Bowsher and Dutro (1957) identified several type sections in the Shanin Lake area just east of the Anaktuvuk River Valley, where they recognized two new formations, a lower Wachsmuth Limestone and an upper Alpha Limestone, and raised the Lisburne to group rank. A third formation, the Wahoo Limestone, was described by Brosgé et al. (1962) at Wahoo Lake near the Echooka River at the western edge of the Philip Smith Mountains, and it was assigned to the upper third of the Lisburne Group.

Most of the limestone units consist of massive, light-gray skeletal wackestone and packstone, with lesser amounts of carbonate mudstone, dolostone, and ooid grainstone. Intervals of dark-gray nobular and bedded chert and interbedded black carbonate mudstone are prevalent in the Wachsmuth Limestone and lower portions of the Alpha Limestone (Fig. 4.2). The stratigraphic boundaries that separate the three formations at the type sections are typically determined by biostratigraphy. The basal contact of the Lisburne Group with the underlying Kayak Shale, however, is typically picked by lithostratigraphic transition, and has been recognized to represent a time-transgressive surface throughout the region. The contact between the Wachsmuth Limestone and the Alpha Limestone in the Shanin Lake area is assigned to the 
upper Visean (e.g., Bowsher and Dutro, 1957; Armstrong et al., 1970). Nearly all the limestone units in the NE Brooks Range, however, record deposition from the Serpukhovian to the middle Moscovian (e.g., Armstrong et al., 1970; Mamet and Armstrong, 1972; Armstrong and Mamet, 1977), indicating that the time-equivalent Wachsmuth Limestone units, exposed in the Shanin Lake area, are not recognized in our field area. The contact between the Alpha Limestone and the Wahoo Limestone is assigned to the Mississippian-Pennsylvanian boundary (SerpukhovianBashkirian), and it roughly corresponds to a gradational change in lithofacies, as the chert nodules and carbonate mudstone intervals of the Alpha Limestone grade into the skeletal packstone and wackestone-dominated intervals of the Wahoo Limestone.

The overall thickness of the Lisburne Group varies across entire Brooks Range, and because of the intense folding and the erosion across its upper surface, its absolute stratigraphic thickness is uncertain. Compyling the previously measured sections from the Franklin, Romanzof, and British Mountains (e.g., Mamet and Armstrong, 1972; Armstrong and Mamet, 1977), we use a thickness of $1000 \mathrm{~m}$ for the Lisburne Group in our cross sections (Plates 1 and 2).

\section{Me - Endicott Group, undivided (Lower-Upper Mississippian)}

The Endicott Group encompasses a thick siliciclastic-dominated succession of Upper Devonian-Lower Mississippian strata that are widely exposed throughout much of the Brooks Range and in the subsurface of the Colville Basin. It is named for its prominent exposure in the Endicott Mountains of the central Brooks Range, where it consists of, in ascending order, the Hunt Fork Shale, Kanayut Conglomerate, and Kayak Shale (Tailleur et al., 1967). In the northeastern Brooks Range, it includes the Kekiktuk Conglomerate, the Kayak Shale, and the

locally defined Itkilyariak Formation of Mull and Magnus (1972). Below, we only describe the 
Kekiktuk Conglomerate and Kayak Shale because they are the only two units from the Endicott Group exposed in our field area.

\section{Mky-Kayak Shale (Lower-Upper Mississippian)}

Like the limestone intervals of the Lisburne Group, the type section of the Kayak Shale was also described in the Shanin Lake area of the Endicott Mountains (Bowsher and Dutro, 1957). The section is predominantly composed of black shale with a quartzarenite or sublitharenite sandstone member at the base and a red-weathering carbonate mudstone and wackestone member at the top. Similar strata are exposed throughout parts of the NE Brooks Range. Brosgé et al. (1962) noted that structural complications restricted direct correlation to the type section at Shanin Lake, and they elected to use the name Kayak(?) Shale instead.

Microfossil evidence indicates that the Kayak Shale, at its type section near Shanin Lake, is late Tournaisian in age (Armstrong et al., 1970). In the NE Brooks Range, however, the oldest limestone intervals in the upper part of the Kayak Shale(?) contain foraminifera that are late Viséan in age (Mamet and Armstrong, 1972; Armstrong and Mamet, 1977), whereas the Kayak Shale(?) intervals in the subsurface at Prudhoe Bay contain fauna as young as middle Serpukhovian age (Armstrong and Mamet, 1974). Nevertheless, the boundaries of the Kayak Shale are defined by lithostratigraphic changes described at Shanin Lake and the NE Brooks Range. We apply the name Kayak Shale to all the rocks positioned above the uppermost coal section of the Kekiktuk Conglomerate and below the black nodular and bedded chert and carbonate mudstone intervals of the lower Alpha Limestone.

Because of the intense deformation across the Kayak Shale interval, its stratigraphic thickness is hard to constrain. At its type section in the Shanin Lake area, the Kayak Shale is 300 m thick (Bowsher and Dutro, 1957). In the NE Brooks Range, the Kayak Shale ranges 
from $<50 \mathrm{~m}$ to $\sim 450 \mathrm{~m}$ thick (Brosgé et al., 1962; Mamet and Armstrong, 1972; Anderson, 1995), and is $\sim 300 \mathrm{~m}$ in the subsurface at Prudhoe Bay (Armstrong and Mamet., 1974). At several locations within the NE Brooks Range, the Kayak Shale interval thins to $<10 \mathrm{~m}$ or is completely absent. For example, on the southeast side of the Jago Stock (Plate 2), the Kayak Shale is only a few meters thick and is exposed as talus slope that separates limestone units of the Lisburne Group from the Kekiktuk Conglomerate. Along strike, the Kayak Shale pinches out, and the Lisburne Group rest directly on the Kekiktuk Conglomerate. In several other locations, the Kekiktuk Conglomerate is the only unit of the Endicott Group exposed. Some authors attribute these thickness variations to local basement highs that persisted throughout Early and Middle Mississippian time (e.g., Armstrong et al., 1974, LePlain et al., 1994). For the structural cross sections presented in this study (Plates 1 and 2) we use a uniform thickness of $200 \mathrm{~m}$ for the Kayak Shale in most parts of our field area. In the headwaters of the Kongakut River, however, Anderson $(1993 ; 1995)$ prescribed a thickness of $~ 400 \mathrm{~m}$ for the Kayak Shale, which we apply to our cross sections in that specific area (Plate 2).

\section{Mkt-Kekiktuk Conglomerate (Lower Mississippian)}

The Kekiktuk Conglomerate defines the lower half of the Endicott Group (Tailleur et al., 1967). The formation was named by Brosgé et al. (1962) for the stream that drains Lake Peters in the Mount Michelson quadrangle (Fig. 4.1), and the type section was described at Whistler Creek (also near Lake Peters). The Kekikituk Conglomerate is found throughout many parts of the NE Brooks Range, as it typically forms ledges and ridges due to its strong resistance to weathering. It is an important marker bed because its base defines a prominent angular unconformity that truncates a highly deformed succession of Neoproterozoic to Devonian strata, what is often called the "pre-Mississippian sequence" (e.g., Moore et al., 1994) or the Franklinian sequence 
(Lerand, 1973). Strauss et al. (2018a) revised much of the sub-Mississippian nomenclature (see below for further details).

At its type section, the Kekiktuk Conglomerate is consist of light- to dark-gray, conglomerate and coarse-grained sandstone that contains subangular to well-rounded sand grains, pebbles and cobbles of detrital chert fragments, quartz grains, and minor amounts of lithic fragments, such as polycrystalline quartz and siltstone. In the thicker sections of the Kekiktuk Conglomerate the sandstone and conglomerate intervals grade into dark-gray shale and siltstone that commonly contain wood fragments, thin $(>0.5 \mathrm{~m})$ coal seams and carbonate mudstone beds that have well-preserved bivalves. The age of the Kekiktuk Conglomerate is constrained only by the rare plant fossils found in sections that contain the coal seams, which assign the upper portions of the Kekiktuk Conglomerate to the Lower Mississippian (Dutro, 1987). In the headwaters of the Kongakut River, the basal unconformity of the Kekiktuk Conglomerate truncates Middle Devonian-Lower Mississippian strata of the Mangaqtaaq and Ulungarat formations (Fig. 4.3D; Anderson and Watt, 1992; Anderson et al., 1994; Anderson, 1995), further supporting the Lower Mississippian assignment of the Kekiktuk Conglomerate. The Kekiktuk intervals in the NE Brooks Range are time correlative, and in some cases, younger than the Kayak Shale intervals of the central Brooks Range (e.g., Dutro, 1987), exemplifying the time-transgress nature of these two units.

The Kekekiktuk Conglomerate is $\sim 100 \mathrm{~m}$ thick at its type section (Brosgé et al., 1962), but its thickness varies across the field area, ranging from $<10 \mathrm{~m}$ in some areas to $\sim 180 \mathrm{~m}$ thick in the subsurface at Prudhoe Bay (Armstrong and Mamet, 1974). We use a uniform thickness of $100 \mathrm{~m}$ for the Kekiktuk Conglomerate in our cross sections (Plates 1 and 2). In most places throughout our field area, however, exposures of the Kekiktuk Conglomerate are $<10 \mathrm{~m}$ thick. 


\section{Dmu - Mangaqtaaq and Ulungarat formations, undivided (Middle Devonian-Lower}

\section{Mississippian(?))}

The Mangaqtaaq and Ulungarat formations compose a southward thickening, siliciclasticdominated, sedimentary wedge exposed in the headwater regions of the Kongakut, Sheenjek, and Chandalar rivers. Originally, these sedimentary units were collectively assigned to the "unnamed slate and sandstone unit" by Brosgé et al. (1962) and then the "Devonian sandstone" (Ds) map unit of Reiser et al. (1980). Later, the work of Anderson and Watts (1992), Anderson et al., (1994), and Anderson (1995) named the two formations and described their type sections. Since the detailed work of Anderson, however, the Mangaqtaaq and Ulungarat formations have received very little study, and many of the map relationships and regional correlations remain uncertain.

The Ulungarat Formation is represented by a coarsening upward succession of siliciclastic strata, which Anderson (1995) divided into four members (A, B, C, and D). Red and brown shale and siltstone intervals are more prevalent in the lower members (A and B), and they typically grade into channelized sandstone and conglomerate beds (member C), which are defined by erosional bases and cross stratification. Fossils recovered from the mudstone intervals of members A and B include inarticulate brachiopods identified as Bicarinatina n. Sp., which assign the lower parts of the succession to the Eifelian Stage (lower Middle Devonian). At the top of the Ulungarat succession, in member D, the thick, cliff-forming conglomerate beds of member $\mathrm{C}$ are overlain by mottled, red shale and siltstone with sparse, laterally discontinuous sandstone lenses. The overlying Mangaqtaaq Formation appears to onlap and truncate the upper members of the Ulungarat Formation, although the contact is typically concealed by vegetation (e.g., Anderson and Watt, 1992; Anderson, 1995). The Mangaqtaaq Formation includes algal 
limestone, sandstone, pebbly sandstone, and black shale. Contacts between these lithologies are typically sharp, reflecting the cyclic character of the Mangaqtaaq Formation. Plant fossils were recovered from the black mudstone intervals at the base of the Mangaqtaaq type section (Anderson and Watt, 1992; Anderson, 1995). The fossils suggest a Lower Devonian-Lower Mississippian assignment.

From the measured sections described by Anderson (1995), the collective thickness of the Mangaqtaaq and Ulungarat formations ranges from $\sim 100$ to $>400 \mathrm{~m}$. In our cross section of the Jago-Aichilik map area (Plate 2), we draw the Ulungarat section as a southward-thickening wedge that reaches a thickness of $\sim 400 \mathrm{~m}$, although Brookian deformation has duplicated much of the section. Many of the map relationships in the southeastern quarter of the Jago-Aichilik map area were taken from the map of Anderson (1993). We also heavily relied on the satellite imagery, using the red and brown color as a marker for the distribution of the UlungaratMangaqtaaq units and the gray and tan resistive unit as a marker for the Kekiktuk Conglomerate. In general, we drew thrust faults where the red and brown Ulungarat units overlie the younger tan Kekiktuk units. These relationships, however, are conjectural, as our traverse to the upper Kongakut River in 2014 revealed that distinguishing between the conglomerate beds of the upper Ulungarat Formation and the Kekiktuk Conglomerate is difficult.

\section{DOcr - Clarence River Group, undivided (Upper Ordovician-Lower Devonian(?))}

The Clarence River Group was defined by Johnson et al. (2016) using detrital zircon U$\mathrm{Pb}$ and muscovite ${ }^{40} \mathrm{Ar} /{ }^{39} \mathrm{Ar}$ geochronology coupled with field evidence from the British and Romanzof mountains in Alaska. The group encompasses a succession of Ordovician-Lower Devonian(?), mostly fine-grained siliciclastic strata. No type section exists for the Clarence River Group, but its name is derived from the Clarence River region, near the Alaska-Yukon border in 
the northern British Mountains (Fig. 4.2). The area was mapped in detail during a joint effort between the United States Geological Survey and the Geological Survey of Canada (Kelley et al., 1994; Lane et al., 1995). From that work, several fossil collections recovered graptolites that were assigned to the Upper Ordovician and the Lower Silurian, along with a single conodont that indicated a latest Silurian or earliest Devonian age. Johnson et al. (2016) showed overlap between the fossil ages from Clarence River region and the Ordovician-Early Devonian(?) detrital mineral ages recovered from strata as far south as the upper Aichilik River $(\sim 100 \mathrm{~km}$ to the southwest).

In the revised stratigraphic scheme of Strauss et al. (2018a), the Clarence River Group is partitioned into two lithostratigraphic units: the Aichilik and Buckland Hills formations (Fig. 4.2). These units have not been formalized because structural complexities generally preclude the measurement of detailed type sections, and the only place where we have definitively observed the contact between the two units is in the headwaters of the Aichilik and Jago River drainages, where brownish olive slaty phyllite and micaceous siltstone intervals of Aichilik formation grade into black to dark grey fine-grained slate, phyllite, and minor thin-bedded sandstone of the Buckland Hills formation. In the lower reaches of the Kongakut River (Plate 1), we have opted to simply map these units as "Clarence River Group, undivided" because of poor exposure and due to the limited time we spent in that area.

\section{Dbh - Buckland Hills formation (Lower Devonian(?))}

The name Buckland Hills formation derives from the work of Lane (2007) and Lane et al. (2016), who described a succession of dark grey siltstone and sandstone, locally interbedded with chert pebble conglomerate in the Buckland Hills of the Herschel Island 1:250,000 quadrangle of northern Yukon (Fig. 4.1). The expanded definition of Johnson et al. (2016) and 
Strauss et al. (2018a) encompasses Reiser et al.’s (1980) “Cambrian phyllite” (€p) and "Cambrian sandstone" (€s) map units in the Romanzof and southern British Mountains and their "Ordovician black slate" (Os) and portions of the undifferentiated "phyllite" (ph) and "slate, argillite, quartzite, and chert" (sc) map units in the northern British Mountains of Alaska. Lane and Cecile (1989), Kelley et al. (1994), Lane et al. (1995, 2016), and Lane (2007) also singled out these strata from the older Firth River Group and Neruokpuk and Leffingwell formations in the northern British Mountains and mapped them as "Silurian argillite" (Sa), "Devonian(?) argillite and subordinate sandstone" (D?a), and "Paleozoic argillite" (Pza) map units, which they correlated with similar strata in the Barn Mountains (Fig. 4.1).

Fine-grained strata within the Buckland Hills formation are mainly composed of black to light green slate and phyllite with discrete zones of micaceous siltstone, all of which commonly contain a prominent penetrative cleavage that destroys primary sedimentary structures. In some local cases, however, the fine-grained intervals are less deformed and preserve trace fossils and/or poorly preserved graptolites, including a handful of Late Ordovician to late Silurian collections (Dutro et al., 1972; Reiser et al., 1980; Lane and Cecile, 1989; Kelley et al., 1994; Lane et al., 1995). Occasionally, these fine-grained intervals are disrupted by $\mathrm{cm}$ - to $\mathrm{m}$-scale olistoliths or olistostromes, which are most commonly composed of subrounded boulders of orange- to white-weathering limestone and dolostone with poorly preserved internal textures (Johnson et al., 2018; Strauss et al., 2018a). Some of these carbonate olistoliths have a distinct mafic volcaniclastic matrix and contain unidentifiable trilobite and brachiopod fossil fragments, all of which resemble similar lithofacies to what is reported in the upper Cambrian Egaksrak formation of the Whale Mountain allochthon (Johnson et al., 2018). 
Sandstone horizons in the Buckland Hills formation consist of thin- to medium-bedded, poorly to moderately sorted, lithic arenite and sublitharenite. These strata occasionally have a distinct orange-weathering hue and locally preserve abundant complex trace fossils (e.g., Lane et al., 1995), various sole marks, soft-sediment deformation structures, and distinct normal grading with several of the classic Bouma subdivisions. In thin section, sandstone horizons from the Buckland Hills formation contain angular to subrounded mono- and polycrystalline quartz, chert, plagioclase, various accessory minerals, and a wide variety of volcanic and sedimentary lithic fragments (Strauss et al., 2018a). Conglomerate horizons in the Buckland Hills formation are generally clast-supported, moderately to well sorted, medium- to thick-bedded, and composed of angular to subangular chert, plagioclase, monocrystalline quartz, and volcanic/plutonic lithic fragments.

The Buckland Hills formation either sits gradationally on strata of the Aichilik formation or rests disconformably on a variety of older strata (Reiser et al., 1980; Mull and Anderson, 1991; Kelley et al., 1994; Lane et al., 1995, 2016). Its upper boundary in the southern British Mountains and Romanzof Mountains is consistently marked by a major fault contact with overlying rocks of the Whale Mountain allochthon (Plates 1 and 2; Johnson et al., 2016, 2018). Where exposed, this contact is either marked by a sharp boundary with the overlying Whale Mountain volcanic rocks or it is represented by a discontinuous mélange, where $\mathrm{cm}$ - to decameter-scale blocks of Whale Mountain, Clarence River, and/or Neruokpuk lithologies are suspended in a black to dark gray shale matrix. Although poorly exposed, this mélange is potentially $>100$ m thick near Dutro et al.'s (1972) trilobite fossil locality along the Leffingwell Fork of the Aichilik River (Fig. 4.1), where >50 m thick blocks of fossiliferous and volcaniclastic limestone and minor mafic volcanic rocks are floating within a diffuse zone of 
highly deformed black shale, slate, and phyllite. Like many of the other sub-Mississippian units in the area, the Buckland Hills formation is typically deformed into tight or isoclinal folds (Fig. 4.4) and imbricated by many unmapped faults. Therefore, its thickness is poorly constrained and roughly ranges from 300 to 1300 m thick. In our cross sections (Plates 1 and 2), the thickness of the Buckland Hill formation varies due to truncation by major thrust faults or the sub-

Mississippian unconformity, but in some places, it is nearly $1000 \mathrm{~m}$ thick.

\section{SOa-Aichilik formation (Upper Ordovician-Upper Silurian)}

The informal Aichilik formation is named after the Aichilik River, which runs through the central part of the Demarcation Point 1:250,000 quadrangle in Alaska (Fig. 4.1). The name was originally proposed by Mull and Anderson (1991) and encompassed Reiser et al.'s (1980) "Cambrian calcareous siltstone and sandstone" (€ss) map unit. The Cambrian age assignment, however, came from a single locality of poorly preserved echinoderm debris (Reiser et al., 1980) and its presumed stratigraphic position beneath the upper Cambrian Whale Mountain volcanic rocks (Dutro et al., 1972). Johnson et al. (2016) subsequently included these strata within the younger Clarence River Group because they appeared lithologically more akin to synorogenic deposits of the Buckland Hills succession. Strauss et al. (2018a) confirmed this correlation with Ordovician-Late Silurian detrital zircon $\mathrm{U}-\mathrm{Pb}$ and muscovite ${ }^{40} \mathrm{Ar} /{ }^{39} \mathrm{Ar}$ ages.

Fine-grained strata within the Aichilik formation are mainly composed of brownish olive slaty phyllite and micaceous siltstone, which commonly contain a prominent penetrative cleavage that destroys the primary sedimentary fabrics. Sandstone horizons in the Aichilik formation are commonly thin- to medium-bedded, moderate to poorly sorted, and consist of micaceous and calcareous quartz and lithic wacke, lithic arenite, and sublitharenite. Locally, these strata preserve flute and other sole marks and display distinct normal grading with various 

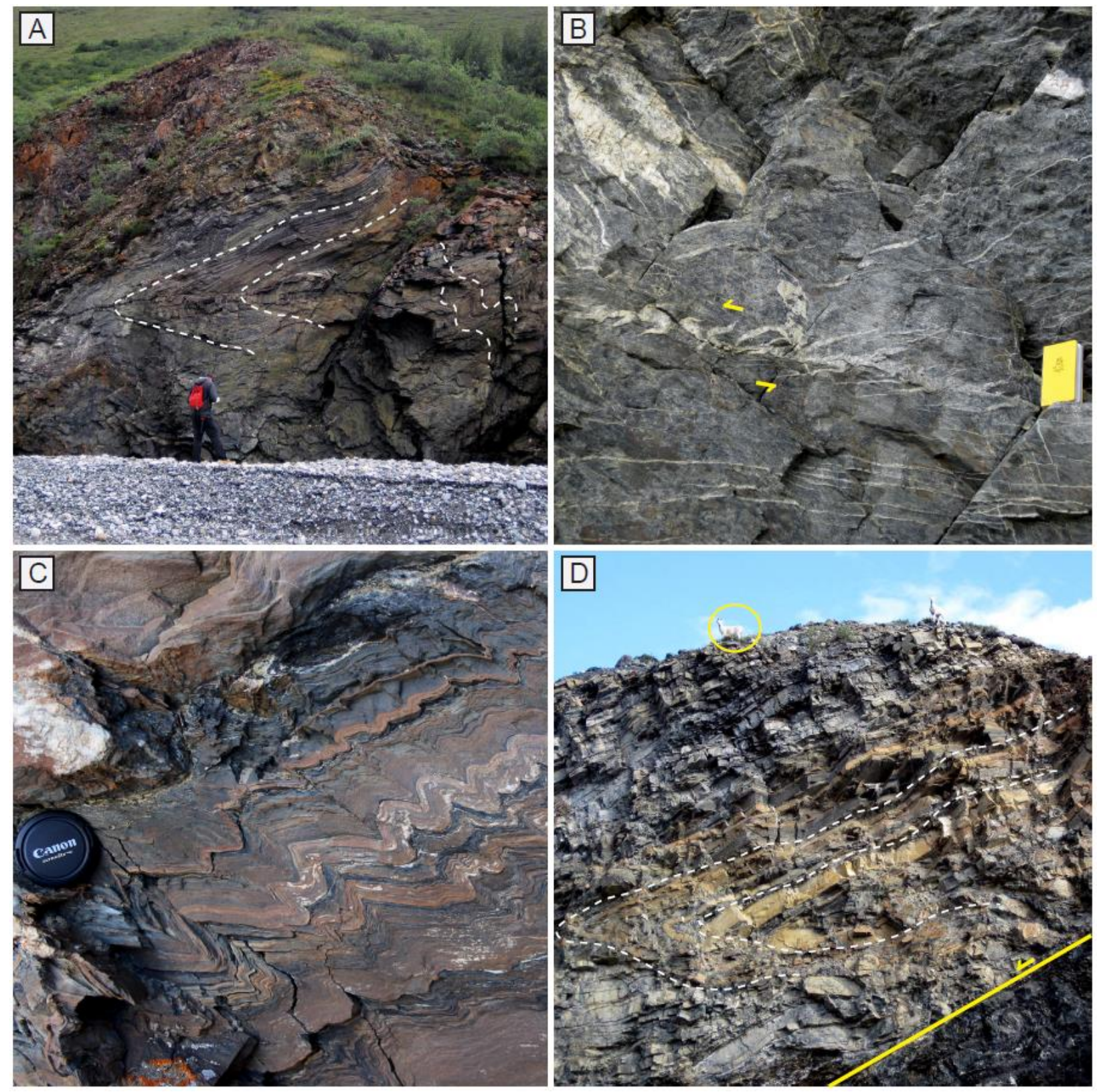

Figure 4.4 Selected field images of sub-Mississippian rocks in the northeastern Brooks Range, Alaska. (A) Looking east along the Kongakut River at sub-horizontal, tight to isoclinal, southverging, class II folds in the Clarence River Group. (B) Looking west along the Kongakut River at sigmoidal veins in the Neruokpuk Formation, showing top-to-the-south shear. (C) Looking west in the upper Jago River, showing tight, north-verging, buckle (class I) folds in the Clarence River Group. (C) Looking northeast along the Kongakut River at sub-horizontal, south-verging, class II folds in Firth River Group strata; Dahl sheep (circled in yellow) are approximately $1.5 \mathrm{~m}$ tall for scale. 
Bouma cycles, including well-developed ripple cross-stratification in Bouma C subdivisions, which in some outcrops are deformed into convolute bedding. Although primary sedimentary fabrics in this unit are commonly destroyed by penetrative cleavages and isoclinal folding, these strata do occasionally preserve indeterminate trace fossils, including Nereites and Paleodictyon(?). In thin section, sandstone horizons from the Aichilik formation contain subangular to subrounded mono- and poly-crystalline quartz, plagioclase, muscovite, various unidentified opaques, and a wide variety of metamorphic, volcanic, and sedimentary lithic fragments. In particular, these strata contain abundant carbonate lithic fragments, most of which are highly recrystallized and therefore do not preserve primary microfacies (Strauss et al., 2018a). The matrix of the lithic wacke horizons consists of abundant sericite, carbonate, and clay mineral masses that may result from the breakdown of feldspar.

Similar to the Buckland Hills formation, the thickness of the Aichilik formation is uncertain. Its distribution and the reports on the thickness of this unit (e.g., Dutro et al., 1972; Reiser et al., 1980; Mull and Anderson, 1991) suggests that it ranges from 300-1500(?) $\mathrm{m}$. It is, however, repeatedly imbricated or tightly folded with the underlying Leffingwell formation in both of our map areas (Plates 1 and 2) and is characterized by significant internal deformation, thus the thickness estimates are likely overestimated due to structural thickening. Based on regional observations in the type area, Strauss et al. (2018a) estimated a thickness of $\sim 600 \mathrm{~m}$, which we have applied to our cross sections in Plates 1 and 2.

\section{O€I - Leffingwell formation (Cambrian(?)-Middle Ordovician)}

The informal Leffingwell formation was defined by Strauss et al., (2018a) as a $<100 \mathrm{~m}$ thick package of maroon, purple, and green phyllite and slate interbedded with black, dark grey, and "bottle green" thin-bedded radiolarian chert that sits disconformably(?) between the lower- 
middle Cambrian Neruokpuk Formation and the Upper Ordovician-Lower Devonian(?) Clarence River Group (Figs. 4.2). It is named after the Leffingwell Fork of the Aichilik River in the Demarcation Point 1:250,000 quadrangle of Alaska (Fig. 4.1), where the Leffingwell formation is well exposed in multiple imbricate thrust panels and folds with the Neruokpuk Formation and the Aichilik formation of the Clarence River Group.

Johnson et al. (2016) originally suggested that this chert-bearing interval marked the base of the Clarence River Group, and that it encompassed Reiser et al.'s (1980) Cambrian "chert and phyllite" (€cp) map unit. In the revised stratigraphic scheme of Strauss et al. (2018a), however, the Leffingwell formation was segregated from the Clarence River Group and assigned to an independent formation. Our maps also consider the Leffingwell formation separate from the Clarence River Group.

In the Firth River area of Yukon (Fig. 4.2), Lane and Cecile (1989) mapped an equivalent Ordovician "argillite and chert" unit (Oac or Oca), whose age designation came from a single Early Ordovician graptolite collection and by correlation with Lower Ordovician graptolitic strata of the Barn Mountains (Cecile, 1988). Strauss et al. (2018a) suggested that the chertbearing strata in the Firth River area are correlative with the Leffingwell formation in Alaska. Direct stratigraphic correlations with the Barn Mountains strata, however, remain uncertain due to potential lithological and geochronological differences (McClelland et al., 2015; Colpron et al., 2018). In the Clarence River area of the northern British Mountains, Reiser et al. (1980), Kelley et al. (1994), and Lane et al. (1995, 2016) also mapped an Ordovician chert-bearing succession.

Stratigraphic relationships in the northern British Mountains are still unclear. The area is structurally complex, and exposure is generally poor. The work of Johnson et al. (2016; 2018), 
Nelson et al. (2018), and Strauss et al. (2018a) suggests there are at least two distinct chertbearing successions of somewhat similar lithological composition, one of which is most likely associated with fault-bounded rocks of the Whale Mountain allochthon and referred to as the informal Ekaluakat formation (see below) and the other of which occupies a similar stratigraphic position to the Leffingwell formation (Fig. 4.2). From our reconnaissance mapping along the northern reaches of the Kongakut River in 2012 (Plate 1), we could not definitively distinguish these two chert-bearing successions in the area, and, therefore, we place many of the units in the area under the umbrella of the Ekaluakat formation. Future mapping efforts in the area are needed to confirm correlations with the map units exposed along the Clarence River. $€_{n}$ - Neruokpuk Formation (lower-middle Cambrian)

The Neruokpuk Formation gets its name from the "Neruokpuk Schist" of Leffingwell (1919), who described a thick succession dark-greenish gray to blueish gray quartzite and "semischist" in the Lake Peters area of the Mt. Michaelson 1:250,000 quadrangle (Fig. 4.1). Following this early work, the Neruokpuk Schist was renamed the Neruokpuk Formation (sensu lato), and its definition was expanded to include nearly all the map units that resided below the sub-Mississippian unconformity (e.g., Brosgé et al., 1962; Reed et al., 1968; Dutro et al., 1972; Norris, 1985). The work of Reiser et al. (1980) in Alaska and Lane (1991) in Yukon, however, applied a more restricted definition to the Neruokpuk Formation (sensu stricto), which was akin to the original definition of Leffingwell (1919). Strauss et al. (2013; 2018a), along with other recent authors (e.g., Johnson et al., 2016; Lane et al., 2016), also applied the restricted definition of Neruokpuk Formation, and it is now defined as the thick succession of dark-greenish gray to brownish-black interbedded sandstone, siltstone, phyllite, slate, and semischist. These strata are 
exposed in multiple east-west-trending antiformal and synformal belts throughout the Franklin, Romanzof, and British mountains (Fig. 4.1; Plates 1 and 2).

Thickness estimates for the Nerukpuk Formation range from $>5$ km (e.g., Leffingwell, 1919, Dutro et al., 1972; Norris, 1985) to <2500 m (Reiser et al., 1980; Johnson et al., 2016; Lane et al., 2016; Strauss et al., 2018a). Although true thickness differences certainly exist in different outcrop belts of the Neruokpuk Formation, these strata are commonly structurally thickened throughout the NE Brooks Range. Southern exposures of the Neruokpuk Formation (i.e., within the Franklin and southern British and Romanzof mountains) are commonly composed of interbedded thin- to very thick-bedded massive quartz arenite, wacke, and "semischist" with subordinate granule conglomerate and micaceous brown, maroon, and lightgreen phyllite, slate, and argillite. In thin section, the sandstone horizons are fine- to very coarsegrained, moderate to poorly sorted, and contain mono- and poly-crystalline quartz, potassium feldspar, and white mica with a wide variety of other accessory grains (Strauss et al., 2018a). The metamorphic grade appears to increase southward, as the Neruokpuk Formation becomes increasingly schistose in the Romanzof and Franklin mountains (e.g., Leffingwell, 1919; Reed, 1968; Sable, 1977).

In the northern part of the field area, in the northernmost British Mountains, the Neruokpuk Formation becomes thinner, and its character becomes difficult to distinguish from the underlying Fish Creek formation of the Firth River Group due to intense imbrication and similar lithofacies. The occurrence of Oldhamia-bearing maroon, green, and purple argillite/slate intervals also becomes more frequent (Lane, 1991; Lane et al., 1995; 2016; Strauss et al., 2018a). The Oldhamia trace fossils suggest that the Neruokpuk Formation is early to middle Cambrian in age (Herbosch and Verniers, 2011; MacNaughton et al., 2016). Oldhamia is also present in the 
lithofacies that resemble the southern exposures of the Neruokpuk Formation (Strauss et al., 2018a), suggesting that the two facies belts can be correlated in terms of chronostratigraphy. Neruokpuk-equivalent units are also found as far south as the Barn Mountains in Yukon (Fig. 4.1; McClelland et al., 2015). Maximum depositional ages for sandstone intervals of the Neruokpuk Formation, constrained by detrital zircon U-Pb geochronology, range from ca. 600$800 \mathrm{Ma}$.

In our maps (Plates 1 and 2), we do not separate the southern and northern lithofacies of the Neruokpuk Formation. We apply a stratigraphic thickness of $1,800 \mathrm{~m}$ in our cross sections. This was taking from the measured sections provided by Sable (1977), who described the Neruokpuk Formation along the Jago River (Fig. 4.1). This thickness was confirmed during our investigation of the region in the summer of 2014.

\section{$€ Z f r$ - Firth River Group, undivided (Cryogenian-Cambrian)}

The Firth River Group was informally defined by Lane et al. (2016) as succession of Neoproterozoic to middle(?) Cambrian siliciclastic and carbonate strata that stratigraphically underlie the Neruokpuk Formation. Its name is derived from the Firth River, which cuts across much of the northern British Mountains in Yukon, where the strata are prominently exposed. In Alaska, these strata were previously referred to as "Sequences D and E" of Dutro et al. (1972), "Domain III" of Mull and Anderson (1991), and more than ten distinct pre-Cambrian carbonatebearing map units of Reiser et al. (1980). The group was formalized by Strauss et al. (2018a) and organized into three informal formations, including the Fish Creek, Malcom River, and Redwacke Creek formations. Strauss et al. (2018a) also used C and Sr isotopic data to correlate the carbonate rocks of the Firth River Group to those exposed in the Shublik and Sadlerochit mountains (Strauss et al., 2018b) and infer a Cryogenian (middle Neoproterozoic) age. The Firth 
River Group remains undivided in the southern British and Romanzof mountains due structural complexity and limited exposure (Plates 1 and 2). Our maps do not delineate the individual formations, but each formation is described sepertally below.

\section{Fish Creek formation (no map units)}

The informal Fish Creek formation was named by Strauss et al. (2018a) after Fish Creek, a tributary of the Malcolm River in the southern Demarcation Point 1:250,000 quadrangle of Yukon (Fig. 4.1). In this area, and throughout other parts of the northern British Mountains of Yukon and Alaska, these strata are well exposed along several tributaries and consists of a lithologically complex succession of calcareous slate, phyllite, and shale, with minor dolomitic sandstone and thin, fine-grained quartzite beds. In Alaska, Reiser et al. (1980) split these strata into individual "Precambrian" map units, including the "phyllite and quartzite of Old Grungy Mountain" (p€pq), "sandstone and dolomite" (p€sd), "brown-weathering limestone and shale" (p€lb), "grey and black slaty shale" (p€s), "limestone and calcareous sandstone" (p€ls), "argillite and limestone" (p€al or p€as), and "phyllite and argillite" (p€pa). The mapping in the

Clarence River area by Kelley et al. (1994) and Lane et al. (1995) included these strata in their "Proterozoic or Cambrian limestone" unit (P€I).

The complex stratigraphic and structural architecture of these strata inhibit accurate thickness estimates, and their relative stratigraphic position is difficult to determine. They are seperated from the underlying Malcolm River formation because fine-grained intervals of shale, argillite, phyllite, and slate are more abundant (Strauss et al., 2018a). Lane et al. (1995, 2016) postulated that these strata may simply be a basinal facies of the more coarse-grained Neruokpuk Formation in the southern part of the field area. Our observations, however, align with those of other mappers in Alaska (e.g., Dutro et al., 1972; Sable, 1977; Reiser et al., 1980; Hanks 1989; 
1993; Strauss et al., 2018a), placing the Firth River Group strata directly beneath the Neruokpuk Formation in the southern British and Romanzof mountains and suggesting the calcareous shale and limestone units grade into the basal sandstone-dominated strata of the Neruokpuk Formation and should therefore remain an independent unit.

\section{Malcolm River formation (no map units)}

The informal Malcolm River formation was named by Strauss et al. (2018a) after the Malcolm River, whose headwaters are in the southern Demarcation Point 1:250,000 quadrangle of Yukon (Fig. 4.1). The Malcolm River formation is widely exposed throughout the northern British Mountains and encompasses Reiser et al.’s (1980) Precambrian limestone-dominated map units (p€l, p€Ir, and Is) in the Demarcation Point quadrangle of Alaska and Lane et al.'s (1995) "Proterozoic or Cambrian limestone" map unit (P€I) in adjacent Yukon. In district locations of the southern British and Romanzof Mountains, intensely deformed exposures of the Malcolm River formation are also present beneath the Neruokpuk Formation in the cores of a Brookian antiforms, specifically along a narrow stretch of the Kongakut River (Plate 1) and in the the headwaters of the Jago River (Plate 2), although we mapped these exposure as "Firth River Group undivided" because they were not examined in detail.

In its type area, the Malcom River formation is $\sim 15$ to $100 \mathrm{~m}$ thick and consists almost exclusively of medium- to thick-bedded, light grey to reddish black interbedded carbonate mudstone, packstone, wackestone, and rudstone with minor intervals of dolomitic wackestone and dark grey slate or phyllite. The Malcolm River formation is distinguished from the overlying Fish Creek formation by its typical gritty texture caused by the mixture of detrital quartz grains and carbonate material. Although many stratigraphic intervals of the Malcolm River formation are massive and/or partially recrystallized into coarse-grained spar, these strata locally display 
normal grading, trough cross-stratification, cut/fill geometries with scour surfaces, and a wide variety of Bouma turbidite subdivisions, which suggest deposition in a deep-marine setting by carbonate-dominated gravity flows.

\section{Redwacke Creek formation (no map units)}

The informal Redwacke Creek formation is named after Redwacke Creek, a tributary of the Egaksrak River (Fig. 4.1), in the northwestern British Mountains of the Demarcation Point 1:250,000 quadrangle in Alaska and is equivalent to the Precambrian "volcaniclastic rocks of Redwacke Creek" (p€v) unit of Reiser et al. (1980). These strata are only exposed near the Redwacke Creek and have not been mapped in any other part of the field area. We examined outcrops of the Redwacke Creek formation $\sim 5 \mathrm{~km}$ east of the Aichilik River during our traverse down the Leffingwell Fork in 2013, as did J.V. Strauss in 2011 during the Elkaluakat River traverse. Based on regional mapping relationships (Reiser et al., 1980; Hanks, 1989; 1993), Strauss et al. (2018a) proposed that the Redwacke Creek formation is the stratigraphically lowest unit in field area; however, the field relationships in the area are poorly constrained, and the Redwacke Creek could represent a lateral facies change or could be bounded by unmapped faults.

The base of the Redwacke Creek formation is not exposed and the overlying contact with the Malcolm River formation is covered by talus. The strata consist of interbedded rusty weathering, dark green medium- to thick-bedded volcaniclastic lithic arenite and wacke, pebble to cobble conglomerate, and minor dark green slate. A distinctive feature of the Redwacke Creek formation are the volcaniclastic sandstone and conglomerate intervals that weather rusty-brown. In thin section, these strata consist of an altered volcanogenic matrix of clay minerals with medium to coarse-grained and subrounded to subangular plagioclase, amphibole, clinopyroxene, 
and monocrystalline and polycrystalline quartz (Strauss et al., 2018a). The overall thickness of the Redwacke Creek formation is unknown, but the main exposures in the northern British Mountains of Alaska range from 50 to $200 \mathrm{~m}$ thick.

\section{Whale Mountain Allochthon (lower Cambrian-Upper Ordovician)}

The Whale Mountain allochthon is a fault-bounded, structural complex of lower Cambrian-Upper Ordovician mafic volcanic and marine sedimentary rocks (Johnson et al., 2016; 2018). Dutro et al. (1972) originally assigned many of these rocks to "sequences A, C, and E" of the expanded Neruokpuk Formation (sensu lato), which contained several members, including the "volcanic and carbonate" and "chert and phyllite" members. These three sequences, however, also included several other members that are now assigned to separate lithostratigraphic units, including the Clarence River Group, the redefined Neruokpuk Formation (sensu stricto), and parts of the Firth River Group (e.g., Johnson et al., 2016; Strauss et al., 2018a). In the stratigraphic scheme of Dutro et al. (1972), nearly all of the members in the NE Brooks Range were assigned to the Cambrian, largely because of two separate trilobite collections from the "volcanic and carbonate member" of "sequences A and C." Included in these collections, was an early Cambrian trilobite genus, Ollenius, which was recovered from carbonate rocks exposed along the Marsh Fork of the Canning River in the southeastern corner of the Mt. Michelson 1:250,000 quadrangle (Fig. 4.1) The second trilobite collection included a late Cambrian Saratogia genus, which was recovered from lithologically similar carbonate rocks exposed along a ridge between the Leffingwell Fork of the Aichilik River and the Egakserak River in the central part of the Demarcation Point 1:250,000 quadrangle in Alaska (see Johnson et al., 2018 and references therein for review). 
Johnson et al. (2016) reported Ordovician-Early Devonian(?) detrital zircon U-Pb ages from strata below the volcanic and carbonate rocks exposed along the Kongakut River, in what are now assigned to the Buckland Hills formation of the Clarence River Group (Strauss et al., 2018a). With the upper Cambrian carbonate and volcanic rocks sitting on Ordovician-Early Devonian(?) strata, Johnson et al. (2016) contended that a major thrust fault separates the two lithostratigraphic domains. A similar relationship exists in the Romanzof Mountains (e.g., Dutro et al., 1972; Johnson et al., 2018; Strauss et al., 2018a). Although the age of the fault is unknown, Johnson et al. $(2016 ; 2018)$ speculated that the emplacement of the Whale Mountain allochthon is linked to early Paleozoic tectonic events associated with the assembly of the North Slope subterrane of Moore et al. (1994). Rocks composing the Whale Mountain allochthon are defined by the five lithostratigraphic units (Fig. 4.2), but because structural complexities generally preclude the measurement of detailed type sections, the units have not been formalized.

\section{€mv-Marsh Fork Volcanic Rocks (lower-upper Cambrian)}

The Marsh Fork volcanic rocks were originally defined as part of the "volcanic and carbonate member" of "sequence A" in the stratigraphic scheme of Dutro et al. (1972). The unit was later split into the "Cambrian volcanic and volcaniclastic rocks" (€v) and the "Cambrian limestone" ( $\mathrm{Cl})$ of Reiser et al. (1980). In a geochemical and petrographic assessment of the volcanic rocks, Moore (1987) applied the Marsh Fork name to a series of basaltic flows that are prominently exposed along the Marsh Fork of the Canning River drainage (Fig. 4.1). The age of the flows was assigned to the lower Cambrian by the Ollenius trilobites collected by Dutro et al. (1972) from carbonate strata that are interlayered with the volcanic rocks. Johnson et al. (2018) used similar geochemical and petrographic techniques to correlate the Marsh Fork volcanic rocks 
across the Romanzof Mountains to the headwaters of the Jago and Aichilik rivers, located in the southwestern corner of the Demarcation Point 1:250,000 quadrangle in Alaska (Fig. 4.1).

Along the Jago and Aichilik rivers, the volcanic rocks occur along an $\sim 300$ to $800 \mathrm{~m}$ thick exposure of greenish-gray, mafic amygdaloidal volcanic flows and subordinate beds of conglomerate, volcaniclastic argillite, and chert. The basalt flows are typically massive or pillowed and individually range from 1 to $10 \mathrm{~m}$ thick. The geochemical and petrographic data from Moore (1987) and Johnson et al. (2018) indicate that the Marsh Fork volcanic rocks have a tholeiitic composition and suggest that they may have erupted in a mid-ocean ridge setting.

\section{€mv-Whale Mountain Volcanic Rocks (lower-upper Cambrian)}

The Whale Mountain volcanic rocks were also originally defined as part of the "volcanic and carbonate member" in the stratigraphic scheme of Dutro et al. (1972), but they formed the upper part of their "sequence C". Moore (1987) differentiated these volcanic rocks from those exposed along the Marsh Fork because of potential differences in age and because of the differences in their geochemical and petrographic character. The name comes from Whale Mountain, a prominent, east-west trending ridge that crosses the middle reaches of the Kongakut River in the Demarcation Point 1:250,000 quadrangle in Alaska (Fig. 4.1). The ridge crosses from the Alaska-Yukon boundary to the Leffingwell Fork of the Aichilik River. The age of the volcanic rocks was originally constrained by a single trilobite assigned to the genus Saratogia, which was recovered by Dutro et al. (1972) from a massive block of carbonate rock exposed at the base of large series of volcanic flows at the western limit of the Whale Mountain ridge, in the area between the Leffingwell Fork and the Egaksrak River (Fig. 4.1).

Like the Marsh Fork volcanic rocks, the Whale Mountain volcanic rocks are typically exposed as massive and pillowed flows of dark-greenish gray basalt that weather olive green and 
are interbedded or interlayered with a variety of volcanic-rich conglomerate, argillite, and other volcaniclastic rocks. Their petrologic and geochemical characteristics, however, are significantly different from the Marsh Fork volcanic rocks. They are typically porphyritic, containing phenocrysts of olivine, clinopyroxene, and plagioclase (Johnson et al., 2018). Geochemically, the Whale Mountain volcanic rocks are enriched in the incompatible elements, including $\mathrm{Ti}, \mathrm{Nb}, \mathrm{Nd}$, and $\mathrm{Zr}$ (Moore, 1987; Goodfellow et al., 1995; Johnson et al., 2018). The geochemical and petrological data suggests that the Whale Mountain volcanic rocks have a composition resembling alkaline basalt that potentially erupted in an ocean island setting (Johnson et al., 2018).

The overall thickness of the volcanic rocks is uncertain. Structural complications and the absence of clear marker beds preclude direct stratigraphic measurements. The same is true for the Marsh Fork volcanic rocks in the Romanzof Mountains. Along the central portion of Whale Mountain ridge, between the Kongakut and Egaksrak rivers, the volcanic rocks are between $\sim 700$ and $1000 \mathrm{~m}$ thick, as estimated from satellite imagery and field observations. These estimates, however, includes thickness additions from the intertongued Egaksrak formation and assumes that the section is not disrupted by unmapped faults.

\section{Ce - Egaksrak Formation (lower-upper Cambrian)}

The Egaksrak formation was defined by Johnson et al. (2018) to include the carbonate rocks that intertongue with the both the Marsh Fork and Whale Mountain volcanic rocks in the British and Romanzof Mountains. This designation replaced the "Cambrian limestone" (Cl) map unit of Reiser et al. (1980). The name was derived from the Egaksrak River in the Demarcation Point 1:250,000 quadrangle in Alaska (Fig. 4.1), which is near the site where Dutro et al. (1972) recovered the late Cambrian trilobites. 
Exposures of the Egaksrak formation typically occur as 10 to $100 \mathrm{~m}$ thick megablocks or olistostromes entrained and deformed with the volcanic rocks. They also occur as discrete layers deposited between volcanic flows, which in some places are $\sim 100 \mathrm{~m}$ thick and extend laterally for $>10 \mathrm{~km}$. The strata are highly variable, consisting of dark-gray- to tan-weathering, intensely sheared and contorted beds of rudstone, massive recrystallized pelloidal and oolitic grainstone and packstone, and finely laminated fossiliferous carbonate mudstone and wackestone. Many the rudstone intervals contain angular to well-rounded, pebble- to sand-sized volcanic lithoclasts. The occurrence of trilobite, agnostoid, and brachiopod fossils are typically found in the laminated, dark-brown and tan carbonate mudstone and wackestone intervals.

We visited the Leffingwell Fork fossil locality of Dutro et al. (1972) twice, once in the summer of 2013 and again in the summer of 2014. In the summer of 2014, we re-sampled the trilobite locality and confirmed the upper Cambrian (lower-middle Fuongian) assignment of the Egaksrak Formation with a collection that included a single agnostoid specimen and at least six individual trilobite specimens (Johnson et al., 2018). A separate collection was recovered in the summer of 2013 from similar exposures of the Egaksrak formation in the headwaters of the Malcolm River, along the Yukon portion of the Whale Mountain ridge. These fossils also confirmed an upper Cambrian assignment for the Egaksrak formation (Johnson et al., 2018). In the Marsh Fork area, Dutro et al. (1972) recovered a trilobite specimen that they identified as the genus Ollenius, indicating that parts of the Egaksrak formation may be assigned to the lower Cambrian. In the summer of 2014, we traversed across the major fault zone, in the headwaters of the Aichilik River, which separates the Whale Mountain allochthon from the underlying Clarence River group. In this location, we discovered a new trilobite locality. Although this locality is more-or-less along strike of Dutro et al.'s (1972) Marsh Fork lower Cambrian locality, 
the recovered fossils at the upper Aichilik River locality more closely align with an upper Cambrian fauna recovered from the Egaksrak formation along the Whale Mountain ridge (Johnson et al., 2018). Johnson et al. (2018), thus suggested that the Egaksrak formation recorded early to late Cambrian carbonate deposition on a collection of volcanic islands that had formed outboard the ancient Laurentian margin.

\section{O€r - Romanzof Formation (Cambrian(?)-Upper Ordovician)}

The Romanzof formation was established in the work of Johnson et al. $(2016 ; 2018)$ and Strauss et al. (2018a). It includes the "chert and phyllite" unit that was established in the mapping efforts of Brosgé et al. (1962), Dutro et al. (1972), and Reiser et al. (1980). Its name is derived from its widespread exposure across in the Romanzof Mountains, but also because Mull and Anderson (1991) applied the name "Romanzof chert" to the same succession of rocks. Johnson et al. $(2016,2018)$ and Strauss et al. (2018) updated the Romanzof chert to the Romanzof formation to include the "Cambrian-Ordovician volcanic wacke and tuffaceous sandstone" (O€w) map unit of Reiser et al. (1980), which appears sparsely interbedded or imbricated with chert and phyllite strata in the headwaters of the Jago and Aichilik rivers.

The Romanzof formation comprises a heterolithic succession of interbedded black, grey, white, and green thin-bedded radiolarian chert, dark-grey, green, and maroon phyllite and slate, and discrete intervals (<50 m thick) of channelized medium- to thick-bedded, dark-green to gray sandstone (Fig. 4.2). The sandstone intervals consist of poorly sorted, angular to subangular, fine- to very coarse-grained (and occasionally granular) massive lithic wacke. In thin section, these deposits are dominated by poorly sorted chert, volcanic lithic fragments, and rare monoand poly-crystalline quartz set within an altered matrix of sericite, clay minerals, and calcite (Strauss et al., 2018a). 
The Romanzof formation is frequently imbricated and deformed into upright isoclinal folds (e.g., Mull and Anderson, 1991). These structural complications preclude any reliable thickness estimates, but its extensive exposure throughout the southern Romanzof Mountains (Plate 2), suggests that it exceeds $500 \mathrm{~m}$ thick. The age of the Romanzof formation is constrained by a collection of Lower-Middle Ordovician biserial graptolites that Moore and Churkin (1984) recovered from the Canning River in the northwestern corner of the Arctic 1:250,000 quadrangle in Alaska (Fig. 4.1). Detrital zircon U-Pb ages from lithic wacke units of the Romanzof Formation, suggests a ca. 452 Ma (Late Ordovician) maximum depositional age (Strauss et al., 2018a).

O€e-Ekaluakat Formation (Cambrian(?)-Upper Ordovician)

The Ekaluakat formation was established in the work of Johnson et al. (2018) and Strauss et al. (2018a) to define a succession of mafic volcanic rocks, volcaniclastic breccia, tuff, chert, phyllite, and slate exposed in the northern British Mountains (Fig. 4.1). The Ekaluakat formation includes the "red and green phyllite" (ph), "Ordovician gray phyllite and chert" (Opc), "Ordovician volcaniclastic and volcanic rocks" (Ovc), and "Ordovician black slate" (Ovc) map units of Reiser et al. (1980). Many of these same map units were described in the Clarence River area along the Alaska-Yukon boundary by Kelly et al. (1994) and Lane et al., (1995). It is named for the Ekaluakat River in the central part of the Demarcation Point 1:250,000 quadrangle in Alaska, which J.V. Strauss visited in the summer of 2011. Rocks of the Ekaluakat formation are also well exposed along the northern bend of the Kongakut River (Plate 1), which we visited in the summer of 2012.

Johnson et al. (2018) and Strauss et al. (2018a) proposed a tentative correlation between the Ekaluakat and the Romanzof formations, suggesting that both formations represent deep- 
marine sedimentary components in the upper parts of the Whale Mountain allochthon. However, some significant lithological differences exist between the two formations. For example, the Ekaluakat formation has a higher volcaniclastic component, including a distinctive, $\sim 1$ to $10 \mathrm{~m}$ thick unit of dark gray volcanic breccia with clasts consisting of both vesicular basalt and recycled sedimentary rocks. The geochemical character of these volcanic units is similar to the Whale Mountain volcanic rocks, although they are slightly more enriched in the incompatible elements (Johnson et al., 2018). Tuff is another common component of the Ekaluakat formation and forms it $10 \mathrm{~cm}$ to $<1 \mathrm{~cm}$ thick horizons or lamination within a greater succession of red and green phyllite, argillite, and slate.

The age of the Ekaluakat formation is constrained by a single Late Ordovician graptolite collected from a succession of black slate that appears interbedded with the volcaniclastic and volcanic rocks along the Alaska-Yukon boundary (Reiser et al., 1980). As noted by Johnson et al. (2016; 2018), Strauss et al. (2018a), and Nelson et al. (2018), the stratigraphic assignment of this fossil locality is unclear, as the graptolite could have come from units now assigned to the Clarence River Group or the Leffingwell Formation. Because we have not spent much time in this area, and because of structural complications and poor exposure, our stratigraphic assignments remain poorly constrained. Johnson et al. (2016) reported 63 concordant detrital zircon $\mathrm{U}-\mathrm{Pb}$ ages from a tuffaceous sandstone unit, containing a nearly unimodal age distribution centered at ca. $500 \mathrm{Ma}$, suggesting that the Ekaluakat formation was deposited no earlier than the late Cambrian and that some of the volcanic rocks are time correlative with the Whale Mountain and Marsh Fork volcanic rocks to the south. 


\section{LITHODEMIC UNITS}

\section{Dgr - Granitic Rocks (Upper Devonian)}

In the central part of the field area, between the Jago and Hulahula rivers, the sedimentary rocks are crosscut by four individual intrusive bodies. The Okpilak Batholith is the largest intrusive body, covering an area of $>400 \mathrm{~km}^{2}$ and reaching surface elevations $>3,000 \mathrm{~m}$. South of the batholith, three smaller bodies or stocks are exposed along a north-south trend in the upper reaches of the Jago River (Plate 2). They are named the Jago, Romanzof, and Sheenjek stocks. The northern bodies were studied in detail by Sable (1977), whereas the southern bodies have not been closely studied. In fact, the southernmost intrusive body, the Sheenjek Stock, had not been discovered until we visited the area in the summer of 2015 .

The northern most intrusive bodies, the Okpilak Batholith and the Jago Stock, consists of light- to medium gray, medium- to coarse-grained granite and quartz monazite, with a mineralogy of potassium feldspar, quartz, plagioclase feldspar, and biotite. In the southern intrusive bodies, the Romanzof and Sheenjek stocks, hornblende becomes abundant and potassium feldspar becomes sparse, shifting the rocks closer to diorite and tonalite compositions. The most reliable radiometric age from the intrusive rocks is the $381 \pm 10 \mathrm{Ma}$, determined from the upper intercept on a $\mathrm{U}-\mathrm{Pb}$ concordia plot of zircon grains collected from the Okpilak batholith and the Jago Stock (Dillon et al., 1987). Reiser et al. (1980) also reported a $432 \pm 1 \mathrm{Ma}$ $\mathrm{K}-\mathrm{Ar}$ age from hornblende in the Romanzof Stock. Preliminary unpublished zircon U-Pb ages from rocks that we collected from the Romanzof and Jago stocks, however, align with the ca. $380 \mathrm{Ma} \mathrm{U}-\mathrm{Pb}$ age from Dillion et al. (1987), as do the ca. 368-375 Ma zircon U-Pb ages from an intrusive suite in the Yukon portion of the NE Brooks Range (Ward et al., 2018), indicating that the K-Ar age of Reiser et al. (1980) is unreliable. 


\section{Dar - Alerted rocks (upper Devonian(?))}

Contact metamorphism and alteration of the country rocks that surround the Devonian intrusive rocks were describe in detail by Sable (1977). In most places, especially at the northern and southern margins of the Okpilak Batholith, the contacts between the granitic rocks and the country rocks are concordant with the orientation of bedding planes of many of the lithostratigraphic units in the area, including the Clarence River Group, Neruokpuk Formation, Firth River Group, and units from the Whale Mountain allochthon. Along the southern margin of the Batholith, and along the southern margin of the Jago Stock (Plate 2), the contact with the Neruokpuk Formation and the Achilik formation coincides with a major thrust fault (Fig. 4.3E). In the map of Reiser et al. (1980), this fault is drawn as the westward continuation of the Whale Mountain thrust (see section of structural style below), which extends eastward into the Kongakut River area (Plate 1).

The granitic rocks do not exhibit definitive chilled margins, and contact metamorphism is rare, suggesting that the emplacement of the granitic rocks occurred at shallow depths and relatively dry conditions. Where contact metamorphism exists, it typically results in hornfels when intruding pelitic units and skarn when intruding impure carbonate units. In most places, however, the contact metamorphism projects no more than a $100 \mathrm{~m}$ into the surrounding country rocks. Along the northwest margin of the Jago Stock and southeast of the Okpilak Batholith, the Neruokpuk Formation is thermally metamorphosed into quartzite and banded gneiss that is repeatedly folded into $\mathrm{m}$ - to cm-scale isoclinal folds (Fig. 4.3). In other areas, Sable (1977) observed infiltration of granitic rocks into minute fractures that cross cut the country rocks, suggesting that the granitic rocks were emplaced by forceful injection. 
The sub-Mississippian unconformity at the base of the Kekiktuk Conglomerate is well exposed in many areas surrounding the granitic rocks, especially on top of the Jago Stock, along the east wall of the Jago River (Fig. 4.3C). This contact is gradational or highly weathered, with fresh granite giving way to rocks with schistose a nd altered textures, and then conglomeratic rocks, which include abundant granitic rock clasts. This suggest that the granitic rocks were subaerially exposed at the time of Kekiktuk deposition (Early Mississippian), as the granitic rocks were reworked and deposited within the conglomerate.

\section{STRUCTURAL STYLE}

\section{Brookian deformation (Mesozoic-Cenozoic)}

Brookian deformation initiated during the Late Jurassic-Early Cretaceous (ca. 160-120 Ma), when the Koyukuk arc collided with the southern margin of the Arctic-Chukotka microplate (e.g., Mull, 1982; Mayfield et al., 1988; Moore et al., 1994; 2015). The collision resulted in high-grade metamorphism of Neoproterozoic-Devonian rocks in the southern Brooks Range and the emplacement of several allochthonous thrust wedges of Upper Devonian-Jurassic continental margin strata in the frontal part of the orogen, including the Endicott Mountains, Picnic Creek, Kelly River, Ipnavik River, and Nuka Ridge allochthons (e.g., Mull, 1982; Mayfield et al., 1988; Moore et al., 1994; 2015). Later phases of Brookian contraction deformed middle and Upper Cretaceous strata of the Colville foreland basin (e.g., Moore et al., 1994; 2004). Fission-track data indicate that these phases occurred during the early Cenozoic (ca. 6045 Ma; e.g., O’Sullivan et al., 1997).

The NE Brooks Range is a prominent structural salient where the deformation front protrudes $>80 \mathrm{~km}$ out from the main east-west axis of the Brooks Range. Like the deformation observed in the subsurface of the Colville basing, the NE Brooks Range salient formed in 
response to late stages of Brookian contraction in the Cenozoic (Wallace and Hanks, 1990; Hanks and Wallace, 1990, Hanks, 1993). These late stages of uplift are also recorded in Cenozoic cooling ages from apatite fission-track data (O’Sullivan, 1993; O’Sullivan and Wallace, 1990).

Two major detachment zones, or décollements, which exist at different structural levels, control the northward propagation and accommodation of shortening in the NE Brooks Range (Wallace and Hanks, 1990). The upper detachment zone resides within the mechanically incompetent Kayak shale, and the competent units of the overlying Lisburne and Sadlerochit groups are repeatedly deformed into upright detachment folds of $\mathrm{m}$ - to $\mathrm{km}$-scale wavelengths (e.g., Wallace and Hanks, 1990; Wallace, 1993; Homza and Wallace, 1997; Atkinson and Wallace, 2003; Jadamec and Wallace, 2014). A lower detachment zone links a series of breakthrough, high-angle thrust faults that originate deep below the sub-Mississippian unconformity and breach across or sole into the Kayak detachment zone.

Fold geometry above the Kayak detachment zone is largely controlled by competent and incompetent unit thicknesses, which vary throughout the field area. In some cases, the Lisburne Group and the lower Sadlerochit units (Echooka Formation) behave as a mechanically homogeneous unit and are folded in concert with one another, producing long wavelength folds (Fig 4.3A). In other parts of the NE Brook Range and at different structural levels, short wavelength, parasitic folds form, particularly where decimeter-scale beds of the lower Lisburne Group (Alpha Limestone) are rhythmically layered into competent and incompetent intervals (Fig 4.3B). The Kayak Shale also exhibits strong mechanical stratigraphy, as interbedded competent limestone intervals are deformed into cylindrical buckle folds and the shale intervals show pressure solution cleavage in the cores of larger Lisburne folds. Occasionally breakthrough 
thrust faults originate in the Kayak shale cut the forelimbs of rotated Lisburne folds, particularly the where interlimb angle of the folds becomes $>90^{\circ}$ and/or where the Kayak Shale interval is thin (Jadamec and Wallace, 2014).

Because our study is focused on deformation of the sub-Mississippian rocks, and because many of the Lisburne detachment folds are below the resolution of our maps, the cross sections shown on Plates 1 and 2 do not account for the shortening and structural thickening of the detachment folds. Folds in Kekiktuk Conglomerate, however, have wavelengths and interlimb angles that are much larger than those in the Lisburne Group, and they define a set of first-order folds related to bending above the basement-derived high-angle thrust faults (reverse faults). In the Kongakut River area, Ellesmerian units appear folded about a subhorizontal, east-west trending axis, whereas in the Jago River area, the Ellesmerian fold axis is slightly rotated, trending at $\sim 75^{\circ}$ but also with a subhorizontal plunge (Fig. 4.5). The contrast between the eastnortheast trends in the Jago River and and east-west trends in the Kongakut River could reflect oroclinal bending durning north-northwest tectonic transport during Cenozoic deformation. Also, uplift and bending associated with basement-derived thrust faults likely caused additional rotation of structures within the Ellesmerian sequence, as progressively deeper structural levels were involved in the later stages of Cenozoic contraction (e.g., Hanks, 1993).

The basement-derived thrust faults are drawn with steep dips $\left(60-70^{\circ}\right)$ that link to a deeper detachment zone and are akin to thick-skinned or "Lauramide" style reverse faults seen elsewhere along the North American Cordillera. These faults typically have low amounts of displacement, but they result in high amounts of structural relief. Some of the faults bring subMississippian units in direct contact with strata of the Ellesmerian sequence. For example, The 
Whale Mountain thrust, which cuts through the middle part of the Kongakut River cross section (Plate 1, A-A' cross section), juxtaposes the Clarence River Group strata and the Whale Mountain volcanic rocks units with Lisburne and Sadlerochit group strata. In the southern part of the Jago River area (Plate 2, cross section B-B'), the basement-derived faults become more closely spaced and they appear to splay, forming smaller synthetic faults as they cross cut the incompetent rocks of the Ulungarat and Mangaqtaaq formations.

Along the east wall of the Jago River valley, the Devonian(?) altered rocks, which are associated with the granitic rocks of the Jago Stock, are displaced by the Whale Mountain thrust and placed above the Lisburne Group strata (4.3E), implying that the granitic rocks were involved with Cenozoic thrusting, as previous authors have suggested (e.g., Hanks and Wallace, 1990; Peapples et al., 1997). The granitic rocks also deflect the northward propagation of Brookian contraction in the area. The major faults appear to bend and, in some cases, form tear faults around the intrusions. This is also supported by the westward rotation of fold axes observed in the Ellesmerian Sequence (Fig. 4.5). Our interpretation, however, differs from previous researches who interpreted the granitic rocks to be involved with a shallow, fold-andthrust belt style of faulting, which resulted in long lateral transport distances of the granitic rocks (e.g., Wallace and Hanks, 1990; Hanks and Wallace; 1990; Peapples et al., 1997). Instead, we propose that the granitic rocks were also cross cut by the basement faults, but at high angles, with much of the shortening accommodated by vertical displacement.

\section{Pre-Mississippian Deformation}

Rocks below the sub-Mississippian unconformity are complexly deformed into tight and isoclinal, class II (similar) folds with inclined to sub-horizontal axial surfaces (Figs. 4.4 and 4.5). The geometry and structural style of the sub-Misissippian units is strongly discordant with the 

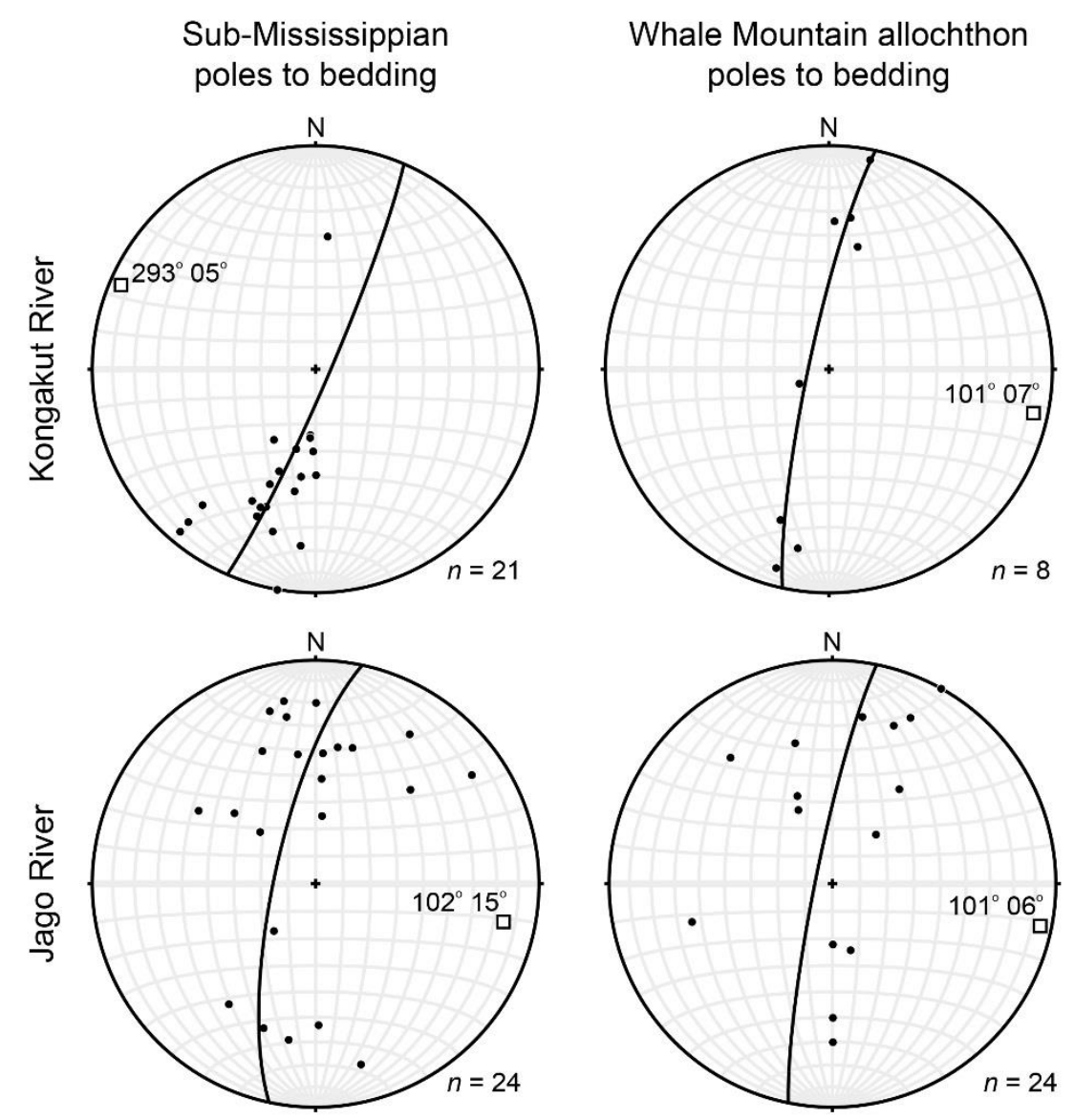

Whale Mountain allochthon

poles to bedding

Ulungarat-Mangaqtaaq poles to bedding

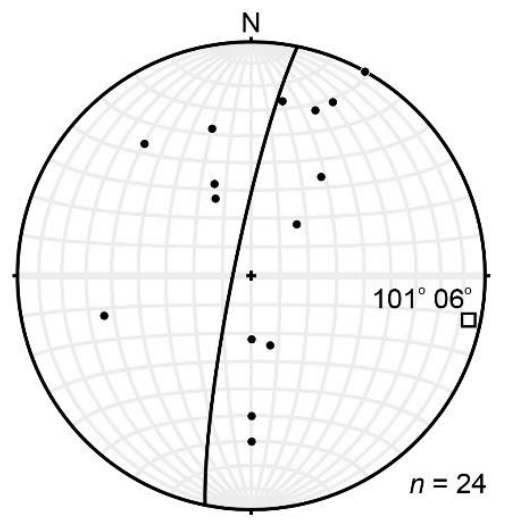

Ellesmerian Sequence

poles to bedding
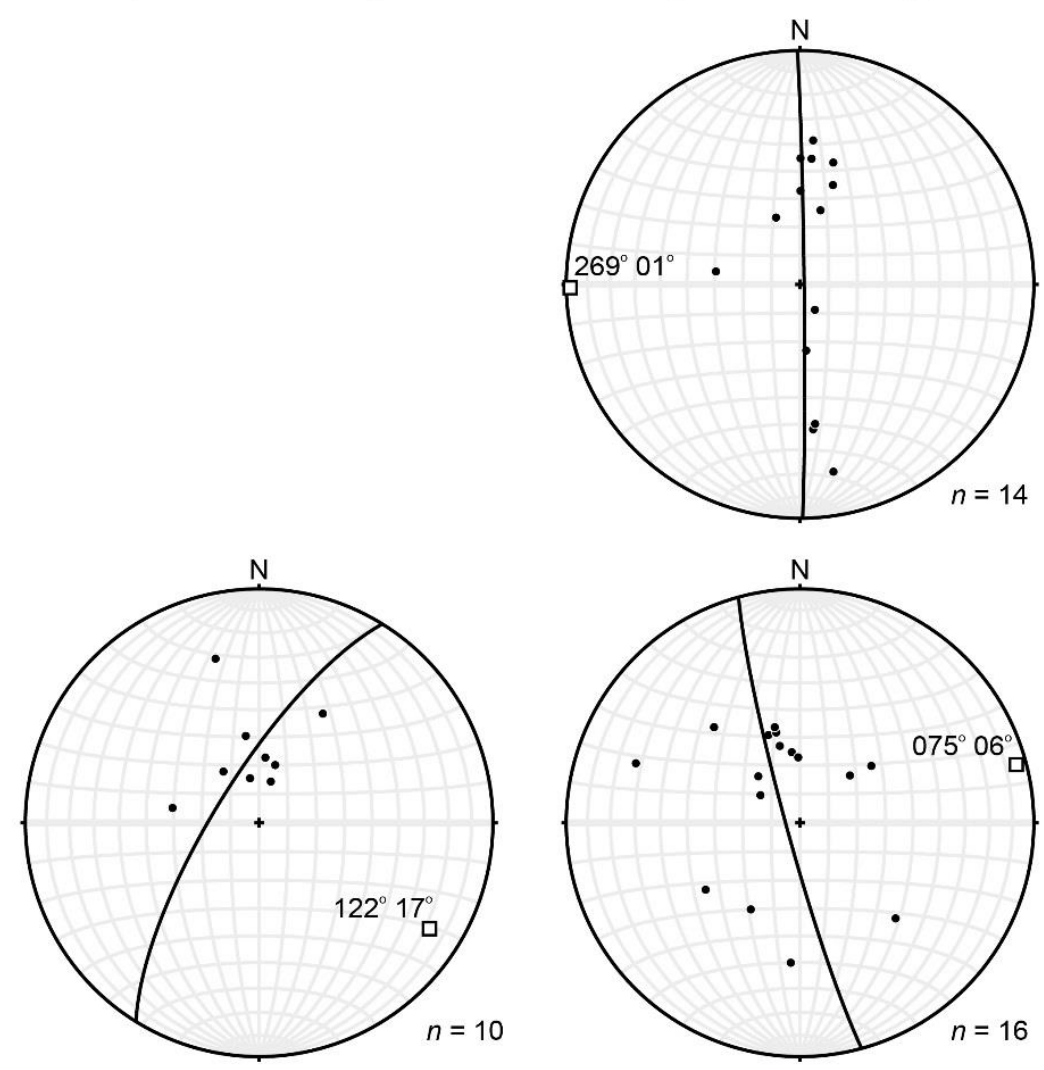

Figure 4.5: Lower-hemisphere, equal-area stereographic projections of poles to bedding planes from rocks in the Jago and Kongakut river areas. Filled circles represent poles to bedding planes, great circles represent calculated best-fit great circle to observed data, and open squares represent calculated fold axes of observed data. 
upright detachment folds observed in the overlying Ellesmerian sequence, and the fabrics and fold trends are truncated by the sub-Mississippian unconformity. Past researches have thus concluded that an earlier phase of deformation is recorded in the sub-Mississippian rocks of the NE Brooks Range (e.g., Reed, 1968; Mull 1982; Oldow et al., 1987; Wallace and Hanks, 1990; Hanks, 1993; Moore et al., 1994; Lane, 2007; Johnson et al., 2016), yet the tectonic context and timing of this phase of deformation is still poorly understood.

Detailed mapping and structural measurements in the Franklin Mountains by Oldow et al. (1987), suggests that the pre-Mississippian deformation is recorded in mesoscopic and microscopic, south-verging, " $\mathrm{D}_{1}$ " folds that are overprinted by later Brookian phases of deformation ( $D_{2}$ and $D_{3}$ phases). Along the lower reaches of the Aichilik River, in the western part of the British Mountains (Fig. 4.1), the work of Hanks et al. (1993) and Hanks (1989) showed that $D_{1}$ structure are predominantly south dipping and instead record north-vergent folding. From surface and subsurface mapping in northern Yukon, Lane (2007) showed that many of the sub-Mississippian folds and fabrics favore south vergence, but the folds are also cut series of north-directed thrust faults (backthrusts). Lane (2007) noted that the structures were intruded by the Late Devonian granitic rocks, indicating that deformation occurred in pre-Late Devonian time, and he named this the Romanzof orogeny.

A series of Brookian thrust faults at the southern limit of our field area expose Middle Devonian-Lower Carboniferous(?) strata of the Ulungarat and Manqataaq formations. These units are gently folded/tilted, and the bedding planes dip to the southeast and closely follow the structural trends in the overlying Ellesmerian Sequence (Fig. 4.5). They are not deformed into the tight and isoclinal folds that exemplify the sub-Mississippian rocks to the north, suggesting that Romanzof deformation may have actually initiated prior to the Middle Devonian. Despite 
this age constraint, interpretations on the tectonic and depositional setting of the Ulungarat strata are uncertain, and it is plausible that these strata were deposited in a foreland basin that formed during the Romanzof orogeny. Conversely, Anderson (1995) interpreted the Ulungarat and Manqataaq formations as being deposited in a rift basin. How far these units have been transported by Brookian deformation is also unclear, but in the B-B' cross section of Plate 2, the Ulungarat and Manqataaq map unit (Dmu) is coupled with the underlying Romanzof formation (O€r) of the Whale Mountain allochthon.

The timing and kinematics of the Whale Mountain allochthon's emplacement are also unclear. As we mentioned above, the base of the allochthon is marked by a major fault zone that separates it from the rest of the sub-Mississippian rocks in the field area. In many places, the Upper Cambrian volcanic and carbonate rocks of the allochthon are juxtaposed with upper strata of the Clarence River Group, defined as the Lower Devonian(?) Buckland Hills formation of Lane et al. (2016) and Strauss et al. (2018a). This requires that emplacement occurred after or during Buckland Hills deposition. Rocks of the allochthon are also intruded by the granitic rocks of the Sheenjek Stock in the headwaters of the Jago River (Plate 2). Assuming that the age of the Sheenjek rocks parallel the ca. 380 Ma zircon U-Pb ages from the neighboring Okpilak Batholith and Jogo Stock (Dillon et al., 1987), the timing of emplacement narrows to an Early-Late Devonian window. Emplacement may have preceded the deposition of Ulungarat rocks in the Middle Devonian, but without further investigation of the contact relationships between the Ulungarat and Whale Mountain allochthon units, this time constraint cannot be confirmed.

We propose, as did Johnson et al. (2016, 2018), that the emplacement of the allochthon was related to, or directly the cause of, the Romanzof orogeny. Whether the emplacement resulted in south- or north-vergent folding of the underlying strata is uncertain. Our maps (Plates 
1 and 2) suggests that fold vergence varies across the NE Brooks Range. In the Kongakut River area, the sub-Mississippian bedding planes and fold axes predominantly dip to the north and favor a south-vergent style of folding (Figs. 4.4 and 4.5). Conversely, most of the units in the Jago River area dip to the south and favor a north-vergent style of folding. The sub-Mississippian strata and related folds are also repeatedly disrupted by both north- and south-directed thrust faults. In addition, none of these structures appear to be significantly reoriented by Brookian deformation, as there is no correspondence between the breakthrough thrust faults and the orientations of the sub-Mississippian fold axes, and displacement on the Brookian thrust faults is relatively small $(\sim 500 \mathrm{~m})$.

In our maps, we depict the Whale Mountain allochthon as a rootless thrust sheet that was emplaced from south to north. Remnants of the emplacing fault are marked by a mélange of blocks derived from the carbonate rocks of the Egaksrak formation, the Whale Mountain and Marsh Fork volcanic rocks, and intensely folded black slate and phyllite units of the Clarence River Group (Johnson et al., 2018; Strauss et al., 2018a). In both field areas, the fault zone is cross cut by the steeper Brookian thrust faults, namely the Romanzof Mountains and Whale Mountain thrust faults. This is particularly well showcased in the headwaters of the Aichilik River, where the Kekiktuk Conglomerate is exposed in both the hanging wall and footwall sides of the Romanzof Mountains thrust (Fig 4.3F), indicating that this is a Brookian fault. The basal thrust of the allochthon thus either merges with the Romanzof Mountains thrust at an angle or it has simply been reactivated by Brookian deformation. Again, the Brookian displacement on this fault is small $(\sim 500 \mathrm{~m})$, which is not enough to account for the emplacement of the allochthon.

The Whale Mountain allochthon should continue as a critical subject of future mapping efforts and research because these rocks potentially represent remnants of an ancient suture zone, 
which separates the North Slope subterrane from the Doonerak arc complex and the southwestern subterranes of Arctic Alaska. Johnson et al. (2018) speculated that this suture zone is, in part, an Arctic equivalent of the Iapetus suture now exposed in parts of New England and the British Isles, which formed during the Caledonian orogeny when Baltica and Laurentia collided with one another. In turn, this suggests that the Romanzof orogeny of Lane (2007) is a local expression or extension of Caledonian deformation in the NE Brooks Range and is likely related to the assembly of the Arctic Alaska-Chukotka microplate.

\section{CONCLUSIONS}

The structural style and stratigraphic architecture of NE Brooks Range is preserved in more than 20 different map units that record two major orogenic events: one linked to Cenozoic phases of the Brookian orogeny and a second, poorly understood, Early-Middle Devonian event known as the Romanzof orogeny. The two 1:75,000 scale maps produced in this study are still a work in progress. Collectively, the recent work of Strauss et al. (2013, 2018a; 2018b), Lane et al. (2016), Colpron et al. (2018), Nelson et al. (2018), and Johnson et al. (2016; 2018) has greatly expanded the knowledge regarding the overall stratigraphy of the NE Brooks Range, but the structural style and architecture, especially that of the sub-Mississippian map units, remains poorly constrained. Future studies need to focus on building more detailed geological maps that incorporate balanced cross sections to illustrate the three-dimensional complexity of the region and address some of the uncertainties mentioned in this study.

\section{ACKNOWLEDGMENTS}

This study was supported by several different funding agencies, the Geological Society of America Student Research fund is one that we are especially thankful for. We would not have been able to haul all those rocks from our field area had we not had the assistance and 
companionship from Blaze Budd, Patrick Frier, and Lyle Nelson. Kirk Sweetsir from Yukon Air Service and the staff at Wright Air Service got us home safely. The hard-working staff at United States Fish and Wildlife Service quickly granted us permission to work in the Arctic National Wildlife Refuge. DEMs were provided by the Polar Geospatial Center under NSF-OPP awards 1043681, 1559691, and 1542736. We are also greatly indebted to Gil Mull for sharing his knowledge and immaculate field notes from $>20$ years of field work in the Brooks Range of Alaska.

\section{REFERENCES}

Anderson, A.V., 1993, Variations in structural geometry across the continental divide thrust front, northeastern Brooks Range, Alaska: Alaska Division of Geological \& Geophysical Surveys Public Data File 93-77, 45 p., 1 sheet, scale 1:25,000 doi: 10.14509/1616

Anderson, A.V., 1995, Stratigraphic variation across a Middle Devonian to Mississippian riftbasin margin and implications for subsequent fold and thrust geometry, northeastern Brooks Range, Alaska: unpublished PhD thesis, University of Alaska Fairbanks. 276 p.

Anderson, A.V., Wallace, W.K., and Mull, C.G., 1994, Depositional record of a major tectonic transition in northern Alaska: Middle Devonian to Mississippian rift-basin margin deposits, upper Kongakut River region, eastern Brooks Range, Alaska, in Thurston, D.K., and Fujita, K., eds., 1992 Proceedings of the International Conference on Arctic Margins: Anchorage, Alaska, U.S. Department of the Interior, Minerals Management Service, p. $71-76$.

Anderson, A.V., and Watts, K.F., 1992, Mangaqtaag Formation lacustrine(?) deposits in the Endicott Group headwaters of the Kongakut River, eastern Brooks Range, Alaska: Public-data File 92-6, Alaska Division of Geological and Geophysical Surveys, 19 p. 
Armstrong, A.K., and Mamet, B.L., 1974. Carboniferous Biostratigraphy, Prudhoe Bay State 1 to Northeastern Brooks Range, Arctic Alaska: American Association of Petroleum Geologists Bulletin v. 58, p. 646-660.

Armstrong, A.K., and Mamet, B.L., 1977, Carboniferous microfacies, microfossils, and corals, Lisburne Group, Arctic Alaska: U.S. Geological Survey Professional Paper 849, 144 p., 8 sheets.

Armstrong, A. K., Mamet, B. L., and Dutro, J, T., Jr., 1970, Foraminiferal zonation and carbonate facies of Carboniferous (Mississippian and Pennsylvanian) Lisburne Group, central and eastern Brooks Range, Arctic Alaska: American Association of Petroleum Geologists Bulletin, v. 54, p. 687-698.

Atkinson, P. K. and Wallace, W. K., 2003, Competent unit thickness variation in detachment folds in the Northeastern Brooks Range, Alaska: geometric analysis and a conceptual model. Journal of Structural Geology, v. 25, p. 1751-1771.

Bird, K.J., and Houseknecht, D.W., 2001, Arctic National Wildlife Refuge, 1002 Area, petroleum assessment, 1998, including economic analysis: U.S. Geological Survey Fact Sheet $028-01$

Bowsher, A. L., and Dutro, J. T., Jr., 1957, The Paleozoic section in the Shainin Lake area, central Brooks Range, Alaska: United States Geological Survey Professional Paper 303A, 39 p.

Brosgé, W.P., Dutro, J.T., Jr., Mangus, M.D., and Reiser, H.N., 1962, Paleozoic sequence in eastern Brooks Range, Alaska: American Association of Petroleum Geologists Bulletin, v. 46, p. $174-198$. 
Cecile, M.P., 1988, Corridor traverse through Barn Mountains, northernmost Yukon: Geological Survey of Canada, Current Research, Part D, Paper 88-1D, p. 99-103.

Colpron, M., McClelland, W.C., and Strauss, J.V., 2018, Detrital zircon U-Pb geochronological and Hf isotopic constraints on the geological evolution of North Yukon, in Piepjohn, K., Strauss, J.V., Reinhardt, L., and McClelland, W.C., eds., Circum-Arctic Structural Events: Tectonic Evolution of the Arctic Margins and Trans-Arctic Links with Adjacent Orogens: Geological Society of America Special Paper 541, doi: 10.1130/2018.2541(19).

Detterman, R.L., Bowsher, A.L., and Dutro, J.T., Jr., 1958, Glaciation on the Arctic Slope of the Brooks Range, northern Alaska: Arctic, v. 11, p. 43-61.

Detterman, R.J., Reiser, H.N., Brosge, N.P. and Dutro, J.T., Jr. 1975. Post-Carboniferous stratigraphy, northeastern Alaska: United States Geological Survey, Professional Paper $886,46 \mathrm{p}$.

Dillon, J.T., Jr., Tilton, G.R., Decker, J., and Kelly, M.J., 1987, Resource implications of magmatic and metamorphic ages for Devonian igneous rocks in the Brooks Range, in Tailleur, I., and Weimer, P., eds., Alaskan north slope geology: Society of Economic Paleontologists and Mineralogists (SEPM) and Alaska Geological Society, Book 50, p. $713-723$.

Dixon, J., 2004, Lower Cretaceous (Albian) to Tertiary strata, Yukon Territory -Northwest Territories (a contribution to the Geological Atlas of the Northern Canadian Mainland Sedimentary Basin): Geological Survey of Canada, Open File 4633, 45 p.

Dutro Jr., J.T., 1987, Revised megafossil biostratigraphic zonation for the Carbonifereous of northern Alaska, in Tailleur, I., and Weimer, P., eds., Alaskan North Slope Geology: Pacific Section, Society of Economic Paleontologists and Mineralogists (SEPM) 
Publication 50, p. 359-364

Dutro, J.T., Jr., Brosgé, W.P., and Reiser, H.N., 1972, Significance of recently discovered Cambrian fossils and reinterpretation of Neruokpuk Formation, northeastern Alaska: American Association of Petroleum Geologists Bulletin, v. 56, p. 808-815.

Goodfellow, W.D., Cecile, M.P., and Leybourne, M.I., 1995, Geochemistry, petrogenesis, and tectonic setting of lower Paleozoic alkalic and potassic volcanic rocks, Northern Canadian Cordilleran Miogeocline: Canadian Journal of Earth Sciences, v. 32, p. $2167-$ 2167, doi: 10.1139/e95-169.

Hanks, C.L., 1989, Preliminary geology of the pre-Mississippian rocks of the Aichilik and Egaksrak River areas, northeastern Brooks Range, Alaska: Alaska Division of Geological and Geophysical Surveys, Public-date File 89-1a, 18 p.

Hanks, C.L., 1993, The Cenozoic structural evolution of a fold-and-thrust belt, northeastern Brooks Range, Alaska: Geological Society of America Bulletin, v. 105, p. 287-305, doi: 10.1130/0016-7606(1993)105<0287:TCSEOA>2.3.CO;2.

Hanks, C.L., and Wallace, W.K., 1990, Cenozoic thrust emplacement of a Devonian batholith, northeastern Brooks Range: Involvement of crystalline rocks in a foreland fold-and-thrust belt: Geology, v. 18, p. 395-398, doi: 10.1130/00917613(1990)018<0395:CTEOAD>2.3.CO;2.

Herbosch, A., and Verniers, J., 2011, What is the biostratigraphic value of the ichnofossil Oldhamia for the Cambrian?: A review: Geologica Belgica, v. 14, no. 3-4, p. 229-248. Homza, T.X., 1991, Geologic map, cross section, and structural geology of an area southwest of Bathtub Ridge, northeastern Brooks Range, Alaska: Alaska Division of Geological \& 
Geophysical Surveys Public Data File 91-9, 21 p., 1 sheet, scale 1:25,000. http://doi.org/10.14509/1476

Homza, T.X., and Wallace, W.K., 1997, Detatchment Folds with Fixed Hinges and Variable Detatchment Depth, Norteastern Brookes Range, Alsaka, in Anastasio, D.J., Erslev, E.A., Fisher, D.M., and Evans, J.P. eds., Journal of Structural Geology, p. 337-354.

Imm, T.A., Dillon, J.T., and Bakke, A.A., 1993, Generalized geologic map of the Arctic National Wildlife Refuge, northeastern Brooks Range, Alaska: Alaska Division of Geological \& Geophysical Surveys Special Report 42, 1 sheet, scale 1:500,000. http://doi.org/10.14509/2641

Jadamec, M.A., and Wallace, W.K., 2014, Thrust-breakthrough of asymmetric anticlines: Observational constraints from surveys in the Brooks Range, Alaska: Journal of Structural Geology, v. 62, p. 109-124, doi: 10.1016/j.jsg.2014.01.012.

Johnson, B.G., Strauss, J.V., Toro, J., Benowitz, J.A., and Ward, W.P., 2016, Geochronological constraints from synorogenic detritus and early Paleozoic accretionary tectonics in the NE Brooks Range: Lithosphere, v. 8, p. 649-667, doi: 10.1130/L533.1.

Johnson, B.G., Strauss, J.V., Taylor, J.F., Ward, W.P., Colpron, M., McClelland, W.C., and Toro, J., 2018, The Whale Mountain allochthon: A relic of the Iapetus Ocean preserved in the northeastern Brooks Range of Alaska and Yukon, in Piepjohn, K., Strauss, J.V., Reinhardt, L., and McClelland, W.C., eds., Circum-Arctic Structural Events: Tectonic Evolution of the Arctic Margins and Trans-Arctic Links with Adjacent Orogens: Geological Society of America Special Paper 541, doi: 10.1130/2018.2541(20). 
Kelley, J.S., Wrucke, C.T., and Lane, L.S., 1994, Pre-Mississippian rocks of the Clarence and Malcolm Rivers area, in Thurston, D.K., and Fujita, K., eds., 1992 Proceedings of the International Conference on Arctic Margins, OCS Study, MMS 94-0040, p. 59-64.

Lane, L.S., 1991, The pre-Mississippian "Neruokpuk Formation,” northeastern Alaska and northwestern Yukon: review and new regional correlation: Canadian Journal of Earth Sciences, v. 28, p. 1521-1533.

Lane, L.S., 2007, Devonian-Carboniferous paleogeography and orogenesis, northern Yukon and adjacent Arctic Alaska: Canadian Journal of Earth Sciences, v. 44, p. 679-694.

Lane, L.S., and Cecile, M.P., 1989, Stratigraphy and structure of the Neruokpuk Formation, northern Yukon: Geological Survey of Canada, Current Research, Part G, Paper 89-1G, p. $57-62$.

Lane, L.S., Gehrels, G.E., and Layer, P.W., 2016, Provenance and paleogeography of the Neruokpuk Formation, northwest Laurentia: An integrated synthesis: Geological Society of America Bulletin, v. 129, p. 239-257, doi: 10.1130/B31234.1.

Lane, L.S., Kelley, J.S., and Wrucke, C.T., 1995, Stratigraphy and structure of the Clarence River area, Yukon-Alaska north slope: a USGS-GSC co-operative project: Geological Society of Canada Current Research 1995-E, p. 1-9.

Leffingwell, E. de K., 1919, The Canning River region, northern Alaska: U.S. Geological Survey Professional Paper 109, 251 p.

LePain, D. L., Crowder, R.K., and Wallace, W.K., 1994, Early Carboniferous transgression on a passive continental margin: Deposition of the Kekiktuk Conglomerate, northeastern Brooks Range, Alaska, American Association of Petroleum Geologists Bulletin, v. 78, p. 679-699. 
Lerand, M., 1973, Beaufort Sea, in McCrossam, R.G., ed., The Future Petroleum Provinces of Canada - Their Geology and Potential: Canadian Society of Petroleum Geology Memoir 1, p. 315-386.

MacNaughton, R.B., Moynihan, D.P., Roots, C.F., and Crowley, J.L., 2016, New occurrences of Oldhamia in eastern Yukon, Canada: Stratigraphic context and implications for Cambrian deep-marine biostratigraphy: Ichnos, v. 23, p. 33-52, 1635 doi:

10.1080/10420940.2015.1127232.

Mamet, B. L., and Armstrong, A. K., 1972, Lisburne Group, Franklin and Romanzof Mountains, northeastern Alaska, in Geological Survey research 1972: United States Geological Survey Professional Paper 800-C, p. C127-C144.

Mayfield, C.F., Tailleur, I.L., and Ellersieck, I., 1988, Stratigraphy, structure, and palinspastic synthesis of the western Brooks Range, northwestern Alaska, in Gryc, George, ed., Geology and Exploration of the National Petroleum Reserve in Alaska, 1974 to 1982:

U.S. Geological Survey Professional Paper 1399, p. 143-186.

McClelland, W.C., Colpron, M., Piepjohn, K., von Gosen, W., Ward, W.P., and Strauss, J.V., 2015, Preliminary detrital zircon geochronology of the Neruokpuk Formation in the Barn Mountains, Yukon, in MacFarlane, K.E., Nordling, M.G., and Sack, P.J., eds., Yukon Exploration and Geology 2014: Yukon Geological Survey, p. 123-143.

Molenaar, C. J., Bird, K. J., and Kirk, A. R. 1987, Cretaceous and Tertiary stratigraphy of northeastern Alaska, in Tailleur, I., and Weimer, P., eds., Alaskan North Slope Geology: Pacific Section, Society of Economic Paleontologists and Mineralogists (SEPM) Publication 50, p. 691-710. 
Moore, T.E., 1987, Geochemistry and the tectonic setting of volcanic rocks of the Franklinian assemblage, central and eastern Brooks Range, in Tailleur, I., and Weimer, P., eds., Alaskan North Slope Geology: Pacific Section, Society of Economic Paleontologists and Mineralogists (SEPM) Publication 50, p. 691-710.

Moore, T.E., and Churkin, M., Jr., 1984, Ordovician and Silurian graptolite discoveries from the Neruokpuk Formation (sensu lato), northeastern and central Brooks Range, Alaska, in Blodgett, R.B., ed., Paleozoic Geology of Alaska and Northwestern Canada Newsletter 1: Alaska Geological Society, p. 21-23.

Moore, T.E., O'Sullivan, P.B., Potter, C.J., and Donelick, R.A., 2015, Provenance and detrital zircon geochronologic evolution of lower Brookian foreland basin deposits of the western Brooks Range, Alaska, and implications for early Brookian tectonism: Geosphere, v. 11, no. 1, p. 93-122, doi: 10.1130/GES01043.1.

Moore, T.E., Potter, C.J., O’Sullivan, P.B., Shelton, K.L., and Underwood, M.B., 2004, Two Stages of Deformation and Fluid Migration in the West-Central Brooks Range Fold and Thrust Belt, Northern Alaska, in Swennen, R., Roure, F., and Granath, J.W. eds., Deformation, fluid flow, and reservoir appraisal in foreland fold and thrust belts, AAPG Hedberg Series, no. 1, p. 157-186.

Moore, T.E., Wallace, W.K., Bird, K.J., Karl, S.M., Mull, C.G., and Dillon, J.T., 1994, Geology of northern Alaska, in Plafker, G., and Berg, H.C., eds., The Geology of Alaska: Boulder, Colorado, Geological Society of America, The Geology of North America, v. G-1, p. 49140. 
Mull, C.G., 1982, Tectonic evolution and structural style of the Brooks Range, Alaska: An illustrated summary, in Powers, R.B., ed., Geologic studies of the Cordilleran thrust belt, Volume 1: Denver, Colorado, Rocky Mountain Association of Geologists, p. 1-45.

Mull, C.G., 1987, Kemik sandstone, Arctic National Wildlife Refuge, northeastern Alaska, in Tailleur, I., and Weimer, P., eds., Alaskan North Slope Geology: Pacific Section, Society of Economic Paleontologists and Mineralogists (SEPM) Publication 50, p. 405-431

Mull, C.G., and Anderson, A.V., 1991, Franklinian Lithotectonic Domains, Northeastern Brooks Range, Alaska: Alaska Division of Geological \& Geophysical Surveys Public Data File 91-5, 40 p., doi: 10.14509/1472.

Mull, C.G., and Mangus, M.D., 1972, Itkilyariak Formation: new Mississippian formation of Endicott Group, Arctic slope of Alaska: American Association of Petroleum Geologists Bulletin, v. 56, p. 1364-1369.

Nelson, L.L., Strauss, J.V., Crockford, P.W., Cox, G.M., Johnson, B.G., Ward, W., Colpron, M., McClelland, W.C., and Macdonald, F.A., 2018, Geochemical constraints on the provenance of pre-Mississippian sedimentary rocks in the North Slope subterrane of Yukon and Alaska, in Piepjohn, K., Strauss, J.V., Reinhart, L., and McClelland, W.C., eds., Circum-Arctic Structural Events: Tectonic Evolution of the Arctic Margins and Trans-Arctic Links with Adjacent Orogens: Geological Society of American Special Paper 541, doi: 10.1130/2018.2541(24).

Norris, D.K., 1981a, Geology, Blow River and Davidson Mountains, Yukon Territory -District of Mackenzie: Geological Survey of Canada, Map 1516A, 1:250,000.

Norris, D.K., 1981b, Geology, Hesrchel Island and Demarcation Point, Yukon Territory: Geological Survey of Canada, Map 1514A, 1:250,000. 
Norris, D.K., 1985, The Neruokpuk Formation, Yukon Territory and Alaska: Geological Survey of Canada, Current Research, Part B, Paper 85-1B, p. 223-229.

Oldow, J.S., Avé Lallemant, H.G., Julian, F.E., and Seidensticker, C.M., 1987, Ellesmerian(?) and Brookian deformation in the Franklin Mountains, northeastern Brooks Range, Alaska, and its bearing on the origin of the Canada Basin (USA): Geology, v. 15, p. 3741, doi: 10.1130/0091-7613(1987)15<37:EABDIT>2.0.CO;2.

O'Sullivan, P.B., 1993, Multiple phases of Tertiary uplift and erosion in the Arctic National Wildlife Refuge, Alaska, revealed by apatite fission track analysis: American Association of Petroleum Geologists Bulletin, v. 77, p. 359-385, doi: 10.1306/BDFF8C0E-171811D7-8645000102C1865D.

O’Sullivan, P.B., Murphy, J.M., and Blythe, A.E., 1997, Late Mesozoic and Cenozoic thermotectonic evolution of the central Brooks Range and adjacent North Slope foreland basin, Alaska: Including fission track results from the Trans-Alaska Crustal Transect (TACT): Journal of Geophysical Research, v. 102, no. 9, p. 20821, doi: 10.1029/96JB03411.

O'Sullivan, P.B., and Wallace, W.K., 2002, Out-of-sequence, basement-involved structures in the Sadlerochit Mountains region of the Arctic National Wildlife Refuge, Alaska: Evidence and implications from fission-track thermochronology: Geological Society of America Bulletin, v. 114, p. 1356-1378, doi: 10.1130/0016-7606(2002)114 $<1356$ :OOSBIS >2.0.CO;2.

Patton, W.W., Jr., 1956, New and redefined formations of Early Cretaceous age, in Gryc, G., and others, American Association of Petroleum Geologists Bulletin, v. 40, p. 219-223. 
Peapples, P.R., Wallace, W.K., Hanks, C.L., O’Sullivan, P.B., and Layer, P.W., 1997, Style, controls, and timing of fold-and-thrust deformation of the Jago stock, northeastern Brooks Range, Alaska: Canadian Journal of Earth Sciences, v. 34, p. 992-1007.

Reed, B. L., 1968, Geology of the Lake Peters area, northeastern Brooks Range, Alaska: U.S. Geological Survey Bulletin, v. 1236, p. 1-132.

Reiser, H.N., 1970, Northeastern Brooks Range-a surface expression of the Prudhoe Bay section, in Proceedings of the geological seminar on The north slope of Alaska, American Association of Petroleum Geologists Pacific Section, p. K1-K3.

Reiser, H.N., Brosgé, W.P., Dutro, J.T., and Detterman, R.L., 1980, Geologic map of the Demarcation Point quadrangle, Alaska: U.S. Geological Survey Map I-1133, 1:250,000 scale.

Sable, E.G., 1977, Geology of the western Romanzof Mountains, Brooks Range, northeastern Alaska: U.S. Geological Survey Professional Paper 897, 84 p.

Schrader, F. C., 1902, Geologic section of the Rocky Mountains in northern Alaska: Geological Society of America Bulletin, v. 13, p. 233-252.

Strauss, J.V., Johnson, B.G., Colpron, M., Nelson, L.L., Perez, J.L., Benowitz, J.A., Ward, W.P., and McClelland, W.C., 2018a,, Pre-Mississippian stratigraphy and provenance of the North Slope subterrane of Arctic Alaska II: Basinal rocks of the northeastern Brooks Range and their significance in circum-Arctic evolution, in Piepjohn, K., Strauss, J.V., Reinhardt, L., and McClelland, W.C., eds., Circum-Arctic Structural Events: Tectonic Evolution of the Arctic Margins and Trans-Arctic Links with Adjacent Orogens: Geological Society of America Special Paper 541, doi: 10.1130/2018.2541(23). 
Strauss, J.V., Macdonald, F.A., and McClelland, W.C., 2018b, Pre-Mississippian stratigraphy and provenance of the North Slope subterrane of Arctic Alaska I: Platformal rocks of the northeastern Brooks Range and their signifi cance in circum-Arctic evolution, in Piepjohn, K., Strauss, J.V., Reinhardt, L., and McClelland, W.C., eds., Circum-Arctic Structural Events: Tectonic Evolution of the Arctic Margins and Trans-Arctic Links with Adjacent Orogens: Geological Society of America Special Paper 541, doi: $10.1130 / 2018.2541(22)$.

Strauss, J.V., Macdonald, F.A., Taylor, J.F., Repetski, J.E., and McClelland, W.C., 2013, Laurentian origin for the North Slope of Alaska: Implications for the tectonic evolution of the Arctic: Lithosphere, v. 5, p. 477-482, doi: 10.1130/L284.1.

Tailleur, I.L., Brosgé, W.P., and Reiser, H.N., 1967, Palinspastic analysis of Devonian rocks in northwestern Alaska, in International Symposium on the Devonian System: Alberta Society of Petroleum Geologists, v. 2, p. 1345-1361.

Wallace, W.K., 1993, Detachment folds and a passive-roof duplex: Examples from the northeastern Brooks Range, Alaska: in Solie, D.N., and Tannian, F., eds., Short notes on Alaskan Geology 1993, Alaska Division of Geological and Geophysical Surveys, Professional Report 113, p. 81-99.

Wallace, W.K., and Hanks, C.L., 1990, Structural provinces of the northeastern Brooks Range, Arctic National Wildlife Refuge, Alaska: American Association of Petroleum Geologists Bulletin, v. 74, p. 1100-1118.

Ward, W.P., Strauss, J.V., Johnson, B.G., McClelland, W.C., Colpron, M., von Gosen, W., Piepjohn, K., Cobble, M., Crockford, P.W., and Landis, J., 2018, Age, geochemistry and significance of Devonian felsic magmatism in the North Slope subterrane, Yukon, in 
Piepjohn, K., Strauss, J.V., Reinhardt, L., and McClelland, W.C., eds., Circum-Arctic Structural Events: Tectonic Evolution of the Arctic Margins and Trans-Arctic Links with Adjacent Orogens: Geological Society of America Special Paper 541, doi:

10.1130/2018.2541(22). 


\section{SUPPLEMENTAL MATERIAL}




\section{Chapter 2 (supplemental material): Detrital geochronology of}

pre-Mississippian strata in the northeastern Brooks Range,

\section{Alaska: Insights into the tectonic evolution of northern Laurentia}

Ben G. Johnson' ${ }^{1}$, Justin V. Strauss², Jaime Toro' ${ }^{1}$, Jeff A. Benowitz ${ }^{3}$, William P. Ward ${ }^{4}$, Jeremy K. Hourigan 5

${ }^{1}$ Department of Geology and Geography, West Virginia University, Morgantown, West Virginia, 26506 USA

${ }^{2}$ Department of Earth Sciences, Dartmouth College, Hanover, New Hampshire 03755, USA

${ }^{3}$ Geophysical Institute, University of Alaska Fairbanks, Fairbanks, Alaska 99775, USA

${ }^{4}$ Department of Earth and Environmental Sciences, University of Iowa, Iowa City, Iowa 52242, USA

${ }^{5}$ Department of Earth and Planetary Sciences, University of California-Santa Cruz, Santa Cruz, California 95064, USA

\section{SAMPLE DESCRIPTIONS}

Reconnaissance scale mapping of the Demarcation Point Quadrangle by Reiser et al. (1980) is the most recent, continuous, and comprehensive geological map available in entire NE Brooks Range. The depositional environments, ages, and contact relationships among these rocks are poorly constrained. For these reasons, we rely on the mapping and unit descriptions of Reiser et al. (1980) from Alaska and of Lane (1991) and Lane et al. (1995; 2015) from Yukon to supplement these data with our own observations from multiple field seasons in the British and Romanzof mountains. All of the samples were collected from map units that are stratigraphically beneath the prominent sub-Mississippian unconformity, which spans most of Arctic Alaska (e.g., 
Moore et al., 1994). Our samples are generally grouped into two major lithostratigraphic successions exposed in the NE Brooks Range: the Neoproterozic-middle Cambrian siliclastic and carbonate units of the Firth River goup (Lane et al., 2016) and Neruokpuk Formation (Leffingwell, 1919; Lane, 1991); and a Lower Ordovician-Lower Devonian succession of turbidities herein referred to as the Clarence River group, which includes the Buckland Hills succession of Lane et al. (2016). A summery table (Table SM2.1) includes sample locations and type of analysis performed in this study. The age constraints from these units, along with age constraints from other pre-Mississippian units in the NE Brooks Range, are outlined in Table SM2.2.

\section{Firth River group and Neruokpuk Formation Samples}

$12 J T 10$ - Map unit of Css of Reiser et al. (1980), east side of the Kongakut River, just below the sub-Mississippian unconformity in the southern British Mountains ( $\mathrm{N}$ 69.113734, W -141.903452): Very coarse- to fine-grained, subrounded, gray quartz arenite with abundant detrital muscovite and very fine-grained authigenic muscovite occupying the interstitial spaces. Sample is considered part of the Neruokpuk Formation based on its detrital zircon age distributions (see Table SM2.3) and was collected just below the sub-Mississippian unconformity.

12JT11 - Map unit of pCn of Reiser et al. (1980), east side of the Kongakut River, southern British Mountains (N 69.157950, W 141.864928): Moderatley-strained, coarse to medium-grained, green, subrounded quartz arenite. Surrounding the quartz grains are weakly developed, but prevalent, strain shadows (Fig. SM2.1A). Beds along the river are massive, up to a $1 \mathrm{~m}$ in thickness, and are tightly folded with with north-dipping axial surfaces. 

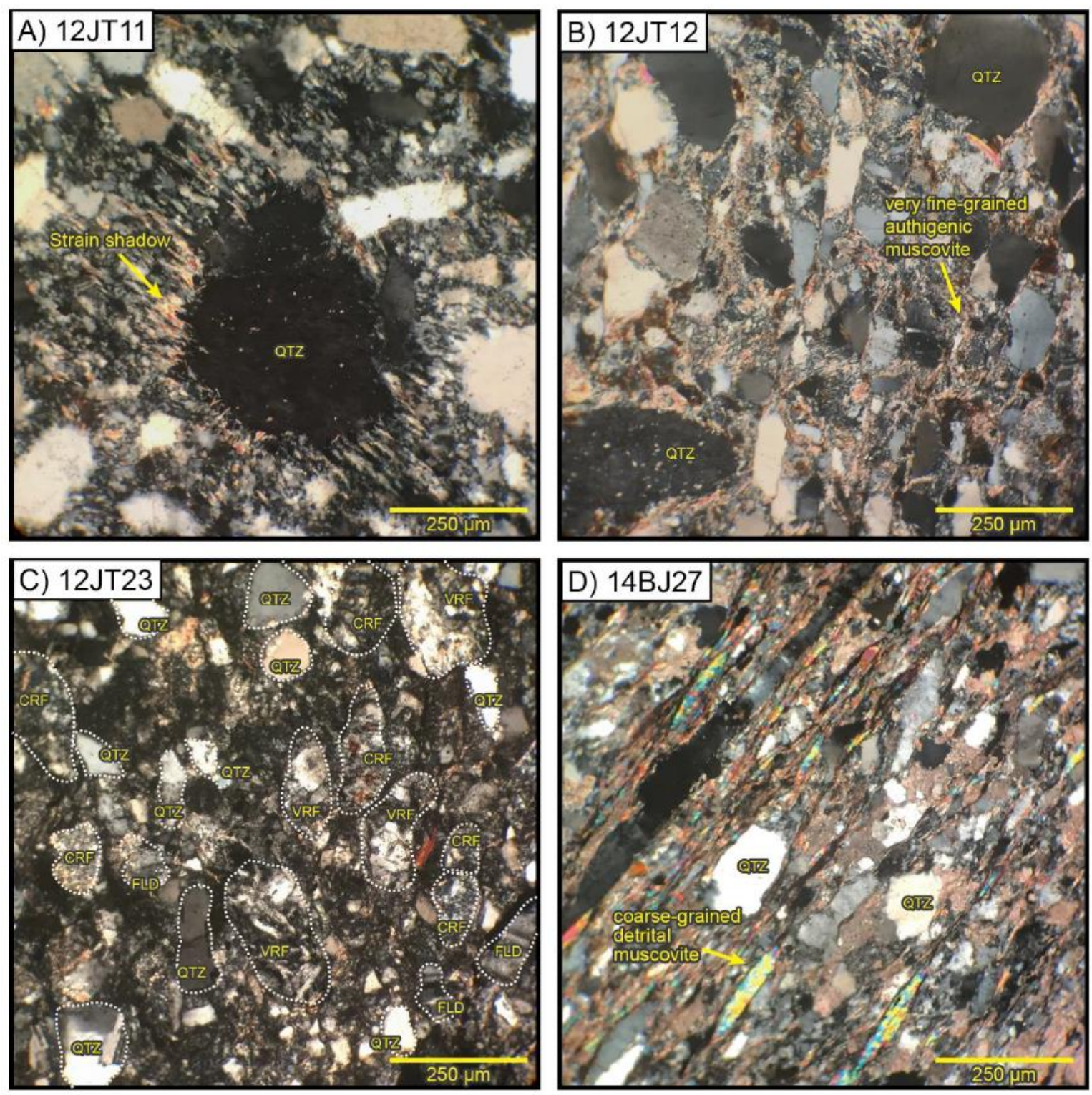

Figure SM2.1: Photomicrographs from the Neruokpuk Formation and the Clarence River Group. (A) Neruokpuk sample 12JT11 strain shadow around single quartz grain. (B) Neruokpuk sample 12JT12 showing fine-grained authigenic muscovite occupying interstitial spaces between quartz grains. (C) Clarence River Group sample 12JT23 showing various compositions of detrital grains, suggesting an immature composition. (D) Clarence River Group sample 14BJ27 showing coarse=grained detrital muscovite grains aligned within cleavage domains that surround larger quartz grains. Abbreviations: CRF-chert rock fragment; FLD-feldspar grain; QTZ-quartz grain; $\mathrm{VRF}$-volcanic rock fragments 
$12 J T 12$ - Map unit of pCn of Reiser et al. (1980), west side of the of the Kongakut River, southern British Mountains (N 69.192398, W 141.868887): Very coarse to fine-grained, subrounded gray lithic arenite, with $>5 \%$ clay matrix. Sample contains small amounts of coarse-grained (250-800 $\mu \mathrm{m})$ detrital(?) muscovite, 10-100 um thick packets of interstitial authigenic muscovite, and occasional feldspar grains (Fig. SM2.1B). Beds along the river are massive, up to a $1 \mathrm{~m}$ in thickness.

12JT13a - Map unit of pCn, Ccp, or Css of Reiser et al. (1980), east side of the of the Kongakut River, southern British Mountains (N 69.227013, W 141.831267): Moderatelystrained, carbonate-cemented, fine- to very fine grained, subrounded, gray lithic arenite, with $>5 \%$ clay matrix. Outcrop is interbedded with phyllite units which contain coarsegrained $(250-800 \mu \mathrm{m})$ detrital(?) muscovite. Sample could be part of the Neruokpuk Formation or lower Clarence River group, as it was sampled near the contact. 12JT31 - Map unit pCpa, Old Grungy Mountain of Reiser et al. (1980), east side of the Kongakut River, northern British Mountains (N 69.387220, W 141.535461): Intensely foliated green-grey argillite cut by numerous quartz veins. Sample is considered part of the Firth River group because of its inferd lower stratigraphic position with respect to the Neruokpuk Formation and its along strike correlation to the carbonate units in the northern British mountains.

12JT32 - Map unit of pCn of Reiser et al. (1980) west side of the Kongakut River, northern British Mountains (N 69.424719, W 141.508195): Coarse to medium-grained, subrounded, gray lithic arenite with minor clay matrix. Beds are massive and up to $1 \mathrm{~m}$ in thickness. 
05LF13 - Map unit of pCn of Reiser et al. (1980) east side of upper Leffingwell Fork of the Aichilik River, southern British Mountains (N 69.185356, W 142.664228): Moderately strained, coarse to very fine-grained, subangular, gray lithic-arenite. Lithic grains are predominantly chert.

$11 L F 13$ - Map unit of pCn of Reiser et al. (1980) east side of the Leffingwell Fork of the Aichilik River, southern British Mountains (N 69.263494, W 142.657930): Moderately strained, coarse- to very fine-grained, angular, green lithic-arenite. Lithic grains are predominantly chert 28LF13 - Map unit of pCn of Reiser et al. (1980) east side of the Leffingwell Fork of the Aichilik River, southern British Mountains (N 69.357533, W 142.858018): Coarse- to fine-grained, rounded, gray quartz arenite with $<5 \%$ clay matrix. Beds are normally graded (Bouma-A sequence turbidites) and up to $0.5 \mathrm{~m}$ thick.

37LF13 - Map unit of pCn of Reiser et al. (1980), west side of the Leffingwell Fork of the Aichilik River, southern British Mountains (N 69.357257, W 142.921486): Coarse- to fine-grained, rounded to, gray lithic arenite with $>5 \%$ clay matrix. Contains coarse- to medium-grained (250-800 $\mu \mathrm{m})$ detrital muscovite, and lithic chert fragments. J1355-617 - Map unit Css of Lane et al., (1995), upper Malcolm River, northern British Mountains in Yukon (N 69.219592, W 140.949294): Carbonate-cemented, medium- to very fine-grained, subrounded, brown quartz arenite. Contains coarse- to medium-grained (250-800 $\mu \mathrm{m})$ detrital muscovite.

\section{Clarence River Group Samples}

12JT22 - Map unit Cp of Reiser et al. (1980), west side of the of the Kongakut River across from Whale Mountain, southern British Mountains (N 69.279048, W 141.727346): 
Carbonate-cemented, coarse- to fine - grained, subrounded lithic arenite with a $>5 \%$ clay matrix Contains lithic chert and metamorphic rock fragments and abundant fine- and coarse-grained $(100-500 \mu \mathrm{m})$ detrital muscovite.

$12 J T 23$ - Map unit Cp or Cs of Reiser et al. (1980), west side of the of the Kongakut River across from Whale Mountain, southern British Mountains (N 69.279912, W 141.747478): Coarse- to medium -grained, angular to subangular, lithic or feldspathic arenite. Contains abundant chert, volcanic, and feldspar detrital grains (Fig. SM2.1C). 12JT24 - Map unit Cp of Reiser et al. (1980), west side of the of the Kongakut River across from Whale Mountain, southern British Mountains (N 69.279912, W 141.747478): Carbonate-cemented, fine- to very fine -grained, subangular, lithic arenite with a $>5 \%$ clay matrix. Contains fine- and coarse-grained (100-500 $\mu \mathrm{m})$ detrital muscovite separated for single-grain, stepwise 40Ar/39Ar analyses (Table SM2.6).

$12 J T 35$ - Map unit Ovc or Os of Reiser et al. (1980), east side of the Kongakut River, northern British Mountains along Caribou Pass (N 69.469365; W 141.469672): Carbonate-cemented, medium- to very fine-grained, subrounded, lithic arenite with abundant detrital carbonate, opaque minerals, and volcanic rock fragments. 09LF13 - Map unit Ccp or Css of Reiser et al. (1980), east side of the Leffingwell Fork of the Aichilik River, southern British Mountains (N 69.264435, W 142.657912): Moderately-strained, carbonate-cemented, subangular, fine-grained phyllite. Contains Medium- and fine-grained (100-800 $\mu \mathrm{m})$ detrital muscovite, which occupy anastomosing cleavage domains.

40LF13 - Map unit Cp of Reiser et al. (1980), east side of the Leffingwell Fork of the Aichilik River, southern British Mountains (N 69.375307, W 142.912505): Medium- to 
very fine -grained, subangular, lithic arenite with abundant detrital muscovite in a >5\% clay matrix. Clay matrix composed of authigenic illite or muscovite. Contains coarse- and fine-grained $(100-800 \mu \mathrm{m})$ detrital muscovite and occasional feldspar minerals.

14BJ27 - Map unit Cp or Css of Reiser et al. (1980), upper Aichilik River, Romanzof Mountains (N 69.117975, W 143.238008): Moderately-strained, carbonate-cemented, subangular, lithic arenite with abundant coarse- to fine-grained $(100-800 \mu \mathrm{m})$ detrital muscovite occupying anastomosing cleavage domains (Fig. SM2.1D).

\section{U-TH-PB GEOCHRONOLOGIC ANALYSES OF ZIRCON}

Detrital zircon grains were extracted from $\sim 2-3 \mathrm{~kg}$ of sample by traditional methods of crushing and grinding, followed by separation with a Gemini table, heavy liquids, and a Frantz magnetic separator at West Virginia University. After separation, the grains (generally hundreds of grains) were hand-picked and incorporated into a $2.5 \mathrm{~cm}$ epoxy mount together with the standards (see following sections for which standards were used). The mounts were polished using 1,500 grit sandpaper followed by $9 \mu \mathrm{m}$ and then $3 \mu \mathrm{m}$ down to a depth of $\sim 20$ microns, and then cleaned in $1 \% \mathrm{HNO}_{3}$ and rinsed in water prior to isotopic analysis.

\section{LA-ICPMS: University of California Santa Cruz}

Detrital zircon U-Pb geochronology conducted at the University of California Santa Cruz laser ablation inductively coupled plasma mass spectrometry (LA-ICPMS) laboratory (Table SM2.3) were analyzed using a single-collector Element XR high-resolution magnetic-sector ICPMS and a Photon Machines Analyte.H $193 \mathrm{~nm}$ ArF excimer laser equipped with a Helex 2volume laser ablation cell. Analytical procedures, tuning parameters, and data reduction techniques closely follow that of Sharman et al. (2013) and Dumitru et al. (2016). Mounted with the separated zircons, the R-33 zircon (419 Ma; Black et al. 2004) was used as a primary 
standard and Plesovice (337 Ma; Sláma et al., 2008) was used as a secondary standard. Approximate concentrations of $\mathrm{U}$ and $\mathrm{Th}$ were calibrated relative to the concentrations from WF2 and Mudtank zircon standards (Woodhead and Hergt, 2005). A $26 \mu \mathrm{m}$ spot diameter was used for all analyses. Each analysis consisted of 30 seconds of integrations with the laser off (for backgrounds), 30 seconds of integrations with the laser firing, and a 20 second delay to purge the previous sample and prepare for the next analysis.

Software used for data reduction included Iolite 2.2 (Paton et al., 2010), and VisualAge add-ons for Igor Pro. followed by an Excel spreadsheet (see below; Sharman et al., 2013). We used Iolite's exponential detrending algorithm, which calibrates to the observed down-hole fractionation of the standards. Iolite also permits efficient inspection of signal intensities, ratios, and ages as they evolved through the 30 seconds of integrations for each grain. Integration regions were generally resized if: (1) drill-through was observed based on a rapid decrease in total beam prior to the end of the integration; (2) erratic fluctuations of ${ }^{204} \mathrm{~Pb}$ compared to values observed in the background-corrected ${ }^{204} \mathrm{~Pb}$ signal; or (3) shallow levels within the pit exhibited substantially different ages compared to deeper levels. We did not apply a ${ }^{204} \mathrm{~Pb}$ correction because average background-subtracted signals are typically less than a conservatively estimated limit of detection. Instead we utilized the ${ }^{207} \mathrm{~Pb}$-corrected ${ }^{206} \mathrm{~Pb} /{ }^{238} \mathrm{U}$ age for ${ }^{206} \mathrm{~Pb} /{ }^{238} \mathrm{U}$ ages <1000 Ma. This is calculated using Isoplot (version 4.15; Ludwig, 2012) based on a two-stage model of terrestrial lead isotope evolution to constrain initial $\mathrm{Pb}$ abundances (Stacey and Kramers, 1975; Table SM2.3). Analyses were rejected when the ${ }^{207} \mathrm{~Pb}$ common lead correction is $>2 \%$ of the uncorrected ${ }^{206} \mathrm{~Pb} /{ }^{238} \mathrm{U}$ age, which excludes some grains with erratic fluctuations in ${ }^{207} \mathrm{~Pb} /{ }^{235} \mathrm{U}$ apparent age (Dumitru et al., 2016). For grains with ${ }^{206} \mathrm{~Pb} /{ }^{238} \mathrm{U}$ ages $>1000 \mathrm{Ma}$, we use uncorrected ${ }^{207} \mathrm{~Pb} /{ }^{206} \mathrm{~Pb}$ ages because our strategy of truncating integration intervals with 
detectable spikey, erratic, persistent fluctuations in ${ }^{204} \mathrm{~Pb}$ above background greatly reduces the magnitude of any potential ${ }^{204} \mathrm{~Pb}$ correction. Analyses with ${ }^{206} \mathrm{~Pb} /{ }^{238} \mathrm{U}$ age $>600 \mathrm{Ma}$ and with excessive discordance ( $>20 \%$ discordance or $>5 \%$ reverse discordance) or high error $(>10 \%$ uncertainty in ${ }^{206} \mathrm{~Pb} /{ }^{238} \mathrm{U}$ or ${ }^{207} \mathrm{~Pb} /{ }^{206} \mathrm{~Pb}$ age) were rejected and not used for interpretation. Zircon ages $<1000 \mathrm{Ma}$. For each sample, the rejected zircons are formatted with the strikethrough text (Table SM2.3).

\section{LA-ICPMS: Stockholm University}

Detrital zircon U-Pb geochronology for sample 40LF13 was conducted by LA-ICPMS techniques at the at the Department of Geological Sciences, Stockholm University laboratory (Table SM2.4) using a Thermo Scientific XSeries-2 single collector quadrupole ICP-MS and a New Wave Research 193UC excimer laser. A $40 \mu \mathrm{m}$ spot diameter was used for all analyses. Analytical procedures, tuning parameters, and data reduction techniques closely follow that of Beranek et al. (2013). Mounted separately from the separated zircon grains, the Plesovice zircon (337 Ma; Sláma et al., 2008) was used as a primary standard and FC-52 zircon (1100 Ma; Paces and Miller, 1993) was used as a secondary standard. The synthetic glass standard, NIST 610, was used for calibration of $\mathrm{U}$ and Th concentrations. Total acquisition time for a single analysis included 50 seconds of integrations with the laser off (for backgrounds), 30 seconds of integrations with the laser firing, and a 50 second delay to purge the previous sample and prepare for the next analysis. The reduction methods, common $\mathrm{Pb}$ corrections, and filtering techniques implemented for sample 40LF13 are the same as those from the University of California Santa Cruz. For each sample, the rejected zircons are formatted with the strikethrough text (Table SM2.4). 


\section{Nordsim-laboratory}

Twenty-six euhedral grains from sample 40LF13 were analyzed by secondary ion mass spectrometry (SIMS) at the NordSIMS facility, Swedish Museum of Natural History (Table SM2.5). The analyses were made using a CAMECA IMS 1280 ion-microprobe following the standardized procedures of Whitehouse et al. (1999) and Whitehouse and Kamber (2005). A $20 \mu \mathrm{m}$ spot size was used. U-Pb ages were calibrated relative to the $1065 \mathrm{Ma}$ zircon standard 91500 (Wiedenbeck et al. 1995). The ${ }^{207} \mathrm{~Pb}$-corrected ${ }^{206} \mathrm{~Pb} /{ }^{238} \mathrm{U}$ age for ${ }^{206} \mathrm{~Pb} /{ }^{238} \mathrm{U}$ ages $<1200$ Ma is calculated using Isoplot (version 4.15; Ludwig, 2012) and based on a two-stage model of terrestrial lead isotope evolution to constrain initial Pb abundances (Stacey and Kramers, 1975; Table SM2.5).

\section{${ }^{40} \mathrm{AR} /{ }^{39} \mathrm{AR}$ GEOCHRONOLOGIC ANALYSES OF MUSCOVITE}

For ${ }^{40} \mathrm{Ar} /{ }^{39} \mathrm{Ar}$ analysis, eight samples were submitted to the Geochronology laboratory at University of Alaska Fairbanks where they were crushed, sieved, washed and hand-picked for muscovite mineral phases. The monitor mineral MMhb-1 (Samson and Alexander, 1987) with an age of $523.2 \pm 0.9 \mathrm{Ma}$ (Spell and McDougall, 2003) was used to monitor neutron flux (and calculate the irradiation parameter, J). The samples and standards were wrapped in aluminum foil and loaded into aluminum cans of $2.5 \mathrm{~cm}$ diameter and $6 \mathrm{~cm}$ height. The samples were irradiated in positions 5c (Sample 12JT13a) and 8b (all other samples) of the uranium enriched research reactor of McMaster University in Hamilton, Ontario, Canada for 20 to 150 megawatthours.

Upon their return from the reactor, the samples and monitors were loaded into $2 \mathrm{~mm}$ diameter holes in a copper tray that was then loaded in an ultra-high vacuum extraction line. The monitors were fused, and the samples heated and/or fused, using a 6-watt argon-ion laser 
following the technique described in York et al. (1981), Benowitz et al. (2014) and Martin et al. (2014). Argon purification was achieved using a liquid nitrogen cold trap and a SAES Zr-Al getter at $400^{\circ} \mathrm{C}$. The samples were analyzed in a VG-3600 mass spectrometer at the Geophysical Institute, University of Alaska Fairbanks. The argon isotopes measured were corrected for system blank and mass discrimination, as well as calcium, potassium and chlorine interference reactions following procedures outlined in McDougall and Harrison (1999). Typical full-system 8 min laser blank values (in moles) were generally $2 \times 10^{-16} \mathrm{~mol} 40 \mathrm{Ar}, 3 \times 10218 \mathrm{~mol} 39 \mathrm{Ar}, 9 \times$ $10^{-18} \mathrm{~mol} 38 \mathrm{Ar}$ and $2 \times 10^{-18} \mathrm{~mol} 36 \mathrm{Ar}$, which are $10-50$ times smaller than the sample/standard volume fractions. Correction factors for nucleogenic interferences during irradiation were determined from irradiated $\mathrm{CaF} 2$ and $\mathrm{K} 2 \mathrm{SO} 4$ as follows: $\left({ }^{39} \mathrm{Ar} /{ }^{37} \mathrm{Ar}\right) \mathrm{Ca}=7.06 \times 10^{-4}$, $\left({ }^{36} \mathrm{Ar} /{ }^{37} \mathrm{Ar}\right) \mathrm{Ca}=2.79 \times 10^{-4}$ and $\left({ }^{40} \mathrm{Ar} /{ }^{39} \mathrm{Ar}\right) \mathrm{K}=0.0297$. Mass discrimination was monitored by running calibrated air shots. The mass discrimination during these experiments was $0.8 \%$ per mass unit. While doing our experiments, calibration measurements were made on a weeklymonthly basis to check for changes in mass discrimination with no significant variation seen during these intervals.

The stepwise ${ }^{40} \mathrm{Ar} /{ }^{39} \mathrm{Ar}$ results for each smaple are presented in Table SM2.6 with all ages quoted to the \pm 1 sigma level and calculated using the constants of Renne et al. (2010). The integrated age is the age given by the total gas measured and is equivalent to a potassium-argon (K-Ar) age. The spectrum results can be viewed in Figures 2.7 and 2.8, and the interpretations are summarized in Table 2.1 of the manuscript. A plateau age is provided when three or more consecutive gas fractions represent at least $60 \%$ of the total gas release and are within two standard deviations of each other (Mean Square Weighted Deviation less than 2.5; see Ludwig, 2012). Pseudo plateau ages (PPA) are reported when two or more consecutive gas fractions 
represent at $50-60 \%$ of the total gas release and are within two standard deviations of each other.

Sample14BJ27 from the Clarence River group was analyzed, in addition to the stepwise techniques, with single-grain fusion ${ }^{40} \mathrm{Ar} /{ }^{39} \mathrm{Ar}$ geochronology on 14 grains to investigate intrasample age variability. Argon was extracted by slowly increasing the power of a focused laser until total fusion of the target muscovite grain. These results are reported in Table SM2.7.

\section{REFERENCES}

Benowitz, J.A., Layer, P.W., and Vanlaningham, S., 2014, Persistent long-term (c. 24 Ma) exhumation in the Eastern Alaska Range constrained by stacked thermochronology, in Mark, F. and Verati, C. eds., Advances in 40Ar/39Ar Dating: from Archaeology to Planetary Sciences: Geological Society, London, Special Publications 378, p. 225-243.

Beranek, L.P., Pease, V.L., Scott, R. a, and Thomsen, T.B., 2013, Detrital zircon geochronology of Ediacaran to Cambrian deep-water strata of the Franklinian basin, northern Ellesmere Island, Nunavut: implications for regional stratigraphic correlations: Canadian Journal of Earth Sciences, v. 50, p. 1007-1018, doi: 10.1139/cjes-2013-0026.

Black, L.P., Kamo, S.L., Allen, C.M., Davis, D.W., Aleinikoff, J.N., Valley, J.W., Mundil, R., Campbell, I.H., Korsch, R.J., Williams, I.S., and Foudoulis, C., 2004, Improved $206 \mathrm{~Pb} / 238 \mathrm{U}$ microprobe geochronology by the monitoring of a trace-element-related matrix effect; SHRIMP, ID-TIMS, ELA-ICP-MS and oxygen isotope documentation for a series of zircon standards: Chemical Geology, v. 205, p. 115-140, doi:

10.1016/j.chemgeo.2004.01.003.

Blodgett, R.B., Rohr, D.M., and Boucot, A.J., 2002, Paleozoic links among some Alaskan accreted terranes and Siberia based on megafossils, in Miller, E.L., Grantz, A., and 
Klemperer, S.L. eds., Tectonic Evolution of the Bering Shelf-Chukchi Sea-Arctic Margin and Adjacent Landmasses, Geological Society of America Special Paper 360, p. 272-290.

Cox, G.M., Strauss, J. V., Halverson, G.P., Schmitz, M.D., McClelland, W.C., Stevenson, R.S., and Macdonald, F. a., 2015, Kikiktat volcanics of Arctic Alaska--Melting of harzburgitic mantle associated with the Franklin large igneous province: Lithosphere, v. 7, no. 3, p. 275-295, doi: 10.1130/L435.1.

Dumitru, T.A., Elder, W.P., Hourigan, J.K., Chapman, A.D., Graham, S.A., and Wakabayashi, J., 2016, Four Cordilleran paleorivers that connected Sevier thrust zones in Idaho to depocenters in California, Washington, Wyoming, and, indirectly, Alaska: Geology, v. 44, no. 1, p. 75-78, doi: 10.1130/G37286.1.

Dutro Jr., J.T., Brosgé, W.P., and Reiser, H.N., 1972, Significance of recently discovered Cambrian fossils and reinterpretation of Neruokpuk Formation, northeastern Alaska: American Association of Petroleum Geologists Bulletin, v. 56, p. 808-815.

Hoffman, H.J., Cecile, M.P., and Lane, L.S., 1994, New occurrences of Oldhamia and other trace fossils in the Cambrian of the Yukon and Ellesmere Island, arctic Canada: Canadian Journal of Earth Sciences, v. 31, p. 767-782, doi: 10.1139/e94-070.

Lane, L.S., 1991, The pre-Mississippian "Neruokpuk Formation," northeastern Alaska and northwestern Yukon: review and new regional correlation: Canadian Journal of Earth Sciences, v. 28, no. 10, p. 1521-1533.

Lane, L.S., and Cecile, M.P., 1989, Stratigraphy and structure of the Neruokpuk Formation, northern Yukon, in Current Research, Part G: Frontier Geoscience program, Arctic Canada, Geological Survey of Canada, Ottawa, ON, Canada, p. 57-62. 
Lane, L.S., Gehrels, G.E., and Layer, P.W., 2016, Provenance and paleogeography of the Neruokpuk Formation, northwest Laurentia: An integrated synthesis: Geological Society of America Bulletin, v. 1, p. 239-257, doi: 10.1130/B31234.1.

Lane, L.S., Kelley, J.S., and Wrucke, C.T., 1995, Stratigraphy and structure of the Clarence River area, Yukon-Alaska north slope: a USGS-GSC co-operative project: Current research: Part E: Geological Survey of Canada Paper 1995-E, p. 1-9.

Leffingwell, E. de K., 1919, The Canning River region, northern Alaska: U.S. Geological Survey Professional Paper 109, 251 p.

Lenz, A.C., and Perry, D.G., 1972, The Neruokpuk Formation of the Barn Mountains and Driftwood Hills, northern Yukon: Its age and graptolite fauna: Canadian Journal of Earth Sciences, v. 9, p. 1129-1138, doi: 10 .1139/e72 -098.

Ludwig, K.R., 2012, User's Manual for Isoplot/Ex, Version 3.75: A Geochronological Toolkit for Microsoft Excel: Berkeley Geochronology Center Special Publication 5, Berkeley.

Moore, T.E., and Churkin Jr., M., 1984, Ordovician and Silurian graptolite discoveries from the Neruokpuk Formation (sensu lato), northeastern and central Brooks Range, Alaska, in Blodgett, R.B. ed., Paleozoic geology of Alaska and northwestern Canada newsletter, Alaska Geological Society, p. 21-23.

Moore, T.E., Wallace, W.K., Bird, K.J., Karl, S.M., Mull, C.G., and Dillon, J.T., 1994, Geology of northern Alaska, in Plafker, G. and Berg, H.C. eds., The Geology of Alaska, Geological Society of America, The Geology of North America, v. G-1, Boulder, Colorado, p. 49-140.

Martin, A.J., Copeland, P., and Benowitz, J.A., 2015, Muscovite 40Ar/39Ar ages help reveal the Neogene tectonic evolution of the southern Annapurna Range, central 
Nepal, in Mukherjee, S., Carosi, R., van der Beek, P.A., Murkherjee, B.K., and Robinson, D.M. eds., Tectonics of the Himalaya, Geological Society of London, Special Publications 412, p. 199-220.

McDougall, I., and Harrison, M.T., 1989, Geochronology and Thermochronology by the 40Ar/39Ar method-2nd ed.: Oxford University Press, New York.

Norris, D.K., 1986, Lower Devonian Road River Formation on the north flank of Romanzof Uplift, northern Yukon Territory, in Current Research, Part A: Geological Survey of Canada Paper 86-1A, p. 801-802.

Paces, J.B., and Miller, J.D., 1993, Precise U-Pb ages of Duluth Complex and related mafic intrusions, northern Minnesota: geochronological insights to physical, petrogenic, paleomagnetic, and tectonomagmatic processes associated with the $1.1 \mathrm{Ga}$ midcontinent rift system: Journal of Geophysical Research: Solid Earth, v. 98, p. 13,977-14,013, doi: $10.1029 / 9$.

Paton, C., Woodhead, J.D., Hellstrom, J.C., Hergt, J.M., Greig, A., and Maas, R., 2010, Improved laser ablation $\mathrm{U}-\mathrm{Pb}$ zircon geochronology through robust downhole fractionation correction: Geochemistry, Geophysics, Geosystems, v. 11, no. 3, doi: 10.1029/2009GC002618.

Reiser, H.N., Brouwers, E., Dutro Jr., J.T., and Detterman, R.L., 1980, Geologic map of the Demarcation Point Quadrangle, Alaska: U.S. Geological Survey Map I-1133, scale $1: 250000,1$ sheet.

Renne, P.R., Mundil, R., Balco, G., Min, K.W., and Ludwig, K.R., 2010, Joint determination of K-40 decay constants and Ar-40*/K-40 for the Fish Canyon sanidine standard, and 
improved accuracy for ${ }^{40} \mathrm{Ar} /{ }^{39} \mathrm{Ar}$ geochronology: Geochimica Et Cosmochimica Acta, v. 74, p. 5349-5367.

Samson, S.D., and Alexander, E.C., 1987, Calibration of the interlaboratory 40Ar39Ar dating standard, MMhb-1: Chemical Geology: Isotope Geoscience Section, v. 66, no. 1-2, p. $27-$ 34, doi: 10.1016/0168-9622(87)90025-X.

Sharman, G.R., Graham, S.A., Grove, M., and Hourigan, J.K., 2013, A reappraisal of the early slip history of the San Andreas fault, central California, USA: Geology, v. 41, no. 7, p. 727-730, doi: 10.1130/G34214.1.

Sláma, J., Košler, I., Condon, D.J., Crowley, J.L., Gerdes, A., Hanchar, J.M., Horstwood, M.S.A., Morris, G.A., Nasdala, L., Norberg, N., Schaltegger, U., Schoene, B., Tubrett, M.N., and Whitehouse, M.J., 2008, Plešovice zircon - A new natural reference material for U-Pb and $\mathrm{Hf}$ isotopic microanalysis: Chemical Geology, v. 249, no. 1-2, p. 1-35, doi: 10.1016/j.chemgeo.2007.11.005.

Spell, T.L., and McDougall, I., 2003, Characterization and calibration of 40Ar/39Ar dating standards: Chemical Geology, v. 198, no. 3-4, p. 189-211, doi: 10.1016/S00092541(03)00005-6.

Stacey, J.S., and Kramers, J.D., 1975, Approximation of terrestrial lead isotope evolution by a two-stage model: Earth and Planetary Science Letters, v. 26, p. 207-221, doi: $10.1016 / 0012-821 X(75) 90088-6$.

Whitehouse, M.J., and Kamber, B.S., 2005, Assigning dates to thin gneissic veins in high-grade metamorphic terranes: A cautionary tale from Akilia, southwest Greenland: Journal of Petrology, v. 46, no. 2, p. 291-318, doi: 10.1093/petrology/egh075. 
Whitehouse, M.J., Kamber, B.S., and Moorbath, S., 1999, Age significance of U-Th-Pb zircon data from early Archaean rocks of west Greenland - a reassessment based on combined ion-microprobe and imaging studies: Chemical Geology, v. 160, no. 3, p. 201-224, doi: 10.1016/S0009-2541(99)00066-2.

York, D., Hall, C.M., Yanase, Y., and Hanes, J.A., 1981, ${ }^{40} \mathrm{Ar} /{ }^{39} \mathrm{Ar}$ dating of terrestrial minerals with a continuous laser: Geophysical Research Letters, v. 8, no. 11, p. 1136-1138. 
TABLE SM2.1: SAMPLE LOCATIONS FROM THE NE BROOKS RANGE, AK

\begin{tabular}{|c|c|c|c|c|}
\hline Sample Name & Latitude & Longitude & Predesignated Map Unit & Analysis \\
\hline \multicolumn{5}{|c|}{ Neruokpuk Formation or Firth River group } \\
\hline 12JT10 & N 69.157950 & W 141.864928 & Css* & U-Pb detrital zircon \\
\hline 12JT11 & N 69.192398 & W 141.868887 & $\mathrm{pCn} n^{*}$ & U-Pb detrital zircon \\
\hline 12JT12 & N 69.227013 & W 141.831267 & $\mathrm{pCn} n^{\star}$ & 40Ar/39Ar muscovite \\
\hline 12JT13a & N 69.387220 & W 141.535461 & $\mathrm{pCn} *$ & 40Ar/39Ar muscovite \\
\hline 12JT31 & N 69.387220 & W 141.535461 & pCpa* & $\mathrm{U}-\mathrm{Pb}$ detrital zircon \\
\hline 12JT32 & N 69.424719 & W 141.508195 & $\mathrm{pCn} n^{*}$ & U-Pb detrital zircon \\
\hline 05LF13 & N 69.185356 & W 142.664228 & $\mathrm{pCn}^{*}$ & U-Pb detrital zircon \\
\hline 11LF13 & N 69.263494 & W 142.657930 & $\mathrm{pCn} *$ & U-Pb detrital zircon \\
\hline 28LF13 & N 69.357533 & W 142.858018 & $\mathrm{pCn} *$ & U-Pb detrital zircon \\
\hline 37LF13 & N 69.357257 & W 142.921486 & $\mathrm{pCn}{ }^{*}$ & U-Pb detrital zircon \\
\hline J1355-617 & N 69.219592 & W 140.949294 & $\mathrm{Css}^{\star \star}$ & U-Pb detrital zircon \\
\hline \multicolumn{5}{|c|}{ Clarence River group } \\
\hline 12JT22 & N 69.279048 & W 141.727346 & $\mathrm{Cp}{ }^{*}$ & U-Pb detrital zircon \\
\hline 12JT23 & N 69.279912 & W 141.747478 & $\mathrm{Cp}{ }^{*}$ & U-Pb detrital zircon \\
\hline 12JT24 & N 69.279912, & W 141.747478 & $\mathrm{Cp}{ }^{*}$ & $\begin{array}{c}\text { 40Ar/39Ar muscovite \& U-Pb } \\
\text { detrital zircon }\end{array}$ \\
\hline 12JT35 & N 69.469365 & W 141.469672 & Os or Ovc* & U-Pb detrital zircon \\
\hline 09LF13 & N 69.264435 & W 142.657912 & Ccp or Css* & 40Ar/39Ar muscovite \\
\hline 40LF13 & N 69.375307 & W 142.912505 & $\mathrm{Cp}{ }^{*}$ & $\begin{array}{c}\text { 40Ar/39Ar muscovite \& U-Pb } \\
\text { detrital zircon }\end{array}$ \\
\hline 14BJ27 & N 69.117975 & W 143.238008 & Cp or Css* & 40Ar/39Ar muscovite \\
\hline
\end{tabular}

*Map units designated by Reiser et al. (1980)

**Map units designated by Lane et al. (1995) 
TABLE SM2.2. GEOCHRONOLOGICAL AND FOSSIL AGE CONSTRAINTS

\begin{tabular}{|c|c|c|c|c|}
\hline Formation/unit & $\begin{array}{c}\text { Data localities } \\
\text { (see Fig. 2) }\end{array}$ & Age/Biostratigraphy & Description & Reference \\
\hline Kikiktat volcanics & 1 & $\begin{array}{c}\text { Neoproterozoic }(719.47 \pm 0.29 \\
\mathrm{Ma})\end{array}$ & $\begin{array}{c}\text { U-Pb age on detrital zircons by chemical abrasion-thermal } \\
\text { ionization mass spectrometry (TIMS) from a volcanoclastic sample } \\
\text { directly overlying basaltic flows of the Kikiktat volcanics }\end{array}$ & Cox et al., 2015 \\
\hline$\underline{\text { Nanook Limestone }}$ & 2 & Cambrian-Ordovician & $\begin{array}{l}\text { Fossil collections: conodont Clavohamulus densus, trilobite } \\
\text { Plethopeltis armatus, trilobite genus Paraplethopeltis, brachiopod } \\
\text { and gastropod genera Tcherskidium n. sp. and Eoconchidium }\end{array}$ & $\begin{array}{l}\text { Blodgett et al., 2002; } \\
\text { 2002; Strauss et al., } \\
\qquad 2013\end{array}$ \\
\hline Neruokpuk Formation & 3 and 4 & Lower-Middle Cambrian & $\begin{array}{c}\text { Oldhamia trace fossil assemblages from green and maroon argillite } \\
\text { units in the British and Barn mountains of Yukon }\end{array}$ & $\begin{array}{l}\text { Hoffman et al., 1994, } \\
\text { Lane and Cecile, } 1989\end{array}$ \\
\hline $\begin{array}{l}\text { Whale Mountain volcanic } \\
\underline{\text { rocks }}\end{array}$ & 5 & Upper Cambrian (Furongian) & $\begin{array}{l}\text { Fossil collections: trilobite genera Geragnostus sp., Saratogia sp.; } \\
\text { brachiopod genus Billingsella sp. }\end{array}$ & Dutro et al., 1972 \\
\hline$\underline{\text { Romanzof chert }}$ & 6 & Middle Ordovician-Llandovery & $\begin{array}{l}\text { Fossil collections: graptolite genera Climacograptus sp, cf. hughesi, } \\
\text { Retiograptus geinitzlanus?, Orthograptus?, and Didymograptus? }\end{array}$ & $\begin{array}{l}\text { Moore and Churkin, } \\
1984\end{array}$ \\
\hline \multirow[t]{3}{*}{$\underline{\text { Clarence River group }}$} & 7 & Cambrian(?) & Echinodem debris & Reiser et al., 1980 \\
\hline & 8 & Ordovician & $\begin{array}{l}\text { Fossil collections: graptolite genera Orthograptus of the } \mathrm{O} \text {. } \\
\text { quadrium-cronatus type }\end{array}$ & Reiser et al., 1980 \\
\hline & 9 & Lower Ordovician and Silurian & $\begin{array}{l}\text { Fossil collections: graptolite genera Monograptus sp., } \\
\text { Didymograptus sp., Goniograptus sp., Tetragraptus sp. }\end{array}$ & Lane and Cecile, 1989 \\
\hline
\end{tabular}


TABLE SM2.2. GEOCHRONOLOGICAL AND FOSSIL AGE CONSTRAINTS

\begin{tabular}{|c|c|c|c|c|}
\hline Formation/unit & $\begin{array}{l}\text { Data localities } \\
\text { (see Fig. 2) }\end{array}$ & Age/Biostratigraphy & Description & Reference \\
\hline & 10 & Ordovician and Silurian & $\begin{array}{c}\text { Fossil collections: graptolite genera Monograptus sp., } \\
\text { Neodiversograptus sp., Dicellograptus sp., Paraglossograptus sp., } \\
\text { Isograptus sp., Didymograptus sp., Goniograptus sp., Tetragraptus } \\
\text { sp. }\end{array}$ & Lenz and Perry, 1972 \\
\hline & 11 & Pridoli & $\begin{array}{l}\text { Fossil collections: graptolite genera Monograptus cf., } M \text {. } \\
\text { transgrediens praecipuus }\end{array}$ & Norford, 1997 \\
\hline Clarence River group & 12 & Early Devonian(?) & Conodont genus Polygnathus sp., with a Color Alteration Index of 5 & Norris, 1986 \\
\hline$\underline{\text { Ulungarat Formation }}$ & 13 & Middle Devonian & $\begin{array}{l}\text { Fossil collections: brachiopod genera Warrenella(?) sp., } \\
\text { Goniophoria sp.; trilobite genus Dechenella sp. }\end{array}$ & Reiser et al., 1980 \\
\hline Devonian plutonic rocks & 14 and 15 & Late Devonian (380-360 Ma) & $\begin{array}{l}\mathrm{Pb} \text {-alpha, } \mathrm{U}-\mathrm{Pb} \text { zircon, and } \mathrm{U}-\mathrm{Pb} \text { titanite ages from the Mount } \\
\text { Sedgwick pluton in northern Yukon and the Okpilak batholith in } \\
\text { Alaska }\end{array}$ & $\begin{array}{l}\text { Sable, 1977; } \\
\text { Mortensen and Bell, } \\
\text { 1991; Dillon et al., } 1987\end{array}$ \\
\hline
\end{tabular}


TABLE SM2.3: LA-ICPMS U-PB ISOTOPIC DATA (UC SANTA CRUZ LAB)

\begin{tabular}{|c|c|c|c|c|c|c|c|c|c|c|c|c|c|c|c|c|c|c|c|}
\hline \multirow[b]{2}{*}{ Analysis } & \multirow[b]{2}{*}{$U$} & \multirow[b]{2}{*}{$\mathrm{U} / \mathrm{Th}$} & \multirow[b]{2}{*}{$206 \mathrm{~Pb}^{*}$} & \multirow[b]{2}{*}{ \pm} & \multirow[b]{2}{*}{ error } & \multicolumn{5}{|c|}{ Isotope ratios } & \multicolumn{6}{|c|}{ Apparent ages (Ma) } & \multirow[b]{2}{*}{ Best age } & \multirow[b]{2}{*}{ \pm} & \multirow[b]{2}{*}{ Conc } \\
\hline & & & & & & $207 \mathrm{~Pb}^{*}$ & \pm & $206 \mathrm{~Pb}^{*}$ & \pm & error & $206 \mathrm{~Pb}^{*}$ & \pm & 207Pb* & \pm & $206 \mathrm{~Pb}^{*}$ & \pm & & & \\
\hline & $(\mathrm{ppm})$ & & $207 \mathrm{~Pb}^{*}$ & $(\%)$ & corr. & $235 U^{*}$ & $(\%)$ & $238 U$ & $(\%)$ & corr. & $238 U^{*}$ & (Ma) & $235 \mathrm{U}$ & (Ma) & $207 \mathrm{~Pb}^{*}$ & (Ma) & (Ma) & (Ma) & $(\%)$ \\
\hline \multicolumn{20}{|c|}{ 12JT10; Neruokpuk Formation (N69.12, W141.90) } \\
\hline 12JT10_83 & 166 & 1.5 & 0.066 & 0.360 & 0.2 & 0.93 & 6.7 & 0.103 & 0.5 & 0.24 & 632 & 29 & 664 & 35 & 790 & 120 & 632 & 29 & 80 \\
\hline 12JT10_51 & 152 & 2.7 & 0.071 & 0.370 & 0.2 & 1.55 & 11.0 & 0.157 & 0.7 & 0.31 & 937 & 41 & 947 & 44 & 990 & 110 & 937 & 41 & 95 \\
\hline 12JT10_87 & 90 & 1.3 & 0.075 & 0.410 & 0.3 & 1.73 & 13.0 & 0.168 & 0.8 & 0.34 & 1002 & 45 & 1016 & 48 & 1060 & 110 & 1060 & 110 & 95 \\
\hline 12JT10_42 & 526 & 3.0 & 0.080 & 0.370 & 0.2 & 2.04 & 14.0 & 0.185 & 0.9 & 0.51 & 1095 & 47 & 1127 & 45 & 1183 & 91 & 1183 & 91 & 93 \\
\hline 12JT10_82 & 307 & 1.4 & 0.086 & 0.400 & 0.3 & 2.58 & 17.0 & 0.216 & 1.0 & 0.51 & 1263 & 53 & 1294 & 48 & 1346 & 89 & 1346 & 89 & 94 \\
\hline 12JT10_34 & 127 & 2.0 & 0.090 & 0.430 & 0.2 & 2.90 & 20.0 & 0.234 & 1.1 & 0.42 & 1358 & 57 & 1386 & 51 & 1413 & 93 & 1413 & 93 & 96 \\
\hline 12JT10_99 & 143 & 2.2 & 0.090 & 0.450 & 0.4 & 3.19 & 22.0 & 0.256 & 1.2 & 0.23 & 1473 & 61 & 1462 & 52 & 1418 & 93 & 1418 & 93 & 104 \\
\hline 12JT10_71 & 305 & 2.7 & 0.090 & 0.420 & 0.1 & 2.92 & 20.0 & 0.242 & 1.1 & 0.60 & 1396 & 58 & 1388 & 51 & 1424 & 88 & 1424 & 88 & 98 \\
\hline 12JT10_73 & 223 & 2.4 & 0.090 & 0.430 & 0.2 & 2.95 & 20.0 & 0.237 & 1.1 & 0.39 & 1370 & 57 & 1395 & 52 & 1426 & 88 & 1426 & 88 & 96 \\
\hline 12JT10_45 & 95 & 1.0 & 0.101 & 0.490 & 0.2 & 3.77 & 26.0 & 0.271 & 1.3 & 0.46 & 1543 & 65 & 1581 & 56 & 1626 & 92 & 1626 & 92 & 95 \\
\hline 12JT10_64 & 66 & 1.3 & 0.108 & 0.540 & 0.3 & 4.52 & 31.0 & 0.309 & 1.5 & 0.40 & 1742 & 74 & 1730 & 57 & 1754 & 95 & 1754 & 95 & 99 \\
\hline 12JT10_95 & 67 & 0.5 & 0.109 & 0.550 & 0.3 & 4.73 & 33.0 & 0.314 & 1.5 & 0.44 & 1759 & 74 & 1774 & 58 & 1760 & 91 & 1760 & 91 & 100 \\
\hline 12JT10_80 & 242 & 1.8 & 0.108 & 0.500 & 0.3 & 4.58 & 30.0 & 0.303 & 1.4 & 0.58 & 1707 & 70 & 1745 & 55 & 1768 & 84 & 1768 & 84 & 97 \\
\hline 12JT10_15 & 48 & 2.0 & 0.108 & 0.540 & 0.3 & 4.82 & 34.0 & 0.321 & 1.6 & 0.49 & 1797 & 77 & 1781 & 58 & 1770 & 92 & 1770 & 92 & 102 \\
\hline 12JT10_56 & 114 & 1.7 & 0.109 & 0.520 & 0.3 & 4.58 & 31.0 & 0.298 & 1.4 & 0.48 & 1681 & 70 & 1746 & 56 & 1786 & 87 & 1786 & 87 & 94 \\
\hline 12JT10_63 & 112 & 1.4 & 0.110 & 0.530 & 0.3 & 4.52 & 31.0 & 0.303 & 1.4 & 0.47 & 1708 & 72 & 1738 & 54 & 1792 & 88 & 1792 & 88 & 95 \\
\hline 12JT10_79 & 141 & 0.7 & 0.110 & 0.510 & 0.3 & 4.66 & 31.0 & 0.299 & 1.4 & 0.49 & 1690 & 69 & 1758 & 56 & 1793 & 85 & 1793 & 85 & 94 \\
\hline 12JT10_47 & 113 & 0.9 & 0.110 & 0.530 & 0.4 & 4.68 & 31.0 & 0.309 & 1.4 & 0.37 & 1734 & 72 & 1759 & 56 & 1796 & 87 & 1796 & 87 & 97 \\
\hline 12JT10_43 & 329 & 1.9 & 0.110 & 0.500 & 0.2 & 4.58 & 30.0 & 0.304 & 1.4 & 0.56 & 1711 & 69 & 1746 & 55 & 1797 & 82 & 1797 & 82 & 95 \\
\hline 12JT10_88 & 240 & 2.5 & 0.111 & 0.510 & 0.2 & 4.85 & 32.0 & 0.320 & 1.5 & 0.66 & 1790 & 73 & 1790 & 56 & 1805 & 84 & 1805 & 84 & 99 \\
\hline 12JT10_66 & 195 & 3.7 & 0.111 & 0.520 & 0.3 & 4.61 & 31.0 & 0.315 & 1.5 & 0.49 & 1767 & 72 & 1753 & 56 & 1808 & 87 & 1808 & 87 & 98 \\
\hline 12JT10_69 & 357 & 2.5 & 0.111 & 0.500 & 0.2 & 4.67 & 31.0 & 0.318 & 1.5 & 0.62 & 1779 & 72 & 1765 & 55 & 1808 & 83 & 1808 & 83 & 98 \\
\hline 12JT10_25 & 111 & 1.7 & 0.111 & 0.530 & 0.3 & 4.69 & 32.0 & 0.304 & 1.4 & 0.41 & 1716 & 70 & 1767 & 57 & 1810 & 85 & 1810 & 85 & 95 \\
\hline 12JT10_20 & 137 & 1.1 & 0.111 & 0.520 & 0.2 & 4.82 & 32.0 & 0.309 & 1.4 & 0.51 & 1737 & 72 & 1787 & 55 & 1813 & 86 & 1813 & 86 & 96 \\
\hline 12JT10_30 & 240 & 1.7 & 0.111 & 0.510 & 0.2 & 4.81 & 32.0 & 0.304 & 1.4 & 0.63 & 1711 & 69 & 1783 & 56 & 1816 & 81 & 1816 & 81 & 94 \\
\hline 12JT10_41 & 154 & 1.1 & 0.111 & 0.530 & 0.2 & 4.65 & 31.0 & 0.306 & 1.4 & 0.48 & 1724 & 72 & 1759 & 57 & 1816 & 88 & 1816 & 88 & 95 \\
\hline
\end{tabular}


TABLE SM2.3: LA-ICPMS U-PB ISOTOPIC DATA (UC SANTA CRUZ LAB)

\begin{tabular}{|c|c|c|c|c|c|c|c|c|c|c|c|c|c|c|c|c|c|c|c|}
\hline \multirow[b]{2}{*}{ Analysis } & \multirow[b]{2}{*}{$\mathrm{U}$} & \multirow[b]{2}{*}{$\mathrm{U} / \mathrm{Th}$} & \multirow[b]{2}{*}{$206 \mathrm{~Pb}^{\star}$} & \multirow[b]{2}{*}{ \pm} & \multirow[b]{2}{*}{ error } & \multicolumn{5}{|c|}{ Isotope ratios } & \multicolumn{6}{|c|}{ Apparent ages (Ma) } & \multirow[b]{2}{*}{ Best age } & \multirow[b]{2}{*}{ \pm} & \multirow[b]{2}{*}{ Conc } \\
\hline & & & & & & $207 \mathrm{~Pb}^{\star}$ & \pm & $206 \mathrm{~Pb}^{*}$ & \pm & error & $206 \mathrm{~Pb}^{*}$ & \pm & $207 \mathrm{~Pb}^{*}$ & \pm & $206 \mathrm{~Pb}^{*}$ & \pm & & & \\
\hline & (ppm) & & 207Pb* & (\%) & corr. & $235 U^{*}$ & (\%) & $238 U$ & $(\%)$ & corr. & $238 U^{*}$ & (Ma) & $235 \mathrm{U}$ & (Ma) & $207 \mathrm{~Pb}^{\star}$ & (Ma) & (Ma) & (Ma) & (\%) \\
\hline 12JT10_16 & 101 & 0.6 & 0.111 & 0.540 & 0.2 & 4.85 & 33.0 & 0.313 & 1.5 & 0.45 & 1753 & 72 & 1790 & 57 & 1818 & 86 & 1818 & 86 & 96 \\
\hline 12JT10_17 & 137 & 1.8 & 0.111 & 0.520 & 0.3 & 4.64 & 31.0 & 0.297 & 1.4 & 0.57 & 1677 & 69 & 1756 & 55 & 1820 & 85 & 1820 & 85 & 92 \\
\hline 12JT10_54 & 96 & 0.9 & 0.112 & 0.540 & 0.2 & 4.76 & 32.0 & 0.303 & 1.4 & 0.51 & 1707 & 71 & 1774 & 56 & 1820 & 86 & 1820 & 86 & 94 \\
\hline 12JT10_53 & 357 & 2.8 & 0.111 & 0.510 & 0.4 & 4.69 & 31.0 & 0.301 & 1.4 & 0.55 & 1696 & 68 & 1766 & 55 & 1821 & 82 & 1821 & 82 & 93 \\
\hline 12JT10_38 & 222 & 0.5 & 0.112 & 0.510 & 0.2 & 4.52 & 30.0 & 0.292 & 1.4 & 0.49 & 1652 & 67 & 1735 & 54 & 1822 & 84 & 1822 & 84 & 91 \\
\hline 12JT10_28 & 281 & 3.9 & 0.112 & 0.510 & 0.3 & 4.66 & 31.0 & 0.298 & 1.4 & 0.56 & 1681 & 68 & 1759 & 54 & 1822 & 84 & 1822 & 84 & 92 \\
\hline 12JT10_39 & 156 & 1.5 & 0.112 & 0.540 & 0.2 & 4.57 & 31.0 & 0.293 & 1.4 & 0.55 & 1657 & 69 & 1740 & 57 & 1823 & 89 & 1823 & 89 & 91 \\
\hline 12JT10_8 & 111 & 1.3 & 0.112 & 0.530 & 0.2 & 4.95 & 33.0 & 0.328 & 1.5 & 0.46 & 1827 & 75 & 1814 & 58 & 1824 & 86 & 1824 & 86 & 100 \\
\hline 12JT10_44 & 268 & 1.4 & 0.112 & 0.510 & 0.2 & 4.73 & 31.0 & 0.307 & 1.4 & 0.56 & 1723 & 70 & 1770 & 56 & 1832 & 83 & 1832 & 83 & 94 \\
\hline 12JT10_40 & 68 & 0.8 & 0.112 & 0.560 & 0.3 & 4.64 & 32.0 & 0.297 & 1.4 & 0.43 & 1673 & 71 & 1755 & 58 & 1833 & 89 & 1833 & 89 & 91 \\
\hline 12JT10_7 & 149 & 1.3 & 0.112 & 0.530 & 0.2 & 4.87 & 33.0 & 0.319 & 1.5 & 0.53 & 1787 & 72 & 1794 & 55 & 1838 & 84 & 1838 & 84 & 97 \\
\hline 12JT10_96 & 88 & 1.3 & 0.112 & 0.550 & 0.3 & 5.01 & 34.0 & 0.322 & 1.5 & 0.36 & 1797 & 74 & 1828 & 56 & 1848 & 93 & 1848 & 93 & 97 \\
\hline 12JT10_21 & 106 & 1.2 & 0.113 & 0.540 & 0.2 & 4.73 & 32.0 & 0.303 & 1.4 & 0.45 & 1702 & 70 & 1779 & 57 & 1849 & 88 & 1849 & 88 & 92 \\
\hline 12JT10_62 & 130 & 2.2 & 0.113 & 0.520 & 0.2 & 4.73 & 32.0 & 0.306 & 1.4 & 0.58 & 1720 & 71 & 1770 & 56 & 1851 & 85 & 1851 & 85 & 93 \\
\hline 12JT10_55 & 39 & 0.7 & 0.115 & 0.590 & 0.4 & 4.85 & 34.0 & 0.306 & 1.5 & 0.41 & 1726 & 75 & 1797 & 61 & 1854 & 99 & 1854 & 99 & 93 \\
\hline 12JT10_75 & 59 & 1.2 & 0.115 & 0.570 & 0.2 & 5.08 & 35.0 & 0.314 & 1.5 & 0.51 & 1758 & 74 & 1829 & 59 & 1882 & 91 & 1882 & 91 & 93 \\
\hline 12JT10_85 & 199 & 2.3 & 0.116 & 0.540 & 0.3 & 5.13 & 34.0 & 0.322 & 1.5 & 0.52 & 1797 & 74 & 1839 & 57 & 1893 & 84 & 1893 & 84 & 95 \\
\hline 12JT10_26 & 253 & 2.4 & 0.116 & 0.530 & 0.1 & 5.20 & 34.0 & 0.316 & 1.5 & 0.59 & 1772 & 70 & 1849 & 56 & 1899 & 82 & 1899 & 82 & 93 \\
\hline 12JT10_65 & 54 & 0.6 & 0.117 & 0.590 & 0.2 & 5.26 & 37.0 & 0.335 & 1.7 & 0.53 & 1861 & 79 & 1853 & 61 & 1903 & 92 & 1903 & 92 & 98 \\
\hline 12JT10_48 & 251 & 1.2 & 0.117 & 0.540 & 0.4 & 5.20 & 34.0 & 0.325 & 1.5 & 0.52 & 1817 & 76 & 1855 & 57 & 1904 & 82 & 1904 & 82 & 95 \\
\hline 12JT10_57 & 107 & 0.9 & 0.117 & 0.560 & 0.3 & 5.16 & 35.0 & 0.314 & 1.5 & 0.49 & 1758 & 72 & 1846 & 58 & 1906 & 86 & 1906 & 86 & 92 \\
\hline 12JT10_46 & 75 & 2.2 & 0.117 & 0.570 & 0.1 & 5.03 & 35.0 & 0.312 & 1.5 & 0.51 & 1750 & 72 & 1828 & 61 & 1911 & 90 & 1911 & 90 & 92 \\
\hline 12JT10_10 & 158 & 2.5 & 0.117 & 0.540 & 0.2 & 5.59 & 37.0 & 0.353 & 1.6 & 0.59 & 1946 & 78 & 1915 & 57 & 1911 & 83 & 1911 & 83 & 102 \\
\hline 12JT10_94 & 239 & 1.3 & 0.117 & 0.540 & 0.3 & 5.41 & 36.0 & 0.333 & 1.5 & 0.55 & 1849 & 74 & 1885 & 57 & 1912 & 81 & 1912 & 81 & 97 \\
\hline 12JT10_12 & 159 & 1.7 & 0.118 & 0.540 & 0.2 & 5.38 & 36.0 & 0.336 & 1.5 & 0.56 & 1866 & 76 & 1882 & 56 & 1917 & 85 & 1917 & 85 & 97 \\
\hline 12JT10_77 & 277 & 1.9 & 0.119 & 0.540 & 0.3 & 5.40 & 36.0 & 0.321 & 1.5 & 0.56 & 1793 & 72 & 1886 & 57 & 1935 & 82 & 1935 & 82 & 93 \\
\hline 12JT10_98 & 237 & 0.9 & 0.119 & 0.540 & 0.2 & 5.76 & 38.0 & 0.348 & 1.6 & 0.59 & 1926 & 78 & 1936 & 58 & 1936 & 85 & 1936 & 85 & 99 \\
\hline 12JT10 86 & 113 & 2.0 & 0.119 & 0.560 & 0.2 & 5.15 & 35.0 & 0.317 & 1.5 & 0.55 & 1772 & 73 & 1848 & 59 & 1938 & 85 & 1938 & 85 & 91 \\
\hline
\end{tabular}


TABLE SM2.3: LA-ICPMS U-PB ISOTOPIC DATA (UC SANTA CRUZ LAB)

\begin{tabular}{|c|c|c|c|c|c|c|c|c|c|c|c|c|c|c|c|c|c|c|c|}
\hline \multirow[b]{2}{*}{ Analysis } & \multirow[b]{2}{*}{$U$} & \multirow[b]{2}{*}{$\mathrm{U} / \mathrm{Th}$} & \multirow[b]{2}{*}{$206 \mathrm{~Pb}^{*}$} & \multirow[b]{2}{*}{ \pm} & \multirow[b]{2}{*}{ error } & \multicolumn{5}{|c|}{ Isotope ratios } & \multicolumn{6}{|c|}{ Apparent ages (Ma) } & \multirow[b]{2}{*}{ Best age } & \multirow[b]{2}{*}{ \pm} & \multirow[b]{2}{*}{ Conc } \\
\hline & & & & & & 207Pb* & \pm & $206 \mathrm{~Pb}^{*}$ & \pm & error & $206 \mathrm{~Pb}^{*}$ & \pm & $207 \mathrm{~Pb}^{*}$ & \pm & $206 \mathrm{~Pb}^{*}$ & \pm & & & \\
\hline & (ppm) & & $207 \mathrm{~Pb}^{*}$ & $(\%)$ & corr. & $235 U^{*}$ & $(\%)$ & $238 U$ & $(\%)$ & corr. & $238 U^{*}$ & (Ma) & $235 U$ & (Ma) & $207 \mathrm{~Pb}^{*}$ & (Ma) & $(\mathrm{Ma})$ & (Ma) & $(\%)$ \\
\hline 12JT10_74 & 105 & 1.1 & 0.120 & 0.590 & 0.2 & 5.34 & 37.0 & 0.320 & 1.5 & 0.38 & 1791 & 73 & 1873 & 57 & 1938 & 85 & 1938 & 85 & 92 \\
\hline 12JT10_36 & 120 & 2.1 & 0.119 & 0.570 & 0.3 & 4.81 & 33.0 & 0.291 & 1.5 & 0.70 & 1644 & 73 & 1779 & 58 & 1939 & 87 & 1939 & 87 & 85 \\
\hline 12JT10_6 & 80 & 0.7 & 0.119 & 0.580 & 0.4 & 5.75 & 39.0 & 0.353 & 1.7 & 0.36 & 1947 & 79 & 1937 & 58 & 1940 & 84 & 1940 & 84 & 100 \\
\hline 12JT10_58 & 1021 & 1.9 & 0.121 & 0.540 & 0.2 & 5.01 & 33.0 & 0.295 & 1.4 & 0.74 & 1668 & 68 & 1821 & 55 & 1966 & 80 & 1966 & 80 & 85 \\
\hline 12JT10_100 & 361 & 0.9 & 0.124 & 0.560 & 0.3 & 5.33 & 35.0 & 0.312 & 1.5 & 0.70 & 1751 & 72 & 1872 & 56 & 2004 & 81 & 2004 & 81 & 87 \\
\hline 12JT10_81 & 73 & 1.5 & 0.126 & 0.620 & 0.3 & 5.97 & 41.0 & 0.342 & 1.7 & 0.52 & 1894 & 79 & 1969 & 57 & 2040 & 84 & 2040 & 84 & 93 \\
\hline 12JT10_11 & 103 & 1.9 & 0.127 & 0.600 & 0.3 & 6.43 & 43.0 & 0.367 & 1.7 & 0.49 & 2020 & 82 & 2033 & 59 & 2048 & 82 & 2048 & 82 & 99 \\
\hline 12JT10_13 & 68 & 0.6 & 0.127 & 0.870 & 0.1 & 5.07 & 43.0 & 0.297 & 1.6 & 0.48 & 1676 & 81 & 1814 & 72 & 2050 & 130 & 2050 & 130 & 82 \\
\hline 12JT10_76 & 235 & 4.6 & 0.127 & 0.570 & 0.4 & 6.25 & 41.0 & 0.350 & 1.6 & 0.53 & 1935 & 78 & 2010 & 58 & 2051 & 81 & 2051 & 81 & 94 \\
\hline 12JT10_19 & 372 & 2.6 & 0.127 & 0.580 & 0.3 & 6.38 & 42.0 & 0.358 & 1.7 & 0.53 & 1973 & 78 & 2028 & 57 & 2056 & 80 & 2056 & 80 & 96 \\
\hline 12JT10_78 & 161 & 1.4 & 0.128 & 0.590 & 0.2 & 6.30 & 42.0 & 0.348 & 1.7 & 0.63 & 1924 & 79 & 2020 & 59 & 2069 & 82 & 2069 & 82 & 93 \\
\hline 12JT10_37 & 157 & 2.8 & 0.130 & 0.610 & 0.4 & 6.03 & 40.0 & 0.338 & 1.6 & 0.50 & 1878 & 78 & 1982 & 56 & 2098 & 80 & 2098 & 80 & 90 \\
\hline 12JT10_27 & 51 & 1.2 & 0.137 & 0.680 & 0.3 & 7.00 & 48.0 & 0.362 & 1.8 & 0.47 & 1993 & 82 & 2105 & 61 & 2179 & 87 & 2179 & 87 & 91 \\
\hline 12JT10_61 & 319 & 4.8 & 0.138 & 0.660 & 0.2 & 6.11 & 41.0 & 0.321 & 1.5 & 0.35 & 1795 & 74 & 1990 & 59 & 2192 & 85 & 2192 & 85 & 82 \\
\hline 12JT10_9 & 110 & 1.4 & 0.140 & 0.650 & 0.1 & 7.82 & 52.0 & 0.417 & 2.0 & 0.63 & 2248 & 89 & 2217 & 62 & 2220 & 81 & 2220 & 81 & 101 \\
\hline 12JT10_29 & 59 & 0.9 & 0.145 & 0.700 & 0.2 & 8.20 & 56.0 & 0.403 & 2.0 & 0.59 & 2184 & 91 & 2253 & 63 & 2292 & 83 & 2292 & 83 & 95 \\
\hline 12JT10_4 & 179 & 1.3 & 0.146 & 0.660 & 0.2 & 8.59 & 57.0 & 0.437 & 2.0 & 0.65 & 2336 & 91 & 2296 & 59 & 2294 & 79 & 2294 & 79 & 102 \\
\hline 12JT10_22 & 248 & 3.2 & 0.145 & 0.660 & 0.2 & 8.04 & 53.0 & 0.393 & 1.8 & 0.67 & 2137 & 84 & 2238 & 60 & 2295 & 77 & 2295 & 77 & 93 \\
\hline 12JT10_68 & 156 & 1.9 & 0.148 & 0.680 & 0.2 & 8.10 & 54.0 & 0.414 & 1.9 & 0.63 & 2235 & 87 & 2242 & 61 & 2318 & 78 & 2318 & 78 & 96 \\
\hline 12JT10_93 & 64 & 1.1 & 0.147 & 0.710 & 0.3 & 8.65 & 59.0 & 0.428 & 2.1 & 0.54 & 2296 & 93 & 2303 & 63 & 2319 & 82 & 2319 & 82 & 99 \\
\hline 12JT10_2 & 117 & 1.0 & 0.148 & 0.690 & 0.2 & 8.89 & 59.0 & 0.445 & 2.1 & 0.66 & 2369 & 93 & 2327 & 62 & 2323 & 80 & 2323 & 80 & 102 \\
\hline 12JT10_23 & 108 & 0.7 & 0.149 & 0.690 & 0.2 & 8.59 & 58.0 & 0.409 & 1.9 & 0.61 & 2211 & 88 & 2294 & 60 & 2326 & 81 & 2326 & 81 & 95 \\
\hline 12JT10_84 & 78 & 1.6 & 0.149 & 0.710 & 0.3 & 8.37 & 57.0 & 0.407 & 1.9 & 0.50 & 2207 & 88 & 2272 & 60 & 2327 & 81 & 2327 & 81 & 95 \\
\hline 12JT10_33 & 119 & 1.6 & 0.149 & 0.690 & 0.3 & 8.04 & 54.0 & 0.388 & 1.8 & 0.54 & 2115 & 85 & 2235 & 60 & 2339 & 81 & 2339 & 81 & 90 \\
\hline 12JT10_1 & 100 & 1.5 & 0.150 & 0.700 & 0.3 & 9.33 & 62.0 & 0.454 & 2.2 & 0.62 & 2413 & 95 & 2366 & 62 & 2342 & 81 & 2342 & 81 & 103 \\
\hline 12JT10_50 & 132 & 1.2 & 0.150 & 0.690 & 0.4 & 8.38 & 56.0 & 0.406 & 1.9 & 0.51 & 2198 & 85 & 2272 & 60 & 2345 & 79 & 2345 & 79 & 94 \\
\hline 12JT10_60 & 299 & 1.4 & 0.152 & 0.690 & 0.3 & 8.77 & 58.0 & 0.410 & 1.9 & 0.66 & 2217 & 87 & 2315 & 58 & 2371 & 76 & 2371 & 76 & 94 \\
\hline 12JT10_31 & 131 & 1.4 & 0.154 & 0.710 & 0.3 & 8.48 & 57.0 & 0.393 & 1.9 & 0.53 & 2136 & 85 & 2284 & 60 & 2395 & 79 & 2395 & 79 & 89 \\
\hline
\end{tabular}


TABLE SM2.3: LA-ICPMS U-PB ISOTOPIC DATA (UC SANTA CRUZ LAB)

\begin{tabular}{|c|c|c|c|c|c|c|c|c|c|c|c|c|c|c|c|c|c|c|c|}
\hline \multirow[b]{2}{*}{ Analysis } & \multirow[b]{2}{*}{$U$} & \multirow[b]{2}{*}{ U/Th } & \multirow[b]{2}{*}{$206 \mathrm{~Pb}^{*}$} & \multirow[b]{2}{*}{ \pm} & \multirow[b]{2}{*}{ error } & \multicolumn{5}{|c|}{ Isotope ratios } & \multicolumn{6}{|c|}{ Apparent ages (Ma) } & \multirow[b]{2}{*}{ Best age } & \multirow[b]{2}{*}{ \pm} & \multirow[b]{2}{*}{ Cono } \\
\hline & & & & & & $207 \mathrm{~Pb}^{*}$ & \pm & $206 \mathrm{~Pb}^{*}$ & \pm & error & $206 \mathrm{~Pb}^{*}$ & \pm & 207Pb* & \pm & $206 \mathrm{~Pb}^{*}$ & \pm & & & \\
\hline & (ppm) & & $207 \mathrm{~Pb}^{\star}$ & (\%) & corr. & $235 U^{*}$ & (\%) & $238 U$ & (\%) & corr. & $238 U^{*}$ & (Ma) & $235 \mathrm{U}$ & (Ma) & $207 \mathrm{~Pb}^{*}$ & (Ma) & (Ma) & (Ma) & (\%) \\
\hline 12JT10_59 & 84 & 1.5 & 0.154 & 0.730 & 0.2 & 8.85 & 60.0 & 0.408 & 1.9 & 0.64 & 2203 & 89 & 2318 & 63 & 2397 & 79 & 2397 & 79 & 92 \\
\hline 12JT10_91 & 312 & 1.8 & 0.163 & 0.730 & 0.3 & 9.90 & 65.0 & 0.441 & 2.0 & 0.72 & 2353 & 92 & 2425 & 61 & 2483 & 77 & 2483 & 77 & 95 \\
\hline 12JT10_70 & 313 & 3.8 & 0.170 & 0.760 & 0.3 & 10.69 & 70.0 & 0.477 & 2.2 & 0.73 & 2513 & 96 & 2495 & 61 & 2554 & 76 & 2554 & 76 & 98 \\
\hline 12JT10_35 & 273 & 1.3 & 0.171 & 0.780 & 0.2 & 10.59 & 70.0 & 0.443 & 2.1 & 0.73 & 2367 & 94 & 2489 & 63 & 2569 & 76 & 2569 & 76 & 92 \\
\hline 12JT10_90 & 169 & 2.8 & 0.172 & 0.780 & 0.4 & 11.08 & 73.0 & 0.473 & 2.2 & 0.61 & 2495 & 97 & 2532 & 60 & 2570 & 76 & 2570 & 76 & 97 \\
\hline 12JT10_14 & 111 & 1.2 & 0.172 & 0.790 & 0.3 & 11.28 & 75.0 & 0.474 & 2.2 & 0.65 & 2500 & 96 & 2547 & 61 & 2576 & 77 & 2576 & 77 & 97 \\
\hline 12JT10_92 & 229 & 1.9 & 0.174 & 0.780 & 0.1 & 11.40 & 75.0 & 0.475 & 2.2 & 0.76 & 2505 & 96 & 2556 & 60 & 2592 & 76 & 2592 & 76 & 97 \\
\hline 12JT10_3 & 168 & 2.6 & 0.175 & 0.810 & 0.2 & 11.67 & 78.0 & 0.493 & 2.3 & 0.59 & 2580 & 100 & 2578 & 62 & 2599 & 78 & 2599 & 78 & 99 \\
\hline 12JT10_49 & 211 & 3.6 & 0.175 & 0.800 & 0.3 & 11.20 & 74.0 & 0.465 & 2.2 & 0.66 & 2459 & 95 & 2540 & 61 & 2608 & 74 & 2608 & 74 & 94 \\
\hline 12JT10_72 & 61 & 1.3 & 0.177 & 0.830 & 0.2 & 11.32 & 77.0 & 0.465 & 2.2 & 0.67 & 2458 & 99 & 2548 & 64 & 2616 & 77 & 2616 & 77 & 94 \\
\hline 12JT10_24 & 432 & 0.6 & 0.178 & 0.800 & 0.2 & 11.16 & 73.0 & 0.444 & 2.1 & 0.79 & 2370 & 91 & 2535 & 62 & 2630 & 75 & 2630 & 75 & 90 \\
\hline 12JT10_67 & 102 & 1.5 & 0.183 & 0.840 & 0.3 & 12.01 & 80.0 & 0.491 & 2.3 & 0.64 & 2580 & 100 & 2605 & 62 & 2674 & 75 & 2674 & 75 & 96 \\
\hline 12JT10_5 & 109 & 1.0 & 0.182 & 0.830 & 0.3 & 12.52 & 83.0 & 0.509 & 2.4 & 0.66 & 2650 & 100 & 2643 & 63 & 2677 & 73 & 2677 & 73 & 99 \\
\hline 12JT10_52 & 44 & 2.6 & 0.184 & 0.880 & 0.1 & 11.81 & 82.0 & 0.464 & 2.3 & 0.70 & 2454 & 99 & 2583 & 65 & 2680 & 80 & 2680 & 80 & 92 \\
\hline 12JT10_97 & 54 & 1.8 & 0.183 & 0.860 & 0.2 & 13.13 & 90.0 & 0.517 & 2.5 & 0.71 & 2680 & 110 & 2685 & 64 & 2681 & 79 & 2681 & 79 & 100 \\
\hline 12JT10_32 & 84 & 0.8 & 0.237 & 1.100 & 0.3 & 18.70 & 120.0 & 0.565 & 2.7 & 0.63 & 2890 & 110 & 3026 & 64 & 3103 & 73 & 3103 & 73 & 93 \\
\hline \multicolumn{20}{|c|}{$>20 \%$ Discordance } \\
\hline 12JT10_89 & 1087 & 2.2 & 0.174 & 0.780 & 0.3 & 2.99 & 20.0 & 0.124 & 0.6 & 0.75 & 756 & 33 & 1405 & 49 & 2591 & 75 & 756 & 33 & 29 \\
\hline \multicolumn{20}{|c|}{ 12JT11; Neruokpuk Formation (N69.16, W141.87) } \\
\hline 12JT11_67 & 537 & 4.0 & 0.077 & 0.350 & 0.2 & 1.76 & 11.0 & 0.169 & 0.7 & 0.44 & 1008 & 41 & 1028 & 41 & 1115 & 92 & 1115 & 92 & 90 \\
\hline 12JT11_71 & 89 & 2.0 & 0.087 & 0.440 & 0.3 & 2.47 & 17.0 & 0.206 & 1.0 & 0.36 & 1205 & 51 & 1260 & 50 & 1380 & 100 & 1380 & 100 & 87 \\
\hline 12JT11_24 & 101 & 2.3 & 0.091 & 0.460 & 0.3 & 2.91 & 20.0 & 0.233 & 1.1 & 0.30 & 1349 & 55 & 1381 & 53 & 1420 & 100 & 1420 & 100 & 95 \\
\hline 12JT11_4 & 319 & 3.0 & 0.092 & 0.420 & 0.3 & 3.13 & 20.0 & 0.251 & 1.1 & 0.49 & 1444 & 56 & 1441 & 48 & 1462 & 86 & 1462 & 86 & 99 \\
\hline 12JT11_45 & 384 & 5.8 & 0.093 & 0.410 & 0.2 & 2.91 & 19.0 & 0.229 & 1.0 & 0.55 & 1330 & 53 & 1385 & 48 & 1474 & 84 & 1474 & 84 & 90 \\
\hline 12JT11_31 & 248 & 1.8 & 0.093 & 0.420 & 0.3 & 3.15 & 20.0 & 0.244 & 1.1 & 0.47 & 1406 & 55 & 1447 & 49 & 1485 & 88 & 1485 & 88 & 95 \\
\hline 12JT11_68 & 143 & 1.4 & 0.102 & 0.480 & 0.3 & 3.57 & 23.0 & 0.257 & 1.2 & 0.45 & 1477 & 60 & 1543 & 52 & 1649 & 87 & 1649 & 87 & 90 \\
\hline 12JT11_36 & 271 & 2.2 & 0.107 & 0.480 & 0.2 & 4.52 & 29.0 & 0.302 & 1.3 & 0.53 & 1704 & 66 & 1735 & 52 & 1743 & 83 & 1743 & 83 & 98 \\
\hline
\end{tabular}


TABLE SM2.3: LA-ICPMS U-PB ISOTOPIC DATA (UC SANTA CRUZ LAB)

\begin{tabular}{|c|c|c|c|c|c|c|c|c|c|c|c|c|c|c|c|c|c|c|c|}
\hline \multirow[b]{2}{*}{ Analysis } & \multirow[b]{2}{*}{$U$} & \multirow[b]{2}{*}{$\mathrm{U} / \mathrm{Th}$} & \multirow[b]{2}{*}{$206 \mathrm{~Pb}^{\star}$} & \multirow[b]{2}{*}{ \pm} & \multirow[b]{2}{*}{ error } & \multicolumn{5}{|c|}{ Isotope ratios } & \multicolumn{6}{|c|}{ Apparent ages (Ma) } & \multirow[b]{2}{*}{ Best age } & \multirow[b]{2}{*}{ \pm} & \multirow[b]{2}{*}{ Conc } \\
\hline & & & & & & 207Pb* & \pm & $206 \mathrm{~Pb}^{*}$ & \pm & error & $206 \mathrm{~Pb}^{*}$ & \pm & $207 \mathrm{~Pb}^{*}$ & \pm & $206 \mathrm{~Pb}^{\star}$ & \pm & & & \\
\hline & (ppm) & & $207 \mathrm{~Pb}^{\star}$ & (\%) & corr. & $235 U^{*}$ & (\%) & $238 U$ & (\%) & corr. & $238 U^{*}$ & (Ma) & $235 \mathrm{U}$ & (Ma) & 207Pb* & (Ma) & (Ma) & (Ma) & (\%) \\
\hline 12JT11_40 & 76 & 1.9 & 0.109 & 0.550 & 0.3 & 4.68 & 32.0 & 0.310 & 1.4 & 0.41 & 1743 & 69 & 1763 & 55 & 1790 & 93 & 1790 & 93 & 97 \\
\hline 12JT11_2 & 77 & 1.2 & 0.110 & 0.540 & 0.2 & 4.95 & 34.0 & 0.330 & 1.5 & 0.56 & 1836 & 73 & 1805 & 57 & 1800 & 90 & 1800 & 90 & 102 \\
\hline 12JT11_1 & 206 & 1.7 & 0.111 & 0.500 & 0.2 & 4.94 & 32.0 & 0.324 & 1.4 & 0.53 & 1810 & 69 & 1805 & 55 & 1811 & 83 & 1811 & 83 & 100 \\
\hline 12JT11_81 & 273 & 1.4 & 0.111 & 0.500 & 0.2 & 4.46 & 28.0 & 0.295 & 1.3 & 0.58 & 1664 & 65 & 1721 & 53 & 1823 & 80 & 1823 & 80 & 91 \\
\hline 12JT11_39 & 102 & 1.4 & 0.113 & 0.540 & 0.3 & 4.95 & 33.0 & 0.317 & 1.4 & 0.48 & 1775 & 70 & 1803 & 56 & 1826 & 87 & 1826 & 87 & 97 \\
\hline 12JT11_79 & 63 & 1.3 & 0.112 & 0.570 & 0.2 & 4.51 & 31.0 & 0.299 & 1.4 & 0.51 & 1683 & 68 & 1730 & 58 & 1828 & 91 & 1828 & 91 & 92 \\
\hline 12JT11_26 & 292 & 2.4 & 0.112 & 0.500 & 0.2 & 4.96 & 32.0 & 0.317 & 1.4 & 0.58 & 1774 & 67 & 1811 & 54 & 1833 & 82 & 1833 & 82 & 97 \\
\hline 12JT11_94 & 167 & 1.3 & 0.112 & 0.510 & 0.2 & 4.57 & 29.0 & 0.301 & 1.3 & 0.54 & 1694 & 66 & 1744 & 55 & 1837 & 84 & 1837 & 84 & 92 \\
\hline 12JT11_16 & 244 & 1.9 & 0.113 & 0.530 & 0.3 & 5.16 & 34.0 & 0.329 & 1.5 & 0.54 & 1829 & 72 & 1849 & 56 & 1842 & 83 & 1842 & 83 & 99 \\
\hline 12JT11_14 & 290 & 2.3 & 0.113 & 0.500 & 0.2 & 5.14 & 33.0 & 0.333 & 1.5 & 0.63 & 1850 & 71 & 1843 & 54 & 1846 & 79 & 1846 & 79 & 100 \\
\hline 12JT11_3 & 93 & 1.0 & 0.114 & 0.540 & 0.2 & 5.37 & 35.0 & 0.347 & 1.6 & 0.47 & 1919 & 75 & 1880 & 55 & 1847 & 88 & 1847 & 88 & 104 \\
\hline 12JT11_110 & 128 & 2.2 & 0.114 & 0.520 & 0.2 & 4.72 & 31.0 & 0.303 & 1.4 & 0.61 & 1706 & 67 & 1770 & 55 & 1857 & 83 & 1857 & 83 & 92 \\
\hline 12JT11_89 & 188 & 1.4 & 0.115 & 0.530 & -0.1 & 4.22 & 30.0 & 0.276 & 1.4 & 0.85 & 1574 & 71 & 1666 & 62 & 1863 & 84 & 1863 & 84 & 84 \\
\hline 12JT11_101 & 470 & 3.4 & 0.115 & 0.500 & 0.3 & 4.79 & 30.0 & 0.304 & 1.3 & 0.61 & 1710 & 66 & 1782 & 53 & 1877 & 77 & 1877 & 77 & 91 \\
\hline 12JT11_93 & 275 & 8.0 & 0.116 & 0.520 & 0.3 & 4.88 & 31.0 & 0.309 & 1.4 & 0.53 & 1737 & 66 & 1796 & 53 & 1888 & 81 & 1888 & 81 & 92 \\
\hline 12JT11_15 & 127 & 2.8 & 0.117 & 0.540 & 0.4 & 5.36 & 35.0 & 0.336 & 1.5 & 0.32 & 1866 & 72 & 1876 & 56 & 1891 & 85 & 1891 & 85 & 99 \\
\hline 12JT11_57 & 406 & 4.0 & 0.116 & 0.510 & 0.2 & 4.95 & 31.0 & 0.311 & 1.4 & 0.60 & 1748 & 68 & 1809 & 54 & 1899 & 78 & 1899 & 78 & 92 \\
\hline 12JT11_109 & 51 & 1.7 & 0.117 & 0.600 & 0.3 & 5.14 & 36.0 & 0.320 & 1.5 & 0.48 & 1785 & 75 & 1837 & 59 & 1904 & 95 & 1904 & 95 & 94 \\
\hline 12JT11_99 & 72 & 1.3 & 0.118 & 0.580 & 0.3 & 5.11 & 34.0 & 0.317 & 1.5 & 0.39 & 1773 & 72 & 1836 & 57 & 1907 & 92 & 1907 & 92 & 93 \\
\hline 12JT11_37 & 100 & 1.0 & 0.117 & 0.550 & 0.3 & 5.43 & 36.0 & 0.340 & 1.5 & 0.47 & 1883 & 74 & 1894 & 56 & 1909 & 88 & 1909 & 88 & 99 \\
\hline 12JT11_17 & 465 & 4.1 & 0.117 & 0.510 & 0.3 & 5.53 & 35.0 & 0.344 & 1.5 & 0.62 & 1905 & 72 & 1905 & 53 & 1909 & 78 & 1909 & 78 & 100 \\
\hline 12JT11_61 & 200 & 2.7 & 0.117 & 0.530 & 0.4 & 5.18 & 33.0 & 0.324 & 1.4 & 0.49 & 1809 & 69 & 1847 & 54 & 1910 & 81 & 1910 & 81 & 95 \\
\hline 12JT11_27 & 440 & 1.9 & 0.117 & 0.540 & 0.2 & 5.42 & 35.0 & 0.334 & 1.5 & 0.62 & 1856 & 73 & 1890 & 56 & 1913 & 82 & 1913 & 82 & 97 \\
\hline 12JT11_73 & 220 & 0.6 & 0.118 & 0.530 & 0.3 & 4.87 & 31.0 & 0.309 & 1.4 & 0.49 & 1735 & 67 & 1799 & 52 & 1918 & 81 & 1918 & 81 & 90 \\
\hline 12JT11_69 & 569 & 4.2 & 0.118 & 0.510 & 0.2 & 4.96 & 31.0 & 0.310 & 1.4 & 0.71 & 1741 & 66 & 1811 & 53 & 1920 & 79 & 1920 & 79 & 91 \\
\hline 12JT11_49 & 228 & 3.3 & 0.118 & 0.520 & 0.4 & 5.20 & 33.0 & 0.323 & 1.4 & 0.48 & 1804 & 70 & 1854 & 54 & 1920 & 80 & 1920 & 80 & 94 \\
\hline 12JT11_97 & 334 & 1.8 & 0.118 & 0.520 & 0.1 & 5.00 & 32.0 & 0.308 & 1.3 & 0.68 & 1734 & 67 & 1821 & 55 & 1924 & 80 & 1924 & 80 & 90 \\
\hline 12JT11_46 & 240 & 2.2 & 0.118 & 0.530 & 0.3 & 5.09 & 32.0 & 0.314 & 1.4 & 0.62 & 1762 & 68 & 1833 & 54 & 1925 & 81 & 1925 & 81 & 92 \\
\hline
\end{tabular}


TABLE SM2.3: LA-ICPMS U-PB ISOTOPIC DATA (UC SANTA CRUZ LAB)

\begin{tabular}{|c|c|c|c|c|c|c|c|c|c|c|c|c|c|c|c|c|c|c|c|}
\hline \multirow[b]{2}{*}{ Analysis } & \multirow[b]{2}{*}{ U } & \multirow[b]{2}{*}{ U/Th } & \multirow[b]{2}{*}{$206 \mathrm{~Pb}^{*}$} & \multirow[b]{2}{*}{ \pm} & \multirow[b]{2}{*}{ error } & \multicolumn{5}{|c|}{ Isotope ratios } & \multicolumn{6}{|c|}{ Apparent ages (Ma) } & \multirow[b]{2}{*}{ Best age } & \multirow[b]{2}{*}{ \pm} & \multirow[b]{2}{*}{ Conc } \\
\hline & & & & & & $207 \mathrm{~Pb}^{*}$ & \pm & $206 \mathrm{~Pb}^{*}$ & \pm & error & $206 \mathrm{~Pb}^{*}$ & \pm & $207 \mathrm{~Pb}^{*}$ & \pm & $206 \mathrm{~Pb}^{*}$ & \pm & & & \\
\hline & (ppm) & & 207Pb* & (\%) & corr. & $235 U^{*}$ & (\%) & $238 U$ & $(\%)$ & corr. & $238 U^{*}$ & (Ma) & $235 \mathrm{U}$ & (Ma) & $207 \mathrm{~Pb}^{\star}$ & (Ma) & (Ma) & (Ma) & (\%) \\
\hline 12JT11_13 & 97 & 1.0 & 0.118 & 0.620 & 0.3 & 5.63 & 40.0 & 0.349 & 1.7 & 0.48 & 1931 & 82 & 1916 & 60 & 1925 & 95 & 1925 & 95 & 100 \\
\hline 12JT11_70 & 75 & 0.4 & 0.119 & 0.560 & 0.2 & 5.02 & 33.0 & 0.314 & 1.5 & 0.59 & 1761 & 70 & 1826 & 55 & 1929 & 86 & 1929 & 86 & 91 \\
\hline 12JT11_75 & 210 & 0.6 & 0.119 & 0.540 & 0.3 & 4.97 & 32.0 & 0.310 & 1.4 & 0.52 & 1744 & 68 & 1812 & 54 & 1930 & 82 & 1930 & 82 & 90 \\
\hline 12JT11_63 & 98 & 1.1 & 0.118 & 0.560 & 0.2 & 5.11 & 33.0 & 0.319 & 1.4 & 0.43 & 1784 & 69 & 1838 & 56 & 1930 & 83 & 1930 & 83 & 92 \\
\hline 12JT11_91 & 136 & 0.5 & 0.119 & 0.540 & 0.3 & 5.04 & 32.0 & 0.311 & 1.4 & 0.45 & 1744 & 67 & 1822 & 54 & 1936 & 82 & 1936 & 82 & 90 \\
\hline 12JT11_28 & 800 & 15.9 & 0.119 & 0.520 & 0.2 & 5.25 & 33.0 & 0.321 & 1.4 & 0.71 & 1793 & 69 & 1860 & 53 & 1936 & 78 & 1936 & 78 & 93 \\
\hline 12JT11_9 & 111 & 0.7 & 0.120 & 0.560 & 0.2 & 5.58 & 36.0 & 0.342 & 1.5 & 0.45 & 1898 & 72 & 1915 & 57 & 1945 & 84 & 1945 & 84 & 98 \\
\hline 12JT11_52 & 73 & 1.2 & 0.121 & 0.580 & 0.2 & 5.48 & 36.0 & 0.331 & 1.5 & 0.54 & 1842 & 73 & 1890 & 57 & 1958 & 86 & 1958 & 86 & 94 \\
\hline 12JT11_106 & 423 & 3.6 & 0.121 & 0.530 & 0.2 & 4.80 & 30.0 & 0.288 & 1.3 & 0.71 & 1633 & 63 & 1784 & 54 & 1972 & 77 & 1972 & 77 & 83 \\
\hline 12JT11_88 & 104 & 1.9 & 0.124 & 0.560 & 0.4 & 5.58 & 35.0 & 0.328 & 1.4 & 0.48 & 1829 & 71 & 1913 & 54 & 2024 & 79 & 2024 & 79 & 90 \\
\hline 12JT11_54 & 122 & 2.1 & 0.128 & 0.590 & 0.3 & 6.28 & 40.0 & 0.359 & 1.6 & 0.48 & 1975 & 77 & 2013 & 56 & 2073 & 84 & 2073 & 84 & 95 \\
\hline 12JT11_23 & 65 & 1.6 & 0.128 & 0.620 & 0.3 & 6.83 & 46.0 & 0.382 & 1.8 & 0.55 & 2080 & 83 & 2083 & 60 & 2082 & 87 & 2082 & 87 & 100 \\
\hline 12JT11_80 & 132 & 1.3 & 0.130 & 0.600 & 0.2 & 5.88 & 38.0 & 0.335 & 1.5 & 0.54 & 1862 & 73 & 1961 & 56 & 2102 & 81 & 2102 & 81 & 89 \\
\hline 12JT11_78 & 136 & 1.2 & 0.132 & 0.600 & 0.2 & 6.14 & 39.0 & 0.343 & 1.5 & 0.55 & 1899 & 73 & 1991 & 56 & 2114 & 79 & 2114 & 79 & 90 \\
\hline 12JT11_66 & 91 & 2.1 & 0.131 & 0.610 & 0.3 & 5.92 & 38.0 & 0.333 & 1.5 & 0.52 & 1851 & 72 & 1962 & 56 & 2117 & 82 & 2117 & 82 & 87 \\
\hline 12JT11_34 & 132 & 3.6 & 0.139 & 0.630 & 0.1 & 7.61 & 49.0 & 0.392 & 1.7 & 0.65 & 2131 & 81 & 2183 & 58 & 2201 & 78 & 2201 & 78 & 97 \\
\hline 12JT11_100 & 200 & 1.4 & 0.139 & 0.620 & 0.1 & 7.04 & 45.0 & 0.369 & 1.6 & 0.68 & 2020 & 77 & 2114 & 56 & 2213 & 78 & 2213 & 78 & 91 \\
\hline 12JT11_25 & 309 & 3.1 & 0.142 & 0.630 & 0.0 & 7.44 & 48.0 & 0.379 & 1.7 & 0.74 & 2070 & 79 & 2167 & 57 & 2244 & 77 & 2244 & 77 & 92 \\
\hline 12JT11_76 & 157 & 3.5 & 0.142 & 0.640 & 0.3 & 7.05 & 45.0 & 0.367 & 1.6 & 0.52 & 2015 & 78 & 2116 & 57 & 2250 & 82 & 2250 & 82 & 90 \\
\hline 12JT11_58 & 220 & 3.2 & 0.145 & 0.650 & 0.0 & 7.72 & 50.0 & 0.393 & 1.7 & 0.69 & 2137 & 79 & 2198 & 58 & 2289 & 77 & 2289 & 77 & 93 \\
\hline 12JT11_30 & 522 & 4.1 & 0.147 & 0.640 & 0.2 & 8.49 & 54.0 & 0.416 & 1.8 & 0.74 & 2241 & 82 & 2284 & 56 & 2314 & 75 & 2314 & 75 & 97 \\
\hline 12JT11_104 & 192 & 3.6 & 0.147 & 0.650 & 0.2 & 8.06 & 52.0 & 0.398 & 1.8 & 0.65 & 2162 & 80 & 2234 & 57 & 2319 & 78 & 2319 & 78 & 93 \\
\hline 12JT11_42 & 124 & 1.2 & 0.149 & 0.680 & 0.2 & 8.12 & 53.0 & 0.402 & 1.8 & 0.64 & 2181 & 83 & 2243 & 60 & 2323 & 78 & 2323 & 78 & 94 \\
\hline 12JT11_72 & 233 & 4.2 & 0.148 & 0.660 & 0.2 & 7.73 & 49.0 & 0.385 & 1.7 & 0.63 & 2099 & 79 & 2199 & 58 & 2325 & 77 & 2325 & 77 & 90 \\
\hline 12JT11_51 & 104 & 2.9 & 0.149 & 0.670 & 0.3 & 7.93 & 51.0 & 0.392 & 1.8 & 0.61 & 2131 & 82 & 2221 & 59 & 2328 & 77 & 2328 & 77 & 92 \\
\hline 12JT11_56 & 110 & 1.5 & 0.149 & 0.680 & 0.3 & 8.15 & 53.0 & 0.401 & 1.8 & 0.59 & 2177 & 84 & 2249 & 59 & 2332 & 77 & 2332 & 77 & 93 \\
\hline 12JT11_18 & 257 & 2.9 & 0.149 & 0.660 & 0.3 & 8.57 & 54.0 & 0.414 & 1.8 & 0.68 & 2234 & 83 & 2292 & 59 & 2333 & 75 & 2333 & 75 & 96 \\
\hline 12JT11 21 & 247 & 3.8 & 0.149 & 0.660 & 0.3 & 8.52 & 54.0 & 0.411 & 1.8 & 0.62 & 2222 & 82 & 2291 & 58 & 2334 & 74 & 2334 & 74 & 95 \\
\hline
\end{tabular}


TABLE SM2.3: LA-ICPMS U-PB ISOTOPIC DATA (UC SANTA CRUZ LAB)

\begin{tabular}{|c|c|c|c|c|c|c|c|c|c|c|c|c|c|c|c|c|c|c|c|}
\hline \multirow[b]{2}{*}{ Analysis } & \multirow[b]{2}{*}{$U$} & \multirow[b]{2}{*}{$\mathrm{U} / \mathrm{Th}$} & \multirow[b]{2}{*}{$206 \mathrm{~Pb}^{*}$} & \multirow[b]{2}{*}{ \pm} & \multirow[b]{2}{*}{ error } & \multicolumn{5}{|c|}{ Isotope ratios } & \multicolumn{6}{|c|}{ Apparent ages (Ma) } & \multirow[b]{2}{*}{ Best age } & \multirow[b]{2}{*}{ \pm} & \multirow[b]{2}{*}{ Conc } \\
\hline & & & & & & $207 \mathrm{~Pb}^{\star}$ & \pm & $206 \mathrm{~Pb}^{*}$ & \pm & error & $206 \mathrm{~Pb}^{*}$ & \pm & 207Pb* & \pm & $206 \mathrm{~Pb}^{*}$ & \pm & & & \\
\hline & (ppm) & & $207 \mathrm{~Pb}^{\star}$ & (\%) & corr. & $235 U^{*}$ & (\%) & $238 \mathrm{U}$ & (\%) & corr. & $238 U^{*}$ & (Ma) & $235 \mathrm{U}$ & (Ma) & $207 \mathrm{~Pb}^{\star}$ & (Ma) & (Ma) & (Ma) & (\%) \\
\hline 12JT11_83 & 452 & 2.0 & 0.149 & 0.650 & 0.2 & 7.85 & 49.0 & 0.389 & 1.7 & 0.69 & 2119 & 78 & 2213 & 57 & 2337 & 74 & 2337 & 74 & 91 \\
\hline 12JT11_38 & 283 & 2.4 & 0.150 & 0.650 & 0.3 & 8.44 & 53.0 & 0.407 & 1.8 & 0.68 & 2206 & 81 & 2279 & 56 & 2343 & 72 & 2343 & 72 & 94 \\
\hline 12JT11_87 & 308 & 3.9 & 0.150 & 0.660 & 0.4 & 7.34 & 46.0 & 0.359 & 1.6 & 0.62 & 1979 & 74 & 2154 & 56 & 2345 & 74 & 2345 & 74 & 84 \\
\hline 12JT11_102 & 343 & 1.4 & 0.152 & 0.660 & 0.3 & 8.59 & 54.0 & 0.406 & 1.8 & 0.65 & 2199 & 80 & 2293 & 57 & 2371 & 75 & 2371 & 75 & 93 \\
\hline 12JT11_35 & 154 & 1.6 & 0.152 & 0.680 & 0.3 & 8.71 & 56.0 & 0.418 & 1.9 & 0.58 & 2250 & 84 & 2305 & 58 & 2371 & 76 & 2371 & 76 & 95 \\
\hline 12JT11_8 & 295 & 2.4 & 0.153 & 0.670 & 0.3 & 9.19 & 58.0 & 0.439 & 1.9 & 0.68 & 2343 & 86 & 2356 & 58 & 2381 & 75 & 2381 & 75 & 98 \\
\hline 12JT11_10 & 403 & 2.5 & 0.157 & 0.690 & -0.1 & 8.42 & 55.0 & 0.393 & 1.8 & 0.87 & 2135 & 82 & 2270 & 59 & 2422 & 75 & 2422 & 75 & 88 \\
\hline 12JT11_74 & 102 & 2.9 & 0.158 & 0.720 & 0.3 & 8.72 & 56.0 & 0.409 & 1.9 & 0.58 & 2207 & 84 & 2307 & 58 & 2430 & 76 & 2430 & 76 & 91 \\
\hline 12JT11_64 & 422 & 3.1 & 0.158 & 0.690 & 0.0 & 8.08 & 52.0 & 0.374 & 1.7 & 0.84 & 2049 & 79 & 2241 & 59 & 2437 & 72 & 2437 & 72 & 84 \\
\hline 12JT11_65 & 277 & 1.5 & 0.158 & 0.700 & 0.3 & 8.75 & 55.0 & 0.405 & 1.8 & 0.68 & 2192 & 81 & 2313 & 56 & 2440 & 75 & 2440 & 75 & 90 \\
\hline 12JT11_48 & 346 & 2.8 & 0.161 & 0.700 & 0.2 & 9.35 & 59.0 & 0.423 & 1.9 & 0.74 & 2278 & 83 & 2372 & 58 & 2469 & 73 & 2469 & 73 & 92 \\
\hline 12JT11_44 & 536 & 2.6 & 0.162 & 0.700 & 0.0 & 8.60 & 55.0 & 0.383 & 1.7 & 0.87 & 2092 & 81 & 2293 & 59 & 2479 & 72 & 2479 & 72 & 84 \\
\hline 12JT11_86 & 119 & 1.8 & 0.162 & 0.730 & 0.2 & 9.11 & 58.0 & 0.419 & 1.9 & 0.62 & 2253 & 85 & 2348 & 59 & 2480 & 76 & 2480 & 76 & 91 \\
\hline 12JT11_85 & 430 & 3.6 & 0.163 & 0.710 & 0.1 & 8.90 & 57.0 & 0.405 & 1.8 & 0.83 & 2188 & 83 & 2327 & 57 & 2484 & 72 & 2484 & 72 & 88 \\
\hline 12JT11_29 & 93 & 1.9 & 0.164 & 0.750 & 0.3 & 10.65 & 68.0 & 0.465 & 2.1 & 0.52 & 2458 & 91 & 2488 & 59 & 2491 & 77 & 2491 & 77 & 99 \\
\hline 12JT11_53 & 62 & 1.2 & 0.164 & 0.790 & 0.4 & 9.63 & 63.0 & 0.430 & 2.0 & 0.44 & 2300 & 91 & 2399 & 61 & 2496 & 80 & 2496 & 80 & 92 \\
\hline 12JT11_20 & 166 & 1.8 & 0.164 & 0.730 & 0.2 & 10.96 & 70.0 & 0.482 & 2.1 & 0.70 & 2532 & 93 & 2521 & 59 & 2499 & 74 & 2499 & 74 & 101 \\
\hline 12JT11_5 & 107 & 2.7 & 0.165 & 0.740 & 0.3 & 10.37 & 66.0 & 0.462 & 2.1 & 0.58 & 2444 & 92 & 2467 & 59 & 2503 & 76 & 2503 & 76 & 98 \\
\hline 12JT11_92 & 203 & 1.5 & 0.166 & 0.730 & 0.2 & 9.86 & 63.0 & 0.434 & 1.9 & 0.65 & 2320 & 85 & 2418 & 58 & 2513 & 75 & 2513 & 75 & 92 \\
\hline 12JT11_90 & 198 & 2.1 & 0.167 & 0.740 & 0.3 & 9.59 & 61.0 & 0.422 & 1.9 & 0.59 & 2272 & 85 & 2395 & 58 & 2523 & 74 & 2523 & 74 & 90 \\
\hline 12JT11_11 & 130 & 2.0 & 0.167 & 0.750 & 0.3 & 11.02 & 70.0 & 0.479 & 2.1 & 0.62 & 2520 & 92 & 2521 & 59 & 2530 & 75 & 2530 & 75 & 100 \\
\hline 12JT11_108 & 470 & 3.2 & 0.174 & 0.760 & 0.2 & 9.84 & 62.0 & 0.412 & 1.8 & 0.81 & 2222 & 83 & 2422 & 59 & 2593 & 72 & 2593 & 72 & 86 \\
\hline 12JT11_19 & 91 & 1.1 & 0.179 & 0.820 & 0.3 & 11.90 & 77.0 & 0.478 & 2.2 & 0.53 & 2515 & 94 & 2595 & 61 & 2653 & 76 & 2653 & 76 & 95 \\
\hline 12JT11_22 & 161 & 1.6 & 0.185 & 0.810 & 0.3 & 13.24 & 84.0 & 0.514 & 2.3 & 0.71 & 2673 & 96 & 2698 & 60 & 2690 & 73 & 2690 & 73 & 99 \\
\hline 12JT11_96 & 33 & 1.8 & 0.191 & 0.920 & 0.3 & 12.15 & 83.0 & 0.474 & 2.3 & 0.67 & 2490 & 100 & 2611 & 64 & 2745 & 81 & 2745 & 81 & 91 \\
\hline \multicolumn{20}{|c|}{$>20 \%$ Discordance } \\
\hline 12JT11_95 & 1291 & 1.8 & 0.132 & 0.580 & 0.1 & 2.03 & 13.0 & 0.113 & 0.5 & 0.86 & 688 & 30 & 1123 & 45 & 2116 & 76 & 688 & 30 & 33 \\
\hline
\end{tabular}


TABLE SM2.3: LA-ICPMS U-PB ISOTOPIC DATA (UC SANTA CRUZ LAB)

\begin{tabular}{|c|c|c|c|c|c|c|c|c|c|c|c|c|c|c|c|c|c|c|c|}
\hline \multirow[b]{2}{*}{ Analysis } & \multirow[b]{2}{*}{$U$} & \multirow[b]{2}{*}{ U/Th } & \multirow[b]{2}{*}{$206 \mathrm{~Pb}^{*}$} & \multirow[b]{2}{*}{ \pm} & \multirow[b]{2}{*}{ error } & \multicolumn{5}{|c|}{ Isotope ratios } & \multicolumn{6}{|c|}{ Apparent ages (Ma) } & \multirow[b]{2}{*}{ Best age } & \multirow[b]{2}{*}{ \pm} & \multirow[b]{2}{*}{ Cono } \\
\hline & & & & & & $207 \mathrm{~Pb}^{*}$ & \pm & $206 \mathrm{~Pb}^{*}$ & \pm & error & $206 \mathrm{~Pb}^{*}$ & \pm & 207Pb* & \pm & $206 \mathrm{~Pb}^{*}$ & \pm & & & \\
\hline & (ppm) & & $207 \mathrm{~Pb}^{\star}$ & (\%) & corr. & $235 U^{*}$ & (\%) & $238 U$ & (\%) & corr. & $238 U^{*}$ & (Ma) & $235 \mathrm{U}$ & (Ma) & $207 \mathrm{~Pb}^{*}$ & (Ma) & (Ma) & (Ma) & (\%) \\
\hline 12JT11_47 & 1544 & 2.5 & 0.103 & 0.460 & -0.5 & 1.77 & 15.0 & 0.123 & 0.8 & 0.96 & 749 & 45 & 1019 & 54 & 1678 & 81 & 749 & 45 & 45 \\
\hline 12JT11_60 & 2035 & 7.5 & 0.112 & 0.490 & -0.1 & 2.00 & 13.0 & 0.131 & 0.6 & 0.82 & 796 & 33 & 1115 & 43 & 1826 & 78 & 796 & 33 & 44 \\
\hline 12JT11_84 & 984 & 2.2 & 0.104 & 0.460 & -0.1 & 2.69 & 17.0 & 0.192 & 0.9 & 0.80 & 1134 & 45 & 1323 & 47 & 1691 & 82 & 1691 & 82 & 67 \\
\hline 12JT11_107 & 536 & 4.9 & 0.113 & 0.500 & -0.3 & 3.91 & 27.0 & 0.253 & 1.3 & 0.93 & 1449 & 67 & 1616 & 58 & 1844 & 79 & 1844 & 79 & 79 \\
\hline 12JT11_103 & 187 & 1.3 & 0.124 & 0.570 & 0.3 & 4.75 & 31.0 & 0.282 & 1.3 & 0.46 & 1601 & 63 & 1774 & 54 & 2006 & 80 & 2006 & 80 & 80 \\
\hline 12JT11_6 & 632 & 2.5 & 0.131 & 0.580 & -0.1 & 3.93 & 26.0 & 0.220 & 1.0 & 0.82 & 1283 & 53 & 1615 & 53 & 2107 & 78 & 2107 & 78 & 61 \\
\hline 12JT11_59 & 560 & 3.8 & 0.134 & 0.580 & -0.1 & 5.30 & 35.0 & 0.290 & 1.4 & 0.91 & 1640 & 69 & 1865 & 57 & 2150 & 75 & 2150 & 75 & 76 \\
\hline 12JT11_77 & 865 & 3.8 & 0.135 & 0.600 & -0.1 & 3.58 & 23.0 & 0.197 & 0.9 & 0.87 & 1159 & 48 & 1550 & 52 & 2162 & 77 & 2162 & 77 & 54 \\
\hline 12JT11_43 & 670 & 2.3 & 0.139 & 0.610 & -0.2 & 5.35 & 35.0 & 0.280 & 1.3 & 0.90 & 1593 & 64 & 1880 & 57 & 2214 & 74 & 2214 & 74 & 72 \\
\hline 12JT11_82 & 638 & 1.5 & 0.142 & 0.640 & 0.0 & 3.41 & 23.0 & 0.178 & 0.8 & 0.84 & 1057 & 46 & 1508 & 53 & 2248 & 77 & 2248 & 77 & 47 \\
\hline 12JT11_62 & 531 & 2.5 & 0.144 & 0.640 & -0.5 & 4.98 & 37.0 & 0.251 & 1.4 & 0.96 & 1440 & 70 & 1791 & 64 & 2281 & 75 & 2281 & 75 & 63 \\
\hline 12JT11_41 & 66 & 4.6 & 0.181 & 1.100 & 0.4 & 8.94 & 71.0 & 0.365 & 2.3 & 0.66 & 1990 & 110 & 2327 & 76 & 2611 & 89 & 2611 & 89 & 76 \\
\hline 12JT11_105 & 499 & 2.1 & 0.180 & 0.780 & 0.2 & 8.87 & 56.0 & 0.358 & 1.6 & 0.79 & 1974 & 75 & 2324 & 58 & 2654 & 72 & 2654 & 72 & 74 \\
\hline \multicolumn{20}{|c|}{$>5 \%$ Reverse Discordance } \\
\hline 12JT11_98 & 22 & 3739.7 & 0.107 & 0.650 & 0.2 & 5.49 & 44.0 & 0.372 & 2.0 & 0.51 & 2036 & 94 & 1878 & 67 & 1730 & 110 & 1730 & 110 & 118 \\
\hline 12JT11_32 & 38 & 3576.4 & 0.109 & 0.590 & 0.3 & 5.69 & 41.0 & 0.379 & 1.9 & 0.49 & 2070 & 88 & 1925 & 61 & 1760 & 100 & 1760 & 100 & 118 \\
\hline 12JT11_50 & 11 & 11344.0 & 0.113 & 0.790 & 0.3 & 6.16 & 53.0 & 0.396 & 2.3 & 0.53 & 2130 & 100 & 1958 & 75 & 1780 & 130 & 1780 & 130 & 120 \\
\hline 12JT11_55 & 51 & 6614.0 & 0.109 & 0.550 & 0.2 & 5.99 & 41.0 & 0.403 & 1.9 & 0.53 & 2187 & 88 & 1975 & 62 & 1786 & 92 & 1786 & 92 & 122 \\
\hline 12JT11_33 & 42 & 1072.9 & 0.112 & 0.560 & 0.2 & 6.16 & 43.0 & 0.399 & 2.0 & 0.58 & 2155 & 90 & 1989 & 61 & 1814 & 95 & 1814 & 95 & 119 \\
\hline 12JT11_12 & 48 & 12465.3 & 0.113 & 0.580 & 0.4 & 6.40 & 44.0 & 0.413 & 2.0 & 0.50 & 2232 & 89 & 2026 & 61 & 1839 & 93 & 1839 & 93 & 121 \\
\hline \multicolumn{20}{|l|}{$>1000$ U ppm } \\
\hline 12JT11_7 & 1375 & 3.5 & 0.078 & 0.340 & 0.2 & 1.85 & 12.0 & 0.172 & 0.8 & 0.60 & 1024 & 41 & 1062 & 41 & 1152 & 87 & 1152 & 87 & 89 \\
\hline \multicolumn{20}{|c|}{ 12JT31; Neruokpuk Formation ( N69.39, W141.53) } \\
\hline 12JT31_108 & 124 & 0.9 & 0.076 & 0.400 & 0.3 & 1.90 & 14.0 & 0.179 & 0.9 & 0.32 & 1058 & 49 & 1076 & 49 & 1100 & 100 & 1100 & 100 & 96 \\
\hline 12JT31_78 & 226 & 2.3 & 0.075 & 0.370 & 0.3 & 1.95 & 14.0 & 0.190 & 1.0 & 0.36 & 1122 & 51 & 1099 & 48 & 1070 & 100 & 1070 & 100 & 105 \\
\hline
\end{tabular}


TABLE SM2.3: LA-ICPMS U-PB ISOTOPIC DATA (UC SANTA CRUZ LAB)

\begin{tabular}{|c|c|c|c|c|c|c|c|c|c|c|c|c|c|c|c|c|c|c|c|}
\hline \multirow[b]{2}{*}{ Analysis } & \multirow[b]{2}{*}{$U$} & \multirow[b]{2}{*}{ U/Th } & \multirow[b]{2}{*}{$206 \mathrm{~Pb}^{\star}$} & \multirow[b]{2}{*}{ \pm} & \multirow[b]{2}{*}{ error } & \multicolumn{5}{|c|}{ Isotope ratios } & \multicolumn{6}{|c|}{ Apparent ages (Ma) } & \multirow[b]{2}{*}{ Best age } & \multirow[b]{2}{*}{ \pm} & \multirow[b]{2}{*}{ Conc } \\
\hline & & & & & & $207 \mathrm{~Pb}^{*}$ & \pm & $206 \mathrm{~Pb}^{*}$ & \pm & error & $206 \mathrm{~Pb}^{*}$ & \pm & $207 \mathrm{~Pb}^{*}$ & \pm & $206 \mathrm{~Pb}^{*}$ & \pm & & & \\
\hline & $(\mathrm{ppm})$ & & $207 \mathrm{~Pb}^{*}$ & $(\%)$ & corr. & $235 U^{*}$ & (\%) & $238 U$ & $(\%)$ & corr. & $238 U^{*}$ & $(\mathrm{Ma})$ & $235 U$ & (Ma) & $207 \mathrm{~Pb}^{*}$ & (Ma) & (Ma) & (Ma) & $(\%)$ \\
\hline 12JT31_12 & 122 & 13.3 & 0.081 & 0.420 & 0.2 & 2.41 & 18.0 & 0.212 & 1.1 & 0.43 & 1236 & 56 & 1243 & 53 & 1230 & 100 & 1230 & 100 & 100 \\
\hline 12JT31_103 & 126 & 2.0 & 0.082 & 0.410 & 0.2 & 2.38 & 17.0 & 0.211 & 1.0 & 0.40 & 1236 & 55 & 1240 & 51 & 1250 & 100 & 1250 & 100 & 99 \\
\hline 12JT31_60 & 289 & 4.0 & 0.081 & 0.380 & 0.2 & 2.40 & 17.0 & 0.215 & 1.1 & 0.48 & 1254 & 55 & 1240 & 50 & 1228 & 94 & 1228 & 94 & 102 \\
\hline 12JT31_67 & 265 & 1.8 & 0.083 & 0.400 & 0.2 & 2.59 & 18.0 & 0.226 & 1.1 & 0.37 & 1315 & 58 & 1297 & 50 & 1279 & 96 & 1279 & 96 & 103 \\
\hline 12JT31_59 & 44 & 1.5 & 0.087 & 0.520 & 0.3 & 2.68 & 21.0 & 0.228 & 1.2 & 0.36 & 1320 & 62 & 1319 & 59 & 1330 & 120 & 1330 & 120 & 99 \\
\hline 12JT31_54 & 253 & 2.0 & 0.089 & 0.420 & 0.1 & 2.88 & 20.0 & 0.238 & 1.2 & 0.50 & 1375 & 61 & 1375 & 52 & 1399 & 94 & 1399 & 94 & 98 \\
\hline 12JT31_98 & 142 & 1.7 & 0.087 & 0.420 & 0.3 & 2.89 & 20.0 & 0.241 & 1.2 & 0.33 & 1390 & 62 & 1378 & 55 & 1359 & 95 & 1359 & 95 & 102 \\
\hline 12JT31_49 & 308 & 4.5 & 0.088 & 0.420 & 0.3 & 3.04 & 21.0 & 0.250 & 1.2 & 0.55 & 1437 & 64 & 1414 & 52 & 1381 & 92 & 1381 & 92 & 104 \\
\hline 12JT31_23 & 223 & 5.0 & 0.108 & 0.500 & 0.2 & 4.93 & 34.0 & 0.332 & 1.7 & 0.67 & 1847 & 81 & 1807 & 59 & 1762 & 84 & 1762 & 84 & 105 \\
\hline 12JT31_81 & 484 & 5.1 & 0.108 & 0.500 & 0.3 & 4.33 & 30.0 & 0.293 & 1.4 & 0.48 & 1657 & 71 & 1699 & 56 & 1767 & 86 & 1767 & 86 & 94 \\
\hline 12JT31_72 & 115 & 2.0 & 0.111 & 0.530 & 0.3 & 5.14 & 36.0 & 0.341 & 1.7 & 0.53 & 1889 & 82 & 1843 & 59 & 1804 & 89 & 1804 & 89 & 105 \\
\hline 12JT31_101 & 71 & 0.7 & 0.111 & 0.550 & 0.1 & 4.96 & 36.0 & 0.320 & 1.6 & 0.50 & 1788 & 79 & 1814 & 63 & 1812 & 93 & 1812 & 93 & 99 \\
\hline 12JT31_84 & 217 & 1.6 & 0.111 & 0.510 & 0.2 & 5.15 & 36.0 & 0.341 & 1.7 & 0.66 & 1892 & 82 & 1847 & 60 & 1813 & 86 & 1813 & 86 & 104 \\
\hline 12JT31_79 & 233 & 2.2 & 0.111 & 0.520 & 0.2 & 5.23 & 36.0 & 0.344 & 1.7 & 0.52 & 1904 & 82 & 1857 & 60 & 1816 & 86 & 1816 & 86 & 105 \\
\hline 12JT31_63 & 160 & 3.2 & 0.111 & 0.530 & 0.3 & 5.01 & 35.0 & 0.332 & 1.7 & 0.42 & 1844 & 80 & 1821 & 59 & 1817 & 88 & 1817 & 88 & 101 \\
\hline 12JT31_88 & 447 & 1.2 & 0.112 & 0.510 & -0.3 & 4.83 & 34.0 & 0.314 & 1.6 & 0.93 & 1762 & 80 & 1782 & 64 & 1822 & 84 & 1822 & 84 & 97 \\
\hline 12JT31_95 & 456 & 2.5 & 0.112 & 0.520 & 0.2 & 4.43 & 31.0 & 0.286 & 1.4 & 0.68 & 1622 & 71 & 1720 & 58 & 1835 & 82 & 1835 & 82 & 88 \\
\hline 12JT31_30 & 58 & 1.8 & 0.112 & 0.570 & 0.1 & 5.35 & 39.0 & 0.339 & 1.7 & 0.49 & 1880 & 83 & 1877 & 63 & 1843 & 99 & 1843 & 99 & 102 \\
\hline 12JT31_104 & 90 & 1.8 & 0.114 & 0.550 & 0.3 & 5.09 & 36.0 & 0.323 & 1.6 & 0.49 & 1804 & 80 & 1832 & 60 & 1845 & 88 & 1845 & 88 & 98 \\
\hline 12JT31_40 & 73 & 1.9 & 0.114 & 0.570 & 0.1 & 5.39 & 39.0 & 0.340 & 1.8 & 0.64 & 1886 & 85 & 1878 & 61 & 1863 & 91 & 1863 & 91 & 101 \\
\hline 12JT31_44 & 287 & 2.0 & 0.115 & 0.530 & 0.1 & 5.60 & 39.0 & 0.352 & 1.8 & 0.71 & 1942 & 83 & 1914 & 60 & 1875 & 83 & 1875 & 83 & 104 \\
\hline 12JT31_89 & 128 & 1.2 & 0.115 & 0.550 & 0.3 & 5.49 & 39.0 & 0.344 & 1.7 & 0.50 & 1909 & 82 & 1901 & 60 & 1878 & 88 & 1878 & 88 & 102 \\
\hline 12JT31_38 & 89 & 2.3 & 0.116 & 0.570 & 0.1 & 5.68 & 41.0 & 0.353 & 1.9 & 0.66 & 1946 & 88 & 1925 & 59 & 1885 & 88 & 1885 & 88 & 103 \\
\hline 12JT31_77 & 384 & 1.4 & 0.117 & 0.530 & 0.4 & 5.66 & 39.0 & 0.358 & 1.8 & 0.18 & 1970 & 83 & 1923 & 60 & 1903 & 89 & 1903 & 89 & 104 \\
\hline 12JT31_46 & 114 & 0.4 & 0.117 & 0.560 & 0.2 & 5.78 & 41.0 & 0.362 & 1.8 & 0.56 & 1990 & 87 & 1940 & 60 & 1909 & 86 & 1909 & 86 & 104 \\
\hline 12JT31_100 & 69 & 1.3 & 0.117 & 0.590 & 0.2 & 4.98 & 36.0 & 0.306 & 1.6 & 0.54 & 1729 & 81 & 1810 & 60 & 1916 & 90 & 1916 & 90 & 90 \\
\hline 12JT31_33 & 370 & 2.8 & 0.117 & 0.540 & 0.1 & 5.95 & 41.0 & 0.365 & 1.8 & 0.76 & 2004 & 86 & 1967 & 62 & 1916 & 83 & 1916 & 83 & 105 \\
\hline 12JT31_80 & 131 & 1.6 & 0.118 & 0.560 & 0.2 & 5.55 & 39.0 & 0.345 & 1.7 & 0.49 & 1909 & 82 & 1908 & 59 & 1919 & 85 & 1919 & 85 & 99 \\
\hline
\end{tabular}


TABLE SM2.3: LA-ICPMS U-PB ISOTOPIC DATA (UC SANTA CRUZ LAB)

\begin{tabular}{|c|c|c|c|c|c|c|c|c|c|c|c|c|c|c|c|c|c|c|c|}
\hline \multirow[b]{2}{*}{ Analysis } & \multirow[b]{2}{*}{$\mathrm{U}$} & \multirow[b]{2}{*}{ U/Th } & \multirow[b]{2}{*}{$206 \mathrm{~Pb}^{*}$} & \multirow[b]{2}{*}{ \pm} & \multirow[b]{2}{*}{ error } & \multicolumn{5}{|c|}{ Isotope ratios } & \multicolumn{6}{|c|}{ Apparent ages (Ma) } & \multirow[b]{2}{*}{ Best age } & \multirow[b]{2}{*}{ \pm} & \multirow[b]{2}{*}{ Conc } \\
\hline & & & & & & $207 \mathrm{~Pb}^{*}$ & \pm & $206 \mathrm{~Pb}^{*}$ & \pm & error & $206 \mathrm{~Pb}^{*}$ & \pm & $207 \mathrm{~Pb}^{*}$ & \pm & $206 \mathrm{~Pb}^{*}$ & \pm & & & \\
\hline & (ppm) & & $207 \mathrm{~Pb}^{\star}$ & (\%) & corr. & $235 U^{*}$ & (\%) & $238 U$ & (\%) & corr. & $238 U^{*}$ & (Ma) & $235 \mathrm{U}$ & (Ma) & $207 \mathrm{~Pb}^{*}$ & (Ma) & (Ma) & (Ma) & (\%) \\
\hline 12JT31_51 & 252 & 1.0 & 0.118 & 0.550 & 0.2 & 5.88 & 41.0 & 0.363 & 1.8 & 0.65 & 1999 & 88 & 1955 & 60 & 1926 & 85 & 1926 & 85 & 104 \\
\hline 12JT31_93 & 474 & 4.1 & 0.119 & 0.540 & 0.2 & 5.11 & 35.0 & 0.313 & 1.5 & 0.67 & 1757 & 75 & 1837 & 58 & 1931 & 83 & 1931 & 83 & 91 \\
\hline 12JT31_68 & 98 & 0.8 & 0.120 & 0.590 & 0.0 & 4.65 & 33.0 & 0.284 & 1.4 & 0.60 & 1612 & 72 & 1754 & 61 & 1944 & 89 & 1944 & 89 & 83 \\
\hline 12JT31_35 & 51 & 1.1 & 0.121 & 0.620 & 0.2 & 6.18 & 45.0 & 0.366 & 1.9 & 0.55 & 2011 & 90 & 1996 & 63 & 1966 & 94 & 1966 & 94 & 102 \\
\hline 12JT31_75 & 152 & 1.3 & 0.122 & 0.570 & 0.1 & 6.14 & 43.0 & 0.367 & 1.8 & 0.65 & 2016 & 87 & 1996 & 62 & 1988 & 84 & 1988 & 84 & 101 \\
\hline 12JT31_5 & 684 & 3.4 & 0.124 & 0.560 & -0.1 & 6.09 & 43.0 & 0.353 & 1.8 & 0.90 & 1949 & 86 & 1987 & 62 & 2006 & 81 & 2006 & 81 & 97 \\
\hline 12JT31_91 & 151 & 3.0 & 0.126 & 0.600 & -0.1 & 6.70 & 48.0 & 0.382 & 1.9 & 0.71 & 2080 & 89 & 2069 & 64 & 2042 & 85 & 2042 & 85 & 102 \\
\hline 12JT31_94 & 368 & 16.1 & 0.126 & 0.580 & 0.2 & 6.33 & 44.0 & 0.362 & 1.8 & 0.63 & 1992 & 84 & 2024 & 58 & 2050 & 83 & 2050 & 83 & 97 \\
\hline 12JT31_92 & 113 & 2.2 & 0.137 & 0.650 & 0.0 & 7.54 & 54.0 & 0.394 & 2.0 & 0.73 & 2141 & 92 & 2175 & 65 & 2185 & 82 & 2185 & 82 & 98 \\
\hline 12JT31_69 & 194 & 1.4 & 0.141 & 0.660 & 0.0 & 8.21 & 57.0 & 0.425 & 2.1 & 0.75 & 2281 & 95 & 2258 & 64 & 2244 & 82 & 2244 & 82 & 102 \\
\hline 12JT31_55 & 171 & 3.0 & 0.145 & 0.680 & 0.2 & 8.29 & 57.0 & 0.418 & 2.1 & 0.56 & 2252 & 94 & 2264 & 64 & 2283 & 81 & 2283 & 81 & 99 \\
\hline 12JT31_1 & 94 & 1.2 & 0.146 & 0.700 & -0.1 & 6.80 & 54.0 & 0.331 & 1.9 & 0.87 & 1838 & 94 & 2077 & 73 & 2290 & 83 & 2290 & 83 & 80 \\
\hline 12JT31_57 & 166 & 1.6 & 0.146 & 0.670 & 0.1 & 8.76 & 61.0 & 0.440 & 2.1 & 0.64 & 2350 & 95 & 2311 & 62 & 2292 & 80 & 2292 & 80 & 103 \\
\hline 12JT31_53 & 311 & 5.5 & 0.147 & 0.670 & 0.2 & 8.48 & 58.0 & 0.419 & 2.0 & 0.65 & 2255 & 93 & 2283 & 62 & 2311 & 78 & 2311 & 78 & 98 \\
\hline 12JT31_82 & 77 & 0.9 & 0.149 & 0.720 & 0.3 & 9.04 & 63.0 & 0.446 & 2.2 & 0.47 & 2370 & 100 & 2341 & 63 & 2319 & 84 & 2319 & 84 & 102 \\
\hline 12JT31_52 & 252 & 2.1 & 0.152 & 0.700 & 0.2 & 9.29 & 64.0 & 0.442 & 2.2 & 0.64 & 2358 & 97 & 2366 & 63 & 2367 & 76 & 2367 & 76 & 100 \\
\hline 12JT31_76 & 147 & 1.5 & 0.154 & 0.720 & 0.2 & 9.24 & 64.0 & 0.440 & 2.2 & 0.61 & 2350 & 96 & 2361 & 62 & 2390 & 79 & 2390 & 79 & 98 \\
\hline 12JT31_58 & 173 & 2.5 & 0.158 & 0.730 & 0.2 & 10.02 & 69.0 & 0.462 & 2.3 & 0.65 & 2450 & 100 & 2434 & 63 & 2430 & 79 & 2430 & 79 & 101 \\
\hline 12JT31_85 & 34 & 1.6 & 0.158 & 0.820 & 0.4 & 10.18 & 74.0 & 0.468 & 2.4 & 0.36 & 2470 & 110 & 2452 & 66 & 2431 & 90 & 2431 & 90 & 102 \\
\hline 12JT31_32 & 125 & 1.4 & 0.157 & 0.740 & -0.1 & 9.69 & 69.0 & 0.445 & 2.3 & 0.85 & 2370 & 100 & 2402 & 66 & 2432 & 79 & 2432 & 79 & 97 \\
\hline 12JT31_11 & 166 & 2.5 & 0.159 & 0.740 & -0.1 & 10.76 & 79.0 & 0.483 & 2.7 & 0.91 & 2540 & 120 & 2491 & 72 & 2445 & 77 & 2445 & 77 & 104 \\
\hline 12JT31_74 & 125 & 2.4 & 0.160 & 0.750 & 0.2 & 10.01 & 70.0 & 0.459 & 2.3 & 0.61 & 2440 & 100 & 2441 & 64 & 2447 & 78 & 2447 & 78 & 100 \\
\hline 12JT31_65 & 145 & 1.2 & 0.160 & 0.740 & 0.1 & 9.93 & 69.0 & 0.455 & 2.2 & 0.70 & 2424 & 97 & 2427 & 64 & 2456 & 79 & 2456 & 79 & 99 \\
\hline 12JT31_73 & 285 & 2.1 & 0.161 & 0.730 & 0.2 & 8.32 & 58.0 & 0.378 & 1.9 & 0.82 & 2062 & 89 & 2264 & 63 & 2466 & 77 & 2466 & 77 & 84 \\
\hline 12JT31_102 & 101 & 2.9 & 0.162 & 0.760 & 0.3 & 10.39 & 72.0 & 0.463 & 2.3 & 0.56 & 2450 & 100 & 2467 & 63 & 2468 & 80 & 2468 & 80 & 99 \\
\hline 12JT31_99 & 222 & 3.5 & 0.162 & 0.740 & 0.3 & 10.15 & 70.0 & 0.453 & 2.2 & 0.67 & 2408 & 99 & 2450 & 65 & 2479 & 78 & 2479 & 78 & 97 \\
\hline 12JT31_56 & 80 & 1.5 & 0.164 & 0.780 & 0.2 & 10.78 & 75.0 & 0.481 & 2.4 & 0.60 & 2530 & 100 & 2503 & 66 & 2494 & 80 & 2494 & 80 & 101 \\
\hline 12JT31_110 & 60 & 1.0 & 0.170 & 0.810 & 0.2 & 10.81 & 77.0 & 0.460 & 2.4 & 0.64 & 2430 & 100 & 2506 & 67 & 2556 & 81 & 2556 & 81 & 95 \\
\hline
\end{tabular}


TABLE SM2.3: LA-ICPMS U-PB ISOTOPIC DATA (UC SANTA CRUZ LAB)

\begin{tabular}{|c|c|c|c|c|c|c|c|c|c|c|c|c|c|c|c|c|c|c|c|}
\hline \multirow[b]{2}{*}{ Analysis } & \multirow[b]{2}{*}{$U$} & \multirow[b]{2}{*}{$\mathrm{U} / \mathrm{Th}$} & \multirow[b]{2}{*}{$206 \mathrm{~Pb}^{*}$} & \multirow[b]{2}{*}{ \pm} & \multirow[b]{2}{*}{ error } & \multicolumn{5}{|c|}{ Isotope ratios } & \multicolumn{6}{|c|}{ Apparent ages (Ma) } & \multirow[b]{2}{*}{ Best age } & \multirow[b]{2}{*}{ \pm} & \multirow[b]{2}{*}{ Conc } \\
\hline & & & & & & 207Pb* & \pm & $206 \mathrm{~Pb}^{*}$ & \pm & error & $206 \mathrm{~Pb}^{*}$ & \pm & $207 \mathrm{~Pb}^{*}$ & \pm & $206 \mathrm{~Pb}^{*}$ & \pm & & & \\
\hline & $(\mathrm{ppm})$ & & $207 \mathrm{~Pb}^{*}$ & (\%) & corr. & $235 U^{*}$ & (\%) & $238 U$ & (\%) & corr. & $238 U^{*}$ & (Ma) & $235 U$ & $(\mathrm{Ma})$ & $207 \mathrm{~Pb}^{*}$ & $(\mathrm{Ma})$ & $(\mathrm{Ma})$ & $(\mathrm{Ma})$ & $(\%)$ \\
\hline 12JT31_42 & 140 & 2.8 & 0.171 & 0.790 & 0.3 & 12.20 & 85.0 & 0.513 & 2.6 & 0.70 & 2670 & 110 & 2623 & 65 & 2560 & 77 & 2560 & 77 & 104 \\
\hline 12JT31_34 & 114 & 2.3 & 0.172 & 0.800 & 0.1 & 12.13 & 86.0 & 0.506 & 2.6 & 0.80 & 2630 & 110 & 2611 & 67 & 2578 & 79 & 2578 & 79 & 102 \\
\hline 12JT31_48 & 77 & 2.7 & 0.173 & 0.810 & 0.3 & 12.04 & 84.0 & 0.498 & 2.5 & 0.70 & 2610 & 110 & 2605 & 66 & 2583 & 78 & 2583 & 78 & 101 \\
\hline 12JT31_62 & 77 & 1.6 & 0.179 & 0.850 & 0.2 & 11.96 & 84.0 & 0.498 & 2.5 & 0.61 & 2600 & 110 & 2597 & 66 & 2633 & 78 & 2633 & 78 & 99 \\
\hline 12JT31_36 & 68 & 2.6 & 0.183 & 0.880 & 0.2 & 13.56 & 97.0 & 0.528 & 2.7 & 0.73 & 2740 & 110 & 2709 & 67 & 2679 & 81 & 2679 & 81 & 102 \\
\hline 12JT31_43 & 216 & 1.8 & 0.184 & 0.840 & 0.3 & 13.89 & 96.0 & 0.541 & 2.7 & 0.81 & 2790 & 120 & 2740 & 65 & 2689 & 75 & 2689 & 75 & 104 \\
\hline 12JT31_83 & 282 & 3.3 & 0.185 & 0.840 & 0.3 & 13.61 & 93.0 & 0.535 & 2.6 & 0.69 & 2760 & 110 & 2723 & 65 & 2696 & 76 & 2696 & 76 & 102 \\
\hline 12JT31_19 & 31 & 1.0 & 0.188 & 0.990 & -0.2 & 14.10 & 110.0 & 0.534 & 3.0 & 0.81 & 2750 & 120 & 2720 & 68 & 2699 & 84 & 2699 & 84 & 102 \\
\hline 12JT31_50 & 114 & 1.2 & 0.186 & 0.860 & 0.2 & 13.86 & 98.0 & 0.540 & 2.7 & 0.77 & 2780 & 110 & 2737 & 65 & 2703 & 77 & 2703 & 77 & 103 \\
\hline 12JT31_39 & 96 & 1.1 & 0.187 & 0.870 & 0.2 & 14.16 & 99.0 & 0.548 & 2.8 & 0.68 & 2820 & 120 & 2757 & 66 & 2716 & 78 & 2716 & 78 & 104 \\
\hline 12JT31_97 & 32 & 1.8 & 0.190 & 0.950 & 0.3 & 13.63 & 99.0 & 0.513 & 2.7 & 0.67 & 2670 & 110 & 2724 & 68 & 2735 & 83 & 2735 & 83 & 98 \\
\hline 12JT31_28 & 51 & 1.1 & 0.199 & 0.950 & 0.3 & 15.70 & 110.0 & 0.561 & 2.9 & 0.72 & 2870 & 120 & 2859 & 65 & 2820 & 78 & 2820 & 78 & 102 \\
\hline \multicolumn{20}{|c|}{$>20 \%$ Discordance } \\
\hline 12JT31_66 & 1800 & 2.8 & 0.112 & 0.510 & 0.1 & 1.70 & 12.0 & 0.111 & 0.5 & 0.71 & 680 & 32 & 1009 & 44 & 1828 & 82 & 680 & 32 & 37 \\
\hline 12JT31_61 & 1394 & 4.1 & 0.123 & 0.560 & 0.3 & 2.04 & 14.0 & 0.123 & 0.6 & 0.67 & 747 & 35 & 1130 & 47 & 1991 & 82 & 747 & 35 & 38 \\
\hline 12JT31_107 & 1425 & 1.8 & 0.130 & 0.590 & 0.2 & 2.43 & 17.0 & 0.134 & 0.7 & 0.74 & 813 & 38 & 1250 & 49 & 2101 & 81 & 813 & 38 & 39 \\
\hline 12JT31_13 & 546 & 2.0 & 0.085 & 0.400 & -0.1 & 1.84 & 16.0 & 0.159 & 1.1 & 0.94 & 941 & 61 & 1041 & 56 & 1313 & 92 & 941 & 61 & 72 \\
\hline 12JT31_70 & 998 & 2.0 & 0.096 & 0.440 & 0.2 & 2.15 & 15.0 & 0.164 & 0.8 & 0.61 & 979 & 44 & 1164 & 47 & 1555 & 88 & 979 & 44 & 63 \\
\hline 12JT31_22 & 171 & 0.6 & 0.090 & 0.450 & 0.3 & 2.28 & 17.0 & 0.184 & 1.1 & 0.70 & 1088 & 57 & 1198 & 52 & 1440 & 94 & 1440 & 94 & 76 \\
\hline 12JT31_90 & 462 & 1.8 & 0.105 & 0.490 & 0.0 & 2.93 & 22.0 & 0.204 & 1.1 & 0.89 & 1192 & 61 & 1379 & 57 & 1713 & 86 & 1713 & 86 & 70 \\
\hline 12JT31_109 & 282 & 1.4 & 0.116 & 0.540 & 0.1 & 4.16 & 30.0 & 0.261 & 1.3 & 0.80 & 1492 & 68 & 1668 & 59 & 1890 & 84 & 1890 & 84 & 79 \\
\hline 12JT31_37 & 461 & 1.5 & 0.116 & 0.540 & -0.1 & 4.24 & 35.0 & 0.260 & 1.7 & 0.96 & 1484 & 86 & 1648 & 73 & 1893 & 83 & 1893 & 83 & 78 \\
\hline 12JT31_16 & 164 & 0.8 & 0.120 & 0.580 & 0.2 & 4.58 & 36.0 & 0.276 & 1.7 & 0.88 & 1569 & 87 & 1745 & 67 & 1966 & 84 & 1966 & 84 & 80 \\
\hline 12JT31_4 & 255 & 2.8 & 0.127 & 0.600 & -0.2 & 4.18 & 33.0 & 0.235 & 1.3 & 0.90 & 1353 & 70 & 1659 & 65 & 2051 & 84 & 2051 & 84 & 66 \\
\hline 12JT31_3 & 618 & 2.9 & 0.131 & 0.600 & -0.1 & 4.03 & 29.0 & 0.220 & 1.2 & 0.92 & 1285 & 62 & 1630 & 58 & 2109 & 81 & 2109 & 81 & 61 \\
\hline 12JT31_47 & 163 & 0.9 & 0.232 & 1.100 & 0.0 & 14.40 & 100.0 & 0.446 & 2.4 & 0.90 & 2380 & 110 & 2768 & 69 & 3069 & 73 & 3069 & 73 & 78 \\
\hline 12JT31_10 & 68 & 0.7 & 0.737 & 3.400 & 0.1 & 56.30 & 400.0 & 0.553 & 2.9 & 0.89 & 2830 & 120 & 4103 & 68 & 4820 & 76 & 4820 & 76 & 59 \\
\hline
\end{tabular}


TABLE SM2.3: LA-ICPMS U-PB ISOTOPIC DATA (UC SANTA CRUZ LAB)

\begin{tabular}{|c|c|c|c|c|c|c|c|c|c|c|c|c|c|c|c|c|c|c|c|}
\hline \multirow[b]{2}{*}{ Analysis } & \multirow[b]{2}{*}{$U$} & \multirow[b]{2}{*}{ U/Th } & \multirow[b]{2}{*}{$206 \mathrm{~Pb}^{*}$} & \multirow[b]{2}{*}{ \pm} & \multirow[b]{2}{*}{ error } & \multicolumn{5}{|c|}{ Isotope ratios } & \multicolumn{6}{|c|}{ Apparent ages (Ma) } & \multirow[b]{2}{*}{ Best age } & \multirow[b]{2}{*}{ \pm} & \multirow[b]{2}{*}{ Conc } \\
\hline & & & & & & 207Pb* & \pm & $206 \mathrm{~Pb}^{*}$ & \pm & error & $206 \mathrm{~Pb}^{*}$ & \pm & 207Pb* & \pm & $206 \mathrm{~Pb}^{*}$ & \pm & & & \\
\hline & $(\mathrm{ppm})$ & & $207 \mathrm{~Pb}^{\star}$ & $(\%)$ & corr. & $235 U^{*}$ & (\%) & $238 U$ & (\%) & corr. & $238 U^{*}$ & (Ma) & $235 \mathrm{U}$ & (Ma) & $207 \mathrm{~Pb}^{*}$ & (Ma) & (Ma) & (Ma) & (\%) \\
\hline 12JT31_87 & 52 & 1.0 & 0.764 & 3.500 & 0.4 & 78.10 & 550.0 & 0.746 & 3.9 & 0.87 & 3580 & 140 & 4433 & 71 & 4883 & 80 & 4883 & 80 & 73 \\
\hline \multicolumn{20}{|c|}{$>5 \%$ Reverse Discordance } \\
\hline 12JT31_41 & 37 & 2.6 & 0.085 & 0.530 & 0.3 & 2.79 & 22.0 & 0.238 & 1.3 & 0.35 & 1371 & 68 & 1346 & 59 & 1270 & 120 & 1270 & 120 & 108 \\
\hline 12JT31_17 & 199 & 4.4 & 0.107 & 0.500 & 0.2 & 4.91 & 34.0 & 0.334 & 1.7 & 0.63 & 1860 & 80 & 1802 & 60 & 1745 & 88 & 1745 & 88 & 107 \\
\hline 12JT31_14 & 46 & 0.9 & 0.108 & 0.550 & 0.2 & 5.42 & 40.0 & 0.355 & 1.9 & 0.56 & 1952 & 88 & 1881 & 63 & 1760 & 95 & 1760 & 95 & 111 \\
\hline 12JT31_2 & 41 & 0.7 & 0.111 & 0.600 & 0.1 & 5.43 & 41.0 & 0.354 & 1.9 & 0.57 & 1949 & 89 & 1885 & 65 & 1786 & 98 & 1786 & 98 & 109 \\
\hline 12JT31_26 & 42 & 0.6 & 0.111 & 0.610 & 0.2 & 5.32 & 40.0 & 0.348 & 1.9 & 0.54 & 1921 & 88 & 1872 & 65 & 1808 & 97 & 1808 & 97 & 106 \\
\hline 12JT31_96 & 67 & 93.7 & 0.111 & 0.540 & 0.3 & 5.99 & 43.0 & 0.386 & 2.0 & 0.63 & 2112 & 95 & 1970 & 63 & 1810 & 91 & 1810 & 91 & 117 \\
\hline 12JT31_6 & 184 & 1.8 & 0.111 & 0.520 & 0.2 & 5.35 & 37.0 & 0.347 & 1.7 & 0.64 & 1919 & 83 & 1876 & 60 & 1812 & 85 & 1812 & 85 & 106 \\
\hline 12JT31_25 & 196 & 1.6 & 0.111 & 0.520 & 0.4 & 5.36 & 37.0 & 0.350 & 1.8 & 0.68 & 1930 & 86 & 1877 & 60 & 1818 & 86 & 1818 & 86 & 106 \\
\hline 12JT31_106 & 95 & 604.0 & 0.113 & 0.540 & 0.2 & 6.14 & 44.0 & 0.396 & 2.1 & 0.66 & 2149 & 95 & 1994 & 61 & 1837 & 91 & 1837 & 91 & 117 \\
\hline 12JT31_86 & 97 & 6413.3 & 0.113 & 0.540 & 0.2 & 6.12 & 44.0 & 0.397 & 2.1 & 0.70 & 2150 & 96 & 1990 & 61 & 1838 & 87 & 1838 & 87 & 117 \\
\hline 12JT31_20 & 138 & 3.8 & 0.113 & 0.530 & 0.2 & 5.49 & 39.0 & 0.353 & 1.8 & 0.62 & 1950 & 85 & 1900 & 61 & 1852 & 91 & 1852 & 91 & 105 \\
\hline 12JT31_7 & 79 & 1.7 & 0.114 & 0.560 & 0.2 & 5.52 & 39.0 & 0.356 & 1.8 & 0.59 & 1961 & 86 & 1897 & 60 & 1856 & 91 & 1856 & 91 & 106 \\
\hline 12JT31_29 & 170 & 1.5 & 0.115 & 0.540 & 0.3 & 5.76 & 40.0 & 0.360 & 1.8 & 0.67 & 1986 & 87 & 1942 & 60 & 1883 & 81 & 1883 & 81 & 105 \\
\hline 12JT31_8 & 39 & 1.2 & 0.118 & 0.610 & 0.1 & 6.20 & 47.0 & 0.376 & 2.0 & 0.63 & 2050 & 93 & 1996 & 65 & 1919 & 94 & 1919 & 94 & 107 \\
\hline 12JT31_27 & 86 & 0.8 & 0.118 & 0.570 & 0.1 & 6.04 & 44.0 & 0.371 & 1.9 & 0.67 & 2031 & 90 & 1974 & 64 & 1920 & 85 & 1920 & 85 & 106 \\
\hline 12JT31_64 & 28 & 515.6 & 0.118 & 0.660 & 0.3 & 6.51 & 51.0 & 0.405 & 2.3 & 0.60 & 2180 & 100 & 2034 & 69 & 1930 & 100 & 1930 & 100 & 113 \\
\hline 12JT31_24 & 45 & 0.5 & 0.138 & 0.680 & 0.4 & 8.26 & 59.0 & 0.436 & 2.3 & 0.54 & 2330 & 100 & 2262 & 65 & 2193 & 90 & 2193 & 90 & 106 \\
\hline 12JT31_31 & 224 & 3.0 & 0.163 & 0.740 & 0.2 & 11.47 & 79.0 & 0.502 & 2.5 & 0.82 & 2620 & 110 & 2560 & 64 & 2487 & 77 & 2487 & 77 & 105 \\
\hline 12JT31_18 & 122 & 3.3 & 0.164 & 0.760 & 0.2 & 11.47 & 80.0 & 0.506 & 2.6 & 0.73 & 2640 & 110 & 2561 & 65 & 2492 & 79 & 2492 & 79 & 106 \\
\hline 12JT31_45 & 112 & 1.1 & 0.165 & 0.770 & 0.3 & 11.66 & 82.0 & 0.509 & 2.6 & 0.77 & 2650 & 110 & 2577 & 68 & 2505 & 80 & 2505 & 80 & 106 \\
\hline 12JT31_15 & 93 & 1.6 & 0.171 & 0.800 & 0.2 & 12.53 & 87.0 & 0.532 & 2.7 & 0.69 & 2750 & 110 & 2648 & 67 & 2565 & 78 & 2565 & 78 & 107 \\
\hline 12JT31_9 & 51 & 1.0 & 0.171 & 0.820 & 0.2 & 13.08 & 93.0 & 0.548 & 2.9 & 0.68 & 2820 & 120 & 2688 & 66 & 2568 & 81 & 2568 & 81 & 110 \\
\hline 12JT31_21 & 83 & 1.9 & 0.174 & 0.820 & 0.2 & 13.08 & 92.0 & 0.548 & 2.8 & 0.71 & 2820 & 110 & 2684 & 67 & 2595 & 80 & 2595 & 80 & 109 \\
\hline
\end{tabular}


TABLE SM2.3: LA-ICPMS U-PB ISOTOPIC DATA (UC SANTA CRUZ LAB)

\begin{tabular}{|c|c|c|c|c|c|c|c|c|c|c|c|c|c|c|c|c|c|c|c|}
\hline \multirow[b]{2}{*}{ Analysis } & \multirow[b]{2}{*}{$U$} & \multirow[b]{2}{*}{$\mathrm{U} / \mathrm{Th}$} & \multirow[b]{2}{*}{$206 \mathrm{~Pb}^{*}$} & \multirow[b]{2}{*}{ \pm} & \multirow[b]{2}{*}{ error } & \multicolumn{5}{|c|}{ Isotope ratios } & \multicolumn{6}{|c|}{ Apparent ages (Ma) } & \multirow[b]{2}{*}{ Best age } & \multirow[b]{2}{*}{ \pm} & \multirow[b]{2}{*}{ Conc } \\
\hline & & & & & & 207Pb* & \pm & $206 \mathrm{~Pb}^{*}$ & \pm & error & $206 \mathrm{~Pb}^{*}$ & \pm & $207 \mathrm{~Pb}^{*}$ & \pm & $206 \mathrm{~Pb}^{*}$ & \pm & & & \\
\hline & (ppm) & & $207 \mathrm{~Pb}^{*}$ & $(\%)$ & corr. & $235 U^{*}$ & $(\%)$ & $238 \mathrm{U}$ & (\%) & corr. & $238 U^{*}$ & (Ma) & $235 \mathrm{U}$ & (Ma) & $207 \mathrm{~Pb}^{*}$ & (Ma) & (Ma) & (Ma) & (\%) \\
\hline 12JT32_12 & 66 & 0.9 & 0.074 & 0.420 & 0.1 & 1.80 & 14.0 & 0.180 & 0.9 & 0.38 & 1063 & 51 & 1040 & 50 & 1030 & 120 & 1030 & 120 & 103 \\
\hline 12JT32_40 & 47 & 2.0 & 0.076 & 0.450 & 0.2 & 1.96 & 16.0 & 0.184 & 1.0 & 0.46 & 1091 & 53 & 1087 & 55 & 1050 & 130 & 1050 & 130 & 104 \\
\hline 12JT32_8 & 66 & 1.5 & 0.077 & 0.450 & 0.4 & 2.02 & 16.0 & 0.188 & 1.0 & 0.15 & 1108 & 53 & 1115 & 52 & 1120 & 110 & 1120 & 110 & 99 \\
\hline 12JT32_71 & 91 & 3.7 & 0.086 & 0.450 & 0.2 & 2.81 & 21.0 & 0.241 & 1.2 & 0.49 & 1388 & 64 & 1356 & 54 & 1340 & 110 & 1340 & 110 & 104 \\
\hline 12JT32_69 & 281 & 3.1 & 0.088 & 0.420 & 0.0 & 3.00 & 21.0 & 0.249 & 1.2 & 0.68 & 1435 & 64 & 1404 & 53 & 1381 & 91 & 1381 & 91 & 104 \\
\hline 12JT32_32 & 20 & 1.7 & 0.092 & 0.660 & 0.3 & 3.10 & 28.0 & 0.241 & 1.4 & 0.42 & 1385 & 72 & 1426 & 68 & 1410 & 150 & 1410 & 150 & 98 \\
\hline 12JT32_44 & 91 & 1.4 & 0.092 & 0.480 & 0.2 & 3.25 & 24.0 & 0.259 & 1.3 & 0.45 & 1483 & 68 & 1463 & 56 & 1460 & 100 & 1460 & 100 & 102 \\
\hline 12JT32_84 & 37 & 1.2 & 0.091 & 0.540 & 0.3 & 3.37 & 26.0 & 0.268 & 1.5 & 0.40 & 1534 & 74 & 1496 & 63 & 1470 & 110 & 1470 & 110 & 104 \\
\hline 12JT32_33 & 366 & 1.3 & 0.092 & 0.430 & 0.1 & 3.43 & 24.0 & 0.269 & 1.3 & 0.63 & 1536 & 68 & 1510 & 54 & 1470 & 88 & 1470 & 88 & 104 \\
\hline 12JT32_31 & 123 & 0.7 & 0.103 & 0.510 & 0.2 & 3.93 & 28.0 & 0.283 & 1.5 & 0.62 & 1601 & 74 & 1623 & 58 & 1658 & 92 & 1658 & 92 & 97 \\
\hline 12JT32_20 & 38 & 0.9 & 0.110 & 0.590 & 0.2 & 4.44 & 34.0 & 0.298 & 1.6 & 0.50 & 1683 & 78 & 1720 & 63 & 1764 & 98 & 1764 & 98 & 95 \\
\hline 12JT32_80 & 56 & 1.8 & 0.110 & 0.570 & 0.3 & 4.94 & 36.0 & 0.333 & 1.7 & 0.41 & 1849 & 84 & 1807 & 61 & 1775 & 95 & 1775 & 95 & 104 \\
\hline 12JT32_45 & 35 & 0.7 & 0.110 & 0.610 & 0.3 & 5.15 & 39.0 & 0.337 & 1.8 & 0.48 & 1869 & 86 & 1828 & 64 & 1790 & 100 & 1790 & 100 & 104 \\
\hline 12JT32_26 & 95 & 1.8 & 0.111 & 0.550 & 0.2 & 4.92 & 36.0 & 0.323 & 1.6 & 0.56 & 1801 & 80 & 1803 & 62 & 1798 & 92 & 1798 & 92 & 100 \\
\hline 12JT32_18 & 128 & 1.4 & 0.110 & 0.520 & 0.2 & 5.16 & 36.0 & 0.337 & 1.7 & 0.61 & 1868 & 81 & 1842 & 60 & 1798 & 88 & 1798 & 88 & 104 \\
\hline 12JT32_46 & 27 & 1.5 & 0.112 & 0.650 & 0.2 & 5.08 & 39.0 & 0.333 & 1.8 & 0.59 & 1846 & 87 & 1813 & 65 & 1810 & 110 & 1810 & 110 & 102 \\
\hline 12JT32_41 & 32 & 0.9 & 0.113 & 0.630 & 0.2 & 5.24 & 41.0 & 0.332 & 1.8 & 0.55 & 1847 & 85 & 1852 & 66 & 1840 & 100 & 1840 & 100 & 100 \\
\hline 12JT32_62 & 25 & 0.6 & 0.115 & 0.670 & 0.3 & 5.29 & 41.0 & 0.335 & 1.9 & 0.40 & 1860 & 90 & 1868 & 67 & 1840 & 110 & 1840 & 110 & 101 \\
\hline 12JT32_87 & 12 & 0.8 & 0.114 & 0.780 & 0.2 & 5.38 & 48.0 & 0.345 & 2.2 & 0.47 & 1890 & 100 & 1847 & 75 & 1840 & 120 & 1840 & 120 & 103 \\
\hline 12JT32_9 & 193 & 1.9 & 0.113 & 0.530 & 0.2 & 5.36 & 37.0 & 0.345 & 1.7 & 0.63 & 1910 & 83 & 1874 & 60 & 1844 & 85 & 1844 & 85 & 104 \\
\hline 12JT32_63 & 146 & 1.5 & 0.113 & 0.540 & 0.1 & 5.33 & 37.0 & 0.346 & 1.7 & 0.64 & 1925 & 86 & 1875 & 62 & 1846 & 86 & 1846 & 86 & 104 \\
\hline 12JT32_99 & 16 & 0.8 & 0.114 & 0.730 & 0.3 & 5.42 & 46.0 & 0.342 & 2.0 & 0.46 & 1899 & 99 & 1861 & 72 & 1850 & 120 & 1850 & 120 & 103 \\
\hline 12JT32_11 & 135 & 1.8 & 0.115 & 0.550 & 0.3 & 4.78 & 34.0 & 0.302 & 1.5 & 0.51 & 1702 & 76 & 1781 & 58 & 1868 & 85 & 1868 & 85 & 91 \\
\hline 12JT32_55 & 25 & 0.8 & 0.115 & 0.680 & 0.1 & 5.55 & 45.0 & 0.345 & 1.9 & 0.51 & 1919 & 93 & 1891 & 71 & 1870 & 100 & 1870 & 100 & 103 \\
\hline 12JT32_43 & 161 & 1.5 & 0.114 & 0.540 & 0.2 & 5.49 & 38.0 & 0.349 & 1.8 & 0.58 & 1932 & 83 & 1899 & 60 & 1870 & 86 & 1870 & 86 & 103 \\
\hline 12JT32_48 & 39 & 2.0 & 0.115 & 0.610 & 0.3 & 5.64 & 42.0 & 0.351 & 1.9 & 0.51 & 1934 & 90 & 1921 & 63 & 1874 & 95 & 1874 & 95 & 103 \\
\hline 12JT32_4 & 53 & 3.0 & 0.115 & 0.600 & 0.4 & 5.61 & 41.0 & 0.353 & 1.8 & 0.38 & 1948 & 87 & 1917 & 64 & 1878 & 97 & 1878 & 97 & 104 \\
\hline 12JT32 56 & 62 & 0.9 & 0.114 & 0.590 & 0.2 & 5.57 & 41.0 & 0.358 & 1.8 & 0.53 & 1972 & 86 & 1911 & 64 & 1882 & 93 & 1882 & 93 & 105 \\
\hline
\end{tabular}


TABLE SM2.3: LA-ICPMS U-PB ISOTOPIC DATA (UC SANTA CRUZ LAB)

\begin{tabular}{|c|c|c|c|c|c|c|c|c|c|c|c|c|c|c|c|c|c|c|c|}
\hline \multirow[b]{2}{*}{ Analysis } & \multirow[b]{2}{*}{$\mathrm{U}$} & \multirow[b]{2}{*}{ U/Th } & \multirow[b]{2}{*}{$206 \mathrm{~Pb}^{*}$} & \multirow[b]{2}{*}{ \pm} & \multirow[b]{2}{*}{ error } & \multicolumn{5}{|c|}{ Isotope ratios } & \multicolumn{6}{|c|}{ Apparent ages (Ma) } & \multirow[b]{2}{*}{ Best age } & \multirow[b]{2}{*}{ \pm} & \multirow[b]{2}{*}{ Conc } \\
\hline & & & & & & $207 \mathrm{~Pb}^{*}$ & \pm & $206 \mathrm{~Pb}^{*}$ & \pm & error & $206 \mathrm{~Pb}^{*}$ & \pm & $207 \mathrm{~Pb}^{*}$ & \pm & $206 \mathrm{~Pb}^{*}$ & \pm & & & \\
\hline & $(\mathrm{ppm})$ & & $207 \mathrm{~Pb}^{*}$ & $(\%)$ & corr. & $235 U^{*}$ & $(\%)$ & $238 U$ & (\%) & corr. & $238 U^{*}$ & $(\mathrm{Ma})$ & $235 U$ & (Ma) & $207 \mathrm{~Pb}^{*}$ & (Ma) & (Ma) & (Ma) & $(\%)$ \\
\hline 12JT32_57 & 26 & 1.2 & 0.116 & 0.670 & 0.2 & 5.77 & 46.0 & 0.363 & 2.0 & 0.45 & 1993 & 94 & 1936 & 70 & 1910 & 110 & 1910 & 110 & 104 \\
\hline 12JT32_38 & 266 & 2.2 & 0.118 & 0.550 & 0.0 & 5.07 & 38.0 & 0.316 & 1.8 & 0.90 & 1771 & 87 & 1834 & 65 & 1923 & 83 & 1923 & 83 & 92 \\
\hline 12JT32_37 & 23 & 0.5 & 0.118 & 0.690 & 0.2 & 5.67 & 45.0 & 0.343 & 1.9 & 0.42 & 1896 & 90 & 1911 & 70 & 1930 & 110 & 1930 & 110 & 98 \\
\hline 12JT32_85 & 28 & 1.0 & 0.117 & 0.650 & 0.3 & 5.76 & 45.0 & 0.356 & 2.0 & 0.51 & 1955 & 93 & 1940 & 66 & 1930 & 100 & 1930 & 100 & 101 \\
\hline 12JT32_81 & 210 & 1.5 & 0.119 & 0.560 & 0.2 & 5.61 & 39.0 & 0.349 & 1.7 & 0.61 & 1926 & 83 & 1914 & 60 & 1933 & 85 & 1933 & 85 & 100 \\
\hline 12JT32_29 & 100 & 1.4 & 0.121 & 0.580 & 0.2 & 6.05 & 43.0 & 0.363 & 1.8 & 0.49 & 1996 & 85 & 1984 & 62 & 1968 & 89 & 1968 & 89 & 101 \\
\hline 12JT32_35 & 54 & 1.2 & 0.122 & 0.610 & 0.3 & 5.90 & 43.0 & 0.352 & 1.8 & 0.51 & 1940 & 86 & 1963 & 63 & 1971 & 95 & 1971 & 95 & 98 \\
\hline 12JT32_7 & 273 & 3.3 & 0.122 & 0.570 & -0.1 & 5.59 & 39.0 & 0.332 & 1.6 & 0.68 & 1852 & 79 & 1910 & 59 & 1989 & 80 & 1989 & 80 & 93 \\
\hline 12JT32_14 & 84 & 1.5 & 0.128 & 0.620 & 0.2 & 6.90 & 49.0 & 0.386 & 2.0 & 0.60 & 2105 & 91 & 2094 & 62 & 2076 & 86 & 2076 & 86 & 101 \\
\hline 12JT32_2 & 142 & 1.2 & 0.132 & 0.620 & 0.3 & 7.30 & 51.0 & 0.400 & 2.0 & 0.57 & 2169 & 92 & 2148 & 61 & 2130 & 81 & 2130 & 81 & 102 \\
\hline 12JT32_17 & 56 & 1.2 & 0.146 & 0.710 & 0.1 & 8.88 & 64.0 & 0.441 & 2.3 & 0.69 & 2350 & 100 & 2321 & 65 & 2303 & 83 & 2303 & 83 & 102 \\
\hline 12JT32_3 & 174 & 2.2 & 0.148 & 0.690 & 0.2 & 7.65 & 53.0 & 0.374 & 1.9 & 0.68 & 2047 & 88 & 2189 & 63 & 2322 & 78 & 2322 & 78 & 88 \\
\hline 12JT32_68 & 14 & 109.5 & 0.156 & 1.100 & 0.0 & 9.47 & 87.0 & 0.435 & 2.5 & 0.57 & 2320 & 110 & 2331 & 87 & 2330 & 130 & 2330 & 130 & 100 \\
\hline 12JT32_53 & 131 & 3.2 & 0.149 & 0.700 & 0.2 & 9.40 & 66.0 & 0.459 & 2.3 & 0.64 & 2440 & 100 & 2378 & 64 & 2331 & 81 & 2331 & 81 & 105 \\
\hline 12JT32_34 & 81 & 3.6 & 0.150 & 0.710 & 0.2 & 9.17 & 65.0 & 0.447 & 2.3 & 0.64 & 2380 & 100 & 2353 & 64 & 2337 & 79 & 2337 & 79 & 102 \\
\hline 12JT32_42 & 51 & 1.6 & 0.151 & 0.740 & 0.2 & 9.63 & 69.0 & 0.463 & 2.4 & 0.61 & 2450 & 100 & 2399 & 65 & 2353 & 82 & 2353 & 82 & 104 \\
\hline 12JT32_92 & 112 & 1.5 & 0.152 & 0.720 & 0.2 & 8.17 & 58.0 & 0.390 & 2.0 & 0.63 & 2119 & 92 & 2254 & 64 & 2368 & 82 & 2368 & 82 & 89 \\
\hline 12JT32_50 & 60 & 0.8 & 0.153 & 0.740 & 0.2 & 9.83 & 70.0 & 0.468 & 2.4 & 0.65 & 2470 & 110 & 2422 & 65 & 2385 & 82 & 2385 & 82 & 104 \\
\hline 12JT32_75 & 168 & 6.8 & 0.169 & 0.800 & 0.1 & 10.99 & 81.0 & 0.482 & 2.6 & 0.16 & 2530 & 110 & 2504 & 70 & 2545 & 76 & 2545 & 76 & 99 \\
\hline 12JT32_13 & 116 & 2.8 & 0.170 & 0.790 & 0.3 & 11.85 & 82.0 & 0.505 & 2.5 & 0.59 & 2640 & 110 & 2597 & 62 & 2555 & 79 & 2555 & 79 & 103 \\
\hline 12JT32_28 & 112 & 1.1 & 0.171 & 0.850 & 0.0 & 9.40 & 72.0 & 0.396 & 2.2 & 0.87 & 2160 & 110 & 2367 & 71 & 2563 & 82 & 2563 & 82 & 84 \\
\hline 12JT32_39 & 127 & 1.5 & 0.172 & 0.800 & 0.3 & 11.67 & 82.0 & 0.492 & 2.6 & 0.80 & 2570 & 110 & 2574 & 67 & 2586 & 80 & 2586 & 80 & 99 \\
\hline 12JT32_1 & 98 & 1.4 & 0.173 & 0.810 & 0.4 & 12.50 & 87.0 & 0.521 & 2.6 & 0.61 & 2700 & 110 & 2643 & 65 & 2587 & 78 & 2587 & 78 & 104 \\
\hline 12JT32_10 & 75 & 1.5 & 0.173 & 0.820 & 0.3 & 12.31 & 86.0 & 0.513 & 2.6 & 0.66 & 2660 & 110 & 2629 & 66 & 2591 & 77 & 2591 & 77 & 103 \\
\hline 12JT32_16 & 84 & 2.0 & 0.175 & 0.820 & 0.4 & 12.13 & 84.0 & 0.502 & 2.6 & 0.64 & 2630 & 110 & 2612 & 66 & 2608 & 79 & 2608 & 79 & 101 \\
\hline 12JT32_36 & 69 & 5.1 & 0.177 & 0.840 & 0.2 & 12.35 & 87.0 & 0.506 & 2.6 & 0.73 & 2640 & 110 & 2630 & 65 & 2621 & 78 & 2621 & 78 & 101 \\
\hline 12JT32_73 & 26 & 1.0 & 0.180 & 0.930 & 0.2 & 12.78 & 97.0 & 0.529 & 3.0 & 0.70 & 2730 & 120 & 2664 & 70 & 2649 & 86 & 2649 & 86 & 103 \\
\hline 12JT32_76 & 22 & 2.4 & 0.182 & 0.940 & 0.2 & 13.01 & 99.0 & 0.536 & 3.0 & 0.61 & 2750 & 120 & 2669 & 71 & 2652 & 89 & 2652 & 89 & 104 \\
\hline
\end{tabular}


TABLE SM2.3: LA-ICPMS U-PB ISOTOPIC DATA (UC SANTA CRUZ LAB)

\begin{tabular}{|c|c|c|c|c|c|c|c|c|c|c|c|c|c|c|c|c|c|c|c|}
\hline \multirow[b]{2}{*}{ Analysis } & \multirow[b]{2}{*}{$U$} & \multirow[b]{2}{*}{ U/Th } & \multirow[b]{2}{*}{$206 \mathrm{~Pb}^{*}$} & \multirow[b]{2}{*}{ \pm} & \multirow[b]{2}{*}{ error } & \multicolumn{5}{|c|}{ Isotope ratios } & \multicolumn{6}{|c|}{ Apparent ages (Ma) } & \multirow[b]{2}{*}{ Best age } & \multirow[b]{2}{*}{ \pm} & \multirow[b]{2}{*}{ Cono } \\
\hline & & & & & & $207 \mathrm{~Pb}^{*}$ & \pm & $206 \mathrm{~Pb}^{*}$ & \pm & error & $206 \mathrm{~Pb}^{*}$ & \pm & 207Pb* & \pm & $206 \mathrm{~Pb}^{*}$ & \pm & & & \\
\hline & $(\mathrm{ppm})$ & & $207 \mathrm{~Pb}^{\star}$ & $(\%)$ & corr. & $235 U^{*}$ & (\%) & $238 U$ & (\%) & corr. & $238 U^{*}$ & (Ma) & $235 U$ & (Ma) & $207 \mathrm{~Pb}^{*}$ & (Ma) & (Ma) & (Ma) & (\%) \\
\hline 12JT32_47 & 172 & 1.9 & 0.180 & 0.830 & 0.2 & 11.94 & 83.0 & 0.480 & 2.4 & 0.75 & 2530 & 100 & 2597 & 66 & 2653 & 78 & 2653 & 78 & 95 \\
\hline 12JT32_5 & 23 & 2.0 & 0.183 & 0.940 & 0.3 & 13.35 & 99.0 & 0.532 & 2.9 & 0.61 & 2740 & 120 & 2693 & 69 & 2675 & 81 & 2675 & 81 & 102 \\
\hline 12JT32_6 & 50 & 1.6 & 0.187 & 0.900 & 0.2 & 13.90 & 99.0 & 0.534 & 2.7 & 0.68 & 2750 & 110 & 2745 & 67 & 2716 & 79 & 2716 & 79 & 101 \\
\hline 12JT32_49 & 57 & 2.3 & 0.194 & 0.930 & 0.3 & 14.60 & 100.0 & 0.547 & 2.8 & 0.71 & 2820 & 120 & 2783 & 67 & 2782 & 80 & 2782 & 80 & 101 \\
\hline 12JT32_65 & 32 & 1.9 & 0.203 & 0.990 & 0.4 & 16.40 & 120.0 & 0.587 & 3.1 & 0.66 & 2970 & 130 & 2893 & 68 & 2837 & 82 & 2837 & 82 & 105 \\
\hline 12JT32_22 & 78 & 4.6 & 0.228 & 1.100 & 0.4 & 19.60 & 140.0 & 0.620 & 3.2 & 0.70 & 3110 & 120 & 3070 & 66 & 3041 & 73 & 3041 & 73 & 102 \\
\hline \multicolumn{20}{|c|}{$>20 \%$ Discordance } \\
\hline 12JT32_88 & 486 & 2.0 & 0.138 & 0.630 & 0.2 & 4.60 & 32.0 & 0.245 & 1.2 & 0.77 & 1409 & 64 & 1750 & 58 & 2193 & 79 & 2193 & 79 & 64 \\
\hline 12JT32_77 & 274 & 1.2 & 0.154 & 0.710 & 0.1 & 6.68 & 47.0 & 0.319 & 1.6 & 0.80 & 1784 & 80 & 2070 & 61 & 2385 & 79 & 2385 & 79 & 75 \\
\hline 12JT32_98 & 193 & 1.6 & 0.155 & 0.730 & -0.2 & 6.84 & 50.0 & 0.318 & 1.7 & 0.85 & 1781 & 83 & 2076 & 67 & 2395 & 80 & 2395 & 80 & 74 \\
\hline \multicolumn{20}{|c|}{$>5 \%$ Reverse Discordance } \\
\hline 12JT32_23 & 86 & 391.9 & 0.077 & 0.460 & 0.3 & 2.35 & 18.0 & 0.219 & 1.2 & 0.28 & 1272 & 62 & 1224 & 54 & 1130 & 120 & 1130 & 120 & 113 \\
\hline 12JT32_25 & 113 & 1.7 & 0.082 & 0.420 & 0.1 & 2.51 & 18.0 & 0.223 & 1.1 & 0.44 & 1294 & 59 & 1273 & 54 & 1226 & 98 & 1226 & 98 & 106 \\
\hline 12JT32_90 & 13 & 0.8 & 0.089 & 0.670 & 0.3 & 3.09 & 29.0 & 0.253 & 1.6 & 0.45 & 1441 & 82 & 1411 & 70 & 1290 & 150 & 1290 & 150 & 112 \\
\hline 12JT32_96 & 44 & 2.1 & 0.087 & 0.500 & 0.2 & 2.91 & 22.0 & 0.251 & 1.4 & 0.39 & 1440 & 70 & 1381 & 59 & 1340 & 110 & 1340 & 110 & 107 \\
\hline 12JT32_100 & 56 & 2.1 & 0.090 & 0.500 & 0.4 & 3.23 & 24.0 & 0.260 & 1.4 & 0.22 & 1488 & 69 & 1455 & 58 & 1400 & 110 & 1400 & 110 & 106 \\
\hline 12JT32_94 & 81 & 2.6 & 0.092 & 0.480 & 0.3 & 3.34 & 24.0 & 0.268 & 1.4 & 0.39 & 1528 & 70 & 1481 & 56 & 1440 & 100 & 1440 & 100 & 106 \\
\hline 12JT32_61 & 26 & 4079.3 & 0.104 & 0.600 & 0.1 & 4.88 & 39.0 & 0.349 & 2.1 & 0.52 & 1911 & 97 & 1783 & 69 & 1660 & 110 & 1660 & 110 & 115 \\
\hline 12JT32_64 & 15 & 1.5 & 0.111 & 0.740 & 0.3 & 5.15 & 44.0 & 0.342 & 2.0 & 0.38 & 1890 & 97 & 1819 & 74 & 1710 & 130 & 1710 & 130 & 111 \\
\hline 12JT32_93 & 13 & 246.1 & 0.105 & 0.690 & 0.1 & 5.94 & 54.0 & 0.404 & 2.6 & 0.61 & 2160 & 120 & 1947 & 82 & 1710 & 130 & 1710 & 130 & 126 \\
\hline 12JT32_51 & 10 & 318.0 & 0.111 & 0.790 & 0.3 & 5.87 & 53.0 & 0.380 & 2.6 & 0.48 & 2040 & 110 & 1933 & 79 & 1730 & 150 & 1730 & 150 & 118 \\
\hline 12JT32_52 & 11 & 489.3 & 0.108 & 0.730 & 0.2 & 5.48 & 48.0 & 0.383 & 2.4 & 0.49 & 2070 & 110 & 1885 & 80 & 1730 & 130 & 1730 & 130 & 120 \\
\hline 12JT32_27 & 25 & 2391.9 & 0.108 & 0.610 & 0.3 & 5.79 & 46.0 & 0.389 & 2.2 & 0.48 & 2110 & 100 & 1931 & 67 & 1740 & 110 & 1740 & 110 & 121 \\
\hline 12JT32_67 & 8 & 660.0 & 0.111 & 0.880 & 0.3 & 5.75 & 56.0 & 0.395 & 2.6 & 0.46 & 2110 & 120 & 1941 & 83 & 1750 & 140 & 1750 & 140 & 121 \\
\hline 12JT32_19 & 15 & 2127.1 & 0.109 & 0.690 & 0.3 & 5.83 & 48.0 & 0.389 & 2.4 & 0.45 & 2100 & 110 & 1933 & 72 & 1760 & 120 & 1760 & 120 & 119 \\
\hline 12JT32_24 & 14 & 0.9 & 0.111 & 0.750 & 0.3 & 5.28 & 45.0 & 0.342 & 2.0 & 0.39 & 1880 & 97 & 1852 & 74 & 1770 & 130 & 1770 & 130 & 106 \\
\hline
\end{tabular}


TABLE SM2.3: LA-ICPMS U-PB ISOTOPIC DATA (UC SANTA CRUZ LAB)

\begin{tabular}{|c|c|c|c|c|c|c|c|c|c|c|c|c|c|c|c|c|c|c|c|}
\hline \multirow[b]{2}{*}{ Analysis } & \multirow[b]{2}{*}{$U$} & \multirow[b]{2}{*}{ U/Th } & \multirow[b]{2}{*}{$206 \mathrm{~Pb}^{*}$} & \multirow[b]{2}{*}{ \pm} & \multirow[b]{2}{*}{ error } & \multicolumn{5}{|c|}{ Isotope ratios } & \multicolumn{6}{|c|}{ Apparent ages (Ma) } & \multirow[b]{2}{*}{ Best age } & \multirow[b]{2}{*}{ \pm} & \multirow[b]{2}{*}{ Conc } \\
\hline & & & & & & 207Pb* & \pm & $206 \mathrm{~Pb}^{*}$ & \pm & error & $206 \mathrm{~Pb}^{*}$ & \pm & 207Pb* & \pm & $206 \mathrm{~Pb}^{*}$ & \pm & & & \\
\hline & (ppm) & & $207 \mathrm{~Pb}^{\star}$ & (\%) & corr. & $235 U^{*}$ & (\%) & $238 U$ & (\%) & corr. & $238 U^{*}$ & (Ma) & $235 \mathrm{U}$ & (Ma) & $207 \mathrm{~Pb}^{*}$ & (Ma) & (Ma) & (Ma) & (\%) \\
\hline 12JT32_70 & 19 & 0.7 & 0.111 & 0.670 & 0.2 & 5.33 & 44.0 & 0.350 & 2.0 & 0.54 & 1925 & 95 & 1846 & 71 & 1820 & 110 & 1820 & 110 & 106 \\
\hline 12JT32_86 & 72 & 1.5 & 0.113 & 0.570 & 0.3 & 5.41 & 39.0 & 0.351 & 1.8 & 0.51 & 1945 & 84 & 1889 & 61 & 1849 & 89 & 1849 & 89 & 105 \\
\hline 12JT32_82 & 71 & 1.9 & 0.114 & 0.570 & 0.1 & 5.55 & 40.0 & 0.362 & 1.9 & 0.59 & 1988 & 89 & 1909 & 61 & 1850 & 90 & 1850 & 90 & 107 \\
\hline 12JT32_91 & 19 & 4845.4 & 0.115 & 0.660 & 0.3 & 6.21 & 49.0 & 0.398 & 2.3 & 0.59 & 2150 & 100 & 1997 & 66 & 1860 & 100 & 1860 & 100 & 116 \\
\hline 12JT32_15 & 114 & 3.2 & 0.114 & 0.550 & 0.2 & 5.72 & 40.0 & 0.360 & 1.8 & 0.48 & 1983 & 85 & 1934 & 60 & 1865 & 88 & 1865 & 88 & 106 \\
\hline 12JT32_97 & 29 & 1.5 & 0.116 & 0.640 & 0.3 & 5.96 & 45.0 & 0.373 & 2.0 & 0.42 & 2042 & 94 & 1961 & 65 & 1870 & 100 & 1870 & 100 & 109 \\
\hline 12JT32_89 & 72 & 1.6 & 0.116 & 0.570 & 0.2 & 5.92 & 43.0 & 0.368 & 1.9 & 0.61 & 2016 & 90 & 1957 & 61 & 1889 & 89 & 1889 & 89 & 107 \\
\hline 12JT32_58 & 13 & 1684.3 & 0.116 & 0.760 & 0.3 & 6.66 & 56.0 & 0.419 & 2.6 & 0.56 & 2230 & 120 & 2036 & 75 & 1890 & 120 & 1890 & 120 & 118 \\
\hline 12JT32_83 & 39 & 844.8 & 0.117 & 0.610 & 0.2 & 6.84 & 52.0 & 0.434 & 2.4 & 0.62 & 2310 & 110 & 2089 & 68 & 1909 & 95 & 1909 & 95 & 121 \\
\hline 12JT32_54 & 29 & 3006.2 & 0.118 & 0.640 & 0.2 & 6.24 & 49.0 & 0.387 & 2.2 & 0.63 & 2100 & 100 & 1991 & 69 & 1911 & 96 & 1911 & 96 & 110 \\
\hline 12JT32_21 & 5 & 22.5 & 0.133 & 1.300 & 0.3 & 7.43 & 81.0 & 0.427 & 3.5 & 0.51 & 2230 & 150 & 2060 & 100 & 1950 & 180 & 1950 & 180 & 114 \\
\hline 12JT32_66 & 43 & 2.2 & 0.133 & 0.660 & 0.3 & 7.40 & 54.0 & 0.414 & 2.2 & 0.63 & 2244 & 99 & 2161 & 66 & 2126 & 87 & 2126 & 87 & 106 \\
\hline 12JT32_60 & 116 & 4.4 & 0.144 & 0.690 & 0.0 & 9.14 & 67.0 & 0.463 & 2.5 & 0.81 & 2460 & 110 & 2342 & 67 & 2278 & 80 & 2278 & 80 & 108 \\
\hline 12JT32_95 & 54 & 1.7 & 0.148 & 0.720 & 0.1 & 9.38 & 68.0 & 0.462 & 2.4 & 0.70 & 2440 & 110 & 2368 & 66 & 2314 & 83 & 2314 & 83 & 105 \\
\hline 12JT32_59 & 60 & 1.7 & 0.152 & 0.730 & 0.3 & 9.77 & 70.0 & 0.472 & 2.5 & 0.68 & 2490 & 110 & 2405 & 65 & 2361 & 81 & 2361 & 81 & 105 \\
\hline 12JT32_72 & 122 & 2.3 & 0.152 & 0.710 & 0.3 & 10.06 & 70.0 & 0.485 & 2.5 & 0.66 & 2550 & 110 & 2437 & 64 & 2363 & 79 & 2363 & 79 & 108 \\
\hline 12JT32_30 & 7 & 0.8 & 0.164 & 1.100 & 0.4 & 11.70 & 100.0 & 0.517 & 3.5 & 0.70 & 2640 & 140 & 2551 & 82 & 2460 & 120 & 2460 & 120 & 107 \\
\hline 12JT32_79 & 93 & 2.6 & 0.169 & 0.800 & 0.2 & 11.94 & 84.0 & 0.520 & 2.7 & 0.68 & 2700 & 110 & 2598 & 66 & 2551 & 83 & 2551 & 83 & 106 \\
\hline 12JT32_78 & 59 & 1.8 & 0.173 & 0.820 & 0.3 & 12.72 & 90.0 & 0.537 & 2.8 & 0.71 & 2770 & 120 & 2652 & 67 & 2595 & 80 & 2595 & 80 & 107 \\
\hline 12JT32_74 & 21 & 0.8 & 0.184 & 0.970 & 0.1 & 13.70 & 100.0 & 0.553 & 3.1 & 0.73 & 2810 & 120 & 2722 & 70 & 2671 & 89 & 2671 & 89 & 105 \\
\hline \multicolumn{20}{|c|}{ 05LF13; Neruokpuk Formation ( N69.18, W142.66) } \\
\hline 05LF13_50 & 229 & 2.4 & 0.079 & 0.170 & 0.2 & 2.06 & 9.7 & 0.190 & 0.8 & 0.62 & 1118 & 46 & 1136 & 32 & 1165 & 45 & 1165 & 45 & 96 \\
\hline 05LF13_58 & 354 & 3.3 & 0.081 & 0.180 & 0.1 & 2.24 & 10.0 & 0.202 & 0.9 & 0.76 & 1186 & 48 & 1194 & 33 & 1215 & 43 & 1215 & 43 & 98 \\
\hline 05LF13_84 & 295 & 4.0 & 0.082 & 0.180 & 0.3 & 2.34 & 11.0 & 0.210 & 0.9 & 0.50 & 1229 & 50 & 1226 & 33 & 1236 & 44 & 1236 & 44 & 99 \\
\hline 05LF13_85 & 126 & 4.1 & 0.082 & 0.190 & 0.3 & 2.51 & 12.0 & 0.224 & 1.0 & 0.49 & 1302 & 53 & 1274 & 34 & 1247 & 44 & 1247 & 44 & 104 \\
\hline 05LF13_26 & 67 & 2.4 & 0.089 & 0.210 & 0.3 & 3.04 & 14.0 & 0.246 & 1.1 & 0.47 & 1419 & 58 & 1416 & 36 & 1398 & 45 & 1398 & 45 & 102 \\
\hline 05LF13_87 & 85 & 3.0 & 0.091 & 0.210 & 0.2 & 3.23 & 15.0 & 0.261 & 1.2 & 0.52 & 1495 & 59 & 1463 & 36 & 1435 & 44 & 1435 & 44 & 104 \\
\hline
\end{tabular}


TABLE SM2.3: LA-ICPMS U-PB ISOTOPIC DATA (UC SANTA CRUZ LAB)

\begin{tabular}{|c|c|c|c|c|c|c|c|c|c|c|c|c|c|c|c|c|c|c|c|}
\hline \multirow[b]{2}{*}{ Analysis } & \multirow[b]{2}{*}{$\mathrm{U}$} & \multirow[b]{2}{*}{ U/Th } & \multirow[b]{2}{*}{$206 \mathrm{~Pb}^{*}$} & \multirow[b]{2}{*}{ \pm} & \multirow[b]{2}{*}{ error } & \multicolumn{5}{|c|}{ Isotope ratios } & \multicolumn{6}{|c|}{ Apparent ages (Ma) } & \multirow[b]{2}{*}{ Best age } & \multirow[b]{2}{*}{ \pm} & \multirow[b]{2}{*}{ Cono } \\
\hline & & & & & & $207 \mathrm{~Pb}^{*}$ & \pm & $206 \mathrm{~Pb}^{*}$ & \pm & error & $206 \mathrm{~Pb}^{*}$ & \pm & 207Pb* & \pm & $206 \mathrm{~Pb}^{*}$ & \pm & & & \\
\hline & (ppm) & & $207 \mathrm{~Pb}^{\star}$ & (\%) & corr. & $235 U^{*}$ & (\%) & $238 U$ & (\%) & corr. & $238 U^{*}$ & (Ma) & $235 \mathrm{U}$ & (Ma) & $207 \mathrm{~Pb}^{*}$ & (Ma) & (Ma) & (Ma) & (\%) \\
\hline 05LF13_43 & 504 & 1.8 & 0.091 & 0.190 & 0.0 & 2.72 & 13.0 & 0.215 & 1.0 & 0.81 & 1258 & 51 & 1335 & 34 & 1454 & 41 & 1454 & 41 & 87 \\
\hline 05LF13_68 & 107 & 2.6 & 0.092 & 0.210 & 0.3 & 3.32 & 16.0 & 0.265 & 1.2 & 0.52 & 1515 & 60 & 1486 & 36 & 1460 & 42 & 1460 & 42 & 104 \\
\hline 05LF13_60 & 178 & 2.2 & 0.092 & 0.200 & 0.2 & 3.12 & 15.0 & 0.245 & 1.1 & 0.60 & 1414 & 56 & 1435 & 36 & 1471 & 43 & 1471 & 43 & 96 \\
\hline 05LF13_6 & 86 & 2.2 & 0.094 & 0.210 & 0.3 & 3.15 & 15.0 & 0.242 & 1.1 & 0.59 & 1398 & 57 & 1444 & 37 & 1500 & 43 & 1500 & 43 & 93 \\
\hline 05LF13_39 & 152 & 1.2 & 0.101 & 0.220 & 0.4 & 4.07 & 19.0 & 0.290 & 1.3 & 0.56 & 1643 & 65 & 1648 & 38 & 1641 & 41 & 1641 & 41 & 100 \\
\hline 05LF13_52 & 76 & 4.2 & 0.102 & 0.230 & 0.0 & 3.73 & 18.0 & 0.264 & 1.2 & 0.70 & 1509 & 60 & 1578 & 39 & 1658 & 43 & 1658 & 43 & 91 \\
\hline 05LF13_13 & 197 & 2.9 & 0.104 & 0.230 & 0.0 & 4.15 & 20.0 & 0.289 & 1.3 & 0.84 & 1639 & 65 & 1664 & 38 & 1689 & 40 & 1689 & 40 & 97 \\
\hline 05LF13_51 & 350 & 2.4 & 0.109 & 0.240 & 0.0 & 3.99 & 20.0 & 0.266 & 1.2 & 0.90 & 1520 & 63 & 1634 & 40 & 1784 & 40 & 1784 & 40 & 85 \\
\hline 05LF13_21 & 83 & 1.1 & 0.110 & 0.250 & 0.2 & 4.61 & 22.0 & 0.304 & 1.4 & 0.67 & 1713 & 68 & 1752 & 38 & 1798 & 42 & 1798 & 42 & 95 \\
\hline 05LF13_32 & 262 & 1.5 & 0.111 & 0.250 & 0.2 & 5.06 & 24.0 & 0.331 & 1.5 & 0.72 & 1843 & 72 & 1829 & 41 & 1815 & 40 & 1815 & 40 & 102 \\
\hline 05LF13_93 & 148 & 1.8 & 0.112 & 0.240 & 0.2 & 4.99 & 23.0 & 0.326 & 1.4 & 0.58 & 1817 & 70 & 1818 & 39 & 1828 & 40 & 1828 & 40 & 99 \\
\hline 05LF13_35 & 117 & 3.2 & 0.112 & 0.250 & 0.2 & 5.06 & 24.0 & 0.329 & 1.5 & 0.62 & 1832 & 72 & 1829 & 39 & 1828 & 41 & 1828 & 41 & 100 \\
\hline 05LF13_8 & 42 & 1.3 & 0.112 & 0.270 & 0.2 & 5.14 & 25.0 & 0.331 & 1.5 & 0.58 & 1845 & 72 & 1840 & 41 & 1839 & 43 & 1839 & 43 & 100 \\
\hline 05LF13_1 & 70 & 1.9 & 0.112 & 0.250 & 0.2 & 5.38 & 25.0 & 0.346 & 1.5 & 0.60 & 1913 & 74 & 1879 & 40 & 1840 & 40 & 1840 & 40 & 104 \\
\hline 05LF13_61 & 100 & 2.6 & 0.113 & 0.250 & 0.3 & 4.82 & 22.0 & 0.312 & 1.4 & 0.56 & 1749 & 67 & 1788 & 39 & 1841 & 40 & 1841 & 40 & 95 \\
\hline 05LF13_67 & 79 & 2.5 & 0.114 & 0.260 & 0.1 & 5.14 & 25.0 & 0.331 & 1.5 & 0.79 & 1843 & 74 & 1841 & 42 & 1852 & 41 & 1852 & 41 & 100 \\
\hline 05LF13_71 & 87 & 3.6 & 0.115 & 0.250 & 0.3 & 4.98 & 23.0 & 0.319 & 1.4 & 0.76 & 1787 & 70 & 1813 & 40 & 1870 & 40 & 1870 & 40 & 96 \\
\hline 05LF13_3 & 185 & 2.5 & 0.115 & 0.270 & -0.3 & 4.98 & 27.0 & 0.310 & 1.6 & 0.94 & 1736 & 78 & 1809 & 47 & 1876 & 42 & 1876 & 42 & 93 \\
\hline 05LF13_24 & 75 & 2.0 & 0.115 & 0.260 & 0.3 & 4.82 & 23.0 & 0.303 & 1.4 & 0.71 & 1705 & 69 & 1788 & 41 & 1878 & 42 & 1878 & 42 & 91 \\
\hline 05LF13_65 & 92 & 2.8 & 0.115 & 0.250 & 0.2 & 5.13 & 24.0 & 0.324 & 1.4 & 0.64 & 1809 & 70 & 1842 & 40 & 1882 & 40 & 1882 & 40 & 96 \\
\hline 05LF13_59 & 230 & 2.8 & 0.116 & 0.250 & 0.2 & 5.10 & 24.0 & 0.320 & 1.4 & 0.74 & 1788 & 69 & 1837 & 39 & 1887 & 39 & 1887 & 39 & 95 \\
\hline 05LF13_15 & 92 & 2.3 & 0.115 & 0.260 & 0.2 & 4.66 & 22.0 & 0.293 & 1.3 & 0.68 & 1658 & 65 & 1760 & 39 & 1888 & 41 & 1888 & 41 & 88 \\
\hline 05LF13_28 & 48 & 0.6 & 0.116 & 0.290 & 0.3 & 5.36 & 26.0 & 0.336 & 1.5 & 0.49 & 1869 & 73 & 1878 & 41 & 1888 & 44 & 1888 & 44 & 99 \\
\hline 05LF13_38 & 49 & 0.5 & 0.116 & 0.270 & 0.1 & 5.30 & 25.0 & 0.328 & 1.5 & 0.64 & 1828 & 72 & 1867 & 41 & 1896 & 42 & 1896 & 42 & 96 \\
\hline 05LF13_14 & 178 & 1.2 & 0.116 & 0.250 & 0.3 & 5.60 & 26.0 & 0.348 & 1.6 & 0.72 & 1924 & 74 & 1915 & 40 & 1896 & 39 & 1896 & 39 & 101 \\
\hline 05LF13_72 & 65 & 1.3 & 0.116 & 0.260 & 0.3 & 5.72 & 27.0 & 0.360 & 1.6 & 0.55 & 1984 & 76 & 1934 & 40 & 1897 & 39 & 1897 & 39 & 105 \\
\hline 05LF13_7 & 130 & 0.6 & 0.116 & 0.250 & 0.3 & 5.65 & 26.0 & 0.349 & 1.5 & 0.63 & 1932 & 73 & 1925 & 40 & 1900 & 39 & 1900 & 39 & 102 \\
\hline 05LF13_94 & 128 & 1.2 & 0.117 & 0.250 & 0.2 & 5.47 & 25.0 & 0.342 & 1.5 & 0.59 & 1897 & 73 & 1899 & 40 & 1903 & 39 & 1903 & 39 & 100 \\
\hline
\end{tabular}


TABLE SM2.3: LA-ICPMS U-PB ISOTOPIC DATA (UC SANTA CRUZ LAB)

\begin{tabular}{|c|c|c|c|c|c|c|c|c|c|c|c|c|c|c|c|c|c|c|c|}
\hline \multirow[b]{2}{*}{ Analysis } & \multirow[b]{2}{*}{$\mathrm{U}$} & \multirow[b]{2}{*}{ U/Th } & \multirow[b]{2}{*}{$206 \mathrm{~Pb}^{*}$} & \multirow[b]{2}{*}{ \pm} & \multirow[b]{2}{*}{ error } & \multicolumn{5}{|c|}{ Isotope ratios } & \multicolumn{6}{|c|}{ Apparent ages (Ma) } & \multirow[b]{2}{*}{ Best age } & \multirow[b]{2}{*}{ \pm} & \multirow[b]{2}{*}{ Conc } \\
\hline & & & & & & $207 \mathrm{~Pb}^{*}$ & \pm & $206 \mathrm{~Pb}^{*}$ & \pm & error & $206 \mathrm{~Pb}^{*}$ & \pm & 207Pb* & \pm & $206 \mathrm{~Pb}^{*}$ & \pm & & & \\
\hline & (ppm) & & $207 \mathrm{~Pb}^{\star}$ & (\%) & corr. & $235 U^{*}$ & (\%) & $238 U$ & (\%) & corr. & $238 U^{*}$ & (Ma) & $235 \mathrm{U}$ & (Ma) & $207 \mathrm{~Pb}^{*}$ & (Ma) & (Ma) & (Ma) & (\%) \\
\hline 05LF13_45 & 72 & 0.7 & 0.117 & 0.270 & 0.3 & 5.31 & 25.0 & 0.330 & 1.5 & 0.60 & 1837 & 72 & 1872 & 40 & 1905 & 41 & 1905 & 41 & 96 \\
\hline 05LF13_92 & 45 & 1.0 & 0.117 & 0.270 & 0.2 & 5.36 & 25.0 & 0.337 & 1.5 & 0.56 & 1872 & 72 & 1881 & 41 & 1905 & 42 & 1905 & 42 & 98 \\
\hline 05LF13_49 & 128 & 0.6 & 0.117 & 0.260 & 0.2 & 5.59 & 26.0 & 0.346 & 1.5 & 0.72 & 1916 & 74 & 1915 & 41 & 1906 & 40 & 1906 & 40 & 101 \\
\hline 05LF13_57 & 223 & 2.5 & 0.117 & 0.260 & 0.0 & 5.04 & 24.0 & 0.313 & 1.4 & 0.88 & 1755 & 71 & 1825 & 40 & 1907 & 39 & 1907 & 39 & 92 \\
\hline 05LF13_66 & 143 & 2.6 & 0.117 & 0.250 & 0.2 & 5.71 & 26.0 & 0.356 & 1.6 & 0.65 & 1963 & 75 & 1932 & 40 & 1909 & 39 & 1909 & 39 & 103 \\
\hline 05LF13_18 & 282 & 2.3 & 0.117 & 0.250 & 0.3 & 5.18 & 24.0 & 0.321 & 1.4 & 0.66 & 1792 & 69 & 1850 & 40 & 1913 & 38 & 1913 & 38 & 94 \\
\hline 05LF13_2 & 287 & 7.0 & 0.117 & 0.250 & 0.2 & 5.43 & 25.0 & 0.335 & 1.5 & 0.69 & 1863 & 71 & 1890 & 40 & 1914 & 40 & 1914 & 40 & 97 \\
\hline 05LF13_4 & 104 & 1.3 & 0.118 & 0.260 & 0.1 & 5.28 & 25.0 & 0.321 & 1.4 & 0.71 & 1794 & 70 & 1867 & 41 & 1931 & 39 & 1931 & 39 & 93 \\
\hline 05LF13_100 & 69 & 0.8 & 0.119 & 0.270 & 0.1 & 5.79 & 27.0 & 0.356 & 1.6 & 0.71 & 1964 & 76 & 1945 & 42 & 1934 & 40 & 1934 & 40 & 102 \\
\hline 05LF13_78 & 199 & 1.2 & 0.119 & 0.250 & 0.3 & 5.80 & 27.0 & 0.357 & 1.6 & 0.68 & 1970 & 75 & 1946 & 40 & 1936 & 38 & 1936 & 38 & 102 \\
\hline 05LF13_11 & 164 & 0.8 & 0.119 & 0.260 & 0.1 & 5.28 & 25.0 & 0.320 & 1.4 & 0.78 & 1792 & 70 & 1865 & 40 & 1938 & 38 & 1938 & 38 & 92 \\
\hline 05LF13_83 & 34 & 1.0 & 0.120 & 0.300 & 0.1 & 5.62 & 28.0 & 0.342 & 1.6 & 0.71 & 1892 & 76 & 1918 & 42 & 1950 & 45 & 1950 & 45 & 97 \\
\hline 05LF13_10 & 71 & 2.2 & 0.121 & 0.300 & 0.0 & 5.55 & 27.0 & 0.336 & 1.5 & 0.46 & 1868 & 73 & 1903 & 40 & 1959 & 43 & 1959 & 43 & 95 \\
\hline 05LF13_79 & 169 & 5.9 & 0.123 & 0.270 & -0.4 & 5.52 & 27.0 & 0.331 & 1.5 & 0.90 & 1841 & 73 & 1904 & 41 & 2001 & 39 & 2001 & 39 & 92 \\
\hline 05LF13_98 & 13 & 1.6 & 0.127 & 0.340 & 0.2 & 6.74 & 34.0 & 0.391 & 1.8 & 0.53 & 2124 & 84 & 2079 & 45 & 2060 & 48 & 2060 & 48 & 103 \\
\hline 05LF13_55 & 220 & 1.4 & 0.129 & 0.290 & -0.5 & 6.38 & 31.0 & 0.359 & 1.6 & 0.86 & 1978 & 76 & 2027 & 42 & 2078 & 40 & 2078 & 40 & 95 \\
\hline 05LF13_34 & 174 & 1.2 & 0.129 & 0.280 & 0.2 & 6.94 & 33.0 & 0.389 & 1.7 & 0.78 & 2118 & 81 & 2104 & 41 & 2083 & 38 & 2083 & 38 & 102 \\
\hline 05LF13_69 & 41 & 1.1 & 0.136 & 0.330 & 0.0 & 7.12 & 35.0 & 0.383 & 1.7 & 0.71 & 2091 & 82 & 2126 & 45 & 2172 & 42 & 2172 & 42 & 96 \\
\hline 05LF13_33 & 115 & 1.9 & 0.136 & 0.300 & 0.1 & 7.62 & 36.0 & 0.403 & 1.8 & 0.71 & 2184 & 82 & 2186 & 42 & 2182 & 38 & 2182 & 38 & 100 \\
\hline 05LF13_89 & 80 & 2.5 & 0.138 & 0.300 & 0.0 & 7.70 & 36.0 & 0.410 & 1.8 & 0.72 & 2215 & 84 & 2198 & 42 & 2203 & 38 & 2203 & 38 & 101 \\
\hline 05LF13_91 & 42 & 1.0 & 0.142 & 0.320 & 0.3 & 8.03 & 38.0 & 0.415 & 1.9 & 0.63 & 2238 & 85 & 2234 & 44 & 2250 & 40 & 2250 & 40 & 99 \\
\hline 05LF13_16 & 153 & 2.2 & 0.143 & 0.310 & 0.0 & 8.31 & 39.0 & 0.419 & 1.9 & 0.69 & 2256 & 85 & 2265 & 42 & 2265 & 38 & 2265 & 38 & 100 \\
\hline 05LF13_54 & 206 & 1.7 & 0.143 & 0.310 & 0.2 & 7.93 & 37.0 & 0.400 & 1.8 & 0.74 & 2169 & 81 & 2222 & 42 & 2268 & 37 & 2268 & 37 & 96 \\
\hline 05LF13_44 & 48 & 1.3 & 0.144 & 0.340 & 0.0 & 8.24 & 40.0 & 0.418 & 1.9 & 0.78 & 2253 & 88 & 2261 & 45 & 2270 & 40 & 2270 & 40 & 99 \\
\hline 05LF13_70 & 75 & 0.5 & 0.147 & 0.320 & 0.2 & 8.68 & 41.0 & 0.432 & 1.9 & 0.75 & 2316 & 88 & 2304 & 43 & 2309 & 38 & 2309 & 38 & 100 \\
\hline 05LF13_95 & 72 & 1.2 & 0.147 & 0.330 & 0.3 & 8.74 & 41.0 & 0.431 & 1.9 & 0.68 & 2311 & 88 & 2310 & 43 & 2310 & 38 & 2310 & 38 & 100 \\
\hline 05LF13_23 & 215 & 2.0 & 0.148 & 0.320 & 0.3 & 8.14 & 38.0 & 0.396 & 1.8 & 0.81 & 2151 & 83 & 2246 & 42 & 2325 & 36 & 2325 & 36 & 93 \\
\hline 05LF13_22 & 82 & 1.1 & 0.148 & 0.320 & 0.3 & 9.26 & 43.0 & 0.453 & 2.0 & 0.61 & 2412 & 91 & 2363 & 43 & 2325 & 37 & 2325 & 37 & 104 \\
\hline
\end{tabular}


TABLE SM2.3: LA-ICPMS U-PB ISOTOPIC DATA (UC SANTA CRUZ LAB)

\begin{tabular}{|c|c|c|c|c|c|c|c|c|c|c|c|c|c|c|c|c|c|c|c|}
\hline \multirow[b]{2}{*}{ Analysis } & \multirow[b]{2}{*}{$\mathrm{U}$} & \multirow[b]{2}{*}{ U/Th } & \multirow[b]{2}{*}{$206 \mathrm{~Pb}^{*}$} & \multirow[b]{2}{*}{ \pm} & \multirow[b]{2}{*}{ error } & \multirow[b]{2}{*}{ 207Pb* } & \multicolumn{3}{|c|}{ Isotope ratios } & \multirow[b]{2}{*}{ error } & \multirow[b]{2}{*}{$206 \mathrm{~Pb}^{\star}$} & \multicolumn{4}{|c|}{ Apparent ages (Ma) } & \multirow[b]{2}{*}{ \pm} & \multirow[b]{2}{*}{ Best age } & \multirow[b]{2}{*}{ \pm} & \multirow[b]{2}{*}{ Conc } \\
\hline & & & & & & & \pm & $206 \mathrm{~Pb}^{*}$ & \pm & & & \pm & 207Pb* & \pm & $206 \mathrm{~Pb}^{*}$ & & & & \\
\hline & (ppm) & & $207 \mathrm{~Pb}^{*}$ & (\%) & corr. & $235 U^{*}$ & (\%) & $238 U$ & (\%) & corr. & $238 U^{*}$ & (Ma) & $235 \mathrm{U}$ & (Ma) & $207 \mathrm{~Pb}^{*}$ & (Ma) & (Ma) & (Ma) & $(\%)$ \\
\hline 05LF13_27 & 173 & 1.7 & 0.151 & 0.320 & 0.1 & 8.43 & 39.0 & 0.404 & 1.8 & 0.84 & 2187 & 83 & 2278 & 43 & 2356 & 37 & 2356 & 37 & 93 \\
\hline 05LF13_62 & 115 & 1.4 & 0.152 & 0.330 & 0.2 & 7.22 & 34.0 & 0.346 & 1.5 & 0.69 & 1914 & 74 & 2140 & 42 & 2369 & 38 & 2369 & 38 & 81 \\
\hline 05LF13_53 & 134 & 3.1 & 0.153 & 0.330 & 0.2 & 8.91 & 41.0 & 0.423 & 1.9 & 0.70 & 2273 & 84 & 2330 & 42 & 2374 & 37 & 2374 & 37 & 96 \\
\hline 05LF13_42 & 164 & 1.0 & 0.153 & 0.330 & 0.3 & 9.42 & 44.0 & 0.444 & 2.0 & 0.74 & 2370 & 88 & 2380 & 43 & 2375 & 37 & 2375 & 37 & 100 \\
\hline 05LF13_40 & 127 & 2.0 & 0.153 & 0.330 & 0.4 & 9.52 & 44.0 & 0.449 & 2.0 & 0.64 & 2389 & 89 & 2388 & 43 & 2378 & 37 & 2378 & 37 & 100 \\
\hline 05LF13_82 & 42 & 2.0 & 0.159 & 0.370 & 0.1 & 9.78 & 47.0 & 0.452 & 2.1 & 0.69 & 2404 & 93 & 2415 & 43 & 2441 & 39 & 2441 & 39 & 98 \\
\hline 05LF13_81 & 84 & 3.2 & 0.159 & 0.410 & 0.2 & 7.68 & 40.0 & 0.359 & 1.7 & 0.79 & 1979 & 81 & 2198 & 47 & 2442 & 43 & 2442 & 43 & 81 \\
\hline 05LF13_25 & 298 & 2.3 & 0.159 & 0.340 & 0.1 & 9.34 & 43.0 & 0.425 & 1.9 & 0.84 & 2281 & 85 & 2373 & 43 & 2443 & 36 & 2443 & 36 & 93 \\
\hline 05LF13_73 & 162 & 2.8 & 0.160 & 0.340 & 0.2 & 8.48 & 39.0 & 0.389 & 1.7 & 0.79 & 2116 & 81 & 2284 & 42 & 2452 & 36 & 2452 & 36 & 86 \\
\hline 05LF13_47 & 78 & 1.5 & 0.163 & 0.350 & 0.2 & 10.32 & 48.0 & 0.459 & 2.0 & 0.70 & 2438 & 91 & 2464 & 44 & 2483 & 37 & 2483 & 37 & 98 \\
\hline 05LF13_88 & 102 & 1.6 & 0.163 & 0.350 & 0.0 & 9.93 & 47.0 & 0.448 & 2.0 & 0.86 & 2387 & 89 & 2429 & 43 & 2484 & 37 & 2484 & 37 & 96 \\
\hline 05LF13_19 & 96 & 1.5 & 0.164 & 0.360 & 0.1 & 9.92 & 47.0 & 0.435 & 2.0 & 0.80 & 2327 & 88 & 2429 & 44 & 2497 & 36 & 2497 & 36 & 93 \\
\hline 05LF13_76 & 43 & 1.4 & 0.165 & 0.380 & 0.2 & 9.69 & 47.0 & 0.431 & 2.0 & 0.75 & 2308 & 90 & 2404 & 45 & 2508 & 39 & 2508 & 39 & 92 \\
\hline 05LF13_99 & 126 & 1.1 & 0.166 & 0.360 & -0.2 & 9.66 & 49.0 & 0.422 & 2.0 & 0.95 & 2264 & 93 & 2396 & 48 & 2514 & 37 & 2514 & 37 & 90 \\
\hline 05LF13_86 & 25 & 1.2 & 0.168 & 0.420 & 0.1 & 8.99 & 46.0 & 0.392 & 1.9 & 0.77 & 2128 & 86 & 2335 & 47 & 2540 & 41 & 2540 & 41 & 84 \\
\hline 05LF13_41 & 71 & 2.4 & 0.172 & 0.380 & 0.1 & 11.69 & 55.0 & 0.490 & 2.2 & 0.72 & 2570 & 94 & 2580 & 43 & 2576 & 36 & 2576 & 36 & 100 \\
\hline 05LF13_31 & 34 & 1.3 & 0.182 & 0.410 & 0.3 & 12.95 & 61.0 & 0.517 & 2.3 & 0.63 & 2688 & 98 & 2677 & 46 & 2671 & 38 & 2671 & 38 & 101 \\
\hline 05LF13_20 & 115 & 1.4 & 0.184 & 0.390 & 0.3 & 12.85 & 60.0 & 0.506 & 2.3 & 0.72 & 2637 & 97 & 2669 & 44 & 2689 & 36 & 2689 & 36 & 98 \\
\hline 05LF13_77 & 121 & 1.4 & 0.185 & 0.390 & 0.2 & 13.28 & 62.0 & 0.527 & 2.3 & 0.83 & 2730 & 100 & 2700 & 45 & 2698 & 34 & 2698 & 34 & 101 \\
\hline 05LF13_96 & 112 & 2.4 & 0.189 & 0.400 & 0.2 & 13.97 & 65.0 & 0.541 & 2.4 & 0.75 & 2790 & 100 & 2749 & 44 & 2729 & 35 & 2729 & 35 & 102 \\
\hline 05LF13_30 & 149 & 2.2 & 0.191 & 0.420 & 0.1 & 12.65 & 60.0 & 0.481 & 2.2 & 0.84 & 2532 & 95 & 2655 & 45 & 2748 & 36 & 2748 & 36 & 92 \\
\hline \multicolumn{20}{|c|}{$>20 \%$ Discordance } \\
\hline 05LF13_63 & 288 & 1.7 & 0.113 & 0.260 & 0.6 & 1.65 & 8.0 & 0.106 & 0.5 & 0.83 & 651 & 30 & 991 & 31 & 1844 & 41 & 651 & 30 & 35 \\
\hline 05LF13_75 & 620 & 3.3 & 0.137 & 0.310 & -0.5 & 2.42 & 13.0 & 0.130 & 0.6 & 0.97 & 787 & 36 & 1246 & 37 & 2185 & 40 & 787 & 36 & 36 \\
\hline 05LF13_74 & 757 & 4.7 & 0.121 & 0.260 & -0.3 & 2.73 & 13.0 & 0.165 & 0.8 & 0.92 & 984 & 42 & 1337 & 36 & 1963 & 39 & 984 & 42 & 50 \\
\hline 05LF13_56 & 362 & 2.0 & 0.096 & 0.220 & 0.2 & 2.45 & 12.0 & 0.183 & 0.8 & 0.67 & 1082 & 45 & 1259 & 33 & 1544 & 43 & 1544 & 43 & 70 \\
\hline 05LF13_48 & 232 & 0.9 & 0.114 & 0.330 & -0.3 & 3.98 & 21.0 & 0.251 & 1.1 & 0.61 & 1442 & 58 & 1621 & 36 & 1856 & 46 & 1856 & 46 & 78 \\
\hline
\end{tabular}


TABLE SM2.3: LA-ICPMS U-PB ISOTOPIC DATA (UC SANTA CRUZ LAB)

\begin{tabular}{|c|c|c|c|c|c|c|c|c|c|c|c|c|c|c|c|c|c|c|c|}
\hline \multirow[b]{2}{*}{ Analysis } & \multirow[b]{2}{*}{$\mathrm{U}$} & \multirow[b]{2}{*}{ U/Th } & \multirow[b]{2}{*}{$206 \mathrm{~Pb}^{*}$} & \multirow[b]{2}{*}{ \pm} & \multirow[b]{2}{*}{ error } & \multirow[b]{2}{*}{ 207Pb* } & \multicolumn{3}{|c|}{ Isotope ratios } & \multirow[b]{2}{*}{ error } & \multirow[b]{2}{*}{$206 \mathrm{~Pb}^{\star}$} & \multicolumn{4}{|c|}{ Apparent ages (Ma) } & \multirow[b]{2}{*}{ \pm} & \multirow[b]{2}{*}{ Best age } & \multirow[b]{2}{*}{ \pm} & \multirow[b]{2}{*}{ Conc } \\
\hline & & & & & & & \pm & $206 \mathrm{~Pb}^{*}$ & \pm & & & \pm & 207Pb* & \pm & $206 \mathrm{~Pb}^{*}$ & & & & \\
\hline & (ppm) & & $207 \mathrm{~Pb}^{*}$ & (\%) & corr. & $235 U^{*}$ & (\%) & $238 U$ & (\%) & corr. & $238 U^{*}$ & (Ma) & $235 \mathrm{U}$ & (Ma) & $207 \mathrm{~Pb}^{*}$ & (Ma) & (Ma) & (Ma) & $(\%)$ \\
\hline 05LF13_5 & 136 & 1.5 & 0.116 & 0.260 & 0.1 & 4.26 & 20.0 & 0.265 & 1.2 & 0.86 & 1517 & 62 & 1686 & 40 & 1901 & 39 & 1901 & 39 & 80 \\
\hline 05LF13_80 & 288 & 3.6 & 0.132 & 0.340 & -0.7 & 5.29 & 30.0 & 0.292 & 1.4 & 0.96 & 1648 & 70 & 1863 & 48 & 2131 & 44 & 2131 & 44 & 77 \\
\hline 05LF13_12 & 585 & 0.9 & 0.150 & 0.320 & -0.2 & 3.64 & 17.0 & 0.175 & 0.8 & 0.89 & 1038 & 43 & 1559 & 38 & 2351 & 36 & 2351 & 36 & 44 \\
\hline 05LF13_90 & 322 & 1.8 & 0.162 & 0.350 & 0.1 & 7.86 & 37.0 & 0.356 & 1.6 & 0.89 & 1962 & 75 & 2214 & 43 & 2474 & 36 & 2474 & 36 & 79 \\
\hline 05LF13_97 & 206 & 2.7 & 0.168 & 0.360 & -0.1 & 7.73 & 37.0 & 0.335 & 1.5 & 0.91 & 1862 & 74 & 2199 & 43 & 2535 & 36 & 2535 & 36 & 73 \\
\hline 05LF13_64 & 85 & 1.7 & 0.181 & 0.420 & -0.2 & 9.65 & 50.0 & 0.384 & 1.9 & 0.92 & 2092 & 87 & 2397 & 49 & 2659 & 38 & 2659 & 38 & 79 \\
\hline 05LF13_9 & 420 & 2.3 & 0.265 & 0.570 & -0.5 & 9.57 & 47.0 & 0.261 & 1.2 & 0.95 & 1495 & 61 & 2395 & 46 & 3273 & 34 & 3273 & 34 & 46 \\
\hline \multicolumn{20}{|c|}{$>5 \%$ Reverse Discordance } \\
\hline 05LF13_46 & 441 & 12.4 & 0.053 & 0.120 & 0.2 & 0.39 & 1.9 & 0.053 & 0.2 & 0.33 & 334 & 14 & 336 & 13 & 329 & 53 & 334 & 14 & 102 \\
\hline 05LF13_37 & 74 & 1.0 & 0.106 & 0.250 & 0.2 & 4.98 & 24.0 & 0.338 & 1.5 & 0.65 & 1876 & 74 & 1814 & 41 & 1724 & 43 & 1724 & 43 & 109 \\
\hline 05LF13_29 & 51 & 1.5 & 0.112 & 0.300 & 0.3 & 6.04 & 31.0 & 0.395 & 1.9 & 0.71 & 2143 & 87 & 1984 & 46 & 1824 & 47 & 1824 & 47 & 117 \\
\hline \multicolumn{20}{|c|}{ 11LF13; Neruokpuk Formation ( N69.26, W142.66) } \\
\hline 11LF13_59 & 307 & 0.9 & 0.077 & 0.350 & 0.2 & 1.93 & 12.0 & 0.188 & 0.8 & 0.47 & 1109 & 46 & 1092 & 43 & 1102 & 95 & 1102 & 95 & 101 \\
\hline 11LF13_43 & 64 & 4.0 & 0.076 & 0.450 & 0.3 & 2.10 & 16.0 & 0.196 & 0.9 & 0.27 & 1156 & 51 & 1143 & 51 & 1130 & 120 & 1130 & 120 & 102 \\
\hline 11LF13_77 & 169 & 1.5 & 0.079 & 0.380 & 0.3 & 2.14 & 14.0 & 0.201 & 0.9 & 0.36 & 1181 & 49 & 1160 & 46 & 1172 & 95 & 1172 & 95 & 101 \\
\hline 11LF13_92 & 97 & 3.5 & 0.084 & 0.430 & 0.3 & 2.36 & 16.0 & 0.208 & 1.0 & 0.41 & 1214 & 51 & 1228 & 50 & 1292 & 97 & 1292 & 97 & 94 \\
\hline 11LF13_36 & 153 & 2.3 & 0.087 & 0.420 & 0.3 & 2.76 & 18.0 & 0.229 & 1.0 & 0.29 & 1329 & 54 & 1347 & 49 & 1364 & 95 & 1364 & 95 & 97 \\
\hline 11LF13_93 & 531 & 1.4 & 0.092 & 0.400 & 0.2 & 3.09 & 20.0 & 0.252 & 1.1 & 0.65 & 1451 & 57 & 1428 & 49 & 1454 & 84 & 1454 & 84 & 100 \\
\hline 11LF13_55 & 127 & 0.9 & 0.105 & 0.490 & 0.2 & 4.47 & 29.0 & 0.318 & 1.4 & 0.52 & 1781 & 70 & 1725 & 53 & 1709 & 88 & 1709 & 88 & 104 \\
\hline 11LF13_53 & 103 & 1.7 & 0.106 & 0.500 & 0.2 & 4.52 & 30.0 & 0.315 & 1.4 & 0.57 & 1764 & 69 & 1734 & 54 & 1741 & 84 & 1741 & 84 & 101 \\
\hline 11LF13_62 & 38 & 1.3 & 0.110 & 0.600 & 0.4 & 4.92 & 35.0 & 0.331 & 1.6 & 0.41 & 1836 & 79 & 1796 & 60 & 1790 & 100 & 1790 & 100 & 103 \\
\hline 11LF13_72 & 194 & 2.9 & 0.110 & 0.490 & 0.3 & 4.77 & 31.0 & 0.322 & 1.4 & 0.59 & 1800 & 70 & 1777 & 54 & 1799 & 81 & 1799 & 81 & 100 \\
\hline 11LF13_74 & 102 & 1.3 & 0.111 & 0.530 & 0.3 & 4.90 & 32.0 & 0.326 & 1.5 & 0.49 & 1818 & 72 & 1801 & 53 & 1810 & 86 & 1810 & 86 & 100 \\
\hline 11LF13_7 & 275 & 1.5 & 0.111 & 0.500 & 0.3 & 4.48 & 29.0 & 0.294 & 1.3 & 0.57 & 1659 & 65 & 1729 & 53 & 1816 & 82 & 1816 & 82 & 91 \\
\hline 11LF13_97 & 177 & 1.5 & 0.111 & 0.510 & 0.3 & 5.02 & 32.0 & 0.335 & 1.5 & 0.52 & 1862 & 72 & 1823 & 54 & 1821 & 82 & 1821 & 82 & 102 \\
\hline 11LF13_99 & 81 & 2.7 & 0.112 & 0.530 & 0.3 & 4.91 & 32.0 & 0.329 & 1.5 & 0.56 & 1835 & 74 & 1801 & 57 & 1829 & 89 & 1829 & 89 & 100 \\
\hline
\end{tabular}


TABLE SM2.3: LA-ICPMS U-PB ISOTOPIC DATA (UC SANTA CRUZ LAB)

\begin{tabular}{|c|c|c|c|c|c|c|c|c|c|c|c|c|c|c|c|c|c|c|c|}
\hline \multirow[b]{2}{*}{ Analysis } & \multirow[b]{2}{*}{$U$} & \multirow[b]{2}{*}{$\mathrm{U} / \mathrm{Th}$} & \multirow[b]{2}{*}{$206 \mathrm{~Pb}^{*}$} & \multirow[b]{2}{*}{ \pm} & \multirow[b]{2}{*}{ error } & \multicolumn{5}{|c|}{ Isotope ratios } & \multicolumn{6}{|c|}{ Apparent ages (Ma) } & \multirow[b]{2}{*}{ Best age } & \multirow[b]{2}{*}{ \pm} & \multirow[b]{2}{*}{ Conc } \\
\hline & & & & & & 207Pb* & \pm & $206 \mathrm{~Pb}^{\star}$ & \pm & error & $206 \mathrm{~Pb}^{*}$ & \pm & $207 \mathrm{~Pb}^{*}$ & \pm & $206 \mathrm{~Pb}^{*}$ & \pm & & & \\
\hline & (ppm) & & $207 \mathrm{~Pb}^{\star}$ & (\%) & corr. & $235 U^{*}$ & (\%) & $238 \mathrm{U}$ & (\%) & corr. & $238 U^{*}$ & (Ma) & $235 \mathrm{U}$ & (Ma) & $207 \mathrm{~Pb}^{*}$ & (Ma) & (Ma) & (Ma) & (\%) \\
\hline 11LF13_64 & 63 & 0.7 & 0.112 & 0.550 & 0.2 & 5.00 & 34.0 & 0.325 & 1.5 & 0.52 & 1814 & 74 & 1807 & 58 & 1832 & 88 & 1832 & 88 & 99 \\
\hline 11LF13_47 & 52 & 1.4 & 0.112 & 0.590 & 0.1 & 5.11 & 36.0 & 0.339 & 1.6 & 0.51 & 1881 & 77 & 1853 & 63 & 1837 & 99 & 1837 & 99 & 102 \\
\hline 11LF13_3 & 209 & 1.9 & 0.113 & 0.510 & 0.3 & 5.09 & 33.0 & 0.329 & 1.5 & 0.57 & 1831 & 71 & 1832 & 54 & 1842 & 80 & 1842 & 80 & 99 \\
\hline 11LF13_51 & 111 & 1.2 & 0.112 & 0.530 & 0.3 & 5.14 & 34.0 & 0.333 & 1.5 & 0.49 & 1851 & 73 & 1838 & 56 & 1843 & 87 & 1843 & 87 & 100 \\
\hline 11LF13_89 & 36 & 0.7 & 0.113 & 0.500 & 0.3 & 5.06 & 32.0 & 0.330 & 1.5 & 0.59 & 1841 & 70 & 1828 & 53 & 1844 & 79 & 1844 & 79 & 100 \\
\hline 11LF13_68 & 87 & 0.5 & 0.114 & 0.550 & 0.2 & 5.01 & 33.0 & 0.327 & 1.5 & 0.48 & 1822 & 72 & 1817 & 57 & 1848 & 89 & 1848 & 89 & 99 \\
\hline 11LF13_84 & 90 & 1.7 & 0.114 & 0.550 & 0.3 & 4.87 & 32.0 & 0.323 & 1.5 & 0.39 & 1801 & 72 & 1796 & 56 & 1849 & 87 & 1849 & 87 & 97 \\
\hline 11LF13_45 & 366 & 3.2 & 0.113 & 0.500 & 0.1 & 5.28 & 34.0 & 0.344 & 1.5 & 0.67 & 1906 & 72 & 1866 & 54 & 1849 & 79 & 1849 & 79 & 103 \\
\hline 11LF13_19 & 115 & 1.7 & 0.113 & 0.530 & 0.2 & 5.21 & 34.0 & 0.332 & 1.5 & 0.53 & 1847 & 73 & 1852 & 55 & 1850 & 85 & 1850 & 85 & 100 \\
\hline 11LF13_58 & 181 & 3.1 & 0.114 & 0.520 & 0.2 & 5.25 & 34.0 & 0.338 & 1.5 & 0.58 & 1882 & 72 & 1858 & 55 & 1856 & 83 & 1856 & 83 & 101 \\
\hline 11LF13_17 & 156 & 1.6 & 0.114 & 0.520 & 0.3 & 5.49 & 35.0 & 0.354 & 1.6 & 0.55 & 1952 & 76 & 1906 & 58 & 1867 & 83 & 1867 & 83 & 105 \\
\hline 11LF13_33 & 33 & 1.2 & 0.114 & 0.600 & 0.3 & 5.42 & 38.0 & 0.339 & 1.7 & 0.55 & 1879 & 83 & 1886 & 62 & 1868 & 96 & 1868 & 96 & 101 \\
\hline 11LF13_9 & 332 & 4.4 & 0.115 & 0.620 & 0.2 & 5.19 & 37.0 & 0.331 & 1.6 & 0.41 & 1841 & 79 & 1852 & 61 & 1871 & 96 & 1871 & 96 & 98 \\
\hline 11LF13_6 & 194 & 1.4 & 0.116 & 0.520 & 0.2 & 5.33 & 34.0 & 0.334 & 1.5 & 0.59 & 1861 & 72 & 1872 & 55 & 1886 & 78 & 1886 & 78 & 99 \\
\hline 11LF13_11 & 63 & 0.8 & 0.117 & 0.590 & 0.3 & 5.51 & 37.0 & 0.343 & 1.6 & 0.41 & 1897 & 77 & 1897 & 58 & 1895 & 91 & 1895 & 91 & 100 \\
\hline 11LF13_15 & 113 & 2.6 & 0.117 & 0.540 & 0.2 & 5.55 & 36.0 & 0.348 & 1.6 & 0.59 & 1923 & 76 & 1915 & 56 & 1900 & 83 & 1900 & 83 & 101 \\
\hline 11LF13_95 & 53 & 0.8 & 0.118 & 0.590 & 0.2 & 5.43 & 38.0 & 0.342 & 1.6 & 0.56 & 1888 & 79 & 1883 & 60 & 1902 & 94 & 1902 & 94 & 99 \\
\hline 11LF13_1 & 149 & 1.0 & 0.117 & 0.530 & 0.2 & 5.54 & 36.0 & 0.346 & 1.6 & 0.61 & 1912 & 75 & 1905 & 57 & 1905 & 84 & 1905 & 84 & 100 \\
\hline 11LF13_91 & 54 & 1.2 & 0.117 & 0.570 & 0.2 & 5.29 & 36.0 & 0.333 & 1.6 & 0.52 & 1850 & 75 & 1865 & 57 & 1906 & 91 & 1906 & 91 & 97 \\
\hline 11LF13_4 & 269 & 1.4 & 0.117 & 0.520 & 0.3 & 5.45 & 35.0 & 0.338 & 1.5 & 0.60 & 1877 & 73 & 1891 & 54 & 1912 & 80 & 1912 & 80 & 98 \\
\hline 11LF13_98 & 218 & 1.9 & 0.117 & 0.520 & 0.3 & 5.48 & 35.0 & 0.351 & 1.6 & 0.58 & 1937 & 74 & 1898 & 55 & 1913 & 81 & 1913 & 81 & 101 \\
\hline 11LF13_41 & 112 & 1.2 & 0.117 & 0.550 & 0.2 & 5.73 & 38.0 & 0.355 & 1.6 & 0.52 & 1961 & 77 & 1929 & 57 & 1913 & 84 & 1913 & 84 & 103 \\
\hline 11LF13_78 & 302 & 3.0 & 0.118 & 0.520 & 0.3 & 5.47 & 35.0 & 0.342 & 1.5 & 0.61 & 1896 & 74 & 1896 & 54 & 1922 & 80 & 1922 & 80 & 99 \\
\hline 11LF13_79 & 387 & 2.5 & 0.118 & 0.520 & 0.1 & 5.14 & 33.0 & 0.324 & 1.5 & 0.80 & 1807 & 72 & 1844 & 55 & 1923 & 79 & 1923 & 79 & 94 \\
\hline 11LF13_57 & 57 & 0.8 & 0.120 & 0.630 & 0.1 & 5.23 & 37.0 & 0.327 & 1.6 & 0.53 & 1819 & 76 & 1849 & 59 & 1925 & 97 & 1925 & 97 & 94 \\
\hline 11LF13_31 & 53 & 0.6 & 0.119 & 0.600 & 0.2 & 5.82 & 40.0 & 0.358 & 1.7 & 0.54 & 1965 & 80 & 1945 & 61 & 1929 & 87 & 1929 & 87 & 102 \\
\hline 11LF13_46 & 71 & 1.0 & 0.118 & 0.570 & 0.2 & 5.81 & 39.0 & 0.358 & 1.7 & 0.52 & 1970 & 78 & 1944 & 59 & 1938 & 86 & 1938 & 86 & 102 \\
\hline 11LF13_81 & 40 & 0.9 & 0.122 & 0.700 & 0.1 & 5.44 & 41.0 & 0.334 & 1.6 & 0.45 & 1857 & 77 & 1875 & 65 & 1960 & 100 & 1960 & 100 & 95 \\
\hline
\end{tabular}


TABLE SM2.3: LA-ICPMS U-PB ISOTOPIC DATA (UC SANTA CRUZ LAB)

\begin{tabular}{|c|c|c|c|c|c|c|c|c|c|c|c|c|c|c|c|c|c|c|c|}
\hline \multirow[b]{2}{*}{ Analysis } & \multirow[b]{2}{*}{$\mathrm{U}$} & \multirow[b]{2}{*}{ U/Th } & \multirow[b]{2}{*}{$206 \mathrm{~Pb}^{*}$} & \multirow[b]{2}{*}{ \pm} & \multirow[b]{2}{*}{ error } & \multicolumn{5}{|c|}{ Isotope ratios } & \multicolumn{6}{|c|}{ Apparent ages (Ma) } & \multirow[b]{2}{*}{ Best age } & \multirow[b]{2}{*}{ \pm} & \multirow[b]{2}{*}{ Conc } \\
\hline & & & & & & 207Pb* & \pm & $206 \mathrm{~Pb}^{*}$ & \pm & error & $206 \mathrm{~Pb}^{\star}$ & \pm & $207 \mathrm{~Pb}^{*}$ & \pm & $206 \mathrm{~Pb}^{*}$ & \pm & & & \\
\hline & $(\mathrm{ppm})$ & & $207 \mathrm{~Pb}^{*}$ & (\%) & corr. & $235 U^{*}$ & (\%) & $238 U$ & (\%) & corr. & $238 U^{*}$ & (Ma) & $235 \mathrm{U}$ & (Ma) & $207 \mathrm{~Pb}^{*}$ & (Ma) & (Ma) & (Ma) & (\%) \\
\hline 11LF13_83 & 49 & 1.0 & 0.120 & 0.590 & 0.3 & 5.60 & 38.0 & 0.340 & 1.6 & 0.51 & 1888 & 77 & 1919 & 59 & 1965 & 89 & 1965 & 89 & 96 \\
\hline 11LF13_29 & 85 & 0.9 & 0.122 & 0.580 & 0.2 & 6.22 & 41.0 & 0.371 & 1.7 & 0.56 & 2037 & 78 & 2004 & 57 & 1976 & 86 & 1976 & 86 & 103 \\
\hline 11LF13_35 & 121 & 2.2 & 0.124 & 0.570 & 0.3 & 6.31 & 41.0 & 0.371 & 1.7 & 0.53 & 2032 & 79 & 2017 & 57 & 2007 & 85 & 2007 & 85 & 101 \\
\hline 11LF13_52 & 101 & 0.6 & 0.124 & 0.580 & 0.2 & 6.34 & 42.0 & 0.377 & 1.7 & 0.60 & 2060 & 80 & 2023 & 57 & 2015 & 85 & 2015 & 85 & 102 \\
\hline 11LF13_24 & 160 & 2.1 & 0.125 & 0.560 & 0.2 & 6.48 & 42.0 & 0.379 & 1.7 & 0.60 & 2072 & 79 & 2042 & 57 & 2022 & 77 & 2022 & 77 & 102 \\
\hline 11LF13_94 & 145 & 1.0 & 0.125 & 0.580 & 0.3 & 5.18 & 34.0 & 0.309 & 1.4 & 0.62 & 1734 & 70 & 1848 & 57 & 2028 & 81 & 2028 & 81 & 86 \\
\hline 11LF13_37 & 231 & 2.5 & 0.126 & 0.560 & 0.3 & 6.51 & 41.0 & 0.377 & 1.7 & 0.65 & 2057 & 79 & 2044 & 55 & 2044 & 81 & 2044 & 81 & 101 \\
\hline 11LF13_56 & 295 & 2.7 & 0.126 & 0.560 & 0.3 & 6.49 & 41.0 & 0.379 & 1.7 & 0.66 & 2068 & 78 & 2045 & 56 & 2046 & 81 & 2046 & 81 & 101 \\
\hline 11LF13_90 & 44 & 1.8 & 0.129 & 0.650 & 0.3 & 6.72 & 46.0 & 0.383 & 1.8 & 0.46 & 2093 & 85 & 2070 & 60 & 2072 & 89 & 2072 & 89 & 101 \\
\hline 11LF13_50 & 80 & 0.9 & 0.130 & 0.610 & 0.2 & 6.70 & 44.0 & 0.381 & 1.8 & 0.59 & 2080 & 82 & 2069 & 59 & 2076 & 85 & 2076 & 85 & 100 \\
\hline 11LF13_49 & 445 & 2.7 & 0.128 & 0.560 & 0.1 & 6.40 & 42.0 & 0.370 & 1.7 & 0.87 & 2030 & 82 & 2034 & 57 & 2077 & 79 & 2077 & 79 & 98 \\
\hline 11LF13_63 & 582 & 4.5 & 0.130 & 0.570 & 0.1 & 6.11 & 39.0 & 0.347 & 1.5 & 0.82 & 1919 & 75 & 1989 & 55 & 2101 & 75 & 2101 & 75 & 91 \\
\hline 11LF13_75 & 44 & 1.5 & 0.131 & 0.660 & 0.3 & 6.62 & 45.0 & 0.378 & 1.8 & 0.45 & 2063 & 84 & 2057 & 59 & 2113 & 86 & 2113 & 86 & 98 \\
\hline 11LF13_10 & 394 & 1.7 & 0.133 & 0.580 & 0.0 & 6.79 & 44.0 & 0.372 & 1.7 & 0.87 & 2042 & 79 & 2083 & 56 & 2133 & 76 & 2133 & 76 & 96 \\
\hline 11LF13_76 & 65 & 1.6 & 0.132 & 0.640 & 0.3 & 6.72 & 45.0 & 0.373 & 1.7 & 0.51 & 2041 & 81 & 2075 & 59 & 2135 & 84 & 2135 & 84 & 96 \\
\hline 11LF13_21 & 189 & 1.3 & 0.136 & 0.610 & 0.3 & 7.91 & 51.0 & 0.419 & 1.9 & 0.57 & 2258 & 84 & 2218 & 57 & 2179 & 79 & 2179 & 79 & 104 \\
\hline 11LF13_88 & 203 & 2.7 & 0.137 & 0.610 & 0.2 & 7.14 & 46.0 & 0.391 & 1.7 & 0.64 & 2128 & 81 & 2131 & 58 & 2180 & 76 & 2180 & 76 & 98 \\
\hline 11LF13_67 & 90 & 1.1 & 0.142 & 0.690 & 0.3 & 7.73 & 52.0 & 0.398 & 1.9 & 0.56 & 2161 & 86 & 2197 & 60 & 2244 & 85 & 2244 & 85 & 96 \\
\hline 11LF13_23 & 167 & 1.3 & 0.143 & 0.630 & 0.1 & 8.67 & 56.0 & 0.441 & 2.0 & 0.70 & 2357 & 86 & 2304 & 60 & 2264 & 78 & 2264 & 78 & 104 \\
\hline 11LF13_70 & 228 & 1.0 & 0.144 & 0.640 & 0.1 & 6.72 & 45.0 & 0.342 & 1.6 & 0.88 & 1902 & 80 & 2077 & 58 & 2275 & 77 & 2275 & 77 & 84 \\
\hline 11LF13_73 & 136 & 1.5 & 0.147 & 0.660 & 0.2 & 8.59 & 56.0 & 0.432 & 1.9 & 0.64 & 2315 & 88 & 2292 & 59 & 2310 & 79 & 2310 & 79 & 100 \\
\hline 11LF13_61 & 215 & 14.8 & 0.148 & 0.660 & 0.3 & 8.79 & 56.0 & 0.442 & 2.0 & 0.64 & 2364 & 90 & 2313 & 58 & 2319 & 76 & 2319 & 76 & 102 \\
\hline 11LF13_86 & 127 & 1.4 & 0.148 & 0.670 & 0.4 & 8.56 & 55.0 & 0.429 & 1.9 & 0.54 & 2302 & 87 & 2289 & 58 & 2329 & 79 & 2329 & 79 & 99 \\
\hline 11LF13_28 & 46 & 3.4 & 0.149 & 0.720 & 0.3 & 8.95 & 60.0 & 0.439 & 2.1 & 0.54 & 2339 & 93 & 2331 & 64 & 2330 & 84 & 2330 & 84 & 100 \\
\hline 11LF13_8 & 158 & 1.9 & 0.150 & 0.670 & 0.3 & 9.12 & 58.0 & 0.445 & 2.0 & 0.66 & 2371 & 88 & 2350 & 59 & 2340 & 74 & 2340 & 74 & 101 \\
\hline 11LF13_54 & 97 & 1.3 & 0.151 & 0.680 & 0.3 & 9.17 & 59.0 & 0.450 & 2.0 & 0.60 & 2394 & 90 & 2355 & 59 & 2361 & 78 & 2361 & 78 & 101 \\
\hline 11LF13_22 & 84 & 0.6 & 0.153 & 0.700 & 0.1 & 9.43 & 62.0 & 0.448 & 2.1 & 0.68 & 2395 & 90 & 2376 & 60 & 2372 & 77 & 2372 & 77 & 101 \\
\hline 11LF13_34 & 275 & 2.1 & 0.157 & 0.690 & 0.2 & 9.85 & 62.0 & 0.458 & 2.0 & 0.72 & 2426 & 89 & 2419 & 59 & 2416 & 75 & 2416 & 75 & 100 \\
\hline
\end{tabular}


TABLE SM2.3: LA-ICPMS U-PB ISOTOPIC DATA (UC SANTA CRUZ LAB)

\begin{tabular}{|c|c|c|c|c|c|c|c|c|c|c|c|c|c|c|c|c|c|c|c|}
\hline \multirow[b]{2}{*}{ Analysis } & \multirow[b]{2}{*}{$\mathrm{U}$} & \multirow[b]{2}{*}{ U/Th } & \multirow[b]{2}{*}{$206 \mathrm{~Pb}^{*}$} & \multirow[b]{2}{*}{ \pm} & \multirow[b]{2}{*}{ error } & \multicolumn{5}{|c|}{ Isotope ratios } & \multicolumn{6}{|c|}{ Apparent ages (Ma) } & \multirow[b]{2}{*}{ Best age } & \multirow[b]{2}{*}{ \pm} & \multirow[b]{2}{*}{ Conc } \\
\hline & & & & & & $207 \mathrm{~Pb}^{*}$ & \pm & $206 \mathrm{~Pb}^{*}$ & \pm & error & $206 \mathrm{~Pb}^{*}$ & \pm & $207 \mathrm{~Pb}^{*}$ & \pm & $206 \mathrm{~Pb}^{\star}$ & \pm & & & \\
\hline & (ppm) & & $207 \mathrm{~Pb}^{\star}$ & $(\%)$ & corr. & $235 U^{*}$ & $(\%)$ & $238 U$ & (\%) & corr. & $238 U^{*}$ & (Ma) & $235 \mathrm{U}$ & (Ma) & $207 \mathrm{~Pb}^{\star}$ & (Ma) & $(\mathrm{Ma})$ & (Ma) & $(\%)$ \\
\hline 11LF13_5 & 35 & 1.4 & 0.159 & 0.770 & 0.3 & 10.06 & 69.0 & 0.465 & 2.3 & 0.58 & 2460 & 100 & 2439 & 65 & 2437 & 85 & 2437 & 85 & 101 \\
\hline 11LF13_2 & 161 & 1.2 & 0.160 & 0.720 & 0.2 & 10.05 & 64.0 & 0.458 & 2.1 & 0.69 & 2430 & 91 & 2442 & 58 & 2457 & 74 & 2457 & 74 & 99 \\
\hline 11LF13_25 & 117 & 2.2 & 0.168 & 0.780 & -0.3 & 11.26 & 75.0 & 0.485 & 2.2 & 0.70 & 2543 & 96 & 2531 & 60 & 2531 & 74 & 2531 & 74 & 100 \\
\hline 11LF13_100 & 207 & 1.7 & 0.170 & 0.750 & 0.3 & 11.22 & 71.0 & 0.493 & 2.2 & 0.76 & 2585 & 95 & 2540 & 61 & 2556 & 72 & 2556 & 72 & 101 \\
\hline 11LF13_65 & 212 & 4.6 & 0.170 & 0.750 & 0.3 & 11.12 & 70.0 & 0.485 & 2.1 & 0.70 & 2548 & 94 & 2534 & 59 & 2561 & 74 & 2561 & 74 & 99 \\
\hline 11LF13_85 & 43 & 0.8 & 0.171 & 0.830 & 0.2 & 11.13 & 76.0 & 0.478 & 2.3 & 0.61 & 2509 & 99 & 2523 & 64 & 2567 & 78 & 2567 & 78 & 98 \\
\hline 11LF13_27 & 272 & 1.3 & 0.172 & 0.750 & 0.3 & 12.17 & 77.0 & 0.515 & 2.3 & 0.76 & 2678 & 97 & 2618 & 59 & 2572 & 73 & 2572 & 73 & 104 \\
\hline 11LF13_16 & 111 & 2.0 & 0.175 & 0.780 & 0.3 & 12.59 & 81.0 & 0.526 & 2.4 & 0.72 & 2720 & 100 & 2647 & 60 & 2602 & 73 & 2602 & 73 & 105 \\
\hline 11LF13_66 & 41 & 1.9 & 0.178 & 0.840 & 0.2 & 11.60 & 78.0 & 0.484 & 2.3 & 0.63 & 2544 & 98 & 2559 & 63 & 2627 & 78 & 2627 & 78 & 97 \\
\hline 11LF13_18 & 47 & 1.0 & 0.179 & 0.840 & 0.3 & 12.52 & 83.0 & 0.509 & 2.4 & 0.65 & 2660 & 100 & 2641 & 63 & 2638 & 78 & 2638 & 78 & 101 \\
\hline 11LF13_12 & 58 & 2.0 & 0.178 & 0.900 & 0.3 & 11.99 & 85.0 & 0.490 & 2.7 & 0.67 & 2560 & 120 & 2597 & 67 & 2639 & 82 & 2639 & 82 & 97 \\
\hline 11LF13_26 & 318 & 5.7 & 0.179 & 0.780 & 0.3 & 12.82 & 81.0 & 0.517 & 2.3 & 0.76 & 2690 & 99 & 2666 & 59 & 2644 & 73 & 2644 & 73 & 102 \\
\hline 11LF13_69 & 159 & 1.3 & 0.180 & 0.800 & 0.3 & 11.53 & 73.0 & 0.478 & 2.1 & 0.67 & 2518 & 93 & 2573 & 61 & 2645 & 74 & 2645 & 74 & 95 \\
\hline 11LF13_48 & 176 & 3.7 & 0.184 & 0.810 & 0.3 & 12.63 & 80.0 & 0.510 & 2.3 & 0.73 & 2657 & 95 & 2657 & 59 & 2682 & 72 & 2682 & 72 & 99 \\
\hline 11LF13_60 & 61 & 1.6 & 0.184 & 0.840 & 0.2 & 12.96 & 85.0 & 0.522 & 2.4 & 0.73 & 2710 & 100 & 2672 & 61 & 2684 & 77 & 2684 & 77 & 101 \\
\hline 11LF13_71 & 83 & 1.9 & 0.185 & 0.840 & 0.3 & 13.15 & 85.0 & 0.522 & 2.4 & 0.66 & 2710 & 100 & 2686 & 60 & 2707 & 75 & 2707 & 75 & 100 \\
\hline 11LF13_30 & 54 & 1.3 & 0.188 & 0.870 & 0.3 & 13.94 & 91.0 & 0.536 & 2.5 & 0.67 & 2770 & 100 & 2747 & 60 & 2723 & 78 & 2723 & 78 & 102 \\
\hline 11LF13_80 & 111 & 1.9 & 0.189 & 0.840 & 0.3 & 13.48 & 86.0 & 0.527 & 2.4 & 0.71 & 2726 & 99 & 2715 & 59 & 2736 & 72 & 2736 & 72 & 100 \\
\hline 11LF13_42 & 114 & 0.8 & 0.198 & 0.880 & 0.2 & 15.33 & 98.0 & 0.569 & 2.6 & 0.73 & 2900 & 110 & 2833 & 60 & 2807 & 71 & 2807 & 71 & 103 \\
\hline 11LF13_32 & 62 & 1.1 & 0.211 & 0.960 & 0.2 & 17.00 & 110.0 & 0.582 & 2.7 & 0.70 & 2960 & 110 & 2928 & 61 & 2909 & 73 & 2909 & 73 & 102 \\
\hline \multicolumn{20}{|c|}{$>20 \%$ Discordance } \\
\hline 11LF13_96 & 519 & 1.3 & 0.123 & 0.540 & 0.2 & 4.48 & 29.0 & 0.274 & 1.3 & 0.86 & 1557 & 66 & 1725 & 55 & 2000 & 76 & 2000 & 76 & 78 \\
\hline \multicolumn{20}{|c|}{$>5 \%$ Reverse Discordance } \\
\hline 11LF13_82 & 42 & 3613.8 & 0.109 & 0.560 & 0.1 & 5.84 & 42.0 & 0.396 & 2.0 & 0.66 & 2147 & 90 & 1939 & 61 & 1762 & 95 & 1762 & 95 & 122 \\
\hline 11LF13_87 & 142 & 1.5 & 0.110 & 0.500 & 0.3 & 5.11 & 33.0 & 0.342 & 1.6 & 0.58 & 1893 & 74 & 1833 & 55 & 1799 & 82 & 1799 & 82 & 105 \\
\hline 11LF13_14 & 217 & 1.9 & 0.112 & 0.500 & 0.2 & 5.38 & 34.0 & 0.352 & 1.6 & 0.61 & 1943 & 73 & 1883 & 56 & 1822 & 79 & 1822 & 79 & 107 \\
\hline
\end{tabular}


TABLE SM2.3: LA-ICPMS U-PB ISOTOPIC DATA (UC SANTA CRUZ LAB)

\begin{tabular}{|c|c|c|c|c|c|c|c|c|c|c|c|c|c|c|c|c|c|c|c|}
\hline \multirow[b]{2}{*}{ Analysis } & \multirow[b]{2}{*}{$\mathrm{U}$} & \multirow[b]{2}{*}{ U/Th } & \multirow[b]{2}{*}{$206 \mathrm{~Pb}^{*}$} & \multirow[b]{2}{*}{ \pm} & \multirow[b]{2}{*}{ error } & \multicolumn{5}{|c|}{ Isotope ratios } & \multicolumn{6}{|c|}{ Apparent ages (Ma) } & \multirow[b]{2}{*}{ Best age } & \multirow[b]{2}{*}{ \pm} & \multirow[b]{2}{*}{ Cono } \\
\hline & & & & & & $207 \mathrm{~Pb}^{*}$ & \pm & $206 \mathrm{~Pb}^{*}$ & \pm & error & $206 \mathrm{~Pb}^{*}$ & \pm & 207Pb* & \pm & $206 \mathrm{~Pb}^{*}$ & \pm & & & \\
\hline & (ppm) & & $207 \mathrm{~Pb}^{\star}$ & (\%) & corr. & $235 U^{*}$ & (\%) & $238 U$ & (\%) & corr. & $238 U^{*}$ & (Ma) & $235 \mathrm{U}$ & (Ma) & $207 \mathrm{~Pb}^{*}$ & (Ma) & (Ma) & (Ma) & (\%) \\
\hline 11LF13_44 & 131 & 5.3 & 0.111 & 0.510 & 0.2 & 5.37 & 35.0 & 0.350 & 1.6 & 0.57 & 1932 & 74 & 1877 & 55 & 1824 & 81 & 1824 & 81 & 106 \\
\hline 11LF13_38 & 50 & 0.8 & 0.113 & 0.600 & 0.2 & 5.60 & 40.0 & 0.357 & 1.8 & 0.58 & 1960 & 84 & 1909 & 61 & 1851 & 94 & 1851 & 94 & 106 \\
\hline 11LF13_20 & 28 & 1.8 & 0.136 & 0.730 & 0.2 & 8.57 & 64.0 & 0.459 & 2.4 & 0.58 & 2430 & 110 & 2274 & 69 & 2153 & 97 & 2153 & 97 & 113 \\
\hline 11LF13_39 & 85 & 2.1 & 0.169 & 0.760 & 0.3 & 12.11 & 79.0 & 0.517 & 2.3 & 0.65 & 2686 & 99 & 2612 & 61 & 2548 & 77 & 2548 & 77 & 105 \\
\hline 11LF13_40 & 44 & 2.2 & 0.174 & 0.830 & 0.2 & 14.67 & 98.0 & 0.613 & 2.9 & 0.59 & 3070 & 120 & 2788 & 62 & 2583 & 79 & 2583 & 79 & 119 \\
\hline \multicolumn{20}{|c|}{ 28LF13; Neruokpuk Formation (N69.36, W142.8) } \\
\hline 28LF13_72 & 613 & 2.4 & 0.102 & 0.470 & 0.0 & 3.37 & 24.0 & 0.243 & 1.3 & 0.85 & 1399 & 65 & 1498 & 57 & 1653 & 85 & 1653 & 85 & 85 \\
\hline 28LF13_1 & 45 & 1.3 & 0.110 & 0.580 & 0.2 & 4.96 & 37.0 & 0.328 & 1.7 & 0.47 & 1828 & 82 & 1803 & 63 & 1793 & 99 & 1793 & 99 & 102 \\
\hline 28LF13_7 & 147 & 1.5 & 0.111 & 0.530 & 0.3 & 5.07 & 35.0 & 0.335 & 1.7 & 0.48 & 1865 & 79 & 1833 & 59 & 1808 & 87 & 1808 & 87 & 103 \\
\hline 28LF13_33 & 513 & 1.5 & 0.111 & 0.520 & -0.3 & 4.33 & 37.0 & 0.289 & 2.0 & 0.96 & 1610 & 100 & 1657 & 74 & 1820 & 85 & 1820 & 85 & 88 \\
\hline 28LF13_10 & 56 & 1.3 & 0.115 & 0.570 & 0.3 & 5.37 & 39.0 & 0.339 & 1.8 & 0.59 & 1883 & 86 & 1878 & 60 & 1873 & 88 & 1873 & 88 & 101 \\
\hline 28LF13_4 & 73 & 0.6 & 0.114 & 0.570 & 0.2 & 5.13 & 37.0 & 0.329 & 1.7 & 0.50 & 1830 & 80 & 1841 & 61 & 1877 & 89 & 1877 & 89 & 97 \\
\hline 28LF13_9 & 72 & 1.3 & 0.115 & 0.570 & 0.3 & 5.50 & 39.0 & 0.347 & 1.8 & 0.51 & 1918 & 84 & 1893 & 60 & 1880 & 90 & 1880 & 90 & 102 \\
\hline 28LF13_95 & 285 & 3.4 & 0.115 & 0.530 & 0.2 & 5.59 & 39.0 & 0.353 & 1.8 & 0.76 & 1944 & 86 & 1916 & 59 & 1883 & 86 & 1883 & 86 & 103 \\
\hline 28LF13_39 & 321 & 3.1 & 0.116 & 0.570 & 0.7 & 4.98 & 35.0 & 0.310 & 1.7 & 0.53 & 1746 & 80 & 1813 & 60 & 1884 & 88 & 1884 & 88 & 93 \\
\hline 28LF13_61 & 518 & 3.3 & 0.116 & 0.530 & 0.0 & 4.36 & 31.0 & 0.275 & 1.4 & 0.85 & 1570 & 72 & 1704 & 57 & 1891 & 82 & 1891 & 82 & 83 \\
\hline 28LF13_29 & 50 & 1.1 & 0.115 & 0.610 & 0.3 & 5.53 & 40.0 & 0.356 & 1.8 & 0.36 & 1964 & 86 & 1895 & 63 & 1892 & 94 & 1892 & 94 & 104 \\
\hline 28LF13_6 & 60 & 0.5 & 0.115 & 0.580 & 0.2 & 5.51 & 40.0 & 0.347 & 1.8 & 0.54 & 1922 & 85 & 1903 & 64 & 1895 & 91 & 1895 & 91 & 101 \\
\hline 28LF13_2 & 87 & 1.6 & 0.117 & 0.580 & 0.4 & 5.54 & 39.0 & 0.344 & 1.7 & 0.41 & 1903 & 83 & 1903 & 61 & 1902 & 88 & 1902 & 88 & 100 \\
\hline 28LF13_18 & 31 & 3.2 & 0.118 & 0.630 & 0.3 & 5.75 & 43.0 & 0.366 & 2.0 & 0.46 & 2008 & 94 & 1938 & 68 & 1923 & 97 & 1923 & 97 & 104 \\
\hline 28LF13_19 & 202 & 2.4 & 0.120 & 0.560 & 0.2 & 5.99 & 41.0 & 0.372 & 1.8 & 0.60 & 2036 & 86 & 1976 & 61 & 1951 & 83 & 1951 & 83 & 104 \\
\hline 28LF13_16 & 38 & 2.0 & 0.121 & 0.640 & 0.3 & 6.23 & 46.0 & 0.373 & 1.9 & 0.41 & 2040 & 91 & 2010 & 65 & 1956 & 93 & 1956 & 93 & 104 \\
\hline 28LF13_64 & 23 & 2.3 & 0.123 & 0.770 & 0.2 & 5.25 & 43.0 & 0.316 & 1.8 & 0.50 & 1763 & 86 & 1861 & 73 & 1980 & 120 & 1980 & 120 & 89 \\
\hline 28LF13_8 & 81 & 1.2 & 0.126 & 0.610 & 0.3 & 6.58 & 47.0 & 0.379 & 1.9 & 0.55 & 2071 & 90 & 2054 & 63 & 2042 & 88 & 2042 & 88 & 101 \\
\hline 28LF13_65 & 287 & 1.9 & 0.127 & 0.590 & -0.2 & 6.76 & 49.0 & 0.389 & 2.1 & 0.91 & 2117 & 98 & 2076 & 65 & 2057 & 80 & 2057 & 80 & 103 \\
\hline 28LF13_14 & 42 & 0.5 & 0.144 & 0.750 & 0.1 & 8.54 & 63.0 & 0.434 & 2.2 & 0.52 & 2320 & 100 & 2293 & 68 & 2268 & 90 & 2268 & 90 & 102 \\
\hline 28LF13_12 & 124 & 1.7 & 0.146 & 0.680 & 0.3 & 8.85 & 62.0 & 0.442 & 2.2 & 0.66 & 2358 & 98 & 2322 & 64 & 2296 & 79 & 2296 & 79 & 103 \\
\hline
\end{tabular}


TABLE SM2.3: LA-ICPMS U-PB ISOTOPIC DATA (UC SANTA CRUZ LAB)

\begin{tabular}{|c|c|c|c|c|c|c|c|c|c|c|c|c|c|c|c|c|c|c|c|}
\hline \multirow[b]{2}{*}{ Analysis } & \multirow[b]{2}{*}{$U$} & \multirow[b]{2}{*}{$\mathrm{U} / \mathrm{Th}$} & \multirow[b]{2}{*}{$206 \mathrm{~Pb}^{*}$} & \multirow[b]{2}{*}{ \pm} & \multirow[b]{2}{*}{ error } & \multicolumn{5}{|c|}{ Isotope ratios } & \multicolumn{6}{|c|}{ Apparent ages (Ma) } & \multirow[b]{2}{*}{ Best age } & \multirow[b]{2}{*}{ \pm} & \multirow[b]{2}{*}{ Conc } \\
\hline & & & & & & $207 \mathrm{~Pb}^{*}$ & \pm & $206 \mathrm{~Pb}^{*}$ & \pm & error & $206 \mathrm{~Pb}^{*}$ & \pm & 207Pb* & \pm & $206 \mathrm{~Pb}^{*}$ & \pm & & & \\
\hline & (ppm) & & $207 \mathrm{~Pb}^{*}$ & $(\%)$ & corr. & $235 U^{*}$ & $(\%)$ & $238 U$ & (\%) & corr. & $238 U^{*}$ & (Ma) & $235 \mathrm{U}$ & (Ma) & $207 \mathrm{~Pb}^{*}$ & (Ma) & (Ma) & (Ma) & $(\%)$ \\
\hline 28LF13_17 & 425 & 2.6 & 0.147 & 0.690 & 0.3 & 7.78 & 54.0 & 0.380 & 1.9 & 0.67 & 2080 & 87 & 2203 & 63 & 2315 & 80 & 2315 & 80 & 90 \\
\hline 28LF13_76 & 136 & 2.1 & 0.152 & 0.730 & -0.2 & 9.28 & 69.0 & 0.448 & 2.3 & 0.83 & 2390 & 100 & 2358 & 69 & 2362 & 83 & 2362 & 83 & 101 \\
\hline 28LF13_82 & 154 & 2.0 & 0.169 & 0.780 & 0.2 & 11.77 & 82.0 & 0.510 & 2.6 & 0.76 & 2660 & 110 & 2587 & 65 & 2546 & 78 & 2546 & 78 & 104 \\
\hline 28LF13_60 & 180 & 1.2 & 0.171 & 0.790 & 0.2 & 11.81 & 82.0 & 0.506 & 2.5 & 0.71 & 2640 & 110 & 2590 & 65 & 2570 & 77 & 2570 & 77 & 103 \\
\hline 28LF13_56 & 105 & 0.7 & 0.173 & 0.810 & 0.2 & 11.87 & 85.0 & 0.506 & 2.7 & 0.79 & 2640 & 110 & 2592 & 67 & 2574 & 80 & 2574 & 80 & 103 \\
\hline 28LF13_13 & 125 & 1.2 & 0.196 & 0.920 & 0.1 & 11.24 & 79.0 & 0.414 & 2.1 & 0.82 & 2233 & 99 & 2542 & 65 & 2792 & 75 & 2792 & 75 & 80 \\
\hline \multicolumn{20}{|c|}{$>20 \%$ Discordance } \\
\hline 28LF13_3 & 2617 & 1.0 & 0.251 & 1.200 & 0.3 & 2.39 & 16.0 & 0.070 & 0.3 & 0.53 & 436 & 21 & 1239 & 49 & 3194 & 72 & 436 & 21 & NA \\
\hline 28LF13_51 & 747 & 0.6 & 0.100 & 0.460 & 0.1 & 1.59 & 11.0 & 0.118 & 0.6 & 0.79 & 715 & 34 & 963 & 43 & 1627 & 82 & 715 & 34 & 44 \\
\hline 12JT11_103 & 187 & 1.3 & 0.124 & 0.570 & 0.3 & 4.75 & 31.0 & 0.282 & 1.3 & 0.46 & 1601 & 63 & 1774 & 54 & 2006 & 80 & 2006 & 80 & 80 \\
\hline 28LF13_69 & 489 & 0.8 & 0.145 & 0.660 & 0.0 & 5.43 & 37.0 & 0.275 & 1.4 & 0.74 & 1566 & 68 & 1888 & 59 & 2281 & 79 & 2281 & 79 & 69 \\
\hline 28LF13_78 & 59 & 1.0 & 0.213 & 1.900 & -0.7 & 10.40 & 140.0 & 0.317 & 1.8 & 0.91 & 1767 & 86 & 2272 & 96 & 2720 & 130 & 2720 & 130 & 65 \\
\hline \multicolumn{20}{|c|}{$>5 \%$ Reverse Discordance } \\
\hline 28LF13_5 & 112 & 3.2 & 0.075 & 0.400 & 0.2 & 1.89 & 14.0 & 0.185 & 0.9 & 0.37 & 1092 & 51 & 1073 & 50 & 1030 & 110 & 1030 & 110 & 106 \\
\hline 28LF13_26 & 192 & 1.9 & 0.083 & 0.400 & 0.2 & 2.64 & 19.0 & 0.236 & 1.2 & 0.47 & 1365 & 61 & 1313 & 52 & 1251 & 97 & 1251 & 97 & 109 \\
\hline 28LF13_55 & 57 & 4.0 & 0.089 & 0.470 & 0.0 & 3.21 & 24.0 & 0.262 & 1.4 & 0.61 & 1498 & 73 & 1446 & 60 & 1380 & 110 & 1380 & 110 & 109 \\
\hline 28LF13_31 & 231 & 3.3 & 0.105 & 0.490 & 0.2 & 4.98 & 35.0 & 0.350 & 1.7 & 0.65 & 1934 & 83 & 1815 & 59 & 1710 & 88 & 1710 & 88 & 113 \\
\hline 28LF13_38 & 121 & 2.3 & 0.106 & 0.520 & 0.1 & 4.99 & 36.0 & 0.351 & 1.8 & 0.52 & 1943 & 85 & 1814 & 60 & 1716 & 90 & 1716 & 90 & 113 \\
\hline 28LF13_66 & 13 & 1514.4 & 0.110 & 0.730 & 0.2 & 6.40 & 55.0 & 0.428 & 2.6 & 0.55 & 2290 & 120 & 2009 & 73 & 1760 & 120 & 1760 & 120 & 130 \\
\hline 28LF13_94 & 17 & 2417.3 & 0.110 & 0.650 & 0.2 & 5.96 & 49.0 & 0.393 & 2.3 & 0.63 & 2120 & 110 & 1962 & 72 & 1770 & 110 & 1770 & 110 & 120 \\
\hline 28LF13_20 & 19 & 3454.9 & 0.110 & 0.670 & 0.2 & 6.02 & 49.0 & 0.395 & 2.3 & 0.53 & 2150 & 100 & 1952 & 69 & 1770 & 110 & 1770 & 110 & 121 \\
\hline 28LF13_92 & 17 & 5206.0 & 0.112 & 0.700 & 0.2 & 6.24 & 53.0 & 0.407 & 2.4 & 0.57 & 2190 & 110 & 1981 & 73 & 1790 & 120 & 1790 & 120 & 122 \\
\hline 28LF13_25 & 91 & 1.0 & 0.110 & 0.540 & 0.1 & 5.53 & 40.0 & 0.369 & 1.9 & 0.63 & 2021 & 88 & 1898 & 62 & 1795 & 87 & 1795 & 87 & 113 \\
\hline 28LF13_86 & 43 & 1.2 & 0.110 & 0.580 & 0.3 & 5.66 & 41.0 & 0.376 & 2.0 & 0.45 & 2052 & 93 & 1928 & 63 & 1797 & 96 & 1797 & 96 & 114 \\
\hline 28LF13_67 & 104 & 1.1 & 0.110 & 0.530 & 0.1 & 5.80 & 41.0 & 0.383 & 1.9 & 0.62 & 2089 & 90 & 1941 & 61 & 1799 & 90 & 1799 & 90 & 116 \\
\hline 28LF13_90 & 274 & 1.6 & 0.110 & 0.510 & 0.0 & 5.27 & 38.0 & 0.351 & 1.9 & 0.87 & 1935 & 90 & 1870 & 63 & 1802 & 82 & 1802 & 82 & 107 \\
\hline
\end{tabular}


TABLE SM2.3: LA-ICPMS U-PB ISOTOPIC DATA (UC SANTA CRUZ LAB)

\begin{tabular}{|c|c|c|c|c|c|c|c|c|c|c|c|c|c|c|c|c|c|c|c|}
\hline \multirow[b]{2}{*}{ Analysis } & \multirow[b]{2}{*}{$U$} & \multirow[b]{2}{*}{$\mathrm{U} / \mathrm{Th}$} & \multirow[b]{2}{*}{$206 \mathrm{~Pb}^{*}$} & \multirow[b]{2}{*}{ \pm} & \multirow[b]{2}{*}{ error } & \multirow[b]{2}{*}{ 207Pb* } & \multicolumn{3}{|c|}{ Isotope ratios } & \multirow[b]{2}{*}{ error } & \multirow[b]{2}{*}{$206 \mathrm{~Pb}^{*}$} & \multicolumn{4}{|c|}{ Apparent ages (Ma) } & \multirow[b]{2}{*}{ \pm} & \multirow[b]{2}{*}{ Best age } & \multirow[b]{2}{*}{ \pm} & \multirow[b]{2}{*}{ Conc } \\
\hline & & & & & & & \pm & $206 \mathrm{~Pb}^{\star}$ & \pm & & & \pm & $207 \mathrm{~Pb}^{*}$ & \pm & $206 \mathrm{~Pb}^{*}$ & & & & \\
\hline & (ppm) & & $207 \mathrm{~Pb}^{*}$ & $(\%)$ & corr. & $235 U^{*}$ & (\%) & $238 U$ & $(\%)$ & corr. & $238 U^{*}$ & (Ma) & $235 \mathrm{U}$ & $(\mathrm{Ma})$ & $207 \mathrm{~Pb}^{*}$ & (Ma) & (Ma) & (Ma) & $(\%)$ \\
\hline 28LF13_75 & 94 & 1.6 & 0.111 & 0.540 & 0.2 & 5.70 & 40.0 & 0.378 & 1.9 & 0.51 & 2065 & 91 & 1926 & 61 & 1803 & 89 & 1803 & 89 & 115 \\
\hline 28LF13_15 & 38 & 0.9 & 0.110 & 0.600 & 0.3 & 5.20 & 39.0 & 0.348 & 1.9 & 0.47 & 1920 & 89 & 1844 & 65 & 1810 & 100 & 1810 & 100 & 106 \\
\hline 28LF13_11 & 95 & 98.7 & 0.111 & 0.530 & 0.2 & 6.28 & 45.0 & 0.410 & 2.1 & 0.68 & 2208 & 96 & 2010 & 63 & 1813 & 88 & 1813 & 88 & 122 \\
\hline 28LF13_93 & 81 & 9219.9 & 0.112 & 0.550 & 0.3 & 6.10 & 44.0 & 0.402 & 2.1 & 0.63 & 2176 & 94 & 1983 & 63 & 1826 & 87 & 1826 & 87 & 119 \\
\hline 28LF13_57 & 55 & 1.2 & 0.113 & 0.570 & 0.1 & 5.85 & 43.0 & 0.378 & 2.0 & 0.58 & 2062 & 91 & 1953 & 63 & 1839 & 91 & 1839 & 91 & 112 \\
\hline 28LF13_50 & 244 & 0.9 & 0.113 & 0.530 & 0.3 & 5.77 & 40.0 & 0.377 & 1.9 & 0.57 & 2067 & 90 & 1940 & 60 & 1840 & 85 & 1840 & 85 & 112 \\
\hline 28LF13_74 & 10 & 0.2 & 0.116 & 0.830 & 0.2 & 6.19 & 56.0 & 0.397 & 2.4 & 0.52 & 2140 & 110 & 1964 & 78 & 1840 & 130 & 1840 & 130 & 116 \\
\hline 28LF13_28 & 60 & 1.3 & 0.112 & 0.550 & 0.2 & 5.36 & 39.0 & 0.351 & 1.8 & 0.57 & 1937 & 86 & 1877 & 60 & 1842 & 93 & 1842 & 93 & 105 \\
\hline 28LF13_84 & 38 & 1.4 & 0.113 & 0.600 & 0.3 & 5.89 & 44.0 & 0.378 & 2.0 & 0.52 & 2063 & 94 & 1954 & 66 & 1844 & 95 & 1844 & 95 & 112 \\
\hline 28LF13_27 & 41 & 0.6 & 0.114 & 0.600 & 0.2 & 5.85 & 44.0 & 0.382 & 2.0 & 0.52 & 2093 & 95 & 1953 & 62 & 1844 & 93 & 1844 & 93 & 114 \\
\hline 28LF13_52 & 101 & 1.5 & 0.113 & 0.550 & 0.2 & 5.55 & 39.0 & 0.359 & 1.8 & 0.59 & 1978 & 88 & 1902 & 62 & 1846 & 90 & 1846 & 90 & 107 \\
\hline 28LF13_48 & 52 & 1.5 & 0.114 & 0.580 & 0.2 & 5.61 & 41.0 & 0.365 & 1.9 & 0.55 & 2003 & 89 & 1913 & 62 & 1849 & 91 & 1849 & 91 & 108 \\
\hline 28LF13_77 & 22 & 7.1 & 0.113 & 0.650 & 0.2 & 6.53 & 52.0 & 0.425 & 2.4 & 0.46 & 2290 & 110 & 2046 & 73 & 1850 & 110 & 1850 & 110 & 124 \\
\hline 28LF13_96 & 38 & 0.9 & 0.115 & 0.620 & 0.2 & 5.84 & 44.0 & 0.372 & 2.0 & 0.61 & 2028 & 95 & 1942 & 65 & 1852 & 99 & 1852 & 99 & 110 \\
\hline 28LF13_47 & 72 & 1.4 & 0.114 & 0.570 & 0.2 & 5.78 & 42.0 & 0.374 & 2.0 & 0.63 & 2046 & 92 & 1938 & 64 & 1868 & 91 & 1868 & 91 & 110 \\
\hline 28LF13_45 & 47 & 2.3 & 0.115 & 0.590 & 0.2 & 5.88 & 43.0 & 0.373 & 2.0 & 0.50 & 2047 & 91 & 1950 & 64 & 1876 & 94 & 1876 & 94 & 109 \\
\hline 28LF13_35 & 116 & 1.3 & 0.116 & 0.550 & 0.1 & 5.66 & 40.0 & 0.363 & 1.8 & 0.58 & 1998 & 86 & 1925 & 61 & 1885 & 88 & 1885 & 88 & 106 \\
\hline 28LF13_68 & 139 & 1.9 & 0.116 & 0.540 & 0.0 & 5.87 & 43.0 & 0.372 & 2.0 & 0.82 & 2043 & 91 & 1961 & 63 & 1888 & 85 & 1888 & 85 & 108 \\
\hline 28LF13_99 & 83 & 1.4 & 0.116 & 0.570 & 0.1 & 5.95 & 43.0 & 0.372 & 1.9 & 0.55 & 2039 & 89 & 1965 & 61 & 1892 & 90 & 1892 & 90 & 108 \\
\hline 28LF13_58 & 68 & 2.9 & 0.116 & 0.570 & 0.2 & 5.97 & 43.0 & 0.380 & 1.9 & 0.59 & 2073 & 91 & 1977 & 62 & 1892 & 85 & 1892 & 85 & 110 \\
\hline 28LF13_81 & 47 & 0.9 & 0.118 & 0.600 & 0.3 & 6.22 & 45.0 & 0.390 & 2.1 & 0.55 & 2120 & 96 & 2005 & 64 & 1894 & 95 & 1894 & 95 & 112 \\
\hline 28LF13_98 & 151 & 1.3 & 0.116 & 0.540 & 0.2 & 6.15 & 43.0 & 0.386 & 2.0 & 0.71 & 2102 & 92 & 1995 & 60 & 1899 & 83 & 1899 & 83 & 111 \\
\hline 28LF13_62 & 179 & 1.4 & 0.117 & 0.550 & 0.2 & 6.00 & 42.0 & 0.377 & 1.9 & 0.59 & 2059 & 88 & 1973 & 59 & 1909 & 84 & 1909 & 84 & 108 \\
\hline 28LF13_97 & 69 & 2.0 & 0.117 & 0.580 & 0.2 & 6.09 & 44.0 & 0.378 & 1.9 & 0.59 & 2068 & 91 & 1980 & 61 & 1909 & 91 & 1909 & 91 & 108 \\
\hline 28LF13_63 & 38 & 0.9 & 0.118 & 0.640 & 0.2 & 5.94 & 44.0 & 0.371 & 2.0 & 0.52 & 2033 & 92 & 1962 & 68 & 1919 & 97 & 1919 & 97 & 106 \\
\hline 28LF13_43 & 96 & 1.2 & 0.117 & 0.570 & 0.2 & 6.24 & 45.0 & 0.398 & 2.1 & 0.61 & 2156 & 95 & 2010 & 63 & 1919 & 87 & 1919 & 87 & 112 \\
\hline 28LF13_23 & 112 & 2.0 & 0.117 & 0.560 & 0.1 & 5.92 & 42.0 & 0.370 & 1.8 & 0.62 & 2038 & 88 & 1966 & 62 & 1920 & 82 & 1920 & 82 & 106 \\
\hline 28LF13 34 & 93 & 0.7 & 0.120 & 0.580 & 0.2 & 6.40 & 46.0 & 0.389 & 2.0 & 0.57 & 2117 & 91 & 2036 & 61 & 1951 & 89 & 1951 & 89 & 109 \\
\hline
\end{tabular}


TABLE SM2.3: LA-ICPMS U-PB ISOTOPIC DATA (UC SANTA CRUZ LAB)

\begin{tabular}{|c|c|c|c|c|c|c|c|c|c|c|c|c|c|c|c|c|c|c|c|}
\hline \multirow[b]{2}{*}{ Analysis } & \multirow[b]{2}{*}{$\mathrm{U}$} & \multirow[b]{2}{*}{$\mathrm{U} / \mathrm{Th}$} & \multirow[b]{2}{*}{$206 \mathrm{~Pb}^{*}$} & \multirow[b]{2}{*}{ \pm} & \multirow[b]{2}{*}{ error } & \multicolumn{5}{|c|}{ Isotope ratios } & \multicolumn{6}{|c|}{ Apparent ages (Ma) } & \multirow[b]{2}{*}{ Best age } & \multirow[b]{2}{*}{ \pm} & \multirow[b]{2}{*}{ Conc } \\
\hline & & & & & & $207 \mathrm{~Pb}^{\star}$ & \pm & $206 \mathrm{~Pb}^{\star}$ & \pm & error & $206 \mathrm{~Pb}^{\star}$ & \pm & $207 \mathrm{~Pb}^{\star}$ & \pm & $206 \mathrm{~Pb}^{*}$ & \pm & & & \\
\hline & $(\mathrm{ppm})$ & & $207 \mathrm{~Pb}^{\star}$ & (\%) & corr. & $235 U^{*}$ & (\%) & $238 U$ & (\%) & corr. & $238 U^{*}$ & (Ma) & $235 \mathrm{U}$ & (Ma) & $207 \mathrm{~Pb}^{\star}$ & (Ma) & (Ma) & (Ma) & $(\%)$ \\
\hline 28LF13_59 & 68 & 1.4 & 0.122 & 0.600 & 0.2 & 6.55 & 47.0 & 0.398 & 2.0 & 0.48 & 2155 & 93 & 2048 & 62 & 1963 & 89 & 1963 & 89 & 110 \\
\hline 28LF13_89 & 45 & 12.9 & 0.123 & 0.630 & 0.1 & 6.45 & 49.0 & 0.385 & 2.1 & 0.68 & 2096 & 98 & 2041 & 67 & 1969 & 95 & 1969 & 95 & 106 \\
\hline 28LF13_83 & 76 & 2.2 & 0.122 & 0.590 & 0.1 & 6.71 & 48.0 & 0.403 & 2.1 & 0.69 & 2179 & 95 & 2070 & 62 & 1975 & 88 & 1975 & 88 & 110 \\
\hline 28LF13_37 & 31 & 0.7 & 0.125 & 0.670 & 0.3 & 7.08 & 53.0 & 0.429 & 2.3 & 0.44 & 2300 & 100 & 2123 & 67 & 2022 & 96 & 2022 & 96 & 114 \\
\hline 28LF13_71 & 45 & 0.8 & 0.130 & 0.660 & 0.3 & 7.75 & 57.0 & 0.438 & 2.3 & 0.57 & 2340 & 100 & 2194 & 67 & 2088 & 89 & 2088 & 89 & 112 \\
\hline 28LF13_22 & 75 & 2.2 & 0.130 & 0.640 & 0.1 & 7.32 & 53.0 & 0.409 & 2.1 & 0.63 & 2215 & 98 & 2142 & 65 & 2096 & 86 & 2096 & 86 & 106 \\
\hline 28LF13_91 & 66 & 1.8 & 0.139 & 0.670 & 0.2 & 8.34 & 60.0 & 0.439 & 2.3 & 0.63 & 2340 & 100 & 2268 & 63 & 2198 & 85 & 2198 & 85 & 106 \\
\hline 28LF13_21 & 133 & 3.1 & 0.143 & 0.670 & 0.2 & 8.73 & 61.0 & 0.451 & 2.3 & 0.68 & 2400 & 100 & 2308 & 63 & 2263 & 81 & 2263 & 81 & 106 \\
\hline 28LF13_100 & 94 & 2.4 & 0.146 & 0.710 & 0.1 & 10.20 & 73.0 & 0.512 & 2.7 & 0.68 & 2660 & 120 & 2454 & 68 & 2299 & 82 & 2299 & 82 & 116 \\
\hline 28LF13_49 & 120 & 1.6 & 0.149 & 0.690 & 0.0 & 10.11 & 71.0 & 0.502 & 2.5 & 0.80 & 2630 & 110 & 2445 & 63 & 2337 & 81 & 2337 & 81 & 113 \\
\hline 28LF13_79 & 96 & 1.6 & 0.149 & 0.710 & 0.2 & 10.47 & 75.0 & 0.509 & 2.6 & 0.72 & 2660 & 110 & 2472 & 65 & 2337 & 78 & 2337 & 78 & 114 \\
\hline 28LF13_54 & 27 & 1.7 & 0.151 & 0.780 & 0.1 & 9.90 & 75.0 & 0.482 & 2.6 & 0.64 & 2530 & 110 & 2414 & 69 & 2346 & 88 & 2346 & 88 & 108 \\
\hline 28LF13_80 & 68 & 2.2 & 0.151 & 0.720 & 0.1 & 10.01 & 71.0 & 0.490 & 2.5 & 0.65 & 2570 & 110 & 2434 & 64 & 2352 & 81 & 2352 & 81 & 109 \\
\hline 28LF13_73 & 61 & 2.0 & 0.151 & 0.740 & 0.2 & 10.05 & 72.0 & 0.486 & 2.5 & 0.63 & 2550 & 110 & 2444 & 66 & 2359 & 83 & 2359 & 83 & 108 \\
\hline 28LF13_40 & 87 & 1.6 & 0.159 & 0.770 & 0.1 & 11.41 & 82.0 & 0.526 & 2.8 & 0.72 & 2720 & 110 & 2561 & 64 & 2445 & 80 & 2445 & 80 & 111 \\
\hline 28LF13_42 & 129 & 2.7 & 0.160 & 0.740 & 0.2 & 11.13 & 77.0 & 0.513 & 2.6 & 0.69 & 2670 & 110 & 2533 & 66 & 2458 & 79 & 2458 & 79 & 109 \\
\hline 28LF13_41 & 194 & 2.6 & 0.166 & 0.780 & 0.1 & 12.25 & 86.0 & 0.551 & 2.8 & 0.69 & 2840 & 120 & 2626 & 66 & 2509 & 79 & 2509 & 79 & 113 \\
\hline 28LF13_85 & 72 & 1.5 & 0.174 & 0.830 & 0.2 & 12.65 & 89.0 & 0.537 & 2.8 & 0.70 & 2780 & 120 & 2654 & 66 & 2587 & 79 & 2587 & 79 & 107 \\
\hline 28LF13_53 & 87 & 1.2 & 0.173 & 0.810 & 0.4 & 13.36 & 93.0 & 0.571 & 2.9 & 0.62 & 2910 & 120 & 2705 & 65 & 2587 & 78 & 2587 & 78 & 112 \\
\hline 28LF13_70 & 135 & 1.8 & 0.174 & 0.800 & 0.2 & 12.71 & 90.0 & 0.544 & 2.8 & 0.80 & 2800 & 120 & 2657 & 66 & 2593 & 78 & 2593 & 78 & 108 \\
\hline 28LF13_88 & 88 & 2.4 & 0.174 & 0.820 & 0.2 & 13.45 & 95.0 & 0.562 & 2.9 & 0.67 & 2870 & 120 & 2708 & 65 & 2597 & 79 & 2597 & 79 & 111 \\
\hline 28LF13_32 & 211 & 2.7 & 0.175 & 0.800 & 0.3 & 13.00 & 89.0 & 0.549 & 2.7 & 0.71 & 2830 & 110 & 2681 & 67 & 2600 & 77 & 2600 & 77 & 109 \\
\hline 28LF13_46 & 25 & 2.3 & 0.186 & 0.930 & 0.2 & 14.70 & 110.0 & 0.590 & 3.2 & 0.72 & 2980 & 130 & 2800 & 71 & 2688 & 85 & 2688 & 85 & 111 \\
\hline 28LF13_36 & 39 & 2.5 & 0.184 & 0.920 & 0.1 & 14.40 & 100.0 & 0.579 & 3.0 & 0.63 & 2940 & 120 & 2768 & 67 & 2690 & 82 & 2690 & 82 & 109 \\
\hline 28LF13_44 & 44 & 2.2 & 0.187 & 0.910 & 0.1 & 15.80 & 120.0 & 0.625 & 3.3 & 0.71 & 3130 & 130 & 2859 & 71 & 2712 & 82 & 2712 & 82 & 115 \\
\hline 28LF13_24 & 23 & 0.4 & 0.189 & 0.950 & 0.2 & 14.50 & 110.0 & 0.567 & 3.1 & 0.70 & 2890 & 120 & 2776 & 66 & 2738 & 82 & 2738 & 82 & 106 \\
\hline 28LF13_87 & 69 & 1.6 & 0.228 & 1.100 & 0.2 & 22.00 & 160.0 & 0.708 & 3.6 & 0.67 & 3450 & 130 & 3178 & 69 & 3034 & 76 & 3034 & 76 & 114 \\
\hline
\end{tabular}


TABLE SM2.3: LA-ICPMS U-PB ISOTOPIC DATA (UC SANTA CRUZ LAB)

\begin{tabular}{|c|c|c|c|c|c|c|c|c|c|c|c|c|c|c|c|c|c|c|c|}
\hline \multirow[b]{2}{*}{ Analysis } & \multirow[b]{2}{*}{$U$} & \multirow[b]{2}{*}{ U/Th } & \multirow[b]{2}{*}{$206 \mathrm{~Pb}^{*}$} & \multirow[b]{2}{*}{ \pm} & \multirow[b]{2}{*}{ error } & \multicolumn{5}{|c|}{ Isotope ratios } & \multicolumn{6}{|c|}{ Apparent ages (Ma) } & \multirow[b]{2}{*}{ Best age } & \multirow[b]{2}{*}{ \pm} & \multirow[b]{2}{*}{ Conc } \\
\hline & & & & & & $207 \mathrm{~Pb}^{*}$ & \pm & $206 \mathrm{~Pb}^{*}$ & \pm & error & $206 \mathrm{~Pb}^{*}$ & \pm & 207Pb* & \pm & $206 \mathrm{~Pb}^{*}$ & \pm & & & \\
\hline & (ppm) & & $207 \mathrm{~Pb}^{*}$ & (\%) & corr. & $235 U^{*}$ & $(\%)$ & $238 U$ & (\%) & corr. & $238 U^{*}$ & (Ma) & $235 \mathrm{U}$ & (Ma) & $207 \mathrm{~Pb}^{*}$ & (Ma) & (Ma) & (Ma) & $(\%)$ \\
\hline \multicolumn{6}{|c|}{$>1000$ U ppm } & & & & & & & & & & & & & & \\
\hline $\begin{array}{l}\text { 12JT11_7 } \\
\text { 12JT22; Cla }\end{array}$ & $\begin{array}{l}1375 \\
\text { nce Riv }\end{array}$ & $\begin{array}{l}3.5 \\
\text { Group }\end{array}$ & $\begin{array}{r}0.078 \\
\text { N69.28, }\end{array}$ & $\begin{array}{l}0.340 \\
1 \mathbf{1 4 1 . 7 3 )}\end{array}$ & 0.2 & 1.85 & 12.0 & 0.172 & 0.8 & 0.60 & 1024 & 41 & 1062 & 41 & 1152 & 87 & 1152 & 87 & 89 \\
\hline 12JT22_8 & 327 & 2.6 & 0.057 & 0.160 & 0.3 & 0.57 & 1.7 & 0.072 & 0.1 & 0.27 & 449 & 8 & 456 & 11 & 495 & 64 & 449 & 8 & NA \\
\hline 12JT22_64 & 227 & 1.5 & 0.056 & 0.160 & 0.3 & 0.57 & 1.8 & 0.075 & 0.1 & 0.23 & 467 & 9 & 460 & 12 & 424 & 66 & 467 & 9 & NA \\
\hline 12JT22_89 & 159 & 1.7 & 0.055 & 0.170 & 0.3 & 0.59 & 1.9 & 0.078 & 0.2 & 0.41 & 486 & 10 & 474 & 12 & 417 & 69 & 486 & 10 & NA \\
\hline 12JT22_13 & 543 & 3.1 & 0.068 & 0.190 & -0.2 & 1.27 & 4.5 & 0.133 & 0.3 & 0.91 & 807 & 19 & 831 & 20 & 876 & 57 & 807 & 19 & 92 \\
\hline 12JT22_65 & 331 & 2.8 & 0.071 & 0.200 & -0.4 & 1.38 & 6.4 & 0.139 & 0.5 & 0.97 & 836 & 29 & 870 & 27 & 969 & 56 & 836 & 29 & 86 \\
\hline 12JT22_82 & 371 & 4.8 & 0.071 & 0.190 & -0.2 & 1.42 & 4.4 & 0.145 & 0.3 & 0.89 & 874 & 18 & 895 & 19 & 947 & 54 & 874 & 18 & 92 \\
\hline 12JT22_68 & 286 & 1.6 & 0.071 & 0.200 & 0.3 & 1.59 & 4.6 & 0.162 & 0.3 & 0.46 & 966 & 17 & 967 & 18 & 964 & 54 & 966 & 17 & 100 \\
\hline 12JT22_12 & 101 & 2.1 & 0.074 & 0.240 & 0.3 & 1.71 & 6.3 & 0.166 & 0.5 & 0.69 & 987 & 27 & 1008 & 24 & 1045 & 66 & 987 & 27 & 94 \\
\hline 12JT22_57 & 569 & 14.0 & 0.072 & 0.190 & 0.2 & 1.64 & 4.7 & 0.166 & 0.3 & 0.76 & 988 & 18 & 986 & 18 & 976 & 54 & 988 & 18 & 101 \\
\hline 12JT22_91 & 190 & 1.4 & 0.072 & 0.200 & 0.2 & 1.63 & 4.9 & 0.166 & 0.3 & 0.63 & 992 & 19 & 984 & 19 & 976 & 57 & 992 & 19 & 102 \\
\hline 12JT22_95 & 701 & 0.6 & 0.071 & 0.190 & 0.3 & 1.64 & 4.6 & 0.168 & 0.3 & 0.54 & 1001 & 17 & 985 & 18 & 960 & 54 & 960 & 54 & 104 \\
\hline 12JT22_98 & 302 & 4.4 & 0.072 & 0.200 & -0.1 & 1.69 & 5.0 & 0.170 & 0.3 & 0.69 & 1013 & 18 & 1006 & 19 & 998 & 56 & 998 & 56 & 102 \\
\hline 12JT22_62 & 401 & 7.2 & 0.074 & 0.200 & -0.2 & 1.73 & 5.3 & 0.168 & 0.3 & 0.36 & 1002 & 18 & 1016 & 19 & 1029 & 55 & 1029 & 55 & 97 \\
\hline 12JT22_55 & 239 & 2.9 & 0.074 & 0.200 & 0.2 & 1.79 & 5.2 & 0.176 & 0.3 & 0.48 & 1046 & 18 & 1040 & 19 & 1031 & 56 & 1031 & 56 & 101 \\
\hline 12JT22_10 & 330 & 5.1 & 0.074 & 0.200 & 0.0 & 1.76 & 5.2 & 0.171 & 0.3 & 0.79 & 1015 & 19 & 1028 & 20 & 1038 & 55 & 1038 & 55 & 98 \\
\hline 12JT22_37 & 307 & 4.9 & 0.074 & 0.200 & 0.1 & 1.75 & 5.1 & 0.170 & 0.3 & 0.70 & 1012 & 19 & 1027 & 19 & 1054 & 55 & 1054 & 55 & 96 \\
\hline 12JT22_20 & 191 & 2.4 & 0.075 & 0.200 & 0.2 & 1.90 & 5.5 & 0.184 & 0.4 & 0.48 & 1088 & 19 & 1080 & 20 & 1057 & 55 & 1057 & 55 & 103 \\
\hline 12JT22_30 & 85 & 0.9 & 0.076 & 0.220 & 0.1 & 1.97 & 6.3 & 0.188 & 0.4 & 0.53 & 1110 & 21 & 1106 & 21 & 1079 & 59 & 1079 & 59 & 103 \\
\hline 12JT22_48 & 187 & 2.9 & 0.076 & 0.210 & 0.4 & 1.86 & 5.4 & 0.176 & 0.3 & 0.31 & 1046 & 19 & 1066 & 19 & 1086 & 56 & 1086 & 56 & 96 \\
\hline 12JT22_93 & 105 & 1.3 & 0.076 & 0.220 & 0.1 & 1.97 & 6.1 & 0.189 & 0.4 & 0.53 & 1114 & 21 & 1104 & 22 & 1099 & 57 & 1099 & 57 & 101 \\
\hline 12JT22_51 & 707 & 5.1 & 0.076 & 0.200 & 0.4 & 1.85 & 5.2 & 0.176 & 0.3 & 0.62 & 1046 & 18 & 1065 & 18 & 1104 & 52 & 1104 & 52 & 95 \\
\hline 12JT22_46 & 388 & 2.6 & 0.077 & 0.210 & 0.2 & 1.84 & 5.4 & 0.173 & 0.4 & 0.73 & 1030 & 19 & 1060 & 19 & 1113 & 54 & 1113 & 54 & 93 \\
\hline 12JT22_50 & 49 & 1.7 & 0.078 & 0.240 & 0.2 & 1.98 & 7.8 & 0.186 & 0.6 & 0.77 & 1098 & 32 & 1110 & 27 & 1137 & 63 & 1137 & 63 & 97 \\
\hline 12JT22_71 & 312 & 1.7 & 0.079 & 0.220 & 0.2 & 2.05 & 6.2 & 0.188 & 0.4 & 0.47 & 1107 & 20 & 1131 & 20 & 1175 & 54 & 1175 & 54 & 94 \\
\hline
\end{tabular}


TABLE SM2.3: LA-ICPMS U-PB ISOTOPIC DATA (UC SANTA CRUZ LAB)

\begin{tabular}{|c|c|c|c|c|c|c|c|c|c|c|c|c|c|c|c|c|c|c|c|}
\hline \multirow[b]{2}{*}{ Analysis } & \multirow[b]{2}{*}{$U$} & \multirow[b]{2}{*}{$\mathrm{U} / \mathrm{Th}$} & \multirow[b]{2}{*}{$206 \mathrm{~Pb}^{*}$} & \multirow[b]{2}{*}{ \pm} & \multirow[b]{2}{*}{ error } & \multicolumn{5}{|c|}{ Isotope ratios } & \multicolumn{6}{|c|}{ Apparent ages (Ma) } & \multirow[b]{2}{*}{ Best age } & \multirow[b]{2}{*}{ \pm} & \multirow[b]{2}{*}{ Conc } \\
\hline & & & & & & 207Pb* & \pm & $206 \mathrm{~Pb}^{*}$ & \pm & error & $206 \mathrm{~Pb}^{*}$ & \pm & 207Pb* & \pm & $206 \mathrm{~Pb}^{*}$ & \pm & & & \\
\hline & (ppm) & & $207 \mathrm{~Pb}^{\star}$ & (\%) & corr. & $235 U^{*}$ & (\%) & $238 \mathrm{U}$ & (\%) & corr. & $238 U^{*}$ & (Ma) & $235 \mathrm{U}$ & (Ma) & 207Pb* & (Ma) & (Ma) & (Ma) & (\%) \\
\hline 12JT22_76 & 33 & 1.0 & 0.080 & 0.270 & 0.2 & 2.04 & 7.2 & 0.188 & 0.4 & 0.32 & 1108 & 22 & 1128 & 24 & 1177 & 67 & 1177 & 67 & 94 \\
\hline 12JT22_92 & 255 & 2.5 & 0.081 & 0.220 & 0.4 & 2.35 & 6.7 & 0.212 & 0.4 & 0.54 & 1239 & 22 & 1226 & 20 & 1219 & 54 & 1219 & 54 & 102 \\
\hline 12JT22_58 & 67 & 1.4 & 0.085 & 0.320 & -0.2 & 2.28 & 9.8 & 0.194 & 0.4 & 0.55 & 1145 & 21 & 1192 & 28 & 1279 & 71 & 1279 & 71 & 90 \\
\hline 12JT22_52 & 237 & 2.1 & 0.085 & 0.230 & 0.1 & 2.50 & 7.3 & 0.214 & 0.4 & 0.74 & 1248 & 23 & 1272 & 22 & 1304 & 53 & 1304 & 53 & 96 \\
\hline 12JT22_54 & 586 & 4.5 & 0.085 & 0.220 & 0.2 & 2.76 & 7.7 & 0.235 & 0.4 & 0.63 & 1358 & 23 & 1344 & 21 & 1313 & 51 & 1313 & 51 & 103 \\
\hline 12JT22_16 & 252 & 3.7 & 0.086 & 0.230 & 0.1 & 2.84 & 8.7 & 0.240 & 0.5 & 0.81 & 1386 & 26 & 1368 & 23 & 1338 & 52 & 1338 & 52 & 104 \\
\hline 12JT22_78 & 304 & 2.1 & 0.086 & 0.230 & 0.3 & 2.84 & 8.0 & 0.240 & 0.5 & 0.54 & 1385 & 23 & 1367 & 21 & 1345 & 51 & 1345 & 51 & 103 \\
\hline 12JT22_7 & 138 & 3.7 & 0.087 & 0.240 & 0.2 & 2.65 & 8.1 & 0.223 & 0.5 & 0.60 & 1298 & 24 & 1315 & 23 & 1354 & 54 & 1354 & 54 & 96 \\
\hline 12JT22_49 & 531 & 3.1 & 0.087 & 0.230 & 0.3 & 2.89 & 8.1 & 0.239 & 0.4 & 0.64 & 1382 & 23 & 1379 & 21 & 1364 & 50 & 1364 & 50 & 101 \\
\hline 12JT22_38 & 700 & 2.6 & 0.088 & 0.230 & -0.2 & 2.61 & 7.5 & 0.215 & 0.4 & 0.89 & 1257 & 22 & 1303 & 22 & 1370 & 51 & 1370 & 51 & 92 \\
\hline 12JT22_18 & 666 & 4.2 & 0.090 & 0.240 & 0.1 & 2.92 & 8.6 & 0.235 & 0.5 & 0.78 & 1362 & 24 & 1387 & 22 & 1415 & 51 & 1415 & 51 & 96 \\
\hline 12JT22_3 & 452 & 2.4 & 0.090 & 0.240 & -0.4 & 2.67 & 8.4 & 0.213 & 0.4 & 0.93 & 1243 & 24 & 1318 & 24 & 1431 & 52 & 1431 & 52 & 87 \\
\hline 12JT22_63 & 667 & 2.7 & 0.091 & 0.240 & 0.2 & 3.16 & 8.8 & 0.252 & 0.5 & 0.73 & 1451 & 24 & 1447 & 22 & 1440 & 50 & 1440 & 50 & 101 \\
\hline 12JT22_2 & 783 & 4.0 & 0.091 & 0.240 & -0.4 & 2.86 & 9.0 & 0.229 & 0.5 & 0.80 & 1327 & 25 & 1368 & 24 & 1444 & 51 & 1444 & 51 & 92 \\
\hline 12JT22_99 & 353 & 4.1 & 0.091 & 0.240 & -0.1 & 2.98 & 8.7 & 0.238 & 0.5 & 0.82 & 1376 & 24 & 1400 & 22 & 1454 & 51 & 1454 & 51 & 95 \\
\hline 12JT22_59 & 140 & 2.1 & 0.092 & 0.250 & 0.2 & 3.15 & 9.1 & 0.250 & 0.5 & 0.52 & 1439 & 24 & 1444 & 22 & 1455 & 52 & 1455 & 52 & 99 \\
\hline 12JT22_100 & 259 & 0.8 & 0.092 & 0.250 & 0.3 & 3.01 & 8.9 & 0.239 & 0.5 & 0.80 & 1382 & 27 & 1409 & 23 & 1474 & 50 & 1474 & 50 & 94 \\
\hline 12JT22_85 & 318 & 2.8 & 0.092 & 0.240 & 0.1 & 3.20 & 9.3 & 0.253 & 0.5 & 0.78 & 1451 & 26 & 1456 & 23 & 1474 & 51 & 1474 & 51 & 98 \\
\hline 12JT22_23 & 279 & 3.2 & 0.094 & 0.250 & 0.3 & 3.56 & 10.0 & 0.273 & 0.5 & 0.74 & 1556 & 27 & 1542 & 23 & 1509 & 50 & 1509 & 50 & 103 \\
\hline 12JT22_74 & 386 & 2.6 & 0.095 & 0.250 & -0.5 & 3.06 & 9.9 & 0.233 & 0.5 & 0.93 & 1348 & 27 & 1418 & 25 & 1533 & 50 & 1533 & 50 & 88 \\
\hline 12JT22_31 & 63 & 2.3 & 0.096 & 0.270 & 0.3 & 3.41 & 10.0 & 0.257 & 0.5 & 0.42 & 1477 & 26 & 1509 & 24 & 1538 & 53 & 1538 & 53 & 96 \\
\hline 12JT22_56 & 717 & 1.7 & 0.098 & 0.260 & -0.3 & 3.89 & 12.0 & 0.287 & 0.6 & 0.95 & 1623 & 31 & 1610 & 25 & 1581 & 49 & 1581 & 49 & 103 \\
\hline 12JT22_69 & 154 & 1.2 & 0.099 & 0.260 & 0.2 & 3.66 & 11.0 & 0.267 & 0.6 & 0.79 & 1525 & 28 & 1561 & 24 & 1601 & 50 & 1601 & 50 & 95 \\
\hline 12JT22_47 & 99 & 1.8 & 0.099 & 0.270 & 0.2 & 3.78 & 12.0 & 0.276 & 0.6 & 0.75 & 1570 & 32 & 1587 & 26 & 1607 & 53 & 1607 & 53 & 98 \\
\hline 12JT22_33 & 174 & 1.1 & 0.099 & 0.270 & 0.2 & 4.10 & 12.0 & 0.300 & 0.6 & 0.66 & 1690 & 29 & 1655 & 24 & 1612 & 49 & 1612 & 49 & 105 \\
\hline 12JT22_45 & 209 & 1.8 & 0.100 & 0.270 & 0.2 & 3.38 & 10.0 & 0.244 & 0.5 & 0.79 & 1404 & 28 & 1500 & 24 & 1626 & 51 & 1626 & 51 & 86 \\
\hline 12JT22_90 & 490 & 7.3 & 0.100 & 0.260 & 0.2 & 4.02 & 11.0 & 0.292 & 0.6 & 0.70 & 1652 & 27 & 1638 & 23 & 1629 & 48 & 1629 & 48 & 101 \\
\hline 12JT22_60 & 339 & 2.7 & 0.102 & 0.270 & 0.2 & 4.07 & 11.0 & 0.291 & 0.5 & 0.59 & 1645 & 27 & 1649 & 23 & 1651 & 48 & 1651 & 48 & 100 \\
\hline
\end{tabular}


TABLE SM2.3: LA-ICPMS U-PB ISOTOPIC DATA (UC SANTA CRUZ LAB)

\begin{tabular}{|c|c|c|c|c|c|c|c|c|c|c|c|c|c|c|c|c|c|c|c|}
\hline \multirow[b]{2}{*}{ Analysis } & \multirow[b]{2}{*}{$U$} & \multirow[b]{2}{*}{$\mathrm{U} / \mathrm{Th}$} & \multirow[b]{2}{*}{$206 \mathrm{~Pb}^{*}$} & \multirow[b]{2}{*}{ \pm} & \multirow[b]{2}{*}{ error } & \multirow[b]{2}{*}{ 207Pb* } & \multicolumn{3}{|c|}{ Isotope ratios } & \multirow[b]{2}{*}{ error } & \multirow[b]{2}{*}{$206 \mathrm{~Pb}^{*}$} & \multicolumn{4}{|c|}{ Apparent ages (Ma) } & \multirow[b]{2}{*}{ \pm} & \multirow[b]{2}{*}{ Best age } & \multirow[b]{2}{*}{ \pm} & \multirow[b]{2}{*}{ Conc } \\
\hline & & & & & & & \pm & $206 \mathrm{~Pb}^{*}$ & \pm & & & \pm & $207 \mathrm{~Pb}^{*}$ & \pm & $206 \mathrm{~Pb}^{*}$ & & & & \\
\hline & $(\mathrm{ppm})$ & & $207 \mathrm{~Pb}^{\star}$ & $(\%)$ & corr. & $235 U^{*}$ & $(\%)$ & $238 U$ & $(\%)$ & corr. & $238 U^{*}$ & (Ma) & $235 \mathrm{U}$ & (Ma) & $207 \mathrm{~Pb}^{\star}$ & (Ma) & $(\mathrm{Ma})$ & (Ma) & $(\%)$ \\
\hline 12JT22_19 & 91 & 1.0 & 0.102 & 0.280 & 0.3 & 3.86 & 11.0 & 0.274 & 0.6 & 0.64 & 1560 & 29 & 1605 & 24 & 1660 & 52 & 1660 & 52 & 94 \\
\hline 12JT22_28 & 287 & 1.5 & 0.102 & 0.270 & 0.4 & 4.06 & 11.0 & 0.287 & 0.6 & 0.65 & 1628 & 28 & 1646 & 23 & 1662 & 48 & 1662 & 48 & 98 \\
\hline 12JT22_25 & 273 & 0.7 & 0.104 & 0.310 & 0.1 & 3.38 & 14.0 & 0.232 & 0.7 & 0.52 & 1339 & 38 & 1487 & 32 & 1678 & 47 & 1678 & 47 & 80 \\
\hline 12JT22_73 & 198 & 2.5 & 0.106 & 0.280 & 0.2 & 4.48 & 13.0 & 0.307 & 0.6 & 0.83 & 1726 & 31 & 1726 & 25 & 1731 & 48 & 1731 & 48 & 100 \\
\hline 12JT22_32 & 855 & 2.7 & 0.106 & 0.280 & 0.1 & 4.38 & 12.0 & 0.298 & 0.6 & 0.90 & 1679 & 29 & 1708 & 24 & 1734 & 48 & 1734 & 48 & 97 \\
\hline 12JT22_35 & 358 & 3.7 & 0.107 & 0.290 & 0.1 & 3.97 & 13.0 & 0.269 & 0.7 & 0.85 & 1536 & 33 & 1625 & 26 & 1740 & 49 & 1740 & 49 & 88 \\
\hline 12JT22_17 & 283 & 1.6 & 0.107 & 0.280 & 0.1 & 4.84 & 14.0 & 0.327 & 0.6 & 0.83 & 1825 & 31 & 1791 & 24 & 1743 & 48 & 1743 & 48 & 105 \\
\hline 12JT22_29 & 446 & 4.4 & 0.107 & 0.280 & 0.3 & 4.70 & 13.0 & 0.318 & 0.6 & 0.76 & 1781 & 30 & 1767 & 24 & 1748 & 48 & 1748 & 48 & 102 \\
\hline 12JT22_83 & 405 & 2.5 & 0.108 & 0.280 & 0.0 & 4.52 & 13.0 & 0.306 & 0.6 & 0.89 & 1719 & 31 & 1734 & 25 & 1761 & 48 & 1761 & 48 & 98 \\
\hline 12JT22_22 & 326 & 1.6 & 0.109 & 0.290 & 0.1 & 4.86 & 14.0 & 0.322 & 0.6 & 0.83 & 1797 & 30 & 1794 & 25 & 1785 & 47 & 1785 & 47 & 101 \\
\hline 12JT22_97 & 86 & 2.1 & 0.110 & 0.300 & 0.2 & 5.04 & 15.0 & 0.335 & 0.7 & 0.67 & 1862 & 32 & 1826 & 25 & 1796 & 50 & 1796 & 50 & 104 \\
\hline 12JT22_9 & 554 & 8.4 & 0.111 & 0.290 & 0.3 & 4.74 & 13.0 & 0.308 & 0.6 & 0.85 & 1732 & 28 & 1774 & 24 & 1814 & 47 & 1814 & 47 & 95 \\
\hline 12JT22_15 & 242 & 2.6 & 0.113 & 0.300 & 0.1 & 5.44 & 18.0 & 0.347 & 0.9 & 0.93 & 1917 & 43 & 1884 & 30 & 1847 & 49 & 1847 & 49 & 104 \\
\hline 12JT22_27 & 161 & 3.1 & 0.113 & 0.300 & 0.2 & 5.13 & 15.0 & 0.329 & 0.7 & 0.76 & 1833 & 34 & 1841 & 25 & 1851 & 49 & 1851 & 49 & 99 \\
\hline 12JT22_72 & 146 & 1.1 & 0.117 & 0.310 & 0.3 & 5.53 & 16.0 & 0.344 & 0.7 & 0.70 & 1904 & 32 & 1905 & 25 & 1908 & 48 & 1908 & 48 & 100 \\
\hline 12JT22_43 & 680 & 2.2 & 0.121 & 0.310 & 0.1 & 5.29 & 16.0 & 0.317 & 0.7 & 0.92 & 1772 & 32 & 1864 & 26 & 1964 & 47 & 1964 & 47 & 90 \\
\hline 12JT22_77 & 190 & 2.5 & 0.123 & 0.320 & 0.3 & 6.36 & 18.0 & 0.378 & 0.7 & 0.64 & 2065 & 33 & 2027 & 25 & 2000 & 46 & 2000 & 46 & 103 \\
\hline 12JT22_61 & 372 & 3.0 & 0.130 & 0.340 & 0.2 & 6.92 & 20.0 & 0.387 & 0.7 & 0.86 & 2109 & 34 & 2100 & 25 & 2092 & 46 & 2092 & 46 & 101 \\
\hline 12JT22_80 & 401 & 1.3 & 0.174 & 0.450 & 0.3 & 11.38 & 32.0 & 0.474 & 0.9 & 0.81 & 2501 & 39 & 2555 & 26 & 2600 & 43 & 2600 & 43 & 96 \\
\hline 12JT22_40 & 371 & 1.2 & 0.184 & 0.480 & 0.1 & 13.44 & 38.0 & 0.530 & 1.0 & 0.88 & 2741 & 43 & 2711 & 27 & 2684 & 43 & 2684 & 43 & 102 \\
\hline 12JT22_81 & 229 & 1.5 & 0.187 & 0.490 & 0.3 & 14.04 & 39.0 & 0.547 & 1.0 & 0.80 & 2811 & 43 & 2752 & 27 & 2711 & 43 & 2711 & 43 & 104 \\
\hline 12JT22_24 & 193 & 2.4 & 0.194 & 0.510 & 0.0 & 14.27 & 44.0 & 0.535 & 1.2 & 0.92 & 2757 & 52 & 2764 & 31 & 2774 & 44 & 2774 & 44 & 99 \\
\hline 12JT22_53 & 56 & 2.5 & 0.203 & 0.540 & -0.1 & 15.75 & 49.0 & 0.561 & 1.2 & 0.90 & 2866 & 50 & 2859 & 31 & 2852 & 44 & 2852 & 44 & 100 \\
\hline 12JT22_6 & 152 & 2.6 & 0.250 & 0.660 & -0.1 & 19.10 & 65.0 & 0.553 & 1.4 & 0.96 & 2834 & 57 & 3046 & 32 & 3185 & 42 & 3185 & 42 & 89 \\
\hline 12JT22_75 & 64 & 1.2 & 0.285 & 0.750 & 0.3 & 28.38 & 81.0 & 0.723 & 1.4 & 0.77 & 3506 & 53 & 3432 & 28 & 3391 & 41 & 3391 & 41 & 103 \\
\hline \multicolumn{20}{|c|}{$>20 \%$ Discordance } \\
\hline 12JT22_34 & 196 & 2.3 & 0.074 & 0.480 & -0.1 & 0.17 & 1.5 & 0.016 & 0.1 & 0.70 & 101 & 7 & 155 & 13 & 880 & 120 & 101 & 7 & NA \\
\hline
\end{tabular}


TABLE SM2.3: LA-ICPMS U-PB ISOTOPIC DATA (UC SANTA CRUZ LAB)

\begin{tabular}{|c|c|c|c|c|c|c|c|c|c|c|c|c|c|c|c|c|c|c|c|}
\hline \multirow[b]{2}{*}{ Analysis } & \multirow[b]{2}{*}{$U$} & \multirow[b]{2}{*}{ U/Th } & \multirow[b]{2}{*}{$206 \mathrm{~Pb}^{*}$} & \multirow[b]{2}{*}{ \pm} & \multirow[b]{2}{*}{ error } & \multirow[b]{2}{*}{ 207Pb* } & \multicolumn{3}{|c|}{ Isotope ratios } & \multirow[b]{2}{*}{ error } & \multirow[b]{2}{*}{$206 \mathrm{~Pb}^{*}$} & \multicolumn{4}{|c|}{ Apparent ages (Ma) } & \multirow[b]{2}{*}{ \pm} & \multirow[b]{2}{*}{ Best age } & \multirow[b]{2}{*}{ \pm} & \multirow[b]{2}{*}{ Conc } \\
\hline & & & & & & & \pm & $206 \mathrm{~Pb}^{*}$ & \pm & & & \pm & 207Pb* & \pm & $206 \mathrm{~Pb}^{*}$ & & & & \\
\hline & (ppm) & & $207 \mathrm{~Pb}^{*}$ & (\%) & corr. & $235 U^{*}$ & $(\%)$ & $238 U$ & (\%) & corr. & $238 U^{*}$ & (Ma) & $235 \mathrm{U}$ & (Ma) & 207Pb* & (Ma) & (Ma) & (Ma) & $(\%)$ \\
\hline 12JT22_42 & 94 & 3.1 & 0.081 & 0.290 & 0.2 & 1.64 & 9.6 & 0.148 & 0.8 & 0.88 & 889 & 46 & 976 & 37 & 1205 & 71 & 889 & 46 & 74 \\
\hline 12JT22_21 & 342 & 3.2 & 0.092 & 0.260 & -0.8 & 2.47 & 13.0 & 0.192 & 0.7 & 0.98 & 1126 & 38 & 1239 & 38 & 1456 & 55 & 1456 & 55 & 77 \\
\hline 12JT22_70 & 467 & 1.6 & 0.113 & 0.390 & -0.8 & 3.95 & 17.0 & 0.251 & 0.5 & 0.94 & 1444 & 27 & 1607 & 24 & 1821 & 39 & 1821 & 39 & 79 \\
\hline 12JT22_94 & 245 & 1.4 & 0.140 & 0.620 & -0.8 & 7.11 & 42.0 & 0.361 & 0.8 & 0.94 & 1986 & 38 & 2073 & 36 & 2164 & 55 & 2164 & 55 & 92 \\
\hline 12JT22_66 & 259 & 1.8 & 0.197 & 2.400 & -1.0 & 21.80 & 580.0 & 0.432 & 5.0 & 1.00 & 2100 & 160 & 2280 & 140 & 2580 & 150 & 2580 & 150 & 81 \\
\hline \multicolumn{20}{|c|}{$>5 \%$ Reverse Discordance } \\
\hline 12JT22_5 & 528 & 2.7 & 0.082 & 0.220 & -0.5 & 2.54 & 8.0 & 0.224 & 0.5 & 0.91 & 1302 & 24 & 1280 & 23 & 1240 & 52 & 1240 & 52 & 105 \\
\hline 12JT22_87 & 202 & 2.4 & 0.085 & 0.230 & 0.3 & 2.79 & 8.0 & 0.240 & 0.5 & 0.57 & 1387 & 24 & 1352 & 21 & 1315 & 52 & 1315 & 52 & 105 \\
\hline 12JT22_88 & 323 & 3.5 & 0.087 & 0.230 & 0.2 & 3.00 & 8.5 & 0.251 & 0.5 & 0.69 & 1441 & 25 & 1407 & 22 & 1367 & 51 & 1367 & 51 & 105 \\
\hline 12JT22_11 & 663 & 4.0 & 0.091 & 0.240 & -0.1 & 3.44 & 11.0 & 0.274 & 0.6 & 0.97 & 1561 & 32 & 1513 & 25 & 1441 & 49 & 1441 & 49 & 108 \\
\hline 12JT22_86 & 184 & 1.0 & 0.095 & 0.260 & 0.2 & 3.84 & 12.0 & 0.292 & 0.6 & 0.74 & 1650 & 32 & 1599 & 26 & 1534 & 51 & 1534 & 51 & 108 \\
\hline 12JT22_1 & 103 & 1.6 & 0.101 & 0.270 & 0.1 & 4.45 & 13.0 & 0.319 & 0.6 & 0.73 & 1782 & 31 & 1720 & 25 & 1638 & 50 & 1638 & 50 & 109 \\
\hline 12JT22_4 & 340 & 1.9 & 0.101 & 0.260 & 0.2 & 4.43 & 13.0 & 0.317 & 0.6 & 0.82 & 1775 & 30 & 1717 & 24 & 1640 & 49 & 1640 & 49 & 108 \\
\hline 12JT22_79 & 323 & 1.7 & 0.106 & 0.280 & 0.3 & 4.89 & 14.0 & 0.336 & 0.6 & 0.73 & 1866 & 31 & 1800 & 24 & 1733 & 48 & 1733 & 48 & 108 \\
\hline 12JT22_84 & 129 & 3.8 & 0.115 & 0.310 & 0.2 & 5.79 & 17.0 & 0.366 & 0.7 & 0.72 & 2012 & 34 & 1945 & 26 & 1874 & 48 & 1874 & 48 & 107 \\
\hline 12JT22_96 & 81 & 1.4 & 0.184 & 0.490 & 0.0 & 13.80 & 41.0 & 0.551 & 1.1 & 0.87 & 2827 & 46 & 2735 & 29 & 2690 & 43 & 2690 & 43 & 105 \\
\hline \multicolumn{20}{|c|}{$>1000$ U ppm } \\
\hline 12JT22_41 & 3312 & 6.8 & 0.062 & 0.170 & 0.2 & 0.43 & 1.3 & 0.050 & 0.1 & 0.55 & 312 & 6 & 361 & 9 & 674 & 56 & 312 & 6 & NA \\
\hline 12JT22_39 & 1612 & 2.7 & 0.079 & 0.300 & 0.0 & 1.26 & 4.7 & 0.118 & 0.3 & 0.28 & 717 & 18 & 824 & 21 & 1108 & 58 & 717 & 18 & 65 \\
\hline 12JT22_44 & 2233 & 5.1 & 0.078 & 0.210 & 0.2 & 1.54 & 4.4 & 0.143 & 0.3 & 0.47 & 859 & 15 & 944 & 17 & 1137 & 52 & 859 & 15 & 76 \\
\hline 12JT22_36 & 1531 & 17.1 & 0.078 & 0.220 & -0.3 & 1.58 & 4.9 & 0.147 & 0.3 & 0.58 & 884 & 16 & 959 & 18 & 1141 & 50 & 884 & 16 & 77 \\
\hline 12JT22_14 & 1501 & 10.7 & 0.070 & 0.180 & -0.1 & 1.53 & 4.5 & 0.157 & 0.3 & 0.95 & 940 & 18 & 943 & 19 & 939 & 54 & 940 & 18 & 100 \\
\hline 12JT22_67 & 1067 & 2.3 & 0.078 & 0.200 & 0.4 & 2.11 & 5.9 & 0.195 & 0.4 & 0.72 & 1146 & 19 & 1151 & 19 & 1156 & 52 & 1156 & 52 & 99 \\
\hline 12JT22_26 & 1141 & 5.1 & 0.081 & 0.210 & -0.3 & 2.04 & 6.7 & 0.182 & 0.4 & 0.95 & 1075 & 23 & 1127 & 23 & 1223 & 51 & 1223 & 51 & 88 \\
\hline
\end{tabular}


TABLE SM2.3: LA-ICPMS U-PB ISOTOPIC DATA (UC SANTA CRUZ LAB)

\begin{tabular}{|c|c|c|c|c|c|c|c|c|c|c|c|c|c|c|c|c|c|c|c|}
\hline \multirow[b]{2}{*}{ Analysis } & \multirow[b]{2}{*}{$\mathrm{U}$} & \multirow[b]{2}{*}{$\mathrm{U} / \mathrm{Th}$} & \multirow[b]{2}{*}{$206 \mathrm{~Pb}^{*}$} & \multirow[b]{2}{*}{ \pm} & \multirow[b]{2}{*}{ error } & \multicolumn{5}{|c|}{ Isotope ratios } & \multicolumn{6}{|c|}{ Apparent ages (Ma) } & \multirow[b]{2}{*}{ Best age } & \multirow[b]{2}{*}{ \pm} & \multirow[b]{2}{*}{ Conc } \\
\hline & & & & & & $207 \mathrm{~Pb}^{*}$ & \pm & $206 \mathrm{~Pb}^{*}$ & \pm & error & $206 \mathrm{~Pb}^{*}$ & \pm & $207 \mathrm{~Pb}^{*}$ & \pm & $206 \mathrm{~Pb}^{\star}$ & \pm & & & \\
\hline & (ppm) & & $207 \mathrm{~Pb}^{\star}$ & (\%) & corr. & $235 U^{*}$ & $(\%)$ & $238 \mathrm{U}$ & (\%) & corr. & $238 U^{*}$ & (Ma) & $235 U$ & (Ma) & $207 \mathrm{~Pb}^{*}$ & (Ma) & (Ma) & (Ma) & $(\%)$ \\
\hline 12JT23_100 & 371 & 1.9 & 0.056 & 0.290 & 0.2 & 0.46 & 3.2 & 0.060 & 0.3 & 0.26 & 373 & 17 & 380 & 22 & 410 & 110 & 373 & 17 & NA \\
\hline 12JT23_99 & 731 & 1.9 & 0.056 & 0.270 & 0.3 & 0.46 & 3.1 & 0.060 & 0.3 & 0.25 & 374 & 17 & 384 & 21 & 440 & 110 & 374 & 17 & NA \\
\hline 12JT23_108 & 247 & 1.4 & 0.056 & 0.300 & 0.2 & 0.47 & 3.4 & 0.060 & 0.3 & 0.18 & 375 & 17 & 388 & 24 & 400 & 110 & 375 & 17 & NA \\
\hline 12JT23_105 & 592 & 1.6 & 0.055 & 0.280 & 0.3 & 0.47 & 3.3 & 0.061 & 0.3 & 0.18 & 382 & 17 & 389 & 23 & 380 & 110 & 382 & 17 & NA \\
\hline 12JT23_110 & 447 & 3.7 & 0.055 & 0.280 & 0.2 & 0.48 & 3.3 & 0.062 & 0.3 & 0.24 & 385 & 17 & 397 & 23 & 430 & 110 & 385 & 17 & NA \\
\hline 12JT23_66 & 263 & 2.2 & 0.059 & 0.360 & 0.2 & 0.50 & 3.8 & 0.063 & 0.3 & 0.20 & 392 & 18 & 406 & 25 & 480 & 120 & 392 & 18 & NA \\
\hline 12JT23_46 & 367 & 1.6 & 0.054 & 0.290 & 0.3 & 0.47 & 3.3 & 0.063 & 0.3 & 0.18 & 392 & 18 & 389 & 23 & 350 & 110 & 392 & 18 & NA \\
\hline 12JT23_92 & 486 & 1.7 & 0.055 & 0.280 & 0.2 & 0.50 & 3.5 & 0.064 & 0.3 & 0.23 & 397 & 18 & 411 & 23 & 390 & 110 & 397 & 18 & NA \\
\hline 12JT23_94 & 327 & 1.7 & 0.056 & 0.300 & 0.1 & 0.50 & 3.6 & 0.064 & 0.3 & 0.28 & 399 & 18 & 416 & 24 & 400 & 110 & 399 & 18 & NA \\
\hline 12JT23_104 & 423 & 2.6 & 0.054 & 0.270 & 0.3 & 0.49 & 3.4 & 0.065 & 0.3 & 0.23 & 403 & 18 & 404 & 23 & 380 & 110 & 403 & 18 & NA \\
\hline 12JT23_98 & 555 & 4.8 & 0.056 & 0.280 & 0.3 & 0.51 & 3.5 & 0.065 & 0.3 & 0.17 & 407 & 18 & 417 & 23 & 430 & 110 & 407 & 18 & NA \\
\hline 12JT23_96 & 837 & 1.8 & 0.055 & 0.260 & 0.2 & 0.51 & 3.4 & 0.065 & 0.3 & 0.41 & 408 & 18 & 418 & 23 & 420 & 110 & 408 & 18 & NA \\
\hline 12JT23_106 & 79 & 3.5 & 0.058 & 0.430 & 0.2 & 0.53 & 4.6 & 0.066 & 0.3 & 0.19 & 412 & 20 & 428 & 31 & 460 & 150 & 412 & 20 & NA \\
\hline 12JT23_107 & 131 & 2.8 & 0.057 & 0.360 & 0.2 & 0.52 & 4.1 & 0.066 & 0.3 & 0.17 & 413 & 19 & 428 & 27 & 470 & 130 & 413 & 19 & NA \\
\hline 12JT23_97 & 319 & 1.7 & 0.055 & 0.300 & 0.3 & 0.50 & 3.6 & 0.066 & 0.3 & 0.14 & 413 & 19 & 411 & 24 & 380 & 110 & 413 & 19 & NA \\
\hline 12JT23_26 & 137 & 2.2 & 0.052 & 0.310 & 0.2 & 0.50 & 3.9 & 0.066 & 0.3 & 0.26 & 414 & 19 & 406 & 26 & 280 & 120 & 414 & 19 & NA \\
\hline 12JT23_27 & 621 & 1.9 & 0.055 & 0.270 & 0.2 & 0.52 & 3.5 & 0.066 & 0.3 & 0.27 & 414 & 19 & 424 & 24 & 390 & 110 & 414 & 19 & NA \\
\hline 12JT23_28 & 401 & 2.0 & 0.053 & 0.270 & 0.2 & 0.51 & 3.6 & 0.067 & 0.3 & 0.24 & 415 & 19 & 415 & 24 & 320 & 110 & 415 & 19 & NA \\
\hline 12JT23_77 & 498 & 1.7 & 0.055 & 0.270 & 0.2 & 0.51 & 3.5 & 0.066 & 0.3 & 0.27 & 415 & 19 & 420 & 24 & 380 & 110 & 415 & 19 & NA \\
\hline 12JT23_29 & 173 & 2.5 & 0.054 & 0.330 & 0.3 & 0.50 & 3.9 & 0.067 & 0.3 & 0.12 & 417 & 19 & 415 & 27 & 300 & 120 & 417 & 19 & NA \\
\hline 12JT23_88 & 148 & 4.2 & 0.052 & 0.330 & 0.2 & 0.48 & 3.9 & 0.067 & 0.3 & 0.19 & 418 & 20 & 402 & 26 & 300 & 130 & 418 & 20 & NA \\
\hline 12JT23_58 & 748 & 1.3 & 0.056 & 0.270 & 0.2 & 0.50 & 3.4 & 0.067 & 0.3 & 0.23 & 418 & 19 & 415 & 23 & 420 & 110 & 418 & 19 & NA \\
\hline 12JT23_36 & 960 & 1.5 & 0.057 & 0.300 & 0.2 & 0.51 & 3.7 & 0.067 & 0.3 & 0.33 & 418 & 19 & 419 & 25 & 460 & 120 & 418 & 19 & NA \\
\hline 12JT23_55 & 383 & 1.7 & 0.054 & 0.280 & 0.2 & 0.50 & 3.5 & 0.067 & 0.3 & 0.23 & 420 & 19 & 409 & 24 & 350 & 110 & 420 & 19 & NA \\
\hline 12JT23_18 & 842 & 1.7 & 0.055 & 0.260 & 0.3 & 0.50 & 3.3 & 0.067 & 0.3 & 0.18 & 420 & 19 & 411 & 23 & 420 & 110 & 420 & 19 & NA \\
\hline 12JT23_2 & 343 & 2.0 & 0.058 & 0.310 & 0.3 & 0.55 & 3.9 & 0.068 & 0.3 & 0.09 & 422 & 19 & 448 & 26 & 500 & 110 & 422 & 19 & NA \\
\hline 12JT23_73 & 421 & 1.8 & 0.056 & 0.280 & 0.2 & 0.53 & 3.7 & 0.068 & 0.3 & 0.29 & 422 & 19 & 433 & 25 & 410 & 110 & 422 & 19 & NA \\
\hline 12JT23_44 & 472 & 1.5 & 0.055 & 0.280 & 0.2 & 0.52 & 3.7 & 0.068 & 0.3 & 0.35 & 423 & 19 & 425 & 24 & 430 & 110 & 423 & 19 & NA \\
\hline
\end{tabular}


TABLE SM2.3: LA-ICPMS U-PB ISOTOPIC DATA (UC SANTA CRUZ LAB)

\begin{tabular}{|c|c|c|c|c|c|c|c|c|c|c|c|c|c|c|c|c|c|c|c|}
\hline \multirow[b]{2}{*}{ Analysis } & \multirow[b]{2}{*}{$U$} & \multirow[b]{2}{*}{$\mathrm{U} / \mathrm{Th}$} & \multirow[b]{2}{*}{$206 \mathrm{~Pb}^{*}$} & \multirow[b]{2}{*}{ \pm} & \multirow[b]{2}{*}{ error } & \multicolumn{5}{|c|}{ Isotope ratios } & \multicolumn{6}{|c|}{ Apparent ages (Ma) } & \multirow[b]{2}{*}{ Best age } & \multirow[b]{2}{*}{ \pm} & \multirow[b]{2}{*}{ Conc } \\
\hline & & & & & & $207 \mathrm{~Pb}^{*}$ & \pm & $206 \mathrm{~Pb}^{*}$ & \pm & error & $206 \mathrm{~Pb}^{*}$ & \pm & $207 \mathrm{~Pb}^{*}$ & \pm & $206 \mathrm{~Pb}^{\star}$ & \pm & & & \\
\hline & (ppm) & & $207 \mathrm{~Pb}^{\star}$ & (\%) & corr. & $235 U^{*}$ & (\%) & $238 \mathrm{U}$ & (\%) & corr. & $238 U^{*}$ & (Ma) & $235 U$ & (Ma) & $207 \mathrm{~Pb}^{*}$ & $(\mathrm{Ma})$ & (Ma) & (Ma) & $(\%)$ \\
\hline 12JT23_90 & 543 & 5.6 & 0.057 & 0.280 & 0.3 & 0.54 & 3.7 & 0.068 & 0.3 & 0.15 & 423 & 19 & 440 & 24 & 480 & 110 & 423 & 19 & NA \\
\hline 12JT23_1 & 623 & 1.8 & 0.056 & 0.270 & 0.2 & 0.54 & 3.7 & 0.068 & 0.3 & 0.24 & 424 & 19 & 440 & 24 & 420 & 110 & 424 & 19 & NA \\
\hline 12JT23_103 & 123 & 2.2 & 0.054 & 0.330 & 0.3 & 0.52 & 4.0 & 0.068 & 0.3 & 0.22 & 425 & 20 & 421 & 26 & 380 & 120 & 425 & 20 & NA \\
\hline 12JT23_56 & 337 & 3.3 & 0.058 & 0.300 & 0.1 & 0.54 & 3.8 & 0.068 & 0.3 & 0.38 & 425 & 19 & 435 & 25 & 500 & 110 & 425 & 19 & NA \\
\hline 12JT23_53 & 254 & 1.6 & 0.057 & 0.320 & 0.2 & 0.54 & 3.9 & 0.068 & 0.3 & 0.26 & 426 & 20 & 435 & 25 & 470 & 120 & 426 & 20 & NA \\
\hline 12JT23_5 & 763 & 1.3 & 0.054 & 0.260 & 0.2 & 0.52 & 3.5 & 0.068 & 0.3 & 0.29 & 426 & 19 & 422 & 23 & 390 & 110 & 426 & 19 & NA \\
\hline 12JT23_79 & 171 & 1.8 & 0.054 & 0.310 & 0.2 & 0.52 & 3.9 & 0.069 & 0.3 & 0.20 & 428 & 20 & 425 & 26 & 360 & 120 & 428 & 20 & NA \\
\hline 12JT23_89 & 201 & 1.5 & 0.054 & 0.310 & 0.2 & 0.53 & 4.0 & 0.069 & 0.3 & 0.24 & 428 & 20 & 430 & 26 & 380 & 120 & 428 & 20 & NA \\
\hline 12JT23_68 & 387 & 1.4 & 0.056 & 0.290 & 0.2 & 0.53 & 3.7 & 0.069 & 0.3 & 0.23 & 428 & 19 & 430 & 24 & 420 & 110 & 428 & 19 & NA \\
\hline 12JT23_60 & 182 & 2.2 & 0.055 & 0.320 & 0.2 & 0.51 & 3.8 & 0.069 & 0.3 & 0.19 & 429 & 20 & 417 & 26 & 410 & 120 & 429 & 20 & NA \\
\hline 12JT23_57 & 96 & 2.8 & 0.056 & 0.380 & 0.4 & 0.52 & 4.2 & 0.069 & 0.4 & 0.05 & 430 & 21 & 421 & 29 & 390 & 140 & 430 & 21 & NA \\
\hline 12JT23_80 & 186 & 1.7 & 0.057 & 0.330 & 0.3 & 0.55 & 4.1 & 0.069 & 0.3 & 0.10 & 430 & 20 & 445 & 27 & 460 & 120 & 430 & 20 & NA \\
\hline 12JT23_81 & 425 & 1.1 & 0.057 & 0.290 & 0.1 & 0.53 & 3.7 & 0.069 & 0.3 & 0.32 & 430 & 19 & 432 & 24 & 480 & 110 & 430 & 19 & NA \\
\hline 12JT23_63 & 664 & 1.7 & 0.055 & 0.270 & 0.3 & 0.51 & 3.5 & 0.069 & 0.3 & 0.27 & 432 & 19 & 416 & 23 & 370 & 110 & 432 & 19 & NA \\
\hline 12JT23_64 & 285 & 1.5 & 0.055 & 0.350 & 0.3 & 0.52 & 4.1 & 0.070 & 0.3 & 0.12 & 433 & 20 & 425 & 28 & 380 & 130 & 433 & 20 & NA \\
\hline 12JT23_87 & 392 & 1.6 & 0.056 & 0.290 & 0.2 & 0.53 & 3.7 & 0.069 & 0.3 & 0.34 & 433 & 20 & 430 & 25 & 420 & 110 & 433 & 20 & NA \\
\hline 12JT23_48 & 178 & 2.9 & 0.056 & 0.330 & 0.3 & 0.55 & 4.1 & 0.070 & 0.3 & 0.13 & 434 & 20 & 440 & 27 & 410 & 120 & 434 & 20 & NA \\
\hline 12JT23_50 & 726 & 1.0 & 0.054 & 0.260 & 0.2 & 0.53 & 3.6 & 0.070 & 0.3 & 0.31 & 434 & 19 & 432 & 24 & 370 & 110 & 434 & 19 & NA \\
\hline 12JT23_102 & 838 & 1.7 & 0.056 & 0.270 & 0.2 & 0.54 & 3.7 & 0.070 & 0.3 & 0.27 & 434 & 19 & 441 & 24 & 450 & 110 & 434 & 19 & NA \\
\hline 12JT23_74 & 326 & 2.0 & 0.055 & 0.280 & 0.3 & 0.55 & 3.8 & 0.070 & 0.3 & 0.20 & 437 & 20 & 443 & 25 & 410 & 110 & 437 & 20 & NA \\
\hline 12JT23_95 & 290 & 1.6 & 0.055 & 0.300 & 0.3 & 0.55 & 3.9 & 0.070 & 0.3 & 0.21 & 438 & 20 & 444 & 26 & 430 & 110 & 438 & 20 & NA \\
\hline 12JT23_69 & 160 & 3.7 & 0.056 & 0.330 & 0.3 & 0.55 & 4.1 & 0.071 & 0.3 & 0.05 & 440 & 21 & 442 & 26 & 420 & 120 & 440 & 21 & NA \\
\hline 12JT23_42 & 321 & 1.8 & 0.053 & 0.290 & 0.2 & 0.52 & 3.7 & 0.071 & 0.3 & 0.17 & 440 & 20 & 421 & 24 & 320 & 110 & 440 & 20 & NA \\
\hline 12JT23_82 & 503 & 1.5 & 0.055 & 0.280 & 0.2 & 0.53 & 3.6 & 0.071 & 0.3 & 0.24 & 444 & 20 & 429 & 24 & 410 & 110 & 444 & 20 & NA \\
\hline 12JT23_10 & 678 & 1.6 & 0.055 & 0.260 & 0.2 & 0.51 & 3.5 & 0.071 & 0.3 & 0.36 & 444 & 20 & 420 & 23 & 380 & 110 & 444 & 20 & NA \\
\hline 12JT23_25 & 192 & 1.8 & 0.055 & 0.320 & 0.4 & 0.55 & 4.1 & 0.072 & 0.3 & 0.13 & 446 & 21 & 447 & 26 & 380 & 120 & 446 & 21 & NA \\
\hline 12JT23_24 & 296 & 3.4 & 0.054 & 0.280 & 0.2 & 0.55 & 3.9 & 0.072 & 0.3 & 0.28 & 446 & 20 & 442 & 26 & 350 & 110 & 446 & 20 & NA \\
\hline 12JT23_21 & 512 & 1.6 & 0.056 & 0.280 & 0.2 & 0.55 & 3.8 & 0.072 & 0.3 & 0.21 & 446 & 20 & 448 & 25 & 430 & 110 & 446 & 20 & NA \\
\hline
\end{tabular}


TABLE SM2.3: LA-ICPMS U-PB ISOTOPIC DATA (UC SANTA CRUZ LAB)

\begin{tabular}{|c|c|c|c|c|c|c|c|c|c|c|c|c|c|c|c|c|c|c|c|}
\hline \multirow[b]{2}{*}{ Analysis } & \multirow[b]{2}{*}{$U$} & \multirow[b]{2}{*}{$\mathrm{U} / \mathrm{Th}$} & \multirow[b]{2}{*}{$206 \mathrm{~Pb}^{*}$} & \multirow[b]{2}{*}{ \pm} & \multirow[b]{2}{*}{ error } & \multicolumn{5}{|c|}{ Isotope ratios } & \multicolumn{6}{|c|}{ Apparent ages (Ma) } & \multirow[b]{2}{*}{ Best age } & \multirow[b]{2}{*}{ \pm} & \multirow[b]{2}{*}{ Conc } \\
\hline & & & & & & $207 \mathrm{~Pb}^{*}$ & \pm & $206 \mathrm{~Pb}^{*}$ & \pm & error & $206 \mathrm{~Pb}^{*}$ & \pm & $207 \mathrm{~Pb}^{*}$ & \pm & $206 \mathrm{~Pb}^{\star}$ & \pm & & & \\
\hline & (ppm) & & $207 \mathrm{~Pb}^{\star}$ & (\%) & corr. & $235 U^{*}$ & $(\%)$ & $238 \mathrm{U}$ & (\%) & corr. & $238 U^{*}$ & (Ma) & $235 U$ & (Ma) & $207 \mathrm{~Pb}^{*}$ & (Ma) & (Ma) & (Ma) & $(\%)$ \\
\hline 12JT23_33 & 571 & 2.8 & 0.056 & 0.280 & 0.3 & 0.55 & 3.8 & 0.072 & 0.3 & 0.12 & 446 & 20 & 445 & 25 & 430 & 110 & 446 & 20 & NA \\
\hline 12JT23_41 & 720 & 2.8 & 0.054 & 0.270 & 0.1 & 0.54 & 3.7 & 0.072 & 0.3 & 0.39 & 446 & 20 & 437 & 24 & 370 & 100 & 446 & 20 & NA \\
\hline 12JT23_12 & 250 & 2.5 & 0.056 & 0.310 & 0.2 & 0.53 & 3.8 & 0.072 & 0.3 & 0.19 & 449 & 21 & 432 & 25 & 420 & 120 & 449 & 21 & NA \\
\hline 12JT23_59 & 570 & 3.1 & 0.057 & 0.280 & 0.3 & 0.55 & 3.8 & 0.072 & 0.3 & 0.13 & 450 & 20 & 446 & 24 & 460 & 110 & 450 & 20 & NA \\
\hline 12JT23_75 & 250 & 4.3 & 0.055 & 0.310 & 0.3 & 0.56 & 4.1 & 0.072 & 0.4 & 0.15 & 451 & 21 & 449 & 26 & 370 & 110 & 451 & 21 & NA \\
\hline 12JT23_30 & 285 & 3.0 & 0.055 & 0.290 & 0.2 & 0.58 & 4.0 & 0.073 & 0.3 & 0.22 & 453 & 20 & 460 & 26 & 420 & 110 & 453 & 20 & NA \\
\hline 12JT23_40 & 178 & 1.7 & 0.055 & 0.340 & 0.4 & 0.54 & 4.1 & 0.073 & 0.4 & 0.04 & 454 & 21 & 442 & 27 & 380 & 120 & 454 & 21 & NA \\
\hline 12JT23_91 & 218 & 3.0 & 0.060 & 0.330 & 0.3 & 0.63 & 4.6 & 0.073 & 0.4 & 0.20 & 454 & 21 & 497 & 29 & 580 & 120 & 454 & 21 & NA \\
\hline 12JT23_67 & 245 & 3.2 & 0.058 & 0.300 & 0.2 & 0.58 & 4.1 & 0.073 & 0.3 & 0.25 & 455 & 21 & 461 & 26 & 490 & 110 & 455 & 21 & NA \\
\hline 12JT23_39 & 131 & 3.1 & 0.055 & 0.330 & 0.1 & 0.55 & 4.3 & 0.073 & 0.4 & 0.31 & 456 & 21 & 441 & 27 & 390 & 120 & 456 & 21 & NA \\
\hline 12JT23_72 & 133 & 2.9 & 0.054 & 0.330 & 0.1 & 0.55 & 4.4 & 0.073 & 0.4 & 0.26 & 456 & 21 & 444 & 28 & 340 & 120 & 456 & 21 & NA \\
\hline 12JT23_3 & 237 & 3.4 & 0.056 & 0.300 & 0.2 & 0.57 & 4.1 & 0.073 & 0.4 & 0.11 & 456 & 21 & 459 & 27 & 420 & 110 & 456 & 21 & NA \\
\hline 12JT23_37 & 337 & 2.4 & 0.055 & 0.290 & 0.2 & 0.55 & 3.9 & 0.073 & 0.4 & 0.29 & 456 & 21 & 445 & 25 & 420 & 110 & 456 & 21 & NA \\
\hline 12JT23_20 & 153 & 2.3 & 0.056 & 0.340 & 0.3 & 0.55 & 4.2 & 0.074 & 0.4 & 0.11 & 458 & 21 & 444 & 27 & 410 & 120 & 458 & 21 & NA \\
\hline 12JT23_23 & 367 & 4.6 & 0.054 & 0.270 & 0.3 & 0.56 & 3.9 & 0.074 & 0.3 & 0.13 & 458 & 21 & 448 & 25 & 340 & 110 & 458 & 21 & NA \\
\hline 12JT23_65 & 459 & 2.3 & 0.055 & 0.270 & 0.3 & 0.55 & 3.8 & 0.074 & 0.3 & 0.22 & 458 & 21 & 444 & 25 & 400 & 110 & 458 & 21 & NA \\
\hline 12JT23_49 & 84 & 5.1 & 0.058 & 0.430 & 0.2 & 0.62 & 5.5 & 0.075 & 0.4 & 0.13 & 467 & 22 & 483 & 35 & 440 & 150 & 467 & 22 & NA \\
\hline 12JT23_45 & 117 & 3.8 & 0.058 & 0.370 & 0.3 & 0.60 & 4.7 & 0.075 & 0.4 & 0.12 & 467 & 22 & 475 & 31 & 470 & 130 & 467 & 22 & NA \\
\hline 12JT23_6 & 857 & 2.0 & 0.058 & 0.270 & 0.2 & 0.59 & 3.9 & 0.075 & 0.4 & 0.33 & 467 & 21 & 469 & 26 & 510 & 110 & 467 & 21 & NA \\
\hline 12JT23_8 & 650 & 2.4 & 0.057 & 0.280 & 0.2 & 0.58 & 3.9 & 0.076 & 0.4 & 0.27 & 469 & 21 & 461 & 25 & 480 & 110 & 469 & 21 & NA \\
\hline 12JT23_14 & 253 & 2.2 & 0.055 & 0.310 & 0.3 & 0.56 & 4.0 & 0.076 & 0.4 & 0.08 & 472 & 21 & 450 & 27 & 420 & 120 & 472 & 21 & NA \\
\hline 12JT23_70 & 407 & 1.7 & 0.056 & 0.280 & 0.3 & 0.58 & 4.0 & 0.076 & 0.4 & 0.24 & 472 & 21 & 466 & 26 & 420 & 110 & 472 & 21 & NA \\
\hline 12JT23_85 & 627 & 2.9 & 0.055 & 0.270 & 0.3 & 0.56 & 3.8 & 0.076 & 0.4 & 0.26 & 474 & 21 & 454 & 25 & 430 & 110 & 474 & 21 & NA \\
\hline 12JT23_38 & 654 & 1.6 & 0.057 & 0.280 & 0.2 & 0.59 & 4.0 & 0.077 & 0.4 & 0.31 & 475 & 21 & 472 & 26 & 490 & 110 & 475 & 21 & NA \\
\hline 12JT23_61 & 629 & 1.6 & 0.057 & 0.280 & 0.3 & 0.58 & 4.0 & 0.077 & 0.4 & 0.26 & 476 & 21 & 464 & 25 & 480 & 110 & 476 & 21 & NA \\
\hline 12JT23_15 & 193 & 2.9 & 0.058 & 0.320 & 0.3 & 0.58 & 4.3 & 0.077 & 0.4 & 0.15 & 477 & 22 & 470 & 27 & 510 & 120 & 477 & 22 & NA \\
\hline 12JT23_13 & 201 & 3.4 & 0.057 & 0.330 & 0.3 & 0.59 & 4.3 & 0.077 & 0.4 & 0.18 & 477 & 22 & 469 & 27 & 480 & 120 & 477 & 22 & NA \\
\hline 12JT23_54 & 466 & 2.0 & 0.055 & 0.280 & 0.2 & 0.58 & 4.0 & 0.077 & 0.4 & 0.27 & 478 & 22 & 465 & 26 & 400 & 110 & 478 & 22 & NA \\
\hline
\end{tabular}


TABLE SM2.3: LA-ICPMS U-PB ISOTOPIC DATA (UC SANTA CRUZ LAB)

\begin{tabular}{|c|c|c|c|c|c|c|c|c|c|c|c|c|c|c|c|c|c|c|c|}
\hline \multirow[b]{2}{*}{ Analysis } & \multirow[b]{2}{*}{$U$} & \multirow[b]{2}{*}{ U/Th } & \multirow[b]{2}{*}{$206 \mathrm{~Pb}^{*}$} & \multirow[b]{2}{*}{ \pm} & \multirow[b]{2}{*}{ error } & \multicolumn{5}{|c|}{ Isotope ratios } & \multicolumn{6}{|c|}{ Apparent ages (Ma) } & \multirow[b]{2}{*}{ Best age } & \multirow[b]{2}{*}{ \pm} & \multirow[b]{2}{*}{ Conc } \\
\hline & & & & & & 207Pb* & \pm & $206 \mathrm{~Pb}^{*}$ & \pm & error & $206 \mathrm{~Pb}^{*}$ & \pm & $207 \mathrm{~Pb}^{*}$ & \pm & $206 \mathrm{~Pb}^{\star}$ & \pm & & & \\
\hline & (ppm) & & $207 \mathrm{~Pb}^{\star}$ & (\%) & corr. & $235 U^{*}$ & (\%) & $238 U$ & (\%) & corr. & $238 U^{*}$ & (Ma) & $235 U$ & (Ma) & $207 \mathrm{~Pb}^{*}$ & $(\mathrm{Ma})$ & (Ma) & (Ma) & (\%) \\
\hline 12JT23_17 & 426 & 2.3 & 0.053 & 0.270 & 0.2 & 0.55 & 3.8 & 0.077 & 0.4 & 0.30 & 479 & 21 & 444 & 24 & 340 & 110 & 479 & 21 & NA \\
\hline 12JT23_62 & 776 & 2.9 & 0.056 & 0.270 & 0.2 & 0.58 & 3.9 & 0.078 & 0.4 & 0.40 & 482 & 22 & 463 & 25 & 430 & 110 & 482 & 22 & NA \\
\hline 12JT23_31 & 88 & 3.0 & 0.055 & 0.400 & 0.3 & 0.59 & 4.9 & 0.078 & 0.4 & 0.01 & 483 & 23 & 466 & 31 & 350 & 140 & 483 & 23 & NA \\
\hline 12JT23_9 & 626 & 3.6 & 0.056 & 0.280 & 0.2 & 0.58 & 4.0 & 0.078 & 0.4 & 0.38 & 483 & 22 & 460 & 26 & 420 & 110 & 483 & 22 & NA \\
\hline 12JT23_51 & 533 & 2.0 & 0.055 & 0.270 & 0.1 & 0.60 & 4.1 & 0.078 & 0.4 & 0.38 & 484 & 22 & 473 & 26 & 390 & 110 & 484 & 22 & NA \\
\hline 12JT23_83 & 261 & 2.8 & 0.056 & 0.300 & 0.2 & 0.61 & 4.3 & 0.080 & 0.4 & 0.21 & 498 & 23 & 479 & 27 & 420 & 120 & 498 & 23 & NA \\
\hline 12JT23_16 & 385 & 1.4 & 0.059 & 0.310 & 0.2 & 0.72 & 5.1 & 0.092 & 0.4 & 0.22 & 569 & 26 & 548 & 30 & 550 & 120 & 569 & 26 & NA \\
\hline 12JT23_78 & 47 & 2.0 & 0.060 & 0.470 & 0.3 & 0.83 & 7.7 & 0.097 & 0.5 & 0.22 & 595 & 30 & 605 & 40 & 540 & 150 & 595 & 30 & NA \\
\hline 12JT23_84 & 41 & 2.1 & 0.064 & 0.480 & 0.4 & 0.85 & 7.6 & 0.100 & 0.5 & 0.17 & 614 & 31 & 611 & 42 & 590 & 150 & 614 & 31 & 104 \\
\hline 12JT23_93 & 475 & 2.1 & 0.063 & 0.300 & 0.2 & 0.95 & 6.5 & 0.105 & 0.5 & 0.26 & 644 & 29 & 675 & 34 & 700 & 100 & 644 & 29 & 92 \\
\hline 12JT23_11 & 905 & 22.7 & 0.070 & 0.320 & 0.0 & 1.40 & 9.3 & 0.150 & 0.7 & 0.62 & 904 & 40 & 886 & 40 & 934 & 98 & 904 & 40 & 97 \\
\hline 12JT23_86 & 892 & 30.0 & 0.078 & 0.350 & 0.1 & 1.98 & 13.0 & 0.188 & 0.9 & 0.80 & 1109 & 48 & 1105 & 46 & 1146 & 93 & 1146 & 93 & 97 \\
\hline 12JT23_32 & 177 & 3.2 & 0.112 & 0.520 & 0.2 & 5.04 & 34.0 & 0.326 & 1.5 & 0.56 & 1817 & 73 & 1826 & 57 & 1827 & 85 & 1827 & 85 & 99 \\
\hline 12JT23_47 & 30 & 0.6 & 0.187 & 0.910 & 0.3 & 13.82 & 95.0 & 0.533 & 2.6 & 0.56 & 2750 & 110 & 2738 & 67 & 2723 & 82 & 2723 & 82 & 101 \\
\hline \multicolumn{20}{|c|}{$>20 \%$ Discordance } \\
\hline 12JT23_109 & 284 & 3.4 & 0.063 & 0.360 & 0.3 & 0.49 & 3.7 & 0.056 & 0.3 & 0.14 & 353 & 16 & 406 & 25 & 690 & 120 & 353 & 16 & NA \\
\hline 12JT23_19 & 113 & 2.8 & 0.086 & 0.550 & 0.3 & 0.90 & 7.2 & 0.079 & 0.4 & 0.13 & 490 & 23 & 647 & 39 & 1280 & 130 & 490 & 23 & NA \\
\hline \multicolumn{20}{|c|}{$>5 \%$ Reverse Discordance } \\
\hline 12JT23_52 & 44 & 1.6 & 0.061 & 0.450 & 0.3 & 0.87 & 7.5 & 0.101 & 0.5 & 0.22 & 621 & 31 & 626 & 41 & 540 & 150 & 621 & 31 & 115 \\
\hline 12JT23_101 & 34 & 3.2 & 0.065 & 0.470 & 0.3 & 1.33 & 11.0 & 0.149 & 0.8 & 0.17 & 896 & 43 & 847 & 51 & 690 & 150 & 896 & 43 & 130 \\
\hline 12JT23_76 & 208 & 0.8 & 0.100 & 0.470 & 0.1 & 4.28 & 29.0 & 0.303 & 1.4 & 0.66 & 1706 & 71 & 1692 & 55 & 1621 & 87 & 1621 & 87 & 105 \\
\hline \multicolumn{20}{|c|}{$>1000 \cup \mathrm{ppm}$} \\
\hline 12JT23_71 & 1946 & 87.5 & 0.055 & 0.280 & 0.4 & 0.32 & 2.2 & 0.042 & 0.2 & 0.17 & 264 & 12 & 285 & 18 & 410 & 110 & 264 & 12 & NA \\
\hline 12JT23_35 & 1737 & 3.6 & 0.078 & 0.370 & 0.4 & 0.48 & 3.2 & 0.046 & 0.2 & 0.49 & 288 & 14 & 396 & 22 & 1149 & 95 & 288 & 14 & NA \\
\hline 12JT23_43 & 2721 & 6.2 & 0.055 & 0.260 & 0.2 & 0.45 & 3.0 & 0.059 & 0.3 & 0.52 & 368 & 17 & 378 & 21 & 420 & 100 & 368 & 17 & NA \\
\hline
\end{tabular}


TABLE SM2.3: LA-ICPMS U-PB ISOTOPIC DATA (UC SANTA CRUZ LAB)

\begin{tabular}{|c|c|c|c|c|c|c|c|c|c|c|c|c|c|c|c|c|c|c|c|}
\hline \multirow[b]{2}{*}{ Analysis } & \multirow[b]{2}{*}{$U$} & \multirow[b]{2}{*}{ U/Th } & \multirow[b]{2}{*}{$206 \mathrm{~Pb}^{*}$} & \multirow[b]{2}{*}{ \pm} & \multirow[b]{2}{*}{ error } & \multicolumn{5}{|c|}{ Isotope ratios } & \multicolumn{6}{|c|}{ Apparent ages (Ma) } & \multirow[b]{2}{*}{ Best age } & \multirow[b]{2}{*}{ \pm} & \multirow[b]{2}{*}{ Conc } \\
\hline & & & & & & $207 \mathrm{~Pb}^{*}$ & \pm & $206 \mathrm{~Pb}^{*}$ & \pm & error & $206 \mathrm{~Pb}^{\star}$ & \pm & $207 \mathrm{~Pb}^{*}$ & \pm & $206 \mathrm{~Pb}^{*}$ & \pm & & & \\
\hline & (ppm) & & $207 \mathrm{~Pb}^{*}$ & $(\%)$ & corr. & $235 U^{*}$ & $(\%)$ & $238 U$ & $(\%)$ & corr. & $238 U^{*}$ & (Ma) & $235 \mathrm{U}$ & (Ma) & $207 \mathrm{~Pb}^{*}$ & (Ma) & (Ma) & (Ma) & $(\%)$ \\
\hline 12JT23_34 & 1261 & 2.0 & 0.055 & 0.270 & 0.3 & 0.49 & 3.3 & 0.065 & 0.3 & 0.46 & 407 & 19 & 401 & 23 & 380 & 110 & 407 & 19 & NA \\
\hline 12JT23_4 & 1664 & 1.7 & 0.057 & 0.260 & 0.2 & 0.52 & 3.4 & 0.067 & 0.3 & 0.38 & 417 & 19 & 426 & 23 & 480 & 100 & 417 & 19 & NA \\
\hline 12JT23_7 & 1136 & 2.2 & 0.055 & 0.260 & 0.2 & 0.52 & 3.5 & 0.070 & 0.3 & 0.36 & 434 & 19 & 424 & 23 & 420 & 110 & 434 & 19 & NA \\
\hline \multicolumn{20}{|c|}{ 12JT24; Clarence River Group (N69.28, W141.75) } \\
\hline 12JT24_8 & 328 & 1.7 & 0.116 & 0.300 & -0.4 & 5.68 & 17.0 & 0.352 & 0.8 & 0.97 & 1941 & 36 & 1926 & 28 & 1898 & 47 & 1898 & 47 & 102 \\
\hline 12JT24_17 & 135 & 0.8 & 0.117 & 0.310 & 0.3 & 5.43 & 15.0 & 0.338 & 0.7 & 0.62 & 1879 & 31 & 1889 & 24 & 1911 & 48 & 1911 & 48 & 98 \\
\hline 12JT24_12 & 137 & 0.9 & 0.117 & 0.310 & 0.3 & 5.44 & 16.0 & 0.337 & 0.6 & 0.56 & 1872 & 31 & 1892 & 24 & 1912 & 47 & 1912 & 47 & 98 \\
\hline 12JT24_6 & 215 & 1.1 & 0.118 & 0.310 & 0.3 & 5.66 & 16.0 & 0.349 & 0.7 & 0.55 & 1930 & 31 & 1925 & 25 & 1920 & 47 & 1920 & 47 & 101 \\
\hline 12JT24_18 & 187 & 0.8 & 0.118 & 0.310 & 0.1 & 5.36 & 16.0 & 0.331 & 0.7 & 0.88 & 1843 & 34 & 1876 & 26 & 1921 & 47 & 1921 & 47 & 96 \\
\hline 12JT24_25 & 95 & 0.9 & 0.120 & 0.330 & 0.1 & 5.07 & 16.0 & 0.309 & 0.6 & 0.61 & 1737 & 31 & 1830 & 26 & 1948 & 50 & 1948 & 50 & 89 \\
\hline 12JT24_1 & 233 & 1.1 & 0.122 & 0.320 & 0.2 & 6.19 & 17.0 & 0.370 & 0.7 & 0.61 & 2029 & 33 & 2003 & 25 & 1978 & 47 & 1978 & 47 & 103 \\
\hline 12JT24_15 & 87 & 1.0 & 0.126 & 0.340 & 0.2 & 6.28 & 18.0 & 0.364 & 0.7 & 0.53 & 2000 & 34 & 2016 & 26 & 2034 & 47 & 2034 & 47 & 98 \\
\hline 12JT24_4 & 193 & 1.3 & 0.136 & 0.360 & 0.1 & 7.35 & 21.0 & 0.391 & 0.8 & 0.73 & 2126 & 35 & 2155 & 26 & 2181 & 46 & 2181 & 46 & 97 \\
\hline 12JT24_14 & 430 & 1.0 & 0.151 & 0.390 & 0.2 & 9.40 & 26.0 & 0.452 & 0.8 & 0.72 & 2403 & 37 & 2377 & 26 & 2357 & 44 & 2357 & 44 & 102 \\
\hline 12JT24_24 & 221 & 2.1 & 0.159 & 0.420 & -0.2 & 9.33 & 28.0 & 0.425 & 0.9 & 0.89 & 2281 & 38 & 2370 & 28 & 2443 & 45 & 2443 & 45 & 93 \\
\hline 12JT24_5 & 344 & 1.6 & 0.162 & 0.420 & 0.3 & 10.43 & 29.0 & 0.468 & 0.9 & 0.68 & 2476 & 38 & 2474 & 26 & 2474 & 44 & 2474 & 44 & 100 \\
\hline 12JT24_2 & 382 & 2.0 & 0.168 & 0.440 & 0.0 & 11.04 & 32.0 & 0.477 & 1.0 & 0.92 & 2512 & 42 & 2525 & 27 & 2535 & 43 & 2535 & 43 & 99 \\
\hline 12JT24_23 & 133 & 1.6 & 0.178 & 0.470 & 0.0 & 11.94 & 35.0 & 0.488 & 1.0 & 0.88 & 2560 & 42 & 2597 & 28 & 2633 & 44 & 2633 & 44 & 97 \\
\hline 12JT24_11 & 183 & 1.3 & 0.186 & 0.480 & 0.3 & 13.75 & 39.0 & 0.538 & 1.0 & 0.75 & 2775 & 43 & 2733 & 26 & 2706 & 43 & 2706 & 43 & 103 \\
\hline 12JT24_22 & 3 & 0.9 & 0.289 & 3.700 & 0.0 & 27.40 & 770.0 & 0.700 & 16.0 & 0.72 & 2960 & 510 & 2780 & 240 & 3230 & 210 & 3230 & 210 & 92 \\
\hline \multicolumn{20}{|c|}{$>20 \%$ Discordance } \\
\hline 12JT24_9 & 945 & 2.1 & 0.147 & 0.380 & -0.6 & 5.66 & 24.0 & 0.283 & 1.0 & 0.99 & 1602 & 50 & 1915 & 35 & 2308 & 44 & 2308 & 44 & 69 \\
\hline 12JT24_20 & 749 & 0.7 & 0.161 & 0.430 & 0.8 & 5.58 & 16.0 & 0.252 & 0.6 & 0.85 & 1449 & 29 & 1914 & 25 & 2467 & 46 & 2467 & 46 & 59 \\
\hline 12JT24_7 & 407 & 0.9 & 0.217 & 0.580 & -0.8 & 12.60 & 64.0 & 0.419 & 1.8 & 0.99 & 2232 & 79 & 2606 & 49 & 2955 & 43 & 2955 & 43 & 76 \\
\hline
\end{tabular}


TABLE SM2.3: LA-ICPMS U-PB ISOTOPIC DATA (UC SANTA CRUZ LAB)

\begin{tabular}{|c|c|c|c|c|c|c|c|c|c|c|c|c|c|c|c|c|c|c|c|}
\hline \multirow[b]{2}{*}{ Analysis } & \multirow[b]{2}{*}{$U$} & \multirow[b]{2}{*}{ U/Th } & \multirow[b]{2}{*}{$206 \mathrm{~Pb}^{*}$} & \multirow[b]{2}{*}{ \pm} & \multirow[b]{2}{*}{ error } & \multicolumn{5}{|c|}{ Isotope ratios } & \multicolumn{6}{|c|}{ Apparent ages (Ma) } & \multirow[b]{2}{*}{ Best age } & \multirow[b]{2}{*}{ \pm} & \multirow[b]{2}{*}{ Conc } \\
\hline & & & & & & $207 \mathrm{~Pb}^{\star}$ & \pm & $206 \mathrm{~Pb}^{*}$ & \pm & error & $206 \mathrm{~Pb}^{\star}$ & \pm & $207 \mathrm{~Pb}^{*}$ & \pm & $206 \mathrm{~Pb}^{*}$ & \pm & & & \\
\hline & $(\mathrm{ppm})$ & & $207 \mathrm{~Pb}^{\star}$ & (\%) & corr. & $235 U^{*}$ & $(\%)$ & $238 U$ & (\%) & corr. & $238 U^{*}$ & (Ma) & $235 \mathrm{U}$ & (Ma) & $207 \mathrm{~Pb}^{*}$ & (Ma) & (Ma) & (Ma) & $(\%)$ \\
\hline$>1000 \mathrm{Uppr}$ & 89 & 0.3 & 0.111 & 0.300 & 0.2 & 5.33 & 16.0 & 0.350 & 0.7 & 0.64 & 1933 & 33 & 1874 & 25 & 1813 & 48 & 1813 & 48 & 107 \\
\hline 12JT24_3 & 1208 & 1.6 & 0.133 & 0.350 & -0.6 & 3.09 & 11.0 & 0.167 & 0.4 & 0.98 & 994 & 23 & 1426 & 26 & 2139 & 45 & 994 & 23 & 46 \\
\hline 12JT24_21 & 1136 & 1.8 & 0.114 & 0.300 & -0.9 & 4.01 & 14.0 & 0.254 & 0.6 & 0.99 & 1456 & 34 & 1621 & 35 & 1857 & 48 & 1857 & 48 & 78 \\
\hline 12JT24_16 & 1121 & 4.1 & 0.130 & 0.350 & -0.9 & 4.47 & 24.0 & 0.248 & 1.1 & 1.00 & 1421 & 56 & 1705 & 47 & 2092 & 48 & 2092 & 48 & 68 \\
\hline 12JT24_19 & 1022 & 6.8 & 0.139 & 0.360 & -0.7 & 6.25 & 22.0 & 0.326 & 0.8 & 0.99 & 1818 & 40 & 2005 & 31 & 2211 & 46 & 2211 & 46 & 82 \\
\hline $\begin{array}{l}\text { 12JT24_10 } \\
\text { 12JT35; Cla }\end{array}$ & $\begin{array}{l}1113 \\
\text { nce Riv }\end{array}$ & Group & 0.146 & $\begin{array}{l}0.380 \\
141.47)\end{array}$ & -0.8 & 5.70 & 19.0 & 0.284 & 0.7 & 0.99 & 1609 & 34 & 1934 & 29 & 2300 & 45 & 2300 & 45 & 70 \\
\hline 12JT35_55 & 315 & 0.6 & 0.059 & 0.140 & 0.2 & 0.58 & 2.8 & 0.071 & 0.3 & 0.47 & 442 & 19 & 465 & 18 & 576 & 52 & 442 & 19 & NA \\
\hline 12JT35_38 & 50 & 0.7 & 0.066 & 0.220 & 0.1 & 0.65 & 3.5 & 0.072 & 0.3 & 0.48 & 447 & 20 & 508 & 21 & 770 & 71 & 447 & 20 & NA \\
\hline 12JT35_46 & 152 & 0.5 & 0.058 & 0.160 & 0.0 & 0.58 & 2.9 & 0.072 & 0.3 & 0.41 & 449 & 20 & 462 & 18 & 519 & 55 & 449 & 20 & NA \\
\hline 12JT35_88 & 36 & 0.5 & 0.060 & 0.310 & 0.1 & 0.59 & 4.0 & 0.072 & 0.4 & 0.21 & 450 & 21 & 472 & 26 & 520 & 110 & 450 & 21 & NA \\
\hline 12JT35_57 & 7 & 4.3 & 0.059 & 0.410 & 0.2 & 0.61 & 4.8 & 0.073 & 0.4 & 0.22 & 454 & 23 & 478 & 30 & 510 & 130 & 454 & 23 & NA \\
\hline 12JT35_2 & 87 & 3.1 & 0.059 & 0.170 & 0.2 & 0.59 & 3.0 & 0.073 & 0.3 & 0.35 & 454 & 20 & 472 & 19 & 533 & 64 & 454 & 20 & NA \\
\hline 12JT35_62 & 343 & 1.1 & 0.059 & 0.140 & 0.2 & 0.60 & 2.8 & 0.073 & 0.3 & 0.38 & 454 & 19 & 474 & 18 & 564 & 52 & 454 & 19 & NA \\
\hline 12JT35_69 & 429 & 0.6 & 0.059 & 0.140 & -0.3 & 0.60 & 2.8 & 0.073 & 0.3 & 0.65 & 456 & 19 & 476 & 18 & 548 & 50 & 456 & 19 & NA \\
\hline 12JT35_34 & 142 & 0.3 & 0.059 & 0.180 & 0.2 & 0.59 & 3.3 & 0.075 & 0.4 & 0.66 & 468 & 24 & 471 & 21 & 542 & 66 & 468 & 24 & NA \\
\hline 12JT35_26 & 547 & 1.3 & 0.059 & 0.140 & 0.3 & 0.61 & 2.9 & 0.076 & 0.3 & 0.40 & 469 & 20 & 485 & 18 & 549 & 53 & 469 & 20 & NA \\
\hline 12JT35_44 & 155 & 3.6 & 0.056 & 0.140 & 0.0 & 0.59 & 2.9 & 0.076 & 0.3 & 0.49 & 471 & 20 & 471 & 18 & 455 & 57 & 471 & 20 & NA \\
\hline 12JT35_89 & 31 & 2.8 & 0.060 & 0.250 & 0.3 & 0.64 & 3.7 & 0.076 & 0.4 & 0.23 & 474 & 21 & 500 & 23 & 569 & 86 & 474 & 21 & NA \\
\hline 12JT35_43 & 585 & 0.3 & 0.059 & 0.130 & 0.3 & 0.63 & 3.0 & 0.077 & 0.3 & 0.45 & 479 & 20 & 498 & 18 & 571 & 49 & 479 & 20 & NA \\
\hline 12JT35_42 & 375 & 0.8 & 0.057 & 0.130 & 0.2 & 0.62 & 2.9 & 0.078 & 0.4 & 0.40 & 483 & 21 & 490 & 18 & 497 & 50 & 483 & 21 & NA \\
\hline 12JT35_15 & 67 & 0.8 & 0.062 & 0.190 & 0.2 & 0.66 & 3.4 & 0.078 & 0.4 & 0.25 & 484 & 21 & 515 & 21 & 655 & 68 & 484 & 21 & NA \\
\hline 12JT35_85 & 221 & 1.2 & 0.058 & 0.140 & 0.1 & 0.63 & 3.1 & 0.079 & 0.4 & 0.42 & 488 & 21 & 498 & 19 & 517 & 52 & 488 & 21 & NA \\
\hline 12JT35_41 & 295 & 2.6 & 0.058 & 0.140 & 0.3 & 0.64 & 3.0 & 0.079 & 0.4 & 0.28 & 490 & 21 & 500 & 19 & 538 & 51 & 490 & 21 & NA \\
\hline 12JT35_12 & 42 & 0.0 & 0.059 & 0.230 & 0.2 & 0.64 & 3.7 & 0.079 & 0.4 & 0.30 & 492 & 22 & 498 & 22 & 515 & 86 & 492 & 22 & NA \\
\hline
\end{tabular}


TABLE SM2.3: LA-ICPMS U-PB ISOTOPIC DATA (UC SANTA CRUZ LAB)

\begin{tabular}{|c|c|c|c|c|c|c|c|c|c|c|c|c|c|c|c|c|c|c|c|}
\hline \multirow[b]{2}{*}{ Analysis } & \multirow[b]{2}{*}{$U$} & \multirow[b]{2}{*}{$\mathrm{U} / \mathrm{Th}$} & \multirow[b]{2}{*}{$206 \mathrm{~Pb}^{*}$} & \multirow[b]{2}{*}{ \pm} & \multirow[b]{2}{*}{ error } & \multicolumn{5}{|c|}{ Isotope ratios } & \multicolumn{6}{|c|}{ Apparent ages (Ma) } & \multirow[b]{2}{*}{ Best age } & \multirow[b]{2}{*}{ \pm} & \multirow[b]{2}{*}{ Conc } \\
\hline & & & & & & $207 \mathrm{~Pb}^{*}$ & \pm & $206 \mathrm{~Pb}^{*}$ & \pm & error & $206 \mathrm{~Pb}^{*}$ & \pm & $207 \mathrm{~Pb}^{*}$ & \pm & $206 \mathrm{~Pb}^{\star}$ & \pm & & & \\
\hline & (ppm) & & $207 \mathrm{~Pb}^{\star}$ & (\%) & corr. & $235 U^{*}$ & $(\%)$ & $238 \mathrm{U}$ & (\%) & corr. & $238 U^{*}$ & (Ma) & $235 U$ & (Ma) & $207 \mathrm{~Pb}^{*}$ & $(\mathrm{Ma})$ & (Ma) & (Ma) & $(\%)$ \\
\hline 12JT35_87 & 83 & 0.9 & 0.056 & 0.160 & 0.2 & 0.61 & 3.1 & 0.079 & 0.4 & 0.19 & 492 & 21 & 483 & 19 & 422 & 64 & 492 & 21 & NA \\
\hline 12JT35_21 & 25 & 3.3 & 0.058 & 0.250 & 0.3 & 0.63 & 3.6 & 0.080 & 0.4 & 0.06 & 493 & 21 & 489 & 23 & 477 & 88 & 493 & 21 & NA \\
\hline 12JT35_61 & 178 & 0.4 & 0.058 & 0.150 & 0.3 & 0.63 & 3.0 & 0.080 & 0.4 & 0.29 & 493 & 21 & 494 & 19 & 511 & 56 & 493 & 21 & NA \\
\hline 12JT35_8 & 52 & 0.6 & 0.059 & 0.200 & 0.3 & 0.66 & 3.5 & 0.080 & 0.4 & 0.17 & 494 & 22 & 510 & 21 & 570 & 74 & 494 & 22 & NA \\
\hline 12JT35_35 & 289 & 0.7 & 0.059 & 0.140 & 0.2 & 0.65 & 3.1 & 0.080 & 0.4 & 0.33 & 494 & 21 & 506 & 19 & 549 & 53 & 494 & 21 & NA \\
\hline 12JT35_25 & 20 & 0.2 & 0.060 & 0.320 & 0.1 & 0.66 & 4.5 & 0.080 & 0.4 & 0.33 & 499 & 23 & 509 & 27 & 520 & 110 & 499 & 23 & NA \\
\hline 12JT35_18 & 215 & 1.0 & 0.059 & 0.160 & 0.2 & 0.65 & 3.3 & 0.081 & 0.4 & 0.29 & 499 & 22 & 510 & 20 & 554 & 61 & 499 & 22 & NA \\
\hline 12JT35_99 & 526 & 0.4 & 0.059 & 0.130 & 0.1 & 0.66 & 3.1 & 0.080 & 0.4 & 0.62 & 499 & 22 & 514 & 19 & 570 & 50 & 499 & 22 & NA \\
\hline 12JT35_30 & 48 & 1.0 & 0.060 & 0.230 & 0.1 & 0.65 & 4.2 & 0.080 & 0.5 & 0.62 & 501 & 27 & 512 & 26 & 561 & 83 & 501 & 27 & NA \\
\hline 12JT35_23 & 108 & 1.7 & 0.056 & 0.200 & 0.3 & 0.63 & 3.3 & 0.081 & 0.4 & 0.17 & 504 & 22 & 495 & 21 & 451 & 79 & 504 & 22 & NA \\
\hline 12JT35_24 & 67 & 0.4 & 0.062 & 0.250 & 0.0 & 0.71 & 4.5 & 0.081 & 0.4 & 0.64 & 505 & 25 & 542 & 26 & 671 & 87 & 505 & 25 & NA \\
\hline 12JT35_100 & 112 & 0.3 & 0.057 & 0.150 & 0.2 & 0.64 & 3.1 & 0.081 & 0.4 & 0.33 & 505 & 21 & 501 & 19 & 490 & 58 & 505 & 21 & NA \\
\hline 12JT35_6 & 115 & 0.9 & 0.058 & 0.170 & 0.1 & 0.65 & 3.3 & 0.081 & 0.4 & 0.41 & 505 & 22 & 507 & 20 & 507 & 65 & 505 & 22 & NA \\
\hline 12JT35_3 & 773 & 0.8 & 0.058 & 0.130 & 0.3 & 0.65 & 3.1 & 0.082 & 0.4 & 0.47 & 505 & 22 & 510 & 19 & 515 & 50 & 505 & 22 & NA \\
\hline 12JT35_58 & 60 & 0.0 & 0.056 & 0.180 & 0.2 & 0.63 & 3.3 & 0.082 & 0.4 & 0.29 & 506 & 22 & 497 & 20 & 446 & 68 & 506 & 22 & NA \\
\hline 12JT35_91 & 84 & 0.6 & 0.066 & 0.210 & 0.1 & 0.76 & 3.9 & 0.082 & 0.4 & 0.32 & 506 & 22 & 571 & 23 & 797 & 67 & 506 & 22 & NA \\
\hline 12JT35_70 & 144 & 4.6 & 0.057 & 0.150 & 0.2 & 0.65 & 3.1 & 0.082 & 0.4 & 0.29 & 506 & 21 & 505 & 19 & 493 & 55 & 506 & 21 & NA \\
\hline 12JT35_16 & 158 & 6.0 & 0.057 & 0.150 & 0.1 & 0.65 & 3.2 & 0.082 & 0.4 & 0.51 & 507 & 22 & 510 & 19 & 495 & 55 & 507 & 22 & NA \\
\hline 12JT35_14 & 617 & 0.8 & 0.058 & 0.130 & 0.2 & 0.65 & 3.0 & 0.082 & 0.4 & 0.46 & 507 & 22 & 509 & 19 & 507 & 49 & 507 & 22 & NA \\
\hline 12JT35_31 & 135 & 0.2 & 0.057 & 0.160 & 0.3 & 0.64 & 3.2 & 0.082 & 0.4 & 0.26 & 508 & 22 & 502 & 20 & 481 & 61 & 508 & 22 & NA \\
\hline 12JT35_10 & 52 & 0.1 & 0.058 & 0.190 & 0.4 & 0.66 & 3.4 & 0.082 & 0.4 & -0.01 & 509 & 22 & 512 & 21 & 505 & 71 & 509 & 22 & NA \\
\hline 12JT35_93 & 62 & 0.1 & 0.061 & 0.190 & 0.2 & 0.68 & 3.6 & 0.082 & 0.4 & 0.53 & 509 & 23 & 527 & 21 & 608 & 65 & 509 & 23 & NA \\
\hline 12JT35_78 & 14 & 2.9 & 0.059 & 0.370 & 0.1 & 0.64 & 4.8 & 0.082 & 0.4 & 0.28 & 510 & 25 & 499 & 30 & 470 & 120 & 510 & 25 & NA \\
\hline 12JT35_11 & 322 & 0.5 & 0.060 & 0.140 & 0.0 & 0.68 & 3.3 & 0.082 & 0.4 & 0.51 & 510 & 22 & 529 & 19 & 601 & 52 & 510 & 22 & NA \\
\hline 12JT35_77 & 35 & 0.2 & 0.058 & 0.230 & 0.3 & 0.66 & 3.7 & 0.082 & 0.4 & 0.28 & 511 & 23 & 516 & 23 & 526 & 81 & 511 & 23 & NA \\
\hline 12JT35_73 & 54 & 0.0 & 0.056 & 0.250 & 0.0 & 0.65 & 4.1 & 0.082 & 0.4 & 0.35 & 511 & 23 & 506 & 25 & 475 & 96 & 511 & 23 & NA \\
\hline 12JT35_52 & 189 & 0.7 & 0.060 & 0.150 & 0.2 & 0.69 & 3.3 & 0.083 & 0.4 & 0.31 & 511 & 22 & 533 & 20 & 608 & 52 & 511 & 22 & NA \\
\hline 12JT35_27 & 8 & 2.1 & 0.059 & 0.390 & 0.2 & 0.68 & 5.3 & 0.082 & 0.4 & 0.18 & 512 & 25 & 511 & 32 & 470 & 130 & 512 & 25 & NA \\
\hline
\end{tabular}


TABLE SM2.3: LA-ICPMS U-PB ISOTOPIC DATA (UC SANTA CRUZ LAB)

\begin{tabular}{|c|c|c|c|c|c|c|c|c|c|c|c|c|c|c|c|c|c|c|c|}
\hline \multirow[b]{2}{*}{ Analysis } & \multirow[b]{2}{*}{$\mathrm{U}$} & \multirow[b]{2}{*}{$\mathrm{U} / \mathrm{Th}$} & \multirow[b]{2}{*}{$206 \mathrm{~Pb}^{*}$} & \multirow[b]{2}{*}{ \pm} & \multirow[b]{2}{*}{ error } & \multicolumn{5}{|c|}{ Isotope ratios } & \multicolumn{6}{|c|}{ Apparent ages (Ma) } & \multirow[b]{2}{*}{ Best age } & \multirow[b]{2}{*}{ \pm} & \multirow[b]{2}{*}{ Conc } \\
\hline & & & & & & $207 \mathrm{~Pb}^{*}$ & \pm & $206 \mathrm{~Pb}^{*}$ & \pm & error & $206 \mathrm{~Pb}^{*}$ & \pm & $207 \mathrm{~Pb}^{*}$ & \pm & $206 \mathrm{~Pb}^{*}$ & \pm & & & \\
\hline & (ppm) & & $207 \mathrm{~Pb}^{*}$ & $(\%)$ & corr. & $235 U^{*}$ & $(\%)$ & $238 U$ & (\%) & corr. & $238 U^{*}$ & $(\mathrm{Ma})$ & $235 \mathrm{U}$ & (Ma) & $207 \mathrm{~Pb}^{*}$ & $(\mathrm{Ma})$ & (Ma) & (Ma) & (\%) \\
\hline 12JT35_47 & 98 & 0.8 & 0.057 & 0.160 & 0.2 & 0.65 & 3.2 & 0.083 & 0.4 & 0.31 & 514 & 22 & 508 & 20 & 481 & 59 & 514 & 22 & NA \\
\hline 12JT35_97 & 18 & 4.1 & 0.056 & 0.270 & 0.2 & 0.65 & 4.1 & 0.084 & 0.4 & 0.19 & 519 & 24 & 507 & 25 & 408 & 97 & 519 & 24 & NA \\
\hline 12JT35_17 & 106 & 0.5 & 0.057 & 0.190 & 0.1 & 0.66 & 3.5 & 0.084 & 0.4 & 0.47 & 519 & 23 & 512 & 22 & 465 & 75 & 519 & 23 & NA \\
\hline 12JT35_63 & 139 & 2.3 & 0.060 & 0.160 & 0.1 & 0.70 & 3.4 & 0.084 & 0.4 & 0.45 & 519 & 23 & 536 & 21 & 599 & 56 & 519 & 23 & NA \\
\hline 12JT35_39 & 7 & 0.1 & 0.065 & 0.520 & 0.0 & 0.78 & 7.9 & 0.085 & 0.6 & 0.45 & 523 & 33 & 547 & 44 & 580 & 150 & 523 & 33 & NA \\
\hline 12JT35_49 & 323 & 0.5 & 0.057 & 0.130 & 0.2 & 0.66 & 3.1 & 0.084 & 0.4 & 0.44 & 523 & 22 & 513 & 19 & 491 & 49 & 523 & 22 & NA \\
\hline 12JT35_37 & 6 & 0.0 & 0.061 & 0.450 & 0.3 & 0.73 & 5.9 & 0.086 & 0.5 & 0.08 & 531 & 27 & 554 & 34 & 580 & 140 & 531 & 27 & NA \\
\hline 12JT35_66 & 217 & 0.9 & 0.058 & 0.140 & 0.2 & 0.68 & 3.3 & 0.087 & 0.4 & 0.39 & 535 & 23 & 528 & 19 & 518 & 54 & 535 & 23 & NA \\
\hline 12JT35_92 & 292 & 2.5 & 0.057 & 0.140 & 0.3 & 0.68 & 3.3 & 0.087 & 0.4 & 0.58 & 540 & 24 & 529 & 20 & 493 & 53 & 540 & 24 & NA \\
\hline 12JT35_36 & 19 & 0.1 & 0.059 & 0.270 & 0.1 & 0.71 & 4.3 & 0.089 & 0.4 & 0.28 & 548 & 25 & 540 & 25 & 527 & 93 & 548 & 25 & NA \\
\hline 12JT35_4 & 186 & 0.3 & 0.060 & 0.180 & 0.0 & 0.73 & 4.2 & 0.090 & 0.4 & 0.70 & 552 & 26 & 554 & 24 & 581 & 68 & 552 & 26 & NA \\
\hline 12JT35_65 & 44 & 0.1 & 0.072 & 0.320 & -0.1 & 0.88 & 5.4 & 0.090 & 0.4 & 0.40 & 554 & 24 & 634 & 29 & 900 & 89 & 554 & 24 & NA \\
\hline 12JT35_90 & 106 & 1.0 & 0.068 & 0.290 & 0.1 & 0.86 & 5.5 & 0.091 & 0.5 & 0.65 & 560 & 31 & 628 & 31 & 909 & 85 & 560 & 31 & NA \\
\hline 12JT35_28 & 31 & 2.0 & 0.057 & 0.260 & 0.2 & 0.69 & 4.8 & 0.092 & 0.6 & 0.43 & 561 & 36 & 527 & 29 & 474 & 94 & 561 & 36 & NA \\
\hline 12JT35_71 & 34 & 0.3 & 0.060 & 0.230 & 0.0 & 0.76 & 4.7 & 0.092 & 0.5 & 0.54 & 565 & 27 & 569 & 26 & 589 & 80 & 565 & 27 & NA \\
\hline 12JT35_60 & 39 & 1.4 & 0.056 & 0.210 & -0.1 & 0.72 & 4.2 & 0.092 & 0.4 & 0.38 & 566 & 25 & 548 & 24 & 437 & 78 & 566 & 25 & NA \\
\hline 12JT35_13 & 157 & 1.9 & 0.063 & 0.190 & -0.3 & 0.89 & 7.0 & 0.101 & 0.7 & 0.91 & 621 & 39 & 643 & 39 & 717 & 63 & 621 & 39 & 87 \\
\hline 12JT35_1 & 231 & 0.8 & 0.085 & 0.190 & 0.0 & 2.35 & 11.0 & 0.201 & 0.9 & 0.66 & 1182 & 48 & 1228 & 34 & 1304 & 44 & 1304 & 44 & 91 \\
\hline \multicolumn{20}{|c|}{$>20 \%$ Discordance } \\
\hline 12JT35_83 & 347 & 0.1 & 0.070 & 0.220 & 0.4 & 0.61 & 3.2 & 0.064 & 0.3 & 0.43 & 398 & 18 & 484 & 20 & 910 & 64 & 398 & 18 & NA \\
\hline 12JT35_74 & 277 & 1.2 & 0.060 & 0.180 & 0.2 & 0.53 & 2.7 & 0.064 & 0.3 & 0.50 & 400 & 18 & 431 & 18 & 597 & 64 & 400 & 18 & NA \\
\hline 12JT35_56 & 406 & 0.9 & 0.068 & 0.170 & -0.2 & 0.69 & 3.4 & 0.074 & 0.3 & 0.75 & 462 & 20 & 534 & 21 & 864 & 51 & 462 & 20 & NA \\
\hline 12JT35_50 & 95 & 0.7 & 0.074 & 0.280 & 0.2 & 0.75 & 4.9 & 0.075 & 0.4 & 0.53 & 463 & 26 & 562 & 27 & 986 & 68 & 463 & 26 & NA \\
\hline 12JT35_22 & 20 & 0.9 & 0.074 & 0.460 & 0.0 & 0.77 & 5.8 & 0.076 & 0.4 & 0.34 & 472 & 23 & 571 & 33 & 940 & 120 & 472 & 23 & NA \\
\hline 12JT35_45 & 204 & 0.1 & 0.062 & 0.200 & 0.7 & 0.69 & 3.5 & 0.080 & 0.4 & -0.27 & 495 & 21 & 534 & 21 & 655 & 64 & 495 & 21 & NA \\
\hline 12JT35_68 & 8 & 0.2 & 0.088 & 0.620 & 0.1 & 1.07 & 9.2 & 0.090 & 0.5 & 0.42 & 553 & 31 & 708 & 43 & 1230 & 140 & 553 & 31 & NA \\
\hline 12JT35_95 & 7 & 0.1 & 0.126 & 1.000 & 0.1 & 1.71 & 18.0 & 0.097 & 0.7 & 0.42 & 593 & 39 & 939 & 65 & 1820 & 160 & 593 & 39 & NA \\
\hline
\end{tabular}


TABLE SM2.3: LA-ICPMS U-PB ISOTOPIC DATA (UC SANTA CRUZ LAB)

\begin{tabular}{|c|c|c|c|c|c|c|c|c|c|c|c|c|c|c|c|c|c|c|c|}
\hline \multirow[b]{2}{*}{ Analysis } & \multirow[b]{2}{*}{$\mathrm{U}$} & \multirow[b]{2}{*}{ U/Th } & \multirow[b]{2}{*}{$206 \mathrm{~Pb}^{*}$} & \multirow[b]{2}{*}{ \pm} & \multirow[b]{2}{*}{ error } & \multirow[b]{2}{*}{ 207Pb* } & \multicolumn{3}{|c|}{ Isotope ratios } & \multirow[b]{2}{*}{ error } & \multirow[b]{2}{*}{$206 \mathrm{~Pb}^{*}$} & \multicolumn{4}{|c|}{ Apparent ages (Ma) } & \multirow[b]{2}{*}{ \pm} & \multirow[b]{2}{*}{ Best age } & \multirow[b]{2}{*}{ \pm} & \multirow[b]{2}{*}{ Conc } \\
\hline & & & & & & & \pm & $206 \mathrm{~Pb}^{*}$ & \pm & & & \pm & $207 \mathrm{~Pb}^{*}$ & \pm & $206 \mathrm{~Pb}^{*}$ & & & & \\
\hline & (ppm) & & $207 \mathrm{~Pb}^{*}$ & $(\%)$ & corr. & $235 U^{*}$ & (\%) & $238 U$ & $(\%)$ & corr. & $238 U^{*}$ & (Ma) & $235 U$ & (Ma) & $207 \mathrm{~Pb}^{*}$ & (Ma) & $(\mathrm{Ma})$ & (Ma) & $(\%)$ \\
\hline 12JT35_54 & 51 & 1.2 & 0.204 & 0.700 & -0.1 & 2.79 & 19.0 & 0.098 & 0.6 & 0.82 & 603 & 33 & 1343 & 52 & 2842 & 57 & 603 & 33 & 21 \\
\hline 12JT35_48 & 12 & 0.1 & 0.077 & 0.570 & 0.2 & 1.19 & 13.0 & 0.123 & 1.3 & 0.59 & 732 & 71 & 727 & 59 & 950 & 150 & 732 & 71 & 77 \\
\hline 12JT35_20 & 4 & 0.1 & 0.093 & 0.610 & 0.4 & 1.89 & 15.0 & 0.150 & 0.9 & 0.35 & 900 & 52 & 1047 & 53 & 1380 & 140 & 900 & 52 & 65 \\
\hline \multicolumn{20}{|c|}{$>1000$ U ppm } \\
\hline 12JT35_84 & 1790 & 0.7 & 0.063 & 0.140 & 0.3 & 0.33 & 1.5 & 0.038 & 0.2 & 0.48 & 241 & 10 & 289 & 12 & 698 & 47 & 241 & 10 & NA \\
\hline
\end{tabular}

1. Best age is chosen to be the 206Pb/238U age for analyses with 206Pb/238U age <1000 Ma otherwise the 206Pb/207Pb age is preferred for analyses with $206 \mathrm{~Pb} / 238 \mathrm{Vage}>1000 \mathrm{Ma}$.

2. Concordance is based on 206Pb/238U age / 206Pb/207Pb age. Value is not reported for 206Pb/238U ages <600 Ma because of large uncertainty in 206Pb/207Pb age and higher sensitivity to discordance; however, some ages were filtered out using graphical discordance on a concordia plot.

3. All uncertainties are reported at the 2-sigma level, and include measurement errors and an additional factor based on MSWD of sets of secondary standards to account for overdispersion of standard measurements

4. Systematic errors (at 2-sigma level) include contributions from U decay constants, composition of common Pb, true age of the standard, and scatter of measured age of the standards, and are as follows: 1.0\% (206Pb/238U) \& $0.9 \%$ $(206 \mathrm{~Pb} / 207 \mathrm{~Pb})$

6. $U$ decay constants and composition as follows: $238 \mathrm{U}=9.8485 \times 10-10,235 \mathrm{U}=1.55125 \times 10-10,238 \mathrm{U} / 235 \mathrm{U}=137.88$. 
TABLE SM2.4: LA-ICPMS U-PB ISOTOPIC DATA (STOCKHOLM UNIVERSITY LAB)

\begin{tabular}{|c|c|c|c|c|c|c|c|c|c|c|c|c|c|c|c|c|c|c|c|}
\hline \multirow[b]{2}{*}{ Analysis } & \multirow[b]{2}{*}{$U$} & \multirow[b]{2}{*}{$206 \mathrm{~Pb}$} & \multirow[b]{2}{*}{$\mathrm{U} / \mathrm{Th}$} & \multirow[b]{2}{*}{$206 \mathrm{~Pb}^{*}$} & \multirow[b]{2}{*}{ \pm} & \multicolumn{5}{|c|}{ Isotope ratios } & \multicolumn{6}{|c|}{ Apparent ages (Ma) } & \multirow[b]{2}{*}{ Best age } & \multirow[b]{2}{*}{ \pm} & \multirow[b]{2}{*}{ Conc } \\
\hline & & & & & & 207Pb* & \pm & $206 \mathrm{~Pb}^{*}$ & \pm & error & $206 \mathrm{~Pb}^{*}$ & \pm & $207 \mathrm{~Pb}^{*}$ & \pm & $206 \mathrm{~Pb}^{*}$ & \pm & & & \\
\hline & $(\mathrm{ppm})$ & $204 \mathrm{~Pb}$ & & $207 \mathrm{~Pb}^{\star}$ & $(\%)$ & $235 U^{*}$ & $(\%)$ & $238 U$ & $(\%)$ & corr. & $238 U^{*}$ & (Ma) & $235 U$ & $(\mathrm{Ma})$ & $207 \mathrm{~Pb}^{\star}$ & (Ma) & (Ma) & (Ma) & $(\%)$ \\
\hline \multicolumn{20}{|c|}{ 40LF13; Clarence River Group (N69.37, W142.91) } \\
\hline 40LF13-87 & 6866 & 654.6 & 2.0 & 0.055 & 0.5 & 0.457 & 4.8 & 0.061 & 0.3 & 0.52 & 380 & 18 & 382 & 33 & 400 & 190 & 380 & 18 & NA \\
\hline 40LF13-85 & 6988 & 1855.0 & 0.7 & 0.097 & 1.4 & 1.050 & 32.0 & 0.065 & 0.5 & 0.90 & 383 & 32 & 680 & 120 & 1490 & 210 & 383 & 32 & NA \\
\hline 40LF13-76 & 136 & 304.4 & 2.9 & 0.058 & 0.5 & 0.530 & 5.0 & 0.067 & 0.2 & 0.52 & 415 & 11 & 428 & 31 & 520 & 180 & 415 & 11 & NA \\
\hline 40LF13-49 & 7468 & 376.0 & 1.2 & 0.089 & 1.3 & 0.830 & 12.0 & 0.071 & 0.3 & 0.29 & 425 & 19 & 602 & 61 & 1290 & 260 & 425 & 19 & NA \\
\hline 40LF13-51 & 37717 & 632.0 & 1.3 & 0.052 & 0.6 & 0.497 & 6.3 & 0.069 & 0.3 & 0.29 & 434 & 21 & 419 & 43 & 300 & 210 & 434 & 21 & NA \\
\hline 40LF13-63 & 1501 & 187.0 & 2.6 & 0.060 & 0.6 & 0.640 & 7.0 & 0.076 & 0.3 & 0.18 & 468 & 16 & 499 & 45 & 600 & 240 & 468 & 16 & NA \\
\hline 40LF13-9 & 13532 & 38.0 & 2.7 & 0.072 & 0.6 & 1.240 & 12.0 & 0.128 & 0.6 & 0.75 & 792 & 24 & 819 & 53 & 970 & 170 & 792 & 24 & 82 \\
\hline 40LF13-57 & 13328 & 637.0 & 6.5 & 0.071 & 0.6 & 1.280 & 15.0 & 0.137 & 0.7 & 0.38 & 821 & 39 & 841 & 58 & 960 & 170 & 821 & 39 & 86 \\
\hline 40LF13-119 & 1081 & 295.5 & 1.6 & 0.074 & 0.6 & 1.420 & 13.0 & 0.142 & 0.4 & 0.48 & 850 & 25 & 900 & 52 & 1030 & 170 & 850 & 25 & 83 \\
\hline 40LF13-93 & 25064 & 248.1 & 12.0 & 0.074 & 0.6 & 1.440 & 13.0 & 0.145 & 0.5 & 0.71 & 863 & 29 & 903 & 54 & 1050 & 160 & 863 & 29 & 82 \\
\hline 40LF13-37 & 24671 & 438.0 & 5.7 & 0.071 & 0.6 & 1.440 & 13.0 & 0.148 & 0.5 & 0.61 & 890 & 30 & 905 & 56 & 930 & 170 & 890 & 30 & 96 \\
\hline 40LF13-78 & 832 & 117.3 & 1.6 & 0.075 & 0.6 & 1.570 & 14.0 & 0.150 & 0.4 & 0.33 & 896 & 26 & 958 & 55 & 1090 & 170 & 896 & 26 & 82 \\
\hline 40LF13-36 & 4682 & 872.0 & 14.5 & 0.074 & 0.6 & 1.570 & 14.0 & 0.152 & 0.5 & 0.48 & 908 & 29 & 955 & 56 & 1040 & 170 & 908 & 29 & 87 \\
\hline 40LF13-89 & 285 & 47.6 & 4.0 & 0.074 & 0.7 & 1.630 & 22.0 & 0.152 & 0.8 & 0.72 & 909 & 45 & 972 & 73 & 1020 & 190 & 909 & 45 & 89 \\
\hline 40LF13-70 & 18726 & 191.0 & 1.4 & 0.072 & 0.6 & 1.490 & 14.0 & 0.153 & 0.7 & 0.41 & 916 & 41 & 926 & 58 & 950 & 170 & 916 & 41 & 96 \\
\hline 40LF13-6 & 554 & 27.0 & 5.9 & 0.071 & 0.6 & 1.530 & 14.0 & 0.154 & 0.5 & 0.28 & 925 & 27 & 939 & 55 & 930 & 180 & 925 & 27 & 99 \\
\hline 40LF13-62 & 13473 & 463.0 & 16.5 & 0.078 & 0.6 & 1.680 & 15.0 & 0.157 & 0.4 & 0.67 & 930 & 26 & 1000 & 56 & 1150 & 160 & 930 & 26 & 81 \\
\hline 40LF13-61 & 1155 & 310.0 & 2.0 & 0.073 & 0.7 & 1.530 & 18.0 & 0.156 & 0.8 & 0.30 & 933 & 44 & 944 & 65 & 1000 & 170 & 933 & 44 & 93 \\
\hline 40LF13-22 & 12937 & 215.0 & 2.2 & 0.075 & 0.7 & 1.610 & 16.0 & 0.157 & 0.7 & 0.46 & 936 & 43 & 975 & 61 & 1080 & 200 & 936 & 43 & 87 \\
\hline 40LF13-118 & 1620 & 144.1 & 1.0 & 0.076 & 0.7 & 1.700 & 18.0 & 0.161 & 0.8 & 0.20 & 955 & 46 & 1003 & 69 & 1080 & 190 & 955 & 46 & 88 \\
\hline 40LF13-24 & 2421 & 155.0 & 2.4 & 0.075 & 0.7 & 1.650 & 16.0 & 0.163 & 0.6 & 0.52 & 970 & 33 & 993 & 57 & 1040 & 170 & 970 & 33 & 93 \\
\hline 40LF13-16 & 2040 & 771.0 & 3.2 & 0.072 & 0.7 & 1.620 & 16.0 & 0.163 & 0.5 & 0.38 & 971 & 31 & 979 & 65 & 940 & 200 & 971 & 31 & 103 \\
\hline 40LF13-120 & 42 & 379.3 & 591.9 & 0.074 & 0.6 & 1.670 & 15.0 & 0.163 & 0.5 & 0.62 & 972 & 27 & 997 & 56 & 1040 & 170 & 972 & 27 & 94 \\
\hline 40LF13-80 & 3079 & 87.8 & 2.0 & 0.077 & 0.7 & 1.710 & 16.0 & 0.164 & 0.5 & 0.29 & 973 & 32 & 1015 & 57 & 1110 & 170 & 973 & 32 & 88 \\
\hline 40LF13-21 & 5883 & 179.0 & 1.6 & 0.076 & 0.7 & 1.650 & 17.0 & 0.165 & 0.6 & 0.42 & 979 & 37 & 1001 & 63 & 1090 & 190 & 979 & 37 & 90 \\
\hline 40LF13-20 & 3505 & 334.0 & 3.4 & 0.072 & 0.6 & 1.650 & 17.0 & 0.164 & 0.7 & 0.50 & 979 & 43 & 985 & 65 & 980 & 190 & 979 & 43 & 100 \\
\hline
\end{tabular}


TABLE SM2.4: LA-ICPMS U-PB ISOTOPIC DATA (STOCKHOLM UNIVERSITY LAB)

\begin{tabular}{|c|c|c|c|c|c|c|c|c|c|c|c|c|c|c|c|c|c|c|c|}
\hline \multirow[b]{2}{*}{ Analysis } & \multirow[b]{2}{*}{ U } & \multirow[b]{2}{*}{$206 \mathrm{~Pb}$} & \multirow[b]{2}{*}{ U/Th } & \multirow[b]{2}{*}{$206 \mathrm{~Pb}^{\star}$} & \multirow[b]{2}{*}{ \pm} & \multicolumn{5}{|c|}{ Isotope ratios } & \multicolumn{6}{|c|}{ Apparent ages (Ma) } & \multirow[b]{2}{*}{ Best age } & \multirow[b]{2}{*}{ \pm} & \multirow[b]{2}{*}{ Conc } \\
\hline & & & & & & $207 \mathrm{~Pb}^{*}$ & \pm & $206 \mathrm{~Pb}^{*}$ & \pm & error & 206Pb* & \pm & $207 \mathrm{~Pb}^{*}$ & \pm & $206 \mathrm{~Pb}^{\star}$ & \pm & & & \\
\hline & (ppm) & $204 \mathrm{~Pb}$ & & $207 \mathrm{~Pb}^{*}$ & $(\%)$ & $235 U^{*}$ & $(\%)$ & $238 U$ & $(\%)$ & corr. & $238 U^{*}$ & (Ma) & $235 U$ & (Ma) & $207 \mathrm{~Pb}^{\star}$ & (Ma) & (Ma) & (Ma) & (\%) \\
\hline 40LF13-67 & 1362 & 100.0 & 1.6 & 0.074 & 0.7 & 1.650 & 16.0 & 0.165 & 0.5 & 0.20 & 985 & 28 & 989 & 62 & 1030 & 190 & 985 & 28 & 96 \\
\hline 40LF13-91 & 17539 & 380.7 & 2.9 & 0.094 & 0.8 & 3.210 & 28.0 & 0.248 & 0.7 & 0.69 & 1429 & 37 & 1457 & 68 & 1510 & 150 & 1510 & 150 & 95 \\
\hline 40LF13-68 & 15760 & 305.0 & 1.6 & 0.095 & 0.8 & 2.710 & 28.0 & 0.213 & 1.3 & 0.94 & 1243 & 68 & 1325 & 79 & 1530 & 150 & 1530 & 150 & 81 \\
\hline 40LF13-74 & 11558 & 160.0 & 2.1 & 0.100 & 0.8 & 3.130 & 32.0 & 0.231 & 1.1 & 0.63 & 1340 & 56 & 1437 & 76 & 1610 & 150 & 1610 & 150 & 83 \\
\hline 40LF13-114 & 1538 & 68.0 & 1.1 & 0.099 & 0.8 & 3.220 & 36.0 & 0.243 & 1.3 & 0.78 & 1405 & 67 & 1456 & 83 & 1610 & 150 & 1610 & 150 & 87 \\
\hline 40LF13-23 & 5556 & 503.0 & 1.4 & 0.101 & 0.8 & 3.760 & 34.0 & 0.271 & 0.8 & 0.33 & 1543 & 38 & 1581 & 71 & 1620 & 160 & 1620 & 160 & 95 \\
\hline 40LF13-71 & 5892 & 62.0 & 1.9 & 0.101 & 0.9 & 3.890 & 36.0 & 0.281 & 0.8 & 0.46 & 1596 & 40 & 1607 & 74 & 1630 & 150 & 1630 & 150 & 98 \\
\hline 40LF13-59 & 3002 & 177.0 & 1.9 & 0.101 & 0.8 & 3.450 & 33.0 & 0.248 & 1.1 & 0.73 & 1427 & 55 & 1508 & 77 & 1650 & 170 & 1650 & 170 & 86 \\
\hline 40LF13-88 & 14093 & 135.0 & 1.6 & 0.102 & 0.8 & 3.920 & 36.0 & 0.277 & 1.3 & 0.63 & 1573 & 64 & 1616 & 77 & 1670 & 150 & 1670 & 150 & 94 \\
\hline 40LF13-4 & 9465 & 58.0 & 1.2 & 0.104 & 0.9 & 3.810 & 34.0 & 0.269 & 0.9 & 0.32 & 1533 & 45 & 1594 & 71 & 1680 & 160 & 1680 & 160 & 91 \\
\hline 40LF13-90 & 3477 & 204.8 & 3.4 & 0.103 & 0.9 & 4.000 & 37.0 & 0.276 & 1.0 & 0.30 & 1571 & 49 & 1632 & 76 & 1680 & 160 & 1680 & 160 & 94 \\
\hline 40LF13-115 & 1052 & 73.9 & 1.8 & 0.104 & 0.9 & 4.220 & 46.0 & 0.296 & 1.5 & 0.56 & 1679 & 79 & 1680 & 88 & 1680 & 160 & 1680 & 160 & 100 \\
\hline 40LF13-104 & 99431 & 427.3 & 1.7 & 0.105 & 0.9 & 3.860 & 36.0 & 0.273 & 1.2 & 0.73 & 1556 & 60 & 1606 & 73 & 1700 & 150 & 1700 & 150 & 92 \\
\hline 40LF13-56 & 2446 & 150.0 & 1.4 & 0.105 & 0.9 & 4.330 & 40.0 & 0.300 & 0.8 & 0.47 & 1691 & 42 & 1696 & 77 & 1720 & 160 & 1720 & 160 & 98 \\
\hline 40LF13-86 & 16324 & 157.0 & 1.8 & 0.108 & 0.9 & 4.020 & 37.0 & 0.277 & 0.9 & 0.51 & 1574 & 47 & 1648 & 72 & 1750 & 160 & 1750 & 160 & 90 \\
\hline 40LF13-54 & 14911 & 105.0 & 1.6 & 0.107 & 0.9 & 4.310 & 43.0 & 0.295 & 1.4 & 0.39 & 1664 & 68 & 1696 & 84 & 1750 & 150 & 1750 & 150 & 95 \\
\hline 40LF13-43 & 2914 & 106.0 & 1.9 & 0.109 & 0.9 & 4.600 & 41.0 & 0.306 & 0.9 & 0.57 & 1718 & 43 & 1746 & 74 & 1790 & 150 & 1790 & 150 & 96 \\
\hline 40LF13-82 & 3408 & 132.6 & 0.9 & 0.110 & 0.9 & 4.530 & 43.0 & 0.306 & 1.4 & 0.68 & 1722 & 69 & 1736 & 80 & 1790 & 150 & 1790 & 150 & 96 \\
\hline 40LF13-58 & 7436 & 125.0 & 3.8 & 0.109 & 0.9 & 4.460 & 40.0 & 0.304 & 1.0 & 0.67 & 1711 & 49 & 1727 & 71 & 1790 & 140 & 1790 & 140 & 96 \\
\hline 40LF13-8 & 993 & 1226.0 & 1.6 & 0.110 & 1.0 & 4.450 & 52.0 & 0.296 & 1.7 & 0.62 & 1686 & 74 & 1726 & 98 & 1800 & 170 & 1800 & 170 & 94 \\
\hline 40LF13-44 & 7827 & 1050.0 & 4.8 & 0.111 & 0.9 & 4.770 & 46.0 & 0.316 & 1.5 & 0.68 & 1768 & 76 & 1778 & 82 & 1820 & 150 & 1820 & 150 & 97 \\
\hline 40LF13-31 & 2183 & 1842.0 & 2.7 & 0.110 & 1.0 & 5.020 & 56.0 & 0.327 & 1.5 & 0.48 & 1825 & 71 & 1820 & 89 & 1830 & 150 & 1830 & 150 & 100 \\
\hline 40LF13-42 & 4261 & 659.0 & 0.7 & 0.114 & 0.9 & 4.050 & 38.0 & 0.260 & 1.1 & 0.73 & 1487 & 54 & 1643 & 75 & 1850 & 150 & 1850 & 150 & 80 \\
\hline 40LF13-81 & 1024 & 791.6 & 3.1 & 0.113 & 0.9 & 4.670 & 48.0 & 0.298 & 1.4 & 0.28 & 1679 & 67 & 1759 & 82 & 1850 & 150 & 1850 & 150 & 91 \\
\hline 40LF13-69 & 4581 & 352.0 & 3.9 & 0.113 & 0.9 & 4.680 & 42.0 & 0.300 & 1.0 & 0.71 & 1691 & 48 & 1766 & 72 & 1850 & 150 & 1850 & 150 & 91 \\
\hline 40LF13-100 & 3303 & 150.0 & 2.7 & 0.114 & 1.0 & 5.130 & 50.0 & 0.328 & 1.6 & 0.49 & 1828 & 78 & 1837 & 84 & 1850 & 160 & 1850 & 160 & 99 \\
\hline 40LF13-10 & 14468 & 1092.0 & 5.4 & 0.114 & 1.0 & 4.720 & 44.0 & 0.299 & 1.0 & 0.09 & 1688 & 50 & 1767 & 79 & 1870 & 150 & 1870 & 150 & 90 \\
\hline 40LF13-77 & 3604 & 108.4 & 1.1 & 0.116 & 1.0 & 4.870 & 43.0 & 0.303 & 0.8 & 0.46 & 1710 & 42 & 1793 & 75 & 1900 & 150 & 1900 & 150 & 90 \\
\hline
\end{tabular}


TABLE SM2.4: LA-ICPMS U-PB ISOTOPIC DATA (STOCKHOLM UNIVERSITY LAB)

\begin{tabular}{|c|c|c|c|c|c|c|c|c|c|c|c|c|c|c|c|c|c|c|c|}
\hline \multirow[b]{2}{*}{ Analysis } & \multirow[b]{2}{*}{$U$} & \multirow[b]{2}{*}{$206 \mathrm{~Pb}$} & \multirow[b]{2}{*}{ U/Th } & \multirow[b]{2}{*}{$206 \mathrm{~Pb}^{*}$} & \multirow[b]{2}{*}{ \pm} & \multicolumn{5}{|c|}{ Isotope ratios } & \multicolumn{6}{|c|}{ Apparent ages (Ma) } & \multirow[b]{2}{*}{ Best age } & \multirow[b]{2}{*}{ \pm} & \multirow[b]{2}{*}{ Conc } \\
\hline & & & & & & 207Pb* & \pm & $206 \mathrm{~Pb}^{*}$ & \pm & error & $206 \mathrm{~Pb}^{*}$ & \pm & $207 \mathrm{~Pb}^{*}$ & \pm & $206 \mathrm{~Pb}^{*}$ & \pm & & & \\
\hline & (ppm) & $204 \mathrm{~Pb}$ & & $207 \mathrm{~Pb}^{\star}$ & (\%) & $235 U^{*}$ & $(\%)$ & $238 U$ & $(\%)$ & corr. & $238 U^{*}$ & (Ma) & $235 U$ & $(\mathrm{Ma})$ & $207 \mathrm{~Pb}^{*}$ & (Ma) & (Ma) & $(\mathrm{Ma})$ & (\%) \\
\hline 40LF13-53 & 1739 & 93.0 & 1.6 & 0.117 & 1.0 & 4.810 & 50.0 & 0.308 & 1.4 & 0.44 & 1730 & 69 & 1789 & 82 & 1900 & 150 & 1900 & 150 & 91 \\
\hline 40LF13-92 & 8736 & 414.0 & 2.4 & 0.117 & 1.0 & 5.240 & 47.0 & 0.330 & 1.0 & 0.36 & 1835 & 48 & 1856 & 75 & 1900 & 140 & 1900 & 140 & 97 \\
\hline 40LF13-83 & 1480 & 1362.0 & 2.5 & 0.122 & 1.0 & 5.250 & 46.0 & 0.317 & 0.9 & 0.39 & 1776 & 46 & 1859 & 76 & 1980 & 150 & 1980 & 150 & 90 \\
\hline 40LF13-3 & 10103 & 29.0 & 1.2 & 0.121 & 1.0 & 5.380 & 46.0 & 0.324 & 0.8 & 0.65 & 1808 & 41 & 1882 & 76 & 1980 & 150 & 1980 & 150 & 91 \\
\hline 40LF13-107 & 39154 & 1328.0 & 2.3 & 0.129 & 1.1 & 6.050 & 56.0 & 0.345 & 1.0 & 0.48 & 1911 & 50 & 1978 & 80 & 2080 & 160 & 2080 & 160 & 92 \\
\hline 40LF13-7 & 2913 & 29.0 & 4.0 & 0.179 & 1.4 & 11.800 & 100.0 & 0.475 & 1.2 & 0.69 & 2504 & 54 & 2590 & 82 & 2650 & 130 & 2650 & 130 & 94 \\
\hline 40LF13-97 & 20514 & 65.7 & 4.1 & 0.185 & 1.6 & 11.900 & 130.0 & 0.467 & 2.5 & 0.70 & 2470 & 110 & 2602 & 88 & 2700 & 140 & 2700 & 140 & 91 \\
\hline 40LF13-66 & 8549 & 133.1 & 0.9 & 0.185 & 1.5 & 12.500 & 110.0 & 0.492 & 1.4 & 0.60 & 2576 & 60 & 2638 & 82 & 2700 & 130 & 2700 & 130 & 95 \\
\hline 40LF13-38 & 17683 & 62.8 & 1.6 & 0.188 & 1.5 & 13.500 & 130.0 & 0.526 & 2.5 & 0.61 & 2720 & 100 & 2714 & 93 & 2720 & 130 & 2720 & 130 & 100 \\
\hline 40LF13-55 & 71268 & 59.3 & 5.0 & 0.190 & 1.5 & 10.700 & 110.0 & 0.408 & 2.2 & 0.96 & 2200 & 100 & 2484 & 97 & 2740 & 130 & 2740 & 130 & 80 \\
\hline 40LF13-113 & 287 & 151.1 & 1.9 & 0.193 & 1.6 & 13.900 & 130.0 & 0.532 & 2.4 & 0.56 & 2750 & 99 & 2738 & 91 & 2760 & 140 & 2760 & 140 & 100 \\
\hline 40LF13-65 & 946 & 76.0 & 1.5 & 0.207 & 1.6 & 12.600 & 120.0 & 0.446 & 1.7 & 0.75 & 2375 & 75 & 2644 & 87 & 2880 & 130 & 2880 & 130 & 82 \\
\hline 40LF13-15 & 17648 & 159.0 & 1.4 & 0.219 & 1.7 & 13.800 & 120.0 & 0.460 & 1.4 & 0.86 & 2436 & 62 & 2735 & 85 & 2990 & 130 & 2990 & 130 & 81 \\
\hline \multicolumn{20}{|c|}{$>20 \%$ Discordance } \\
\hline 40LF13-50 & 8354 & 418.5 & 8.3 & 0.143 & 1.5 & 3.410 & 52.0 & 0.166 & 0.8 & 0.81 & 898 & 49 & 1480 & 110 & 2230 & 180 & 898 & 49 & 40 \\
\hline 40LF13-45 & 1126 & 572.0 & 0.8 & 0.097 & 0.8 & 1.800 & 17.0 & 0.137 & 0.6 & 0.79 & 796 & 37 & 1044 & 60 & 1560 & 150 & 796 & 37 & 51 \\
\hline 40LF13-34 & 82558 & 1433.0 & 1.8 & 0.156 & 1.3 & 4.570 & 43.0 & 0.215 & 0.6 & 0.76 & 1255 & 33 & 1739 & 78 & 2390 & 100 & 2390 & 100 & 53 \\
\hline 40LF13-102 & 10006 & 612.4 & 0.7 & 0.180 & 1.5 & 6.630 & 76.0 & 0.276 & 1.6 & 0.76 & 1572 & 78 & 2057 & 93 & 2650 & 140 & 2650 & 140 & 59 \\
\hline 40LF13-84 & 4882 & 21.0 & 1.3 & 0.126 & 1.1 & 4.000 & 38.0 & 0.232 & 0.7 & 0.19 & 1345 & 38 & 1631 & 76 & 2030 & 160 & 2030 & 160 & 66 \\
\hline 40LF13-101 & 436 & 329.0 & 4.8 & 0.080 & 0.7 & 1.480 & 13.0 & 0.137 & 0.4 & 0.36 & 812 & 23 & 923 & 55 & 1210 & 160 & 812 & 23 & 67 \\
\hline 40LF13-11 & 392 & 297.6 & 4.6 & 0.080 & 0.7 & 1.250 & 15.0 & 0.117 & 0.7 & 0.71 & 792 & 24 & 819 & 64 & 1180 & 170 & 792 & 24 & 67 \\
\hline 40LF13-46 & 1288 & 628.0 & 1.1 & 0.101 & 0.8 & 2.900 & 26.0 & 0.211 & 0.7 & 0.36 & 1234 & 36 & 1382 & 67 & 1630 & 160 & 1630 & 160 & 76 \\
\hline 40LF13-48 & 2632 & 768.0 & 4.9 & 0.077 & 0.6 & 1.540 & 14.0 & 0.147 & 0.4 & 0.46 & 876 & 25 & 946 & 55 & 1120 & 160 & 876 & 25 & 78 \\
\hline 40LF13-79 & 841 & 887.0 & 1.3 & 0.080 & 0.7 & 1.730 & 15.0 & 0.158 & 0.5 & 0.55 & 932 & 28 & 1017 & 57 & 1190 & 160 & 932 & 28 & 78 \\
\hline 40LF13-64 & 1379 & 224.0 & 12.1 & 0.072 & 0.6 & 1.310 & 11.0 & 0.132 & 0.4 & 0.60 & 792 & 24 & 851 & 52 & 1000 & 160 & 792 & 24 & 79 \\
\hline
\end{tabular}


TABLE SM2.4: LA-ICPMS U-PB ISOTOPIC DATA (STOCKHOLM UNIVERSITY LAB)

\begin{tabular}{|c|c|c|c|c|c|c|c|c|c|c|c|c|c|c|c|c|c|c|c|}
\hline \multirow[b]{2}{*}{ Analysis } & \multirow[b]{2}{*}{$U$} & \multirow[b]{2}{*}{$206 \mathrm{~Pb}$} & \multirow[b]{2}{*}{$\mathrm{U} / \mathrm{Th}$} & \multirow[b]{2}{*}{$206 \mathrm{~Pb}^{\star}$} & \multirow[b]{2}{*}{ \pm} & \multicolumn{5}{|c|}{ Isotope ratios } & \multicolumn{6}{|c|}{ Apparent ages (Ma) } & \multirow[b]{2}{*}{ Best age } & \multirow[b]{2}{*}{ \pm} & \multirow[b]{2}{*}{ Conc } \\
\hline & & & & & & 207Pb* & \pm & $206 \mathrm{~Pb}^{*}$ & \pm & error & $206 \mathrm{~Pb}^{*}$ & \pm & 207Pb* & \pm & $206 \mathrm{~Pb}^{\star}$ & \pm & & & \\
\hline & (ppm) & $204 \mathrm{~Pb}$ & & $207 \mathrm{~Pb}^{\star}$ & (\%) & $235 U^{*}$ & (\%) & $238 U$ & (\%) & corr. & $238 U^{*}$ & (Ma) & $235 U$ & (Ma) & $207 \mathrm{~Pb}^{\star}$ & $(\mathrm{Ma})$ & (Ma) & (Ma) & (\%) \\
\hline 40LF13-52 & 2199 & 160.1 & 1.4 & 0.069 & 0.6 & 1.460 & 14.0 & 0.155 & 0.7 & 0.51 & 929 & 42 & 919 & 61 & 880 & 180 & 929 & 42 & 106 \\
\hline 40LF13-25 & 212531 & 321.6 & 2.0 & 0.068 & 0.6 & 1.450 & 15.0 & 0.154 & 0.7 & 0.50 & 924 & 42 & 917 & 63 & 860 & 170 & 924 & 42 & 107 \\
\hline 40LF13-26 & 2091 & 150.4 & 1.3 & 0.064 & 0.9 & 1.080 & 14.0 & 0.126 & 1.0 & 0.08 & 792 & 24 & 754 & 57 & 680 & 290 & 792 & 24 & 116 \\
\hline 40LF13-72 & 1393 & 503.4 & 4.2 & 0.062 & 0.6 & 0.990 & 11.0 & 0.117 & 0.6 & 0.52 & 792 & 24 & 694 & 55 & 650 & 190 & 792 & 24 & 122 \\
\hline 40LF13-60 & 556 & 154.9 & 1.0 & 0.059 & 0.6 & 0.802 & 9.2 & 0.099 & 0.5 & 0.48 & 792 & 24 & 598 & 51 & 570 & 190 & 792 & 24 & 139 \\
\hline \multicolumn{20}{|c|}{$>10 \%$ uncertainty in $206 \mathrm{~Pb} / 238 \mathrm{U}$ or $207 \mathrm{~Pb} / 206 \mathrm{~Pb}$ age } \\
\hline 40LF13-94 & 72364 & 45.0 & 1.8 & 0.093 & 0.8 & 3.260 & 31.0 & 0.256 & 0.9 & 0.68 & 1467 & 47 & 1466 & 73 & 1490 & 150 & 1490 & 150 & 98 \\
\hline 40LF13-39 & 1720 & 1056.0 & 2.7 & 0.092 & 0.8 & 2.590 & 24.0 & 0.204 & 0.8 & 0.85 & 1197 & 41 & 1296 & 67 & 1470 & 150 & 1470 & 150 & 81 \\
\hline 40LF13-73 & 688 & 172.0 & 1.7 & 0.158 & 1.5 & 0.920 & 11.0 & 0.041 & 0.4 & 0.88 & 226 & 23 & 660 & 59 & 2420 & 160 & 226 & 23 & NA \\
\hline 40LF13-47 & 42041 & 704.1 & 3.9 & 0.092 & 0.8 & 2.970 & 33.0 & 0.230 & 1.1 & 0.83 & 1332 & 57 & 1401 & 74 & 1460 & 150 & 1460 & 150 & 91 \\
\hline 40LF13-95 & 2126 & 140.0 & 1.0 & 0.100 & 0.9 & 3.860 & 35.0 & 0.282 & 0.9 & 0.01 & 1608 & 48 & 1610 & 81 & 1620 & 170 & 1620 & 170 & 99 \\
\hline 40LF13-32 & 11296 & 518.5 & 2.5 & 0.090 & 0.7 & 2.390 & 27.0 & 0.201 & 1.0 & 0.64 & 1184 & 53 & 1244 & 67 & 1420 & 150 & 1420 & 150 & 83 \\
\hline 40LF13-40 & 17248 & 44.0 & 2.5 & 0.093 & 0.8 & 2.990 & 28.0 & 0.235 & 0.7 & 0.48 & 1361 & 38 & 1407 & 75 & 1500 & 160 & 1500 & 160 & 91 \\
\hline 40LF13-17 & 8083 & 75.0 & 2.2 & 0.092 & 0.8 & 3.010 & 29.0 & 0.236 & 0.7 & 0.52 & 1365 & 38 & 1414 & 75 & 1470 & 160 & 1470 & 160 & 93 \\
\hline 40LF13-14 & 6584 & 69.4 & 2.2 & 0.092 & 0.9 & 3.330 & 40.0 & 0.278 & 1.6 & 0.54 & 1581 & 79 & 1500 & 88 & 1460 & 160 & 1460 & 160 & 108 \\
\hline 40LF13-19 & 6879 & 47.0 & 3.2 & 0.089 & 0.7 & 2.920 & 26.0 & 0.240 & 0.8 & 0.54 & 1384 & 40 & 1389 & 64 & 1420 & 160 & 1420 & 160 & 97 \\
\hline 40LF13-5 & 1205 & 639.0 & 3.2 & 0.090 & 0.8 & 2.870 & 28.0 & 0.239 & 1.1 & 0.75 & 1378 & 58 & 1369 & 74 & 1410 & 160 & 1410 & 160 & 98 \\
\hline 40LF13-1 & 2307 & 843.0 & 3.6 & 0.096 & 0.9 & 2.440 & 23.0 & 0.189 & 0.8 & 0.47 & 1114 & 45 & 1259 & 74 & 1560 & 180 & 1560 & 180 & 71 \\
\hline 40LF13-35 & 9914 & 190.6 & 3.3 & 0.082 & 0.7 & 2.210 & 23.0 & 0.195 & 0.9 & 0.23 & 1150 & 47 & 1180 & 70 & 1260 & 150 & 1260 & 150 & 91 \\
\hline 40LF13-41 & 20845 & 421.4 & 2.7 & 0.086 & 0.7 & 3.270 & 35.0 & 0.277 & 1.3 & 0.71 & 1576 & 65 & 1474 & 76 & 1340 & 160 & 1340 & 160 & 118 \\
\hline 40LF13-33 & 15087 & 188.0 & 3.8 & 0.090 & 0.7 & 2.960 & 27.0 & 0.240 & 0.8 & 0.59 & 1385 & 42 & 1395 & 68 & 1420 & 170 & 1420 & 170 & 98 \\
\hline 40LF13-13 & 3686 & 317.4 & 2.2 & 0.082 & 0.7 & 2.240 & 22.0 & 0.194 & 0.9 & 0.44 & 1144 & 48 & 1189 & 71 & 1250 & 150 & 1250 & 150 & 92 \\
\hline 40LF13-30 & 10363 & 114.0 & 0.8 & 0.098 & 0.9 & 3.300 & 32.0 & 0.247 & 0.9 & 0.21 & 1439 & 45 & 1476 & 76 & 1580 & 190 & 1580 & 190 & 91 \\
\hline 40LF13-18 & 6089 & 224.0 & 6.6 & 0.083 & 0.7 & 1.970 & 18.0 & 0.174 & 0.6 & 0.69 & 1036 & 31 & 1103 & 63 & 1270 & 160 & 1270 & 160 & 82 \\
\hline 40LF13-2 & 4804 & 64.0 & 2.2 & 0.083 & 0.8 & 2.070 & 21.0 & 0.181 & 0.6 & 0.31 & 1074 & 35 & 1143 & 72 & 1320 & 170 & 1320 & 170 & 81 \\
\hline 40LF13-99 & 7792 & 541.2 & 3.6 & 0.081 & 0.7 & 2.070 & 19.0 & 0.192 & 0.9 & 0.50 & 1132 & 48 & 1139 & 66 & 1220 & 160 & 1220 & 160 & 93 \\
\hline 40LF13-75 & 1925 & 425.0 & 2.5 & 0.078 & 0.6 & 2.010 & 18.0 & 0.188 & 0.6 & 0.61 & 1110 & 31 & 1121 & 61 & 1140 & 150 & 1140 & 150 & 97 \\
\hline
\end{tabular}


TABLE SM2.4: LA-ICPMS U-PB ISOTOPIC DATA (STOCKHOLM UNIVERSITY LAB)

\begin{tabular}{|c|c|c|c|c|c|c|c|c|c|c|c|c|c|c|c|c|c|c|c|}
\hline \multirow[b]{2}{*}{ Analysis } & \multirow[b]{2}{*}{$\mathrm{U}$} & \multirow[b]{2}{*}{$206 \mathrm{~Pb}$} & \multirow[b]{2}{*}{ U/Th } & \multirow[b]{2}{*}{$206 \mathrm{~Pb}^{*}$} & \multirow[b]{2}{*}{ \pm} & \multicolumn{5}{|c|}{ Isotope ratios } & \multicolumn{6}{|c|}{ Apparent ages (Ma) } & \multirow[b]{2}{*}{ Best age } & \multirow[b]{2}{*}{ \pm} & \multirow[b]{2}{*}{ Conc } \\
\hline & & & & & & 207Pb* & \pm & $206 \mathrm{~Pb}^{*}$ & \pm & error & $206 \mathrm{~Pb}^{*}$ & \pm & $207 \mathrm{~Pb}^{*}$ & \pm & $206 \mathrm{~Pb}^{*}$ & \pm & & & \\
\hline & (ppm) & $204 \mathrm{~Pb}$ & & 207Pb* & $(\%)$ & $235 U^{*}$ & $(\%)$ & $238 U$ & $(\%)$ & corr. & $238 U^{*}$ & (Ma) & $235 \mathrm{U}$ & (Ma) & $207 \mathrm{~Pb}^{*}$ & (Ma) & $(\mathrm{Ma})$ & (Ma) & (\%) \\
\hline 40LF13-96 & 3853 & 438.0 & 5.6 & 0.081 & 0.7 & 2.210 & 19.0 & 0.199 & 0.5 & 0.42 & 1172 & 29 & 1186 & 57 & 1210 & 160 & 1210 & 160 & 97 \\
\hline 40LF13-108 & 15023 & 529.0 & 2.1 & 0.080 & 0.7 & 2.110 & 19.0 & 0.189 & 0.5 & 0.45 & 1117 & 27 & 1149 & 61 & 1190 & 160 & 1190 & 160 & 94 \\
\hline 40LF13-98 & 2020 & 551.0 & 2.7 & 0.078 & 0.6 & 2.060 & 18.0 & 0.190 & 0.5 & 0.60 & 1121 & 29 & 1133 & 60 & 1160 & 160 & 1160 & 160 & 97 \\
\hline 40LF13-103 & 4398 & 30.0 & 2.9 & 0.085 & 0.8 & 2.500 & 23.0 & 0.213 & 0.6 & 0.15 & 1244 & 32 & 1274 & 65 & 1300 & 180 & 1300 & 180 & 96 \\
\hline 40LF13-112 & 2427 & 547.4 & 3.3 & 0.080 & 0.6 & 1.990 & 19.0 & 0.181 & 0.8 & 0.48 & 1069 & 44 & 1111 & 63 & 1220 & 170 & 1220 & 170 & 88 \\
\hline 40LF13-109 & 732 & 55.0 & 1.1 & 0.114 & 1.4 & 0.770 & 18.0 & 0.047 & 0.7 & 0.94 & 275 & 39 & 572 & 99 & 1880 & 240 & 275 & 39 & NA \\
\hline 40LF13-106 & 22516 & 351.0 & 3.2 & 0.078 & 0.7 & 1.860 & 17.0 & 0.175 & 0.5 & 0.42 & 1036 & 27 & 1068 & 62 & 1170 & 170 & 1170 & 170 & 89 \\
\hline 40LF13-117 & 1465 & 84.0 & 1.0 & 0.083 & 0.8 & 1.900 & 18.0 & 0.168 & 0.5 & 0.33 & 1001 & 27 & 1079 & 67 & 1290 & 190 & 1290 & 190 & 78 \\
\hline 40LF13-116 & 2257 & 244.0 & 1.4 & 0.078 & 0.6 & 1.880 & 18.0 & 0.174 & 0.8 & 0.51 & 1036 & 42 & 1070 & 65 & 1140 & 170 & 1140 & 170 & 91 \\
\hline 40LF13-111 & 27467 & 132.0 & 2.4 & 0.077 & 0.7 & 1.870 & 18.0 & 0.179 & 0.5 & 0.30 & 1059 & 29 & 1081 & 62 & 1120 & 170 & 1120 & 170 & 95 \\
\hline 40LF13-110 & 203 & 66.3 & 2.3 & 0.078 & 0.7 & 1.950 & 21.0 & 0.180 & 0.9 & 0.24 & 1071 & 45 & 1104 & 65 & 1160 & 180 & 1160 & 180 & 92 \\
\hline 40LF13-105 & 886 & 40.0 & 1.9 & 0.077 & 0.7 & 1.950 & 20.0 & 0.181 & 0.7 & 0.33 & 1069 & 36 & 1088 & 69 & 1150 & 190 & 1150 & 190 & 93 \\
\hline 40LF13-27 & 63 & 74.9 & 1.2 & 0.077 & 0.7 & 1.860 & 20.0 & 0.176 & 0.8 & 0.33 & 1042 & 44 & 1073 & 65 & 1110 & 190 & 1110 & 190 & 94 \\
\hline 40LF13-28 & 206 & 542.6 & 5.3 & 0.070 & 0.6 & 1.660 & 18.0 & 0.171 & 0.8 & 0.60 & 1018 & 42 & 993 & 65 & 930 & 170 & 930 & 170 & 109 \\
\hline 40LF13-12 & 409 & 70.6 & 2.5 & 0.072 & 0.7 & 1.690 & 19.0 & 0.179 & 0.8 & 0.59 & 1062 & 45 & 1010 & 69 & 960 & 190 & 960 & 190 & 111 \\
\hline 40LF13-29 & 20218 & 123.0 & 2.2 & 0.099 & 0.8 & 3.120 & 29.0 & 0.228 & 0.8 & 0.73 & 1322 & 40 & 1433 & 72 & 1600 & 160 & 1600 & 160 & 83 \\
\hline
\end{tabular}

1. Best age is chosen to be the 206Pb/238U age for analyses with 206 Pb/238U age <1000 Ma otherwise the 206Pb/207Pb age is preferred for analyses with 206Pb/238Uage >1000 Ma.

2. Concordance is based on 206Pb/238U age / 206Pb/207Pb age. Value is not reported for 206Pb/238U ages <600 Ma because of large uncertainty in 206 Pb/207Pb age and higher sensitivity to discordance; however, some ages were filtered out using graphical discordance on a concordia plot.

3. All uncertainties are reported at the 2-sigma level, and include measurement errors and an additional factor based on MSWD of sets of secondary standards to account for overdispersion of standard measurements

4. Systematic errors (at 2-sigma level) include contributions from U decay constants, composition of common Pb, true age of the standard, and scatter of measured age of the standards, and are as follows: $1.0 \%$ (206Pb/238U) \& $0.9 \%$ $(206 \mathrm{~Pb} / 207 \mathrm{~Pb})$

6. $U$ decay constants and composition as follows: $238 \mathrm{U}=9.8485 \times 10-10,235 \mathrm{U}=1.55125 \times 10-10,238 \mathrm{U} / 235 \mathrm{U}=137.88$. 
TABLE SM2.5: SIMS U-TH-PB ISOTOPIC DATA (NORDSIM-LAB, STOCKHOLM)

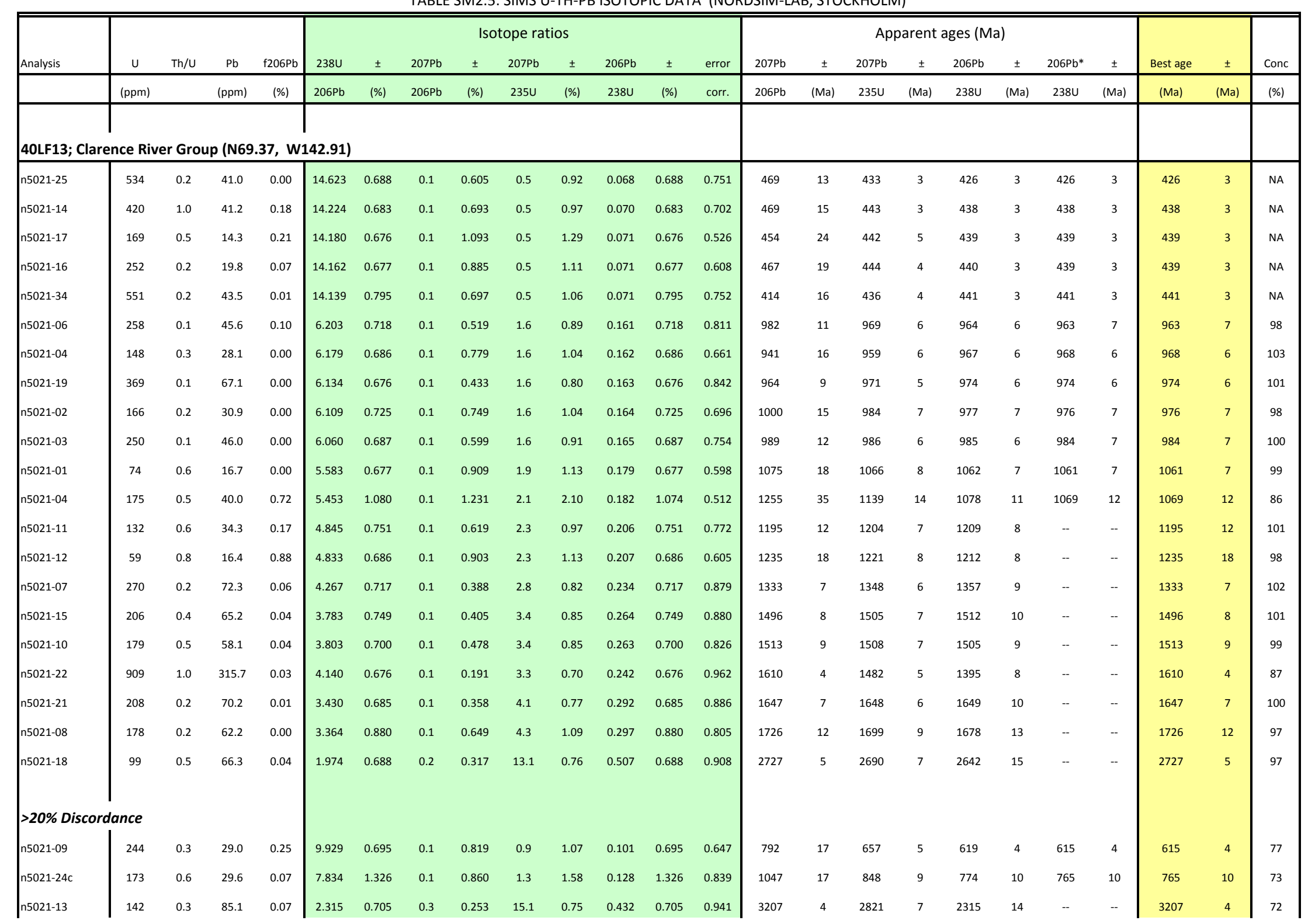


TABLE SM2.5: SIMS U-TH-PB ISOTOPIC DATA (NORDSIM-LAB, STOCKHOLM)

\begin{tabular}{|c|c|c|c|c|c|c|c|c|c|c|c|c|c|c|c|c|c|c|c|c|c|c|c|c|}
\hline \multirow[b]{2}{*}{ Analysis } & \multirow[b]{2}{*}{$u$} & \multirow[b]{2}{*}{$T h / U$} & \multirow[b]{2}{*}{$\mathrm{Pb}$} & \multirow[b]{2}{*}{$\mathrm{f} 206 \mathrm{~Pb}$} & \multicolumn{9}{|c|}{ Isotope ratios } & \multicolumn{8}{|c|}{ Apparent ages (Ma) } & \multirow[b]{2}{*}{ Best age } & \multirow[b]{2}{*}{ \pm} & \multirow[b]{2}{*}{ Con } \\
\hline & & & & & 2384 & \pm & $207 \mathrm{~Pb}$ & \pm & $207 \mathrm{~Pb}$ & \pm & $206 \mathrm{~Pb}$ & \pm & error & $207 \mathrm{~Pb}$ & \pm & $207 \mathrm{~Pb}$ & \pm & $206 \mathrm{~Pb}$ & \pm & $206 \mathrm{~Pb}^{*}$ & \pm & & & \\
\hline & (ppm) & & $(\mathrm{ppm})$ & (\%) & $206 \mathrm{~Pb}$ & $(\%)$ & $206 \mathrm{~Pb}$ & $(\%)$ & 2350 & (\%) & 2380 & $(\%)$ & corr. & $206 \mathrm{~Pb}$ & (Ma) & 2350 & (Ma) & $238 U$ & (Ma) & $238 U$ & (Ma) & (Ma) & (Ma) & (\%) \\
\hline \multicolumn{25}{|c|}{$>10 \%$ uncertainty in $206 \mathrm{~Pb} / 238 \mathrm{U}$ or $207 \mathrm{~Pb} / 206 \mathrm{~Pb}$ age } \\
\hline n5021-20 & 384 & 0.4 & 26.1 & 4.11 & 16.779 & 1.063 & 0.1 & 2.921 & 0.4 & 6.41 & 0.057 & 1.028 & 0.160 & 383 & 136 & 362 & 20 & 358 & 4 & 358 & 4 & 358 & 4 & NA \\
\hline \multicolumn{25}{|c|}{$>1000 \cup \mathrm{ppm}$} \\
\hline n5021-23 & 2051 & 0.3 & 181.1 & 2.50 & 13.197 & 2.028 & 0.1 & 1.266 & 0.6 & 3.80 & 0.074 & 1.980 & 0.520 & 672 & 68 & 497 & 15 & 459 & 9 & 456 & 9 & 456 & 9 & NA \\
\hline
\end{tabular}

1. Age uncertainties are reported at the 1-sigma level.

2. 207-corrected 206Pb*/238U age calculated using the 207Pb correction of Ludwig (2012), assuming an initial Pb composition of Stacey and Kramers (1975) two-stage model

3. Best age is determind using a $1000 \mathrm{Ma}$ cutoff between 207 corrected 206Pb/238U and 206Pb/207Pb ages

4. Concordance is based on $206 \mathrm{~Pb} / 238 \mathrm{U}$ age $/ 206 \mathrm{~Pb} / 207 \mathrm{~Pb}$ age, with $100 \%$ = concordant.

5. Concordance is not reported for 206Pb/238U ages $<600 \mathrm{Ma}$ because of large uncertainty in 206Pb/207Pb age. 
TABLE SM2.6: STEPWISE ${ }^{40} \mathrm{Ar} /{ }^{39} \mathrm{Ar}$ ISOTOPE COMPOSITIONS OF MUSCOVITE (UNIVERSITY OF ALASKA FAIRBANKS LAB)

\begin{tabular}{|c|c|c|c|c|c|c|c|c|c|c|c|c|c|c|c|c|}
\hline L.Power & Cumulative & Age & \pm & ${ }^{40} \mathrm{Ar} /{ }^{39} \mathrm{Ar}$ & \pm & ${ }^{37} \mathrm{Ar} /{ }^{39} \mathrm{Ar}$ & \pm & ${ }^{36} \mathrm{Ar} /{ }^{39} \mathrm{Ar}$ & \pm & $\%$ Atm. & $\mathrm{Ca} / \mathrm{K}$ & \pm & $\mathrm{Cl} / \mathrm{K}$ & \pm & $40^{*} /{ }^{39} \mathrm{~K}$ & \pm \\
\hline$(\mathrm{mW})$ & $39 \mathrm{Ar}$ & (Ma) & (Ma) & meas. & abs. & meas. & abs. & meas. & abs. & ${ }^{40} \mathrm{Ar}$ & meas. & abs. & meas. & abs. & meas. & abs. \\
\hline \multicolumn{17}{|c|}{ 12JT13A; Neruokpuk Formation (N69.23, W142.83) } \\
\hline 1250 & 0.020 & 320 & 10 & 53.41837 & 1.199 & 0.57285 & 0.01385 & 0.01104 & 0.00426 & 6.02322 & 1.05152 & 0.0254 & 0.00184 & 0.00029 & 50.19327 & 1.71 \\
\hline 1500 & 0.051 & 384 & 9 & 62.93955 & 1.415 & 0.03971 & 0.00226 & 0.00547 & 0.00226 & 2.56597 & 0.07286 & 0.0042 & 0.00095 & 0.00019 & 61.29732 & 1.55 \\
\hline 1750 & 0.311 & 403 & 7 & 65.19665 & 1.309 & 0.00639 & 0.0004 & 0.00156 & 0.0003 & 0.70754 & 0.01172 & 0.0007 & 0.00021 & 0.00006 & 64.70615 & 1.3 \\
\hline 2000 & 0.343 & 398 & 8 & 64.46249 & 1.296 & 0.00668 & 0.00256 & 0.00212 & 0.00246 & 0.97176 & 0.01226 & 0.0047 & 0.00023 & 0.0002 & 63.80696 & 1.48 \\
\hline 2500 & 0.435 & 406 & 10 & 65.26705 & 1.822 & 0.00285 & 0.00106 & 0.00019 & 0.00117 & 0.08444 & 0.00523 & 0.002 & 0.00021 & 0.00012 & 65.18239 & 1.85 \\
\hline 3000 & 0.520 & 405 & 9 & 65.21331 & 1.642 & 0.00302 & 0.00168 & 0.00074 & 0.00099 & 0.33515 & 0.00554 & 0.0031 & 0.00063 & 0.00016 & 64.96528 & 1.67 \\
\hline 4000 & 0.839 & 405 & 8 & 65.37231 & 1.365 & 0.00206 & 0.0003 & 0.00121 & 0.00024 & 0.54765 & 0.00378 & 0.0006 & 0.00047 & 0.00009 & 64.98485 & 1.36 \\
\hline 5000 & 0.926 & 409 & 9 & 66.14311 & 1.622 & 0.00439 & 0.0011 & 0.00141 & 0.00095 & 0.62961 & 0.00806 & 0.002 & 0.00062 & 0.00015 & 65.69735 & 1.64 \\
\hline 9000 & 1.000 & 406 & 10 & 66.05637 & 1.694 & 0.00474 & 0.00135 & 0.00287 & 0.00135 & 1.28225 & 0.0087 & 0.0025 & 0.00041 & 0.00011 & 65.18027 & 1.73 \\
\hline Integrated & NA & 402 & 4 & 65.07973 & 0.625 & 0.01634 & 0.00036 & 0.00167 & 0.00026 & 0.75452 & 0.02998 & 0.0007 & 0.00043 & 0.00004 & 64.55996 & 0.63 \\
\hline
\end{tabular}

Weighted average of $\mathrm{J}$ from standards $=3.869 \mathrm{e}-03+/-2.644 \mathrm{e}-05$

\section{JT12; Neruokpuk Formation (N69.21, W142.85)}

\begin{tabular}{|c|c|c|c|c|c|c|c|c|c|c|c|c|c|c|c|c|}
\hline 500 & 0.003 & 1620 & 800 & 603.566 & 412.6 & -0.37142 & 1.51956 & 0.11062 & 0.59655 & 5.4211 & -0.6813 & 2.7867 & 0.28427 & 0.23894 & 570.6683 & 427 \\
\hline 750 & 0.009 & 6820 & 889 & 16910.1557 & 8534 & -0.23958 & 0.82984 & 0.17091 & 0.39572 & 0.29878 & -0.4395 & 1.5221 & 0.72563 & 0.37878 & 16856.75 & 8507 \\
\hline 1000 & 0.015 & 5604 & 790 & 8346.9325 & 3831 & -0.18762 & 0.58919 & -0.14799 & 0.24816 & -0.52374 & -0.3442 & 1.0808 & 0.29422 & 0.15674 & 8389.507 & 3850 \\
\hline 1250 & 0.023 & 4404 & 535 & 4049.13861 & 1315 & -0.02915 & 0.46053 & -0.24431 & 0.25612 & -1.7829 & -0.0535 & 0.845 & 0.07736 & 0.06763 & 4121.216 & 1340 \\
\hline 1500 & 0.040 & 3138 & 282 & 1854.54956 & 350.4 & 0.13124 & 0.2669 & 0.03719 & 0.10986 & 0.59198 & 0.24083 & 0.4898 & 0.04556 & 0.03707 & 1843.712 & 350 \\
\hline 1750 & 0.067 & 852 & 88 & 210.00748 & 20.17 & -0.01861 & 0.13546 & -0.09125 & 0.06946 & -12.84136 & -0.0342 & 0.2485 & -0.01373 & 0.01616 & 236.9387 & 30.5 \\
\hline 2000 & 0.110 & 372 & 68 & 85.66562 & 4.968 & 0.0349 & 0.10114 & -0.01463 & 0.0587 & -5.05189 & 0.06403 & 0.1856 & -0.00707 & 0.01141 & 89.96437 & 18.1 \\
\hline 2500 & 0.205 & 305 & 25 & 77.4225 & 2.522 & 0.02952 & 0.05007 & 0.01751 & 0.01988 & 6.6829 & 0.05416 & 0.0919 & -0.00065 & 0.00514 & 72.22223 & 6.33 \\
\hline 3000 & 0.328 & 342 & 18 & 84.31936 & 2.109 & 0.00769 & 0.02934 & 0.00854 & 0.0149 & 2.99216 & 0.01412 & 0.0538 & 0.00076 & 0.00403 & 81.76802 & 4.86 \\
\hline 4000 & 0.546 & 423 & 13 & 102.40705 & 2.044 & 0.00933 & 0.02229 & -0.00436 & 0.01038 & -1.25882 & 0.01711 & 0.0409 & -0.00193 & 0.00229 & 103.6668 & 3.7 \\
\hline 5000 & 0.844 & 433 & 9 & 107.92189 & 1.251 & -0.00008 & 0.01348 & 0.00527 & 0.00737 & 1.44445 & -0.0002 & 0.0247 & 0.00215 & 0.00158 & 106.3337 & 2.5 \\
\hline 9000 & 1.000 & 750 & 19 & 204.08624 & 5.418 & 0.02821 & 0.02564 & 0.00668 & 0.01 & 0.96556 & 0.05177 & 0.0471 & -0.00019 & 0.00353 & 202.0903 & 6.13 \\
\hline Integrated & NA & 1086 & 11 & 324.2262 & 3.513 & 0.00929 & 0.01466 & 0.00015 & 0.00685 & 0.0137 & 0.01705 & 0.0269 & 0.00767 & 0.00174 & 324.1542 & 4.05 \\
\hline
\end{tabular}

Weighted average of $\mathrm{J}$ from standards $=2.552 \mathrm{e}-03+/-1.290 \mathrm{e}-05$ 
TABLE SM2.6: STEPWISE ${ }^{40} \mathrm{Ar} /{ }^{39} \mathrm{Ar}$ ISOTOPE COMPOSITIONS OF MUSCOVITE (UNIVERSITY OF ALASKA FAIRBANKS LAB)

\begin{tabular}{|c|c|c|c|c|c|c|c|c|c|c|c|c|c|c|c|c|}
\hline L.Power & Cumulative & Age & \pm & ${ }^{40} \mathrm{Ar} /{ }^{39} \mathrm{Ar}$ & \pm & ${ }^{37} \mathrm{Ar} /{ }^{39} \mathrm{Ar}$ & \pm & ${ }^{36} \mathrm{Ar} /{ }^{39} \mathrm{Ar}$ & \pm & $\%$ Atm. & $\mathrm{Ca} / \mathrm{K}$ & \pm & $\mathrm{Cl} / \mathrm{K}$ & \pm & $40 * 1^{39} \mathrm{~K}$ & \pm \\
\hline$(\mathrm{mW})$ & 39Ar & (Ma) & (Ma) & meas. & abs. & meas. & abs. & meas. & abs. & ${ }^{40} \mathrm{Ar}$ & meas. & abs. & meas. & abs. & meas. & abs. \\
\hline \multicolumn{17}{|c|}{ 37LF13; Neruokpuk Formation (N69.35, W142.92) } \\
\hline 300 & 0.003 & 965 & 306 & 338.35877 & 125 & 0.24518 & 0.32707 & 0.20635 & 0.18196 & 18.01676 & 0.44994 & 0.6003 & -0.01132 & 0.03238 & 277.4212 & 114 \\
\hline 500 & 0.011 & 1191 & 125 & 391.02303 & 50.97 & 0.09062 & 0.09897 & 0.08079 & 0.07466 & 6.10371 & 0.16629 & 0.1816 & -0.01901 & 0.01225 & 367.1517 & 52.6 \\
\hline 750 & 0.036 & 1680 & 47 & 626.61827 & 25.66 & -0.01214 & 0.02922 & 0.07768 & 0.02752 & 3.66358 & -0.0223 & 0.0536 & -0.00788 & 0.00296 & 603.6278 & 26 \\
\hline 1000 & 0.080 & 2174 & 28 & 918.59537 & 20.26 & -0.00776 & 0.02178 & 0.00481 & 0.01458 & 0.15484 & -0.0142 & 0.04 & -0.0016 & 0.00162 & 917.1384 & 20.7 \\
\hline 1250 & 0.148 & 2337 & 31 & 1048.55519 & 24.17 & -0.1052 & 0.06373 & 0.02379 & 0.02024 & 0.6714 & -0.193 & 0.1169 & 0.00061 & 0.00219 & 1041.408 & 24.7 \\
\hline 1500 & 0.247 & 2470 & 20 & 1151.82654 & 16.98 & 0.00497 & 0.00816 & 0.00205 & 0.0053 & 0.05255 & 0.00911 & 0.015 & -0.0003 & 0.0008 & 1151.196 & 17 \\
\hline 1750 & 0.373 & 2544 & 13 & 1216.58198 & 11.26 & 0.00109 & 0.00471 & 0.00331 & 0.00399 & 0.08041 & 0.002 & 0.0087 & -0.00135 & 0.00076 & 1215.575 & 11.3 \\
\hline 2000 & 0.570 & 2542 & 11 & 1214.71634 & 10.05 & -0.00203 & 0.00336 & 0.00092 & 0.00285 & 0.02232 & -0.0037 & 0.0062 & -0.00075 & 0.00062 & 1214.414 & 10.1 \\
\hline 2500 & 0.642 & 2519 & 25 & 1192.11588 & 22.18 & -0.00489 & 0.00982 & -0.0042 & 0.00857 & -0.10415 & -0.009 & 0.018 & -0.00165 & 0.00135 & 1193.324 & 22.4 \\
\hline 3000 & 0.712 & 2520 & 25 & 1194.4757 & 21.76 & 0.05342 & 0.01025 & -0.00026 & 0.00687 & -0.0067 & 0.09802 & 0.0188 & -0.00211 & 0.00229 & 1194.571 & 21.9 \\
\hline 4000 & 0.763 & 2494 & 43 & 1168.81183 & 36.75 & -0.00741 & 0.02052 & -0.00999 & 0.01219 & -0.2525 & -0.0136 & 0.0377 & -0.0041 & 0.00149 & 1171.727 & 37 \\
\hline 5000 & 0.839 & 2498 & 27 & 1172.45674 & 23.66 & 0.01464 & 0.01924 & -0.00957 & 0.0096 & -0.24134 & 0.02687 & 0.0353 & -0.0025 & 0.0014 & 1175.269 & 23.9 \\
\hline 9000 & 1.000 & 2214 & 13 & 946.21915 & 9.873 & -0.00959 & 0.00786 & -0.00189 & 0.00364 & -0.05883 & -0.0176 & 0.0144 & -0.00003 & 0.00101 & 946.7397 & 9.94 \\
\hline Integrated & NA & 2418 & 9 & 1108.62244 & 5.424 & -0.00362 & 0.0054 & 0.00397 & 0.00246 & 0.10581 & -0.0066 & 0.0099 & -0.00143 & 0.0004 & 1107.417 & 5.47 \\
\hline J1355-67; N & uokpuk For & tion (N & $.22, \mathrm{~V}$ & $e-03+/-1.290$ & e-05 & & & & & & & & & & & \\
\hline 300 & 0.012 & 3459 & 122 & 2321.41507 & 184.5 & 0.01542 & 0.08792 & 0.14396 & 0.04093 & 1.83249 & 0.02829 & 0.1613 & 0.0609 & 0.0114 & 2278.871 & 181 \\
\hline 500 & 0.029 & 2853 & 97 & 1551.10766 & 105 & -0.09852 & 0.06385 & 0.11502 & 0.03779 & 2.19177 & -0.1808 & 0.1171 & 0.05957 & 0.00788 & 1516.976 & 103 \\
\hline 750 & 0.073 & 1150 & 26 & 368.3193 & 10.28 & 0.27838 & 0.03078 & 0.06314 & 0.01432 & 5.06017 & 0.51088 & 0.0565 & 0.03504 & 0.00288 & 349.7223 & 10.6 \\
\hline 1000 & 0.137 & 805 & 13 & 227.39017 & 4.083 & 0.02439 & 0.01575 & 0.02287 & 0.00746 & 2.9716 & 0.04475 & 0.0289 & 0.01366 & 0.00193 & 220.608 & 4.53 \\
\hline 1250 & 0.219 & 928 & 14 & 265.65263 & 4.96 & -0.00247 & 0.01296 & 0.00545 & 0.00621 & 0.60668 & -0.0045 & 0.0238 & 0.00656 & 0.00141 & 264.011 & 5.26 \\
\hline 1500 & 0.348 & 1366 & 14 & 444.9106 & 6.422 & 0.00103 & 0.00735 & 0.00243 & 0.00347 & 0.16126 & 0.0019 & 0.0135 & 0.00169 & 0.00086 & 444.1638 & 6.49 \\
\hline 1750 & 0.432 & 1197 & 13 & 368.05256 & 4.803 & -0.00844 & 0.01578 & -0.00566 & 0.00901 & -0.45426 & -0.0155 & 0.029 & 0.00252 & 0.00177 & 369.6924 & 5.51 \\
\hline 2000 & 0.527 & 1483 & 13 & 498.45203 & 6.119 & -0.00852 & 0.0098 & -0.00709 & 0.00444 & -0.4205 & -0.0156 & 0.018 & 0.00151 & 0.00178 & 500.5152 & 6.28 \\
\hline 2500 & 0.670 & 1607 & 14 & 562.31926 & 7.51 & -0.00797 & 0.00734 & -0.00596 & 0.00339 & -0.31296 & -0.0146 & 0.0135 & 0.00035 & 0.00078 & 564.0461 & 7.6 \\
\hline 3000 & 0.762 & 1534 & 12 & 524.28648 & 5.99 & 0.00512 & 0.01032 & -0.00523 & 0.00383 & -0.29496 & 0.00939 & 0.0189 & 0.00045 & 0.00091 & 525.8051 & 6.11 \\
\hline 4000 & 0.860 & 1513 & 13 & 513.88416 & 6.506 & -0.00094 & 0.01141 & -0.00552 & 0.00537 & -0.31753 & -0.0017 & 0.0209 & -0.0011 & 0.00091 & 515.4857 & 6.72 \\
\hline 5000 & 0.968 & 1748 & 13 & 642.36088 & 7.106 & -0.0068 & 0.01095 & 0.00209 & 0.00425 & 0.09611 & -0.0125 & 0.0201 & 0.00015 & 0.00105 & 641.7107 & 7.21 \\
\hline
\end{tabular}


TABLE SM2.6: STEPWISE ${ }^{40} \mathrm{Ar} /{ }^{39} \mathrm{Ar}$ ISOTOPE COMPOSITIONS OF MUSCOVITE (UNIVERSITY OF ALASKA FAIRBANKS LAB)

\begin{tabular}{|c|c|cc|cccccccccccccccccccc}
\hline \hline L.Power & Cumulative & Age & \pm & ${ }^{40} \mathrm{Ar} /{ }^{39} \mathrm{Ar}$ & \pm & ${ }^{37} \mathrm{Ar} /{ }^{39} \mathrm{Ar}$ & \pm & ${ }^{36} \mathrm{Ar} /{ }^{39} \mathrm{Ar}$ & \pm & $\% \mathrm{Atm}$. & $\mathrm{Ca} / \mathrm{K}$ & \pm & $\mathrm{Cl} / \mathrm{K}$ & \pm & $40 * /{ }^{39} \mathrm{~K}$ & \pm \\
\hline$(\mathrm{mW})$ & $39 \mathrm{Ar}$ & $(\mathrm{Ma})$ & $(\mathrm{Ma})$ & meas. & abs. & meas. & abs. & meas. & abs. & ${ }^{40} \mathrm{Ar}$ & meas. & abs. & meas. & abs. & meas. & abs. \\
\hline 9000 & 1.000 & 1661 & 49 & 597.54691 & 26.82 & 0.09344 & 0.03293 & 0.01428 & 0.0148 & 0.70475 & 0.17147 & 0.0604 & 0.0046 & 0.004 & 593.3454 & 27 \\
Integrated & NA & 1498 & 7 & 509.70986 & 2.456 & 0.01228 & 0.00392 & 0.00633 & 0.00187 & 0.36663 & 0.02254 & 0.0072 & 0.00541 & 0.00044 & 507.8159 & 2.51 \\
\hline
\end{tabular}

Weighted average of $\mathrm{J}$ from standards $=2.552 \mathrm{e}-03+/-1.290 \mathrm{e}-05$

\section{JT24; Clarence River Group (N69.28, W142.75)}

\begin{tabular}{|c|c|c|c|c|c|c|c|c|c|c|c|c|c|c|c|c|}
\hline 300 & 0.009 & 2516 & 23 & 1201.69233 & 19.29 & 0.10832 & 0.02861 & 0.03768 & 0.0231 & 0.92585 & 0.19877 & 0.0525 & 0.01487 & 0.00263 & 1190.628 & 20.3 \\
\hline 500 & 0.026 & 160 & 14 & 46.34279 & 0.846 & 0.12311 & 0.01746 & 0.03373 & 0.01083 & 21.49637 & 0.22591 & 0.0321 & 0.00735 & 0.00097 & 36.36062 & 3.26 \\
\hline 750 & 0.066 & 176 & 6 & 41.26508 & 0.491 & 0.10065 & 0.00738 & 0.00391 & 0.00425 & 2.78203 & 0.1847 & 0.0135 & 0.00513 & 0.0007 & 40.09105 & 1.34 \\
\hline 1000 & 0.132 & 266 & 3 & 64.24004 & 0.349 & 0.21559 & 0.00437 & 0.00628 & 0.00256 & 2.86456 & 0.39563 & 0.008 & 0.0041 & 0.00026 & 62.38049 & 0.83 \\
\hline 1250 & 0.218 & 391 & 3 & 95.6962 & 0.414 & 0.50521 & 0.00611 & 0.00247 & 0.00186 & 0.71892 & 0.92731 & 0.0112 & 0.00164 & 0.00032 & 95.01265 & 0.69 \\
\hline 1500 & 0.305 & 417 & 3 & 102.18777 & 0.597 & 0.88318 & 0.0107 & 0.00091 & 0.00207 & 0.19052 & 1.62153 & 0.0197 & 0.0017 & 0.0003 & 102.0271 & 0.85 \\
\hline 1750 & 0.383 & 427 & 4 & 103.95041 & 0.815 & 1.22978 & 0.01418 & -0.00244 & 0.003 & -0.78995 & 2.25843 & 0.0261 & 0.00231 & 0.00037 & 104.8327 & 1.21 \\
\hline 2000 & 0.452 & 421 & 4 & 103.34382 & 0.67 & 1.44857 & 0.01275 & 0.00175 & 0.00248 & 0.38469 & 2.66065 & 0.0234 & 0.00242 & 0.00032 & 103.0221 & 0.99 \\
\hline 2500 & 0.528 & 422 & 4 & 103.69194 & 0.948 & 1.78087 & 0.01828 & 0.00177 & 0.0022 & 0.36371 & 3.27177 & 0.0336 & 0.00331 & 0.00025 & 103.4153 & 1.15 \\
\hline 3000 & 0.604 & 411 & 3 & 100.85195 & 0.645 & 1.03541 & 0.00899 & 0.00203 & 0.00203 & 0.50922 & 1.90123 & 0.0165 & 0.00227 & 0.00024 & 100.3823 & 0.88 \\
\hline 4000 & 0.702 & 515 & 3 & 129.51304 & 0.583 & 0.04882 & 0.00262 & -0.00084 & 0.00164 & -0.19508 & 0.08959 & 0.0048 & 0.00062 & 0.00018 & 129.7404 & 0.76 \\
\hline 5000 & 0.798 & 531 & 3 & 134.13874 & 0.775 & 0.03375 & 0.00316 & -0.00007 & 0.00196 & -0.01841 & 0.06194 & 0.0058 & 0.00054 & 0.00029 & 134.1369 & 0.97 \\
\hline 9000 & 1.000 & 585 & 2 & 150.78829 & 0.653 & 0.05422 & 0.00148 & 0.0013 & 0.0008 & 0.25188 & 0.09949 & 0.0027 & 0.001 & 0.00012 & 150.3846 & 0.69 \\
\hline Integrated & NA & 484 & 2 & 121.24043 & 0.225 & 0.57079 & 0.00211 & 0.00217 & 0.00064 & 0.49026 & 1.04774 & 0.0039 & 0.00211 & 0.00008 & 120.6651 & 0.29 \\
\hline
\end{tabular}

Weighted average of $\mathrm{J}$ from standards $=2.552 \mathrm{e}-03+/-1.290 \mathrm{e}-05$

09LF13; Clarence River Group (N69.27, W142.66)

\begin{tabular}{|c|c|c|c|c|c|c|c|c|c|c|c|c|c|c|c|c|}
\hline 300 & 0.002 & 157 & 191 & 88.43796 & 19 & 0.43686 & 0.24279 & 0.17878 & 0.15593 & 59.71627 & 0.80183 & 0.4458 & 0.04587 & 0.02911 & 35.62514 & 45.4 \\
\hline 500 & 0.003 & 354 & 185 & 414.00764 & 77.99 & 0.21412 & 0.3233 & 1.11284 & 0.26159 & 79.4311 & 0.39295 & 0.5934 & 0.00729 & 0.0377 & 85.16359 & 49 \\
\hline 750 & 0.007 & 346 & 73 & 99.71511 & 8.496 & 0.59234 & 0.09498 & 0.05672 & 0.06041 & 16.76501 & 1.08732 & 0.1744 & -0.00025 & 0.01128 & 83.00788 & 19.2 \\
\hline 1000 & 0.015 & 318 & 90 & 113.28026 & 5.146 & 1.37815 & 0.08649 & 0.12801 & 0.07826 & 33.30012 & 2.53118 & 0.159 & -0.00471 & 0.00714 & 75.6116 & 23.3 \\
\hline 1250 & 0.032 & 462 & 16 & 115.4099 & 2.278 & 0.4475 & 0.02834 & 0.00323 & 0.01304 & 0.79557 & 0.82136 & 0.052 & 0.00328 & 0.00389 & 114.4985 & 4.47 \\
\hline 1500 & 0.052 & 460 & 18 & 114.53848 & 2.788 & 0.01394 & 0.02396 & 0.0019 & 0.01421 & 0.49053 & 0.02557 & 0.044 & 0.00263 & 0.00325 & 113.9482 & 5.03 \\
\hline 1750 & 0.085 & 464 & 10 & 115.93303 & 0.826 & 0.00412 & 0.01311 & 0.00303 & 0.00888 & 0.77111 & 0.00755 & 0.0241 & 0.0019 & 0.00156 & 115.0099 & 2.75 \\
\hline 2000 & 0.149 & 465 & 6 & 115.92671 & 1.321 & 0.00679 & 0.00614 & 0.00181 & 0.00428 & 0.46128 & 0.01246 & 0.0113 & 0.00091 & 0.00083 & 115.363 & 1.83 \\
\hline 2500 & 0.502 & 456 & 2 & 113.22081 & 0.663 & 0.00097 & 0.0018 & 0.00086 & 0.00076 & 0.2232 & 0.00179 & 0.0033 & 0.00068 & 0.00021 & 112.9386 & 0.7 \\
\hline
\end{tabular}


TABLE SM2.6: STEPWISE ${ }^{40} \mathrm{Ar} /{ }^{39} \mathrm{Ar}$ ISOTOPE COMPOSITIONS OF MUSCOVITE (UNIVERSITY OF ALASKA FAIRBANKS LAB)

\begin{tabular}{|c|c|cc|cccccccccccccccccccccccc}
\hline \hline L.Power & Cumulative & Age & \pm & ${ }^{40} \mathrm{Ar} /{ }^{39} \mathrm{Ar}$ & \pm & ${ }^{37} \mathrm{Ar} /{ }^{39} \mathrm{Ar}$ & \pm & ${ }^{36} \mathrm{Ar} /{ }^{39} \mathrm{Ar}$ & \pm & $\% \mathrm{Atm}$. & $\mathrm{Ca} / \mathrm{K}$ & \pm & $\mathrm{Cl} / \mathrm{K}$ & \pm & $40 * /{ }^{39} \mathrm{~K}$ & \pm \\
\hline$(\mathrm{mW})$ & $39 \mathrm{Ar}$ & $(\mathrm{Ma})$ & $(\mathrm{Ma})$ & meas. & abs. & meas. & abs. & meas. & abs. & ${ }^{40} \mathrm{Ar}$ & meas. & abs. & meas. & abs. & meas. & abs. \\
\hline 3000 & 0.633 & 462 & 3 & 114.65743 & 0.579 & 0.00343 & 0.00326 & -0.00001 & 0.0019 & -0.0023 & 0.0063 & 0.006 & 0.00083 & 0.0004 & 114.6307 & 0.81 \\
4000 & 0.805 & 457 & 3 & 113.18677 & 0.728 & -0.00033 & 0.00203 & -0.00025 & 0.00187 & -0.06408 & -0.0006 & 0.0037 & 0.00038 & 0.00027 & 113.2296 & 0.92 \\
5000 & 0.935 & 453 & 3 & 112.12498 & 0.658 & -0.00107 & 0.00298 & 0.00021 & 0.00234 & 0.05523 & -0.002 & 0.0055 & 0.00037 & 0.00035 & 112.0333 & 0.95 \\
9000 & 1.000 & 452 & 5 & 113.31269 & 0.882 & 0.00756 & 0.00655 & 0.00556 & 0.00404 & 1.45038 & 0.01388 & 0.012 & 0.00051 & 0.00063 & 111.6406 & 1.48 \\
Integrated & NA & 456 & 3 & 113.9384 & 0.325 & 0.02393 & 0.00159 & 0.00414 & 0.00112 & 1.07193 & 0.04391 & 0.0029 & 0.00077 & 0.0002 & 112.6896 & 0.46 \\
\hline
\end{tabular}

Weighted average of $\mathrm{J}$ from standards $=2.552 \mathrm{e}-03+/-1.290 \mathrm{e}-05$

40LF13; Clarence River Group (N69.27, W142.91)

\begin{tabular}{|c|c|c|c|c|c|c|c|c|c|c|c|c|c|c|c|c|}
\hline 300 & 0.001 & 389 & 78 & 115.35378 & 17.54 & -0.37574 & 0.18991 & 0.07085 & 0.05291 & 18.18179 & -0.6893 & 0.3483 & -0.06542 & 0.03118 & 94.33106 & 21 \\
\hline 500 & 0.005 & 303 & 30 & 86.41989 & 4.833 & -0.15123 & 0.0618 & 0.04968 & 0.02268 & 17.00843 & -0.2775 & 0.1134 & -0.02012 & 0.01331 & 71.68892 & 7.78 \\
\hline 750 & 0.018 & 290 & 9 & 74.51792 & 1.481 & -0.03504 & 0.0197 & 0.02058 & 0.00648 & 8.16893 & -0.0643 & 0.0362 & -0.00336 & 0.00413 & 68.40164 & 2.35 \\
\hline 1000 & 0.048 & 341 & 5 & 85.61713 & 0.95 & -0.01637 & 0.00803 & 0.01339 & 0.00336 & 4.62579 & -0.03 & 0.0147 & -0.00221 & 0.00134 & 81.62739 & 1.34 \\
\hline 1250 & 0.089 & 402 & 3 & 97.69264 & 0.755 & -0.01194 & 0.00653 & -0.00044 & 0.00191 & -0.13062 & -0.0219 & 0.012 & -0.0018 & 0.00099 & 97.78968 & 0.94 \\
\hline 1500 & 0.151 & 420 & 3 & 102.92471 & 0.843 & -0.01602 & 0.00359 & 0.00034 & 0.00148 & 0.09911 & -0.0294 & 0.0066 & -0.00098 & 0.00067 & 102.7919 & 0.95 \\
\hline 1750 & 0.253 & 428 & 2 & 105.04168 & 0.506 & -0.00367 & 0.0025 & 0.00003 & 0.00098 & 0.00747 & -0.0067 & 0.0046 & -0.00018 & 0.00042 & 105.0039 & 0.58 \\
\hline 2000 & 0.387 & 437 & 1 & 107.48511 & 0.314 & -0.00325 & 0.00174 & 0.00011 & 0.00062 & 0.03159 & -0.006 & 0.0032 & -0.00002 & 0.00031 & 107.4212 & 0.36 \\
\hline 2500 & 0.583 & 436 & 2 & 107.59678 & 0.475 & -0.00311 & 0.00113 & 0.00092 & 0.00044 & 0.25179 & -0.0057 & 0.0021 & 0.00036 & 0.00023 & 107.296 & 0.49 \\
\hline 3000 & 0.700 & 435 & 2 & 106.89616 & 0.489 & -0.00443 & 0.00241 & 0.00001 & 0.00082 & 0.00181 & -0.0081 & 0.0044 & -0.00032 & 0.00035 & 106.8642 & 0.55 \\
\hline 4000 & 0.795 & 436 & 3 & 107.84393 & 0.864 & -0.00438 & 0.00293 & 0.00234 & 0.00102 & 0.64175 & -0.008 & 0.0054 & -0.00039 & 0.00048 & 107.122 & 0.91 \\
\hline 5000 & 0.855 & 435 & 3 & 107.2692 & 0.58 & -0.01161 & 0.00456 & 0.00108 & 0.00151 & 0.2998 & -0.0213 & 0.0084 & -0.00134 & 0.00069 & 106.9171 & 0.73 \\
\hline 9000 & 1.000 & 437 & 2 & 107.66128 & 0.523 & -0.00459 & 0.00165 & -0.00009 & 0.00045 & -0.02368 & -0.0084 & 0.003 & -0.00032 & 0.00031 & 107.6567 & 0.54 \\
\hline Integrated & NA & 428 & 2 & 105.39693 & 0.19 & -0.00722 & 0.0009 & 0.00143 & 0.00032 & 0.40131 & -0.0132 & 0.0017 & -0.00056 & 0.00016 & 104.9438 & 0.21 \\
\hline
\end{tabular}

Weighted average of $\mathrm{J}$ from standards $=2.552 \mathrm{e}-03+/-1.290 \mathrm{e}-05$

\section{BJ27; Clarence River Group (N69.26, W142.66)}

\begin{tabular}{|c|c|c|c|c|c|c|c|c|c|c|c|c|c|c|c|c|}
\hline 300 & 0.000 & 54 & 959 & 114.84144 & 76.91 & -0.53091 & 1.02887 & 0.35544 & 0.64215 & 91.5197 & -0.9738 & 1.8864 & 0.03664 & 0.08129 & 9.73273 & 177 \\
\hline 500 & 0.001 & 496 & 609 & 194.44896 & 116.9 & -1.32435 & 1.07553 & 0.31223 & 0.4767 & 47.51183 & -2.4277 & 1.9698 & -0.01014 & 0.05384 & 101.9517 & 143 \\
\hline 750 & 0.002 & 308 & 322 & 88.2614 & 29.13 & -0.30494 & 0.44824 & 0.09532 & 0.2231 & 31.95326 & -0.5594 & 0.8221 & 0.00615 & 0.02981 & 60.02586 & 68.2 \\
\hline 1000 & 0.006 & 369 & 78 & 81.88084 & 5.858 & -0.07164 & 0.09376 & 0.02946 & 0.05486 & 10.64424 & -0.1315 & 0.172 & 0.00837 & 0.00688 & 73.13501 & 17 \\
\hline 1250 & 0.017 & 498 & 33 & 103.40061 & 3.975 & -0.0374 & 0.04099 & 0.0031 & 0.02234 & 0.88883 & -0.0686 & 0.0752 & 0.00527 & 0.00303 & 102.4494 & 7.69 \\
\hline 1500 & 0.036 & 482 & 20 & 98.72939 & 1.918 & -0.01541 & 0.01932 & 0.00012 & 0.0143 & 0.03635 & -0.0283 & 0.0355 & 0.00022 & 0.00175 & 98.66274 & 4.64 \\
\hline
\end{tabular}


TABLE SM2.6: STEPWISE ${ }^{40} \mathrm{Ar} /{ }^{39} \mathrm{Ar}$ ISOTOPE COMPOSITIONS OF MUSCOVITE (UNIVERSITY OF ALASKA FAIRBANKS LAB)

\begin{tabular}{|c|c|cc|ccccccccccccc}
\hline \hline L.Power & Cumulative & Age & \pm & ${ }^{40} \mathrm{Ar} /{ }^{39} \mathrm{Ar}$ & \pm & ${ }^{37} \mathrm{Ar} /{ }^{39} \mathrm{Ar}$ & \pm & ${ }^{36} \mathrm{Ar} /{ }^{39} \mathrm{Ar}$ & \pm & $\% \mathrm{Atm}$. & $\mathrm{Ca} / \mathrm{K}$ & \pm & $\mathrm{Cl} / \mathrm{K}$ & \pm & $40 * /{ }^{39} \mathrm{~K}$ & \pm \\
\hline$(\mathrm{mW})$ & $39 \mathrm{Ar}$ & $(\mathrm{Ma})$ & $(\mathrm{Ma})$ & meas. & abs. & meas. & abs. & meas. & abs. & ${ }^{40} \mathrm{Ar}$ & meas. & abs. & meas. & abs. & meas. & abs. \\
\hline 1750 & 0.088 & 479 & 8 & 99.41472 & 1.239 & -0.00833 & 0.00757 & 0.0044 & 0.00456 & 1.30772 & -0.0153 & 0.0139 & 0.00083 & 0.00067 & 98.08477 & 1.82 \\
2000 & 0.212 & 477 & 4 & 97.3561 & 0.671 & -0.00184 & 0.00342 & -0.00052 & 0.00198 & -0.15654 & -0.0034 & 0.0063 & 0.00029 & 0.00023 & 97.47862 & 0.89 \\
2500 & 0.606 & 474 & 2 & 96.86885 & 0.295 & 0.00003 & 0.00126 & -0.00002 & 0.00071 & -0.0052 & 0.00006 & 0.0023 & 0.00037 & 0.0001 & 96.84419 & 0.36 \\
3000 & 0.677 & 467 & 6 & 96.07133 & 1.025 & -0.00207 & 0.00533 & 0.00249 & 0.00322 & 0.76496 & -0.0038 & 0.0098 & -0.00036 & 0.00047 & 95.30681 & 1.39 \\
4000 & 0.772 & 469 & 4 & 95.69016 & 0.706 & -0.0109 & 0.00471 & -0.00023 & 0.00242 & -0.071 & -0.02 & 0.0086 & -0.00015 & 0.00035 & 95.72764 & 1.01 \\
5000 & 0.816 & 478 & 8 & 96.50584 & 0.942 & -0.0121 & 0.00761 & -0.00406 & 0.00522 & -1.24123 & -0.0222 & 0.014 & 0.00084 & 0.0007 & 97.67279 & 1.81 \\
9000 & 1.000 & 471 & 3 & 96.23921 & 0.371 & -0.00401 & 0.00171 & -0.0002 & 0.00154 & -0.06022 & -0.0074 & 0.0031 & 0.00026 & 0.00021 & 96.26718 & 0.59 \\
Integrated & NA & 473 & 2 & 96.85517 & 0.217 & -0.00531 & 0.00145 & 0.00065 & 0.00088 & 0.19958 & -0.0097 & 0.0027 & 0.00038 & 0.00012 & 96.63186 & 0.34 \\
\hline
\end{tabular}

Weighted average of $\mathrm{J}$ from standards $=3.107 \mathrm{e}-03+/-8.884 \mathrm{e}-06$ 
TABLE SM2.7: SINGLE-GRAIN MUSCOVITE TOTAL FUSION ${ }^{40} \mathrm{Ar} /{ }^{39} \mathrm{Ar}$ ISOTOPE COMPOSITIONS (UNIVERSITY OF ALASKA FAIRBANKS LAB)

\begin{tabular}{|c|c|c|c|c|c|c|c|c|c|c|c|c|c|c|c|}
\hline \multicolumn{16}{|c|}{ 14BJ27; Clarence River Group (N69.27, W142.66) } \\
\hline Grain \# & Age & \pm & ${ }^{40} \mathrm{Ar} /{ }^{39} \mathrm{Ar}$ & \pm & ${ }^{37} \mathrm{Ar} /{ }^{39} \mathrm{Ar}$ & \pm & ${ }^{36} \mathrm{Ar} /{ }^{39} \mathrm{Ar}$ & \pm & $\%$ Atm. & $\mathrm{Ca} / \mathrm{K}$ & \pm & $\mathrm{Cl} / \mathrm{K}$ & \pm & $40^{\star / 39} \mathrm{~K}$ & \pm \\
\hline & (Ma) & (Ma) & meas. & abs. & meas. & abs. & meas. & abs. & ${ }^{40} \mathrm{Ar}$ & meas. & abs. & meas. & abs. & meas. & abs. \\
\hline 1 & 480 & 1 & 99.44526 & 0.19 & -0.00156 & 0.002 & 0.00362 & 0.00019 & 1.07697 & -0.00286 & 0.003 & 0.00053 & 0.00003 & 98.34477 & 0.196 \\
\hline $2^{*}$ & 472 & 7 & 104.98345 & 1.216 & -0.01182 & 0.024 & 0.02915 & 0.00369 & 8.2087 & -0.02169 & 0.044 & 0.00221 & 0.00069 & 96.33761 & 1.558 \\
\hline 3 & 481 & 1 & 99.48791 & 0.279 & -0.00628 & 0.004 & 0.00335 & 0.00053 & 0.99688 & -0.01152 & 0.007 & 0.00053 & 0.00011 & 98.4663 & 0.317 \\
\hline $4^{*}$ & 473 & 4 & 107.26563 & 0.713 & -0.02762 & 0.011 & 0.03622 & 0.00189 & 9.98271 & -0.05068 & 0.021 & 0.00041 & 0.0003 & 96.52899 & 0.852 \\
\hline $5^{*}$ & 468 & 6 & 101.70489 & 1.051 & -0.02394 & 0.031 & 0.02068 & 0.00287 & 6.0113 & -0.04392 & 0.057 & 0.00002 & 0.00059 & 95.56157 & 1.301 \\
\hline 6 & 496 & 7 & 105.02431 & 0.567 & -0.0089 & 0.027 & 0.00983 & 0.00552 & 2.76735 & -0.01633 & 0.05 & 0.00113 & 0.00081 & 102.0884 & 1.722 \\
\hline 7 & 481 & 2 & 100.69176 & 0.346 & 0.00195 & 0.002 & 0.00764 & 0.00056 & 2.24176 & 0.00357 & 0.003 & 0.00045 & 0.00017 & 98.40559 & 0.377 \\
\hline 8 & 521 & 5 & 109.91415 & 0.899 & -0.00517 & 0.009 & 0.00653 & 0.00248 & 1.7553 & -0.00949 & 0.017 & 0.00171 & 0.00089 & 107.95525 & 1.148 \\
\hline 9 & 490 & 2 & 105.17606 & 0.318 & 0.00146 & 0.006 & 0.01554 & 0.00165 & 4.36627 & 0.00268 & 0.012 & 0.00109 & 0.00042 & 100.55549 & 0.577 \\
\hline 10 & 441 & 2 & 90.85636 & 0.36 & -0.00846 & 0.01 & 0.0056 & 0.00144 & 1.82134 & -0.01553 & 0.018 & 0.00054 & 0.00045 & 89.17186 & 0.554 \\
\hline 11 & 464 & 2 & 95.82278 & 0.341 & -0.00132 & 0.002 & 0.00405 & 0.00054 & 1.24955 & -0.00243 & 0.005 & 0.00054 & 0.00015 & 94.59601 & 0.372 \\
\hline 12 & 491 & 1 & 102.87943 & 0.269 & 0.00455 & 0.004 & 0.00708 & 0.00072 & 2.03427 & 0.00835 & 0.008 & 0.00067 & 0.00017 & 100.75781 & 0.339 \\
\hline 13 & 462 & 4 & 97.28589 & 0.756 & -0.00042 & 0.005 & 0.01081 & 0.00126 & 3.28414 & -0.00077 & 0.008 & 0.00044 & 0.00029 & 94.06213 & 0.82 \\
\hline $14^{*}$ & 475 & 7 & 105.39561 & 1.033 & -0.0014 & 0.055 & 0.02828 & 0.00474 & 7.93031 & -0.00258 & 0.102 & 0.00074 & 0.00266 & 97.00997 & 1.692 \\
\hline
\end{tabular}

Weighted average of $\mathrm{J}$ from standards $=3.107 \mathrm{e}-03+/-8.884 \mathrm{e}-06$

* Single-grain total fusion age used in weighted mean age calculation presented in manuscript (Fig. 7) 


\section{Chapter 3 (supplemental material): The Whale Mountain}

\section{allochthon: a relic of the Iapetus Ocean preserved in the}

\section{northeastern Brooks Range, Alaska}

Benjamin G. Johnson ${ }^{1}$, Justin V. Strauss², John F. Taylor ${ }^{3}$, William P. Ward ${ }^{4}$, Maurice Colpron $^{5}$, William C. McClelland ${ }^{4}$, Jaime Toro ${ }^{1}$

${ }^{1}$ Department of Geology and Geography, West Virginia University, Morgantown, West Virginia, 26506 USA

${ }^{2}$ Department of Earth Sciences, Dartmouth College, Hanover, New Hampshire 03755, USA

${ }^{3}$ Department of Geoscience, Indiana University of Pennsylvania, Indiana, Pennsylvania 15705

USA

${ }^{4}$ Department of Earth and Environmental Sciences, University of Iowa, Iowa City, Iowa 52242, USA

${ }^{5}$ Yukon Geological Survey, Whitehorse, Yukon, Canada YIA 2 C6

\section{LA-ICPMS U-Pb Zircon Geochronology}

$\mathrm{U}-\mathrm{Pb}$ isotopic ratios for zircon from two volcaniclastic samples from the Whale Mountain allochthon were analyzed by LA-ICPMS at the University of Arizona LaserChron Center. Instrument setup, tuning, run parameters, standard-unknown bracketing, and data reduction followed that of Gehrels et al. $(2006,2008)$ and Gehrels and Pecha (2014). The separated zircon grains were ablated with a Photon Machines Analyte G2 excimer laser with a HelEx ablation cell using a spot diameter of $20 \mu \mathrm{m}$. The ablation pit was $\sim 12 \mu \mathrm{m}$ in depth using an energy density of $\sim 5 \mathrm{~J} / \mathrm{cm}^{2}$, repetition rate of $8 \mathrm{hz}$, and an ablation time of 10 seconds. Each analysis included counting for 5 seconds with the laser off for backgrounds and 10 seconds with 
the laser firing for peak intensities, followed by a 20 second delay to purge the previous sample and to save the files.

The measured intensities for each analysis were imported into the Arizona LaserChron Center's data reduction program, "agecalc," which reduces the data, alerts users to unusual analyses (e.g., large age uncertainty), calculates ages, and produces a publication ready data table (e.g., Table SM3.2). Three types of zircon grains with known ages were mounted along with unknown grains from our sample set. These were used as primary standards to assess reproducibility and analytical uncertainty of the unknown analyses from our sample set, and they include the Sri Lanka $\left({ }^{206} \mathrm{~Pb} /{ }^{238} \mathrm{U}\right.$ age of $563.2 \pm 4.8 \mathrm{Ma}, 2$, Gehrels et al., 2008), FC-52 $\left({ }^{206} \mathrm{~Pb} /{ }^{207} \mathrm{U}\right.$ age of $1099.0 \pm 0.6 \mathrm{Ma}$; Paces and Miller, 1993), and $\mathrm{R} 33\left({ }^{206} \mathrm{~Pb} /{ }^{238} \mathrm{U}\right.$ age of 420.53 $\pm 0.16 \mathrm{Ma}, 2$, Mattinson, 2010). For each analysis, the errors in determining ${ }^{206} \mathrm{~Pb} /{ }^{238} \mathrm{U}$ and ${ }^{206} \mathrm{~Pb} /{ }^{204} \mathrm{~Pb}$ result in a measurement error of $\sim 1 \%-2 \%$ (at the $2 \sigma$ level) in the ${ }^{206} \mathrm{~Pb} /{ }^{238} \mathrm{U}$ age. The errors in measurement of ${ }^{206} \mathrm{~Pb} /{ }^{207} \mathrm{~Pb}$ and ${ }^{206} \mathrm{~Pb} /{ }^{204} \mathrm{~Pb}$ also result in $\sim 1 \%-2 \%$ (at the $2 \sigma$ level) uncertainty in age for grains that are $>900 \mathrm{Ma}$, but are substantially larger for younger grains due to the low intensity of the ${ }^{207} \mathrm{~Pb}$ signal. For this reason, we report a "Best Age" in Table SM3.2, which selects from the either the ${ }^{206} \mathrm{~Pb} /{ }^{238} \mathrm{U}$ or ${ }^{206} \mathrm{~Pb} /{ }^{207} \mathrm{~Pb}$ age using a cutoff of $900 \mathrm{Ma}$ in the ${ }^{206} \mathrm{~Pb} /{ }^{238} \mathrm{U}$ age. Analyses that are $>20 \%$ discordant or $>5 \%$ reverse discordant (by comparison of ${ }^{206} \mathrm{~Pb} / 238 \mathrm{U}$ and ${ }^{206} \mathrm{~Pb} /{ }^{207} \mathrm{~Pb}$ ages) were filtered out and rejected from any further interpretation.

\section{Zircon Lu-Hf Isotopic Analysis}

A subset of the zircon grains were analyzed for their Lu-Hf isotopic composition using a $\mathrm{Nu}$ Instruments HR-ICP-MS connected to a Photon Machines Analyte G2 excimer laser equipped with a HelEX cell at the Arizona LaserChron Center. Instrument setup, tuning, run parameters, standard-unknown bracketing, and data reduction followed that of Gehrels and 
Pecha (2014). In each analysis, a $40 \mu \mathrm{m}$ diameter ablation site is centered over the previously excavated $\mathrm{U}-\mathrm{Pb}$ analysis pit. The analytical routine consists of a 40 second on-peak background measurement, a 60 second laser ablation measurement, and a 15 second washout time. Using a typical laser effluence of $\sim 5 \mathrm{~J} / \mathrm{cm}^{2}$ and pulse rate of $7 \mathrm{~Hz}$, the ablation rate is $\sim 0.8$ microns per second. Unknown analyses were bracketed by several standard, including R33, SL2, Plesovice, Temora-2, FC-52, 91500, and Mud Tank (Woodhead and Hergt 2005; Sláma et al. 2008;

Bahlburg et al. 2010; Vervoort 2010). 


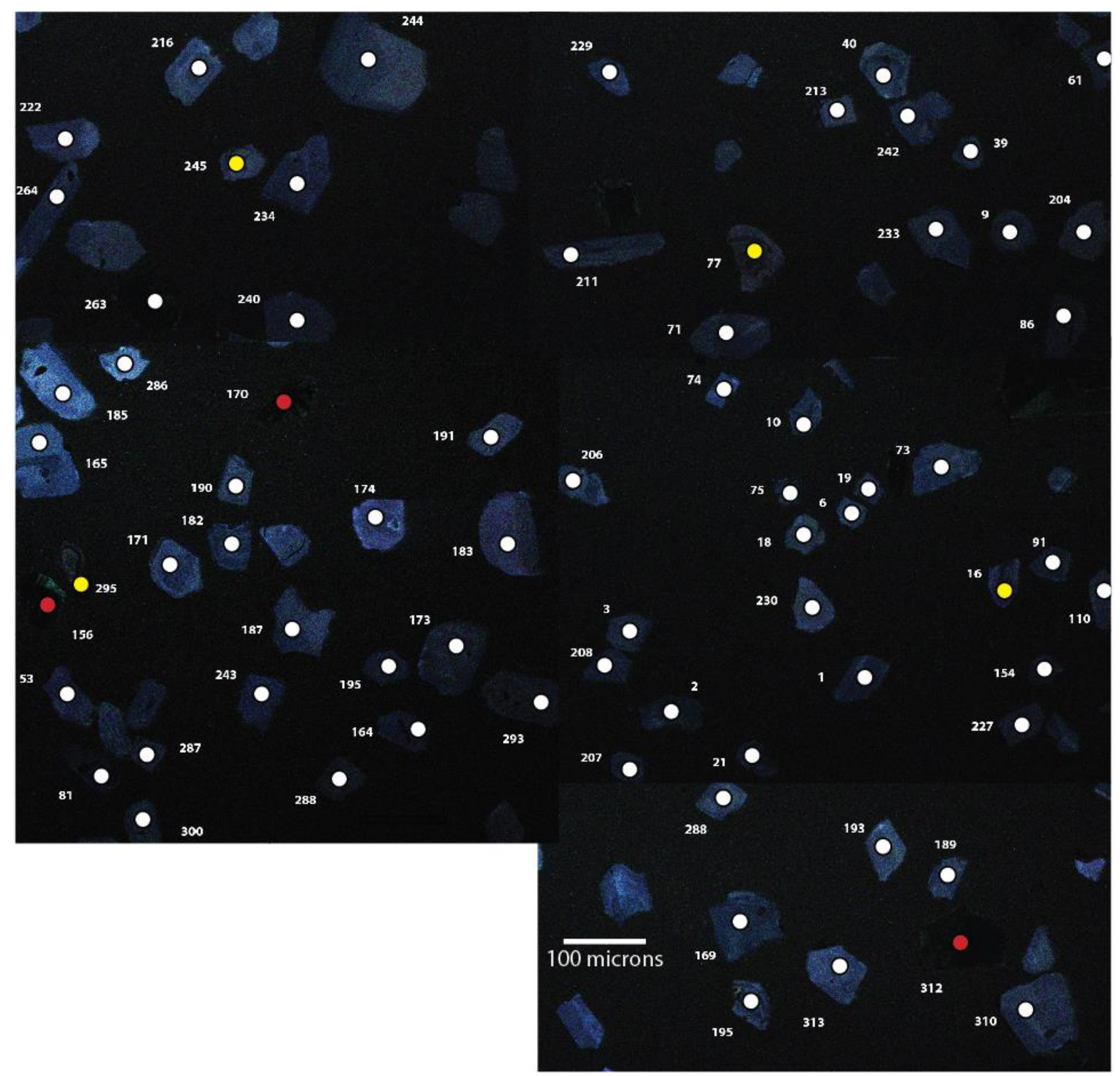

Figure SM3.1: Cathodoluminescence images of selected zircon grains from 15BJ06. White dots show the $20 \mu \mathrm{m}$ ablation site of grains in Table SM3.2; Yellow dots show ablation site of potential contaminated grains, also shown in Table SM3.2; Red dots show ablation site of grains with spurious zircon chemistry that are not included in Table SM3.2. 


\section{References}

Bahlburg, H., Vervoort, J.D., and DuFrane, S.A., 2010, Plate tectonic significance of Middle Cambrian and Ordovician siliciclastic rocks of the Bavarian facies, Armorican terrane assemblage, Germany- $\mathrm{U}-\mathrm{Pb}$ and $\mathrm{Hf}$ isotope evidence from detrital zircons: Gondwana Research, v. 17, p. 223-235, doi:10.1016/j.gr.2009.11.007.

Gehrels, G.E., Valencia, V., and Pullen, A., 2006, Detrital zircon geochronology by Laser Ablation Multicollector ICP-MS at the Arizona LaserChron Center, in Loszewski, T., and Huff, W., eds., Geochronology: Emerging Opportunities, Paleontology Society Short Course: Paleontology Society Papers, v. 11, 10 p.

Gehrels, G.E., Valencia, V., and Ruiz, J., 2008, Enhanced precision, accuracy, efficiency, and spatial resolution of $\mathrm{U}-\mathrm{Pb}$ ages by laser ablation-multicollector-inductively coupled plasma-mass spectrometry: Geochemistry Geophysics Geosystems, v. 9, Q03017, doi:10.1029/2007GC001805.

Gehrels, G.E., and Pecha, M., 2014, Detrital zircon U-Pb geochronology and Hf isotope geochemistry of Paleozoic and Triassic passive margin strata of western North America: Geosphere, v. 10, p. 49-65, doi:10.1130/GES00889.1.

Mattinson, J.M., 2010, Analysis of the relative decay constants of $235 \mathrm{U}$ and $238 \mathrm{U}$ by multi-step CA-TIMS measurements of closed-system natural zircon samples: Chemical Geology, v. 275, p. 186-198, doi:10.1016/j.chemgeo.2010.05.007.

Paces, J.B., and Miller, J.D., 1993, Precise U-Pb ages of Duluth Complex and related mafic intrusions, northern Minnesota: geochronological insights to physical, petrogenic, paleomagnetic, and tectonomagmatic processes associated with the $1.1 \mathrm{Ga}$ midcontinent 
rift system: Journal of Geophysical Research: Solid Earth, v. 98, p. 13,977-14,013, doi: 10.1029/9.

Sláma, J., Košler, J., Condon, D.J., Crowley, J.L., Gerdes, A., Hanchar, J.M., Horstwood, M.S., Morris, G.A., Nasdala, L., Norberg, N. and Schaltegger, U., 2008, Plešovice zircon-a new natural reference material for $\mathrm{U}-\mathrm{Pb}$ and $\mathrm{Hf}$ isotopic microanalysis: Chemical Geology, v. 249, p. 1-35, doi: 10.1016/j.chemgeo.2007.11.005

Stacey, J.S., and Kramers, J.D., 1975, Approximation of terrestrial lead isotope evolution by a two-stage model: Earth and Planetary Science Letters, v. 26, p. 207-221, doi: 10.1016/0012-821X(75)90088-6.

Vervoort, J.D., 2010, Hf analysis in zircon by LA-MC-ICPMS: Promise and pitfalls: Geological Society of America Abstracts with Programs, v. 42, p. 667.

Woodhead, J.D., and Hergt, J.M., 2007, A preliminary appraisal of seven natural zircon reference materials for in situ Hf isotope determination: Geostandards and Geoanalytical Research, v. 29, p. 183-195. 
Table SM3.1: SAMPLE LOCATIONS FROM THE WHALE MOUNTAIN ALLOCHTHON

\begin{tabular}{|c|c|c|c|c|}
\hline Sample Number & Latitude & Longitude & Stratigraphic Unit & Analysis \\
\hline \multicolumn{5}{|l|}{ Southern Belt } \\
\hline 14BJ22 & N 69.117 & W 143.173 & Marsh Fork volcanic rocks & WR-Geochem \\
\hline 14BJ24 & N 69.117 & W 143.178 & Marsh Fork volcanic rocks & WR-Geochem \\
\hline 15BJ08 & N 69.069 & W 143.907 & Marsh Fork volcanic rocks & WR-Geochem \\
\hline 15BJ06 & N 69.108 & W 143.894 & Marsh Fork volcanic rocks & U-Pb \& Lu-hf \\
\hline $\mathrm{J} 1475$ & N 69.116 & W 143.256 & Egaksrak formation & Fossil location \\
\hline \multicolumn{5}{|l|}{ Central Belt } \\
\hline 12JT13B & N 69.251 & W 141.729 & Whale Mountain volcanic rocks & WR-Geochem \\
\hline 12JT14 & N 69.251 & W 141.729 & Whale Mountain volcanic rocks & WR-Geochem \\
\hline 12JT15 & N 69.251 & W 141.729 & Whale Mountain volcanic rocks & WR-Geochem \\
\hline 12JT16 & N 69.251 & W 141.729 & Whale Mountain volcanic rocks & WR-Geochem \\
\hline 12JT17 & N 69.251 & W 141.729 & Whale Mountain volcanic rocks & WR-Geochem \\
\hline 12JT18 & N 69.251 & W 141.729 & Whale Mountain volcanic rocks & WR-Geochem \\
\hline 12JT19 & N 69.251 & W 141.729 & Whale Mountain volcanic rocks & WR-Geochem \\
\hline 12JT20 & N 69.251 & W 141.729 & Whale Mountain volcanic rocks & WR-Geochem \\
\hline 12JT21 & N 69.247 & W 141.723 & Whale Mountain volcanic rocks & WR-Geochem \\
\hline 17LF13 & N 69.347 & W 142.639 & Whale Mountain volcanic rocks & WR-Geochem \\
\hline 18LF13 & N 69.347 & W 142.639 & Whale Mountain volcanic rocks & WR-Geochem \\
\hline 19LF13 & N 69.347 & W 142.639 & Whale Mountain volcanic rocks & WR-Geochem \\
\hline 20LF13 & N 69.347 & W 142.639 & Whale Mountain volcanic rocks & WR-Geochem \\
\hline 21LF13 & N 69.347 & W 142.639 & Whale Mountain volcanic rocks & WR-Geochem \\
\hline 22LF13 & N 69.347 & W 142.639 & Whale Mountain volcanic rocks & WR-Geochem \\
\hline 23LF13 & N 69.347 & W 142.639 & Whale Mountain volcanic rocks & WR-Geochem \\
\hline 13MC-062 & N 69.176 & W 140.924 & Whale Mountain volcanic rocks & WR-Geochem \\
\hline 13MC-063 & N 69.169 & W 140.879 & Whale Mountain volcanic rocks & WR-Geochem \\
\hline 13MC-065 & N 69.169 & W 140.882 & Whale Mountain volcanic rocks & WR-Geochem \\
\hline 13JVS-362 & N 69.184 & W 140.921 & Whale Mountain volcanic rocks & WR-Geochem \\
\hline 13WW23 & N 69.182 & W 140.924 & Whale Mountain volcanic rocks & U-Pb \& Lu-hf \\
\hline $\mathrm{J} 1352$ & N 69.184 & W 140.917 & Egaksrak formation & Fossil location \\
\hline $\mathrm{J} 1480$ & N 69.346 & W 142.656 & Egaksrak formation & Fossil location \\
\hline \multicolumn{5}{|l|}{ Northern Belt } \\
\hline 12JT37 & N 69.469 & W 141.468 & Ekaluakat formation & WR-Geochem \\
\hline 12JT39 & N 69.456 & W 141.451 & Ekaluakat formation & WR-Geochem \\
\hline
\end{tabular}

Note: WR-Geochem stands for whole-rock geochemical analysis 
TABLE SM3.2: LA-ICPMS U-Pb ISOTOPIC DATA

\begin{tabular}{|c|c|c|c|c|c|c|c|c|c|c|c|c|c|c|c|c|c|c|c|}
\hline \multirow[b]{2}{*}{ Analysis } & \multirow[b]{2}{*}{$U$} & \multirow[b]{2}{*}{$206 \mathrm{~Pb}$} & \multirow[b]{2}{*}{$\mathrm{U} / \mathrm{Th}$} & \multirow[b]{2}{*}{$206 \mathrm{~Pb}^{\star}$} & \multirow[b]{2}{*}{ \pm} & \multicolumn{5}{|c|}{ Isotope ratios } & \multicolumn{6}{|c|}{ Apparent ages (Ma) } & \multirow[b]{2}{*}{ Best age } & \multirow[b]{2}{*}{ \pm} & \multirow[b]{2}{*}{ Conc } \\
\hline & & & & & & $207 \mathrm{~Pb}^{*}$ & \pm & $206 \mathrm{~Pb}^{\star}$ & \pm & error & $206 \mathrm{~Pb}^{*}$ & \pm & $207 \mathrm{~Pb}^{*}$ & \pm & $206 \mathrm{~Pb}^{\star}$ & \pm & & & \\
\hline & (ppm) & $204 \mathrm{~Pb}$ & & $207 \mathrm{~Pb}^{\star}$ & $(\%)$ & $235 U^{*}$ & $(\%)$ & $238 U$ & $(\%)$ & corr. & $238 U^{*}$ & $(\mathrm{Ma})$ & $235 \mathrm{U}$ & (Ma) & $207 \mathrm{~Pb}^{\star}$ & $(\mathrm{Ma})$ & $(\mathrm{Ma})$ & $(\mathrm{Ma})$ & $(\%)$ \\
\hline \multicolumn{20}{|c|}{ 13WW23; Whale Mountain volcanic rocks (central belt; N69182, W140.924) } \\
\hline $13 W W 24-55$ & 634 & 44178 & 1.0 & 17.344 & 2.1 & 0.6227 & 7.1 & 0.0783 & 6.8 & 0.96 & 486 & 32 & 492 & 28 & 517 & 45 & 486 & 32 & 94 \\
\hline 13WW24-56 & 112 & 14897 & 1.2 & 17.526 & 3.4 & 0.6249 & 3.9 & 0.0794 & 2.0 & 0.51 & 493 & 10 & 493 & 15 & 494 & 74 & 493 & 10 & 100 \\
\hline $13 W W 24-53$ & 175 & 30946 & 1.7 & 17.308 & 2.1 & 0.6424 & 4.0 & 0.0806 & 3.5 & 0.86 & 500 & 17 & 504 & 16 & 521 & 46 & 500 & 17 & 96 \\
\hline 13WW24-59 & 199 & 30104 & 1.7 & 16.896 & 1.9 & 0.6690 & 5.6 & 0.0820 & 5.2 & 0.94 & 508 & 26 & 520 & 23 & 574 & 41 & 508 & 26 & 89 \\
\hline 13WW24-58 & 116 & 32355 & 1.2 & 17.091 & 3.0 & 0.6636 & 5.8 & 0.0823 & 5.0 & 0.85 & 510 & 24 & 517 & 24 & 549 & 66 & 510 & 24 & 93 \\
\hline $13 W W 24-57$ & 278 & 48440 & 1.7 & 17.231 & 2.0 & 0.6637 & 2.6 & 0.0829 & 1.7 & 0.63 & 514 & 8 & 517 & 11 & 531 & 45 & 514 & 8 & 97 \\
\hline \multicolumn{20}{|c|}{$>20 \%$ Discordance } \\
\hline 13WW24-54 & 107 & 19777 & 1.2 & 13.238 & 9.7 & 0.8213 & 10.1 & 0.0789 & 2.5 & 0.25 & 489 & 12 & 609 & 46 & 1083 & 196 & 489 & 12 & 45 \\
\hline \multicolumn{20}{|c|}{ 15BJ06; Marsh Fork volcanic rocks (southern belt; N69.108, W143.894) } \\
\hline 15BJ06-202 & 163 & 93547 & 1.0 & 17.236 & 2.4 & 0.6100 & 3.3 & 0.0763 & 2.3 & 0.68 & 474 & 10 & 484 & 13 & 530 & 53 & 474 & 10 & 89 \\
\hline 15BJ06-001 & 130 & 46589 & 0.8 & 17.308 & 2.2 & 0.6255 & 3.2 & 0.0785 & 2.3 & 0.73 & 487 & 11 & 493 & 12 & 521 & 47 & 487 & 11 & 93 \\
\hline 15BJ06-278 & 106 & 97855 & 1.9 & 17.074 & 3.4 & 0.6383 & 3.9 & 0.0790 & 2.0 & 0.51 & 490 & 9 & 501 & 16 & 551 & 74 & 490 & 9 & 89 \\
\hline 15BJ06-155 & 277 & 39032 & 0.9 & 17.141 & 1.8 & 0.6358 & 2.8 & 0.0790 & 2.1 & 0.76 & 490 & 10 & 500 & 11 & 542 & 39 & 490 & 10 & 90 \\
\hline 15BJ06-248 & 97 & 28710 & 1.4 & 17.590 & 2.0 & 0.6270 & 2.7 & 0.0800 & 1.7 & 0.64 & 496 & 8 & 494 & 10 & 486 & 45 & 496 & 8 & 102 \\
\hline 15BJ06-115 & 69 & 12511 & 1.1 & 17.574 & 4.2 & 0.6295 & 4.9 & 0.0802 & 2.6 & 0.52 & 497 & 12 & 496 & 19 & 488 & 93 & 497 & 12 & 102 \\
\hline 15BJ06-260 & 254 & 40924 & 1.2 & 17.690 & 1.8 & 0.6258 & 2.8 & 0.0803 & 2.2 & 0.78 & 498 & 10 & 494 & 11 & 473 & 39 & 498 & 10 & 105 \\
\hline 15BJ06-293 & 98 & 36533 & 1.9 & 16.884 & 2.6 & 0.6560 & 3.3 & 0.0803 & 2.0 & 0.61 & 498 & 10 & 512 & 13 & 576 & 56 & 498 & 10 & 87 \\
\hline 15BJ06-080 & 68 & 26811 & 1.1 & 17.442 & 2.7 & 0.6355 & 3.5 & 0.0804 & 2.2 & 0.63 & 498 & 10 & 500 & 14 & 504 & 59 & 498 & 10 & 99 \\
\hline 15BJ06-249 & 107 & 33981 & 1.3 & 16.918 & 2.0 & 0.6559 & 2.9 & 0.0805 & 2.1 & 0.73 & 499 & 10 & 512 & 11 & 571 & 42 & 499 & 10 & 87 \\
\hline 15BJ06-206 & 146 & 174000 & 1.3 & 17.484 & 2.2 & 0.6347 & 3.0 & 0.0805 & 2.1 & 0.69 & 499 & 10 & 499 & 12 & 499 & 49 & 499 & 10 & 100 \\
\hline 15BJ06-167 & 155 & 234322 & 1.8 & 17.520 & 2.0 & 0.6336 & 2.5 & 0.0805 & 1.6 & 0.64 & 499 & 8 & 498 & 10 & 495 & 43 & 499 & 8 & 101 \\
\hline 15BJ06-291 & 286 & 81360 & 0.8 & 17.290 & 2.1 & 0.6421 & 2.9 & 0.0805 & 1.9 & 0.67 & 499 & 9 & 504 & 11 & 524 & 47 & 499 & 9 & 95 \\
\hline 15BJ06-268 & 48 & 14287 & 1.7 & 16.593 & 4.0 & 0.6693 & 4.4 & 0.0806 & 1.9 & 0.42 & 499 & 9 & 520 & 18 & 613 & 86 & 499 & 9 & 81 \\
\hline 15BJ06-227 & 64 & 21797 & 1.2 & 17.325 & 2.6 & 0.6415 & 3.3 & 0.0806 & 2.1 & 0.63 & 500 & 10 & 503 & 13 & 519 & 56 & 500 & 10 & 96 \\
\hline 15BJ06-241 & 84 & 103733 & 1.6 & 16.983 & 2.6 & 0.6546 & 3.2 & 0.0806 & 1.9 & 0.58 & 500 & 9 & 511 & 13 & 563 & 56 & 500 & 9 & 89 \\
\hline 15BJ06-266 & 199 & 37789 & 1.4 & 17.269 & 1.9 & 0.6441 & 2.8 & 0.0807 & 2.0 & 0.72 & 500 & 10 & 505 & 11 & 526 & 42 & 500 & 10 & 95 \\
\hline 15BJ06-236 & 71 & 16377 & 1.7 & 17.672 & 2.8 & 0.6295 & 3.7 & 0.0807 & 2.3 & 0.64 & 500 & 11 & 496 & 14 & 475 & 63 & 500 & 11 & 105 \\
\hline 15BJ06-270 & 91 & 48704 & 1.2 & 17.057 & 2.8 & 0.6524 & 3.6 & 0.0807 & 2.3 & 0.63 & 500 & 11 & 510 & 14 & 553 & 61 & 500 & 11 & 90 \\
\hline 15BJ06-246 & 77 & 42754 & 1.6 & 16.916 & 2.7 & 0.6580 & 3.4 & 0.0807 & 2.1 & 0.62 & 500 & 10 & 513 & 14 & 571 & 58 & 500 & 10 & 88 \\
\hline
\end{tabular}


TABLE SM3.2: LA-ICPMS U-Pb ISOTOPIC DATA

\begin{tabular}{|c|c|c|c|c|c|c|c|c|c|c|c|c|c|c|c|c|c|c|c|}
\hline \multirow[b]{2}{*}{ Analysis } & \multirow[b]{2}{*}{$\mathrm{U}$} & \multirow[b]{2}{*}{$206 \mathrm{~Pb}$} & \multirow[b]{2}{*}{$\mathrm{U} / \mathrm{Th}$} & \multirow[b]{2}{*}{$206 \mathrm{~Pb}^{\star}$} & \multirow[b]{2}{*}{ \pm} & \multicolumn{5}{|c|}{ Isotope ratios } & \multicolumn{6}{|c|}{ Apparent ages (Ma) } & \multirow[b]{2}{*}{ Best age } & \multirow[b]{2}{*}{ \pm} & \multirow[b]{2}{*}{ Conc } \\
\hline & & & & & & $207 \mathrm{~Pb}^{*}$ & \pm & $206 \mathrm{~Pb}^{\star}$ & \pm & error & $206 \mathrm{~Pb}^{*}$ & \pm & $207 \mathrm{~Pb}^{*}$ & \pm & $206 \mathrm{~Pb}^{\star}$ & \pm & & & \\
\hline & $(\mathrm{ppm})$ & $204 \mathrm{~Pb}$ & & $207 \mathrm{~Pb}^{\star}$ & $(\%)$ & $235 U^{*}$ & $(\%)$ & $238 \mathrm{U}$ & $(\%)$ & corr. & $238 U^{*}$ & (Ma) & $235 \mathrm{U}$ & (Ma) & $207 \mathrm{~Pb}^{*}$ & (Ma) & (Ma) & (Ma) & $(\%)$ \\
\hline 15BJ06-276 & 113 & 59878 & 1.4 & 16.492 & 2.8 & 0.6764 & 3.4 & 0.0809 & 2.0 & 0.58 & 502 & 10 & 525 & 14 & 626 & 60 & 502 & 10 & 80 \\
\hline 15BJ06-144 & 84 & 43418 & 1.6 & 17.257 & 3.4 & 0.6471 & 4.0 & 0.0810 & 2.1 & 0.53 & 502 & 10 & 507 & 16 & 528 & 75 & 502 & 10 & 95 \\
\hline 15BJ06-275 & 43 & 17931 & 1.5 & 17.392 & 2.8 & 0.6423 & 3.4 & 0.0810 & 1.9 & 0.56 & 502 & 9 & 504 & 14 & 511 & 62 & 502 & 9 & 98 \\
\hline 15BJ06-104 & 159 & 67233 & 1.5 & 17.198 & 2.0 & 0.6498 & 2.8 & 0.0811 & 2.0 & 0.72 & 502 & 10 & 508 & 11 & 535 & 43 & 502 & 10 & 94 \\
\hline 15BJ06-222 & 27 & 20331 & 1.4 & 17.346 & 5.6 & 0.6445 & 6.0 & 0.0811 & 2.1 & 0.36 & 503 & 10 & 505 & 24 & 516 & 123 & 503 & 10 & 97 \\
\hline 15BJ06-264 & 94 & 49399 & 1.5 & 16.948 & 2.1 & 0.6597 & 2.9 & 0.0811 & 1.9 & 0.67 & 503 & 9 & 514 & 12 & 567 & 47 & 503 & 9 & 89 \\
\hline 15BJ06-239 & 201 & 62966 & 1.3 & 17.526 & 1.9 & 0.6384 & 2.6 & 0.0811 & 1.8 & 0.68 & 503 & 9 & 501 & 10 & 494 & 42 & 503 & 9 & 102 \\
\hline 15BJ06-010 & 164 & 48694 & 1.9 & 17.136 & 2.3 & 0.6530 & 3.2 & 0.0811 & 2.3 & 0.70 & 503 & 11 & 510 & 13 & 543 & 50 & 503 & 11 & 93 \\
\hline 15BJ06-137 & 84 & 36451 & 2.2 & 16.965 & 2.0 & 0.6598 & 2.7 & 0.0812 & 1.8 & 0.66 & 503 & 9 & 515 & 11 & 565 & 44 & 503 & 9 & 89 \\
\hline 15BJ06-129 & 55 & 34203 & 1.4 & 16.987 & 3.3 & 0.6592 & 4.2 & 0.0812 & 2.6 & 0.61 & 503 & 13 & 514 & 17 & 562 & 73 & 503 & 13 & 90 \\
\hline 15BJ06-294 & 96 & 164226 & 1.2 & 16.746 & 2.5 & 0.6687 & 3.0 & 0.0812 & 1.7 & 0.56 & 503 & 8 & 520 & 12 & 593 & 55 & 503 & 8 & 85 \\
\hline 15BJ06-043 & 50 & 35947 & 2.0 & 17.214 & 2.4 & 0.6514 & 3.2 & 0.0813 & 2.1 & 0.66 & 504 & 10 & 509 & 13 & 533 & 52 & 504 & 10 & 95 \\
\hline 15BJ06-084 & 93 & 26152 & 2.0 & 17.012 & 2.6 & 0.6591 & 3.5 & 0.0813 & 2.3 & 0.67 & 504 & 11 & 514 & 14 & 559 & 57 & 504 & 11 & 90 \\
\hline 15BJ06-161 & 58 & 31078 & 1.9 & 16.881 & 3.5 & 0.6645 & 4.1 & 0.0814 & 2.2 & 0.54 & 504 & 11 & 517 & 17 & 576 & 75 & 504 & 11 & 88 \\
\hline 15BJ06-212 & 115 & 58019 & 1.8 & 17.431 & 2.3 & 0.6436 & 3.5 & 0.0814 & 2.6 & 0.75 & 504 & 13 & 505 & 14 & 506 & 50 & 504 & 13 & 100 \\
\hline 15BJ06-126 & 155 & 40541 & 2.0 & 16.542 & 1.9 & 0.6782 & 3.0 & 0.0814 & 2.3 & 0.77 & 504 & 11 & 526 & 12 & 620 & 42 & 504 & 11 & 81 \\
\hline 15BJ06-243 & 50 & 51904 & 1.3 & 17.590 & 3.2 & 0.6379 & 4.0 & 0.0814 & 2.4 & 0.61 & 504 & 12 & 501 & 16 & 486 & 70 & 504 & 12 & 104 \\
\hline 15BJ06-261 & 220 & 29833 & 0.9 & 17.497 & 1.8 & 0.6413 & 2.6 & 0.0814 & 1.9 & 0.74 & 504 & 9 & 503 & 10 & 497 & 39 & 504 & 9 & 101 \\
\hline 15BJ06-238 & 225 & 212825 & 1.6 & 17.383 & 1.9 & 0.6457 & 2.8 & 0.0814 & 2.1 & 0.75 & 504 & 10 & 506 & 11 & 512 & 41 & 504 & 10 & 99 \\
\hline 15BJ06-060 & 164 & 32024 & 1.2 & 17.387 & 2.1 & 0.6455 & 3.1 & 0.0814 & 2.3 & 0.75 & 504 & 11 & 506 & 12 & 511 & 46 & 504 & 11 & 99 \\
\hline 15BJ06-117 & 31 & 27726 & 1.6 & 16.448 & 4.5 & 0.6831 & 4.9 & 0.0815 & 2.0 & 0.41 & 505 & 10 & 529 & 20 & 632 & 96 & 505 & 10 & 80 \\
\hline 15BJ06-253 & 79 & 35365 & 1.5 & 17.595 & 3.0 & 0.6390 & 3.6 & 0.0815 & 2.0 & 0.56 & 505 & 10 & 502 & 14 & 485 & 65 & 505 & 10 & 104 \\
\hline 15BJ06-013 & 91 & 16334 & 1.2 & 17.433 & 2.2 & 0.6449 & 3.1 & 0.0815 & 2.1 & 0.70 & 505 & 10 & 505 & 12 & 505 & 49 & 505 & 10 & 100 \\
\hline 15BJ06-306 & 185 & 201949 & 1.4 & 17.381 & 2.0 & 0.6469 & 3.0 & 0.0816 & 2.2 & 0.74 & 505 & 11 & 507 & 12 & 512 & 44 & 505 & 11 & 99 \\
\hline 15BJ06-285 & 55 & 16943 & 1.5 & 17.207 & 2.7 & 0.6535 & 3.6 & 0.0816 & 2.4 & 0.66 & 505 & 12 & 511 & 14 & 534 & 59 & 505 & 12 & 95 \\
\hline 15BJ06-185 & 51 & 24721 & 1.3 & 17.506 & 3.4 & 0.6424 & 4.3 & 0.0816 & 2.7 & 0.62 & 505 & 13 & 504 & 17 & 496 & 75 & 505 & 13 & 102 \\
\hline 15BJ06-190 & 179 & 27223 & 1.7 & 17.367 & 2.2 & 0.6478 & 2.8 & 0.0816 & 1.7 & 0.62 & 506 & 8 & 507 & 11 & 514 & 48 & 506 & 8 & 98 \\
\hline 15BJ06-302 & 144 & 40501 & 1.3 & 17.398 & 2.0 & 0.6467 & 3.1 & 0.0816 & 2.3 & 0.75 & 506 & 11 & 506 & 12 & 510 & 45 & 506 & 11 & 99 \\
\hline 15BJ06-228 & 125 & 50560 & 1.6 & 17.317 & 2.7 & 0.6498 & 3.3 & 0.0816 & 2.0 & 0.59 & 506 & 10 & 508 & 13 & 520 & 59 & 506 & 10 & 97 \\
\hline 15BJ06-234 & 54 & 23957 & 1.3 & 17.489 & 3.2 & 0.6439 & 3.8 & 0.0817 & 2.1 & 0.54 & 506 & 10 & 505 & 15 & 498 & 70 & 506 & 10 & 102 \\
\hline 15BJ06-078 & 71 & 28210 & 1.6 & 17.336 & 3.4 & 0.6499 & 4.3 & 0.0817 & 2.7 & 0.62 & 506 & 13 & 508 & 17 & 518 & 74 & 506 & 13 & 98 \\
\hline 15BJ06-113 & 100 & 127931 & 1.7 & 17.263 & 2.1 & 0.6532 & 2.8 & 0.0818 & 1.8 & 0.64 & 507 & 9 & 510 & 11 & 527 & 47 & 507 & 9 & 96 \\
\hline 15BJ06-182 & 217 & 134171 & 1.2 & 17.135 & 2.4 & 0.6582 & 3.1 & 0.0818 & 2.0 & 0.63 & 507 & 10 & 514 & 13 & 543 & 53 & 507 & 10 & 93 \\
\hline
\end{tabular}


TABLE SM3.2: LA-ICPMS U-Pb ISOTOPIC DATA

\begin{tabular}{|c|c|c|c|c|c|c|c|c|c|c|c|c|c|c|c|c|c|c|c|}
\hline \multirow[b]{2}{*}{ Analysis } & \multirow[b]{2}{*}{ U } & \multirow[b]{2}{*}{$206 \mathrm{~Pb}$} & \multirow[b]{2}{*}{$\mathrm{U} / \mathrm{Th}$} & \multirow[b]{2}{*}{$206 \mathrm{~Pb}^{*}$} & \multirow[b]{2}{*}{ \pm} & \multicolumn{5}{|c|}{ Isotope ratios } & \multicolumn{6}{|c|}{ Apparent ages (Ma) } & \multirow[b]{2}{*}{ Best age } & \multirow[b]{2}{*}{ \pm} & \multirow[b]{2}{*}{ Conc } \\
\hline & & & & & & 207Pb* & \pm & $206 \mathrm{~Pb}^{*}$ & \pm & error & $206 \mathrm{~Pb}^{*}$ & \pm & $207 \mathrm{~Pb}^{*}$ & \pm & $206 \mathrm{~Pb}^{*}$ & \pm & & & \\
\hline & (ppm) & $204 \mathrm{~Pb}$ & & $207 \mathrm{~Pb}^{*}$ & $(\%)$ & $235 U^{*}$ & (\%) & $238 \mathrm{U}$ & $(\%)$ & corr. & $238 U^{*}$ & $(\mathrm{Ma})$ & $235 \mathrm{U}$ & $(\mathrm{Ma})$ & $207 \mathrm{~Pb}^{\star}$ & (Ma) & (Ma) & (Ma) & $(\%)$ \\
\hline 15BJ06-072 & 30 & 24608 & 2.2 & 17.628 & 4.2 & 0.6401 & 5.0 & 0.0818 & 2.6 & 0.53 & 507 & 13 & 502 & 20 & 481 & 93 & 507 & 13 & 105 \\
\hline 15BJ06-191 & 43 & 21809 & 1.9 & 17.087 & 3.3 & 0.6606 & 3.9 & 0.0819 & 2.1 & 0.54 & 507 & 10 & 515 & 16 & 549 & 72 & 507 & 10 & 92 \\
\hline 15BJ06-122 & 237 & 213323 & 0.9 & 17.432 & 1.5 & 0.6479 & 2.4 & 0.0819 & 1.9 & 0.77 & 507 & 9 & 507 & 10 & 506 & 34 & 507 & 9 & 100 \\
\hline 15BJ06-232 & 117 & 87640 & 1.6 & 16.863 & 2.5 & 0.6700 & 4.0 & 0.0819 & 3.1 & 0.77 & 508 & 15 & 521 & 16 & 578 & 55 & 508 & 15 & 88 \\
\hline 15BJ06-022 & 137 & 28775 & 1.2 & 17.162 & 2.8 & 0.6584 & 3.4 & 0.0819 & 1.9 & 0.55 & 508 & 9 & 514 & 14 & 540 & 62 & 508 & 9 & 94 \\
\hline 15BJ06-231 & 191 & 70959 & 1.6 & 17.323 & 1.8 & 0.6526 & 2.5 & 0.0820 & 1.8 & 0.71 & 508 & 9 & 510 & 10 & 519 & 39 & 508 & 9 & 98 \\
\hline 15BJ06-050 & 65 & 45598 & 1.9 & 17.049 & 2.7 & 0.6633 & 3.3 & 0.0820 & 1.9 & 0.56 & 508 & 9 & 517 & 13 & 554 & 60 & 508 & 9 & 92 \\
\hline 15BJ06-175 & 46 & 11223 & 1.3 & 17.084 & 3.7 & 0.6620 & 4.4 & 0.0820 & 2.4 & 0.54 & 508 & 12 & 516 & 18 & 550 & 80 & 508 & 12 & 92 \\
\hline 15BJ06-087 & 46 & 40117 & 1.3 & 16.812 & 3.6 & 0.6728 & 4.1 & 0.0820 & 2.0 & 0.49 & 508 & 10 & 522 & 17 & 585 & 78 & 508 & 10 & 87 \\
\hline 15BJ06-089 & 303 & 40065 & 0.9 & 17.195 & 1.8 & 0.6579 & 2.9 & 0.0820 & 2.2 & 0.77 & 508 & 11 & 513 & 12 & 536 & 40 & 508 & 11 & 95 \\
\hline 15BJ06-135 & 82 & 38302 & 1.7 & 17.092 & 2.8 & 0.6621 & 3.5 & 0.0821 & 2.0 & 0.58 & 508 & 10 & 516 & 14 & 549 & 61 & 508 & 10 & 93 \\
\hline 15BJ06-058 & 45 & 84961 & 1.2 & 16.614 & 3.5 & 0.6812 & 4.2 & 0.0821 & 2.3 & 0.55 & 509 & 11 & 527 & 17 & 610 & 75 & 509 & 11 & 83 \\
\hline 15BJ06-025 & 125 & 31844 & 1.4 & 17.257 & 2.4 & 0.6559 & 3.0 & 0.0821 & 1.8 & 0.60 & 509 & 9 & 512 & 12 & 528 & 53 & 509 & 9 & 96 \\
\hline 15BJ06-225 & 152 & 69242 & 1.9 & 17.492 & 1.8 & 0.6472 & 2.8 & 0.0821 & 2.2 & 0.78 & 509 & 11 & 507 & 11 & 498 & 39 & 509 & 11 & 102 \\
\hline 15BJ06-226 & 86 & 46602 & 1.6 & 17.119 & 2.9 & 0.6615 & 3.7 & 0.0821 & 2.2 & 0.61 & 509 & 11 & 516 & 15 & 545 & 63 & 509 & 11 & 93 \\
\hline 15BJ06-012 & 117 & 30186 & 1.6 & 17.058 & 2.5 & 0.6639 & 3.3 & 0.0821 & 2.2 & 0.66 & 509 & 11 & 517 & 13 & 553 & 54 & 509 & 11 & 92 \\
\hline 15BJ06-064 & 32 & 51667 & 1.4 & 16.593 & 3.0 & 0.6827 & 3.7 & 0.0822 & 2.2 & 0.59 & 509 & 11 & 528 & 15 & 613 & 64 & 509 & 11 & 83 \\
\hline 15BJ06-136 & 98 & 146274 & 1.8 & 17.068 & 3.1 & 0.6637 & 3.7 & 0.0822 & 2.0 & 0.55 & 509 & 10 & 517 & 15 & 552 & 68 & 509 & 10 & 92 \\
\hline 15BJ06-119 & 117 & 47855 & 2.1 & 17.501 & 1.9 & 0.6473 & 2.8 & 0.0822 & 2.0 & 0.72 & 509 & 10 & 507 & 11 & 497 & 42 & 509 & 10 & 102 \\
\hline 15BJ06-194 & 121 & 122999 & 1.8 & 17.250 & 1.9 & 0.6573 & 2.9 & 0.0822 & 2.2 & 0.75 & 509 & 11 & 513 & 12 & 529 & 43 & 509 & 11 & 96 \\
\hline 15BJ06-105 & 100 & 49968 & 1.7 & 16.974 & 2.1 & 0.6686 & 2.6 & 0.0823 & 1.5 & 0.59 & 510 & 8 & 520 & 11 & 564 & 46 & 510 & 8 & 90 \\
\hline 15BJ06-014 & 98 & 46387 & 1.5 & 17.087 & 2.4 & 0.6644 & 3.3 & 0.0823 & 2.2 & 0.67 & 510 & 11 & 517 & 13 & 549 & 53 & 510 & 11 & 93 \\
\hline 15BJ06-203 & 138 & 63878 & 1.9 & 17.113 & 2.6 & 0.6635 & 3.8 & 0.0824 & 2.8 & 0.74 & 510 & 14 & 517 & 15 & 546 & 56 & 510 & 14 & 93 \\
\hline 15BJ06-171 & 74 & 42870 & 1.6 & 17.319 & 2.2 & 0.6557 & 3.0 & 0.0824 & 2.0 & 0.68 & 510 & 10 & 512 & 12 & 520 & 48 & 510 & 10 & 98 \\
\hline 15BJ06-307 & 39 & 20744 & 2.0 & 17.500 & 4.4 & 0.6490 & 5.2 & 0.0824 & 2.8 & 0.53 & 510 & 14 & 508 & 21 & 497 & 97 & 510 & 14 & 103 \\
\hline 15BJ06-301 & 85 & 25716 & 1.9 & 17.133 & 3.1 & 0.6630 & 4.0 & 0.0824 & 2.6 & 0.64 & 510 & 13 & 516 & 16 & 544 & 67 & 510 & 13 & 94 \\
\hline 15BJ06-062 & 129 & 91579 & 1.2 & 17.406 & 2.3 & 0.6527 & 3.3 & 0.0824 & 2.4 & 0.72 & 510 & 12 & 510 & 13 & 509 & 50 & 510 & 12 & 100 \\
\hline 15BJ06-229 & 270 & 39040 & 1.3 & 17.540 & 1.9 & 0.6477 & 2.9 & 0.0824 & 2.2 & 0.76 & 510 & 11 & 507 & 12 & 492 & 42 & 510 & 11 & 104 \\
\hline 15BJ06-151 & 24 & 19320 & 1.3 & 17.536 & 4.1 & 0.6479 & 4.8 & 0.0824 & 2.5 & 0.52 & 510 & 12 & 507 & 19 & 493 & 91 & 510 & 12 & 104 \\
\hline 15BJ06-124 & 81 & 49641 & 1.5 & 17.246 & 2.6 & 0.6588 & 3.2 & 0.0824 & 1.9 & 0.58 & 510 & 9 & 514 & 13 & 529 & 58 & 510 & 9 & 96 \\
\hline 15BJ06-290 & 76 & 25694 & 1.9 & 17.440 & 2.6 & 0.6515 & 3.7 & 0.0824 & 2.6 & 0.71 & 510 & 13 & 509 & 15 & 505 & 57 & 510 & 13 & 101 \\
\hline 15BJ06-065 & 152 & 28754 & 1.2 & 17.058 & 1.8 & 0.6660 & 2.9 & 0.0824 & 2.3 & 0.79 & 510 & 11 & 518 & 12 & 553 & 40 & 510 & 11 & 92 \\
\hline 15BJ06-242 & 74 & 45814 & 1.5 & 17.204 & 2.4 & 0.6605 & 3.5 & 0.0824 & 2.4 & 0.71 & 510 & 12 & 515 & 14 & 535 & 54 & 510 & 12 & 96 \\
\hline
\end{tabular}


TABLE SM3.2: LA-ICPMS U-Pb ISOTOPIC DATA

\begin{tabular}{|c|c|c|c|c|c|c|c|c|c|c|c|c|c|c|c|c|c|c|c|}
\hline \multirow[b]{2}{*}{ Analysis } & \multirow[b]{2}{*}{$\mathrm{U}$} & \multirow[b]{2}{*}{$206 \mathrm{~Pb}$} & \multirow[b]{2}{*}{$\mathrm{U} / \mathrm{Th}$} & \multirow[b]{2}{*}{$206 \mathrm{~Pb}^{*}$} & \multirow[b]{2}{*}{ \pm} & \multicolumn{5}{|c|}{ Isotope ratios } & \multicolumn{6}{|c|}{ Apparent ages (Ma) } & \multirow[b]{2}{*}{ Best age } & \multirow[b]{2}{*}{ \pm} & \multirow[b]{2}{*}{ Conc } \\
\hline & & & & & & $207 \mathrm{~Pb}^{*}$ & \pm & $206 \mathrm{~Pb}^{\star}$ & \pm & error & $206 \mathrm{~Pb}^{*}$ & \pm & 207Pb* & \pm & $206 \mathrm{~Pb}^{*}$ & \pm & & & \\
\hline & (ppm) & $204 \mathrm{~Pb}$ & & $207 \mathrm{~Pb}^{\star}$ & $(\%)$ & $235 U^{*}$ & (\%) & $238 U$ & (\%) & corr. & $238 U^{*}$ & (Ma) & $235 \mathrm{U}$ & (Ma) & $207 \mathrm{~Pb}^{*}$ & (Ma) & (Ma) & (Ma) & (\%) \\
\hline 15BJ06-073 & 87 & 26924 & 1.6 & 17.177 & 2.1 & 0.6615 & 3.2 & 0.0824 & 2.4 & 0.75 & 511 & 12 & 516 & 13 & 538 & 46 & 511 & 12 & 95 \\
\hline 15BJ06-197 & 183 & 120634 & 1.2 & 17.069 & 2.1 & 0.6660 & 2.8 & 0.0824 & 1.8 & 0.65 & 511 & 9 & 518 & 11 & 552 & 47 & 511 & 9 & 93 \\
\hline 15BJ06-311 & 100 & 42300 & 1.0 & 16.921 & 3.5 & 0.6720 & 4.0 & 0.0825 & 2.1 & 0.52 & 511 & 10 & 522 & 16 & 571 & 75 & 511 & 10 & 89 \\
\hline 15BJ06-150 & 158 & 245577 & 1.9 & 17.297 & 2.3 & 0.6575 & 3.1 & 0.0825 & 2.0 & 0.65 & 511 & 10 & 513 & 12 & 523 & 52 & 511 & 10 & 98 \\
\hline 15BJ06-289 & 179 & 64058 & 1.7 & 17.079 & 2.2 & 0.6659 & 2.5 & 0.0825 & 1.3 & 0.51 & 511 & 6 & 518 & 10 & 550 & 47 & 511 & 6 & 93 \\
\hline 15BJ06-217 & 65 & 40825 & 2.0 & 17.356 & 2.7 & 0.6553 & 4.0 & 0.0825 & 3.0 & 0.74 & 511 & 15 & 512 & 16 & 515 & 60 & 511 & 15 & 99 \\
\hline 15BJ06-096 & 42 & 236354 & 1.5 & 17.027 & 3.6 & 0.6681 & 4.2 & 0.0825 & 2.3 & 0.54 & 511 & 11 & 520 & 17 & 557 & 78 & 511 & 11 & 92 \\
\hline 15BJ06-003 & 46 & 45551 & 2.1 & 17.197 & 2.8 & 0.6615 & 3.5 & 0.0825 & 2.2 & 0.62 & 511 & 11 & 516 & 14 & 535 & 60 & 511 & 11 & 95 \\
\hline 15BJ06-032 & 190 & 66997 & 0.9 & 17.058 & 2.1 & 0.6671 & 2.9 & 0.0825 & 2.0 & 0.69 & 511 & 10 & 519 & 12 & 553 & 46 & 511 & 10 & 92 \\
\hline 15BJ06-297 & 46 & 33227 & 1.7 & 17.359 & 3.6 & 0.6555 & 3.9 & 0.0825 & 1.4 & 0.36 & 511 & 7 & 512 & 15 & 515 & 79 & 511 & 7 & 99 \\
\hline 15BJ06-145 & 58 & 29157 & 2.0 & 17.407 & 3.2 & 0.6537 & 3.6 & 0.0825 & 1.7 & 0.46 & 511 & 8 & 511 & 15 & 509 & 71 & 511 & 8 & 100 \\
\hline 15BJ06-128 & 173 & 162542 & 1.4 & 17.541 & 1.4 & 0.6487 & 2.4 & 0.0825 & 1.9 & 0.81 & 511 & 9 & 508 & 10 & 492 & 31 & 511 & 9 & 104 \\
\hline 15BJ06-187 & 41 & 36321 & 1.6 & 16.924 & 3.9 & 0.6725 & 4.4 & 0.0825 & 2.2 & 0.49 & 511 & 11 & 522 & 18 & 570 & 84 & 511 & 11 & 90 \\
\hline 15BJ06-114 & 66 & 28763 & 1.3 & 17.389 & 3.4 & 0.6548 & 4.1 & 0.0826 & 2.2 & 0.54 & 511 & 11 & 511 & 16 & 511 & 75 & 511 & 11 & 100 \\
\hline 15BJ06-160 & 96 & 25311 & 1.6 & 17.452 & 2.4 & 0.6525 & 2.9 & 0.0826 & 1.7 & 0.58 & 512 & 8 & 510 & 12 & 503 & 52 & 512 & 8 & 102 \\
\hline 15BJ06-074 & 44 & 28434 & 1.1 & 17.240 & 4.2 & 0.6606 & 4.9 & 0.0826 & 2.5 & 0.51 & 512 & 12 & 515 & 20 & 530 & 92 & 512 & 12 & 97 \\
\hline 15BJ06-298 & 243 & 132932 & 0.9 & 17.319 & 1.7 & 0.6577 & 2.8 & 0.0826 & 2.2 & 0.80 & 512 & 11 & 513 & 11 & 520 & 37 & 512 & 11 & 98 \\
\hline 15BJ06-189 & 81 & 42627 & 1.4 & 16.909 & 2.4 & 0.6736 & 3.4 & 0.0826 & 2.3 & 0.69 & 512 & 11 & 523 & 14 & 572 & 53 & 512 & 11 & 89 \\
\hline 15BJ06-002 & 215 & 158409 & 1.6 & 17.542 & 1.7 & 0.6493 & 3.0 & 0.0826 & 2.5 & 0.83 & 512 & 12 & 508 & 12 & 492 & 38 & 512 & 12 & 104 \\
\hline 15BJ06-154 & 56 & 23730 & 1.4 & 17.029 & 2.5 & 0.6691 & 3.2 & 0.0826 & 2.0 & 0.63 & 512 & 10 & 520 & 13 & 557 & 54 & 512 & 10 & 92 \\
\hline 15BJ06-257 & 91 & 195778 & 1.9 & 17.229 & 2.2 & 0.6615 & 2.8 & 0.0827 & 1.8 & 0.63 & 512 & 9 & 516 & 11 & 531 & 48 & 512 & 9 & 96 \\
\hline 15BJ06-024 & 137 & 28151 & 1.3 & 17.249 & 2.3 & 0.6610 & 3.1 & 0.0827 & 2.1 & 0.68 & 512 & 10 & 515 & 13 & 529 & 50 & 512 & 10 & 97 \\
\hline 15BJ06-034 & 71 & 41928 & 1.4 & 16.571 & 2.9 & 0.6880 & 3.6 & 0.0827 & 2.2 & 0.60 & 512 & 11 & 532 & 15 & 616 & 62 & 512 & 11 & 83 \\
\hline 15BJ06-103 & 147 & 81165 & 0.9 & 17.200 & 1.7 & 0.6629 & 2.5 & 0.0827 & 1.8 & 0.72 & 512 & 9 & 516 & 10 & 535 & 38 & 512 & 9 & 96 \\
\hline 15BJ06-284 & 280 & 28582 & 0.9 & 17.046 & 1.5 & 0.6690 & 2.6 & 0.0827 & 2.1 & 0.82 & 512 & 11 & 520 & 11 & 555 & 32 & 512 & 11 & 92 \\
\hline 15BJ06-085 & 130 & 91408 & 1.3 & 17.209 & 2.4 & 0.6627 & 3.5 & 0.0827 & 2.6 & 0.73 & 512 & 13 & 516 & 14 & 534 & 53 & 512 & 13 & 96 \\
\hline 15BJ06-211 & 282 & 143573 & 0.8 & 17.358 & 1.5 & 0.6572 & 2.6 & 0.0827 & 2.2 & 0.82 & 512 & 11 & 513 & 11 & 515 & 33 & 512 & 11 & 100 \\
\hline 15BJ06-015 & 126 & 41323 & 1.2 & 17.335 & 2.5 & 0.6581 & 3.3 & 0.0827 & 2.2 & 0.67 & 512 & 11 & 513 & 13 & 518 & 54 & 512 & 11 & 99 \\
\hline 15BJ06-169 & 178 & 39066 & 1.2 & 17.487 & 2.9 & 0.6525 & 3.8 & 0.0828 & 2.4 & 0.64 & 513 & 12 & 510 & 15 & 499 & 64 & 513 & 12 & 103 \\
\hline 15BJ06-053 & 48 & 46801 & 1.3 & 16.991 & 3.4 & 0.6717 & 4.2 & 0.0828 & 2.4 & 0.57 & 513 & 12 & 522 & 17 & 562 & 75 & 513 & 12 & 91 \\
\hline 15BJ06-180 & 45 & 223993 & 2.0 & 17.108 & 3.3 & 0.6671 & 3.9 & 0.0828 & 1.9 & 0.50 & 513 & 9 & 519 & 16 & 547 & 73 & 513 & 9 & 94 \\
\hline 15BJ06-256 & 84 & 37321 & 2.0 & 17.416 & 2.7 & 0.6554 & 3.5 & 0.0828 & 2.2 & 0.62 & 513 & 11 & 512 & 14 & 508 & 60 & 513 & 11 & 101 \\
\hline 15BJ06-230 & 27 & 41578 & 1.8 & 17.006 & 3.9 & 0.6713 & 4.3 & 0.0828 & 1.8 & 0.41 & 513 & 9 & 522 & 17 & 560 & 85 & 513 & 9 & 92 \\
\hline
\end{tabular}


TABLE SM3.2: LA-ICPMS U-Pb ISOTOPIC DATA

\begin{tabular}{|c|c|c|c|c|c|c|c|c|c|c|c|c|c|c|c|c|c|c|c|}
\hline \multirow[b]{2}{*}{ Analysis } & \multirow[b]{2}{*}{$\mathrm{U}$} & \multirow[b]{2}{*}{$206 \mathrm{~Pb}$} & \multirow[b]{2}{*}{$\mathrm{U} / \mathrm{Th}$} & \multirow[b]{2}{*}{$206 \mathrm{~Pb}^{\star}$} & \multirow[b]{2}{*}{ \pm} & \multicolumn{5}{|c|}{ Isotope ratios } & \multicolumn{6}{|c|}{ Apparent ages (Ma) } & \multirow[b]{2}{*}{ Best age } & \multirow[b]{2}{*}{ \pm} & \multirow[b]{2}{*}{ Conc } \\
\hline & & & & & & $207 \mathrm{~Pb}^{*}$ & \pm & $206 \mathrm{~Pb}^{\star}$ & \pm & error & $206 \mathrm{~Pb}^{*}$ & \pm & $207 \mathrm{~Pb}^{*}$ & \pm & $206 \mathrm{~Pb}^{\star}$ & \pm & & & \\
\hline & $(\mathrm{ppm})$ & $204 \mathrm{~Pb}$ & & $207 \mathrm{~Pb}^{\star}$ & $(\%)$ & $235 U^{*}$ & $(\%)$ & $238 \mathrm{U}$ & $(\%)$ & corr. & $238 U^{*}$ & (Ma) & $235 \mathrm{U}$ & (Ma) & $207 \mathrm{~Pb}^{*}$ & (Ma) & (Ma) & (Ma) & $(\%)$ \\
\hline 15BJ06-066 & 70 & 25105 & 1.1 & 17.529 & 2.5 & 0.6513 & 3.2 & 0.0828 & 2.1 & 0.64 & 513 & 10 & 509 & 13 & 493 & 55 & 513 & 10 & 104 \\
\hline 15BJ06-305 & 145 & 93255 & 1.3 & 17.364 & 2.2 & 0.6581 & 3.0 & 0.0829 & 2.0 & 0.67 & 513 & 10 & 513 & 12 & 514 & 48 & 513 & 10 & 100 \\
\hline 15BJ06-134 & 72 & 28534 & 1.5 & 17.475 & 3.4 & 0.6540 & 4.1 & 0.0829 & 2.3 & 0.55 & 513 & 11 & 511 & 16 & 500 & 75 & 513 & 11 & 103 \\
\hline 15BJ06-035 & 72 & 45811 & 1.8 & 16.614 & 2.5 & 0.6880 & 3.0 & 0.0829 & 1.7 & 0.58 & 513 & 9 & 532 & 13 & 610 & 53 & 513 & 9 & 84 \\
\hline 15BJ06-123 & 111 & 139781 & 1.2 & 17.364 & 2.4 & 0.6583 & 3.7 & 0.0829 & 2.8 & 0.76 & 513 & 14 & 514 & 15 & 514 & 53 & 513 & 14 & 100 \\
\hline 15BJ06-100 & 29 & 17831 & 1.3 & 17.460 & 4.6 & 0.6549 & 5.2 & 0.0829 & 2.5 & 0.48 & 514 & 12 & 511 & 21 & 502 & 101 & 514 & 12 & 102 \\
\hline 15BJ06-283 & 273 & 237236 & 0.8 & 17.371 & 1.8 & 0.6584 & 2.6 & 0.0829 & 1.9 & 0.72 & 514 & 9 & 514 & 10 & 513 & 40 & 514 & 9 & 100 \\
\hline 15BJ06-005 & 88 & 192337 & 1.1 & 17.388 & 3.2 & 0.6579 & 4.3 & 0.0830 & 2.9 & 0.68 & 514 & 14 & 513 & 17 & 511 & 70 & 514 & 14 & 101 \\
\hline 15BJ06-051 & 210 & 131258 & 1.6 & 17.434 & 2.0 & 0.6570 & 2.8 & 0.0831 & 1.9 & 0.68 & 514 & 9 & 513 & 11 & 505 & 45 & 514 & 9 & 102 \\
\hline 15BJ06-204 & 35 & 38992 & 1.9 & 16.966 & 3.7 & 0.6752 & 4.3 & 0.0831 & 2.1 & 0.49 & 514 & 10 & 524 & 18 & 565 & 82 & 514 & 10 & 91 \\
\hline 15BJ06-224 & 84 & 54550 & 1.9 & 17.501 & 2.5 & 0.6549 & 3.3 & 0.0831 & 2.1 & 0.64 & 515 & 10 & 511 & 13 & 497 & 56 & 515 & 10 & 104 \\
\hline 15BJ06-127 & 56 & 138723 & 2.0 & 16.693 & 3.1 & 0.6867 & 4.0 & 0.0831 & 2.5 & 0.64 & 515 & 13 & 531 & 16 & 600 & 66 & 515 & 13 & 86 \\
\hline 15BJ06-063 & 67 & 41444 & 1.2 & 17.192 & 2.4 & 0.6670 & 2.9 & 0.0832 & 1.7 & 0.58 & 515 & 9 & 519 & 12 & 536 & 52 & 515 & 9 & 96 \\
\hline 15BJ06-299 & 40 & 78687 & 1.2 & 16.723 & 3.3 & 0.6858 & 3.7 & 0.0832 & 1.7 & 0.47 & 515 & 9 & 530 & 15 & 596 & 71 & 515 & 9 & 86 \\
\hline 15BJ06-267 & 64 & 27766 & 1.4 & 17.558 & 3.2 & 0.6532 & 3.8 & 0.0832 & 2.1 & 0.56 & 515 & 11 & 510 & 15 & 490 & 70 & 515 & 11 & 105 \\
\hline 15BJ06-147 & 86 & 66631 & 1.3 & 16.900 & 2.5 & 0.6787 & 3.5 & 0.0832 & 2.4 & 0.70 & 515 & 12 & 526 & 14 & 573 & 54 & 515 & 12 & 90 \\
\hline 15BJ06-059 & 55 & 190792 & 1.5 & 17.356 & 3.1 & 0.6612 & 3.6 & 0.0832 & 1.9 & 0.53 & 515 & 10 & 515 & 15 & 515 & 68 & 515 & 10 & 100 \\
\hline 15BJ06-199 & 179 & 42081 & 1.1 & 17.382 & 1.7 & 0.6604 & 2.6 & 0.0832 & 1.9 & 0.74 & 515 & 10 & 515 & 10 & 512 & 38 & 515 & 10 & 101 \\
\hline 15BJ06-007 & 64 & 20658 & 1.6 & 17.350 & 3.0 & 0.6616 & 3.6 & 0.0833 & 2.1 & 0.58 & 516 & 10 & 516 & 15 & 516 & 65 & 516 & 10 & 100 \\
\hline 15BJ06-075 & 128 & 185827 & 1.1 & 17.150 & 2.3 & 0.6694 & 3.1 & 0.0833 & 2.1 & 0.67 & 516 & 10 & 520 & 13 & 541 & 51 & 516 & 10 & 95 \\
\hline 15BJ06-271 & 93 & 37691 & 1.9 & 17.159 & 2.9 & 0.6692 & 3.7 & 0.0833 & 2.3 & 0.62 & 516 & 12 & 520 & 15 & 540 & 64 & 516 & 12 & 95 \\
\hline 15BJ06-031 & 60 & 20886 & 2.1 & 16.985 & 3.6 & 0.6764 & 4.4 & 0.0833 & 2.6 & 0.59 & 516 & 13 & 525 & 18 & 562 & 78 & 516 & 13 & 92 \\
\hline 15BJ06-142 & 105 & 55153 & 1.9 & 17.406 & 2.4 & 0.6604 & 3.0 & 0.0834 & 1.9 & 0.61 & 516 & 9 & 515 & 12 & 509 & 53 & 516 & 9 & 101 \\
\hline 15BJ06-157 & 163 & 42504 & 1.6 & 17.463 & 2.0 & 0.6583 & 3.1 & 0.0834 & 2.4 & 0.76 & 516 & 12 & 514 & 13 & 502 & 44 & 516 & 12 & 103 \\
\hline 15BJ06-215 & 43 & 39103 & 1.6 & 17.453 & 2.9 & 0.6589 & 4.2 & 0.0834 & 2.9 & 0.71 & 516 & 15 & 514 & 17 & 503 & 64 & 516 & 15 & 103 \\
\hline 15BJ06-037 & 50 & 27044 & 1.2 & 17.215 & 3.2 & 0.6685 & 4.1 & 0.0835 & 2.5 & 0.61 & 517 & 12 & 520 & 17 & 533 & 71 & 517 & 12 & 97 \\
\hline 15BJ06-110 & 37 & 22228 & 2.1 & 17.291 & 3.7 & 0.6656 & 4.6 & 0.0835 & 2.7 & 0.58 & 517 & 13 & 518 & 19 & 523 & 82 & 517 & 13 & 99 \\
\hline 15BJ06-168 & 222 & 63309 & 1.0 & 17.343 & 1.6 & 0.6642 & 2.5 & 0.0835 & 2.0 & 0.77 & 517 & 10 & 517 & 10 & 517 & 35 & 517 & 10 & 100 \\
\hline 15BJ06-292 & 60 & 27158 & 1.4 & 17.470 & 2.9 & 0.6596 & 3.5 & 0.0836 & 2.0 & 0.57 & 517 & 10 & 514 & 14 & 501 & 64 & 517 & 10 & 103 \\
\hline 15BJ06-108 & 123 & 46730 & 1.3 & 17.248 & 1.6 & 0.6681 & 2.5 & 0.0836 & 2.0 & 0.79 & 517 & 10 & 520 & 10 & 529 & 34 & 517 & 10 & 98 \\
\hline 15BJ06-083 & 127 & 28747 & 1.9 & 17.427 & 2.1 & 0.6619 & 2.8 & 0.0837 & 1.8 & 0.65 & 518 & 9 & 516 & 11 & 506 & 46 & 518 & 9 & 102 \\
\hline 15BJ06-164 & 71 & 148396 & 2.1 & 17.403 & 2.8 & 0.6628 & 3.2 & 0.0837 & 1.5 & 0.48 & 518 & 8 & 516 & 13 & 509 & 62 & 518 & 8 & 102 \\
\hline 15BJ06-026 & 70 & 104685 & 2.0 & 17.301 & 2.7 & 0.6668 & 3.6 & 0.0837 & 2.3 & 0.66 & 518 & 12 & 519 & 15 & 522 & 59 & 518 & 12 & 99 \\
\hline
\end{tabular}


TABLE SM3.2: LA-ICPMS U-Pb ISOTOPIC DATA

\begin{tabular}{|c|c|c|c|c|c|c|c|c|c|c|c|c|c|c|c|c|c|c|c|}
\hline \multirow[b]{2}{*}{ Analysis } & \multirow[b]{2}{*}{$\mathrm{U}$} & \multirow[b]{2}{*}{$206 \mathrm{~Pb}$} & \multirow[b]{2}{*}{$\mathrm{U} / \mathrm{Th}$} & \multirow[b]{2}{*}{$206 \mathrm{~Pb}^{*}$} & \multirow[b]{2}{*}{ \pm} & \multicolumn{5}{|c|}{ Isotope ratios } & \multicolumn{6}{|c|}{ Apparent ages (Ma) } & \multirow[b]{2}{*}{ Best age } & \multirow[b]{2}{*}{ \pm} & \multirow[b]{2}{*}{ Conc } \\
\hline & & & & & & $207 \mathrm{~Pb}^{*}$ & \pm & $206 \mathrm{~Pb}^{\star}$ & \pm & error & $206 \mathrm{~Pb}^{*}$ & \pm & $207 \mathrm{~Pb}^{*}$ & \pm & $206 \mathrm{~Pb}^{*}$ & \pm & & & \\
\hline & (ppm) & $204 \mathrm{~Pb}$ & & $207 \mathrm{~Pb}^{\star}$ & $(\%)$ & $235 U^{*}$ & (\%) & $238 U$ & (\%) & corr. & $238 U^{*}$ & (Ma) & $235 \mathrm{U}$ & (Ma) & $207 \mathrm{~Pb}^{*}$ & (Ma) & (Ma) & (Ma) & (\%) \\
\hline 15BJ06-023 & 111 & 35458 & 1.4 & 17.518 & 2.6 & 0.6595 & 3.5 & 0.0838 & 2.3 & 0.66 & 519 & 11 & 514 & 14 & 495 & 58 & 519 & 11 & 105 \\
\hline 15BJ06-041 & 31 & 40414 & 2.0 & 16.988 & 3.2 & 0.6801 & 4.0 & 0.0838 & 2.4 & 0.61 & 519 & 12 & 527 & 17 & 562 & 70 & 519 & 12 & 92 \\
\hline 15BJ06-196 & 88 & 32419 & 1.7 & 17.152 & 2.7 & 0.6743 & 3.2 & 0.0839 & 1.8 & 0.55 & 519 & 9 & 523 & 13 & 541 & 59 & 519 & 9 & 96 \\
\hline 15BJ06-098 & 59 & 41799 & 1.7 & 16.523 & 3.1 & 0.7000 & 4.0 & 0.0839 & 2.5 & 0.63 & 519 & 12 & 539 & 17 & 622 & 67 & 519 & 12 & 83 \\
\hline 15BJ06-109 & 27 & 21776 & 0.8 & 17.521 & 4.5 & 0.6605 & 5.0 & 0.0839 & 2.1 & 0.42 & 520 & 10 & 515 & 20 & 494 & 100 & 520 & 10 & 105 \\
\hline 15BJ06-208 & 73 & 32267 & 1.4 & 17.112 & 3.1 & 0.6766 & 3.7 & 0.0840 & 1.9 & 0.52 & 520 & 10 & 525 & 15 & 546 & 69 & 520 & 10 & 95 \\
\hline 15BJ06-056 & 63 & 44603 & 1.9 & 17.214 & 3.4 & 0.6729 & 3.9 & 0.0840 & 1.8 & 0.46 & 520 & 9 & 522 & 16 & 533 & 75 & 520 & 9 & 98 \\
\hline 15BJ06-004 & 59 & 31709 & 2.1 & 17.234 & 3.5 & 0.6722 & 4.3 & 0.0840 & 2.4 & 0.56 & 520 & 12 & 522 & 18 & 531 & 78 & 520 & 12 & 98 \\
\hline 15BJ06-106 & 293 & 131732 & 1.1 & 17.268 & 1.9 & 0.6709 & 2.7 & 0.0840 & 2.0 & 0.72 & 520 & 10 & 521 & 11 & 526 & 41 & 520 & 10 & 99 \\
\hline 15BJ06-036 & 33 & 37219 & 1.0 & 17.350 & 4.2 & 0.6678 & 4.9 & 0.0840 & 2.6 & 0.52 & 520 & 13 & 519 & 20 & 516 & 93 & 520 & 13 & 101 \\
\hline 15BJ06-091 & 112 & 134304 & 1.5 & 16.981 & 2.6 & 0.6823 & 3.3 & 0.0840 & 1.9 & 0.59 & 520 & 10 & 528 & 13 & 563 & 58 & 520 & 10 & 92 \\
\hline 15BJ06-018 & 81 & 47044 & 2.0 & 17.262 & 2.8 & 0.6713 & 3.7 & 0.0840 & 2.3 & 0.64 & 520 & 12 & 521 & 15 & 527 & 62 & 520 & 12 & 99 \\
\hline 15BJ06-310 & 26 & 29208 & 1.8 & 17.434 & 3.9 & 0.6650 & 4.4 & 0.0841 & 2.0 & 0.46 & 520 & 10 & 518 & 18 & 505 & 85 & 520 & 10 & 103 \\
\hline 15BJ06-061 & 54 & 34669 & 1.4 & 16.887 & 2.6 & 0.6866 & 3.6 & 0.0841 & 2.5 & 0.68 & 520 & 12 & 531 & 15 & 575 & 57 & 520 & 12 & 91 \\
\hline 15BJ06-287 & 84 & 93786 & 1.9 & 17.352 & 2.5 & 0.6682 & 3.2 & 0.0841 & 2.0 & 0.63 & 521 & 10 & 520 & 13 & 516 & 54 & 521 & 10 & 101 \\
\hline 15BJ06-193 & 74 & 115381 & 2.3 & 17.352 & 2.6 & 0.6684 & 3.2 & 0.0841 & 1.8 & 0.57 & 521 & 9 & 520 & 13 & 516 & 57 & 521 & 9 & 101 \\
\hline 15BJ06-033 & 135 & 62924 & 1.2 & 17.260 & 1.9 & 0.6724 & 3.0 & 0.0842 & 2.4 & 0.78 & 521 & 12 & 522 & 12 & 527 & 42 & 521 & 12 & 99 \\
\hline 15BJ06-314 & 74 & 32933 & 2.0 & 17.105 & 3.1 & 0.6795 & 4.0 & 0.0843 & 2.5 & 0.62 & 522 & 12 & 526 & 17 & 547 & 69 & 522 & 12 & 95 \\
\hline 15BJ06-216 & 42 & 10218 & 1.6 & 17.411 & 4.3 & 0.6677 & 4.9 & 0.0843 & 2.4 & 0.50 & 522 & 12 & 519 & 20 & 508 & 94 & 522 & 12 & 103 \\
\hline 15BJ06-188 & 547 & 155902 & 0.6 & 17.500 & 1.4 & 0.6644 & 2.8 & 0.0843 & 2.4 & 0.87 & 522 & 12 & 517 & 11 & 497 & 31 & 522 & 12 & 105 \\
\hline 15BJ06-055 & 115 & 754043 & 1.7 & 17.100 & 2.7 & 0.6803 & 3.4 & 0.0844 & 2.0 & 0.59 & 522 & 10 & 527 & 14 & 548 & 60 & 522 & 10 & 95 \\
\hline 15BJ06-198 & 25 & 10815 & 1.5 & 16.925 & 4.1 & 0.6880 & 4.7 & 0.0845 & 2.3 & 0.49 & 523 & 11 & 532 & 19 & 570 & 90 & 523 & 11 & 92 \\
\hline 15BJ06-121 & 175 & 68675 & 1.0 & 17.155 & 1.8 & 0.6790 & 2.5 & 0.0845 & 1.8 & 0.71 & 523 & 9 & 526 & 10 & 541 & 38 & 523 & 9 & 97 \\
\hline 15BJ06-112 & 84 & 167171 & 1.7 & 17.282 & 2.5 & 0.6746 & 3.5 & 0.0846 & 2.4 & 0.69 & 523 & 12 & 524 & 14 & 525 & 55 & 523 & 12 & 100 \\
\hline 15BJ06-186 & 84 & 24793 & 1.3 & 16.952 & 1.9 & 0.6879 & 2.8 & 0.0846 & 2.1 & 0.75 & 523 & 11 & 532 & 12 & 567 & 41 & 523 & 11 & 92 \\
\hline 15BJ06-017 & 49 & 109121 & 1.7 & 17.113 & 3.1 & 0.6822 & 3.7 & 0.0847 & 2.1 & 0.57 & 524 & 11 & 528 & 15 & 546 & 67 & 524 & 11 & 96 \\
\hline 15BJ06-132 & 107 & 55274 & 1.7 & 17.382 & 2.4 & 0.6717 & 3.0 & 0.0847 & 1.8 & 0.61 & 524 & 9 & 522 & 12 & 512 & 52 & 524 & 9 & 102 \\
\hline 15BJ06-086 & 50 & 22011 & 1.7 & 17.498 & 2.6 & 0.6679 & 3.2 & 0.0848 & 1.9 & 0.59 & 525 & 10 & 519 & 13 & 497 & 57 & 525 & 10 & 105 \\
\hline 15BJ06-179 & 63 & 31495 & 1.8 & 17.352 & 2.8 & 0.6741 & 3.7 & 0.0848 & 2.5 & 0.66 & 525 & 12 & 523 & 15 & 516 & 61 & 525 & 12 & 102 \\
\hline 15BJ06-237 & 277 & 119454 & 0.8 & 17.360 & 1.7 & 0.6741 & 2.5 & 0.0849 & 1.8 & 0.71 & 525 & 9 & 523 & 10 & 515 & 38 & 525 & 9 & 102 \\
\hline 15BJ06-006 & 35 & 13962 & 2.2 & 17.324 & 3.4 & 0.6769 & 3.8 & 0.0851 & 1.8 & 0.47 & 526 & 9 & 525 & 16 & 519 & 74 & 526 & 9 & 101 \\
\hline 15BJ06-205 & 46 & 27020 & 1.9 & 16.373 & 3.7 & 0.7167 & 4.0 & 0.0851 & 1.6 & 0.40 & 527 & 8 & 549 & 17 & 642 & 79 & 527 & 8 & 82 \\
\hline 15BJ06-090 & 149 & 78466 & 1.9 & 17.149 & 2.3 & 0.6843 & 3.2 & 0.0851 & 2.2 & 0.68 & 527 & 11 & 529 & 13 & 541 & 51 & 527 & 11 & 97 \\
\hline
\end{tabular}


TABLE SM3.2: LA-ICPMS U-Pb ISOTOPIC DATA

\begin{tabular}{|c|c|c|c|c|c|c|c|c|c|c|c|c|c|c|c|c|c|c|c|}
\hline \multirow[b]{2}{*}{ Analysis } & \multirow[b]{2}{*}{$\mathrm{U}$} & \multirow[b]{2}{*}{$206 \mathrm{~Pb}$} & \multirow[b]{2}{*}{ U/Th } & \multirow[b]{2}{*}{$206 \mathrm{~Pb}^{*}$} & \multirow[b]{2}{*}{ \pm} & \multicolumn{5}{|c|}{ Isotope ratios } & \multicolumn{6}{|c|}{ Apparent ages (Ma) } & \multirow[b]{2}{*}{ Best age } & \multirow[b]{2}{*}{ \pm} & \multirow[b]{2}{*}{ Conc } \\
\hline & & & & & & $207 \mathrm{~Pb}^{*}$ & \pm & $206 \mathrm{~Pb}^{\star}$ & \pm & error & $206 \mathrm{~Pb}^{*}$ & \pm & 207 $\mathrm{Pb}^{*}$ & \pm & $206 \mathrm{~Pb}^{*}$ & \pm & & & \\
\hline & (ppm) & $204 \mathrm{~Pb}$ & & $207 \mathrm{~Pb}^{\star}$ & $(\%)$ & $235 U^{*}$ & $(\%)$ & $238 U$ & $(\%)$ & corr. & $238 U^{*}$ & (Ma) & $235 \mathrm{U}$ & (Ma) & $207 \mathrm{~Pb}^{*}$ & (Ma) & (Ma) & (Ma) & $(\%)$ \\
\hline 15BJ06-149 & 114 & 34808 & 1.7 & 17.164 & 2.3 & 0.6846 & 3.4 & 0.0852 & 2.5 & 0.74 & 527 & 13 & 530 & 14 & 540 & 50 & 527 & 13 & 98 \\
\hline 15BJ06-102 & 49 & 40008 & 2.0 & 16.838 & 3.1 & 0.6981 & 3.7 & 0.0852 & 2.2 & 0.58 & 527 & 11 & 538 & 16 & 581 & 67 & 527 & 11 & 91 \\
\hline 15BJ06-027 & 87 & 35345 & 1.6 & 17.277 & 2.2 & 0.6824 & 2.9 & 0.0855 & 2.0 & 0.68 & 529 & 10 & 528 & 12 & 525 & 47 & 529 & 10 & 101 \\
\hline 15BJ06-213 & 38 & 28582 & 1.7 & 16.980 & 3.6 & 0.6954 & 4.3 & 0.0856 & 2.3 & 0.54 & 530 & 12 & 536 & 18 & 563 & 79 & 530 & 12 & 94 \\
\hline 15BJ06-220 & 33 & 13865 & 0.9 & 17.262 & 3.2 & 0.6850 & 4.1 & 0.0858 & 2.6 & 0.63 & 530 & 13 & 530 & 17 & 527 & 70 & 530 & 13 & 101 \\
\hline 15BJ06-181 & 37 & 34478 & 1.4 & 16.973 & 3.0 & 0.6968 & 3.5 & 0.0858 & 1.7 & 0.49 & 531 & 9 & 537 & 14 & 564 & 66 & 531 & 9 & 94 \\
\hline 15BJ06-177 & 51 & 41861 & 1.3 & 17.206 & 2.2 & 0.6891 & 3.7 & 0.0860 & 2.9 & 0.79 & 532 & 15 & 532 & 15 & 534 & 49 & 532 & 15 & 100 \\
\hline 15BJ06-195 & 109 & 154670 & 1.7 & 17.139 & 2.2 & 0.6924 & 3.6 & 0.0861 & 2.8 & 0.79 & 532 & 14 & 534 & 15 & 543 & 48 & 532 & 14 & 98 \\
\hline 15BJ06-265 & 146 & 29612 & 1.5 & 17.329 & 1.7 & 0.6872 & 2.6 & 0.0864 & 1.9 & 0.74 & 534 & 10 & 531 & 11 & 519 & 38 & 534 & 10 & 103 \\
\hline 15BJ06-045 & 44 & 28165 & 1.2 & 17.238 & 3.9 & 0.6927 & 4.6 & 0.0866 & 2.4 & 0.53 & 535 & 12 & 534 & 19 & 530 & 85 & 535 & 12 & 101 \\
\hline 15BJ06-210 & 59 & 146544 & 1.5 & 17.375 & 3.6 & 0.6878 & 4.1 & 0.0867 & 2.0 & 0.48 & 536 & 10 & 531 & 17 & 513 & 79 & 536 & 10 & 104 \\
\hline 15BJ06-049 & 32 & 13329 & 1.9 & 17.059 & 4.2 & 0.7007 & 4.7 & 0.0867 & 2.1 & 0.44 & 536 & 11 & 539 & 19 & 553 & 91 & 536 & 11 & 97 \\
\hline 15BJ06-042 & 81 & 83826 & 1.8 & 17.269 & 2.0 & 0.6942 & 3.1 & 0.0869 & 2.3 & 0.74 & 537 & 12 & 535 & 13 & 526 & 45 & 537 & 12 & 102 \\
\hline 15BJ06-099 & 67 & 25385 & 1.5 & 16.846 & 2.9 & 0.7130 & 3.4 & 0.0871 & 1.9 & 0.55 & 538 & 10 & 547 & 15 & 580 & 63 & 538 & 10 & 93 \\
\hline 15BJ06-130 & 52 & 31116 & 1.4 & 17.080 & 2.7 & 0.7111 & 3.4 & 0.0881 & 2.1 & 0.61 & 544 & 11 & 545 & 15 & 550 & 59 & 544 & 11 & 99 \\
\hline 15BJ06-046 & 68 & 200485 & 0.8 & 8.940 & 1.6 & 5.0788 & 2.4 & 0.3293 & 1.8 & 0.75 & 1835 & 29 & 1833 & 21 & 1830 & 29 & 1830 & 29 & 100 \\
\hline 15BJ06-081 & 851 & 204103 & 0.6 & 5.810 & 1.2 & 9.6076 & 2.6 & 0.4048 & 2.4 & 0.90 & 2191 & 44 & 2398 & 24 & 2578 & 19 & 2578 & 19 & 85 \\
\hline \multicolumn{20}{|c|}{$>20 \%$ Discordance } \\
\hline 15BJ06-159 & 379 & 119943 & 0.8 & 16.507 & 2.1 & 0.6610 & 2.6 & 0.0791 & 1.5 & 0.59 & 491 & 7 & 515 & 10 & 624 & 45 & 491 & 7 & 79 \\
\hline 15BJ06-020 & 48 & 28854 & 1.7 & 16.241 & 3.1 & 0.6861 & 3.7 & 0.0808 & 2.1 & 0.56 & 501 & 10 & 530 & 15 & 659 & 67 & 501 & 10 & 76 \\
\hline 15BJ06-028 & 32 & 84872 & 1.8 & 16.038 & 4.3 & 0.7022 & 4.9 & 0.0817 & 2.3 & 0.47 & 506 & 11 & 540 & 21 & 686 & 93 & 506 & 11 & 74 \\
\hline 15BJ06-166 & 49 & 40597 & 1.6 & 16.077 & 3.7 & 0.7014 & 4.6 & 0.0818 & 2.8 & 0.61 & 507 & 14 & 540 & 19 & 681 & 79 & 507 & 14 & 74 \\
\hline 15BJ06-118 & 96 & 59722 & 1.7 & 14.789 & 3.6 & 0.7653 & 3.9 & 0.0821 & 1.6 & 0.41 & 509 & 8 & 577 & 17 & 857 & 75 & 509 & 8 & 59 \\
\hline 15BJ06-250 & 118 & 95334 & 1.9 & 16.082 & 2.4 & 0.7099 & 3.0 & 0.0828 & 1.8 & 0.61 & 513 & 9 & 545 & 13 & 680 & 51 & 513 & 9 & 75 \\
\hline 15BJ06-125 & 162 & 50083 & 1.8 & 16.066 & 3.0 & 0.7191 & 3.4 & 0.0838 & 1.6 & 0.47 & 519 & 8 & 550 & 14 & 682 & 64 & 519 & 8 & 76 \\
\hline 15BJ06-040 & 131 & 70295 & 1.4 & 15.841 & 2.5 & 0.7294 & 3.4 & 0.0838 & 2.3 & 0.68 & 519 & 12 & 556 & 15 & 713 & 53 & 519 & 12 & 73 \\
\hline 15BJ06-139 & 72 & 42771 & 2.0 & 16.063 & 3.8 & 0.7231 & 4.5 & 0.0842 & 2.4 & 0.54 & 521 & 12 & 553 & 19 & 683 & 81 & 521 & 12 & 76 \\
\hline 15BJ06-068 & 86 & 31193 & 1.2 & 15.239 & 2.6 & 0.7667 & 3.2 & 0.0847 & 1.8 & 0.57 & 524 & 9 & 578 & 14 & 794 & 55 & 524 & 9 & 66 \\
\hline 15BJ06-071 & 42 & 67013 & 1.9 & 14.536 & 6.3 & 0.8218 & 7.0 & 0.0866 & 2.9 & 0.42 & 536 & 15 & 609 & 32 & 893 & 130 & 536 & 15 & 60 \\
\hline 15BJ06-069 & 55 & 11947 & 1.8 & 13.509 & 8.0 & 0.8944 & 8.6 & 0.0876 & 3.1 & 0.36 & 542 & 16 & 649 & 41 & 1042 & 161 & 542 & 16 & 52 \\
\hline 15BJ06-300 & 218 & 40136 & 0.7 & 9.763 & 2.6 & 3.0556 & 3.3 & 0.2164 & 2.0 & 0.61 & 1263 & 23 & 1422 & 25 & 1668 & 48 & 1668 & 48 & 76 \\
\hline 15BJ06-038 & 961 & 64229 & 2.4 & 9.235 & 1.7 & 3.6215 & 2.7 & 0.2426 & 2.1 & 0.77 & 1400 & 26 & 1554 & 22 & 1771 & 32 & 1771 & 32 & 79 \\
\hline
\end{tabular}


TABLE SM3.2: LA-ICPMS U-Pb ISOTOPIC DATA

\begin{tabular}{|c|c|c|c|c|c|c|c|c|c|c|c|c|c|c|c|c|c|c|c|}
\hline \multirow[b]{2}{*}{ Analysis } & \multirow[b]{2}{*}{ U } & \multirow[b]{2}{*}{$206 \mathrm{~Pb}$} & \multirow[b]{2}{*}{ U/Th } & \multirow[b]{2}{*}{$206 \mathrm{~Pb}^{*}$} & \multirow[b]{2}{*}{ \pm} & \multicolumn{5}{|c|}{ Isotope ratios } & \multicolumn{6}{|c|}{ Apparent ages (Ma) } & \multirow[b]{2}{*}{ Best age } & \multirow[b]{2}{*}{ \pm} & \multirow[b]{2}{*}{ Cono } \\
\hline & & & & & & $207 \mathrm{~Pb}^{*}$ & \pm & $206 \mathrm{~Pb}^{\star}$ & \pm & error & $206 \mathrm{~Pb}^{*}$ & \pm & $207 \mathrm{~Pb}^{\star}$ & \pm & $206 \mathrm{~Pb}^{\star}$ & \pm & & & \\
\hline & $(\mathrm{ppm})$ & $204 \mathrm{~Pb}$ & & $207 \mathrm{~Pb}^{\star}$ & $(\%)$ & $235 U^{*}$ & $(\%)$ & $238 U$ & $(\%)$ & corr. & $238 U^{*}$ & $(\mathrm{Ma})$ & $235 U$ & $(\mathrm{Ma})$ & $207 \mathrm{~Pb}^{*}$ & $(\mathrm{Ma})$ & $(\mathrm{Ma})$ & $(\mathrm{Ma})$ & $(\%)$ \\
\hline \multicolumn{20}{|c|}{$>5 \%$ Reverse Discordance } \\
\hline 15BJ06-252 & 84 & 40335 & 1.4 & 17.718 & 2.6 & 0.6218 & 3.4 & 0.0799 & 2.2 & 0.65 & 496 & 10 & 491 & 13 & 470 & 57 & 496 & 10 & 106 \\
\hline 15BJ06-308 & 56 & 18472 & 1.3 & 17.704 & 3.2 & 0.6282 & 4.0 & 0.0807 & 2.3 & 0.59 & 500 & 11 & 495 & 16 & 471 & 71 & 500 & 11 & 106 \\
\hline 15BJ06-158 & 71 & 15673 & 1.6 & 17.800 & 3.1 & 0.6250 & 3.7 & 0.0807 & 2.0 & 0.53 & 500 & 9 & 493 & 14 & 459 & 70 & 500 & 9 & 109 \\
\hline 15BJ06-162 & 77 & 33709 & 1.9 & 17.705 & 3.5 & 0.6320 & 3.9 & 0.0812 & 1.8 & 0.46 & 503 & 9 & 497 & 16 & 471 & 77 & 503 & 9 & 107 \\
\hline 15BJ06-148 & 73 & 13500 & 1.9 & 17.794 & 2.3 & 0.6289 & 3.4 & 0.0812 & 2.5 & 0.74 & 503 & 12 & 495 & 13 & 460 & 51 & 503 & 12 & 109 \\
\hline 15BJ06-244 & 61 & 25898 & 1.3 & 17.676 & 3.6 & 0.6339 & 4.3 & 0.0813 & 2.4 & 0.56 & 504 & 12 & 499 & 17 & 475 & 79 & 504 & 12 & 106 \\
\hline 15BJ06-277 & 50 & 61628 & 1.5 & 17.961 & 3.2 & 0.6240 & 4.0 & 0.0813 & 2.4 & 0.59 & 504 & 11 & 492 & 16 & 439 & 72 & 504 & 11 & 115 \\
\hline 15BJ06-019 & 57 & 33539 & 1.4 & 17.712 & 3.4 & 0.6338 & 4.2 & 0.0814 & 2.4 & 0.58 & 505 & 12 & 498 & 16 & 471 & 75 & 505 & 12 & 107 \\
\hline 15BJ06-052 & 54 & 28509 & 2.3 & 17.652 & 3.0 & 0.6365 & 3.8 & 0.0815 & 2.3 & 0.60 & 505 & 11 & 500 & 15 & 478 & 67 & 505 & 11 & 106 \\
\hline 15BJ06-280 & 57 & 26989 & 1.6 & 17.705 & 3.7 & 0.6364 & 4.2 & 0.0817 & 2.0 & 0.47 & 506 & 10 & 500 & 17 & 471 & 82 & 506 & 10 & 107 \\
\hline 15BJ06-233 & 51 & 27352 & 1.7 & 17.665 & 3.6 & 0.6379 & 4.0 & 0.0817 & 1.9 & 0.47 & 506 & 9 & 501 & 16 & 476 & 79 & 506 & 9 & 106 \\
\hline 15BJ06-258 & 109 & 28685 & 1.5 & 17.691 & 2.9 & 0.6377 & 3.9 & 0.0818 & 2.6 & 0.67 & 507 & 13 & 501 & 15 & 473 & 63 & 507 & 13 & 107 \\
\hline 15BJ06-207 & 84 & 39013 & 0.9 & 17.984 & 2.4 & 0.6274 & 3.4 & 0.0818 & 2.4 & 0.71 & 507 & 12 & 494 & 13 & 437 & 54 & 507 & 12 & 116 \\
\hline 15BJ06-163 & 274 & 27927 & 1.1 & 17.663 & 1.9 & 0.6398 & 2.7 & 0.0820 & 1.9 & 0.71 & 508 & 9 & 502 & 11 & 477 & 43 & 508 & 9 & 107 \\
\hline 15BJ06-274 & 117 & 34347 & 1.6 & 17.733 & 2.4 & 0.6377 & 3.0 & 0.0820 & 1.9 & 0.63 & 508 & 9 & 501 & 12 & 468 & 52 & 508 & 9 & 109 \\
\hline 15BJ06-221 & 36 & 20341 & 1.7 & 18.039 & 4.0 & 0.6274 & 4.7 & 0.0821 & 2.4 & 0.52 & 509 & 12 & 494 & 18 & 430 & 89 & 509 & 12 & 118 \\
\hline 15BJ06-209 & 65 & 44772 & 1.4 & 17.687 & 2.7 & 0.6410 & 3.3 & 0.0822 & 1.9 & 0.58 & 509 & 9 & 503 & 13 & 474 & 59 & 509 & 9 & 108 \\
\hline 15BJ06-008 & 52 & 20604 & 1.9 & 17.859 & 3.0 & 0.6351 & 4.1 & 0.0823 & 2.7 & 0.66 & 510 & 13 & 499 & 16 & 452 & 68 & 510 & 13 & 113 \\
\hline 15BJ06-255 & 45 & 11939 & 1.7 & 17.741 & 3.3 & 0.6397 & 4.3 & 0.0823 & 2.7 & 0.63 & 510 & 13 & 502 & 17 & 467 & 73 & 510 & 13 & 109 \\
\hline 15BJ06-088 & 60 & 23249 & 2.0 & 18.035 & 2.9 & 0.6296 & 3.6 & 0.0824 & 2.2 & 0.62 & 510 & 11 & 496 & 14 & 430 & 64 & 510 & 11 & 119 \\
\hline 15BJ06-240 & 30 & 12590 & 1.4 & 18.002 & 4.0 & 0.6311 & 4.6 & 0.0824 & 2.2 & 0.48 & 510 & 11 & 497 & 18 & 434 & 90 & 510 & 11 & 118 \\
\hline 15BJ06-146 & 39 & 26905 & 1.5 & 17.608 & 4.6 & 0.6457 & 5.1 & 0.0825 & 2.3 & 0.45 & 511 & 11 & 506 & 20 & 483 & 101 & 511 & 11 & 106 \\
\hline 15BJ06-303 & 95 & 68710 & 1.3 & 17.643 & 2.9 & 0.6448 & 3.5 & 0.0825 & 1.9 & 0.55 & 511 & 9 & 505 & 14 & 479 & 64 & 511 & 9 & 107 \\
\hline 15BJ06-116 & 85 & 35223 & 1.1 & 17.632 & 2.2 & 0.6458 & 2.9 & 0.0826 & 1.9 & 0.65 & 511 & 9 & 506 & 12 & 481 & 49 & 511 & 9 & 106 \\
\hline 15BJ06-039 & 64 & 26846 & 1.7 & 17.672 & 3.9 & 0.6443 & 4.4 & 0.0826 & 2.0 & 0.45 & 512 & 10 & 505 & 17 & 475 & 86 & 512 & 10 & 108 \\
\hline 15BJ06-176 & 70 & 215027 & 2.2 & 17.877 & 2.8 & 0.6371 & 3.5 & 0.0826 & 2.1 & 0.59 & 512 & 10 & 501 & 14 & 450 & 63 & 512 & 10 & 114 \\
\hline 15BJ06-286 & 40 & 511982 & 1.8 & 17.946 & 3.6 & 0.6353 & 4.5 & 0.0827 & 2.6 & 0.58 & 512 & 13 & 499 & 18 & 441 & 81 & 512 & 13 & 116 \\
\hline 15BJ06-201 & 138 & 31585 & 1.6 & 17.613 & 2.0 & 0.6476 & 2.7 & 0.0827 & 1.7 & 0.64 & 512 & 8 & 507 & 11 & 483 & 45 & 512 & 8 & 106 \\
\hline 15BJ06-076 & 122 & 29197 & 1.4 & 17.686 & 2.4 & 0.6456 & 3.1 & 0.0828 & 2.1 & 0.65 & 513 & 10 & 506 & 13 & 474 & 53 & 513 & 10 & 108 \\
\hline 15BJ06-313 & 65 & 52904 & 1.8 & 17.658 & 2.7 & 0.6467 & 3.4 & 0.0828 & 2.1 & 0.61 & 513 & 10 & 506 & 14 & 477 & 60 & 513 & 10 & 107 \\
\hline 15BJ06-172 & 78 & 35662 & 1.9 & 17.814 & 2.3 & 0.6412 & 3.1 & 0.0828 & 2.1 & 0.66 & 513 & 10 & 503 & 12 & 458 & 52 & 513 & 10 & 112 \\
\hline
\end{tabular}


TABLE SM3.2: LA-ICPMS U-Pb ISOTOPIC DATA

\begin{tabular}{|c|c|c|c|c|c|c|c|c|c|c|c|c|c|c|c|c|c|c|c|}
\hline \multirow[b]{2}{*}{ Analysis } & \multirow[b]{2}{*}{$U$} & \multirow[b]{2}{*}{$206 \mathrm{~Pb}$} & \multirow[b]{2}{*}{$\mathrm{U} / \mathrm{Th}$} & \multirow[b]{2}{*}{$206 \mathrm{~Pb}^{*}$} & \multirow[b]{2}{*}{ \pm} & \multicolumn{5}{|c|}{ Isotope ratios } & \multicolumn{6}{|c|}{ Apparent ages (Ma) } & \multirow[b]{2}{*}{ Best age } & \multirow[b]{2}{*}{ \pm} & \multirow[b]{2}{*}{ Conc } \\
\hline & & & & & & $207 \mathrm{~Pb}^{\star}$ & \pm & $206 \mathrm{~Pb}^{\star}$ & \pm & error & $206 \mathrm{~Pb}^{\star}$ & \pm & $207 \mathrm{~Pb}^{*}$ & \pm & $206 \mathrm{~Pb}^{*}$ & \pm & & & \\
\hline & (ppm) & $204 \mathrm{~Pb}$ & & $207 \mathrm{~Pb}^{*}$ & $(\%)$ & $235 U^{*}$ & $(\%)$ & $238 U$ & $(\%)$ & corr. & $238 U^{*}$ & $(\mathrm{Ma})$ & $235 U$ & $(\mathrm{Ma})$ & 207Pb* & $(\mathrm{Ma})$ & $(\mathrm{Ma})$ & $(\mathrm{Ma})$ & $(\%)$ \\
\hline 15BJ06-214 & 103 & 36135 & 1.4 & 17.699 & 2.4 & 0.6456 & 3.0 & 0.0829 & 1.9 & 0.61 & 513 & 9 & 506 & 12 & 472 & 53 & 513 & 9 & 109 \\
\hline 15BJ06-141 & 54 & 36631 & 1.7 & 17.815 & 3.7 & 0.6416 & 4.2 & 0.0829 & 2.1 & 0.50 & 513 & 10 & 503 & 17 & 458 & 81 & 513 & 10 & 112 \\
\hline 15BJ06-219 & 55 & 35025 & 1.4 & 17.655 & 3.6 & 0.6477 & 4.3 & 0.0829 & 2.3 & 0.53 & 514 & 11 & 507 & 17 & 478 & 80 & 514 & 11 & 108 \\
\hline 15BJ06-047 & 91 & 36516 & 1.1 & 17.570 & 2.5 & 0.6533 & 3.7 & 0.0833 & 2.7 & 0.74 & 516 & 13 & 511 & 15 & 488 & 55 & 516 & 13 & 106 \\
\hline 15BJ06-165 & 157 & 84956 & 1.1 & 17.638 & 1.8 & 0.6509 & 3.0 & 0.0833 & 2.3 & 0.79 & 516 & 12 & 509 & 12 & 480 & 41 & 516 & 12 & 107 \\
\hline 15BJ06-133 & 64 & 20564 & 1.8 & 17.811 & 2.6 & 0.6447 & 3.6 & 0.0833 & 2.5 & 0.70 & 516 & 13 & 505 & 14 & 458 & 58 & 516 & 13 & 113 \\
\hline 15BJ06-079 & 32 & 8881 & 0.8 & 17.928 & 3.9 & 0.6409 & 4.8 & 0.0833 & 2.7 & 0.57 & 516 & 13 & 503 & 19 & 444 & 87 & 516 & 13 & 116 \\
\hline 15BJ06-173 & 136 & 25282 & 1.6 & 17.636 & 1.6 & 0.6532 & 2.6 & 0.0835 & 2.0 & 0.77 & 517 & 10 & 510 & 10 & 480 & 36 & 517 & 10 & 108 \\
\hline 15BJ06-309 & 65 & 39136 & 1.6 & 17.589 & 2.9 & 0.6555 & 3.8 & 0.0836 & 2.6 & 0.67 & 518 & 13 & 512 & 15 & 486 & 63 & 518 & 13 & 107 \\
\hline 15BJ06-247 & 171 & 140436 & 1.7 & 17.604 & 2.3 & 0.6555 & 3.0 & 0.0837 & 2.0 & 0.65 & 518 & 10 & 512 & 12 & 484 & 51 & 518 & 10 & 107 \\
\hline 15BJ06-094 & 64 & 63901 & 2.3 & 17.621 & 2.3 & 0.6552 & 3.1 & 0.0837 & 2.0 & 0.65 & 518 & 10 & 512 & 12 & 482 & 51 & 518 & 10 & 108 \\
\hline 15BJ06-288 & 82 & 38733 & 1.6 & 17.758 & 3.1 & 0.6514 & 4.0 & 0.0839 & 2.5 & 0.63 & 519 & 13 & 509 & 16 & 465 & 68 & 519 & 13 & 112 \\
\hline 15BJ06-070 & 38 & 15834 & 1.5 & 17.991 & 2.7 & 0.6433 & 4.1 & 0.0839 & 3.0 & 0.74 & 520 & 15 & 504 & 16 & 436 & 61 & 520 & 15 & 119 \\
\hline 15BJ06-282 & 38 & 19400 & 2.1 & 17.588 & 4.8 & 0.6582 & 5.5 & 0.0840 & 2.7 & 0.48 & 520 & 13 & 514 & 22 & 486 & 106 & 520 & 13 & 107 \\
\hline 15BJ06-200 & 75 & 26537 & 1.2 & 17.765 & 2.5 & 0.6530 & 3.2 & 0.0841 & 2.0 & 0.62 & 521 & 10 & 510 & 13 & 464 & 56 & 521 & 10 & 112 \\
\hline 15BJ06-057 & 79 & 56052 & 2.0 & 17.679 & 2.5 & 0.6575 & 3.0 & 0.0843 & 1.7 & 0.57 & 522 & 8 & 513 & 12 & 475 & 54 & 522 & 8 & 110 \\
\hline 15BJ06-304 & 75 & 20040 & 1.8 & 17.699 & 3.3 & 0.6574 & 4.0 & 0.0844 & 2.2 & 0.55 & 522 & 11 & 513 & 16 & 472 & 74 & 522 & 11 & 111 \\
\hline 15BJ06-140 & 53 & 38819 & 1.9 & 17.549 & 2.5 & 0.6632 & 3.5 & 0.0844 & 2.4 & 0.69 & 522 & 12 & 517 & 14 & 491 & 56 & 522 & 12 & 106 \\
\hline 15BJ06-296 & 49 & 24493 & 1.5 & 17.531 & 2.9 & 0.6659 & 3.5 & 0.0847 & 1.9 & 0.55 & 524 & 10 & 518 & 14 & 493 & 64 & 524 & 10 & 106 \\
\hline 15BJ06-138 & 59 & 38203 & 1.6 & 17.932 & 2.9 & 0.6520 & 3.9 & 0.0848 & 2.7 & 0.68 & 525 & 14 & 510 & 16 & 443 & 64 & 525 & 14 & 118 \\
\hline 15BJ06-009 & 49 & 14680 & 1.5 & 17.687 & 2.8 & 0.6614 & 3.6 & 0.0848 & 2.2 & 0.62 & 525 & 11 & 515 & 15 & 474 & 63 & 525 & 11 & 111 \\
\hline 15BJ06-093 & 77 & 26297 & 1.4 & 17.767 & 3.0 & 0.6611 & 3.5 & 0.0852 & 1.9 & 0.54 & 527 & 10 & 515 & 14 & 464 & 66 & 527 & 10 & 114 \\
\hline 15BJ06-315 & 216 & 8440759 & 1.8 & 17.505 & 1.9 & 0.6719 & 3.0 & 0.0853 & 2.3 & 0.78 & 528 & 12 & 522 & 12 & 496 & 42 & 528 & 12 & 106 \\
\hline 15BJ06-030 & 160 & 122865 & 1.3 & 17.525 & 1.8 & 0.6713 & 2.7 & 0.0853 & 2.1 & 0.76 & 528 & 10 & 521 & 11 & 494 & 39 & 528 & 10 & 107 \\
\hline 15BJ06-095 & 56 & 21416 & 1.0 & 17.645 & 2.8 & 0.6725 & 3.5 & 0.0861 & 2.1 & 0.60 & 532 & 11 & 522 & 14 & 479 & 62 & 532 & 11 & 111 \\
\hline 15BJ06-048 & 88 & 41100 & 1.4 & 17.750 & 2.1 & 0.6721 & 2.7 & 0.0865 & 1.7 & 0.62 & 535 & 9 & 522 & 11 & 466 & 46 & 535 & 9 & 115 \\
\hline 15BJ06-152 & 111 & 26487 & 0.9 & 17.445 & 2.3 & 0.6866 & 3.1 & 0.0869 & 2.1 & 0.69 & 537 & 11 & 531 & 13 & 504 & 50 & 537 & 11 & 107 \\
\hline 15BJ06-178 & 28 & 22951 & 1.6 & 17.419 & 4.4 & 0.7279 & 5.2 & 0.0920 & 2.8 & 0.53 & 567 & 15 & 555 & 22 & 507 & 96 & 567 & 15 & 112 \\
\hline \multicolumn{20}{|c|}{ Contamination(?) } \\
\hline 15BJ06-295 & 601 & 74913 & 3.2 & 20.730 & 2.6 & 0.0814 & 3.6 & 0.0122 & 2.6 & 0.70 & 78 & 2 & 79 & 3 & 111 & 61 & 78 & 2 & NA \\
\hline 15BJ06-077 & 691 & 31702 & 1.2 & 21.059 & 2.4 & 0.0965 & 3.1 & 0.0147 & 2.0 & 0.65 & 94 & 2 & 94 & 3 & 74 & 57 & 94 & 2 & NA \\
\hline
\end{tabular}


TABLE SM3.2: LA-ICPMS U-Pb ISOTOPIC DATA

\begin{tabular}{|c|c|c|c|c|c|c|c|c|c|c|c|c|c|c|c|c|c|c|c|}
\hline \multirow[b]{2}{*}{ Analysis } & \multirow[b]{2}{*}{ U } & \multirow[b]{2}{*}{$206 \mathrm{~Pb}$} & \multirow[b]{2}{*}{$\mathrm{U} / \mathrm{Th}$} & \multirow[b]{2}{*}{$206 \mathrm{~Pb}^{*}$} & \multirow[b]{2}{*}{ \pm} & \multicolumn{5}{|c|}{ Isotope ratios } & \multicolumn{6}{|c|}{ Apparent ages (Ma) } & \multirow[b]{2}{*}{ Best age } & \multirow[b]{2}{*}{ \pm} & \multirow[b]{2}{*}{ Conc } \\
\hline & & & & & & 207Pb* & \pm & $206 \mathrm{~Pb}^{\star}$ & \pm & error & $206 \mathrm{~Pb}^{*}$ & \pm & $207 \mathrm{~Pb}^{*}$ & \pm & $206 \mathrm{~Pb}^{*}$ & \pm & & & \\
\hline & (ppm) & $204 \mathrm{~Pb}$ & & 207Pb* & $(\%)$ & $235 U^{*}$ & $(\%)$ & $238 \mathrm{U}$ & $(\%)$ & corr. & $238 U^{*}$ & $(\mathrm{Ma})$ & $235 \mathrm{U}$ & $(\mathrm{Ma})$ & 207Pb* & $(\mathrm{Ma})$ & $(\mathrm{Ma})$ & $(\mathrm{Ma})$ & $(\%)$ \\
\hline 15BJ06-016 & 438 & 19822 & 1.6 & 21.438 & 2.8 & 0.1017 & 3.4 & 0.0158 & 1.9 & 0.57 & 101 & 2 & 98 & 3 & 31 & 67 & 101 & 2 & NA \\
\hline 15BJ06-192 & 202 & 23558 & 2.2 & 21.215 & 4.2 & 0.1122 & 4.7 & 0.0173 & 2.2 & 0.46 & 110 & 2 & 108 & 5 & 56 & 100 & 110 & 2 & NA \\
\hline 15BJ06-245 & 83 & 19745 & 3.3 & 19.689 & 3.9 & 0.1938 & 4.4 & 0.0277 & 2.1 & 0.48 & 176 & 4 & 180 & 7 & 231 & 90 & 176 & 4 & NA \\
\hline \multicolumn{20}{|l|}{ Pb loss(?) } \\
\hline 15BJ06-131 & 706 & 117177 & 1.7 & 18.257 & 1.8 & 0.4272 & 2.7 & 0.0566 & 2.0 & 0.75 & 355 & 7 & 361 & 8 & 403 & 40 & 355 & 7 & NA \\
\hline
\end{tabular}

1. Best age is chosen to be the 206Pb/238U age for analyses with 206Pb/238U age <900 Ma otherwise the 206Pb/207Pb age is preferred for analyses with $206 \mathrm{~Pb} / 238 \mathrm{Uage}>900 \mathrm{Ma}$.

2. Concordance is based on $206 \mathrm{~Pb} / 238 \mathrm{U}$ age / 206Pb/207Pb age. Value is not reported for $206 \mathrm{~Pb} / 238 \mathrm{U}$ ages <400 Ma because of large uncertainty in $206 \mathrm{~Pb} / 207 \mathrm{~Pb}$ age and higher sensitivity to discordance.

3. All uncertainties are reported at the 1-sigma level, and include measurement errors and an additional factor based on MSWD of sets of secondary standards to account for overdispersion of standard measurements

4. Systematic errors (at 2-sigma level) include contributions from $U$ decay constants, composition of common Pb, true age of the standard, and scatter of measured age of the standards, and are as follows: $1.0 \%(206 \mathrm{~Pb} / 238 \mathrm{U})$ \& $0.9 \%(206 \mathrm{~Pb} / 207 \mathrm{~Pb})$

5. Common $\mathrm{Pb}$ correction is from measured 204Pb with common Pb composition interpreted from Stacey and Kramers (1975), and Common Pb composition assigned uncertainties of 1.5 for $206 \mathrm{~Pb} / 204 \mathrm{~Pb}, 0.3$ for $207 \mathrm{~Pb} / 204 \mathrm{~Pb}$, and 2.0 for $208 \mathrm{~Pb} / 204 \mathrm{~Pb}$.

6. $U$ decay constants and composition as follows: $238 \mathrm{U}=9.8485 \times 10-10,235 \mathrm{U}=1.55125 \times 10-10,238 \mathrm{U} / 235 \mathrm{U}=137.88$. 
TABLE SM3.3: Hf ISOTOPIC DATA

\begin{tabular}{|c|c|c|c|c|c|c|c|c|c|c|c|}
\hline Sample & $\left({ }^{176} \mathrm{Yb}+{ }^{176} \mathrm{Lu}\right) /{ }^{176} \mathrm{Hf}(\%)$ & Volts $\mathrm{Hf}$ & ${ }^{176} \mathrm{Hf} /{ }^{177} \mathrm{Hf}$ & $\pm(1 \sigma)$ & ${ }^{176} \mathrm{Lu} /{ }^{177} \mathrm{Hf}$ & $\begin{array}{c}{ }^{1 / 6} \mathrm{Hf}^{117 /} \mathrm{Hf} \\
(\mathrm{T}) \\
\end{array}$ & E-Hf (0) & $\mathrm{E}-\mathrm{Hf}(0) \pm(1 \sigma)$ & E-Hf (T) & Age (Ma) & $\pm(1 \sigma)$ \\
\hline \multicolumn{12}{|c|}{ 13WW23; Whale Mountain volcanic rock (central belt; N69.182, W140.924) } \\
\hline 13WW24-055 & 46.9 & 2.5 & 0.282638 & 0.000032 & 0.002581 & 0.282615 & -5.2 & 1.1 & 4.8 & 486 & 32 \\
\hline 13WW24-056 & 12.8 & 3.7 & 0.282709 & 0.000025 & 0.000735 & 0.282702 & -2.7 & 0.9 & 8.1 & 493 & 10 \\
\hline 13WW24-053 & 28.2 & 2.5 & 0.282622 & 0.000036 & 0.001634 & 0.282607 & -5.8 & 1.3 & 4.9 & 500 & 17 \\
\hline 13WW24-059 & 30.9 & 3.2 & 0.282685 & 0.000030 & 0.001699 & 0.282668 & -3.6 & 1.1 & 7.2 & 508 & 26 \\
\hline 13WW24-058 & 21.9 & 3.3 & 0.282779 & 0.000027 & 0.001445 & 0.282765 & -0.2 & 1.0 & 10.7 & 510 & 24 \\
\hline 13WW24-057 & 13.5 & 2.8 & 0.282628 & 0.000034 & 0.000797 & 0.282620 & -5.6 & 1.2 & 5.6 & 514 & 8 \\
\hline \multicolumn{12}{|c|}{ 15BJ06; Marsh Fork volcanic rocs (southern belt; N69.108, W143.894) } \\
\hline 15BJ06-297 & 14.7 & 3.1 & 0.282745 & 0.000029 & 0.000711 & 0.282738 & -1.4 & 1.0 & 9.7 & 511 & 7 \\
\hline 15BJ06-145 & 16.6 & 3.6 & 0.282721 & 0.000029 & 0.000775 & 0.282714 & -2.2 & 1.0 & 8.9 & 511 & 8 \\
\hline 15BJ06-257 & 13.4 & 3.7 & 0.282674 & 0.000024 & 0.000600 & 0.282668 & -3.9 & 0.8 & 7.3 & 512 & 9 \\
\hline 15BJ06-256 & 15.7 & 3.0 & 0.282707 & 0.000029 & 0.000681 & 0.282700 & -2.8 & 1.0 & 8.4 & 513 & 11 \\
\hline 15BJ06-063 & 20.4 & 1.3 & 0.282753 & 0.000047 & 0.001136 & 0.282742 & -1.1 & 1.7 & 10.0 & 515 & 9 \\
\hline
\end{tabular}

1. Hf fractionation is corrected by comparing measured 179Hf/177Hf against known 179/177 (line by line). Beta Hf is applied as a power law.

2. Yb fractionation is corrected by comparing measured $173 \mathrm{Yb} / 171 \mathrm{Yb}$ against known 173/171 (line by line) if $171 \mathrm{Yb}$ intensity is more than $\sim 1 \mathrm{mv}$. Beta $\mathrm{Yb}$ is applied as a power law.

a. If $171 \mathrm{Yb}$ intensity is less than can be measured reliably, Beta Hf is used to correct for $\mathrm{Yb}$ fractionation.

$b$. The actual cutoff used is determined from the analysis of standards during the same session

3. Data are filtered by intensity of $\mathrm{Hf}$

4. Data are filtered by removing 1 max and 1 min value (out of 60).

5. Data are aflso filtered by $95 \%$ filter (rejected if outside of 2-sigma std dev of full set)

6. Uncertainties are standard error of the mean, expressed at 1-sigma 